UNIVERSIDADE DE SÃO PAULO

ESCOLA POLITÉCNICA

SÉRGIO ROBERTO ANDRADE DANTAS

Evaluation of the effect of $\mathrm{TiO}_{2}$ treatments on the reflectance to solar and luminous radiation of coating mortars

Avaliação do efeito de tratamentos com $\mathrm{TiO}_{2}$ sobre as refletâncias a radiação solar e luminosa de argamassas de revestimento 


\section{SÉRGIO ROBERTO ANDRADE DANTAS}

Evaluation of the effect of $\mathrm{TiO}_{2}$ treatments on the reflectance to solar and luminous radiation of coating mortars

\section{Revised Version}

Doctoral thesis presented to the Postgraduate Program in Civil Engineering at the Polytechnic School of the University of São Paulo for obtaining the Doctorate Degree in Sciences

Area of Concentration: Civil and Urban Construction Engineering

Advisor: $\operatorname{Prof}^{(a)}$. Dr ${ }^{(a)}$. Kai Loh

São Paulo 
Autorizo a reprodução e divulgação total ou parcial deste trabalho, por qualquer meio convencional ou eletrônico, para fins de estudo e pesquisa, desde que citada a fonte.

Este exemplar foi revisado e corrigido em relação à versão original, sob responsabilidade única do autor e com a anuência de seu orientador.

São Paulo, 05 de outubro de 2021

Assinatura do autor:

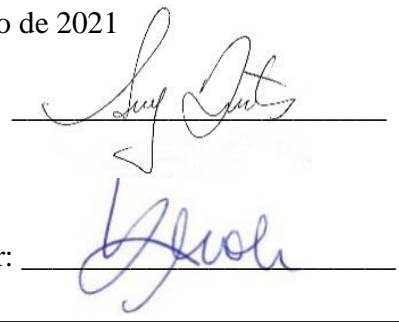

\section{Catalogação-na-publicação}

Dantas, Sérgio Roberto Andrade

Evaluation of the effect of $\mathrm{TiO}_{2}$ treatments on the reflectance to solar and luminous radiation of coating mortars / S. R. A. Dantas -- versão corr. -- São Paulo, 2021.

$255 \mathrm{p}$.

Tese (Doutorado) - Escola Politécnica da Universidade de São Paulo. Departamento de Engenharia de Construção Civil.

1.Fotocatálise 2. Dióxido de titânio - dispersão - efeito - tratamento avaliação 3.Radiação ultravioleta - deterioração - revestimento de fachadas 4.Argamassa - reologia - degradação - processos - fibras artificiais I.Universidade de São Paulo. Escola Politécnica. Departamento de Engenharia de Construção Civil II.t. 
DANTAS, S. R. A. Evaluation of the effect of $\mathrm{TiO}_{2}$ treatments on the reflectance to solar and luminous radiation of coating mortars. 2021. 255 p. Thesis (Doctoral degree in sciences) - Polytechnic School, University of São Paulo, 2021.

Approved on: 13/ 09 / 2021

Doctoral Committee

Prof $^{(a)}$. Dr ${ }^{(a)}$. Kai Loh (Advisor)

Institution: Escola Politécnica da Universidade de São Paulo (EPUSP)

Judgment:

Prof $^{(a)}$. Dr ${ }^{(a)}$. Denise Carpena Coitinho Dal Molin

Institution: Escola de Engenharia da Universidade Federal do Rio Grande do Sul (UFRGS)

Judgment:

\section{Prof. Dr. Douglas Gouvêa}

Institution: Escola Politécnica da Universidade de São Paulo (PMT/USP)

Judgment:

Prof $^{(a)}$. Dr ${ }^{(a)}$. Kelen Almeida Dornelles

Institution: Instituto de Arquitetura e Urbanismo da Universidade de São Paulo / São Carlos (IAU/USP-São Carlos)

Judgment:

\section{Prof $^{(a)}$. Dr ${ }^{(a)}$. Rosana Maria Caram}

Institution: Instituto de Arquitetura e Urbanismo da Universidade de São Paulo / São Carlos (IAU/USP-São Carlos)

Judgment: 
Neste momento em que as palavras não são capazes ou suficientes para suprir todo o sentimento de gratidão. Onde a mais bela e extensa dissertação não seria capaz de abarcar a todos em quem me apoiei para continuar no caminho e aqui ter chegado. Onde a prosaica enumeração de nomes não conseguiria atingir o que a cada um, em especial, eu gostaria de manifestar, me ponho em completa posição de devedor.

Assim, me valho deste breve relato para agradecer, de forma geral e em igual teor, a todas as pessoas que estiveram cotidianamente presentes, ou apenas de passagem por todo esse longo percurso que foi a produção deste trabalho, não havendo assim, razões para distinções ou posições hierárquicas, pois de cada um foi absorvido muito mais que palavras, gestos ou orientações. De alguns vieram a construção de um lastro de amizade e companheirismo, de outros a palavra que incentivou e ajudou a persistir. Mas, sobretudo, de todos vieram as experiências que permitiram o acúmulo do aprendizado e que com o passar do tempo se tornaram a base do que hoje considero como CONHECIMENTO.

Da mesma forma, gostaria de agradecer ao Instituto de Pesquisas Tecnológicas de São Paulo (IPT) e sua fundação (FIPT) pelo apoio financeiro e institucional por meio do Programa Novos Talentos $N^{o}$ 01/2017. Estendendo este agradecimento também à Coordenação de Aperfeiçoamento de Pessoal de Nível Superior - Brasil (CAPES) - Código Financeiro 001, pela bolsa que permitiu completar este sonho. 


\section{RESUMO}

DANTAS, Sérgio Roberto Andrade. Avaliação do efeito de tratamentos com $\mathrm{TiO}_{2}$ sobre as refletâncias a radiação solar e luminosa de argamassas de revestimento. 2021. 255 p. Tese (Doutorado em ciências) - Escola Politécnica da Universidade de São Paulo, 2021.

Assim que a argamassa é aplicada na fachada, inicia-se um processo contínuo de degradação que perdurará durante toda a sua vida útil. Na obra, os mecanismos de avaliação das propriedades das argamassas, nomeadamente a sua aplicabilidade, são habitualmente realizados de forma sensorial e táctil. É prática comum os pedreiros aumentarem a quantidade de água sem nenhum controle, utilizando apenas sua experiência e preferência pela consistência da argamassa. Com base no conhecimento empírico, tais procedimentos induzem a muitos erros que prejudicam a qualidade da argamassa e não permitem a medição de quaisquer parâmetros reológicos possíveis para quantificar a trabalhabilidade do material. Para matrizes de cimento, as propriedades reológicas das dispersões são governadas pela microestrutura do sistema, e a dispersão de partículas representa um desafio que precisa ser abordado para o uso de nanomateriais nessas misturas. Em argamassas com adição de $\mathrm{TiO}_{2}$, as características das partículas, como tamanho e morfologia, podem ser responsáveis pelas diferentes atividades fotocatalíticas. Além disso, a rugosidade da superfície pode afetar como as partículas de $\mathrm{TiO}_{2}$ podem ser ativadas pela radiação solar devido à incidência de sombra causada pelas diferentes escalas de rugosidade existentes nas superfícies. Os materiais utilizados nas fachadas não respondem apenas ao estado estético do edifício, mas têm um papel fundamental no seu equilíbrio térmico, onde materiais que apresentam elevados valores de refletividade reduzem os ganhos térmicos e resultam numa técnica passiva eficiente para reduzir a procura de energia eléctrica no condicionamento térmico de ambientes e melhoria do conforto térmico interno e externo. Além disso, o aumento da refletância solar e da emissão térmica nas fachadas pode ser uma estratégia viável para ajudar a reduzir as ilhas de calor urbanas. No entanto, o contato constante dessas superfícies com agentes de degradação pode diminuir significativamente esses benefícios ao longo do tempo com a exposição à corrosão causada por ácidos, desgaste acelerado, incrustação devido a partículas de fuligem e a incidência direta de radiação UV que causa descoloração e aparência de manchas. Como resultado, os revestimentos tornam-se mais opacos, afetando seu equilíbrio térmico e estética visual ao longo do tempo. Nesse contexto, o uso de revestimentos tratados com $\mathrm{TiO}_{2}$ não apenas ajuda na manutenção desses revestimentos ao longo do tempo, mas também mantém a refletância solar e de luminosidade das fachadas dos edifícios, tornando-as mais eficientes ao manter seus valores iniciais de refletância por longos períodos. Assim, o estudo avaliou experimentalmente superfícies tratadas com $\mathrm{TiO}_{2}$ - formas em pó e suspensão - e as comparou com superfícies pintadas de branco, observando a manutenção das características iniciais de refletância à radiação solar e refletância luminosa dessas superfícies, visando sua baixa manutenção e melhor performance, mostrando-se como uma possível alternativa às argamassas pintadas. A refletância à radiação solar medida foi de acordo com os procedimentos ASTM E1918-16 e ANSI/ASHRAE-74. As medições foram realizadas utilizando dois piranômetros Kipp \& Zonen, Delft/Holland modelo CM3, com comprimentos de onda de $305-2800 \mathrm{~nm}$ e radiação máxima de $2.000 \mathrm{~W} / \mathrm{m}^{2}$. O sinal gerado variou de 0 - 50 $\mathrm{mV}$ e a sensibilidade de $0-35 \mu \mathrm{V} / \mathrm{W} / \mathrm{m}^{2}$. Um datalogger ALMEMO, modelo 2890-9 com display de 6,5 dígitos e saída RS232, foi empregado para a aquisição dos dados. Já para a refletância luminosa, foi adotado um procedimento baseado na ASTM D2244-21. As medidas foram realizadas em espectrofotômetro Color Guide Sphere difuso/spin $8^{\circ} \mathrm{com}$ medidas geométricas de $45^{\circ} / 0^{\circ}$ circular, área de medição de 400 - $700 \mathrm{~nm}$, resolução espectral de 20 
nm e faixa fotométrica de $0-100 \%$, resolução de 0,01 . Foram considerados o iluminante D65 e o observador com $10^{\circ}$ e reprodutibilidade $<0,02 \Delta \mathrm{E}^{*}$. Os resultados indicaram que as amostras pintadas mantiveram sua refletância inicial à radiação solar após três anos de exposição, terminando com $73 \%$ de seu índice. A comparação entre os corpos-de-prova pintados e os tratados com pó de $\mathrm{TiO}_{2}$ mostrou uma diferença de $28,25 \%$ em relação à refletância à radiação solar. Por outro lado, a comparação entre as amostras tratadas com $\mathrm{TiO}_{2}$ em pó e as amostras tratadas com $\mathrm{TiO}_{2}$ em forma de suspensão mostrou uma diferença de 8,5\% no índice de refletância à radiação solar, não indicando preferência uma vez que ambas apresentaram a mesma eficácia em média após três anos de exposição. Em relação à luminosidade, após trinta e sete meses da exposição natural, os corpos-de-prova pintados de branco tiveram os melhores resultados que os corpos-de-prova com suspensão de $\mathrm{TiO}_{2}$ e os corpos-de-prova com $\mathrm{TiO}_{2}$ em pó. Além disso, quanto à absortividade, os corpos-de-prova pintados de branco podem ser considerados com baixa absortividade. Em contraste, as amostras tratadas com suspensão de $\mathrm{TiO}_{2}$ e aquelas tratadas com pó de $\mathrm{TiO}_{2}$ podem ter absortividade média. Sobre a percepção estética, o estudo conclui que, para o usuário final, não há diferenças significantes nos exemplares pintados de branco. Em contrapartida, para as outras amostras com $\mathrm{TiO}_{2}$ (pó e suspensão), o usuário final pode notar a diferença de cor muito bem em três anos de exposição. Portanto, esta pesquisa visa contribuir para o preenchimento de uma lacuna no que diz respeito aos estudos de refletividade de diferentes tratamentos de $\mathrm{TiO}_{2}$ (pó e suspensão) em argamassas, fazendo uma avaliação comparativa com argamassas pintadas e expostas ao ambiente urbano em longo prazo, demonstrando não apenas a eficácia do processo fotocatalítico por medidas de refletância à radiação solar e refletância luminosa, mas também a manutenção dessas propriedades nas argamassas ao longo do tempo.

Palavras-chave: Fotocatálise. Dióxido de titânio: dispersão - efeito - tratamento - avaliação. Radiação ultravioleta: deterioração - revestimento de fachadas. Argamassa: reologia degradação - processos - fibras artificiais. 


\begin{abstract}
DANTAS, Sérgio Roberto Andrade. Evaluation of the effect of $\mathrm{TiO}_{2}$ treatments on the reflectance to solar and luminous radiation of coating mortars. 2021. 255 p. Thesis (Doctoral degree in sciences) - Polytechnic School, University of São Paulo, 2021.
\end{abstract}

As soon as a mortar is applied to a facade, a continuous degradation process begins and will last during its entire service life. At the worksite, the mechanisms for evaluating the properties of mortars, particularly their applicability, are usually carried out in a sensorial and tactile way. It is common practice for masons to increase the amount of water without any control, only using their experience and preference of mortar consistency. Based on empirical knowledge, such procedures induce many errors that impair the mortar quality and do not enable the measurement of any possible rheological parameters to quantify the material workability. For cement matrixes, the rheological properties of dispersions are governed by the microstructure of the system, and particle dispersion poses a challenge that needs to be addressed for the use of nanomaterials in those mixtures. In mortars with $\mathrm{TiO}_{2}$ addition, particle characteristics such as size and morphology can account for the different photocatalytic activities. Moreover, the surface roughness can affect how $\mathrm{TiO}_{2}$ particles can be activated by solar radiation due to the incidence of shadow caused by the different roughness scales existing on surfaces. The materials used on the facades do not respond only to the building's aesthetic condition but have an essential role in their thermal balance, where materials that present high reflectivity values reduce thermal gains and result in an efficient passive technique to reduce demand for electrical energy in the thermal conditioning of environments and improve indoor and outdoor thermal comfort. Furthermore, the increase in solar reflectance and thermal emittance on the facades can be a feasible strategy to help reduce urban heat islands. However, the constant contact of those surfaces with degradation agents can significantly diminish those benefits over time with the exposition to the corrosion caused by acids, accelerated wear, fouling due to soot particles, and the direct incidence of UV radiation that causes discoloration and the appearance of stains. As a result, the coatings become more opaque, affecting their thermal balance and visual aesthetic over time. In this context, using coatings treated with $\mathrm{TiO}_{2}$ helps in the maintenance of these coatings over time. It maintains the solar and lightness reflectance of the building facades, making them more efficient by maintaining their initial reflectance values over long periods. Thus, the study evaluated surfaces experimentally treated with $\mathrm{TiO}_{2}$ - powder and suspension forms and compared them with white painted surfaces, observing the maintenance of the initial characteristics of reflectance to solar radiation and lightness reflectance of these surfaces, aiming at its low maintenance and better performance, showing itself as a possible alternative to painted mortars. Reflectance to solar radiation measured was according to ASTM E191816 and ANSI/ASHRAE-74 procedures. The measurements were carried using two Kipp \& Zonen pyranometers sensors, Delft / Holland model CM3, with wavelengths range of 305 $2800 \mathrm{~nm}$ and maximum radiation of $2000 \mathrm{~W} / \mathrm{m}^{2}$. The signal generated varied from $0-50 \mathrm{mV}$ and the sensitivity from $0-35 \mu \mathrm{V} / \mathrm{W} / \mathrm{m}^{2}$. A datalogger ALMEMO, model 2890-9 with a 6.5-digit display and RS232 output, was employed for data acquisition. While, to the lightness reflectance, a procedure based on the ASTM D2244-21 was adopted. The measurements were done using a Color Guide Sphere diffuse $/ 8^{\circ}$ spin spectrophotometer with geometric measurements of $45^{\circ} / 0^{\circ}$ circular, with 400 - $700 \mathrm{~nm}$ measurement area, $20 \mathrm{~nm}$ spectral resolution, and photometric range $0-100 \%, 0.01$ resolution. The illuminant D65 and observer with $10^{\circ}$ and reproducibility $<0.02 \Delta \mathrm{E}^{*}$ were considered. Results indicated that painted specimens maintained their initial reflectance to solar radiation after three years of exposure 
ending with $73 \%$ of their index. The comparison between the painted specimens and specimens treated with $\mathrm{TiO}_{2}$ powder showed a difference between $28.25 \%$ regarding their reflectance to solar radiation. On the other hand, the comparison between the samples treated with $\mathrm{TiO}_{2}$ in powder and specimens treated with $\mathrm{TiO}_{2}$ in suspension form shows a difference of $8.5 \%$ in reflectance index to solar radiation, not indicating a preference since both showed the same effectiveness in mean after three years of exposure. Concerning the lightness, after thirty-seven months of the natural exposition, the white painted specimens had the best results than specimens with $\mathrm{TiO}_{2}$ suspensions and specimens with $\mathrm{TiO}_{2}$ in powder. Beyond, regarding the absorptivity, the white painted specimens could be considered with low absorptivity. In contrast, the specimens treated with $\mathrm{TiO}_{2}$ suspension and those treated with $\mathrm{TiO}_{2}$ powder could be medium absorptivity. About the aesthetic perception, the study concludes that there are no significant differences in the white painted specimens for the final user. In contrast, for the other specimens with $\mathrm{TiO}_{2}$ (powder and suspension), the final user can notice the color difference very well in three years of exposure. Therefore, this research aims to contribute to filling a gap concerning reflectivity studies of different treatments of $\mathrm{TiO}_{2}$ (powder and suspension) on mortar by making a comparative assessment with painted mortars and exposed to the urban environment in the long term, demonstrating not only the effectiveness of the photocatalytic process by measurements of reflectance to solar radiation and luminous reflectance but also the maintenance of those properties in the mortars over time.

Keywords: Photocatalysis. Titanium dioxide: dispersion - effect - treatment - evaluation. Ultraviolet radiation: deterioration - facade coating. Mortar: rheology - degradation processes - artificial fibers. 
$\begin{array}{lll}\text { Figure } 1 & \text { Structure of the thesis } & 15\end{array}$

$\begin{array}{lll}\text { Figure } 2 \text { Difference in particle size of } \mathrm{TiO}_{2} & 18\end{array}$

$\begin{array}{lll}\text { Figure } 3 & \text { Dispersion of } \mathrm{TiO}_{2} \text { particles in the cementitious matrix } & 19\end{array}$

Figure $4 \quad$ The heterogeneous photocatalytic process on the particle surface 20

$\begin{array}{lll}\text { Figure } 5 & \text { Electromagnetic wave spectrum } & 21\end{array}$

$\begin{array}{lll}\text { Figure } 6 & \text { Formation of water drop } & 24\end{array}$

$\begin{array}{lll}\text { Figure } 7 & \text { Photo-induced superhydrophilicity phenomenon } & 24\end{array}$

$\begin{array}{lll}\text { Figure } 8 & \text { Photocatalytic and Self-cleaning process - Part I } & 25\end{array}$

Figure 9 Photocatalytic and Self-cleaning process - Part II 25

Figure $10 \quad$ Photocatalytic and Self-cleaning process - Part III 26

Figure 11 Summary of whole mechanism action of the photocatalysis 26

$\begin{array}{lll}\text { Figure } 12 \text { Experimental program } & 31\end{array}$ 


\section{Chapter 1 Introduction}

$\begin{array}{lll}1.1 & \text { Purpose of the study } & 12\end{array}$

$\begin{array}{lll}1.2 & \text { Ph.D. structure } & 13\end{array}$

$\begin{array}{lll}\text { Chapter } 2 \text { Literature review } & 16\end{array}$

$\begin{array}{lll}2.1 & \mathrm{TiO}_{2} \text { particle size } & 18\end{array}$

2.2 Photocatalytic process 20

2.3 Self-cleaning effect 22

$\begin{array}{lll}2.4 & \text { Solar radiation and luminous reflectance } & 27\end{array}$

Chapter 3 Methodology and relationship between articles 30

Chapter 4 Summary of results $\quad 35$

$\begin{array}{lll}\text { Chapter } 5 \text { Conclusions } & 39\end{array}$

Chapter 6 Prospective research topics 43

References $\quad 44$

$\begin{array}{lr}\text { Appendices } & 50\end{array}$

Appendix A Photocatalytic performance of white cement mortars exposed in urban atmosphere (Article A)

Appendix B Influence of polypropylene microfibre (PPMF) dispersion procedure on fresh and hardened rendering mortar (Article B) 70

Appendix C Influence of the nano $\mathrm{TiO}_{2}$ dispersion procedure on fresh and hardened rendering mortar properties (Article C)

Appendix D Evaluation of rheological properties of mortar with $\mathrm{TiO}_{2}$ addition (Article D)

Appendix E Effects of surface roughness and light scattering on the activation on $\mathrm{TIO}_{2}$ on mortar photocatalytic process (Article E)

Appendix F Comparison of reflectance to solar radiation between mortars treated with $\mathrm{TiO}_{2}$ and painted mortars after three years of exposure (Article $\mathbf{F}$ )

Appendix $\mathrm{G}$ Maintenance of initial lightness on mortars treated with $\mathrm{TiO}_{2}$ in the long term (Article G)

Appendix H Surface topography of the specimens 235

Appendix I Roughness profile of the specimens 239

Appendix J Scanning electron microscopy (SEM) of the specimens 246

Appendix K Elemental mapping (EDS) of the specimens 253 


\section{CHAPTER 1}

\section{INTRODUCTION}

In the 1970s, after the oil crisis and influenced by global warming awareness, research on the possibility of using sunlight as an energy source was intensified. During this decade, Fujishima and Honda demonstrated the market potential of heterogeneous photocatalysis, while Frank and Bard examined $\mathrm{TiO}_{2}$ using cyanide decomposed in water, leading to increased interest in the use of $\mathrm{TiO}_{2}$ in environmental applications [1,2].

The photocatalysis of cement-based materials was tested for the first time based on the intuition of Luigi Cassar ${ }^{1}$ in 1995. The decomposition of colored/colorless organic compounds was quantified in the same year utilizing photocatalytic cement-based materials. In 1996, the NOx decomposition was also verified [3].

The first official publication on these products was presented in 1997 by Cassar et al. [4] in an Italian congress on innovative materials. Since that period, the development of photocatalytic cement has been carried out with increasing innovative solutions, from the self-cleaning performance to the depolluting effect [3]. However, only after the strict environmental standards imposed by authorities in some European countries have research groups stimulated the development of new strategies to reduce aqueous and gaseous pollutants $[5,6]$.

The photocatalytic processes in buildings using $\mathrm{TiO}_{2}$ as new technology progressed rapidly with the development of construction materials, such as ceramic tiles, paving blocks, glass, paints, concrete pavements, and coatings for air/water purification and antibacterial roles. Nevertheless, the higher impact for material dissemination was undoubtedly due to the PICADA $^{2}$ project $(2002-2005)$ created by the European Union, whose objective was to investigate the potential of using building materials with photocatalytic properties for the environment de-pollution urban centers. The first and meaningful application was in the "Dives in Misericordia" church in Rome (2003), using photocatalytic cement-based materials [7-9].

The photocatalytic process is the most widely studied and applied in different sectors such as chemical, architecture, air/water treatment, hygiene sanitation, environmental protection, and the automotive industry [10-16]. Among the photo-semiconductors (e.g., $\mathrm{ZnO}, \mathrm{WO}_{3}, \mathrm{MoO}_{3}$,

\footnotetext{
${ }^{1}$ Past director of R\&D department - Italcementi Group

${ }^{2}$ Photocatalytic Innovative Covering Application for De-pollution Assessment
} 
$\mathrm{ZrO}_{2}, \mathrm{SnO}_{2}$, and $\alpha-\mathrm{Fe}_{2} \mathrm{O}_{3}$ ), $\mathrm{TiO}_{2}$ is one of the most promising oxides for commercial solar applications, mainly due to its photochemical stability and high oxidation power, high resistance to photo corrosion in aqueous environments, safety and cost than other photocatalytic materials $[7,17,18]$. These characteristics have attracted much attention as photo-functional material for self-cleaning, antifogging, self-sterilizing, and antibacterial agents, besides the high industrial interests due to the advantages of using these particles in building materials $[2,7,19]$.

Research continues for further improvements on photocatalytic technology. The extension of its potential uses and some gains in the performance of photocatalytic applications have been related to advances in nanotechnology. The manufacture of new photocatalysts using nanotechnologies showed that it is possible to improve faster photocatalytic materials and with higher efficiency, and, in the future, this technology could provide solutions to most major modern dilemmas, such as depletion of fossil fuel stocks, progressive pollution of natural resources and global warming $[1,19,20]$.

Therefore, a large field of research regarding the use of $\mathrm{TiO}_{2}$ in several applications is continually presented, especially in the civil construction sector, such as coating facades, where the discussion about thermal comfort and aesthetics is a matter that concerns not only civil construction professionals but also building users. In this context, objective aspects such as reflectance to solar radiation (building heating) and subjective aspects (aesthetic satisfaction) are highly relevant investigations. This is because the former responds to the greater or lesser heating of the building's facades. In contrast, the latter, in addition to having great human sensitivity, is often based on group research, and its acceptability is related to cultural aspects.

\subsection{PURPOSE OF THE STUDY}

Most studies concerning the use of $\mathrm{TiO}_{2}$ in cementitious materials are directed to the efficiency in photodegradation of pollutants and the production of specimens on a laboratory scale, aiming to reduce stains caused by dyes. On the other hand, studies on the reflectivity of coating mortars treated with $\mathrm{TiO}_{2}$, carried out essentially under natural conditions of exposure to UV radiation and using large specimens in direct comparison with white paint for long periods, still lack more observation.

Thus, this study evaluated surfaces experimentally treated with $\mathrm{TiO}_{2}$ and compared with white painted surfaces, observing the maintenance of the initial characteristics of reflectance to solar 
radiation and luminous reflectance of these surfaces, aiming at its low maintenance and better thermal performance, showing itself as a possible alternative to painted mortars. For the sake of comparison, two aspects are considered: i) the use of white paint on these coatings to maintain their reflectance to solar radiation and luminous reflectance, and therefore, keeping the surfaces cooler and; ii) the use of $\mathrm{TiO}_{2}$ treated mortars, with the same purpose, but for a more extended period, using for this the self-cleaning property and without using paint, thus mitigating the production costs of the building's facade system.

Therefore, this research aims to contribute to filling a gap concerning reflectivity studies of different treatments of $\mathrm{TiO}_{2}$ (powder and suspension) on mortar by making a comparative assessment with painted mortars and exposed to the urban environment in the long term, demonstrating not only the effectiveness of the photocatalytic process by measurements of reflectance to solar radiation and luminous reflectance but also the maintenance of those properties in the mortars over time.

\subsection{Ph.D. STRUCTURE}

The thesis was structured in the form of gathering articles, where each paper deals with a specific part of the study aiming to treat the variables that could lead to the inefficiency of the photocatalytic process, concerning the addition of two different samples of $\mathrm{TiO}_{2}$ powder with different particle sizes in the cementitious matrix and the application of various $\mathrm{TiO}_{2}$ suspensions (two prepared at the laboratory and two commercial) as a coating.

According to the literature, the addition of $\mathrm{TiO}_{2}$ brings some problems such as the ideal content to trigger the photocatalytic process; its efficiency below that expected; the presence of dirt spots and cracks; the difficulty of dispersion in the cementitious matrix; and the influence on the workability and rheological constitution of mortars. In the same way, the application of $\mathrm{TiO}_{2}$ suspensions, despite not causing the aforementioned problems, presents a challenge in evaluating its durability on the surface in long exposure and the lack of studies about the subject. Thus, a sequence in the investigations concerning these problems was adopted and, as a result, the production of the articles.

The analysis starts with the final results of the author's master's degree, where the content of $\mathrm{TiO}_{2}$ added to the cementitious matrix was discussed concerning the reflectance to solar radiation and luminous reflectance over time. Hereafter, in the continuation of the research, now as a Ph.D. candidate, questions about the fiber's addition and $\mathrm{TiO}_{2}$ dispersion to the new cementitious matrix were raised. Thus, at this moment, the research first discussed the 
addition of polypropylene microfibers to prevent possible cracking of the coating when in a hardened state, and then the study about the $\mathrm{TiO}_{2}$ dispersion procedure to avoid the aggregation of the compound. Afterward, to finish the characterization phase of the coating, there was an investigation regarding the rheology of mixtures, seeking the best conditions for coating applications.

Afterward, the research evaluated the application of the $\mathrm{TiO}_{2}$ suspensions on the surfaces of the specimens. In that stage, it starts the studies on the influence of surface roughness in the UV radiation scattering regarding the activation of $\mathrm{TiO}_{2}$ when considering the treatments used. Finally, to complete the study, the surfaces were evaluated concerning the performance of the treatments of $\mathrm{TiO}_{2}$ regarding the reflectance to solar radiation and the luminous reflectance over time.

Thus, the final structure of this thesis is divided into six chapters that compose the body of the research and seven published articles that integrate the appendices section. The chapters presented are structured according to the following order:

- Chapter 1. Introduction: an overview of the utilization of $\mathrm{TiO}_{2}$ in different fields, identifying the problems and challenges of the technology.

- Chapter 2. Literature review: an approach of the fundamental concepts about the different uses of $\mathrm{TiO}_{2}$ in civil construction, where the knowledge gap is highlighted and shows the research's importance.

- Chapter 3. Summary of methodology: this part summarizes the most relevant information about the methods used in each paper to achieve the final objective. Besides, the chapter intends to work as a guide to the articles' sequence.

- Chapter 4. Summary of results: this section presents the main results obtained in each of the articles included in the appendices section. Moreover, the main contribution of each study is shown, and the relevance of the results is highlighted individually.

- Chapter 5. Conclusions: the results are compiled in a single chapter that summarizes the research contribution regarding using mortars treated with $\mathrm{TiO}_{2}$ as coatings for buildings.

- Chapter: 6. Prospective research topics: considering the results found, some investigations are suggested to continue the knowledge about the behavior of $\mathrm{TiO}_{2}$ and its efficacy when used in cementitious materials. 
The appendices section contains the collection of papers. Each of them deals with a specific part of the study to create a sequence to isolate and evaluate the variables that could lead to the inefficiency of the photocatalytic process.

Thereby, the structure of the thesis can be summarized as shown in Figure 1.

Figure 1 - Structure of the thesis

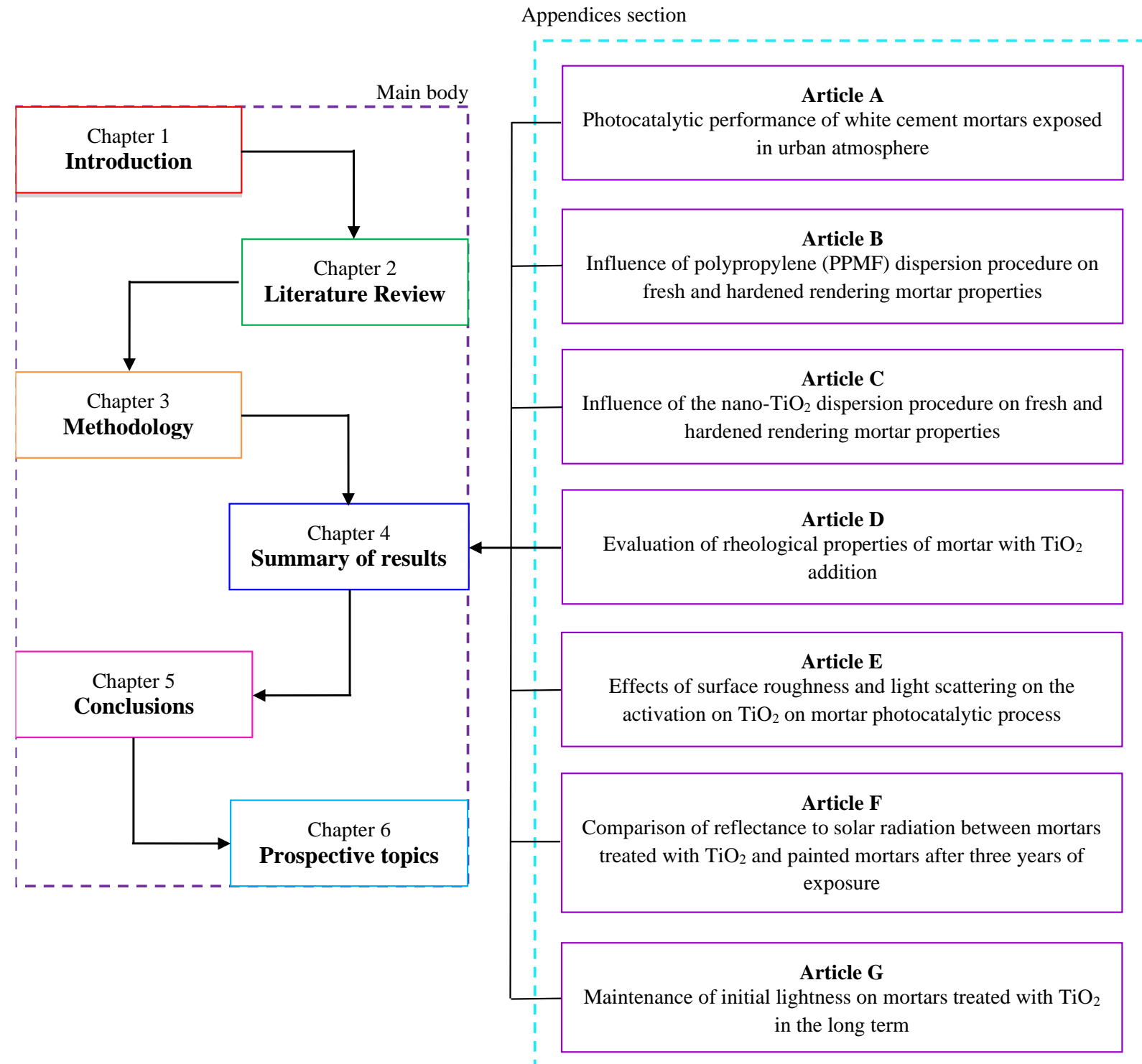

Source: Author (2021) 


\section{CHAPTER 2}

\section{LITERATURE REVIEW}

Undoubtedly, for civil construction professionals and owners, the main objective and desire are that buildings could maintain their characteristics for much longer, particularly when it comes to the color and stability of their facades. However, although the loss of aesthetics in the buildings is an everyday phenomenon, it must be remembered that it will be challenging to maintain or recover such properties without adequate and constant maintenance of these surfaces.

In densely urbanized cities with high levels of urban pollution, damage to the building facades can be observed with the appearance of pathologies generally associated with the deposition of atmospheric pollutants and the proliferation of microorganisms. Soiling and staining of the facade have increased caused by the severity of atmospheric pollution over the last decades, impacting the quality of the buildings' urban environment and life-cycle costs. Furthermore, it is recognized that many of the substances directly emitted by vehicles and industry in the environment or indirectly produced through photochemical reactions represent a severe hazard for human health.

Therefore, the use of construction materials that allow for more outstanding durability, minimizing aesthetic damage, and conservation costs are relevant as they could postpone the maintenance of the facades. To this end, several studies [7, 21-26] have shown that using $\mathrm{TiO}_{2}$ in cementitious materials can be an efficient technique for this objective by the electrochemical process known as heterogeneous photocatalysis.

According to the literature, photocatalysis in cementitious materials provides an efficient strategy against the de-pollution of air, showing a valuable alternative for keeping surfaces clean and ensuring cooling properties, increasing thermal comfort, reducing the cooling energy consumption of buildings, and mitigating urban heat islands [27,28]. Additionally, the nature of the cement matrix is particularly suitable for the addition of $\mathrm{TiO}_{2}$ particles that makes cement an ideal substrate for photocatalysis promoting photo-oxidation [7, 23, 29-31].

The effect of environmental de-pollution by photocatalytic materials has already been demonstrated by nitrogen oxides (NOx) and volatile organic compound (VOC) decomposition. Most studies have chosen these pollutants as representative due to their potential health risks and the generating photochemical air pollution. Moreover, several other compounds were evaluated during the following years aiming at the same purpose [7,9]. 
The fine powder of $\mathrm{TiO}_{2}$ can be used in different ways, such as dispersed in an aqueous solution (slurry), anchored on a suitable support, or even in a fluidized bed, where many materials have been evaluated as substrates to support $\mathrm{TiO}_{2}$ [32]. However, studies conducted by Maranhão [33] concluded that for $\mathrm{TiO}_{2}$, use it is necessary to employ an adhesion promoter, as a post-treatment (first, the application of the water repellent and on it the suspension of $\mathrm{TiO}_{2}$ ), and not adding to the matrix of the material, because, in addition to the increase in cost, $\mathrm{TiO}_{2}$ loses its photocatalytic power as the phenomena of hydration and carbonation occur.

In their studies, Pereira et al. [21] tested specimens with surfaces smoothed to evaluate the influence of roughness on the process's effectiveness. As a result, less self-cleaning was observed for the smoother surfaces. On the other hand, the Casagrande studies [26] showed no correlation between surface roughness and NOx degradation. In addition, according to Melo [22], the roughness or final texture of the surface is a vital factor in optimizing the degradation process of the pollutant.

According to Fujishima, Rao, and Tryk [2], because it is a natural and straightforward process, dependent only on the excitation of electrons and subsequent release of bandgap energy, without any consumption of $\mathrm{TiO}_{2}$, surfaces treated with $\mathrm{TiO}_{2}$ have a remarkably high degree of durability. Thus, facades that have or are coated with a photocatalyst can provide the hydrophilic surface properties leading to a decrease in the degree of soiling of these surfaces, perhaps washed by rainfall, or sprayed with water at times and times, thus promoting a self-cleaning effect.

Furthermore, heterogeneous photocatalysis has not been limited to cementitious materials; other self-cleaning and smart materials markets are growing. Applications in materials such as PVC, enameled ceramic plates, foggy mirrors, self-cleaning glasses, air purifiers, and antibactericidal water are examples of products with photocatalytic properties. In this context, it can be said that there are no external surfaces where the technology cannot be applied and that all of them also have the potential to become photocatalytic, either by adding the semiconductor in the cementitious matrix or by using it as coating film $[6,8,34]$.

Besides, the activation of the photocatalytic process also can be feasible, even in internal coatings. One of the alternatives, when there is no incidence of ultraviolet radiation, is to increase the sensitivity of $\mathrm{TiO}_{2}$ to visible light to obtain an efficient substance, even when it is applied in an indoor environment. In this case, the $\mathrm{TiO}_{2}$ must be modified by introducing 
other chemical elements that lead the absorption in a more extensive wavelength range. As a result, photocatalysis can be used in many fields of civil construction and environments where the $\mathrm{TiO}_{2}$ photocatalytic surface coatings could be applied, improving surface durability and wear resistance $[34,35]$.

\section{1 $\mathrm{TiO}_{2}$ PARTICLE SIZE}

The use of $\mathrm{TiO}_{2}$ nanoparticles (TiNPs) is common in photocatalytic processes, and many authors have addressed its addition in the anatase phase to cement coatings aiming to obtain self-cleaning surfaces by the photocatalytic activity under the action of solar radiation [3640]. In contrast, the few investigations with $\mathrm{TiO}_{2}$ microparticles (TiMPs) reinforce the idea of the low efficacy of larger particles for the same purpose $[29,41]$.

In general, the reduction of particle size causes a decrease in electron-hole recombination, producing a higher surface area, which can improve the efficiency of the photocatalyst in the reaction. The relationship between surface area and photocatalysis has an essential role in the choice of the semiconductor since an increase or decrease in a surface area influences the photocatalyst activity.

In this context, the most crucial point is when the particles go from TiNPs to the TiMPs, making the photodegradation slow. This is because high-performance particles can be obtained to increase $\mathrm{TiO} 2$ activity with the reduction of particle size. As a result, the action of the photocatalyst tends to decrease the smaller the size of these particles [11]. On the other hand, studies have been demonstrated that TiMPs, even with a lower surface area, have more effectiveness in photon absorption and electron-hole generation leading to better photocatalytic performance [41]. The difference in $\mathrm{TiO}_{2}$ particle size is shown in Figure 2.

Figure 2 - Difference in particle size of $\mathrm{TiO}_{2}$

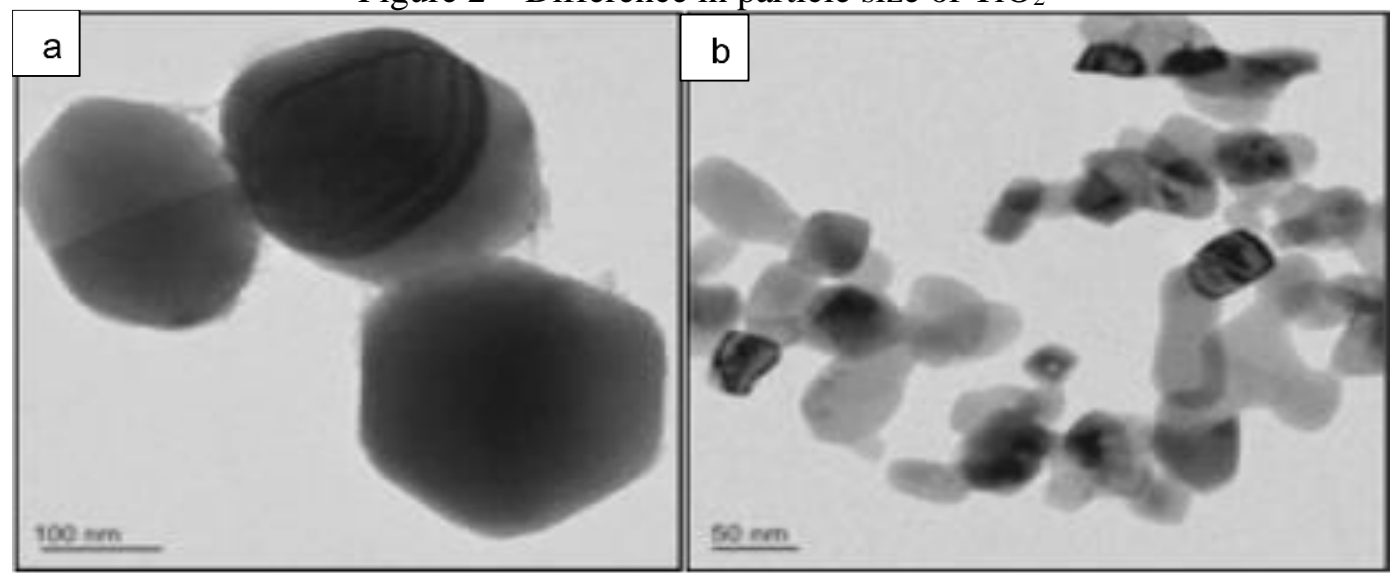

Note: Standard $\mathrm{TiO}_{2}(\mathrm{a}) ; \mathrm{Nano}_{\mathrm{TiO}}(\mathrm{b})$.

Source: Allen et al. [31] 
The control of the shape and size of TiNPs is significant since their photocatalytic activity depends not only on their scales but also on their shape. Both characteristics significantly affect optical, electronic, and catalytic properties because of differences in the surface area, the number of active sites, and the quantum size effect [38]. Moreover, among the factors that may influence the photocatalytic processes, three are considered of greater relevance: the number of active sites on the surface of the coating; the size and morphology of $\mathrm{TiO}_{2}$ particles; and its crystalline structure $[42,43]$.

According to the literature, the TiNPs are considered efficient for obtaining external surfaces with self-cleaning properties, and photocatalysis in conjunction with water repellency is the most studied process $[33,44]$. On the other hand, when TiNPs are added to cement-based materials, there is a high impact on the fresh and hardened properties of the material and a strong tendency to form agglomerates due to their ultra-fine size $[45,46]$.

Finally, the mixing of $\mathrm{TiO}_{2}$ in cement causes higher density and changes the morphology and chemical compositions of the cement hydration products. [37]. In the same way, the addition of $\mathrm{TiO}_{2}$ in powder in the cement paste presents homogeneity problems because the product is introduced in the dry state (Figure 3). On the other hand, some studies demonstrated that the efficiency process could be increased if the $\mathrm{TiO}_{2}$ is applied as a suspension $[47,48]$.

Figure 3 -Dispersion of $\mathrm{TiO}_{2}$ particles in the cementitious matrix

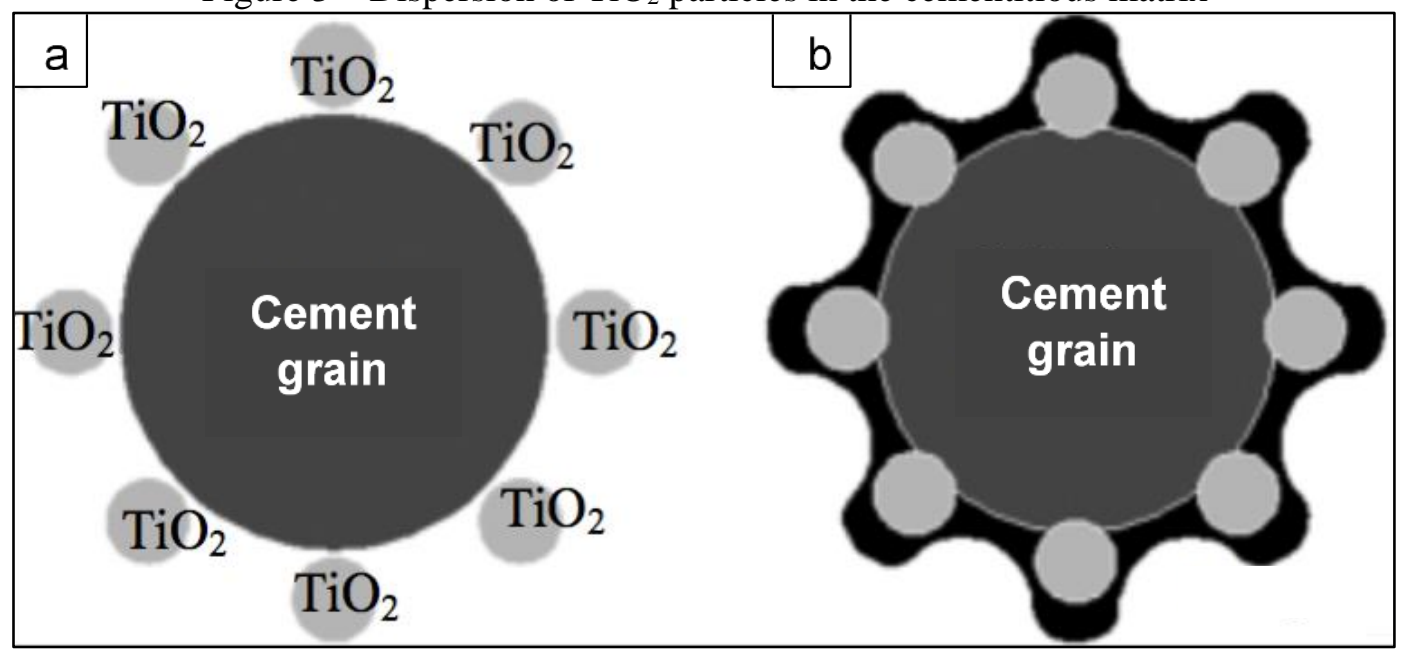

Note: Dry dispersion (a); Hydrate dispersion (b).

Source: Adapted by Casagrande; Chen, Kou, and Poon [26, 49].

Therefore, to fully understand the behavior and, consequently, the effectiveness of $\mathrm{TiO}_{2}$ on the photocatalytic process, added to the cementitious matrix or applied to the surfaces, the interaction of $\mathrm{TiO}_{2}$ particles at the nano and micrometric scales, as well as its dispersion 
process on these surfaces, need to be investigated. This was explored in Articles $\mathbf{C}$ and $\mathbf{E}$ in this thesis.

\subsection{PHOTOCATALYTIC PROCESS}

A heterogeneous photocatalyst is a semiconducting substance that can be chemically activated by radiation. The heterogeneous photocatalysis process uses a UV light band (natural or artificial) with a wavelength less than $400 \mathrm{~nm}$ to photo-excite a semiconductor catalyst, whose contact with water and the presence of oxygen activates and accelerates the speed of a chemical reaction.

A semiconductor is characterized by Valence Band (VB); Conduction Band (CB), and the region between them is called a bandgap. If a photosemiconductor is irradiated by light with energy matching or greater than its band gap energy (Eg), an electron $\left(\mathrm{e}^{-}\right)$in an electronfilled valence band (VB) is excited to a vacant conduction band (CB), leaving a positive hole $(\mathrm{h}+)$ in the VB. Valence band holes (hVB+) are powerful oxidants, whereas conduction band electrons $\left(\mathrm{eCB}^{-}\right)$are reductants. These photogenerated electrons and positive holes drive reduction and oxidation, respectively, of different compounds, not necessarily adsorbed on the surface of the photocatalyst, as shown in Figure 4 and equations from 1 to 7.

Figure 4 - The heterogeneous photocatalytic process on the particle surface

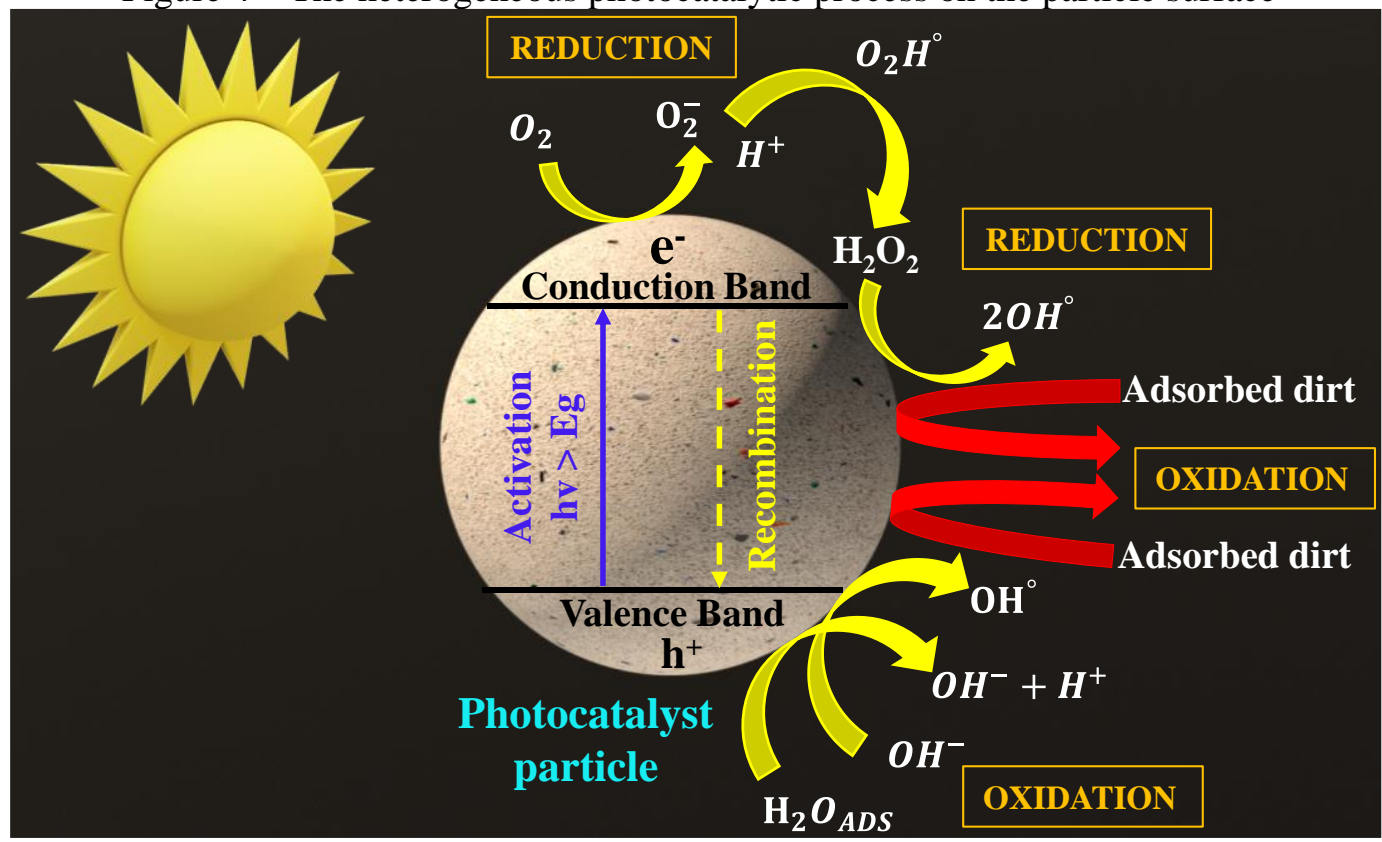

Source: Adapted from Spasiano et al. [1]

$\mathrm{TiO}_{2} \stackrel{h v}{\rightarrow} \mathrm{TiO}_{2}\left(e_{B C}^{-}+h_{B V}^{+}\right)$

Eq. 1

$e_{B C}^{-}+O_{2} \rightarrow O_{2}^{-}$

Eq. 2 
$\mathrm{O}_{2}^{-}+\mathrm{H}^{+} \rightarrow \mathrm{O}_{2} \mathrm{H}^{\circ}$

$\mathrm{H}^{+}+\mathrm{O}_{2}^{-}+\mathrm{O}_{2} \mathrm{H}^{\circ} \rightarrow \mathrm{H}_{2} \mathrm{O}_{2}+\mathrm{O}_{2}$

Eq. 4

$\mathrm{H}_{2} \mathrm{O}_{2} \stackrel{h v}{\rightarrow} 2 \mathrm{OH}^{\circ}$

Eq. 5

$h_{B V}^{+}+H_{2} O_{A D S} \rightarrow \mathrm{OH}^{-}+H^{+}$

Eq. 6

$h_{B V}^{+}+O H^{-} \rightarrow O H^{\circ}$

Eq. 7

$\mathrm{TiO}_{2}$ is a semiconductor that absorbs radiation in the UV range of $315-380 \mathrm{~nm}$. The anatase crystalline phase has a range of $3.2 \mathrm{eV}$, corresponding to a wavelength of approximately 380 $\mathrm{nm}$. In contrast, the rutile crystalline phase has a range of $3.0 \mathrm{eV}$, which corresponds to a wavelength of $413 \mathrm{~nm}$ [50]. The $\mathrm{TiO}_{2}$ with more extensive commercial application absorbs, in the ultraviolet range, around 3\% - 5\% of the solar energy that reaches the terrestrial surface. Thus, the $\mathrm{TiO}_{2}$ does not take advantage of all the solar radiation incidents in the photocatalytic processes, although much effort has been dedicated to developing photocatalysts that can increase the absorption to the visible spectrum [51,52]. Figure 5 shows the electromagnetic wave spectrum to each wavelength according to ISO-9288 [53].

Figure 5 - Electromagnetic wave spectrum

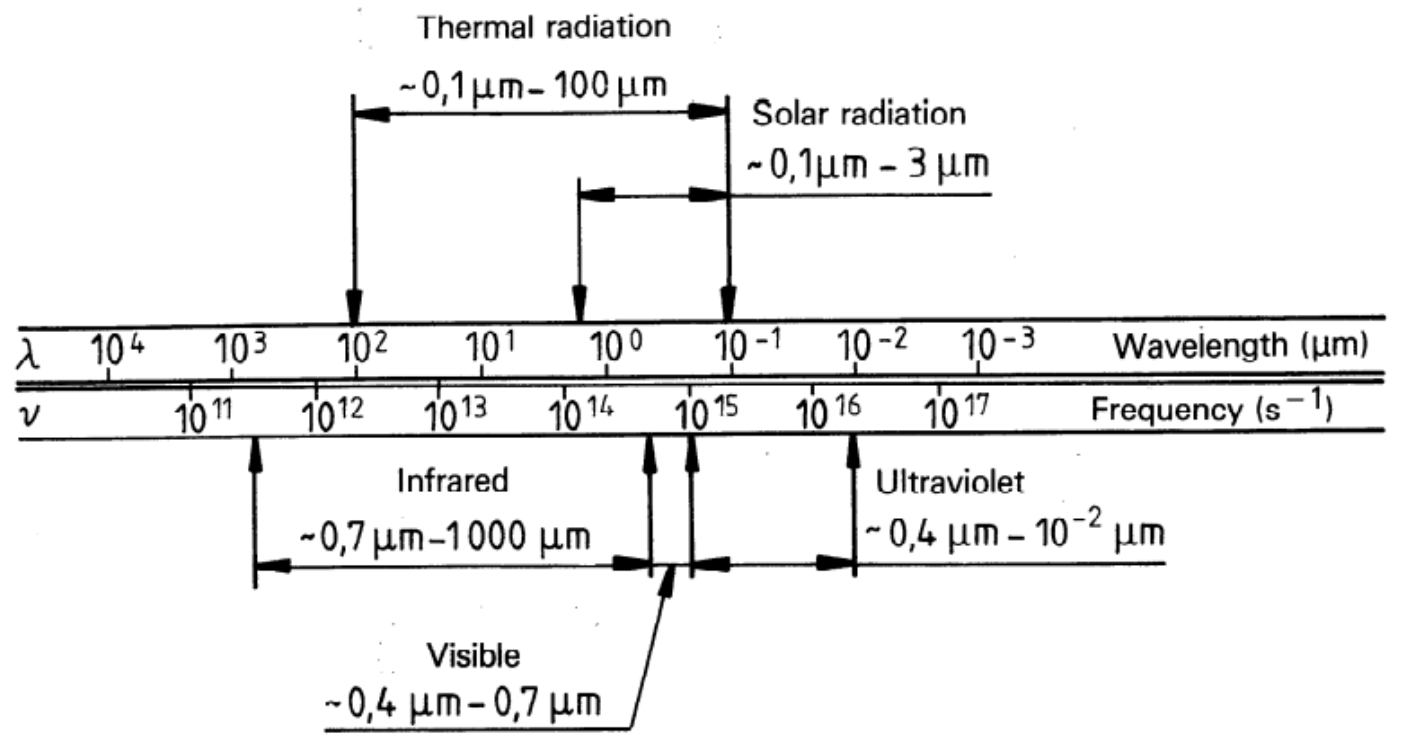

Source: ISO-9288 [53]

According to Dantas et al. [54], at noon in the city of São Paulo (Brazil), the total solar radiation energy is $\approx 1.8 \times 10^{25} \mathbf{e V}$. Considering that only $5 \%$ of this amount would be required for $\mathrm{TiO}_{2}$ activation, the quantity of energy will be $\approx \mathbf{9 . 0} \times \mathbf{1 0}^{\mathbf{2 3}} \mathbf{e V}$. On the other hand, if it were considered the lowest rate $(3 \%)$ required for $\mathrm{TiO}_{2}$ activation, the energy absorbed would be $\approx 2.7 \times \mathbf{1 0}^{22} \mathbf{e V}$. Therefore, considering these values and that the activation energy 
of $\mathrm{TiO}_{2}$ is in the order of a few eV $(3.0 \mathrm{eV}$ and $3.2 \mathrm{eV})$, it can be observed that the solar radiation energy in the early hours of the day will be enough to promote the activation of $\mathrm{TiO}_{2}$.

The photocatalytic activity is strongly dependent on the competition between the surface transfer of charge carriers and electron-hole recombination. Suppose a suitable scavenger or surface defect is available to trap the photogenerated electrons or holes. In that case, recombination is limited, and further photocatalytic reactions may occur that yield mineralization products during prolonged reaction periods [1]. Thereby, the efficiency of photocatalysis depends on the competition between the withdrawn of the electron from the surface of the semiconductor and the electron/gap pair recombination process, which results in heat release. This happens because the semiconductors have an incomplete valence layer and a conducting layer separated by a bandgap (hv) compatible with the energy supplied by the solar radiation in the UV band $[33,50,55]$.

\subsection{SELF-CLEANING EFFECT}

It has recently been understood how hydrophobic and hydrophilic surfaces work. This effect has existed for millions of years and is now recognized as the 'lotus effect.' When observed under a microscope, a lotus leaf exhibits some bumps of micrometer size. The bumps are composed of nanometer-sized structures. This can help a water drop stay on the lotus leaf without spreading on it. The waxy substance on the lotus leaf also helps the water drop to form the droplet and not spread on the surface. When the water drop rolls on the leaf, it collects the dirt on the surface and makes the surface clean.

Another interesting natural phenomenon is known as the 'petal effect.' It can be easily seen in common flowers (e.g., rose). If water is sprinkled on flowers, minuscule droplets can be observed. These droplets cling to the petals so strongly that even if the flower is turned upside down, the droplets do not fall under gravity. This effect is due to micropapillae of $\sim 16 \mu \mathrm{m}$ diameter and $\sim 7 \mu \mathrm{m}$ height with micropapillae folds $\sim 730 \mathrm{~nm}$ size.

Scientists have tried to use this phenomenon to artificially obtain hydrophilic/hydrophobic surfaces in various materials of various shapes and sizes. One can even make coatings that would not only make a surface just hydrophobic or hydrophilic but can also change nature in a controlled way using external stimuli, such as an electric field or irradiation applications with UV light or X-rays [56]. 
In the civil construction sector, the use of Advanced Oxidation Processes (AOP) has increased, and the self-cleaning effect by the photocatalytic process is undoubtedly the main objective to be achieved by specifiers when thinking about the photocatalysis applied to cementitious materials, especially in building facades.

It is known that both professionals and users intend to maintain the aesthetic aspect of the facades as much as possible with the least maintenance by the self-cleaning effect. However, it is essential to know that photocatalysis is a photochemical process and will exist by itself, regardless of self-cleaning. On the other hand, self-cleaning is a product of photocatalysis caused by the interaction of water/surface, either by rain or mechanical washing. Although they work together, they must be seen as independent processes.

For self-cleaning to occur, a set of factors that enable the triggering of this effect on the surface treated with $\mathrm{TiO}_{2}$ is necessary. Among these factors are $\mathrm{TiO}_{2}$ activation by solar radiation and consequent photo-oxidation of compounds. However, we must remember that $\mathrm{TiO}_{2}$ alone does not complete the process but only triggers photocatalysis and leaves the role of cleaning of the surface to the water. In other words, without the presence of water (rain or mechanical washing), the process started with photocatalysis will not be completed, and, consequently, there will not be the desired self-cleaning.

The wettability phenomenon is understood in terms of hydrophobicity/hydrophobicity and the contact angle a water drop makes with the surface. Depending on the contact angle of the water drop, one can quantify the amount of hydrophilicity or hydrophobicity. The contact angle depends upon the surface roughness, surface condition, and surface material, where the interaction between liquid and solid surface is essential.

When the contact angle is less than $90^{\circ}$, the surface is known as hydrophilic, and if more than $90^{\circ}$, it is known as hydrophobic. If the angle is above $\approx 150^{\circ}$, it is superhydrophobic, and if less than $\approx 20^{\circ}$, it is superhydrophilic. The angles which distinguish between superhydrophilic and hydrophilic or hydrophobic and superhydrophobic are not very precise and could vary within $5^{\circ}-10^{\circ}[56]$, as illustrated in Figure 6. 
Figure 6 - Formation of water drop

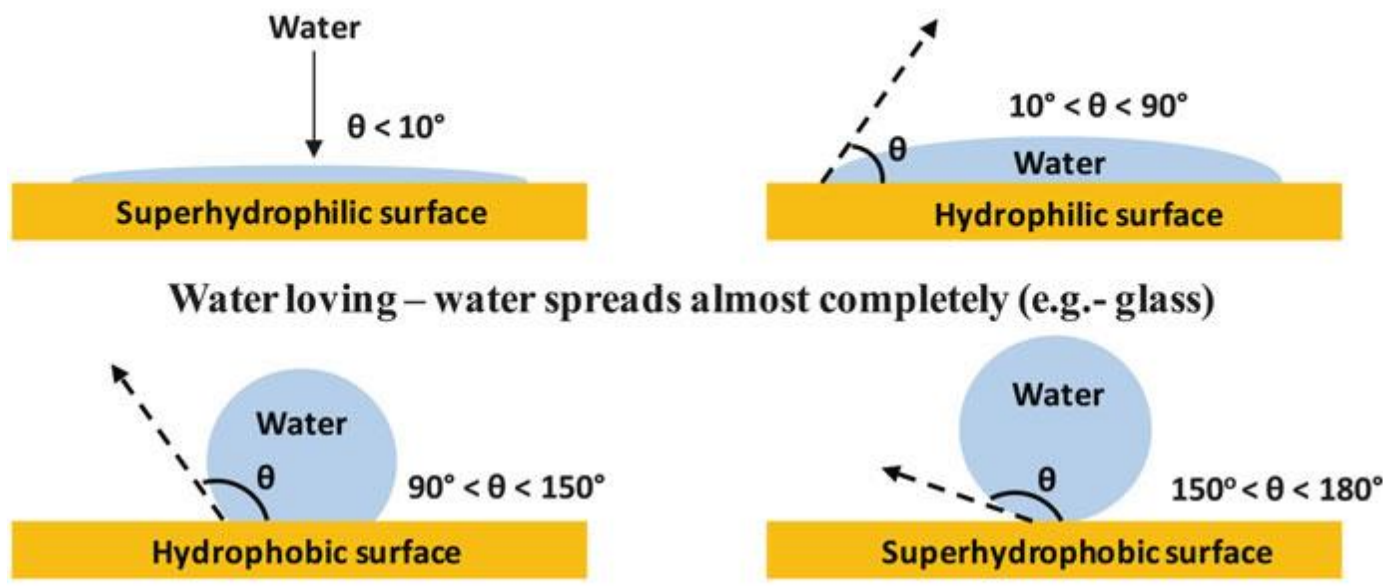

\section{Water hating - a water bead is formed (e.g.- teflon pan, lotus leaf)}
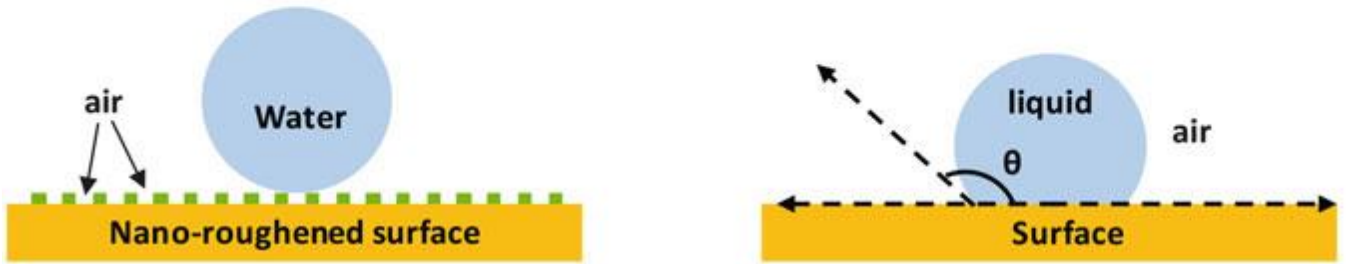

Source: Kulkarni [56]

From the concepts mentioned above and its application on surfaces treated with $\mathrm{TiO}_{2}$, it can be observed that after the $\mathrm{TiO}_{2}$ is excited by UV radiation, the positive holes diffuse to the surface, react with water molecules adsorbed on it, produce hydroxyl radicals, and increases the number of hydroxyl groups on the $\mathrm{TiO}_{2}$ surface during irradiation [57]. Simultaneously, the contact angle between $\mathrm{TiO}_{2}$ surfaces and water molecules gradually approaches near zero. This phenomenon is called photo-induced superhydrophilicity. Therefore, if the water is added to the irradiated $\mathrm{TiO}_{2}$ surface, it does not form spherical droplets as shown in Fig. 7a but forms a highly uniform thin film, as shown in Figure $7 \mathrm{~b}$.

Figure 7 - Photo-induced superhydrophilicity phenomenon

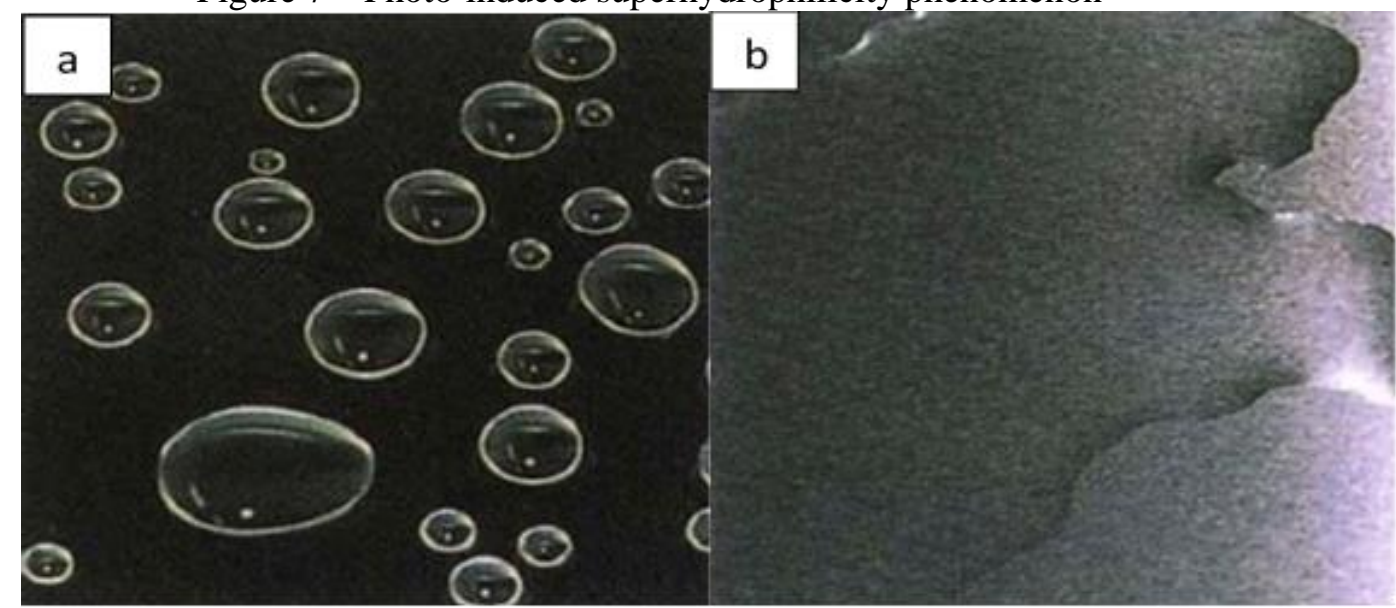

Note: Hydrophobic surface without $\mathrm{TiO}_{2}$ (a); Superhydrophilic surface with $\mathrm{TiO}_{2}$ film formation (b). Source: Maranhão [33] 
Overall, from the concepts showed before, the self-cleaning process on the cementitious surface could be summarized and presented in the sequence described in Figures 8, 9, and 10.

Figure 8 - Photocatalytic and Self-cleaning process - Part I
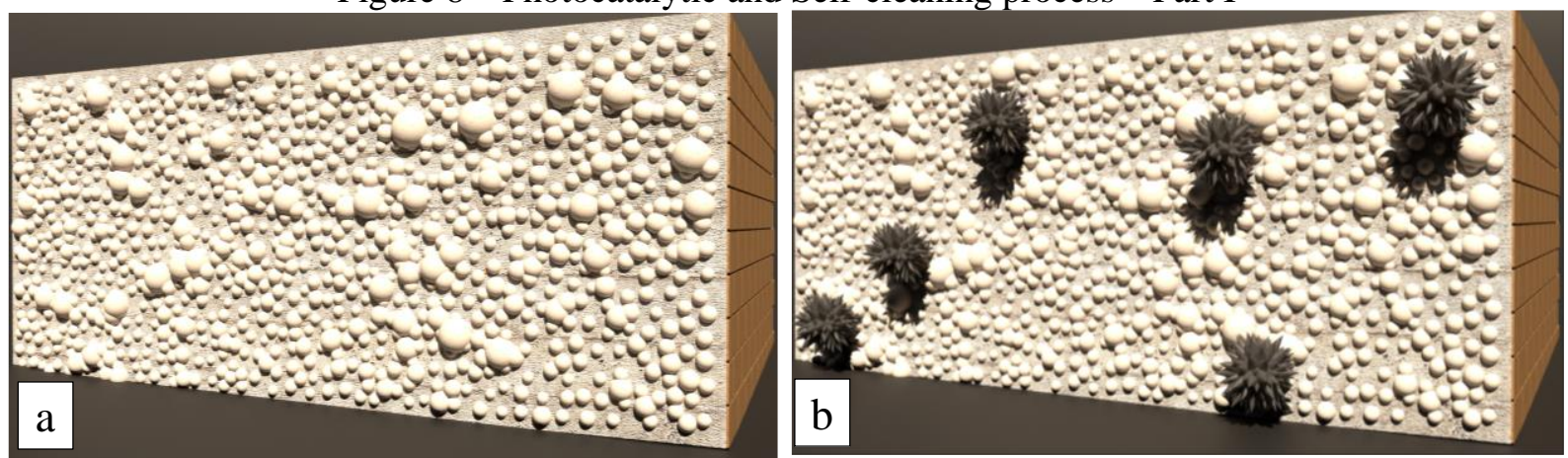

Note: Ideal dispersion of $\mathrm{TiO}_{2}$ on the surface - cake cover (a); Dispersion of dirt particles on the surface (b)

Source: Author (2021

Figure 9 - Photocatalytic and Self-cleaning process - Part II

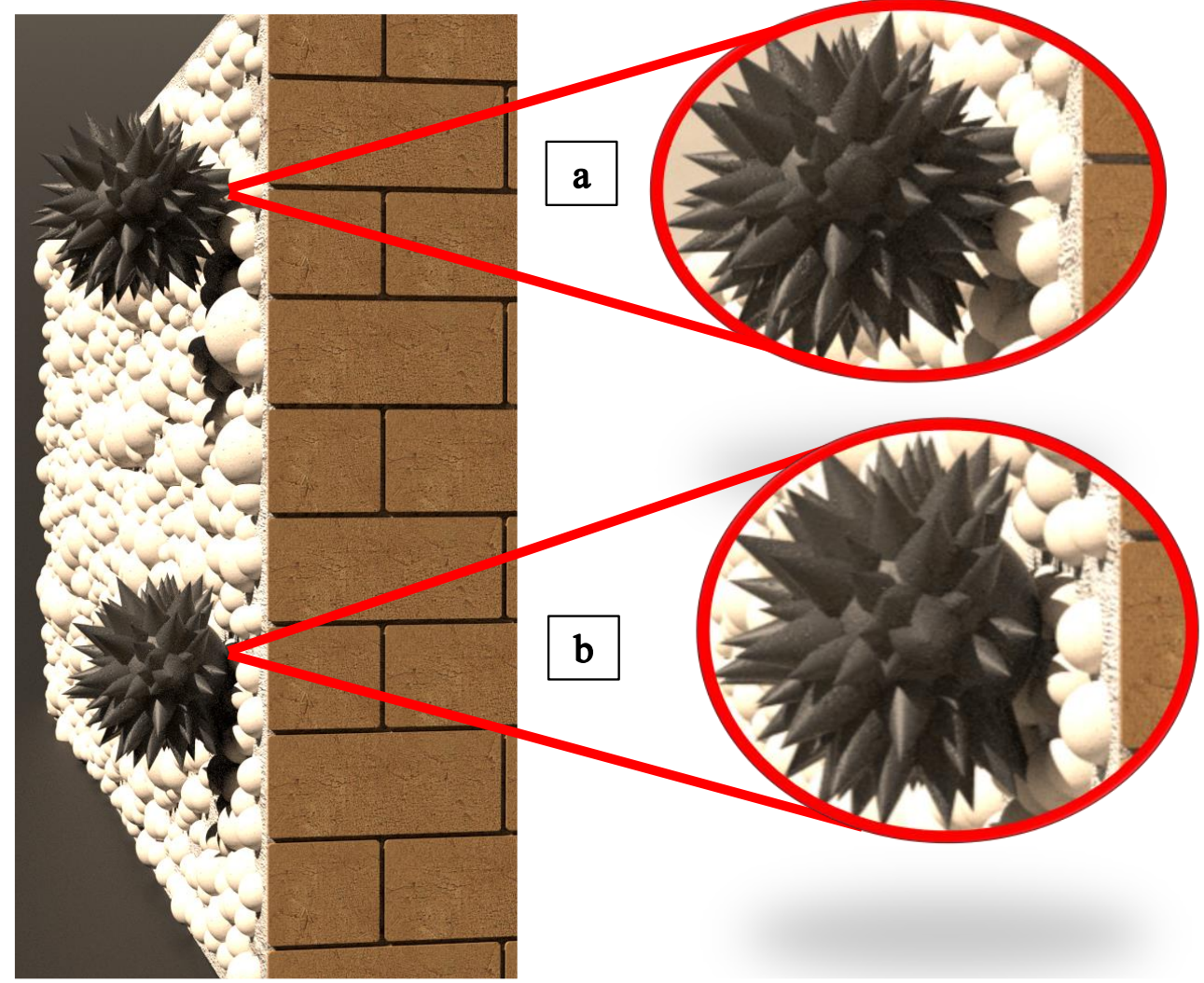

Note: Dirt particle adhesion (a); Oxidation of adhered dirt particle - breaks of contact angles (b) Source: Author (2021) 
Figure 10 - Photocatalytic and Self-cleaning process - Part III

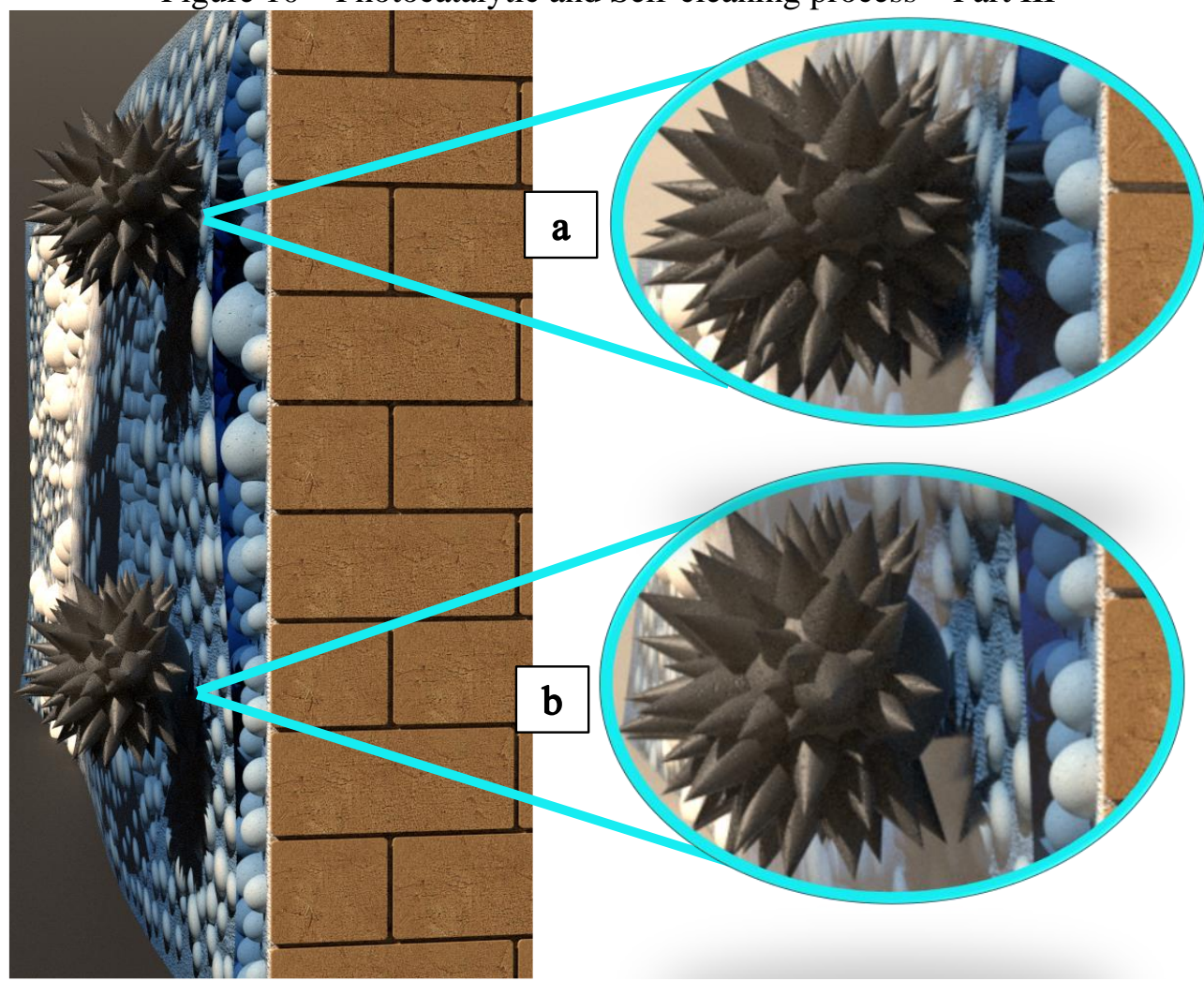

Note: Particle without contact angle breaks - stained surface (a); Particle carried away by rain - selfcleaning process $(b)$

Source: Author (2021)

Thus, as along the same line, the whole mechanism action of the photocatalysis can be summarized in Figure 11.

Figure 11 - Summary of whole mechanism action of the photocatalysis

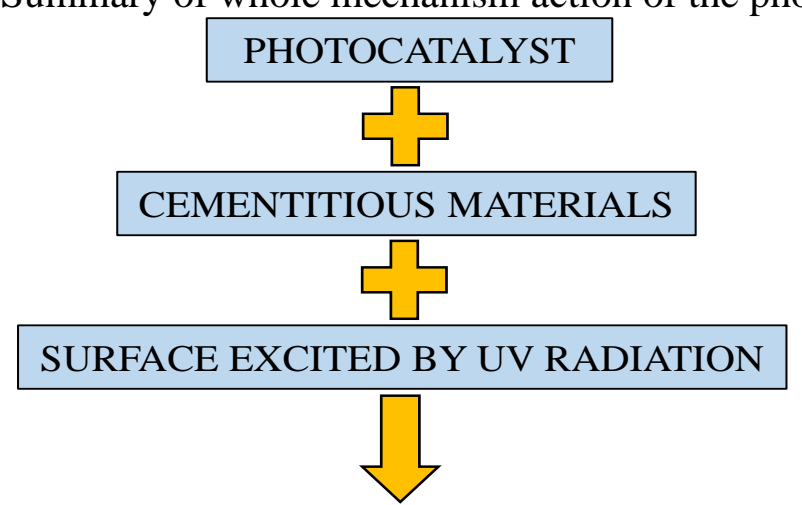

\section{OXIDIZING AND HYDROPHILIC SURFACES}

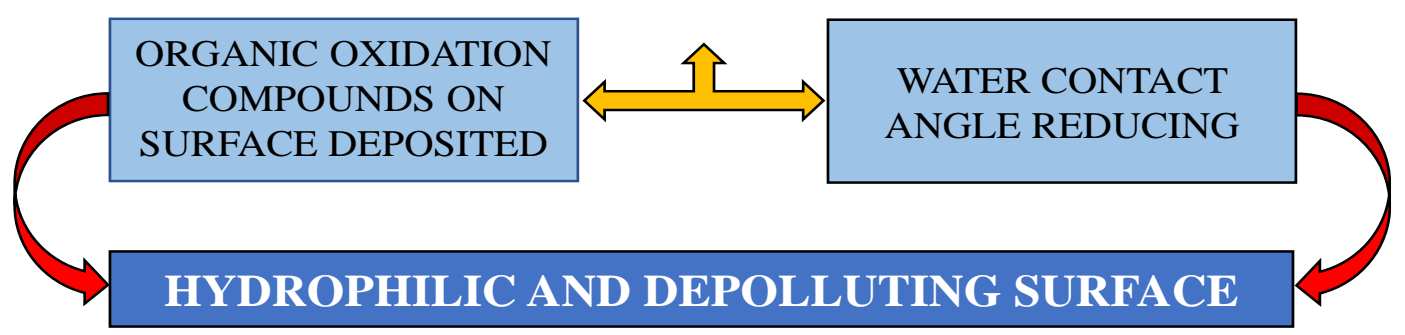

Source: Author (2021) 


\subsection{SOLAR RADIATION AND LUMINOUS REFLECTANCE}

The materials used in facades play an essential role in the thermal balance of a city, where the increasing solar reflectance and longwave thermal emittance on the facades can be a feasible strategy against not only the building's warming but also helping to reduce urban heat islands. The use of coatings with high reflectivity results in an efficient passive technique improving indoor and outdoor thermal comfort and lessening the demand for electricity as to the thermal conditioning of environments [28, 58-62].

On average, urban overheating causes an additional peak electricity demand close to 21 $( \pm 10.4) \mathrm{W}$ per degree of temperature increase and person, and a supplemental cooling energy penalty close to $0.7 \mathrm{kWh}$ per square meter of city and degree of temperature increase. Thus, the categorization of external coating materials according to their solar reflectivity index allows for a more appropriate selection regarding their gain in reducing surface temperatures and reducing the energy consumption of buildings $[58,63,64]$.

The reflectance of a building's coating usually is characterized by the percentage of total solar reflectance, where low values are associated with darker colors, while light colors typically have a high index [65]. An optimum solar reflectance should define according to a building's use, insulation, and weather conditions [66]. Therefore, the total solar reflectance optimization can be valuable to match the best external coating characteristics with the building environment. Also, in particular, by decreasing the reflectivity of surrounding surfaces and ground, the energy output of the facades of the building can drop down to $-37 \%$ in the worst case [67].

According to Aoyama et al. [68], solar reflectance decreased by 5\% to $10 \%$ between three and six months with self-cleaning paint and $20 \%$ to $23 \%$ with conventional paint. The decrease of solar reflectance was likely due to dirt accumulation, and self-cleaning paint retained its cleanliness better than traditional paint after outdoor exposure. After one year, solar reflectance decreased by $8 \%$ with self-cleaning paint and $17 \%$ with conventional paint.

The use of retroreflective (RR) materials have demonstrated as higher cooling potential than traditional coatings, and new coatings as the thermochromic coatings, can respond thermally to the environment and change reversibly their color presenting high advantages, show itself as another option in the war against the heat gains by the buildings $[58,69,70]$.

Materials that have low absorptance and high emissivities are known as reflective or "cool" materials. There are several types with that classification available for use in buildings 
surfaces, but most of them are white or light colors. White coatings have been promoted for the benefit of reducing the cooling load because of their high solar reflectance, as well as for the ability to protect the surface from ultraviolet degradation [71,72]. In addition, cool white coatings and white membranes can reach an average of $45^{\circ} \mathrm{C}$, depending on local ambient conditions [58]. On the other hand, dark colors applied to exterior surfaces can increase solar heat gains absorbing more radiation, impacting the buildings' energy performance and the outdoor air temperatures [70,73]. However, the need for colored products is growing because the aesthetic of dark colors is preferred in many cases.

Dark colors applied to exterior surfaces can increase solar heat gains by absorbing more radiation. In this case, the effect of UV radiation is more significant, and for this reason, darker colors are more affected by UV radiation because of the degradation [71,74]. Besides, it must also be pointed out that buildings displaying an exterior coating with a total solar reflectance value lower than $25 \%$ become very dark and can, thus, be considered by the public opinion, not aesthetic [75].

Considering that the human eye is much more sensitive to lightness than chromaticness, if the energy emitted by the source is low, the color will appear as a more or less dark shade. If the energy is high, the color will be perceived as vivid and brilliant. So, adding to the emitted color a white light (e.g., sunlight), whose spectral energy density is more or less uniform at all wavelengths, the color will become all the paler and more whitish the higher this spectral density concerning pure color energy [76].

Thus, the need to develop coatings capable of maintaining their reflective characteristics over time can be observed, increasing the potential for reflection of solar radiation to these surfaces and reducing heat gains in buildings [71]. In this context, using materials with photocatalytic properties can be an alternative since the soiling accumulation and UV radiation effect on the surface reduces the coatings' solar reflectance after exposure to natural weathering. The photocatalytic material uses UV radiation to activate the process, promoting the self-cleaning effect and allowing for more outstanding durability of these surfaces.

Therefore, as what happens in the painted surfaces, the study of aspects concerning the reflectance to solar radiation and luminous reflectance in the surfaces treated with $\mathrm{TiO}_{2}$ can be observed as it can provide answers as to the behavior of the material under natural exposure conditions and better-exploring characteristics, such as durability and efficiency over the years. 
Moreover, those two aspects, as well as in painted surfaces, have the utmost importance in the process of producing and evaluating building facades because one responds to the thermal comfort of the building and adjacent (reflectance to solar radiation). The other, besides elucidating the thermal behavior of the building, according to the use of colors, responds to the aesthetic aspect (luminous reflectance) as well. 


\section{CHAPTER 3}

\section{METHODOLOGY AND RELATIONSHIP BETWEEN ARTICLES}

The photocatalytic process is influenced by several factors such as the mortar characteristics, roughness surface, mixing and application procedure, $\mathrm{TiO}_{2}$ characteristics, amount of photoactive particles on the surface, size and morphology of $\mathrm{TiO}_{2}$ particles, and its crystalline structure.

This research was based on results observed in previous studies that guided some resolutions, such as the mixture evaluation methods, fiber addition, and $\mathrm{TiO}_{2}$ content that would be used to produce new mixtures. Thus, a new experimental program was developed to investigate how some factors, as cited before, could influence the photocatalytic effectiveness on mortars exposed in the long term and consequently in the reflectance results.

Therefore, the first step of this analysis starts with the results obtained by the author in the master's ${ }^{3}$ degree. In that research, tests were carried out to evaluate the reflectance to solar radiation and color perception on white mortars with the same type and different content of $\mathrm{TiO}_{2}$ and exposed to the urban environment over time. The specimens were produced with $\mathrm{TiO}_{2}$ addition of $1 \%, 5 \%, 10 \%$ concerning the total dry powder mass compared to specimens without $\mathrm{TiO}_{2}$ (painted and unpainted), both used as a reference.

The reflectance to solar radiation was measured in the surface of specimens for thirty-six months with monthly measurements and once more after mechanical washing in forty-one months of exposure to observe the restoration of the initial condition concerning reflectance to solar radiation. Concerning the color, it was measured at the beginning of exposure and fortyone months after to observe the changes when compared to the initial color condition. Unexposed specimens were also tested as references of primary color, and the results were published in Article A.

However, after specimen exposition, some problems were observed regarding the mortar, causing damage to the surfaces, such as little workability, higher porosity, and many cracks due to the refraction and dispersion of $\mathrm{TiO}_{2}$, which indicated the necessity of new studies on mixtures for the continuation of the research. Consequently, a new experimental program was

\footnotetext{
${ }^{3}$ DANTAS, S. R. A. A eficácia da adição do $\mathbf{T i O}_{2}$ em argamassas quanto à manutenção das condições iniciais em termos da sua refletância à radiação solar. São Paulo, 2016. 137 f. Dissertação (Mestrado Profissional) - Instituto de Pesquisas Tecnológicas do Estado de São Paulo, São Paulo, 2016.
} 
designed. The $\mathrm{TiO}_{2}$ concentration was stipulated at $5 \%$ concerning the cement mass, and more parameters were included to improve the latest mixtures of mortars, as shown in Figure 12.

Figure 12 - Experimental program

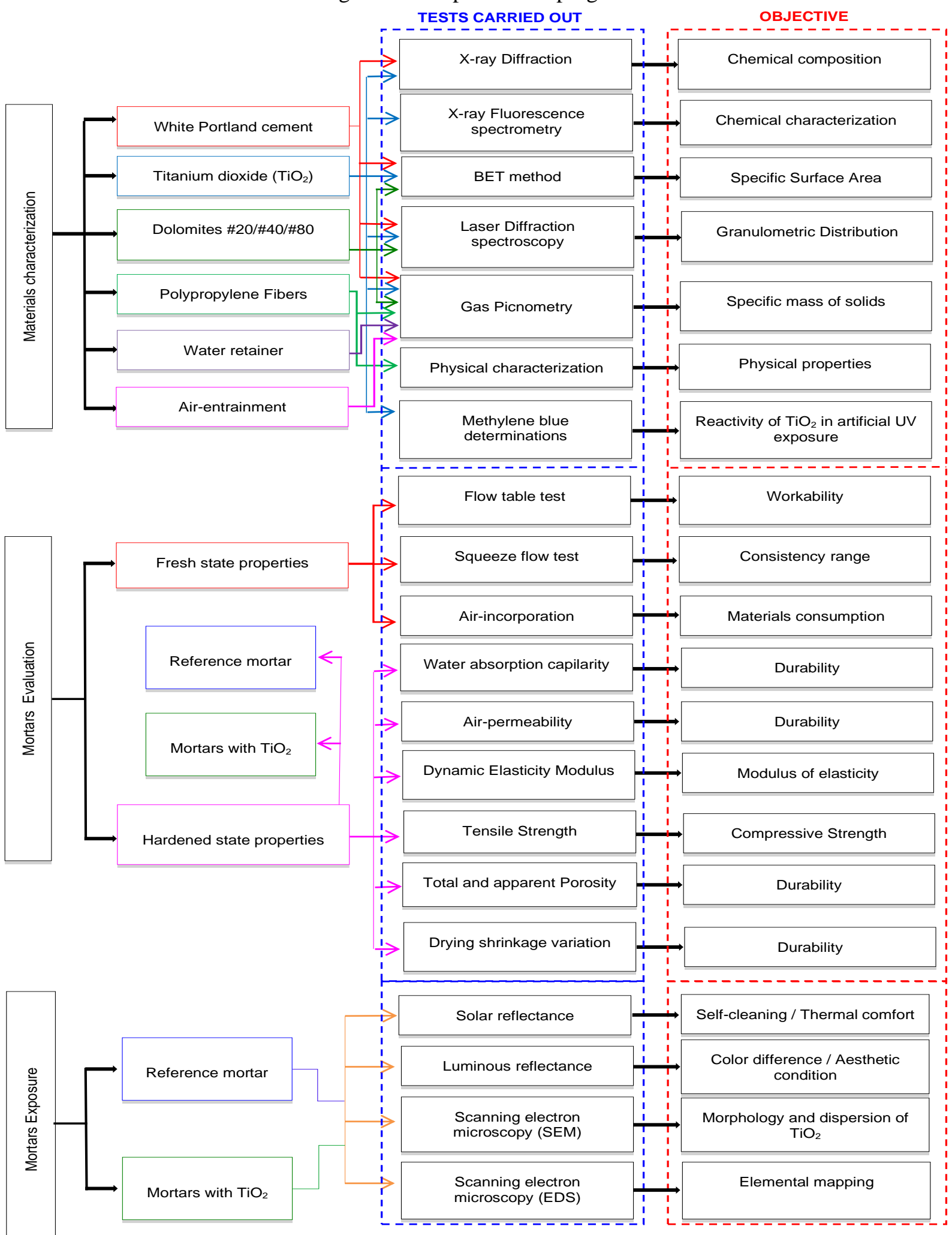

Source: Author (2021) 
To prevent cracks from reappearing with the new application of the mortars, one of the strategies to solve this problem was polypropylene microfibers (PPMF) added to the cementitious matrix. The objective was to evaluate the impact of adding fibers to the mixture through a homogeneous dispersion and observe its effectiveness in preventing the occurrence of cracks and shrinkage in the mortar.

The mortars were prepared with two different PPMF dispersion conditions and were compared to reference mortars prepared without PPMF addition. Changes in the fresh properties were monitored using the flow table, squeeze flow, and air-entrainment tests. The hardened state was characterized by capillary water absorption, air-permeability, dynamic elastic modulus, tensile strength according to the Brazilian standard, and porosity by Archimedes immersion method. In general, we can say that the strategy of PPMF addition was an excellent solution to the cracking and shrinkage problem, and the results are presented in Article B.

After that investigation, the study about the dispersion of $\mathrm{TiO}_{2}$ was done, where characteristics such as size and specific surface areas of $\mathrm{TiO}_{2}$ particles were considered since they can significantly influence the final results regarding the homogeneity of the compound. The best fiber dispersion condition results were maintained, and five new mortar mixtures were prepared; one used as a reference and without $\mathrm{TiO}_{2}$ addition and four with the addition of two commercial $\mathrm{TiO}_{2}$ samples. This investigation aimed to evaluate two dispersion conditions with two $\mathrm{TiO}_{2}$ commercial samples (P25 and PC105) in powdered form.

The mortars in all formulations were prepared using the same dry materials and, the water content was modified to maintain the same mortar consistency, controlled using a flow table test. As well as in Article B, the same tests were determined in the fresh and hardened properties of the mortars. The results of this investigation can be found in Article C.

Based on the results presented in Article $\mathrm{C}$, the compositions that showed the best dispersion condition with the fibers and powdered $\mathrm{TiO}_{2}$ were chosen to be applied on concrete base prototypes with dimensions of $1.20 \mathrm{~m} \times 1.20 \mathrm{~m}$. To evaluate the impact of $\mathrm{TiO}_{2}$ addition on the rheology of the compositions and their yields, tests were previously performed in the laboratory, monitoring the characteristics in the fresh state using a flow table test, airentrainment, and squeeze flow. The amount of kneading water was changed to maintain a spread of $220 \pm 10 \mathrm{~mm}$, and the content of air-entrained was kept constant at around $25 \%$.

In the second stage, the compositions were mixed at a construction site according to the same 
criteria adopted in the laboratory, observing the maintenance of the previous characteristics. Before the application, the bases were previously normalized using roughcast to decrease water absorption, improve adhesion, and avoid high consumption of mortars. Afterward, a blind test was performed to assess the mason sensitivity during the handling and application of mortars, and the results were published in Article D.

After finishing the mortars, we waited for twenty-eight days for the field-cured, and then the $\mathrm{TiO}_{2}$ suspension application was made in some specimens. In this part of the experiment, four suspensions of $\mathrm{TiO}_{2}$ (two commercial and two produced in a laboratory) were applied as a spray - as recommended by the manufacturer - and compared with reference mortars without $\mathrm{TiO}_{2}$ and painted with white commercial acrylic paint. As well as the suspension, the paint was applied by spray to maintain the same application pattern.

Finally, the new experimental design was done, and the mortars were exposed to the urban environment with different treatments of $\mathrm{TiO}_{2}$. They were evaluated comparatively with each other and with a painted surface. Therefore, all exposed compositions were previously determined in the laboratory and present the best conditions regarding rheology and its properties in a fresh and hardened state. The specimens were positioned towards the Northwest face looking for the highest incidence of solar radiation, choosing to maintain the previous configuration used since it proved to be perfectly adequate.

In the first assessment after the exposure of the specimens, the influence of surface roughness on the activation of $\mathrm{TiO}_{2}$ and its participation in the scattering of light, causing greater or lesser activation of the compound, was done. Therefore, for a better observation of the problem, an investigation was carried out to evaluate the effects of this activation on different scales of roughness and light scattering on mortar surfaces.

Using the mortar samples applied, the effects of $\mathrm{TiO}_{2}$ activation on mortar surfaces with distinct treatments of $\mathrm{TiO}_{2}$ were observed, either in powder or suspension form. The samples were observed at different scales, with an observation path from the larger scale to a more refined scale.

The study using an optical profilometry test to observe the surface microscopic distribution, following the scanning electron microscopy (SEM) to identify the morphology and formation of $\mathrm{TiO}_{2}$ film from the suspensions, and finally, the EDS elemental mapping to observe the presence and dispersion of $\mathrm{TiO}_{2}$ powder when added to the mortar. The results of the investigation were published in Article E. 
After the specimen's exposure to the environment, they were monitored to evaluate the effectiveness of $\mathrm{TiO}_{2}$ treatments, using reflectance tests to solar radiation and luminous reflectance over the years, where, although both areas can be intertwined, for a better explanation of the results, the investigation was divided into two parts.

In the first part, samples with $\mathrm{TiO}_{2}$ powder addition and $\mathrm{TiO}_{2}$ suspensions were measured and compared to the behavior of paint concerning the reflectance variation to solar radiation over time. The effectiveness was estimated to explore how climate and product type affect the loss of solar reflectance on mortars exposed in the long term.

Reflectance to solar radiation measured was according to ASTM E1918-16 and ANSI/ASHRAE-74 procedures. The measurements were carried using two Kipp \& Zonen pyranometers sensors, Delft / Holland model CM3, with wavelengths range of $305-2800 \mathrm{~nm}$ and maximum radiation of $2000 \mathrm{~W} / \mathrm{m}^{2}$. The signal generated varied from $0-50 \mathrm{mV}$ and the sensitivity from $0-35 \mu \mathrm{V} / \mathrm{W} / \mathrm{m}^{2}$. A datalogger ALMEMO, model 2890-9 with a 6.5-digit display and RS232 output, was employed for data acquisition. The results can be found in Article F.

As a second part of the studies and the final article of this thesis, investigations on lightness reflectance over three years are presented. This research measured the effectiveness of different types of $\mathrm{TiO}_{2}$ with the distinct application form on mortar as a function to maintain initial lightness reflectance conditions on specimen's exposure to the environment.

For the previous determination of the photocatalytic reactivity of $\mathrm{TiO}_{2}$ samples, the methylene blue dye test was degraded in the laboratory. Samples of solutions containing $\mathrm{TiO}_{2}$, and methylene blue were prepared, and then the solutions were exposed to artificial UV radiation with times of $0 \mathrm{~min}, 60 \mathrm{~min}, 120 \mathrm{~min}$, and $240 \mathrm{~min}$ with constant stirring. After exposure, the absorbance was measured at a wavelength of $660 \mathrm{~nm}$.

To determine the lightness reflectance, a procedure based on the ASTM D2244-21 was adopted. The measurements were done using a Color Guide Sphere diffuse $/ 8^{\circ}$ spin spectrophotometer with geometric measurements of $45^{\circ} / 0^{\circ}$ circular, with $400-700 \mathrm{~nm}$ measurement area, $20 \mathrm{~nm}$ spectral resolution, and photometric range $0-100 \%, 0.01$ resolution. The illuminant D65 and observer with $10^{\circ}$ and reproducibility $<0.02 \Delta \mathrm{E}^{*}$ were considered, and the results can be found in Article G. 


\section{CHAPTER 4}

SUMMARY OF RESULTS

As in the methodology chapter, the results will be presented individually and chronologically, allowing a better understanding of the studies. The first part of the results is related to Article A, which dealt with the study of different content of $\mathrm{TiO}_{2}$ added to the mixture, where efficiency was observed through measurements concerning reflectance to solar radiation and luminous reflectance.

Much is still discussed about the concentration of $\mathrm{TiO}_{2}$ to be added to the cementitious matrix to trigger the process of photocatalysis, and several researchers have tested various levels of concentration in multiple experiments. Although some researchers point out in their experiments that lower concentrations of $\mathrm{TiO}_{2}$ showed better performance, others point out the need to better evaluate the effectiveness of using higher levels of $\mathrm{TiO}_{2}$ in this process.

The definition of $\mathrm{TiO}_{2}$ concentrations used $(1 \%, 5 \%, 10 \%)$ was based on concentrations presented in other studies. After 41 months of exposure and after the washing procedure, the results showed that the painted mortar and the mortars with different $\mathrm{TiO}_{2}$ additions presented statistically the same reflectance to solar radiation. Also, the specimens with the addition of different $\mathrm{TiO}_{2}$ content did not show significant differences between them. All samples exhibited color changes in luminous reflectance, but the painted mortars presented higher color change than specimens with $\mathrm{TiO}_{2}$ additions.

Those results corroborate with other studies about the non-direct correlation between the $\mathrm{TiO}_{2}$ content incorporated and its photocatalytic efficiency. Furthermore, it was shown that the content to be used must be previously studied according to the final objective to be achieved.

As a continuation, we have the results indicated by Article B. The study was carried out to evaluate the influence of a polypropylene microfibre (PPMF) dispersion procedure on fresh and hardened state properties rendering mortars.

The mortars present drying shrinkage over time, usually at the first ages, depending on the volume of paste and the aggregates present in the mixture. According to some results, the use of fibres as a reinforcing mechanism can mitigate the stresses developed. The shrinkage decreases with increasing fibre dosage in mortar compositions. The following organic fibres (polypropylene, polymer, nylon, palm, and straw) are the most used, increasing hardness and flexibility, reducing shrinkage, and resisting micro-cracks. 
Based on the literature review, this study was done to show the influence of the polypropylene microfibre dispersion procedure on the properties of rendering mortars in a fresh and hardened state, where the results showed that the fresh mortar properties were not affected by the dispersion procedure and all hardened mortar properties were statistically similar, except the dimensional variation of the specimens. The result also shows that adding polypropylene microfibers in a dispersed form was more effective in controlling the total drying shrinkage than the direct addition of fibers to the cementitious matrix (as recommended by the manufacturer) or the reference mortar. Another point to be highlighted was that the fiber dispersion condition did not impact the rheological properties or the properties in a hardened state, except for retraction, which was precisely the objective. The tests showed that a better dispersion of the fibers leads to less retraction, solving the problem found during previous studies.

The uniformity of nanoparticle dispersion into rendering mortar affects the properties of materials. Particle size and shape and adding to the mixture are points of great importance that should be considered.

Regarding the literature data, additional factors influence the photocatalytic efficiency of the different $\mathrm{TiO}_{2}$ samples. Particle characteristics such as size, morphology, or surface constitution account for the different photocatalytic activities. In particular, catalyst particle size seems to have a noticeable influence on photocatalytic activity. Thus, the main goal of this study was to experimentally evaluate the impact of $\mathrm{TiO}_{2}$ dispersion on fresh and hardened rendering mortar properties, and the results can be seen in Article $\mathbf{C}$.

The results showed that the fresh and hardened mortar properties were affected by the dispersion procedure and the characteristics of the $n-\mathrm{TiO}_{2}$ samples, indicating that adding $n$ $\mathrm{TiO} 2$ in a dispersed form was more effective in controlling fresh and hardened mortar properties. The results showed that the drying shrinkage is not influenced by the dispersion procedure but by the characteristics of $n-\mathrm{TiO}_{2}$. Besides, it was observed that regardless of the $n$ - $\mathrm{TiO}_{2}$ sample, when the compound was more efficiently dispersed, the properties in the hardened state were more satisfactory, even though kneading water was maintained for each product. In other words, the dispersion process improved microstructural homogeneity, potentializing the effects of the cement and $n-\mathrm{TiO}_{2}$ on the mixtures.

Mechanisms for evaluating the rheological properties of mortars, particularly their applicability, are usually carried out in a sensorial and tactile way and not by their physical 
behavior. It is common practice for masons to deliberately increase the amount of water without any control, only using their experience and preference of mortar consistency when the mortar does not show the desired characteristic. Based on empirical knowledge, such procedures are subjective, induce many errors that impair the mortar quality, and do not enable us to measure any possible rheological parameters to quantify the material workability.

Thus, in this study, the rheological properties of mortars with and without $\mathrm{TiO}_{2}$ addition were evaluated on a laboratory scale to define similar workability between them and the mason's sensitivity during the mortar application in-situ correlating the results after both procedures. The results in Article D showed that after the experimental program was carried out, all mortars were considered similar, although the yield of the compositions with $\mathrm{TiO}_{2}$ addition was lower than the reference composition. Those results are based on the physical parameters of the formulations and can be explained with the rheological indices obtained by the squeeze flow test.

To assess the activation of $\mathrm{TiO}_{2}$ as a function of different roughness scales, the study discussed how this roughness could influence the different forms of application of $\mathrm{TiO} 2$ during light scattering on mortar surfaces. The results of this investigation can be found in Article E, and conclusions demonstrated that the activation of $\mathrm{TiO}_{2}$ by diffuse solar radiation is more important than direct solar radiation and the micro-roughness has no direct relationship with the activation of $\mathrm{TiO}_{2}$. Also, the presence of different roughness scales and the use of the same particle size of $\mathrm{TiO}_{2}$ affect the dispersion process of $\mathrm{TiO}_{2}$. Besides, different particle sizes of $\mathrm{TiO}_{2}$ could help form $\mathrm{TiO}_{2}$ magnetic mesh, which improves system efficiency. At the same time, the suspension of $\mathrm{TiO}_{2}$ does not guarantee better effectiveness of the system due to imperfect film formation.

As a final part of this research, the studies regarding the reflectance to solar radiation of mortars exposed to the urban environment are presented. Increasing solar reflectance and thermal emittance on the facades can be a feasible strategy against the building's warming. It can also reduce urban heat islands, improve indoor and outdoor thermal comfort, and reduce the buildings' energy consumption.

Coating with $\mathrm{TiO}_{2}$ can be an alternative to maintain this solar reflectance of building envelope and make those cooler by maintaining their initially high solar reflectance values over long periods, besides their environmental benefits concerning the depolluting properties. In that context, the results about the reflectance to solar radiation can be found in Article F. 
Results indicated that painted specimens maintained their initial reflectance to solar radiation after three years of exposure ending with $73 \%$ of their index. The comparison between the painted specimens and specimens treated with $\mathrm{TiO}_{2}$ powder showed a difference between $28.25 \%$ regarding their reflectance to solar radiation. On the other hand, the comparison between the samples treated with $\mathrm{TiO}_{2}$ in powder and specimens treated with $\mathrm{TiO}_{2}$ in suspension form shows a difference of $8.5 \%$ in reflectance index to solar radiation, not indicating a preference since both showed the same effectiveness in mean after three years of exposure.

The importance of colors is not limited to the aesthetic but also other parameters like thermal comfort. Painting light colors on the building's external surfaces increases its reflection to the solar radiation, reducing the heat gains, while dark colors can increase solar heat gains absorbing more radiation. Regarding the $\mathrm{TiO}_{2}$ answer to the lightness on the facade, different samples of $\mathrm{TiO}_{2}$ were tested. First, in the laboratory as to methylene blue dye degradation and second in a natural environment using various forms of treating (suspension and powder) on mortars, measured by a spectrophotometer over three years to determine the loss of lightness over time Article G.

The methylene blue test showed that the $\mathrm{TiO}_{2}-\mathrm{P} 25 \mathrm{p}$, $\mathrm{TiO}_{2}-\mathrm{PC}-\mathrm{S} 7 \mathrm{~s}$, and $\mathrm{TiO}_{2}-\mathrm{E} 502 \mathrm{~s}$ samples had the same effectiveness after exposure to artificial UV radiation, while the $\mathrm{TiO}_{2}-\mathrm{PClO5p}$ sample presented the worst performance. Concerning the lightness, after thirty-seven months of the natural exposition, the white painted specimens had the best results than specimens with $\mathrm{TiO}_{2}$ suspensions and specimens with $\mathrm{TiO}_{2}$ in powder. Moreover, regarding the absorptivity, the white painted specimens could be considered with low absorptivity. In contrast, the specimens treated with $\mathrm{TiO}_{2}$ suspension and those treated with $\mathrm{TiO}_{2}$ powder could be medium absorptivity. About the visual aesthetic perception, the study concludes that for the final user, there is no significant difference in white painted specimens, while for the other (powder and suspension), the color difference can be noticed very well in three years of exposure. 


\section{CHAPTER 5}

This research focused on evaluating the effect of $\mathrm{TiO}_{2}$ treatments on the reflectance to solar and luminous radiation of coating mortars considering two forms of treatments on the surfaces and concerning the addition of two different samples of $\mathrm{TiO}_{2}$ powder with different particle sizes in the cementitious matrix, and the application of two different samples of $\mathrm{TiO}_{2}$ suspension as a coating.

The results of the study were published in seven different papers where each one deals with a specific part of the study aiming to treat the variables that could lead to the inefficiency of the photocatalytic process, as the $\mathrm{TiO}_{2}$ content; the influence of polypropylene microfibers, $\mathrm{TiO}_{2}$ dispersion; the rheological properties of mortars; the $\mathrm{TiO}_{2}$ activation, and finally, the reflectance to solar and luminous radiation.

Thus, based on the experimental program results, the main conclusions are shown beneath. The specific findings that can be found in the particular papers attached in this document:

Photocatalytic performance of white cement mortars exposed in urban atmosphere (Paper A)

After three years of exposure, mortars with different content of $\mathrm{TiO}_{2}$ exhibited a statistically equivalent reflectance, indicating that there is no direct relationship between the content of $\mathrm{TiO}_{2}$ used and the effectiveness of photocatalytic mortars.

$>$ The color differences observed increased over the years in all specimens concerning the components $(\Delta \mathrm{L}, \Delta \mathrm{a}$, and $\Delta \mathrm{b})$.

$>$ It was observed that a long exposure time to be necessary to determine the differences concerning the maintenance of the initial conditions of the mortars with added $\mathrm{TiO}_{2}$.

Influence of polypropylene microfibre (PPMF) dispersion procedure on fresh and hardened rendering mortar properties (Paper $B$ )

The dispersion procedure had no significant change in the spreading, indicating that all the mortars presented similar consistency during application and better control of the drying shrinkage.

$>$ The dispersion procedure potentially increases the effect of the polypropylene microfibre on dimensional variation control as it guarantees fibre homogeneity in rendering mortars. 
Influence of the nano $\mathrm{TiO}_{2}$ dispersion procedure on fresh and hardened rendering mortar properties (Paper $C$ )

The addition method and the $\mathrm{TiO}_{2}$ sample used directly influence the dispersion results once the dispersion condition shows a significant spread change in all the mortars.

$>$ Regardless of the type of $\mathrm{TiO}_{2}$ sample, when it is more efficiently dispersed, the properties in the hardened state are more satisfactory, despite the volume of water maintained. The dispersion process improved microstructural homogeneity, potentializing the effects of the cement and the $\mathrm{TiO}_{2}$ on the mixtures.

$>$ Concerning the drying shrinkage results, this phenomenon is much more associated with the $\mathrm{TiO}_{2}$ sample and the amount of water used in the mixture than with the $\mathrm{TiO}_{2}$ dispersion procedure.

\section{Evaluation of rheological properties of mortar with $\mathrm{TiO}_{2}$ addition (Paper D)}

$>$ The $\mathrm{TiO}_{2}$ type was responsible for the changes in the rheological behavior of mortar according to the consistency index and rheological parameter obtained from the power-law in squeeze flow.

Although the workability of mortars with $\mathrm{TiO}_{2}$ addition was considered similar by the mason, differences were detected by the squeeze flow test in the laboratory and reflected in the yield.

$>$ Changes in yield can be evaluated based on IPS (Interparticle Separation Distance) which presented an excellent correlation, showing the impact of the physical parameters of each composition on the performance during the application.

Effects of surface roughness and light scattering on the activation of $\mathrm{TiO}_{2}$ on mortar photocatalytic process (Paper E)

$\mathrm{TiO}_{2}$ activation is not limited only to direct solar radiation but diffuse solar radiation, which is as or more important because of the longer surface irradiation time.

$>$ Micro-roughness has no direct relationship with the activation of $\mathrm{TiO}_{2}$. However, it can supply a higher adhesion to dirt and prevent the activation of $\mathrm{TiO}_{2}$.

$>$ The presence of different roughness scales and the same $\mathrm{TiO}_{2}$ particle size affect the dispersion of $\mathrm{TiO}_{2}$ on surfaces.

$>$ Different $\mathrm{TiO}_{2}$ particle sizes can help shape the $\mathrm{TiO}_{2}$ pixelated network and enhance its activation, thus improving system efficiency. 
$\mathrm{TiO}_{2}$ suspension does not guarantee better effectiveness since the formation of an imperfect film layer on the surface, caused by a deficient application or the characteristics of the $\mathrm{TiO}_{2}$ particles used, reduces UV radiation and consequently system efficiency.

Comparison of reflectance to solar radiation between mortars treated with $\mathrm{TiO}_{2}$ and painted mortars after three years of exposure (Paper F)

$>$ Painted specimens maintained their initial reflectance to solar radiation after three years of exposure ending with $73 \%$ of their index.

$>$ The comparison between the painted specimens with the specimens treated with $\mathrm{TiO}_{2}$ powder showed a difference between $28.25 \%$ regarding their reflectance to solar radiation. The final user would already perceive that difference in terms of absorption and color change.

$>$ The comparison between the specimens treated with $\mathrm{TiO}_{2}$ in powder and specimens treated with $\mathrm{TiO}_{2}$ in suspension form shows a difference of $8.5 \%$ in reflectance index to solar radiation. The final user will not perceive the absorption and color change result and not indicate their preference since both showed the same effectiveness in mean after three years of exposure.

\section{Maintenance of initial lightness on mortars treated with $\mathrm{TiO}_{2}$ in the long term (Paper G)}

Determining the methylene blue dye in the laboratory, the $\mathrm{TiO}_{2}-\mathrm{E} 502 \mathrm{~s}$ presented a better efficiency degrading about $80 \%$ of the compound already in the first $60 \mathrm{~min}$ of exposure. However, at the end of the tests, considering the remaining content of the dye, it is possible to say that $\mathrm{TiO}_{2}-\mathrm{E} 502 \mathrm{~s}, \mathrm{TiO}_{2}-\mathrm{P} 25 \mathrm{p}$, and $\mathrm{TiO}_{2}-\mathrm{PC}-\mathrm{S} 7 \mathrm{~s}$ samples have the same effectiveness ( $\pm 99.9 \%$ ), even providing different degradation of the dye over time. About the $\mathrm{TiO}_{2}-\mathrm{PC} 105 \mathrm{p}$ sample, this presented the worst performance, degrading only $29.5 \%$ of the compound.

$>$ Over three years of exposure, the white painted specimens showed the best results compared to the other. Besides, all $\mathrm{TiO}_{2}$ suspensions had better results than the $\mathrm{TiO}_{2}$ powder. Nevertheless, among the $\mathrm{TiO}_{2}$ suspensions, it cannot be said that there is the best, since all of them presented the same results when seen with the naked eye;

$>$ White painted specimens could be classified as white coating since it presents after three years of exposure 86.26 CIELab units of their lightness and absorptivity below 0.30 . 
$>$ The specimens covered by $\mathrm{TiO}_{2}-\mathrm{P} 25 \mathrm{~s}, \mathrm{TiO}_{2}-\mathrm{PC} 105 \mathrm{~s}, \mathrm{TiO}_{2}-\mathrm{PC}-\mathrm{S} 7 \mathrm{~s}$, and $\mathrm{TiO}_{2}-\mathrm{E} 502 \mathrm{~s}$ suspension showed lightness values of $65.85,68.48,69.70$, and 69.87 CIELab units, respectively, could be considered white membranes as well, offering intermediate absorptivity.

$>$ The specimens $\mathrm{TiO}_{2}-\mathrm{P} 25 \mathrm{p}$ and $\mathrm{TiO}_{2}-\mathrm{PC} 105 \mathrm{p}$ with $\mathrm{TiO}_{2}$ addition can be considered with a medium absorptivity and off-white color since they show after thirty-seven months of exposure, values of 61.39 and 60.99 CIELab units of their lightness, respectively.

$>$ Concerning the visual aesthetic perception, the study concludes that no significant difference in painted specimens for the final user over three years. On the other hand, to all other examples treated with $\mathrm{TiO}_{2}$ (suspensions and powder), the changes can be noticed very well when considered in the same period.

Therefore, according to the results obtained for reflectance to solar radiation and luminous reflectance, a general conclusion can be reached that the replacement of paint by materials with addition or application of $\mathrm{TiO}_{2}$ suspension, when considering only the three years of exposure of the mortars, is not justified, although the mortars treated with $\mathrm{TiO}_{2}$ present relevant results at the beginning of their application.

This is because the paint in these three years of exposure still presents considerable durability complying with the requirements regarding reflectance to solar radiation and luminous reflectance. Unlike surfaces treated with $\mathrm{TiO}_{2}$ that show medium or low performance in three years of exposure, considering the exact requirements.

On the other hand, this same period of exposure was not enough to observe the degradation of the protective film on painted surfaces, and consequently, the drop in its performance, which would demonstrate the need for a possible intervention (repainting) of the surfaces. The same occurs for surfaces treated with $\mathrm{TiO}_{2}$, where even with small recoveries and lower reflectance to solar radiation and luminous reflectance indices than painted surfaces, they are still not entirely stable in terms of loss of performance when evaluated on the same criteria.

Thereby, according to the results found, there is a need for continuity in the measurement/evaluation of specimens regarding the reflectance to solar radiation and luminous reflectance. It is necessary so that it is possible to observe more precisely the appropriate time for an intervention, in other words, the right time to repainting or reapplication $\mathrm{TiO}_{2}$ treatments on the surfaces. 


\section{CHAPTER 6}

PROSPECTIVE RESEARCH TOPICS

Considering the studies produced and results found in this thesis, some prospective investigations can be suggested and related to the following topics:

I. Considering the tribological process and its impact on the dispersion of $\mathrm{TiO}_{2}$ particles and consequent influence on the self-cleaning process, the investigation should be better studied.

II. About the formation of the $\mathrm{TiO}_{2}$ pixelated network theory, we suggest experimenting with a higher range of particles of $\mathrm{TiO}_{2}$ distributed as possible, such as $1 \mathrm{~nm}$ to $80 \mu \mathrm{m}$, in a prototype scale and observe the pixel network formation, the agglomeration of the $\mathrm{TiO}_{2}$, the influence of workability, and the $\mathrm{TiO}_{2}$ activation in that condition.

III. The inquisition about the $\mathrm{TiO}_{2}$ suspension for more time to verifies the moment of the product reapplication, observing the performance concerning self-cleaning efficiency and the film's durability.

IV. The observation of specimens for periods more extended than three years to assess the behavior of surfaces in terms of reflectance to solar and light radiation and whether surfaces treated with $\mathrm{TiO}_{2}$ become competitive with the paint over the years.

V. Carrying out a financial study of the real cost of initial application of the different treatments with $\mathrm{TiO}_{2}$ and comparing it with the painting, observing if this cost is amortized over time when considering the effectiveness of the products evaluated.

VI. Considerations of the pigmented concrete and mortar with adding, or suspension application of $\mathrm{TiO}_{2}$, aiming to expand the use of the technique beyond white.

VII. Analysis of the adsorption of inorganic species such as phosphates, sulfates, chlorides, carbonates, and nitrates on the surface of $\mathrm{TiO}_{2}$ impairing its catalytic activity.

VIII. Exploration about the decrease in the catalytic activity of $\mathrm{TiO}_{2}$ due to the leaching on the surface exposed in the natural environment. 
[1] SPASIANO, D.; MAROTTA, R.; MALATO, S.; FERNÁNDEZ-IBÁÑEZ, P. Solar photocatalysis: Materials, reactors, some commercial, and pre-industrialized applications. A comprehensive approach. Applied Catalysis B: Environmental, v.170-171, p.90-123, 2015.

[2] FUJISHIMA, A.; RAO, T. N.; TRYK, D. A. Titanium Dioxide Photocatalysis. Journal of Photochemistry and Photobiology C: Photochemistry Reviews, v.1, p.1-21, 2000.

[3] Italcementi Group. Case study: The Italcementi TX ACTIVE® story. In Cristal Global Conference, 17 Nov., p. 1 - 59, London, 2011.

[4] CASSAR, L., PEPE, C., PIMPINELLI, N., AMADELLI, R., BONATO, T. Cementitious materials, and photocatalysis. In FAST Seminar: Materials: Research and Technological Perspectives at the Thresholds of 2000. Milan, 10-14 Nov. 1997. [In Italian].

[5] CASSAR, L.; PEPE, C.; TOGNON, G.; GUERRINI, G. L.; AMADELLI, R. White cement for architectural concrete, possessing photocatalytic properties. In: Int. Congress on the Chemistry of cement, 11th, p.2012-2021, 2003, Durban. Anais... Durban: Int. Congress on the Chemistry of cement, 2003.

[6] CASSAR, Luigi. Photocatalysis of Cementitious Materials: Clean Building and Clean Air. Mrs. Bulletin, p.1-4, 2004.

[7] CHEN, J.; POON, C. Photocatalytic construction and building materials: From fundamentals to applications. Building and Environment, v.44, p.1899-1906, 2009.

[8] LUCAS, S.S.; FERREIRA, V. M.; AGUIAR, J. I. Barroso de. Incorporation of titanium dioxide nanoparticles in mortars: Influence of microstructure in the hardened state properties and photocatalytic activity. Cement and Concrete Research, v.43, p.112-120, 2013.

[9] DANTAS, S. R. A. A eficácia da adição do $\mathrm{TiO}_{2}$ em argamassas quanto à manutenção das condições iniciais em termos da sua refletância à radiação solar. 2016.137 f. Dissertação (Mestrado Profissional) - Curso de Habitação: Planejamento, Gestão e Projeto, Instituto de Pesquisas Tecnológicas do Estado de São Paulo - IPT, São Paulo, 2016.

[10] SPASIANO, D.; RODRIGUEZ, L. del P. P.; OLlEROS, C. J.; MALATO, S.; MAROTTA, R.; ANDREOZZI, R. $\mathrm{TiO}_{2} / \mathrm{Cu}$ (II) photocatalytic production of benzaldehyde from benzyl alcohol in solar pilot plant reactor. Applied Catalysis B: Environmental, v.136137, p.56-63, 2013.

[11] OHAMA, Y.; VAN GEMERT, D. Application of Titanium Dioxide Photocatalysis to Construction Materials: State-of-the-Art. Report of The RILEM Technical Committee 194TDP, 2011.

[12] DENGWEI. J.; GUO, L.; ZHAO, L., ZHANG, X.; LIU, H.; LI, M.; SHEN, S.; LIU, G.; HU, X.; ZHANG, X.; ZHANG, K.; MA, L.; PENGHUI GUO, P. Efficient solar hydrogen production by photocatalytic water splitting: From fundamental study to pilot demonstration. Hydrogen Energy, v.35, p.7087-7097, 2010. 
[13] MALATO, S.; FERNÁNDEZ-IBÁÑEZ, P.; MALDONADO, M. I.; BLANCO, J.; GERNJAK, W. Decontamination and disinfection of water by solar photocatalysis: Recent overview and trends. Catalysis Today, v.147, p.1-59, 2009.

[14] HASHIMOTO, K.; IRIE, H.; FUJISHIMA, A. $\mathrm{TiO}_{2}$ Photocatalysis: A Historical Overview and Future Prospects. Applied Physics, v.44, p.8269-8285, 2005. doi:10.1143/JJAP.44.8269.

[15] BANHEMANN, D. W, Photocatalytic water treatment: solar energy applications. Solar Energy, v.77, p.445-459, 2004.

[16] MILLS, A; LEE, S. K. A web-based overview of semiconductor photochemistry-based current commercial applications. Photochemistry and Photobiology A: Chemistry, v.152, p.233-247, 2002.

[17] FUJISHIMA, A.; HASHIMOTO, K.; WATANABE, T. $\mathrm{TiO}_{2}$ Photocatalysis: Fundamentals and Applications, BKC Inc., Tokyo, 1999.

[18] STELlman, J. M. Encyclopedia of Occupational Health and Safety: Chemical, industries, and occupations. 4. ed. International Labour Organization, 1998.

[19] CHEN, X.; MAO, S. S. Titanium dioxide nanomaterials: synthesis, properties, modifications, and applications. Chemical Reviews. v.107, p.2891-2959, 2007.

[20] TONG, H.; OUYANG, S.; BI, Y.; UMEZAWA, N.; OSHIKIRI, M.; YE, J. Nanophotocatalytic materials: possibilities and challenges. Advanced Materials. v.24, p.229-251, 2012.

[21] PEREIRA, M. A. C.; TORGAL, F. P.; JALALI, S. Capacidade de auto-limpeza de argamassas contendo $\mathrm{TiO}_{2}\left(\mathrm{TiO}_{2}\right)$. In: CONGRESSO NACIONAL DE ARGAMASSAS DE CONSTRUÇÃO, 3., 2010, Lisboa. Conference Object. Lisboa, Portugal. C-TAC Comunicações a Conferências Nacionais, p.1-9, 2010.

[22] MELO, J. V. S. de, Desenvolvimento de peças pré-moldadas de concreto fotocatalíticas para pavimentação e purificação do ar. 2011. 208 f. Dissertação (Mestrado) - Programa de Pós-Graduação em Engenharia Civil, Universidade Federal de Santa Catarina, Florianópolis, 2011.

[23] FOLli, A.; PADE, C.; HANSEN, T. B.; DE MARCO, T.; MACPHEE, D. E. TiO 2 photocatalysis in cementitious systems: Insights into self-cleaning and depollution chemistry. Cement and Concrete Research, v. 42, p.539-548, 2012.

[24] YU, J. C. Deactivation and Regeneration of Environmentally Exposed Titanium Dioxide $\left(\mathrm{TiO}_{2}\right)$ Based Products. E183413 Hong Kong: The Chinese University of Hong Kong, 2003. 21 p. Prepared for the Environmental Protection Department, HKSAR.

[25] POON, C; CHEUNG, E. No Removal Efficiency of Photocatalytic Paving Blocks Prepared with Recycled Materials. Construction and Building Materials, v.21, p.17461753, 2007.

[26] CASAGRANDE, C. A. Estudo da incorporação de partículas de titânia em 
argamassas fotocatalíticas. 2012. 103 f. Dissertação (Mestrado) - Curso de Ciência e Engenharia de Materiais, Programa de Ciência e Engenharia de Materiais, Universidade Federal de Santa Catarina, Florianópolis, 2012.

[27] WU, Y.; KRISHNAN, P.; ZHANG, M-H.; YU, E L. Using photocatalytic coating to maintain solar reflectance and lower cooling energy consumption of buildings. Energy and building, v.164, p.176-186, 2018.

[28] WERLE, A. P.; SOUZA, M. L. de; LOH, K.; ANDO, R.; JOHN, V. M. The performance of a self-cleaning cool cementitious surface. Energy and building, v.114, p. 200-205, 2016.

[29] MUNAFÒ, P.; GOFFREDO, G. B.; QUAGLIARINI, E. TiO 2 -based nanocoatings for preserving architectural stone surfaces: An overview. Construction and Building Materials, v.84, p.201-218, 2015.

[30] RUOT, B.; PLASSAIS, A.; OLIVE, F.; GUILLOT, L.; BONAFOUS, L. TiO 2 -containing cement pastes, and mortars: Measurements of the photocatalytic efficiency using a rhodamine B-based colorimetric test. Solar Energy, v.83, p.1794-1801, 2009.

[31] ALLEN, N. S. et al. Photocatalytic titania based surfaces: Environmental benefits Polymer Degradation and Stability, v.93, p.1632-1646, 2008.

[32] SALEIRO, G. T.; CARDOSO, S. 1.; HOLANDA, J. N. F. Avaliação das fases cristalinas de dióxido de titânio suportado em cerâmica vermelha - Evaluation of the crystalline phases of supported titanium dioxide in red ceramic. Cerâmica, São Paulo, v. 56, n. 338, p.162-167, abr. 2010.

[33] MARANHÃO, F. L. Método para redução de mancha nas vedações externas de edifícios. 2009. 107 f. Tese (Doutorado) - Departamento de Engenharia de Construção Civil., Escola Politécnica, Universidade de São Paulo, São Paulo, 2009.

[34] PARAMÉS, J.; BRITO, J. de. Materiais de construção nanotecnológicos de autolimpeza - Self-cleaning nanotechnologic construction materials. Teoria e Prática na Engenharia Civil, n.15, p.55-62, 2010.

[35] HASSAN, M. M.; Dylla, H.; Mohammad, L. N.; Rupnow, T. Evaluation of the durability of titanium dioxide photocatalyst coating for concrete pavement. Construction and Building Materials, v.24, p.1456-1461, 2010.

[36] DARIANI, R. S.; ESMAEILI, A.; MORTEZAALI, A.; DEHGHANPOUR, S. Photocatalytic reaction and degradation of methylene blue on $\mathrm{TiO}_{2}$ nano-sized particles. Optik, v.127, p.7143-7154, 2016.

[37] FENG, D; Xie, N.; GONG, C.; LENG, Z.; XIAO, H.; LI, H.; SHI X. Portland Cement Paste Modified by $\mathrm{TiO}_{2}$ Nanoparticles: A Microstructure Perspective. Industrial \& Engineering Chemistry Research, v.52, p.11575-11582, 2013.

[38] LIAO, D. L.; LIAO, B.Q. Shape, size, and photocatalytic activity control of TiO2 nanoparticles with surfactants. Journal of Photochemistry and Photobiology A: Chemistry, v.187, p.363-369, 2007. 
[39] LIAO, D. L.; WU, G.S.; LIAO, B.Q. Zeta potential of shape-controlled TiO2 nanoparticles with surfactants. Colloids and Surfaces A: Physicochemical and Engineering Aspects, v.348, p.270-275, 2009.

[40] OLIVEIRA, A. H. P. de; MOURA, J. A. S.; OlIVEIRA, H. P. de. Preparação e Caracterização de Microfibras de Poli (Álcool Vinílico) / Dióxido de Titânio. Polímeros, Instituto de Pesquisa em Ciência dos Materiais, Universidade Federal do Vale do São Francisco - UNIVASF. Juazeiro, 2012.

[41] PINHO, L.; MOSQUERA, M. J. Photocatalytic activity of $\mathrm{TiO}_{2}-\mathrm{SiO}_{2}$ nanocomposites applied to buildings: Influence of particle size and loading. Applied Catalysis B: Environmental, v.134-135, p.205-221, 2013.

[42] JANG, H. D.; KIM, S. Effect of Particle Size and phase composition of titanium dioxide on photocatalytic properties. Journal of Nanoparticles Research, v.3, p.141-147, 2001.

[43] WADE, J. An investigation of TiO-ZnFe O Nanocomposites for visible light photocatalysis. Dissertação (mestrado). University of South Florida, Department of Electrical Engineering. 108p. 2005.

[44] MILANESI, F, "Siloxane-TiO ${ }_{2}$ Hybrid Nanocomposites. The Structure of the Hydrophobic Layer", Physical Chemistry, 114, p. 8287-8293, 2010.

[45] SENFF L; LABRINCHA, J. A; FERREIRA, V. M; HOTZA, D; REPETTE, W. L. Effect of nano-silica on rheology and fresh properties of cement pastes and mortars. Construction and Building Materials, v.23, p.2487- 2491, 2009.

[46] SENFF, L; HOTZA, D; REPETTE, W. L; FERREIRA, V. M; LABRINCHA, J. A. Effect of nanosílica and microsílica on the microstructure and the hardened properties of cement pastes and mortars. Advance in Applied Ceramics, v.109, p.104-110, 2010.

[47] HUSKEN, G.; HUNGER, M.; BROUWERS, H.J.H. Experimental study of photocatalytic concrete products for air purification. Building and Environment, v. 44, p. 2463-2474, 2009.

[48] BONAFOUS, L.; CASSAR, L.; CASSAT, P.; COLOMBET, P.; GUILLOT, L.; COLOMBET, F. Photocatalytic granular mixture for mortar and concrete and its use, 2009.

[49] CHEN, J.; KOU, S.; POON, C. Photocatalytic cement-based materials: Comparison of nitrogen oxides and toluene removal potentials and evaluation of self-cleaning performance, Building and Environment, v. 46, p.1827-1833, 2011.

[50] DIOS, J. de; CAMPO, J. M. del; COLORADO, D. Decontamination through photocatalytic $\mathrm{TiO} 2$ additions. Past, Present, and Future. 2nd International Conference on Emerging Trends in Engineering and Technology (icetet'2014), May 30-31, 2014. London (United Kingdom), [s.1.], p.145-152,30 May 2014. International Institute of Engineers.

[51] LI, D.; HUANG, H.; CHEN, X.; CHEN, Z.; LI, W.; YE, D.; FU, X. New synthesis of excellent visible-light $\mathrm{TiO}_{2}-\mathrm{xNx}$ photocatalyst using a very simple method. Solid State 
Chemistry, v.180, p. 2630-2634, 2007.

[52] MILLS, A.; HUNTE, S. L. An overview of semiconductor photocatalysis, Journal of photochemistry and Photobiology A: Chemistry, v.108, p.1-35, 1997.

[53] INTERNATIONAL ORGANIZATION FOR STANDARDIZATION. 9288: Thermal insulation - Heat transfer by radiation - Physical quantities and definitions. 1 ed. Geneve Switzerland: Copyright Iso, 1989. 6 p.

[54] DANTAS, S. R. A.; ROMANO, RC DE O.; VITTORINO, F.; LOH, K. Effects of surface roughness and light scattering on the activation of $\mathrm{TiO} 2$ on mortar photocatalytic process. Construction and Building Materials, v. 270, p. 121421, 2021.

[55] NOGUEIRA, R. F. P.; JARDIM, W. F. A fotocatálise heterogênea e sua aplicação ambiental. Química Nova, Campinas, v.21, p.69-72, 1998. Trimestral.

[56] KULKARNI, S. K. Nanotechnology: Principles and Practices. Third edition. New Delhi, India: Springer, 2015

[57] WANG, R.; HASHIMOTO, K.; FUJISHIMA, A.; CHIKUNI, M.; KOJIMA, E.; KITAMURA, A.; SHIMOHIGOSHI, M.; WATANABE, T. Photogeneration of Highly Amphiphilic $\mathrm{TiO}_{2}$ Surfaces. Advanced Materials, v.10, p.135-138, 1998.

[58] SANTAMOURIS, M; SYNNEFA, A; KARLESSIET, T. Using Advanced Cool Materials in the Urban Built Environment to Mitigate Heat Islands and Improve Thermal Comfort Conditions. Solar Energy, v. 85, n. 12, p. 3085-3102, 2011.

[59] AKBARI, H.; LEVINSON, R.; STERN, S. Procedure for measuring the solar reflectance of flat or curved roofing assemblies. Solar Energy, v.82, p. 648-655, 2008.

[60] SANTAMOURIS, M.; PAPANIKOLAOU, N.; LIVADA, I.; KORONAKIS, I.; GEORGAKIS, C.; ARGIRIOU, A.; ASSIMAKOPOULOS, D. N. On the impact of urban climate on the energy consumption of buildings, Solar Energy, v.70, p. 201-216, 2001.

[61] GIVONI, B. Climate considerations in building and urban design. New York: Van Nostrand Reinhold; 1998.

[62] DORNELLES, K. A.; RORIZ, V.; RORIZ, M. Determination of the solar absorptance of opaque surfaces. In: 24th International Conference on Passive and Low Energy Architecture, 2007, Singapore. Proceedings of the 24th PLEA. 2007,1:452-9.

[63] ALCHAPAR, N. L.; CORREA, E. N.; CANTÓN, M. A. Índice de reflectancia solar de revestimentos verticales: potencial para la mitigación de la isla de calor urbana. Ambiente Construído, Porto Alegre, v. 12, n. 3, p.107-123, jul./set. 2012.

[64] SANTAMOURIS, M; FIORITO, F. On the impact of modified urban albedo on ambient temperature and heat related mortality. Solar Energy. V.216, p. 493-507, 202.

[65] GRANADEIRO, V.; ALMEIDA, M.; SOUTO, T.; LEAL, V.; MACHADO, J.; MENDES, A. Thermochromic Paints on External Surfaces: Impact Assessment for a Residential Building through Thermal and Energy Simulation. Energies. v.13, p.1912, 2020. 
[66] ROMEO, C.; ZINZI, M. Impact of a cool roof application on the energy and comfort performance in an existing non-residential building. A Sicilian case study, Energy and Building, v. 67, p. 647-657, 2013.

[67] BOCCALATTE, A.; FOSSA, M.; MÉNÉZO, C. Best arrangement of BIPV surfaces for future NZEB districts while considering urban heat island effects and the reduction of reflected radiation from solar façades. Renewable and Sustainable Energy Reviews, v.160, p. 686-697, 2020.

[68] AOYAMA, T.; SONODA, T.; NAKANISHI, Y.; TANABE, J.; TAKEBAYASHI, H. Study on aging of solar reflectance of the self-cleaning high reflectance coating. Energy and Buildings. V. 157, p. 92-100, 2017.

[69] ROSSI, F.; PISELLO, AL.; NICOLINI, A.; FILIPPONI, M.; PALOMBO, M. Analysis of retroreflective surfaces for urban heat island mitigation: a new analytical model. Applied Energy. v.114, p. 621-631, 2014.

[70] ROSSI, F.; CASTELlANI, B.; PRESCIUTTI, A.; MORINI, E.; FILIPPONI, M.; NICOLINI, A.; SANTAMOURIS, M. Retroreflective façades for urban heat island mitigation: Experimental investigation and energy evaluations. Applied Energy. v.145, p. 8$20,2015$.

[71] DORNELLES, K. A.; CARAM, R. M.; SICHIERI, E. P. Natural weathering of cool coatings and its effect on solar reflectance of roof surfaces. Energy Procedia, v. 78, p. 1587$1592,2015$.

[72] DORNELlES, K. A.; CARAM, R. M.; SICHIERI, E. P. Absortância solar e desempenho térmico de tintas frias para uso no envelope construtivo. Paranoá (UnB), v.12, p. 55-64, 2014 (in Portuguese).

[73] BUENO, B.; NORFORD, L.; PIGEON, G.; BRITTER, R. A. Resistance-capacitance network model for the analysis of the interactions between the energy performance of buildings and the urban climate. Building Environment. v.54, p.16-25, 2012.

[74] GOULART, S. Sustainability in Buildings and Urban Spaces - Discipline Thermal Performance of Buildings - Energy Efficiency Laboratory in buildings, Federal University of Santa Catarina, UFSC - handout - Available at:

https://labeee.ufsc.br/sites/default/files/disciplinas/ECV5161 Sustentabilidade apostila 0 0.pdf Accessed on 16.02.2021 (in Portuguese).

[75] SOUTO, T.; ALMEIDA, M.; VÍTOR LEAL, MACHADO, J.; MENDES, A.. Total Solar Reflectance Optimization of the External Paint Coat in Residential Buildings Located in Mediterranean Climates. Energies, v.13, p. 2729, 2020.

[76] LOPES, J. M. B. Cor e Luz. Lisbon, 2003. Instituto Superior Técnico, University of Lisbon, Lisbon, 2003 (in Portuguese). 
APPENDICES 


\title{
APPENDIX A - PHOTOCATALYTIC PERFORMANCE OF WHITE CEMENT MORTARS EXPOSED IN URBAN ATMOSPHERE ${ }^{4}$ (Article A)
}

\begin{abstract}
This study aimed to evaluate the photocatalytic performances of different $n-\mathrm{TiO}_{2}$ contents added to white mortars with respect to the light reflection (evaluated by visual and CIE L ${ }^{*}{ }^{*} \mathrm{~b}^{*}$ scale) and the reflectance of the mortar surfaces exposed to solar radiation in the urban environment. Specimens with a dimension of $1.2 \mathrm{~m} \times 1.2 \mathrm{~m}$ were fabricated with added $\mathrm{n}$ $\mathrm{TiO}_{2}$ contents of $1 \%, 5 \%$, and $10 \%$ with respect to the total dry powder mass. The performances of these specimens were then compared with two sets of specimens without n$\mathrm{TiO}_{2}$, namely, painted and unpainted, and both were used as references. To conduct an in situ experiment, the mortars were mixed and applied by a mason. The results revealed that after 41 months of exposure and the washing of the specimens, the painted mortars and the mortars with different $\mathrm{n}-\mathrm{TiO}_{2}$ contents exhibited a statistically equivalent reflectance under exposure to solar radiation. No significant differences were observed between the surfaces of the specimens with the added $n-\mathrm{TiO}_{2}$ contents with respect to the reflectance under exposure to solar radiation within the same time period. All the specimens exhibited colour changes due to an increased accumulation of dirt, which can be attributed to an increase in the surface roughness of the specimens, in addition to a decrease in rainfall over the duration of exposure.
\end{abstract}

Keywords: Photocatalysis, $\mathrm{n}-\mathrm{TiO}_{2}$, solar radiation, reflectance, colour perception, CIEL ${ }^{*}{ }^{*} \mathrm{~b}^{*}$.

\footnotetext{
${ }^{4}$ Sérgio Roberto Andrade Dantas, Fúlvio Vittorino \& Kai Loh. Photocatalytic Performance of White Cement Mortars Exposed in Urban Atmosphere. Global Journal of Researches in Engineering: C - Chemical Engineering. Volume 19. Issue 2. Version 1.0. Year 2019. Online ISSN: 2249-4596 \& Print ISSN: 0975-5861 <https://www.engineeringresearch.org/index.php/GJRE/article/view/1967>
} 


\section{INTRODUCTION}

Corrective maintenance is typically carried out on facades as a result of changes in their visual appearance. A self-cleaning surface is expected to maintain its original appearance and reflectance under exposure to solar radiation for more time than the conventional coatings used in the facades of buildings. There has been an increase in the use of façade coatings with high solar reflectance characteristics, in addition to retro-reflective materials, which reflect direct solar radiation towards the sky and not in the direction of other buildings [1-6]. An increase in the light and thermal reflectance of building facades could be an effective strategy for the reduction of urban warming, to improve indoor thermal comfort and the energy consumption of heating, ventilation, and air conditioning (HVAC) systems [7-10], which results in the mitigation of the urban heat island effect [11]. However, the constant contact between coatings and environmental degradation agents, the incidence of ultraviolet radiation [12], and the coating roughness [13] tend to decrease the reflectance and induce changes in color over time.

The role of nano titanium dioxide $\left(\mathrm{n}-\mathrm{TiO}_{2}\right)$ in the decontamination of water and the oxidation of several organic atmospheric pollutants as a result of the photocatalytic activity is well established. Moreover, although photocatalysis is not considered a reliable technology for breaking down large quantities of dirt, it can be applied to prevent accumulation $[14,15]$. The process is an alternative for maintaining surface cleanliness and clarity, in addition to constant solar reflectance, which ensures the proper operation of cooling properties [16].

Because of the large bandgap and high photocatalytic activity, $\mathrm{n}-\mathrm{TiO}_{2}$ is commonly used in photocatalysis processes. Several researchers [17-25] have investigated the addition of $n-\mathrm{TiO}_{2}$ in its anatase mineralogical form to cement coatings to evaluates self-cleaning surfaces upon exposure to solar radiation. Also, self-cleaning and photocatalytic materials can add market value to buildings because of the improved maintenance of the optical performance of their facades.

Krishnan et al. [26] revealed that the photocatalytic activity is significantly degraded by the presence of calcium and sulfur from the substrate, which may accumulate on the surface of the coating and penetrate the $\mathrm{n}-\mathrm{TiO}_{2}$ lattice, thus weakening the photocatalytic effect. The surface finish should maintain its properties over time; so, it should resist environmental agents' action that leads to gradual erosion [14], which reduces the performance of buildings concerning the reflectance under exposure to solar radiation and the aesthetic. 
So, the maintenance of color and reflectance is critical to the useful life of the buildings, and this study offers other insight into the effectiveness of photocatalytic coatings when evaluated for a long time.

\section{EXPERIMENTAL PROGRAM}

The tests were carried out on specimens with dimensions of $1.2 \mathrm{~m} \times 1.2 \mathrm{~m}$ under exposure to an urban environment for forty-one months in the city of São Paulo (Latitude: 23 33'15 "S; Longitude: $46^{\circ} 44^{\prime} 1 " \mathrm{~W}$ ) in the northwest direction, to maximize exposure to sunlight, as shown in Figure 1. A slope of $33^{\circ}$ is used concerning the ground to obtain (i) a higher solar radiation index; and (ii) to prevent the stagnation of rainwater on the specimen surfaces, thus limiting the proliferation of microorganisms.

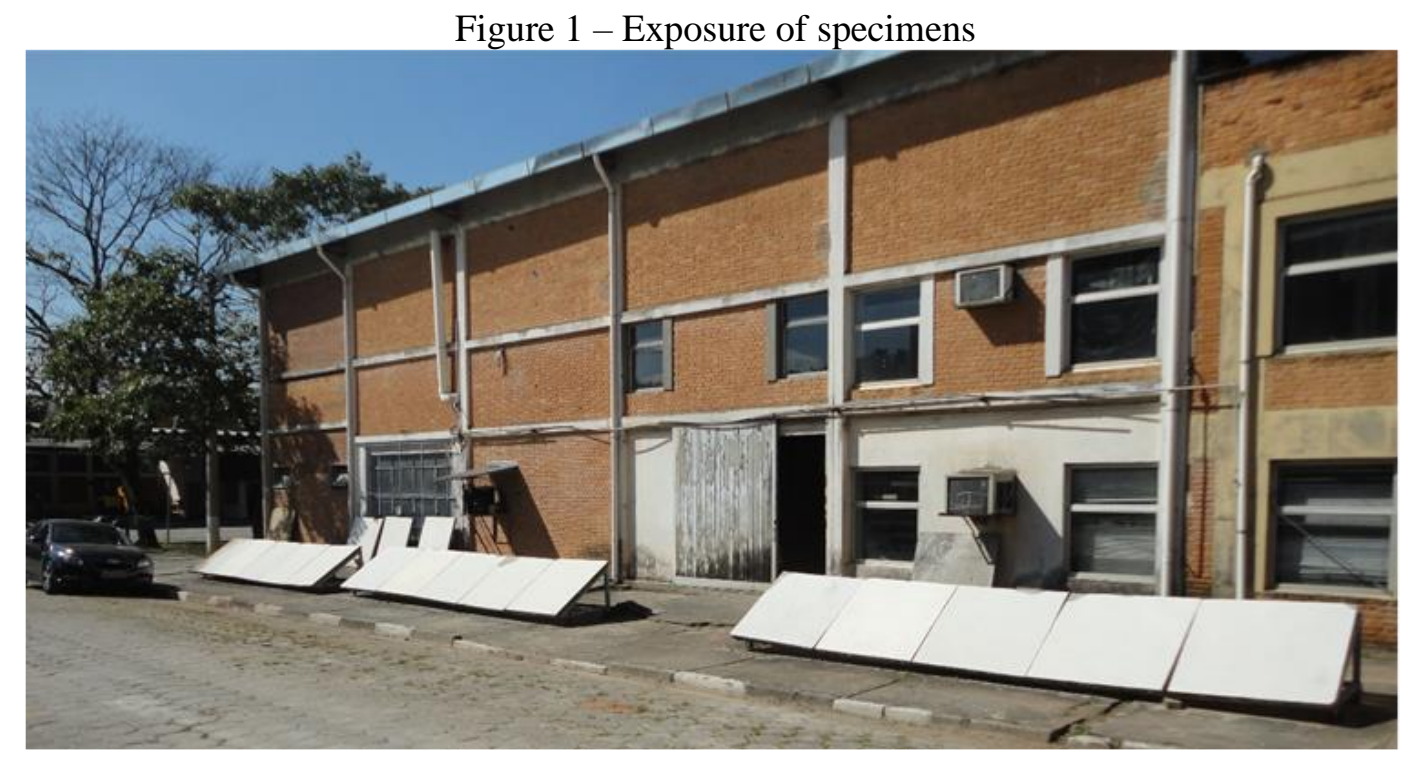

Source: Author (2019)

The mortars were applied by a mason, with a maximum thickness of $1 \mathrm{~cm}$ and with the absolute minimum roughness to obtain a high reflectance. The substrate was finished with cement paste to achieve regularisation, the homogenization of water absorption, enhanced adhesion, and to prevent an increase in the consumption of the mortars.

The reflectance under exposure to solar radiation was measured for thirty-six months at monthly intervals. After washing the mortars, after forty-one months of exposure, a measurement was then carried out to verify the restoration of the photocatalytic activity. The color was measured at the beginning of the exposure period and after forty-one months of exposure to compare the initial and final color conditions. Moreover, unexposed specimens are used as references for the initial color. 


\subsection{Materials}

All the mortar compositions were formulated using white Portland cement (WHITE CEM I 52.5R EN 197-1); dolomites \#20, \#40, and \#80; an air-entraining agent based on sodium lauryl sulfate molecules; and water-retaining agents based on cellulosic ether molecules. The $\mathrm{n}-\mathrm{TiO}_{2}$ used in this study was $100 \%$ anatase (ACTiVTM PC105 Ultrafine), recommended by the manufacturer for applications in the photocatalysis processes.

Twenty specimens were produced, fifteen exposed to the urban atmosphere, and five used as references of the initial color. The samples were classified into five types (A, B, C, D, and E) and divided into four groups $(1,2,3$, and 4$)$.

The mortars classified as $\mathrm{A}$ and $\mathrm{B}$ represent compositions formulated without $\mathrm{n}-\mathrm{TiO}_{2}$ and as a benchmark. Type-B mortars are painted, whereas type-A mortars were unpainted. The type-C, type-D, and type-E mortars were unpainted, and they represent the compositions formulated with the direct addition of different $n-\mathrm{TiO}_{2}$ contents to the mixture. Table 1 presents the terminology and exposure conditions of the specimens.

Table 1 - Composition of mortar specimens

\begin{tabular}{ccccccc}
\hline Groups & $\begin{array}{c}\text { Mortars A } \\
\text { (unpainted) } \\
0 \% \mathrm{TiO}_{2}\end{array}$ & $\begin{array}{c}\text { Mortars B } \\
\text { (painted) } \\
0 \% \mathrm{TiO}_{2}\end{array}$ & $\begin{array}{c}\text { Mortars C } \\
\text { (unpainted) } \\
1 \% \mathrm{TiO}_{2}\end{array}$ & $\begin{array}{c}\text { Mortars D } \\
\text { (unpainted) } \\
5 \% \mathrm{TiO}_{2}\end{array}$ & $\begin{array}{c}\text { Mortars E } \\
\text { (unpainted) } \\
10 \% \mathrm{TiO}_{2}\end{array}$ & Exposure \\
\hline 1 & $\mathrm{~A} 1$ & $\mathrm{~B} 1$ & $\mathrm{C} 1$ & $\mathrm{D} 1$ & $\mathrm{E} 1$ & \\
2 & $\mathrm{~A} 2$ & $\mathrm{~B} 2$ & $\mathrm{C} 2$ & $\mathrm{D} 2$ & $\mathrm{E} 2$ & Exposed \\
3 & $\mathrm{~A} 3$ & $\mathrm{~B} 3$ & $\mathrm{C} 3$ & $\mathrm{D} 3$ & $\mathrm{E} 3$ & \\
4 & $\mathrm{~A} 4$ & $\mathrm{~B} 4$ & $\mathrm{C} 4$ & $\mathrm{D} 4$ & $\mathrm{E} 4$ & Unexposed \\
\hline
\end{tabular}

Source: Author (2019)

\subsubsection{Raw Material Characteristics}

Table 2 shows the characteristics of the raw materials, in accordance with a study by Dantas et al. [27]. For determination of the specific surface area (SSA), the Brunauer-Emmett-Teller (BET) method was employed, and the real density analysis was determined using the He pycnometer method. The particle size distribution of finer particles was determined using laser granulometry, and the dolomite particle size distribution was determined using a dynamic image analyzer.

The mineralogical compositions of the white Portland cement (WPC) and $\mathrm{n}-\mathrm{TiO}_{2}$ were determined by X-ray diffraction using the Rietveld analysis method. The chemical composition of the cement was determined by the Brazilian Association of Technical Standards (ABNT) and ASTM standards. 
Table 2 - Raw material characteristics

\begin{tabular}{lccccc}
\hline \multicolumn{1}{c}{ Materials } & \multicolumn{3}{c}{ Diameter $(\mu \mathrm{m})$} & Specific surface area & Average density \\
& $\mathrm{d}_{10}$ & $\mathrm{~d}_{50}$ & $\mathrm{~d}_{90}$ & $\left(\mathrm{~g} / \mathrm{cm}^{3}\right)$ \\
\hline White Portland cement & 2.6 & 17.7 & 19.5 & 0.86 & 3.05 \\
Dolomite \#20 & 975.1 & 1242.1 & 1620.5 & 0.16 & 2.90 \\
Dolomite \#40 & 24.3 & 230.0 & 739.6 & 0.56 & 2.94 \\
Dolomite \#80 & 4.5 & 38.3 & 133.9 & 0.80 & 2.81 \\
$\mathrm{n}^{-\mathrm{TiO}_{2}}$ & 0.66 & 1.50 & 4.59 & 79.8 & 3.62 \\
\hline
\end{tabular}

Source: Author (2019)

\subsubsection{Mortar specimens composition}

Each composition was prepared with a different $\mathrm{n}-\mathrm{TiO}_{2}(1 \%, 5 \%$, and $10 \%)$ and water contents to ensure the same workability for all, as defined by the experience of the mason during the mixing. This procedure was adopted to conduct an in-situ experiment. Table 3 shows the consumption of each raw material.

Table 3 - Composition in volume to produce $1000 \mathrm{~cm}^{3}$ of mortar

\begin{tabular}{lccccc}
\hline Materials & $\begin{array}{c}\text { Mortars A } \\
\text { (unpainted) } \\
0 \% \mathrm{TiO}_{2}\end{array}$ & $\begin{array}{c}\text { Mortars B } \\
\text { (painted) } \\
0 \% \mathrm{TiO}_{2}\end{array}$ & $\begin{array}{c}\text { Mortars C } \\
\text { (unpainted) } \\
1 \% \mathrm{TiO}_{2}\end{array}$ & $\begin{array}{c}\text { Mortars D } \\
\text { (unpainted) } \\
5 \% \mathrm{TiO}_{2}\end{array}$ & $\begin{array}{c}\text { Mortars E } \\
\text { (unpainted) } \\
10 \% \mathrm{TiO}_{2}\end{array}$ \\
\hline WPC & 117.6 & 117.6 & 116.1 & 106.9 & 99.2 \\
Dolomite \# 20 & 68.7 & 68.7 & 67.9 & 62.5 & 58.0 \\
Dolomite \# 40 & 386.6 & 386.6 & 381.8 & 351.5 & 326.1 \\
Dolomite \# 80 & 106.4 & 106.4 & 105.0 & 96.7 & 89.7 \\
Water retained & 1.5 & 1.5 & 1.5 & 1.4 & 1.4 \\
Air-entrainment & 0.2 & 0.2 & 0.2 & 0.1 & 0.1 \\
water & 319.0 & 319.0 & 322.1 & 355.9 & 379.2 \\
n-TiO & --- & --- & 5.4 & 25.0 & 46.3 \\
\hline
\end{tabular}

Source: Author (2019)

\section{METHODS}

\subsection{Measuring reflectance indices}

The reflectance values were determined following the methods given in the ASTM and ASHRAE standards [28,29]. All measurements were carried out from $11 \mathrm{~h} 00$ to $13 \mathrm{~h} 00$ because of the highest incidence of global solar radiation on the specimen surfaces. The measurements were carried using two pyranometers, with measuring ranges of 305-2800 nm and maximum measuring ranges of up to $2000 \mathrm{~W} / \mathrm{m}^{2}$, with an output signal of $0-50 \mathrm{mV}$ and sensitivity of $10-35 \mu \mathrm{V} / \mathrm{W} / \mathrm{m}^{2}$. A data acquisition system was employed using a datalogger with a 6.5-digit display and conversion rate (maximum) of 10 measurements per second, with an RS232 output. An acquisition rate of 1 measurement per second and acquisition time of 20 $\mathrm{s}$ are employed by a previous study by Dantas, Vittorino, and Loh [12]. Figure 2 presents the measurement procedure. 
Figure 2. Measurement procedure
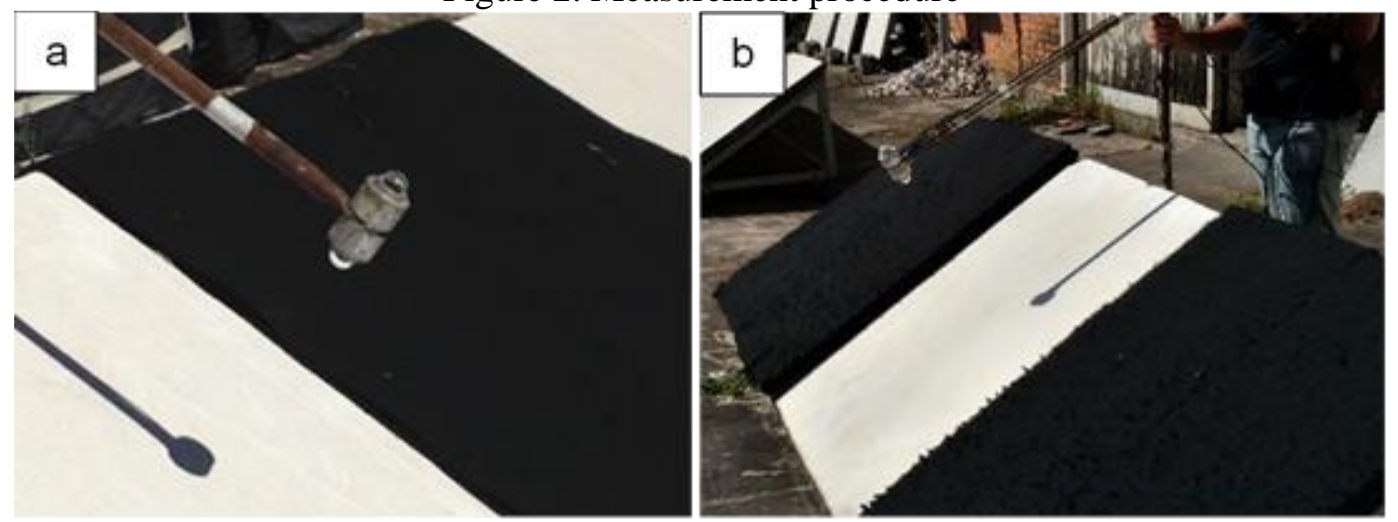

Note: Pyranometers (a); Data collection (b)

Source: Author (2019)

\subsection{Measurement of color}

The evaluation of the color differences and yellowing index (YE) was carried out by the ASTM standard [30], using a Spectro-Guide Sphere $\mathrm{d} / 8^{\circ}$ spin spectrophotometer with geometric dimensions of 45 circ./0, d/8. A measurement area within the range of 400-700 nm, the spectral resolution of $20 \mathrm{~nm}$, photometric area of $0-100 \%(0.01)$, and standard observer D65 with an aperture angle of $10^{\circ}$ were employed. The measuring procedure was carried out as previously described by Dantas, Vittorino, and Loh [12].

\subsection{Optical microscopy analyses}

Surface samples were obtained from the specimens and stored in plastic bags. No preparation process was carried out on the samples before to ensure the maintenance of the as-exposed state. The surface textures of the mortars and the surface $\mathrm{n}-\mathrm{TiO}_{2}$ dispersions were observed using an Eclipse electronic microscope with a 40-fold increase, a fibre optic illuminator, and a digital camera with a resolution of 3.2 megapixels.

\section{RESULTS AND DISCUSSION}

Observation of the samples over the exposure period revealed a direct relationship between the solar and luminous reflectance, rainfall incidence, and roughness of the samples. An increase in the roughness of the mortars over the exposure period was observed, which allowed for an increase in the accumulation of dirt on the specimens. In combination with the low rainfall during the first year of exposure, this resulted in a higher impregnation of the samples by dirt.

Visual inspection using an optical microscope revealed an increase in the roughness of the specimen surfaces. The images revealed that the type-B specimen exhibited a lower roughness 
than the other specimens in the early stages of the exposure period. Also, a lower rugosity can prevent impregnation and ease the removal of dirt by rainfall, resulting in an increased reflectance under exposure to solar and luminous radiation. However, this is not observed after twenty-four months of exposure, when the acrylic film exhibited degradation, allowing for increased accumulation of dirt on the surfaces of type-B specimens. Figure 3 presents the surfaces of the mortars.

Figure 3. The surface roughness of specimens

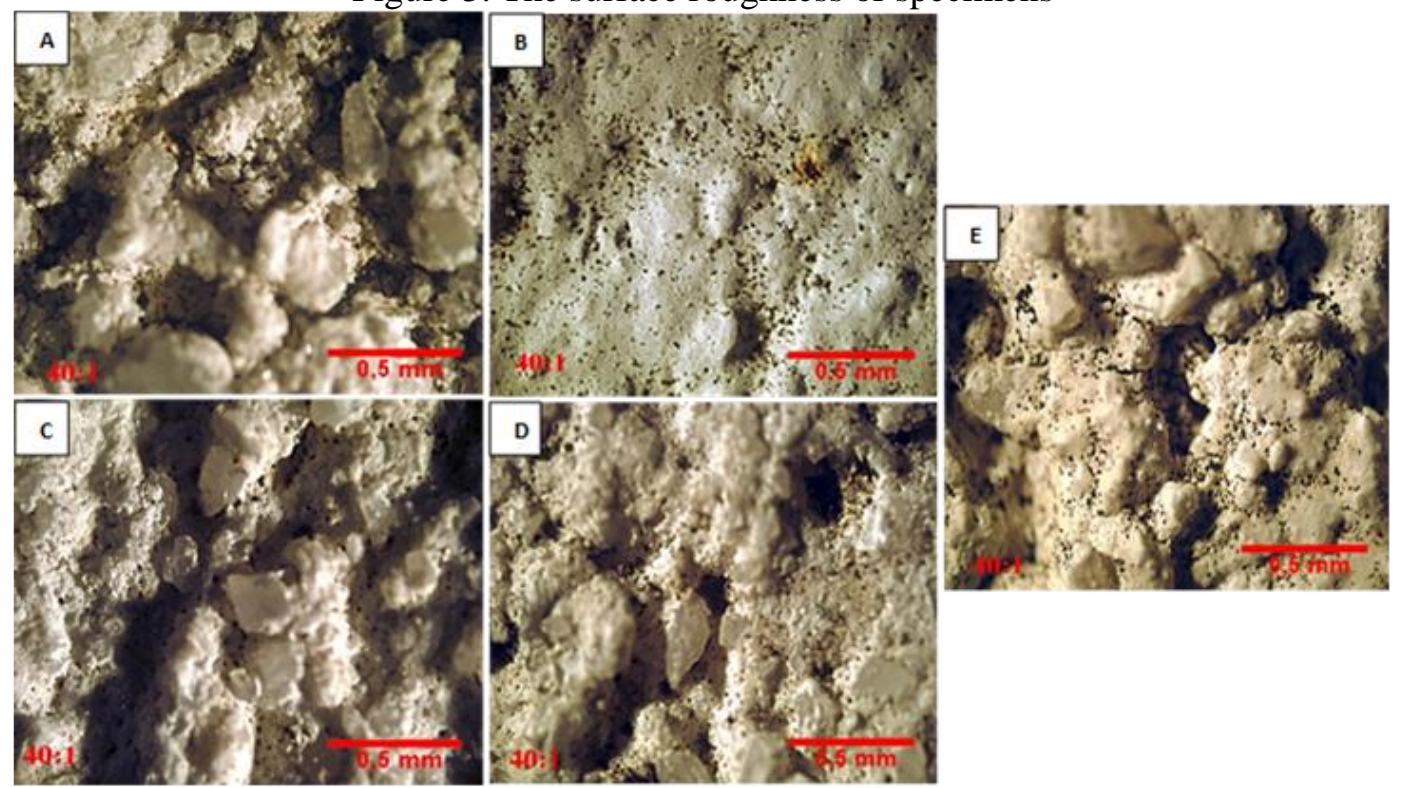

Source: Author (2019)

\subsection{Solar reflectance results}

The mortars exhibited similar behaviors concerning solar radiation reflectance. Therefore, the results for each mortar evaluated can be presented concerning the mean reflectance, as suggested by Dantas, Vittorino, and Loh [12] and Dantas and Vittorino [31].

Figure 4 presents the mean (average of three values of each sample) reflectance of the specimens over the forty-one months of exposure to the urban environment. Figures 5 and 6 present the total global solar radiation incident on the horizontal surfaces and the total monthly rainfall in São Paulo, respectively. 
Figure 4. Mean reflectance of mortars after forty-one months of exposure to an urban environment

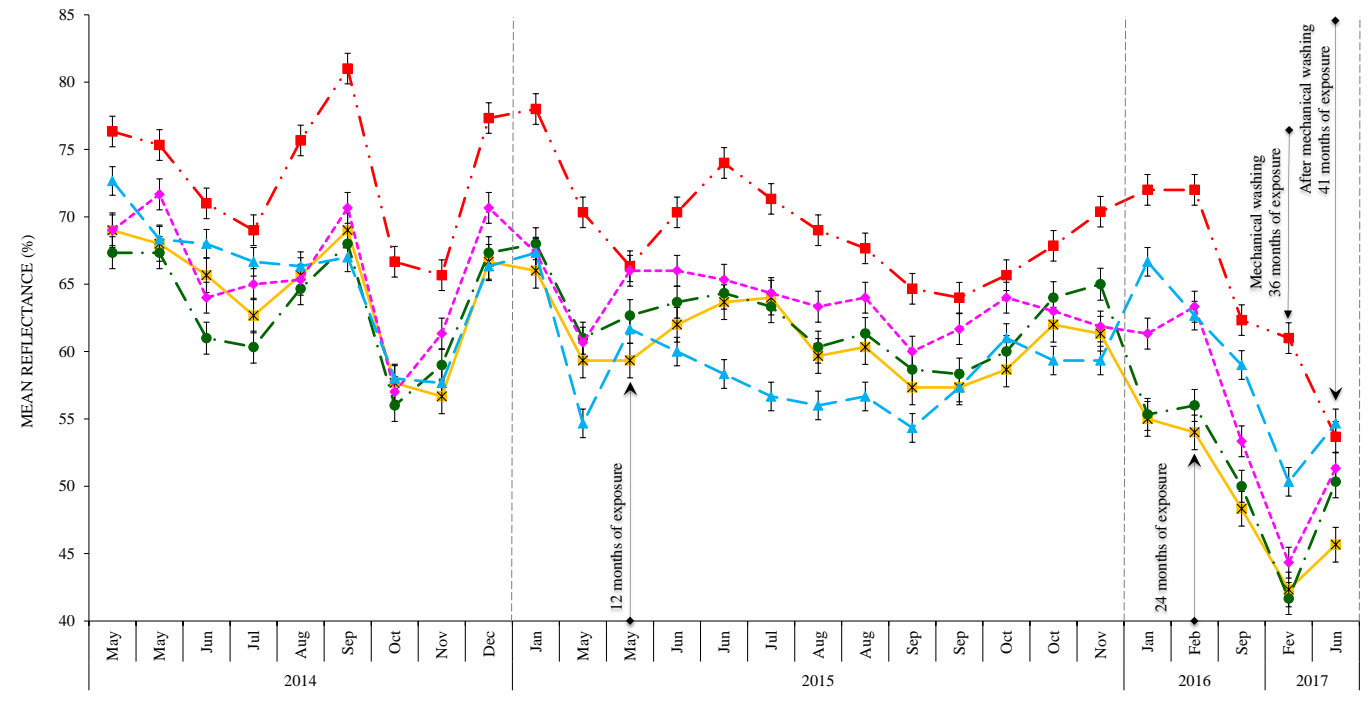

Source: Author (2019)

Figure 5. Solar radiation on horizontal surfaces in São Paulo city

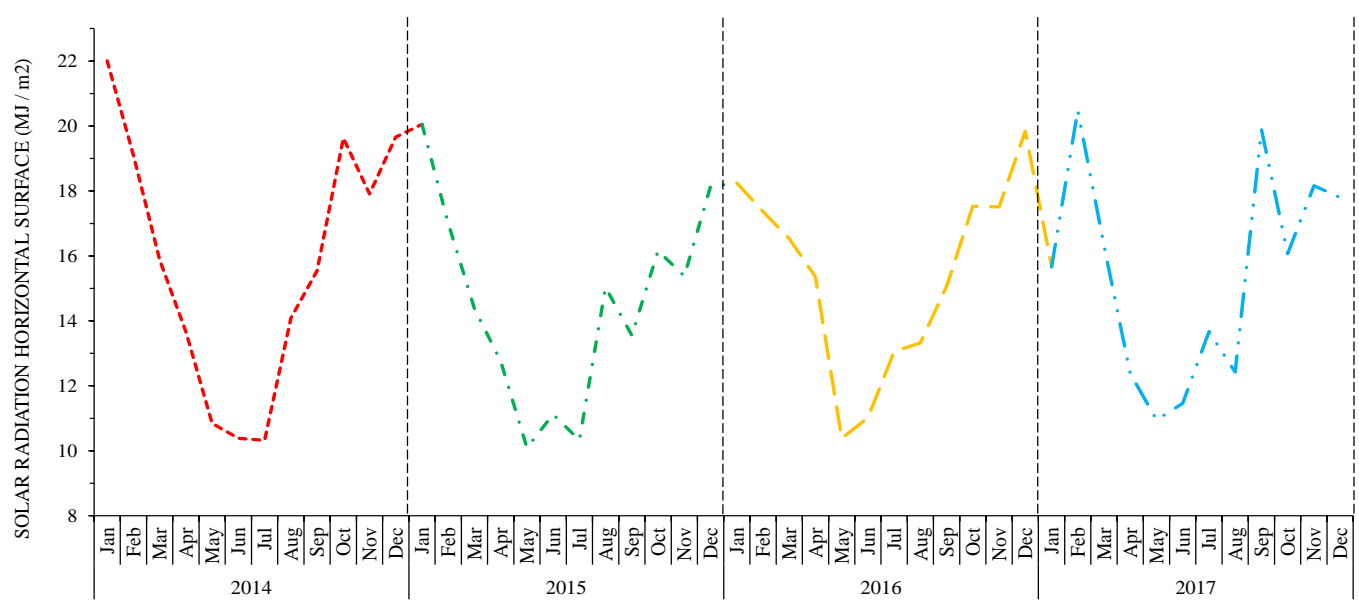

Source: Institute of Astronomy, Geophysics and Atmospheric Sciences (2019)

Figure 6. São Paulo city monthly rainfall

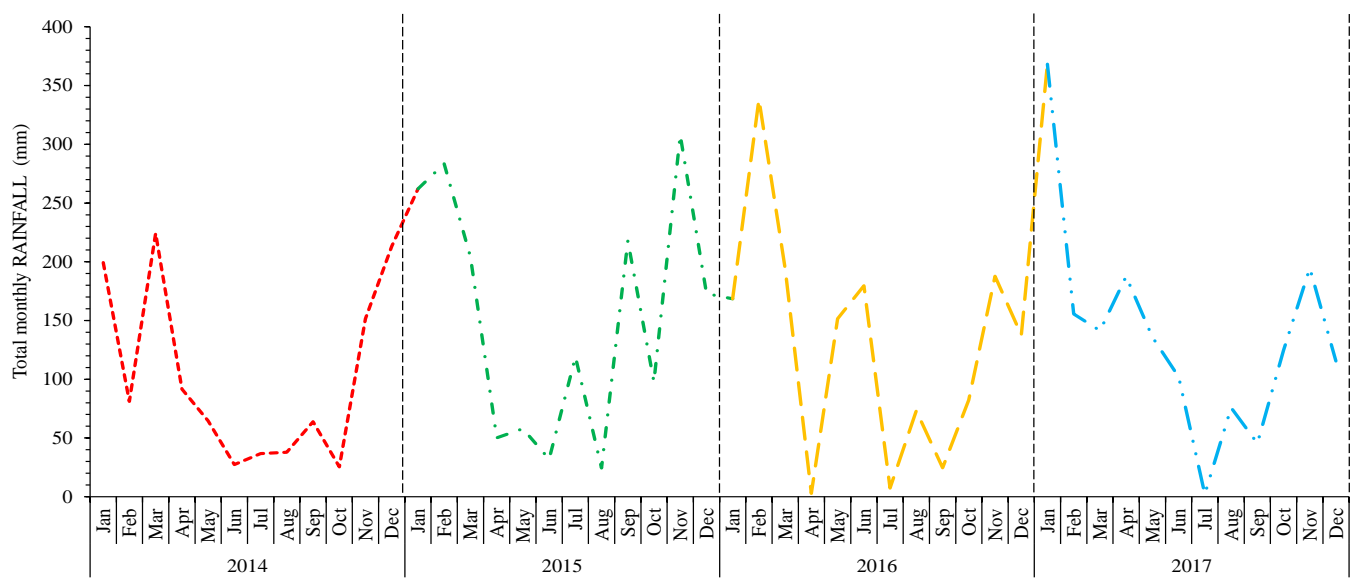

Source: Institute of Astronomy, Geophysics and Atmospheric Sciences / National Institute of Meteorology (2019) 
During the first twelve months of exposure, type-B specimens exhibited a noticeable high reflectance, given that the acrylic paint did not exhibit degradation. Moreover, no marked differences are observed among the reflectance results of the other mortar groups, which could be considered to have equal values. For type-A mortar, a decrease in reflectance was expected due to the natural aging process, which results from the accumulation of dirt. For types $\mathrm{C}, \mathrm{D}$, and $\mathrm{E}$, their initial reflectance values were expected to remain stable for a more extended period. Also, the slight differences observed between their reflectance values were due to the different $\mathrm{n}-\mathrm{TiO}_{2}$ contents. However, after one year of exposure, this behavior was not noticed because of the lack of rainfall and high impregnation of the specimen surfaces by dirt.

After twelve months, type-E mortars exhibited a decrease in reflectance under exposure to solar radiation compared with the other mortars. This difference remained significant until the $16^{\text {th }}$ month of exposure. However, with a longer exposure time, an essential difference in the behavior of the mortars was observed. The increase in reflectance from September (2015) to October (2015) was related to the high rainfall that occurred during this period (Figure 6) and the increase in solar radiation (Figure 5) associated with the beginning of the spring season. These two factors contributed to the cleaning of the specimen surfaces and increased photocatalytic activity during this period.

From October (2015) to January (2016), the seasonal changes caused mortars variation. At the beginning of the summer season, there was an increase in the incidence of solar radiation and a decrease in rainfall. Because of this, different effects occurred on the mortar's surfaces, which can be attributed to the variation of precipitation, the surface's roughness, and their levels of dirt impregnation.

In the second year (2016), considerable differences in the reflectance values under exposure to solar radiation were observed in all specimens. From February 2016 to February 2017, the mortars exhibited a continuous and significant decrease in reflectance. This behavior can be attributed to the low rainfall over these two years, impregnating the specimen surfaces with dirt.

In the third year (2017), a significant decrease was observed in reflectance values under exposure to solar radiation in all the specimens. Over the three years of exposure, apart from the type-B sample, all the mortars exhibited a higher impregnation by dirt, which limited the photocatalytic activity. After that, the samples were cleaned using a washing machine to 
reproduce the process commonly employed for cleaning building facades. Figure 7 presents some examples before and after the washing.

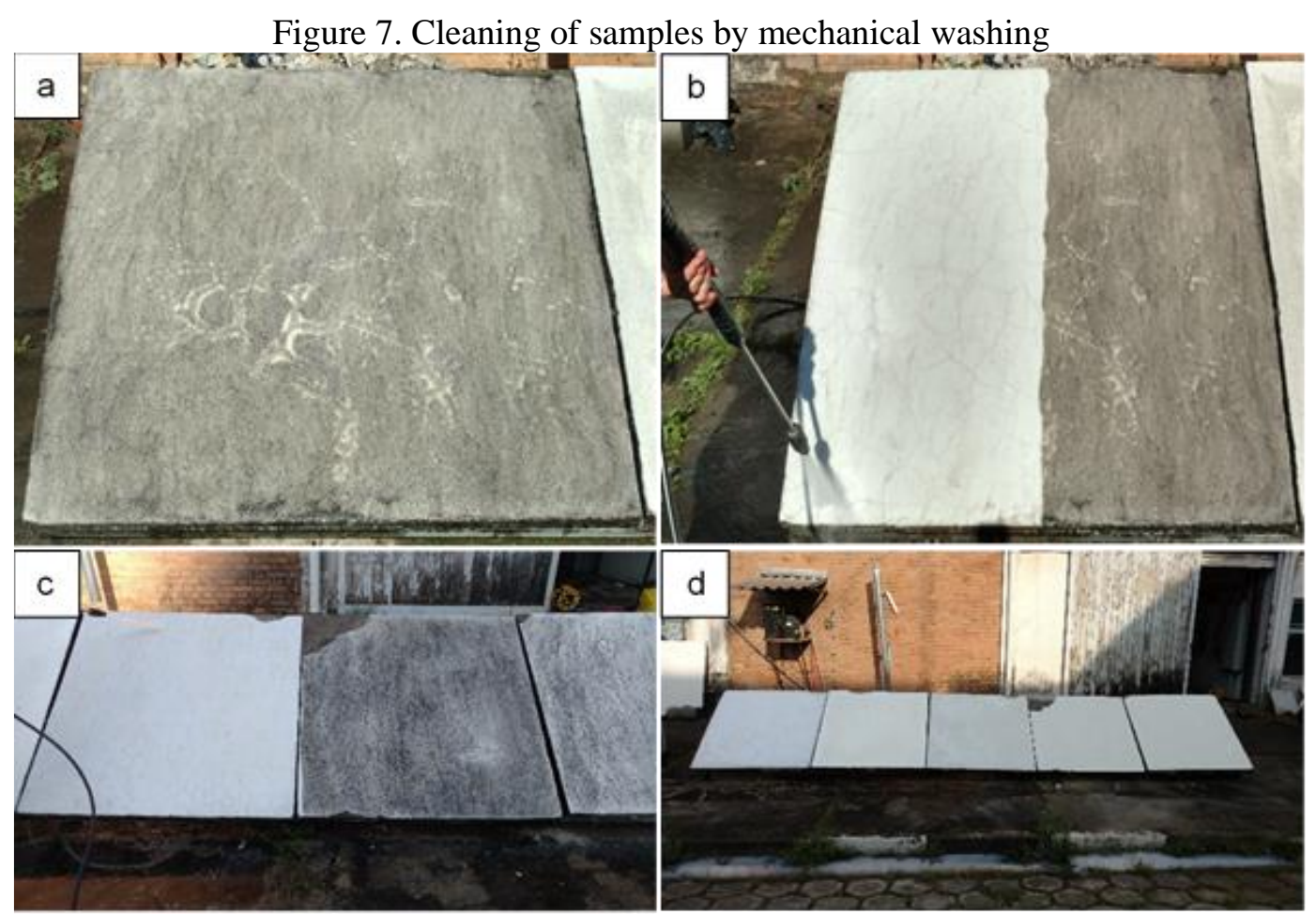

Note: Before washing (a); During washing (b); Difference between specimens (c); After washing (d). Source: Author (2019)

After washing ( $41^{\text {st }}$ month) and a short exposure period, a reflectance measurement was carried out. The main objective was to verify the restoration of the photocatalytic activity and the initial color. The final measurement, after the washing, revealed that the reflectance of type-B specimens under exposure to solar radiation is not restored. This loss of reflectance under exposure to solar radiation can be attributed to the degradation of the paint film, which resulted in the exposure of the mortar to a higher impregnation by dirt. Nevertheless, after washing, all the other mortars exhibited a restoration concerning their reflectance under exposure to solar radiation.

The addition of different $\mathrm{n}-\mathrm{TiO}_{2}$ contents to the mortars did not result in statistical differences between reflectance characteristics under exposure to solar radiation after washing. These results reveal that the mortars' photocatalytic process's effectiveness is not dependent on the added $\mathrm{n}-\mathrm{TiO}_{2}$ content.

\subsection{Color change results}

To evaluate the white color, the CIE $\mathrm{L}^{*} \mathrm{a} \mathrm{b}^{*}$ components $(\Delta \mathrm{L} / \Delta \mathrm{a} / \Delta \mathrm{b})$ are individually considered for a better perception of the changes in the shades of the mortars. The 
components were calculated using simple arithmetic differences. Figure 8 presents the initial values and the differences between the colors at the beginning of exposure and after forty-one months of exposure, following the washing of the specimens.

Figure 8. Changes in the color of mortars by CIE L*a*b*
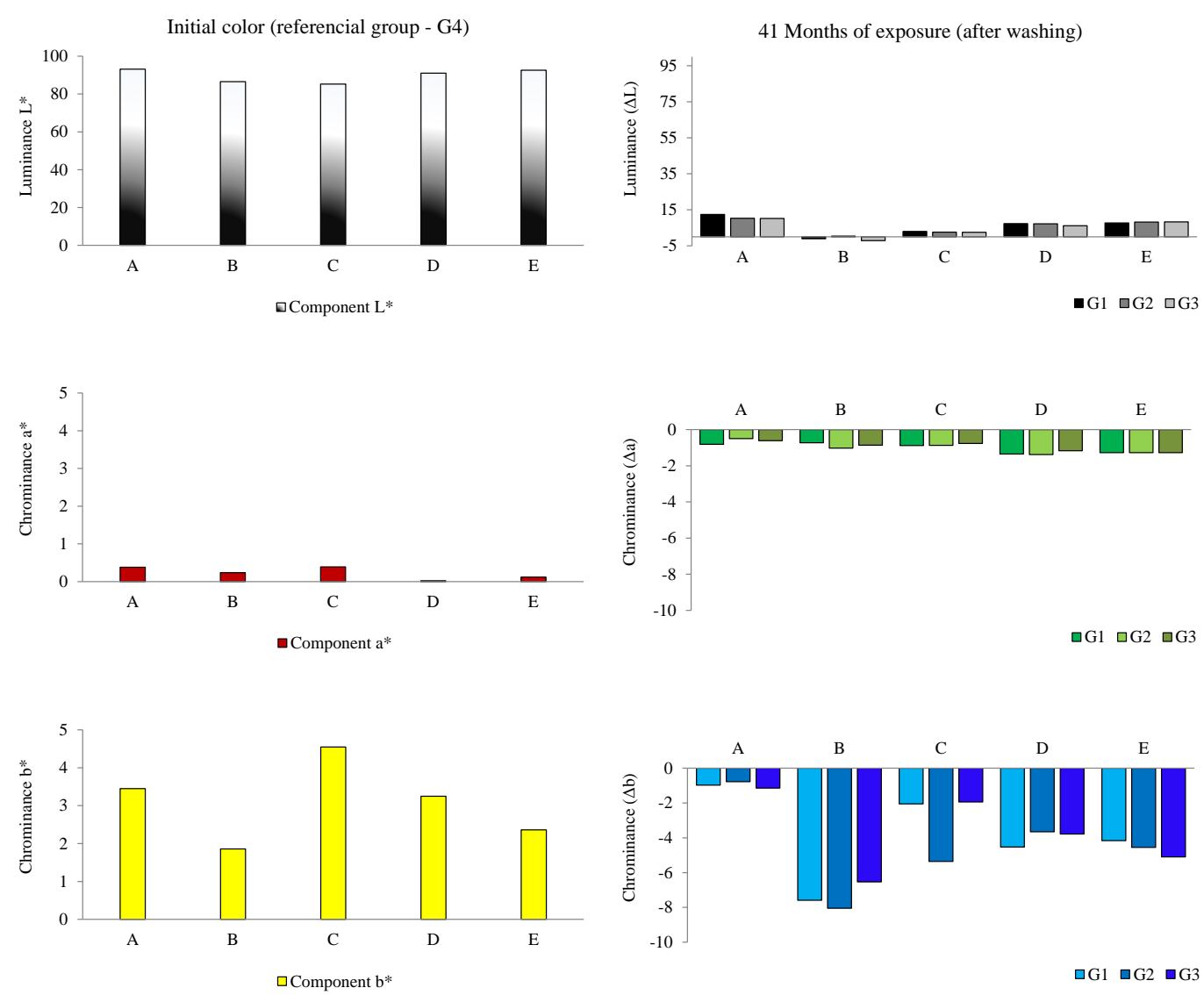

Source: Author (2019)

After forty-one months of exposure and washing, significant differences between the luminance $(\Delta \mathrm{L})$ values of type-B and type-C mortars are not observed. Type-A, type-D, and type-E mortars exhibited more noticeable differences in color concerning luminance $(\Delta \mathrm{L})$. This behavior is expected for type-A mortars, which were not subject to pre-treatment (e.g., painting or water repellent), thus allowing for a higher deposition of dirt on the surface.

The photocatalytic activity was expected to be more effective for the type-D and type-E mortars because of the higher levels of $\mathrm{n}-\mathrm{TiO}_{2}$ contents used in the mixtures. However, no differences were observed between the mortars concerning luminance $(\Delta \mathrm{L})$, which indicates that an increase in the added $\mathrm{n}-\mathrm{TiO}_{2}$ content does not influence the photocatalytic activity. Besides, the incidence of solar radiation and the amount of rainfall on the specimens impact photocatalytic activity. As previously highlighted, the ineffectiveness of the photocatalytic activity can connect to (i) the increased accumulation of dirt on the specimen surfaces; (ii) 
increases in the surface roughness of the mortars, and (iii) the impact of $\mathrm{n}-\mathrm{TiO}_{2}$ nondispersion that resulted in the formation of agglomerates, as shown in Figure 9.

Figure 9. n- $\mathrm{TiO}_{2}$ agglomerates of E-type mortars

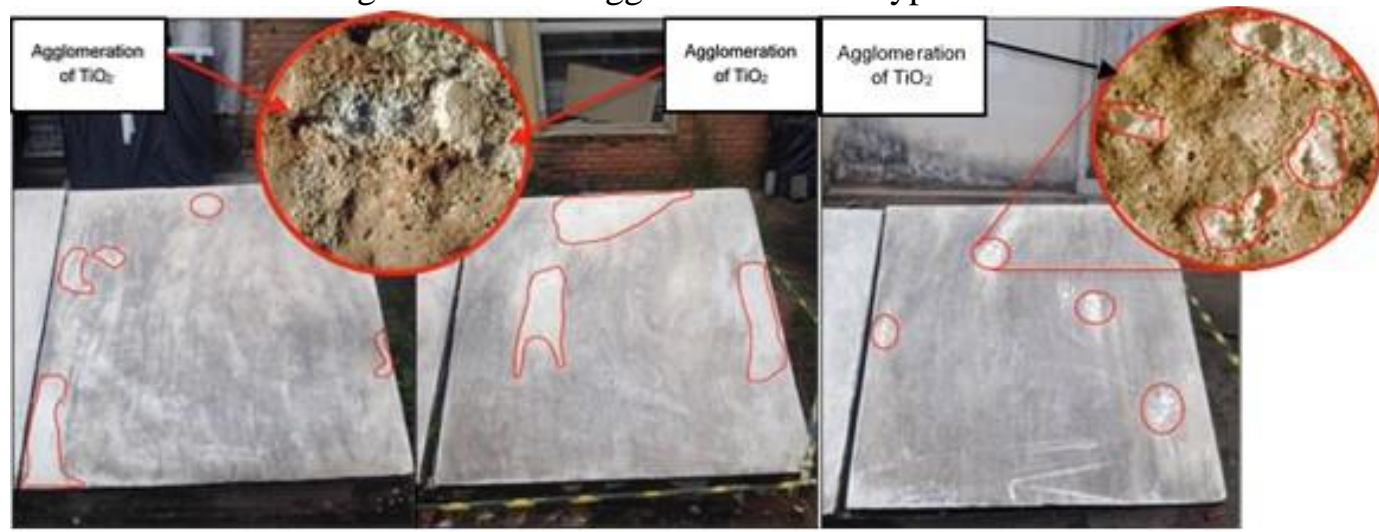

Source: Author (2019)

The evaluation of the luminance $(\Delta \mathrm{L})$ observes a significant color difference between type-B and type- $\mathrm{A}$ (unpainted and without $\mathrm{n}-\mathrm{TiO}_{2}$ ), type-D, and type-E mortars (higher $\mathrm{n}-\mathrm{TiO}_{2}$ content). When compared with type-C mortar (low $\mathrm{n}-\mathrm{TiO}_{2}$ content), no observed marked color differences. Moreover, concerning the chrominance components ( $\Delta \mathrm{a}$ and $\Delta \mathrm{b}$ ), color differences were observed in all mortars.

From the evaluation of the $\Delta \mathrm{a}$ component (green and red), no noticeable color differences were observed between all mortars. These results indicated that there were no significant differences between type-B specimens and the other mortars to this chromatic component. The $\Delta \mathrm{b}$ component (blue and yellow) exhibited the most significant color differences. Is observed marked differences in type-B specimens, which were in good agreement with the reflectance measurements under exposure to solar radiation, due to the degradation of the acrylic resin in the paint composition.

In general, type-A mortars exhibited the least significant difference concerning chrominance. This behavior is associated with the high deterioration of specimen A1, which led to the displacement of the mortar, thus altering the general data.

Among the mortars with the added $\mathrm{n}-\mathrm{TiO}_{2}$ contents, type- $\mathrm{C}$ mortar exhibited the slightest significant color difference, whereas type-D and type-E mortars exhibited the same degree of color difference, which was more significant than that of type-C mortar.

Thus, concerning the difference of color (measured according to CIE L*a*b* scale), differences in the chromatic components of the mortars were observed upon evaluation after forty-one months of exposure, following the washing, as shown in Figure 8. 
a) Type-A mortars exhibited more significant color perception differences concerning luminance $(\Delta \mathrm{L})$ and lower chrominance $(\Delta \mathrm{a}$ and $\Delta \mathrm{b})$.

b) Type-B specimens exhibited less significant color perception differences concerning luminance $(\Delta \mathrm{L})$ and more considerable color perception differences concerning the chrominance component $\Delta \mathrm{b}$. Moreover, no observes significant color perception differences concerning the chrominance component $\Delta \mathrm{a}$.

c) Type-C mortars exhibited less significant color perception differences than type-B specimens concerning luminance $(\Delta \mathrm{L})$. Moreover, a less significant color difference was observed in the chrominance component $\Delta \mathrm{b}$ with type-D and type-E mortars. No watches significant color differences in the chrominance component $\Delta \mathrm{a}$.

d) Type-D and type-E mortars exhibited more significant color perception differences concerning the luminance $(\Delta \mathrm{L})$ and the chrominance component $\Delta \mathrm{b}$. However, no one observes the considerable color difference in the chrominance component $\Delta \mathrm{a}$.

The yellowing index (YE) determined by the spectrophotometer (Figure 10) was higher for type-B specimens than others. The yellowing of the specimens was also observable using the naked eye when compared with other white-color surfaces. This change was due to the degradation of the acrylic film of the paint over the long-term exposure.

Figure 10. Yellowing index (YE) by CIE L*a*b*

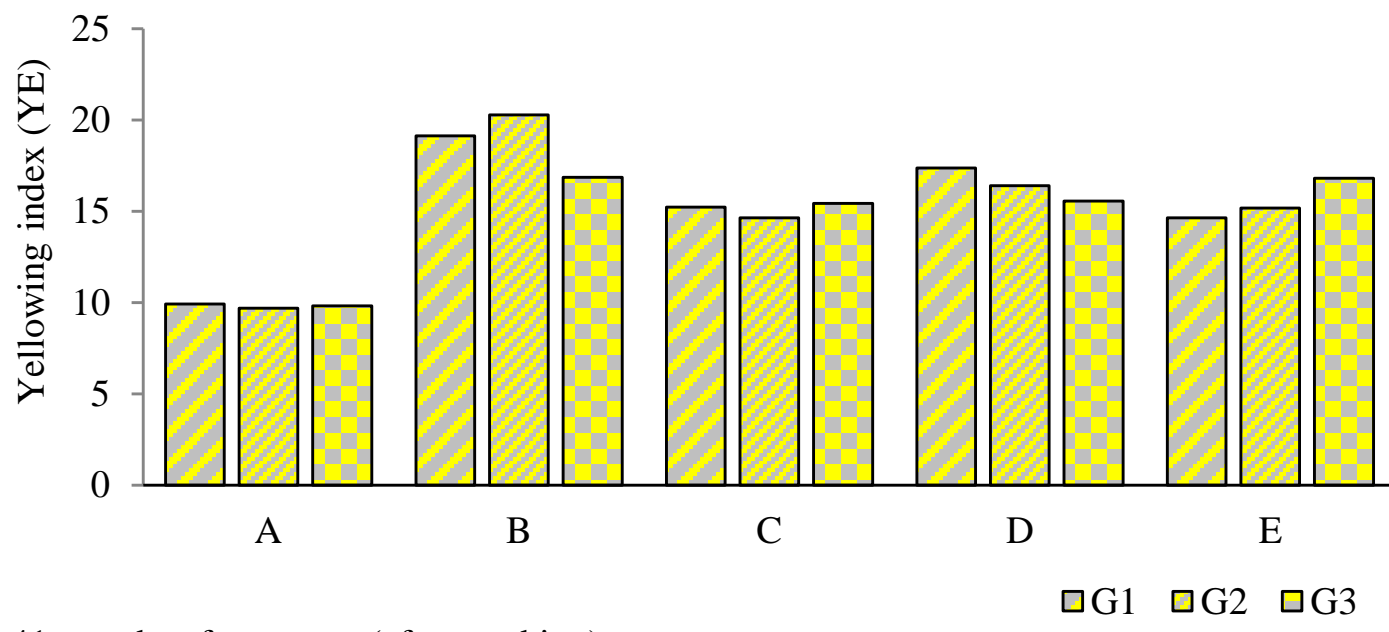

Note: 41 months of exposure (after washing)

Source: Author (2019)

It is reasonable to use $\Delta \mathrm{E}$ as a measure the difference between the visual appearances of two given colors. Although the results indicated by $\Delta \mathrm{E}$ can be used to determine color differentiation, this should only be considered a general guide since it is possible to obtain a $\Delta \mathrm{E}$ value of less than 1.0 for two colors that appear different. 
The definition of $\Delta \mathrm{E}$ differs slightly depending on the formula used, indicating that it may not always be reliable. Hence, observations made by the human eye may be required to verify the final answer, and more significantly, to provide a delimitation of the acceptable minimum and maximum limits for a specific application.

Considering that human eyes are more sensitive to luminance than chrominance, it may appear as though a surface has lost luminance $(\Delta \mathrm{L})$, when it has instead lost chrominance $(\Delta \mathrm{a}$ and $\Delta \mathrm{b}$ ), which ranges from green to red or blue to yellow colors, resulting from the presence of fungi or soot.

After washing, all the specimens exhibited white color surfaces, in the observation by the naked eye. However, compared with the colors, in the beginning, different shades were observed for the specimens. Considering that the perception of color change is intrinsically subjective and dependent on the personal judgment of each observer, the perception of the white color is exclusively dependent on the type of lighting in which the surfaces are evaluated and the intensity of the light. The specimens were exposed to an urban environment, which implies variations in the observer's visual perception concerning the time of day, degree of occurrence, and amount of rainfall during the surface evaluation. However, the spectrophotometer indicates the same color, independent of the weather conditions. Figure 11 presents the differences in the color perceptions of the mortars at the beginning $\left(t=1^{\text {st }}\right.$ month) and end ( $\mathrm{t}=41^{\text {st }}$ month $)$ of the exposure period.

This differentiation is associated with two factors, as follows.

a) The chromatic components $(\Delta \mathrm{a}$ and $\Delta \mathrm{b})$ contributed significantly to the results obtained using the spectrophotometer, as the loss of the initial white color.

b) The light is reflected by the surface of the specimens, which results in a phenomenon referred to as metamerism. Because of the limitations of the spectrophotometer, this phenomenon was not detected using the equipment. 
Figure 11. Color perception of specimens

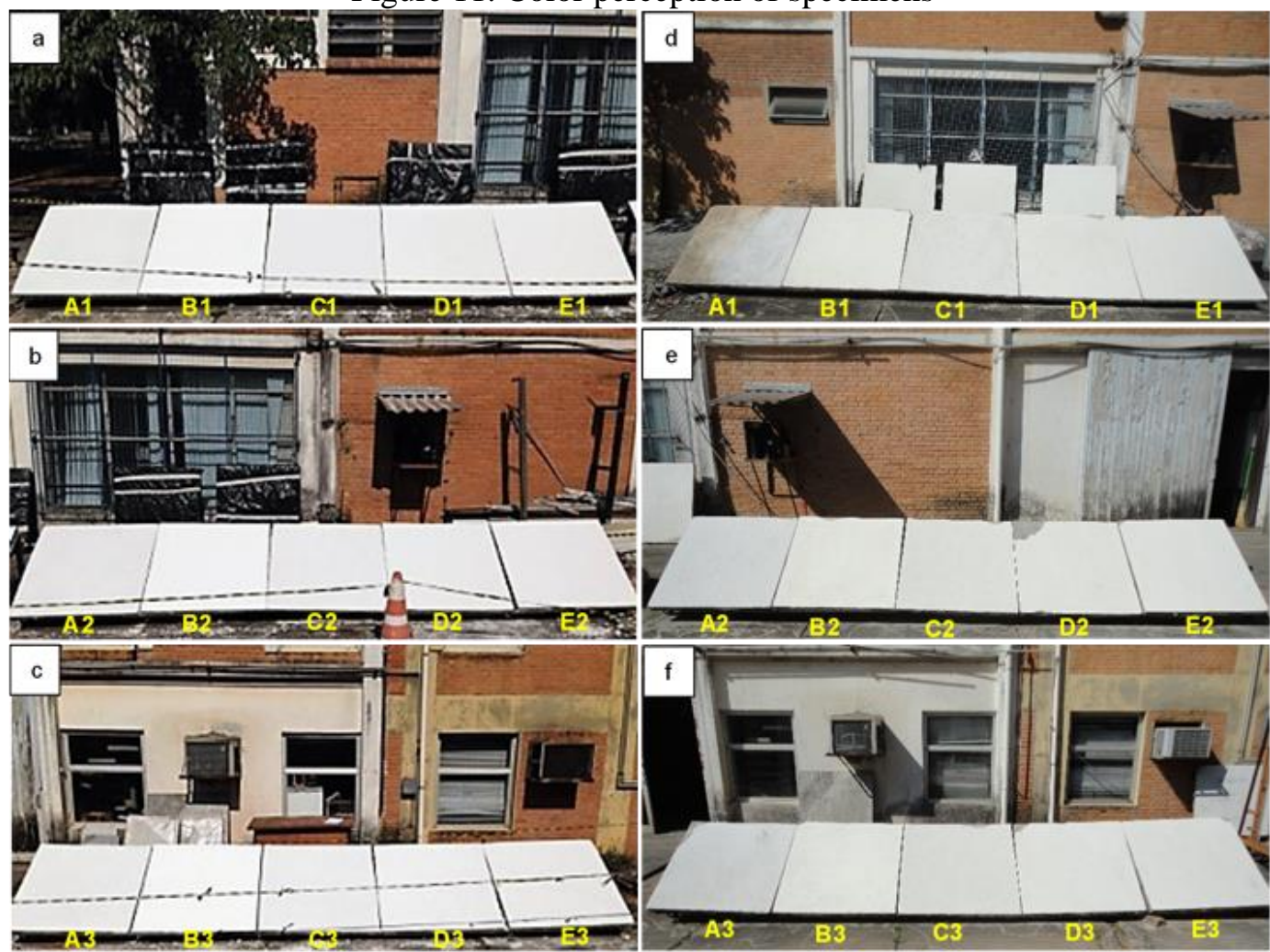

Note: $1^{\text {st }}$ month (a, b, and c); $41^{\text {st }}$ month $(\mathrm{d}, \mathrm{e}$, and $\mathrm{f})$

Source: Author (2019)

\section{CONCLUSIONS}

The use of specimens with larger sizes $(1.2 \mathrm{~m} \times 1.2 \mathrm{~m})$ facilitated the analysis of the photocatalytic effect with $\mathrm{n}-\mathrm{TiO}_{2}$ and the color differences. It was possible to observe the influences that are generally unobservable when small specimens are employed; such as the influence of the mason during the application, the in-situ mixing process, the pollution in the accumulation of dirt, and the heterogeneity of the specimens, which typically occurs during the application of mortars.

The results obtained in this study, therefore, revealed the following.

After three years, the mortars with higher $\mathrm{n}-\mathrm{TiO}_{2}$ contents exhibited a reflectance statistically equivalent to that of the other mortars under exposure to solar radiation. This indicates that the effectiveness of the photocatalytic mortars is not dependent on the added $\mathrm{n}-\mathrm{TiO}_{2}$ content.

$>$ Concerning the color differences (measured according to the CIE L*a*b* scale), there was a significant difference between the luminance $(\Delta \mathrm{L})$ of type-B specimens (painted and without $\mathrm{n}-\mathrm{TiO}_{2}$ ) and those of type-A (unpainted and without $\mathrm{n}-\mathrm{TiO}_{2}$ ), type- $\mathrm{D}$, and type-E (higher $\mathrm{n}-\mathrm{TiO}_{2}$ content) mortars. Concerning type-C mortars (low n- $\mathrm{TiO}_{2}$ 
content), no observes significant color differences. However, it observes increased color differences in all specimens about the chrominance components $(\Delta \mathrm{a}$ and $\Delta \mathrm{b})$.

$>$ The rugosity of the surfaces and the rainfall indices influenced the self-cleaning effect throughout the study.

A vital thing observed is that the evaluations carried out within a short period of exposure to an urban environment did not reveal the effectiveness of the added n- $\mathrm{TiO}_{2}$. So, higher exposure time is necessary to determine the differences concerning the maintenance of the initial conditions of the mortars with added $\mathrm{n}-\mathrm{TiO}_{2}$ contents compared with the painted mortars. 


\section{REFERENCE}

[1] R. Levinson, P. Berdahl, H. Akbari, "Solar spectral optical properties of pigments - Part II: Survey of common colorants," Sol. Energy Mater. Sol. Cells, vol. 89, pp. 351-389, 2005.

[2] R. Levinson et al., "Methods of creating solar-reflective nonwhite surfaces and their application to residential roofing materials," Sol. Energy Mater. Sol. Cells, vol. 91, pp. 304314, 2007.

[3] A. Synnefa, M. Santamouris, K. Apostolakis, "On the development, optical properties and thermal performance of cool colored coatings for the urban environment," Sol. Energy, vol. 81, pp. 488-497, 2007.

[4] E. S. Cozza, M. Alloisio, A. Comite, G. Di Tanna, S. Vicini, "NIR-reflecting properties of new paints for energy-efficient buildings," Sol. Energy, vol. 116, pp. 108-116, 2015.

[5] F. Rossi, A. L. Pisello, A. Nicolini, M. Filipponi, M. Palombo, "Analysis of retroreflective surfaces for urban heat island mitigation: A new analytical model," Appl. Energy, vol. 114, pp. 621-631, 2014.

[6] F. Rossi et al., "Retroreflective facades for urban heat island mitigation: Experimental investigation and energy evaluations," Appl. Energy, vol. 145, pp. 8-20, 2015.

[7] R. Levinson, H. Akbari, "Potential benefits of cool roofs on commercial buildings: Conserving energy, saving money, and reducing emission of greenhouse gases and air pollutants," Energy Effic., vol. 3, pp. 53-109, 2010.

[8] A. L. Pisello, F. Rossi, F. Cotana, "Summer and winter effect of innovative cool roof tiles on the dynamic thermal behavior of buildings," Energies, vol. 7, pp. 2343-2361, 2014.

[9] M. Zinzi, S. Agnoli, "Cool and green roofs. An energy and comfort comparison between passive cooling and mitigation urban heat island techniques for residential buildings in the Mediterranean region,” Energy Build., vol. 55, pp. 66-76, 2012.

[10] P. J. Rosado, D. Faulkner, D. P. Sullivan, R. Levinson, "Measured temperature reductions and energy savings from a cool tile roof on a central California home," Energy Build., vol. 80, pp. 57-71, 2014.

[11] M. Santamouris, "Cooling the cities - A review of reflective and green roof mitigation technologies to fight heat island and improve comfort in urban environments," Sol. Energy, vol. 103, pp. 682-703, 2014.

[12] S. R. A. Dantas, F. Vittorino, K. Loh, "The effectiveness of $\mathrm{TiO}_{2}$ additions to mortar to maintain initial conditions in terms of its reflectance to solar radiation," Ambiente Construído, vol. 17, pp. 39-56, 2017.

[13] P. Ikematsu, Reflectance study and its influence on the thermal behavior of corresponding reflective and conventional coloring inks. Dissertation (Master's in science), 134 f, São Paulo University, 2007 [in Portuguese]. 
[14] M. V. Diamanti, B. Del Curto, M. Ormellese, M. P. Pedeferri, "Photocatalytic and selfcleaning activity of colored mortars containing $\mathrm{TiO}_{2}$," Constr. Build. Mater., vol. 46, pp. 167-174, 2013.

[15] M. V. Diamanti et al., "Long term self-cleaning and photocatalytic performance of anatase added mortars exposed to the urban environment," Constr. Build. Mater., vol. 96, pp. 270-278, 2015.

[16] A. P. Werle, M. L. De Souza, K. Loh, R. Ando, and V. M. John, "The performance of a self-cleaning cool cementitious surface,” Energy Build., vol. 114, pp. 200-205, 2016.

[17] A. Fujishima, T. N. Rao, D. A. Tryk, "Titanium dioxide photocatalysis,” J. Photochem. Photobiol. C Photochem. Rev., vol. 1, pp. 1-21, 2000.

[18] L. Cassar, C. Pepe, G. Tognon, G. L. Guerrini, R. Amadelli, "White Cement for Architectural Concrete, Possessing Photocatalytic Properties," 11th Int. Congr. Chem. Cem., pp. 2012-2021, 2003.

[19] K. V. S. Rao, M. Subrahmanyam, P. Boule, "Immobilized $\mathrm{TiO}_{2}$ photocatalyst during long-term use: Decrease of its activity," Appl. Catal. B Environ., vol. 49, pp. 239-249, 2004.

[20] M. D. Gurol, "Photo-Catalytic Construction Materials and Reduction in Air Pollutants," 2006.

[21] C. S. Poon, E. Cheung, "NO removal efficiency of photocatalytic paving blocks prepared with recycled materials," Constr. Build. Mater., vol. 21, pp. 1746-1753, 2007.

[22] M. V. Diamanti, M. Ormellese, M. Pedeferri, "Characterization of photocatalytic and superhydrophilic properties of mortars containing titanium dioxide," Cem. Concr. Res., vol. 38, pp. 1349-1353, 2008.

[23] J. Chen, C. sun Poon, "Photocatalytic construction and building materials: From fundamentals to applications,” Build. Environ., vol. 44, pp. 1899-1906, 2009.

[24] A. Folli, C. Pade, T. B. Hansen, T. De Marco, D. E. MacPhee, "TiO 2 photocatalysis in cementitious systems: Insights into self-cleaning and depollution chemistry," Cem. Concr. Res., vol. 42, pp. 539-548, 2012.

[25] S. S. Lucas, V. M. Ferreira, J. L. B. De Aguiar, "Incorporation of titanium dioxide nanoparticles in mortars - Influence of microstructure in the hardened state properties and photocatalytic activity," Cem. Concr. Res., vol. 43, pp. 112-120, 2013.

[26] P. Krishnan, M. H. Zhang, L. Yu, H. Feng, "Photocatalytic degradation of particulate pollutants and self-cleaning performance of $\mathrm{TiO}_{2}$-containing silicate coating and mortar," Constr. Build. Mater., vol. 44, pp. 309-316, 2013.

[27] S. R. A. Dantas, R. Serafini, R. C. de O. Romano, F. Vittorino, K. Loh, "Influence of the nano $\mathrm{TiO}_{2}$ dispersion procedure on fresh and hardened rendering mortar properties," Constr. Build. Mater., vol. 215, pp.544-556, 2019. 
[28] ASTM E1918-16, "Standard Test Method for Measuring Solar Reflectance of Horizontal and Low-Sloped Surfaces in the Field," ASTM Int., vol. i, pp. 18-20, 2016.

[29] ANSI/ASHRAE 74, "Method for measuring solar optical properties of materials, procedure E".1988.

[30] ASTM D2244-16, "Standard Practice for Calculation of Color Tolerances and Color Differences from Instrumentally Measured Color Coordinates," ASTM Int., p. 12, 2016.

[31] DANTAS, S. R. A. The efficacy of $\mathbf{T i O}_{2}$ addition to mortars in maintaining the initial conditions in terms of their reflectance to solar radiation. $2016.137 \mathrm{f}$. Dissertation (Professional Master's Degree) - Housing Course: Planning, Management and Project, Technological Research Institute of the State of São Paulo - IPT, São Paulo, 2016 [In Portuguese]. 


\title{
APPENDIX B - INFLUENCE OF POLYPROPYLENE MICROFIBRE (PPMF) DISPERSION PROCEDURE ON FRESH AND HARDENED RENDERING MORTAR $^{5}$ (Article B)
}

\begin{abstract}
This study was carried out to evaluate the influence of a polypropylene microfibre (PPMF) dispersion procedure on fresh and hardened state properties of rendering mortars. Specimens prepared with two different PPMF dispersion procedures were evaluated comparatively with reference specimens prepared without adding PPMF. Changes in the fresh properties were monitored using flow table, squeeze flow, and air-entrainment tests. The hardened state was characterized by capillary water absorption, air-permeability, dynamic elastic modulus (E), tensile strength according to the Brazilian test, and porosity by the Archimedes immersion method. Results show that the fresh mortar properties were not affected by dispersion procedure, and all hardened mortar properties were statistically similar, except for the dimensional variation of the specimens. The study also shows that adding polypropylene microfibres in a dispersed form was more effective in terms of controlling total drying shrinkage than directly adding fibres to the cementitious matrix (as recommended by the manufacturer) or the reference mortar.
\end{abstract}

Keywords: Polypropylene microfibre. Dispersion procedure. Drying shrinkage. Rendering mortars. Facade degradation process.

\footnotetext{
${ }^{5}$ Dantas, S. R. A., Serafini, R., Romano, R. C. de O., Vittorino, F., Loh, K. Influence of polypropylene microfibre (PPMF) dispersion procedure on fresh and hardened rendering mortar properties. Ambiente Construído, Porto Alegre, v. 20, n. 2, p. 7-23, abr./jun. 2020. 


\section{$1 \quad$ INTRODUCTION}

Facade finishing entails protective layers that enhance the durability and service life of a building. Therefore, their characteristics must be maintained over time to attend minimum performance levels required by regulations. It is well documented that fibres improve many properties of mortars, including tensile strength, flexural strength, thermal shock strength, toughness, and can reduce drying shrinkage (ŞANAL; ÖZYURT; HOSSEINI, 2016; GESOGLU et al., 2016; YOUSEFIEH et al., 2017; AFROUGHSABET; BIOLZI; MONTEIR, 2018; GUO; YANG; GAO, 2019). In this context, controlling properties such as modulus of elasticity, mechanical properties, permeability, water absorption, and retraction is extremely important to meet design requirements so that coatings last over time.

As soon as a mortar is applied on a facade, a continuous degradation process begins and will last during the entire service life of the element. The first manifestation is the presence of dirt spots and cracks, generally attributed to dimensional changes which, over time, may lead to overlapping deterioration mechanisms. Depending on the environmental characteristics, anomalies can occur due to loss of adhesion, leading to detachments because of the loss of cohesion (GASPAR; BRITO, 2010).

Rendering mortars are exposed to a permanent state of tension during their service life since they have a large area over volume ratio and can be applied in different kinds of substrates under distinct environmental conditions. Therefore, factors of formulation (e.g., aggregates, pastes, thickness of the mortar layer), and external factors such as environmental conditions, mixing procedure, application, and curing conditions can affect the development of hardened state properties and performance in conditions of use (BASTOS, 2001 ${ }^{6}$ apud SILVA; CAMPITELI, 2008).

Among these factors, porosity can be highlighted. This property significantly influences the hardened properties and is intrinsically linked to composition, application procedures, and curing processes. According to Toledo Filho et al. $\left(2005^{7}\right.$ apud ALY; SANJAYAN; COLLINS, 2008), the higher drying shrinkage observed in matrix incorporating fibres was

\footnotetext{
${ }^{6}$ BASTOS, P. K. X. Retração e desenvolvimento de propriedades mecânicas de argamassas mistas de revestimento. São Paulo, 2001. 172 f. Tese (Doutorado em Engenharia da Construção Civil e Urbana) Programa de Pós-Graduação em Engenharia Civil, Escola Politécnica, Universidade de São Paulo, São Paulo, 2001.

${ }^{7}$ TOLEDO FILHO, R. D. et al. Free, restrained and drying shrinkage of cement mortar composites reinforced with vegetable fibres. Cement and Concrete Composites, v. 27, p. 537-546, 2005.
} 
attributed to increased porosity. Scrivener et al. (1996 apud ALY; SANJAYAN; COLLINS, 2008) reported that the tendency for pores to be connected is much higher in the vicinity of aggregate particles, which may be a similar case for PP fibres. This helps explain the higher sorptivity and the greater water loss during drying shrinkage of concretes with PP fiber.

Developing industrialized mortar coatings with air-entraining additives and water retainers based on cellulose molecules is common. Air-entraining admixtures are useful in plasticizing mixes to improve the workability of mortar and reduce the amount of mixing water. However, this addition induces the introduction of air bubbles, which, despite making the application easier, can affect some coating properties, mainly due to the increase in the porosity. Besides, a reduction in modulus of elasticity and compressive strength may also occur after the hardening process (ROMANO; TORRES; PILEGGI, 2015; SILVA et al., 2009).

The quality and durability of mortar coating are directly linked to its capacity to absorb deformations, measured by the modulus of elasticity (SILVA; CAMPITELI, 2008). The reduction of the modulus of elasticity is a beneficial factor, both for laying and wall covering. Thus, the smaller the modulus, the higher the deformation capacity of the mortar, reducing the possibility of cracking in the hardened state. Moreover, permeability is a relevant property due to its relationship with the access of aggressive agents to the substrate (QUARCIONI et al., 2011).

The mortars also present drying shrinkage over time, usually at the first ages. Shrinkage can be defined as the deformation of cementitious materials of any external mechanical solicitation in a constant thermodynamic environment. Therefore, drying shrinkage represents the numerical value of mortar deformation due to the water exchange with the external environment (ITIM; EZZIANE; KADRI, 2011).

Drying shrinkage usually depends on the volume of paste and the aggregates present in the mixture. The shrinkage intensity can also be affected by other factors as the continuity of its capillary network and density. It can be defined as the reduction in the volume of the unloaded and unrestrained element at a constant temperature, and the leading cause of such deformation is the loss of water during the drying process (ITIM; EZZIANE; KADRI, 2011; GÜNEYISI; GESOG; ÖZBAY, 2010; VALCUENDE et al., 2012; CARLSWÄRD, 2006).

\footnotetext{
${ }^{8}$ SCRIVENER, K. L.; NEMATI, K.; M. Percolation of pore space in the cement past/aggregate interfacial zone of concrete. Cement and Concrete Research, v. 26, n. 1, p. 35-40, 1996.
} 
Results presented in Altoubat and Lange (2001) showed a slight increase in shrinkage when fibrillated polypropylene fibres were added to the cement compositions, but according to Bouziadi, Boulekbache, and Hamrat (2016), the use of fibres as a reinforcing mechanism can mitigate the stresses developed upon drying. Shrinkage decreases with increasing fibre dosage in mortar compositions, in which the following organic fibres are the most used: polypropylene; polymer; nylon; palm; and straw (NILI; AFROUGHSABET, 2010), increasing the hardness and flexibility, reducing shrinkage and resisting to micro-cracks.

This study was done to show the influence of the polypropylene microfibre dispersion procedure on the properties of rendering mortars in a fresh and hardened state.

\section{EXPERIMENTAL PROGRAMME}

\subsection{Materials}

The reference mortar composition used in this work was formulated using white Portland cement (EUROPEAN..., 2000), dolomites \#20, \#40, and \#80, an air-entraining agent, and water retention agents based on cellulosic ether molecules. White Portland cement was used to produce higher reflective surfaces, later evaluated by reflectance measurements to solar radiation and colorimetry. The use of grey Portland cement could significantly influence the measurements obtained due to their coloration.

The amount of water and aggregates was kept constant in all the mixtures. Polypropylene microfibers were used. The fibre content was added, considering the total volume of material used in the mortar composition $(0.14 \%$-vol.) according to that indicated by the manufacturer to use in-situ work. The physical characteristics of Polypropylene microfibres are shown in Table 1.

Table 1 - Polypropylene microfibre specification

\begin{tabular}{lllll}
\hline \multicolumn{1}{c}{ Item } & \multicolumn{1}{c}{ Physical properties } & \multicolumn{1}{c}{ Properties } & Reference & $\begin{array}{c}\text { Permissible } \\
\text { range }\end{array}$ \\
\hline Material & $100 \% \mathrm{PP}$ & Length $(\mathrm{mm})$ & 6 & 5 to 6 \\
Type & Monofilament & Diameter (micron) & 12 & 9 to 13 \\
Colour & Natural & Diameter (dtex) & 1.1 & $\leq 1.2$ \\
Fusion point & $160^{\circ} \mathrm{C}$ & Frequency of fibers (fibers $/ \mathrm{kg})$ & - & 1.62 billion \\
Ignition point & $365^{\circ} \mathrm{C}$ & Tenacity (cN/dTex) & 10 & $\geq 9.5$ \\
Modulus of elasticity & $9 \mathrm{Gpa}$ & Elongation $(\%)$ & 22 & $\leq 25$ \\
Tenacity & $865 \mathrm{Mpa} / 9.5 \mathrm{cN} / \mathrm{dtex}$ & Product Moisture (\%) & 1.8 & $\leq 2$ \\
Density & 0.91 & Degree of dispersion & Level 2 & 2 to 3 \\
\hline
\end{tabular}

Source: Author (2020) 
The comparisons were performed using three sets of specimens and are described in Table 2. The materials used were selected based on the assumption of maintaining the same matrix previously evaluated, as shown in Table 3.

Table 2 - Description of the specimens

\begin{tabular}{cccc}
\hline Mixtures & Description & Specimens & Quant \\
\hline AR & Reference mortar (without PPMF) & cylindrical / prismatic & $05 / 03$ \\
AR+FPA & Mortar with addition PPMF in a grouped form & cylindrical / prismatic & $05 / 03$ \\
AR+FPD & Mortar with addition dispersed PPMF & cylindrical / prismatic & $05 / 03$ \\
\hline
\end{tabular}

Source: Author (2020)

Table 3 - Consumption, in $\mathrm{kg} / \mathrm{m}^{3}$, of each raw material

\begin{tabular}{lc}
\hline White Portland cement & 333.15 \\
Dolomite \# 20 & 185.08 \\
Dolomite \# 40 & 1054.96 \\
Dolomite \# 80 & 277.62 \\
Water retainer & 1.94 \\
Air-entrainment & 0.16 \\
Water & 363.81 \\
Polypropylene microfibers & 1.33 \\
\hline
\end{tabular}

Source: Author (2020)

\section{METHODS}

\subsection{Characteristics of raw materials}

The specific surface area (SSA) of materials was measured using the BET method. N2 gas/vapor adsorption was used on a Belsorp Max instrument with pretreatment of the specimens at a temperature of $60^{\circ} \mathrm{C}$ and a pressure of $7 \times 10-5 \mathrm{MPa}$ for $24 \mathrm{~h}$ in a Belprep II vac instrument. The real density analysis was determined using the Helium pycnometry method in a Quantachrome MVP 5DC multipycnometer. The particle size distribution of the finer particles was determined using laser granulometry in a Malvern Mastersizer LongBed with a detection range of $0.1-355 \mu \mathrm{m}$, and the dolomite particle size and shape characterization was characterized using a Dynamic Image Analyser (QicPic - Sympatec) with a detection range of $1-4000 \mu \mathrm{m}$.

Table 4 shows the specific surface area and parameters related to the particle diameter for raw materials, while Figure 1 illustrates the particle size distribution.

Table 4 - Raw materials characteristic

\begin{tabular}{lcccc}
\hline \multicolumn{1}{c}{ Materials } & \multicolumn{2}{c}{ Particle size $(\mu \mathrm{m})$} & Specific surface area \\
& $\mathrm{d}-10$ & $\mathrm{~d}-50$ & $\mathrm{~d}-90$ & $\left(\mathrm{~m}^{2} / \mathrm{g}\right)$ \\
\hline White Portland cement & 2.6 & 17.7 & 19.5 & 0.86 \\
Dolomite \#20 & 975.1 & 1242.1 & 1620.5 & 0.16 \\
Dolomite \#40 & 24.3 & 230.0 & 739.6 & 0.56
\end{tabular}


Dolomite \#80

4.5

38.3

133.9

0.80

Source: Author (2020)

Figure 1 - Particle size distributions of materials

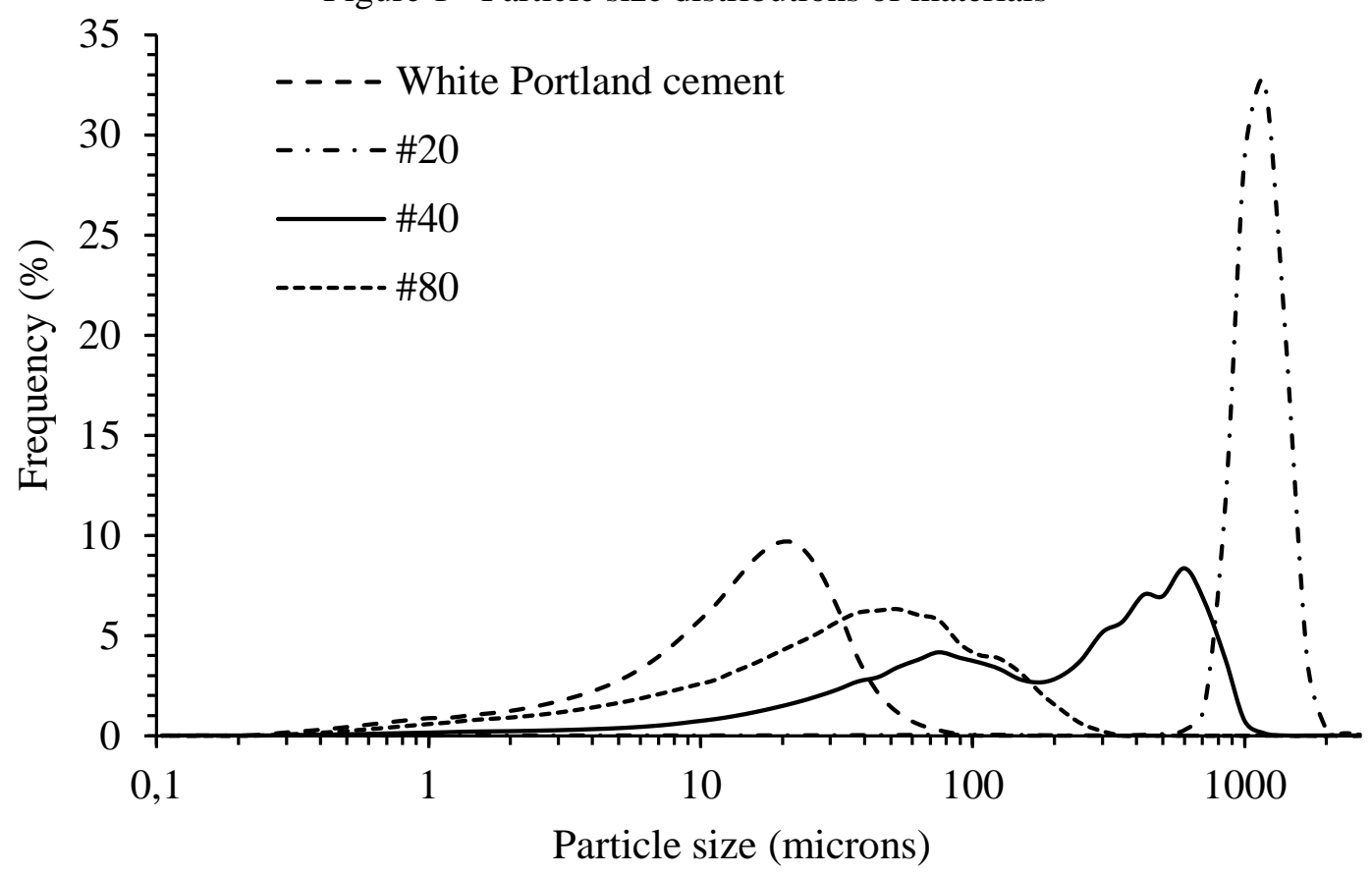

Source: Author (2020)

Based on the proportions among the raw materials shown in Table 2, the resulting granulometric curve in the compositions is presented in Figure 2. It was also chosen to give the cumulative curve, in which the results of characteristic particle diameters are also shown. As observed in Figure 2, the standard composition shows particle size continuity, with $90 \%$ of the particles smaller than $850 \mu \mathrm{m}$.

Figure 2 - Particle size distributions of compositions

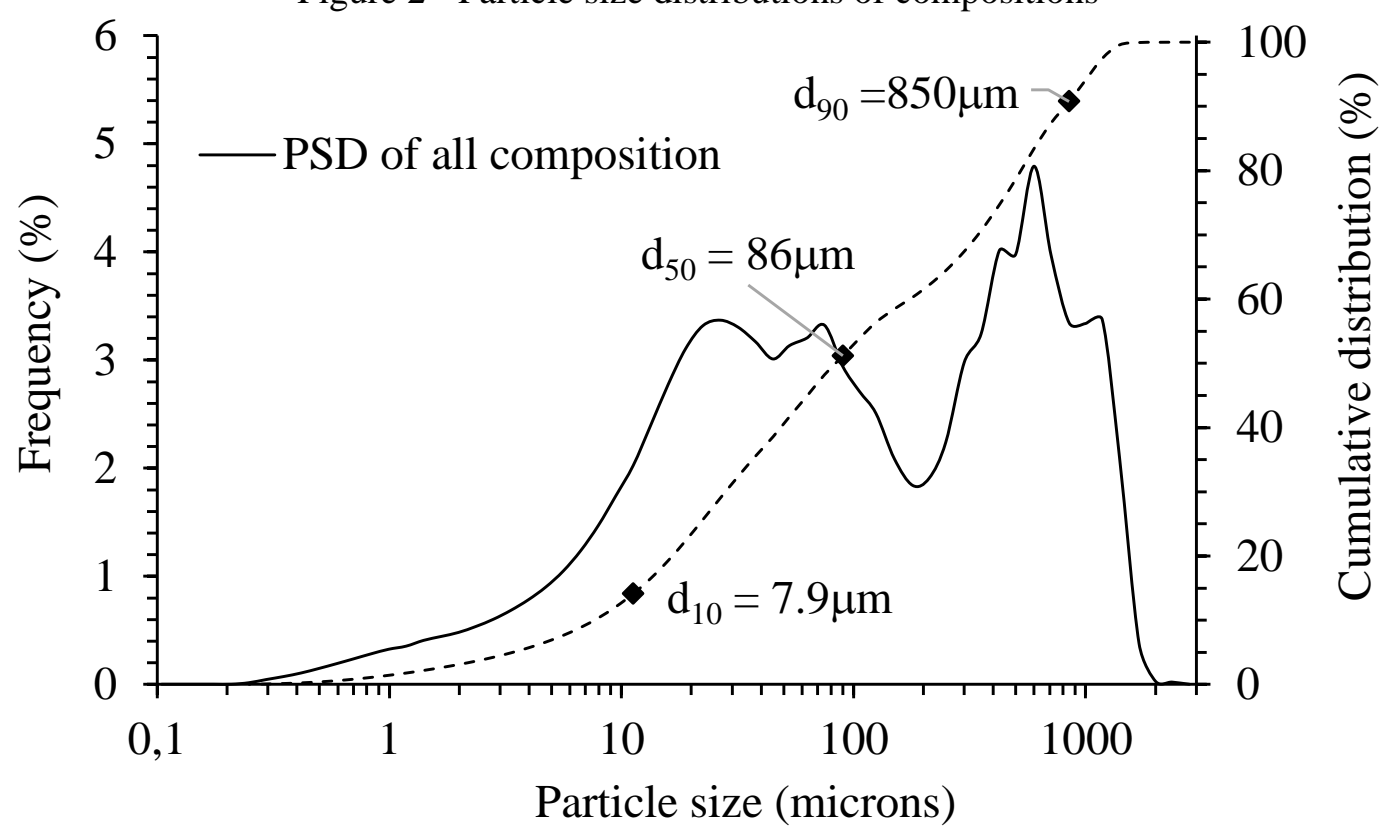

Source: Author (2020) 
Figure 3 shows the quantitative mineralogical composition of white Portland cement, obtained by X-ray diffraction using the Rietveld method of analysis by powder diffraction, according to C1365-06 (AMERICAN..., 2011). Equipment used: Rigaku model Windmax 1000, operating on copper $\mathrm{K} \alpha$ rad radiation with $40 \mathrm{kV}-20 \mathrm{~mA}$ and $2 \%$ min sweep ${ }^{9}$. Table 5 shows the chemical composition determined according to ABNT (ABNT, 2012a, 2012b, 2012c, 1997, 2013, 2012d, 2012e) and ASTM (AMERICAN..., 2015) standard.

Figure 3 - X-ray Diffraction of White Portland Cement

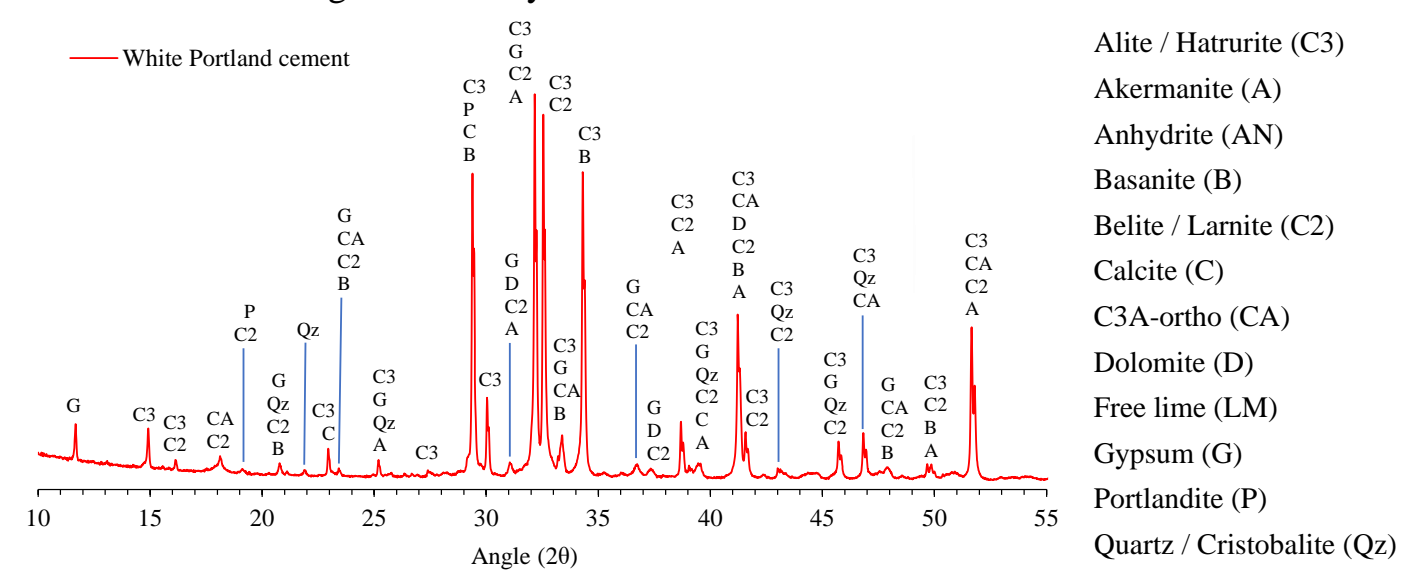

\begin{tabular}{|c|c|c|c|c|}
\hline Phase & Molecular formula & ICSD code & ICDD code & $\%$ \\
\hline Alite & $3 \mathrm{CaO} . \mathrm{SiO}_{2}$ & $81100 / 22501$ & - & 67.5 \\
\hline Belite & $2 \mathrm{CaO} \cdot \mathrm{SiO}_{2}$ & 421708 & - & 18.6 \\
\hline Calcite & $\mathrm{CaCO}_{3}$ & - & 96-901-6707 & 4.3 \\
\hline Gypsium & $\mathrm{CaSO}_{4} \cdot 2 \mathrm{H}_{2} \mathrm{O}$ & 27876 & - & 3.3 \\
\hline Orthorhombic tricalcium aluminate & $3 \mathrm{CaO} . \mathrm{Al}_{2} \mathrm{O}_{3}$ & 6287 & - & 1.9 \\
\hline Portlandite & $\mathrm{Ca}(\mathrm{OH})_{2}$ & 202223 & - & 1.9 \\
\hline Calcium and magnesium carbonate & $\mathrm{CaMg}\left(\mathrm{CO}_{3}\right)_{2}$ & 31209 & - & 0.5 \\
\hline Quartz & $\mathrm{SiO}_{2}$ & - & 96-900-6688 & 0.6 \\
\hline Bassanite & $\mathrm{CaSO}_{4 .}{ }^{1} / 2 \mathrm{H}_{2} \mathrm{O}$ & - & 96-101-0919 & 0.5 \\
\hline Akernite-gelenite & $\begin{array}{l}\mathrm{Ca}_{2}\left(\mathrm{Al}_{0.46} \mathrm{Mg}_{0.54}\right) \\
{\left[\left(\mathrm{Al}_{0.46} \mathrm{Si}_{1.54}\right) \mathrm{O}_{7}\right]}\end{array}$ & 160345 & 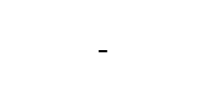 & 0.2 \\
\hline Free lime & $\mathrm{CaO}$ & - & 96-900-6738 & 0.2 \\
\hline Anhydrite & $\mathrm{CaSO}_{4}$ & 27474 & - & 0.2 \\
\hline
\end{tabular}

Source: Author (2020)

${ }^{9}$ Compound identification was performed using Panalytical X-pert HighScore Plus software (version 4.5 (4.5.0.22741) and diffraction patterns and structures provided by the free Crystallography Open Database (COD) database in 2016) and, eventually, diffraction patterns and ICDD (International Center for Diffraction Data) and ICSD (International Center for Structure Data) structures, respectively. 
Table 5 - Chemical composition of cement

\begin{tabular}{|c|c|c|}
\hline Compound & White CEM I (\%) & Limited NBR-12989/93 (CPB) \\
\hline LOI & 2.48 & $\leq 27.0$ \\
\hline $\mathrm{SiO}_{2}$ & 21.6 & --- \\
\hline $\mathrm{Al}_{2} \mathrm{O}_{3}$ & 4.60 & --- \\
\hline $\mathrm{FeO}_{3}$ & 0.33 & --- \\
\hline $\mathrm{CaO}$ & 67.5 & --- \\
\hline $\mathrm{MgO}$ & 0.59 & $\leq 10.0$ \\
\hline $\mathrm{SO}_{3}$ & 2.83 & $\leq 4.0$ \\
\hline $\mathrm{Na}_{2} \mathrm{O}$ & 0.13 & --- \\
\hline $\mathrm{K}_{2} \mathrm{O}$ & 0.61 & --- \\
\hline Alkaline equivalent $\left(\right.$ in $\mathrm{Na}_{2} \mathrm{O}$ ) & 0.53 & --- \\
\hline $\mathrm{CaO}$ & 2.26 & --- \\
\hline RI & 0.43 & $\leq 7.0$ \\
\hline $\mathrm{CO}_{2}$ & 0.67 & $\leq 25.0$ \\
\hline
\end{tabular}

Note: Alkaline equivalent $\left(\right.$ in $\left.\mathrm{Na}_{2} \mathrm{O}\right)=\% \mathrm{Na}_{2} \mathrm{O}+0.658 \times \% \mathrm{~K}_{2} \mathrm{O}$ and LOI: Loss on ignition. Source: Author (2020)

\subsection{Mixing process}

The mixing procedure of the raw materials used to prepare the specimens is detailed below and presents only small differences.

Reference mortar - AR (without PPMF): all the water was put into the bowl of the Hobart N50 mixer, then all the dry powder was added for 1 minute with the equipment turned off. A time of 30s was given for particle wetting, followed by water and dry powder mixing for 90 seconds [30s speed 1 (low), 30s speed 2 (high), and 30s speed 1(low)].

AR+FPA (sample with grouped PPMF): the microfibres and dry powder were homogenized in a plastic bag for 30 s before adding them to the bowl. The following steps were the same described for the reference specimen.

AR+FPD (sample with dispersed PPMF): microfibres were added to the bowl and dispersed with water for 90s using these speeds: 30s speed 1 (low), 30s speed 2 (high), and 30s speed 1 (low). Next, all the dry powder was added for 1 minute with the equipment turned off. The remaining process was the same described for the reference specimen.

Homogenization of the fibre with the dry powders was done in a plastic bag for 30 seconds to separate the fibres before putting all the material into the mixing equipment. The fibres are commercialized in a tangled form, making it difficult to homogenize them while mixing the mortar. The pre-mixing in a plastic bag can even be done by the worker on-site to obtain a better homogenization of the fibers. 


\subsection{Fresh state properties}

The fresh state properties were evaluated using a flow table test (ABNT, 2016), squeeze flow test (ABNT, 2010), and air incorporation using the gravimetric method (ABNT, 2005a).

Flow table test: the test is performed by positioning the conical mould centrally on the table and filling it with three successive layers of mortars, with approximately equal heights. It is then tamped fifteen, ten, and five times, respectively, with a tamping rod. The mortar should be levelled out, bypassing the metal ruler close to the edge of the conical mould with short back and forth movements, eliminating any particles around the frame with a clean, dry cloth. The conical mould is then removed vertically, and the crank is turned so that the table goes up and down 30 times in 30s smoothly. After the last turn, the spread is measured using a caliper. These measurements should be performed in terms of the diameter, and they were taken in pairs of points uniformly distributed along the perimeter (ABNT, 2016).

Squeeze flow: tests were conducted on a universal testing machine (Instron 5569) with a $1 \mathrm{kN}$ load cell. Samples were prepared in a metallic plate with smooth surfaces to guarantee a nonabsorption condition, and a cylindric mould (diameter of $101 \mathrm{~mm}$ and width of $20 \mathrm{~mm}$ ) was used. The tests were performed using a displacement rate of $0.1 \mathrm{~mm} / \mathrm{s}$ to a maximum displacement of $18 \mathrm{~mm}$ or maximum load of $1 \mathrm{kN}$, as shown in Figure 4.

Air-entrainment: tests were performed according to the gravimetric method, using a cup of $400 \mathrm{ml}$ volume and determining the mass needed to fill it. The values of air entrainment were calculated based on the mortar's water content and the real density of the dry powder.

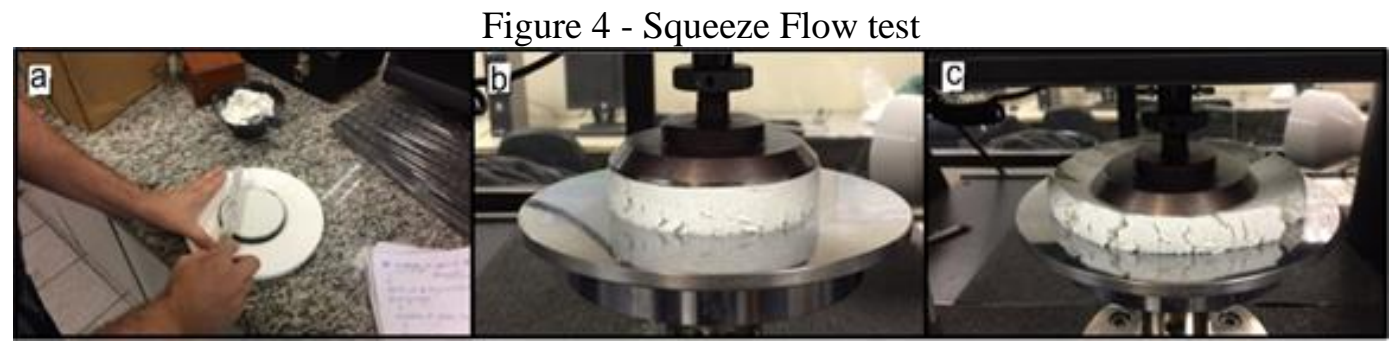

Source: Author (2020)

\subsection{Hardened state properties}

The moulded specimens were cured for 28 days under controlled temperature and humidity conditions (respectively, at $23^{\circ} \mathrm{C}$ and $50 \%$ ). The hardened properties were monitored by water absorption by capillarity (ABNT, 2005c), air-permeability, dynamic elasticity modulus (E) (ABNT, 2009), tensile strength by the Brazilian testing method (ABNT, 2011), porosity 
(Archimedes method), and drying shrinkage test (ABNT, 2005b). The results obtained were statistically evaluated using one-way ANOVA followed by the Tukey statistical test.

Porosity: measured according to the Archimedes water immersion test, based on the dry, wet, and immersed mass. The mass is determined on dried specimens and after immersion in water and under vacuum during $2.5 \mathrm{~h}$. The total porosity was calculated according to Eq. (1), where $\rho R E L$ is the relative density of mortar.

Total porosity $(\%)=(1-\rho$ REL $) \times 100 \%$

Eq. 1

Air-permeability: measured according to the vacuum-decay method (SELMO, 1986; SALVADOR, 2005; ROMANO, 2013). The apparatus used was a vacuum pump connected to a suction chamber that is in contact with the surface of the mortar. When the vacuum pump is turned on, a transducer registers the pressure variations in function of time until the pressure stabilizes. Samples were sealed using PVC plastic to guarantee the unidirectional flow. The test starts when the vacuum is turned off, and the time it takes for the applied vacuum pressure to extinguish is quantified. The permeability (expressed in $\mathrm{k} 1$ (m2) values) is calculated using the Forchheimer equation Eq. (2), considering two basic hypotheses: negligible air-compressibility and using just the linear part of the equation.

$\frac{\Delta P}{L}=\frac{\mu}{k_{1}} v_{S}+\frac{\rho}{k_{2}} v_{S}^{2}$

$\mathrm{L}$ is the sample thickness, and $\mu$ and $\rho$ are, respectively, the fluid viscosity and density, vs. is the speed of air-percolation, and $\Delta \mathrm{P}$ is the pressure variation, for which vs. $\mu$, and $\rho$ are measured or calculated. The term $\rho v s / k 1$ shows the viscous effect of fluid-solid interaction, while the term $\rho v s 2 / \mathrm{k} 2$ represents the inertial effects. The terms $\mathrm{k} 1$ and $\mathrm{k} 2$ are thus known as Darcian and non-Darcian permeability constants. However, k2 was not used to compare the results in this work (INNOCENTINI, 2009).

Dynamic elasticity modulus (E): measured according to the Brazilian standard (ABNT, 2009) using PUNDIT (Portable Ultrasonic Non-destructive Digital Indicating Tester) equipment with frequency transducers of $200 \mathrm{kHz}$ and a circular cross-section with a diameter of $20 \mathrm{~mm}$.

Tensile strength in diametrical compression: measured according to the Brazilian standard (ABNT, 2011) using Emic DL10000 equipment with continuously applied load at a speed of $400 \mathrm{~N} / \mathrm{s}$ until the rupture in test specimens.

Water absorption by capillarity: the specimen was partially sealed with beeswax at one of their ends at the height of $\pm 3 \mathrm{~cm}$ to avoid water absorption, thus forcing the water to penetrate 
only by the contact area. Afterward, the specimens were placed on grids inside a box with a 1 $\mathrm{cm}$ height of water. The water absorption of the samples was determined to weigh in the following intervals: $0 \mathrm{~h}$ (dry mass), 15', 30', 1h, 2h, 4h, 8h, 24h, and 48h.

Dimensional variation (shrinkage): measured according to Brazilian standards (ABNT, 2005b), using $25 \times 25 \times 285(\mathrm{~mm})$ test specimens. The dimensional change of the samples was determined by a comparator clock with a resolution of $0.001 \mathrm{~mm}$ at intervals of 2 times a day for 28 days.

\subsection{Statistical analysis}

Two statistical methods were used to determine the influence of fibre dispersion: one-way ANOVA and the Tukey test for comparative evaluation between pairs. These methods were used to indicate which dispersion method showed the lowest variation.

\section{RESULTS AND DISCUSSION}

\subsection{Fresh state properties}

Table 6 shows the spreading of the mortars obtained by the flow-table test and the air incorporation results.

Table 6 - Entrained air and flow table test results

\begin{tabular}{ccccc}
\hline Mixtures & $\begin{array}{c}\text { Spreading } \\
(\mathrm{mm})\end{array}$ & $\begin{array}{c}\text { Mortar mass } \\
(\mathrm{g}) \mathrm{mc}\end{array}$ & $\begin{array}{c}\text { Entrained air } \\
(\%)\end{array}$ & $\begin{array}{c}\text { Water added } \\
(\mathrm{g})\end{array}$ \\
\hline AR & 226.3 & $1,563.7$ & 24.0 & 425.0 \\
AR+FPA & 223.5 & $1,543.1$ & 26.2 & 425.0 \\
AR+FPD & 227.3 & $1,544.3$ & 26.1 & 425.0 \\
\hline
\end{tabular}

Note: $\mathrm{mc}=$ container mass + mortar mass.

Source: Author (2020)

The rendering mortars need to present spreading capacity to be considered adequate to be applied in a facade. Results indicate that all mortars show the same consistency and sufficient spreading power, demonstrating that the use of the dispersion method of PPMF does not affect the mortar consistency. However, the addition of PPMF, even without a change in the dispersion procedure, increased air incorporation when compared to the reference mortar.

The squeeze flow method has been used to evaluate the rheological behavior of pastes, plasters, extruded building materials, and different types of mortars as an alternative, complementary method. This method has been adopted to simulate processing and application conditions, for instance, to slip, the material-shear element interfaces, and measuring fibrecontaining pastes. The test's geometry changes during gap reduction and creates flow conditions similar to those that involve the processing and application of mortars, such as 
pumping and spraying, spreading and finishing, and squeezing between bricks. This method was recently standardized in Brazil (ABNT, 2010) for rendering and masonry mortars.

The squeeze flow test does not simulate the most common problem: the loss of contact between the material and sheer element, especially for materials with plastic characteristics such as mortars. This method is adequate to evaluate mixtures with any level of consistency and combinations with the addition of fibres. In the case of rendering mortars, the test simulates the processing conditions as spreading and finishing.

According to Afroughsabet, Biolzi, and Monteiro (2018) and Sun and Xub (2009), an increase in the content of PP fibres results in a reduction in workability. Thus, the choice for evaluating the fresh state by the squeeze flow method was based on the fact that the use of the fibre and its dispersion procedure could affect the workability of the mortars, which is difficult to identify only with the consistency table test. Thus, it was possible to more carefully monitor the impact of the dispersion procedure of the fibres on the workability of the coating. Figure 5 shows the results obtained in the mortars after 5 min of mixing.

Similar curves indicated that workability was not affected even with the imposition of a more severe shear condition. The qualitative perception of the consistency of the mortar was also maintained, according to the mason who applied the material. This is a relevant factor since the mobility of the mix is of significant importance in real-scale applications. The result obtained showed the same consistency for the three mixtures studied (AR, AR+FPA, and $\mathrm{AR}+\mathrm{FPD})$ using the same fibre content $(0.14 \%$ in volume) for the compositions.

The three stages of the test were observed: in the first one, applying a small displacement, the material behaves as a solid exhibiting an elastic deformation, which is related to the material yield stress. The elongation and radial shear can be observed by increasing the displacement, exceeding the forces that kept the material under elastic behavior, indicating that the mortar is flowing. Large deformations without a significant increase in the compressive load can suggest that these mortars present adequate workability, so they are easy to apply. The squeeze flow test simulates the mortars which are used in different spreading conditions.

In the last stage of the test, there is a significant increase in the compressive load, even with low material deformation, because dolomite particles are in contact, increasing the frictional forces and a more substantial interaction through interlacing of fibres, causing some restrictive effects to the flow. This third stage is characterized by the behavior in which the application of this kind of material tends to be hampered due to the high loads involved. 
Figure 5 - Squeeze flow results

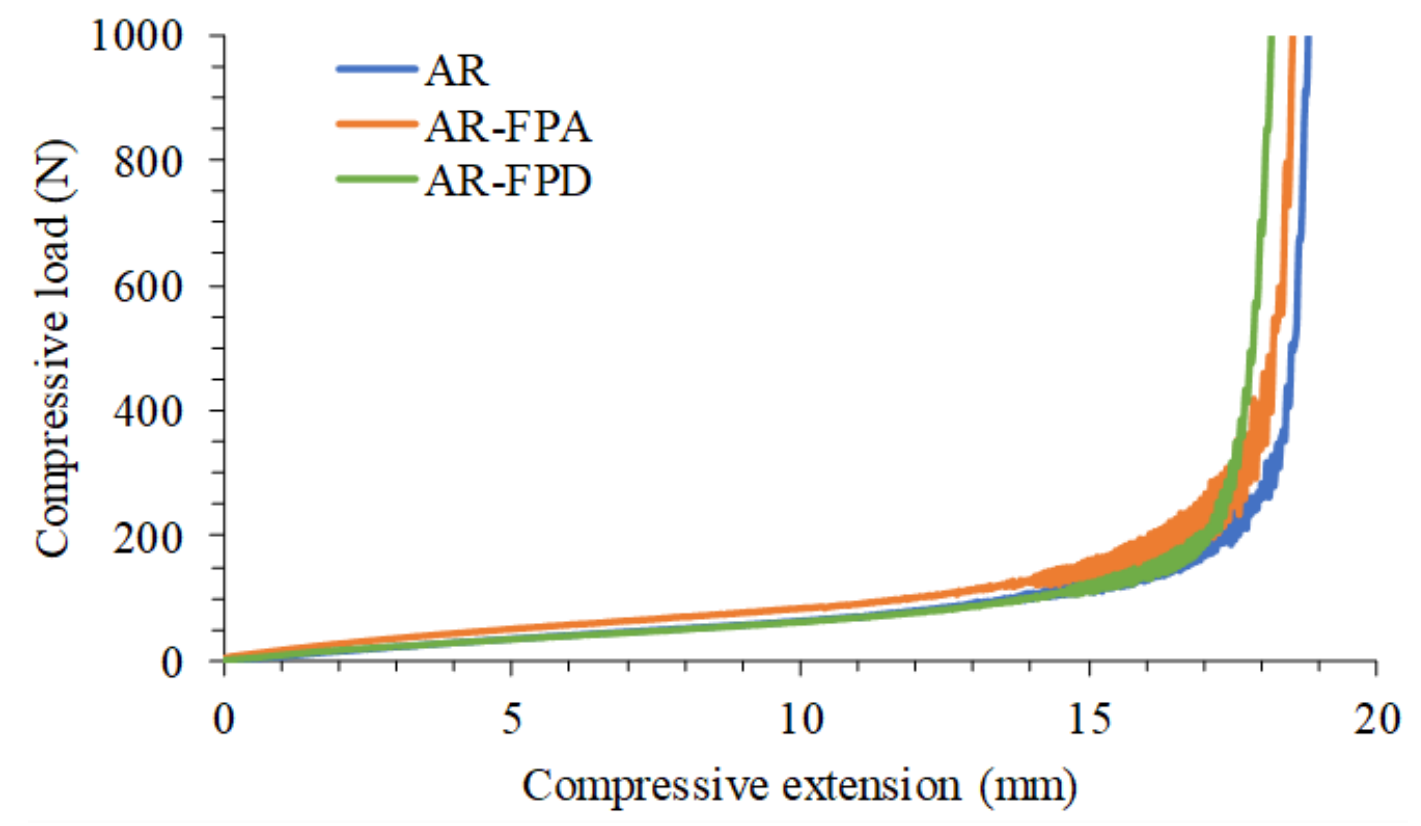

Source: Author (2020)

\subsection{Hardened state properties}

The properties of PPMF were evaluated as a function of the dispersion procedure. Figure 6 summarizes the results of the hardened properties of each mortar, such as porosity, airpermeability, modulus of elasticity, and tensile strength.

The total porosity and dynamic modulus elasticity of the mortars show a significant correlation $\left(\mathrm{R}^{2}=0.87\right)$. A decreasing trend line is observed, which means a higher total porosity results in a smaller modulus of elasticity. The smaller the modulus, the higher the deformation capacity of the mortar, thus reducing the possibility of cracking in the hardened state (SILVA et al., 2009). The reduction of the modulus of elasticity is paired with the decrease of the mechanical properties due to the increase in total porosity. According to Aly, Sanjayan, and Collins (2008), the addition of PP fibres increases the nano-porosity and provides a more refined micro-pore-structure, which influences the drying shrinkage rate and results in high porosity in the vicinity of PP fibres due to the increase in mesopores in this zone.

The amount of water absorbed by a material is associated with the void content present in its microstructure, which, in turn, determines the porosity of the material (QUARCIONI et al., 2011). The use of polypropylene fibres significantly affects the microstructure of the mortar as it reduces the amount, size, and orientation of $\mathrm{CH}$ crystals and generates microvoids. 
Another effect is that it reduces the voids and micro-cracking at the interfacial transition zone between aggregate and cement paste (SUN; XUB, 2009).

The air-permeability and apparent porosity tests between mortars showed a very poor correlation $\left(\mathrm{R}^{2}=0.22\right)$. The results show that the higher the apparent porosity, the greater the air-permeability of the mortars.

The tensile strength versus the total porosity of the system in the experimental test showed a moderate correlation $\left(\mathrm{R}^{2}=0.55\right)$. This correlation was expected; however, in this study, an observation could not be done since statistical evaluations proved that there are no differences between the mortars in the function of porosity or mechanical strength. Therefore, it cannot be related to the results of the shrinkage presented later.

However, according to Islam and Das Gupta (2016), the addition of polypropylene fibre provides adequate tensile strength to concrete in addition to controlling shrinkage cracks. Ramezanianpour et al. (2013) state that adding PP fibres to concrete reduces the compressive strength, but splitting tensile and flexural strengths increase first and then decrease with a higher amount of fibre.

According to Ma, Tan, and Wu (2002), when small quantities of polypropylene macrofibres are mixed into the cement matrix, the interlocking network characteristics of the fibres will prevent the large particles from sedimenting. The amount of bleed water may be reduced. On the other hand, because of the cohesion between the fibre and the cement matrix, the tensile strength of the fresh concrete will increase. If the tensile strength of the fresh concrete is larger than the tensile stress, the plastic shrinkage cracking will decrease or even be eliminated.

According to Afroughsabet, Biolzi, and Monteiro (2018), the presence of fibres has a considerable influence on the mechanical properties of concrete. The reduction in mechanical properties may be concerned regarding laying for structural masonry or even regular masonry. However, it does not tend to be of great importance for rendering mortars, except for adherence and integrity purposes. Among the three mixtures evaluated, mortar AR+FPD presented the lowest elastic modulus values due to the higher porosity.

According to Aly, Sanjayan, and Collins (2008), PP fibres increase the elastic modulus of cementitious materials. The results showed that the higher the content of admixed PP fibres, the lower the cracking resistance of the mixture. However, the elasticity versus air permeability dynamic modulus evaluation shows a very poor correlation $\left(\mathrm{R}^{2}=0.25\right)$. In 
general, it can be observed that all the mixtures presented similar dynamic modulus of elasticity values, as well as values of air permeability, not allowing the selection of a better option. However, the mortar AR+FPD appears to be the only one that presents a more linear behavior when compared to its peers and with smaller variance when compared to the others.

Figure 6 - Summary of hardened mortar properties

$\square$ Total porosity $(\%)$

$\square$ Apparent porosity $(\%)$

Air permeability $\left(\mathrm{x} 10-11 \mathrm{~m}^{2}\right)$
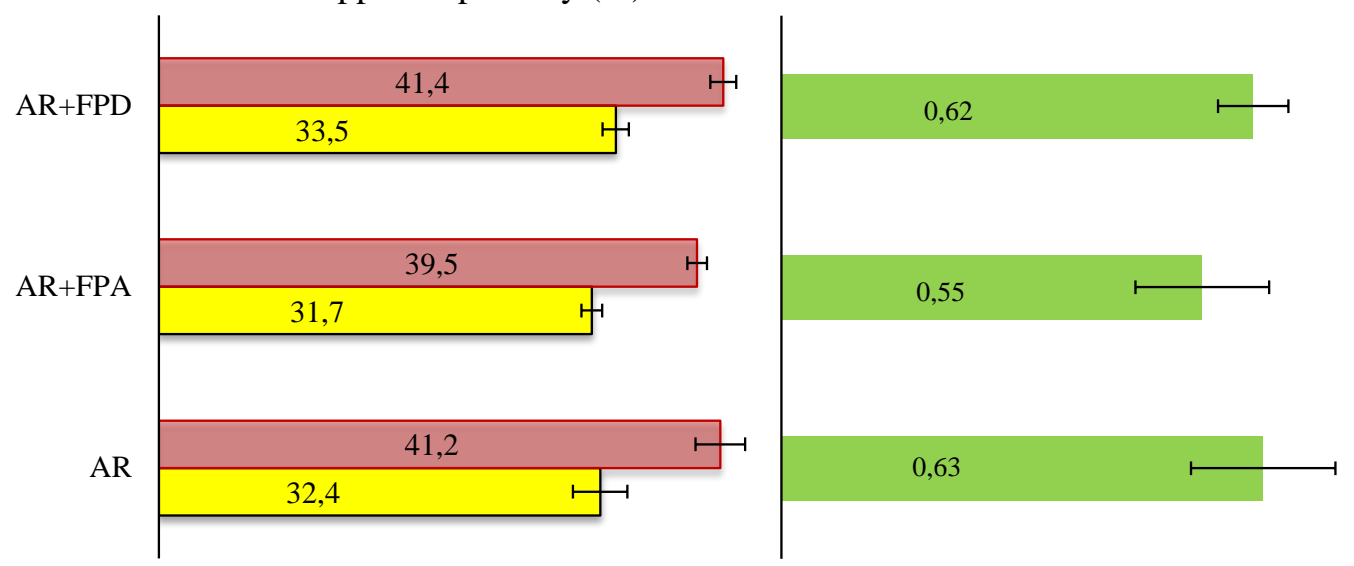

Tensile strength in diametral compression

Dynamic modulus of elasticity (GPa)
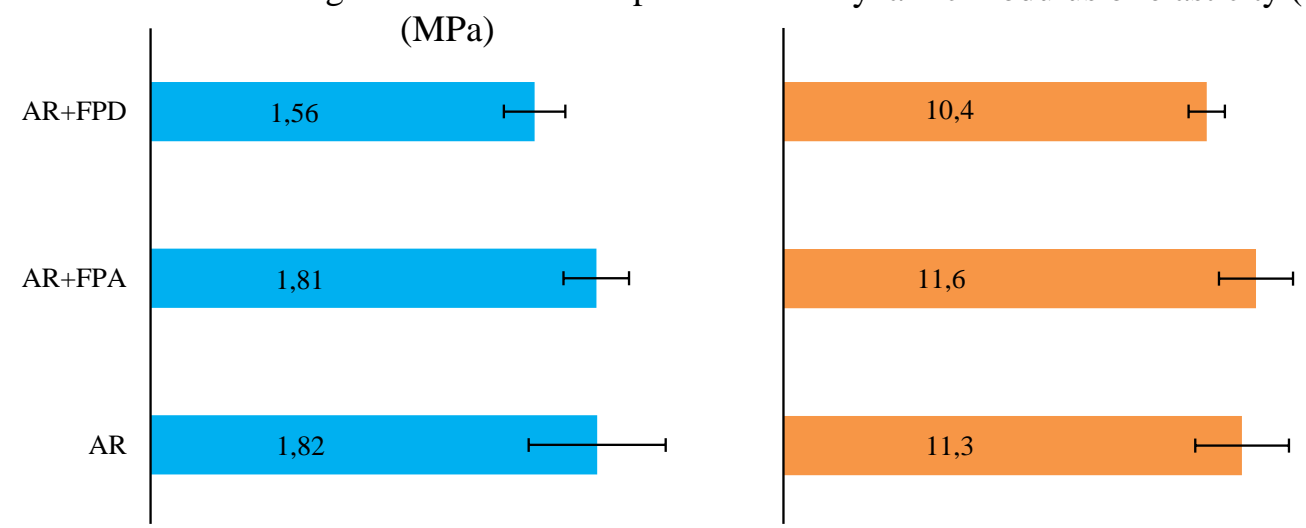

Source: Author (2020)

Although no statistically significant difference was observed in any of the cases, and the porosity variation was small, the correlation between the porosity and the other properties in the hardened state is of great importance. The statistical analysis was conducted between sample groups, and the similarity between them was confirmed. In the same specimen, the porosity was measured, the other properties were also evaluated, making the correlation between them relevant. Figure 7 shows the correlation properties in the hardened state. 
Figure 7 - Correlations of hardened mortar properties
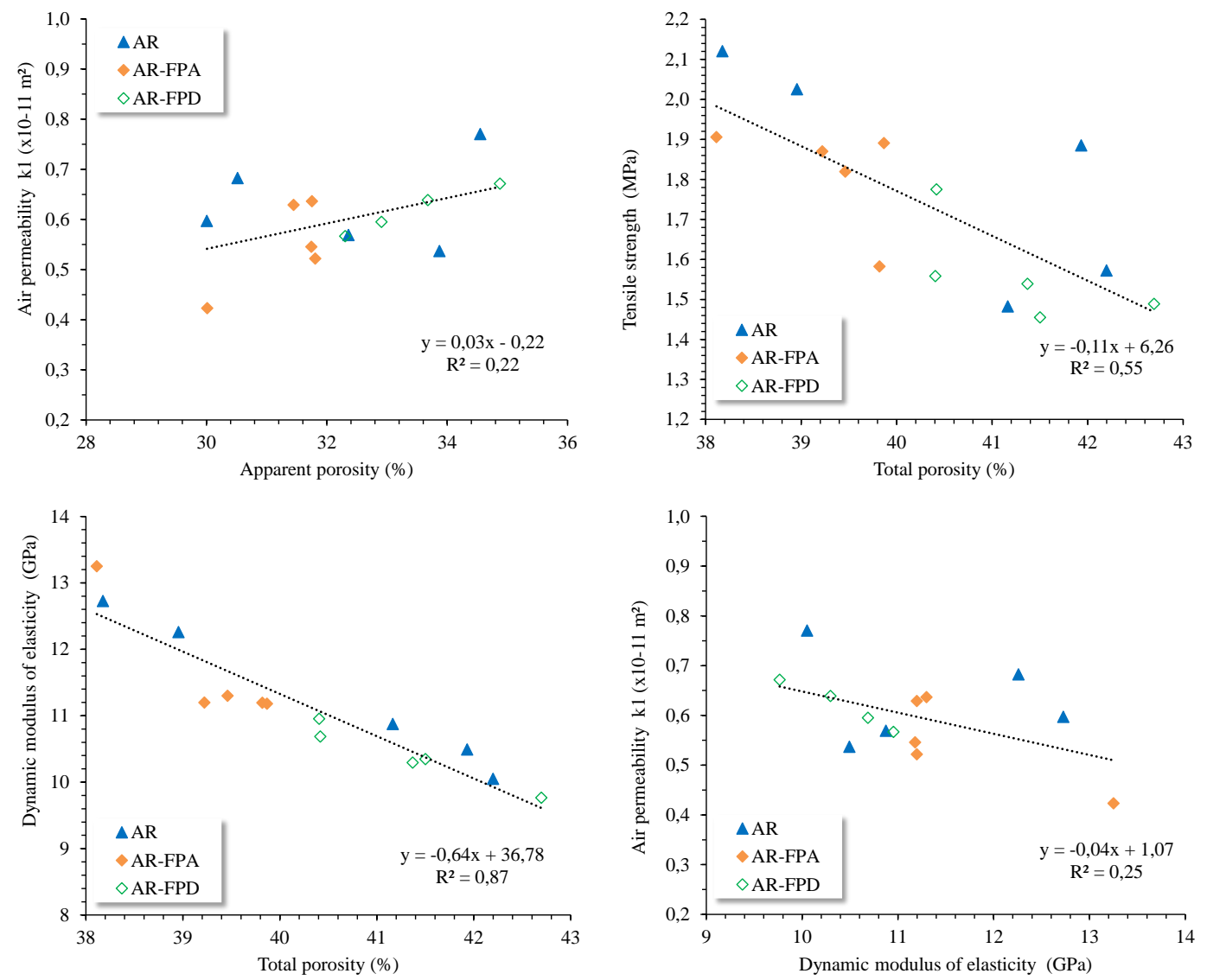

Source: Author (2020)

\subsection{Permeability of the mortars}

Polypropylene fibres have hydrophobic levels, which protect them against wetting with cement paste. The hydrophobic nature of polypropylene does not affect the amount of water needed for cementitious materials; therefore, the presence of polypropylene fibres can cause a delay in starting the degradation process by reducing permeability and the amount of shrinkage (KAKOOEI et al., 2012).

For water absorption tests on rendering mortars, all mixtures reached saturation after 48 hours of immersion. The addition of air-entraining admixtures in the studied mortars shows a larger internal volume of air for the reference mortar (AR) and a slight reduction of the capillarity coefficient when compared to the other two mortars AR+FPA and AR+FPD. The higher formation of microscopic air bubbles in the AR mixtures leads to the interruption of the capillaries and consequently prevents the absorption of water inside the mortars (SILVA et al., 2009; QUARCIONI et al., 2009).

According to Saiz-Martínez et al. (2018), in terms of water absorption by capillarity, a higher absorption coefficient was obtained in recycled mortars due to higher air content. In the case 
of fibre addition, a slight decrease in this coefficient is not significant; that is why it cannot be concluded that including fibres leads to better material behavior in this respect.

According to Islam and Das Gupta (2016), with the addition of polypropylene fibre, both water and gas permeability coefficients were increased. Thus, the water and gas permeability increase in coefficients might suggest restricting the use of polypropylene fibre content in the case of structural elements exposed to water (such as water tanks, dams, spillways, swimming pools) and harmful gases.

The permeability of mortars at the age of 28 days was evaluated using the capillary coefficient obtained through water absorption as a function of time. The average results of the capillary coefficient for each mortar are shown in Figure 8.

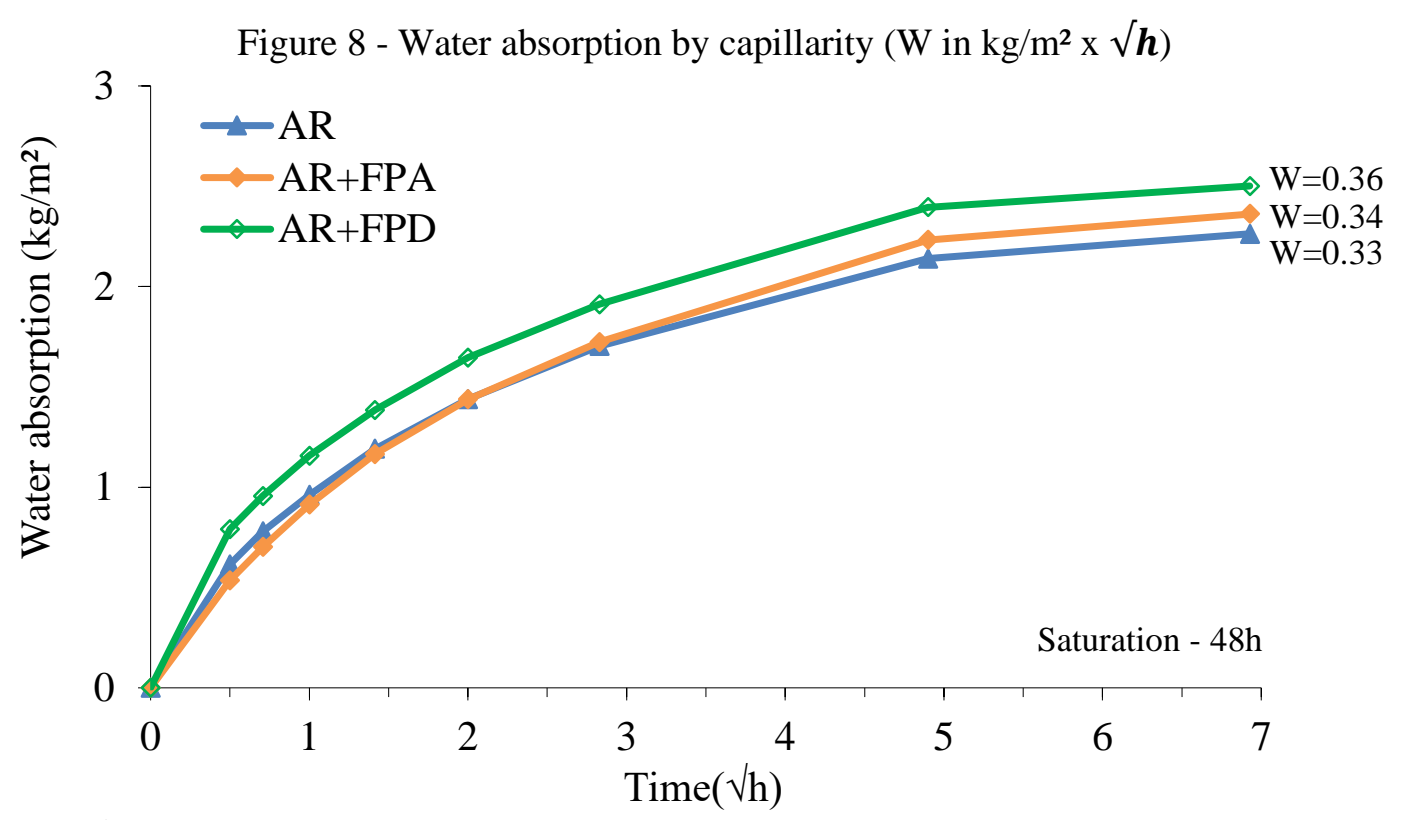

Source: Author (2020)

\subsection{Drying shrinkage}

The behavioral prediction forms of mortars are very complex to be identified since such a phenomenon is an interaction of several physical mechanisms influenced by many parameters (MEHTA; MONTEIRO, 2008) and is intimately related to the change in relative humidity (RH) due to the evaporation of free water from the capillary pores in the cement paste (CARLSWÄRD, 2006).

The addition of any type and fibre content results in a reduction in the drying shrinkage. A higher decline in the shrinkage strain can be attained due to increasing the fibre volume fraction (AFROUGHSABET; BIOLZI; MONTEIRO, 2018). However, while polypropylene fibres, in general, are effective in controlling plastic shrinkage cracking in cementitious 
materials, a finer fibre is more effective than a coarser one, and a longer fibre is more effective than a shorter one. Further, fibre fibrillations appear to be highly effective in controlling plastic shrinkage cracking (BANTHIA; GUPTA, 2006).

Polypropylene fibre can improve the toughness of the mortar, effectively inhibiting the drying shrinkage and enhancing the anti-cracking properties. The added amount of PP fibre in aeolian sand mortar is appropriate to be $1.3 \mathrm{~kg} / \mathrm{m}^{3}$ (GUO; YANG; GAO, 2019). Besides, the experimental results have shown that the addition of short polypropylene fibres to the mortar mixture was more efficient at restraining crack formation due to plastic shrinkage (PELISSER et al., 2010).

Figure 9 shows the evolution of the drying shrinkage as a function of time. Each point in the curve corresponds to the mean retraction values of three groups of specimens. The results show the same tendency in the drying shrinkage intensity at the beginning of the process. However, the drying shrinkage rate is much higher at the end of the 28 days for blends with microfibres added in a grouped form. On the other hand, the shrinkage decreases when the microfibres are added dispersedly to the mixture.

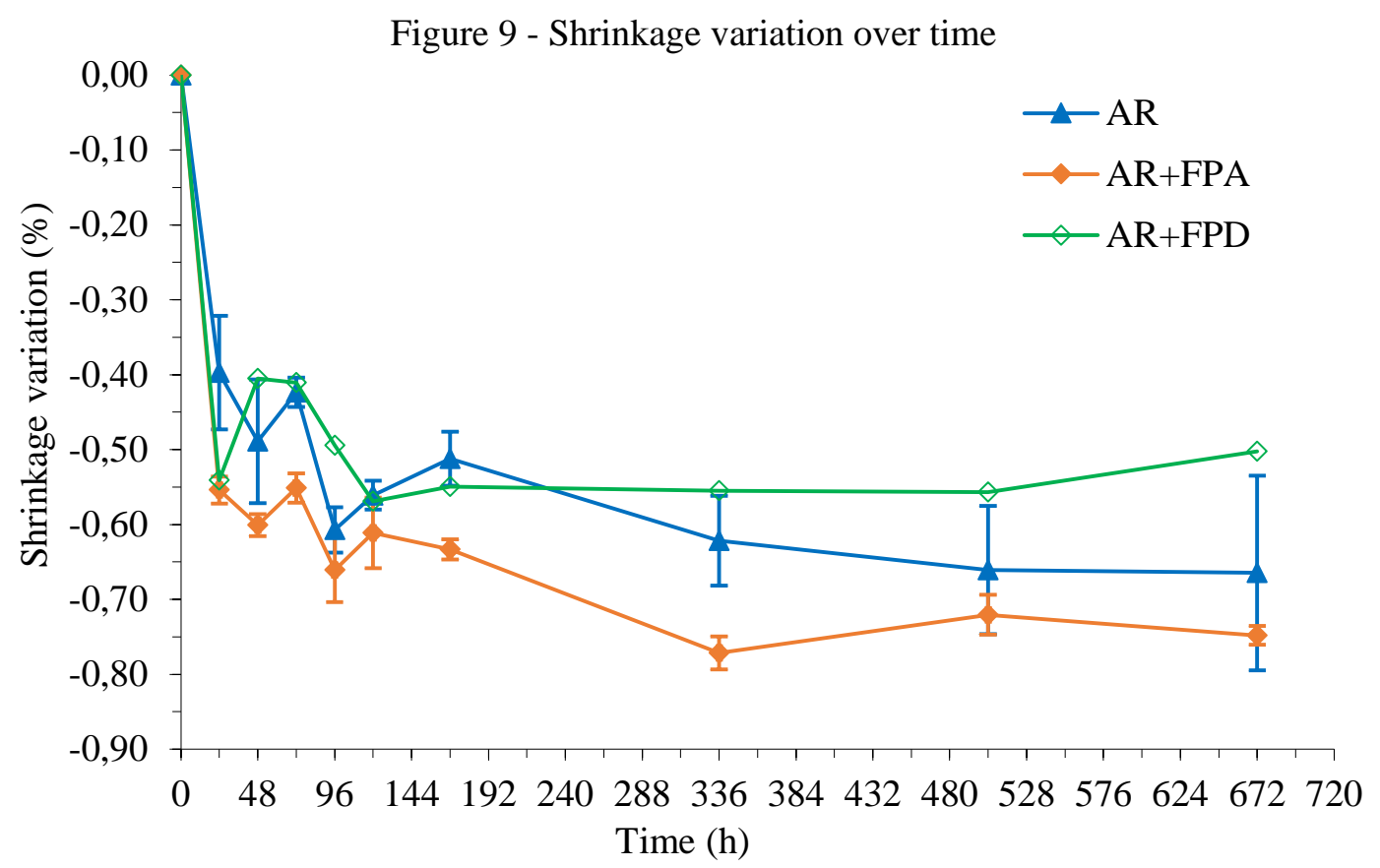

Source: Author (2020)

The AR+FPA composition presented the highest shrinkage values (75\%) among the samples tested. The final measured shrinkage of the mortars AR and AR+FPD were $66 \%$ and 50\%, respectively. The results indicate that with the better dispersion of the fibre, less shrinkage and less distribution of the results were quantified. The link that hinders the propagation of 
the micro-cracks has been achieved satisfactorily, converging with the results presented by Ma, Tan, and Wu (2002), Nili and Afroughsabet (2010) and Guo, Yang and Gao (2019).

The polypropylene fibres cannot prevent the movement of cement paste at an early age and maintain the volume stability because of its low elastic modulus (BOUZIADI; BOULEKBACHE; HAMRA, 2016). However, adding fibres not only decreases cracking due to drying shrinkage but also defers the initial cracking time in a way that the first crack appears after $144 \mathrm{~h}$, according to Yousefieh et al. (2017).

The most important factor influencing the drying shrinkage is the amount and composition of cement paste, in addition to the structural geometry and drying conditions (CARLSWÄRD, 2006). In practice, this implies that the shrinkage for a given w/c-ratio can be reduced by minimizing the water amount and maximizing the content of coarse aggregates. According to Nmai et al. (19985 apud CARLSWÄRD, 2006), the effect of coarse aggregates on the shrinkage is two-fold. A high coarse aggregate content will reduce the water and paste demand of the mix while providing restraint to the drying shrinkage of the paste. Hard and rigid aggregates such as dolomite, granites, feldspar, limestone, and quartz should be used to maximize the restraining action and produce concrete with low shrinkage.

Considering that the most critical factor influencing the drying shrinkage is the amount and composition of the cement paste and that the mortars have the same structure (same content of fibres and coarse aggregate) and the same w/c ratio, it can be concluded that the control of retraction is directly associated with the mode of dispersion of the fibre.

According to Guo, Yang, and Gao (2019), if the PP fibre was dispersed uniformly, the cracks in mortar encounter the PP fibre in expansion, and the presence of the fibre will force the cracks to change its development direction, or prevent the damages from forming smaller micro-cracks, then the development trend of the mortar micro-cracks will be limited. Therefore, the dispersion method facilitated its distribution throughout the mixture, reducing the occurrence of micro-cracks in the mortar over time.

One of the functions of the fibre is to increase the resistance to retraction tensions. It was observed that the use in the tangled form (mixed according to the manufacturers' recommendation) caused the formation of clumps that resulted in greater dimensional variation than that observed for the reference sample (without fibre), not allowing them to spread throughout the surface of the samples. 


\subsection{Statistical analysis}

To evaluate the impact of the PPMF dispersion procedure, the ANOVA test was used. All parameters were statistically assessed and presented the same results. Therefore, only one example of the ANOVA test was shown, as observed in the instance of tensile strength in Table 7.

Table 7 - Summary of statistical analysis of variance evaluating the impact of PPMF dispersion procedure in the tensile strength

\begin{tabular}{|c|c|c|c|c|c|c|}
\hline Group & Count & Sum & Average & Variance & & \\
\hline AR & 5 & 9.09 & 1.82 & 0.078 & & \\
\hline $\mathrm{AR}+\mathrm{FPA}$ & 5 & 9.07 & 1.81 & 0.018 & & \\
\hline $\mathrm{AR}+\mathrm{FPD}$ & 5 & 7.82 & 1.56 & 0.016 & & \\
\hline Source of variation & SQ & Gl & MQ & Fcalc & P-value & Fcritic \\
\hline Between groups & 0.21 & 2 & 0.11 & 2.86 & 0.10 & 3.89 \\
\hline In the groups & 0.44 & 12 & 0.04 & & & \\
\hline Total & 0.66 & 14 & & & & \\
\hline
\end{tabular}

Source: Author (2020)

Table 8 presents a comparative summary of the values of F, Fcritic, and Proof Value (p-value) to all parameters evaluated.

Table 8 - Summary of statistical analysis of variance evaluating the impact of PPMF dispersion procedure in others

\begin{tabular}{lcccc}
\multicolumn{1}{c}{ Property } & p-value & F & F-critic & Result \\
\hline Total Porosity & 0.08 & 3.18 & 3.89 & Statistically similar \\
Apparent porosity & 0.09 & 3.03 & 3.89 & Statistically similar \\
Tensile strength & 0.10 & 2.86 & 3.89 & Statistically similar \\
Modulus of elasticity & 0.12 & 2.49 & 3.89 & Statistically similar \\
Air-permeability & 0.49 & 0.75 & 3.89 & Statistically similar \\
Water absorption by capillarity - W & 0.34 & 1.19 & 3.89 & Statistically similar \\
\hline
\end{tabular}

Source: Author (2020)

\section{CONCLUSIONS}

The results obtained in this study showed:

The dispersion procedure had no significant change in the spreading, indicating that all the mortars present similar consistency during application;

In the hardened state, porosity, tensile strength, modulus of elasticity, air-permeability, and water absorption by capillarity were statistically similar to the properties observed for the reference mortar and are not a function of the fibre dispersion methods;

$>$ The use of dispersed fibres resulted in better control of the drying shrinkage and is statistically different from the other compositions evaluated; and 
The effect of the polypropylene microfibre on dimensional variation control is potentially increased by dispersion procedure as it guarantees fibre homogeneity on rendering mortars. 


\section{REFERENCES}

AFROUGHSABET, V.; BIOLZI, L.; MONTEIRO, P. J. M. The effect of steel and polypropylene fibers on the chloride diffusivity and drying shrinkage of high-strength concrete. Composites Part B, v. 139, p. 84-96, 2018.

ALTOUBAT, S. A.; LANGE, D. A. Creep, shrinkage and cracking of restrained concrete at early age. ACI Materials Journal, v. 98, p. 323-331, 2001.

ALY, T.; SANJAYAN, J. G.; COLLINS, F. Effect of polypropylene fibers on shrinkage and cracking of concretes. Materials and Structures, v. 41, p. 1741-1753, 2008.

AMERICAN SOCIETY FOR TESTING AND MATERIALS. C114-15: standard test methods for chemical analysis of hydraulic cement. West Conshohocken, 2015.

AMERICAN SOCIETY FOR TESTING AND MATERIALS. C1365-06: standard test method for determination of the proportion of phases in Portland cement and Portland-cement clinker using x-ray powder diffraction analysis. Pennsylvania, 2011.

ASSOCIAÇÃO BRASILEIRA DE NORMAS TÉCNICAS. NBR 13276: argamassa para assentamento e revestimento de paredes e tetos: determinação do índice de consistência. Rio de Janeiro, 2016.

ASSOCIAÇÃO BRASILEIRA DE NORMAS TÉCNICAS. NBR 13278: argamassa para assentamento e revestimento de paredes e tetos: determinação da densidade de massa e do teor de ar incorporado. Rio de Janeiro 2005a.

ASSOCIAÇÃO BRASILEIRA DE NORMAS TÉCNICAS. NBR 13810: água: determinação de metais: método de espectrometria de absorção atômica por chama. Rio de Janeiro, 1997.

ASSOCIAÇÃO BRASILEIRA DE NORMAS TÉCNICAS. NBR 15259: argamassa para assentamento e revestimento de paredes e tetos: determinação da absorção de água por capilaridade e do coeficiente de capilaridade. Rio de Janeiro, 2005c.

ASSOCIAÇÃO BRASILEIRA DE NORMAS TÉCNICAS. NBR 15261: argamassa para assentamento e revestimento de paredes e tetos: determinação da variação dimensional (retração ou expansão linear). Rio de Janeiro, 2005b.

ASSOCIAÇÃO BRASILEIRA DE NORMAS TÉCNICAS. NBR 15630: argamassa para assentamento e revestimento de paredes e tetos: determinação do módulo de elasticidade dinâmico através da propagação de onda ultrassônica. Rio de Janeiro, 2009.

ASSOCIAÇÃO BRASILEIRA DE NORMAS TÉCNICAS. NBR 15839: argamassa de assentamento e revestimento de paredes e tetos: caracterização reológica pelo método squeeze-flow. Rio de Janeiro, 2010.

ASSOCIAÇÃO BRASILEIRA DE NORMAS TÉCNICAS. NBR 7222: concreto e argamassa: determinação da resistência à tração por compressão diametral de corpos de prova cilíndricos. Rio de Janeiro 2011. 
ASSOCIAÇÃO BRASILEIRA DE NORMAS TÉCNICAS. NBR NM 11-2: cimento Portland: análise química: determinação de óxidos principais por complexometria: parte 2: método ABNT. Rio de Janeiro, 2012b.

ASSOCIAÇÃO BRASILEIRA DE NORMAS TÉCNICAS. NBR NM 13: cimento Portland: análise química: determinação de óxido de cálcio livre pelo etilenoglicol. Rio de Janeiro, 2013.

ASSOCIAÇÃO BRASILEIRA DE NORMAS TÉCNICAS. NBR NM 16: cimento Portland: análise química: determinação de anidrido sulfúrico. Rio de Janeiro, 2012c.

ASSOCIAÇÃO BRASILEIRA DE NORMAS TÉCNICAS. NBR NM 18: cimento Portland: análise química: determinação de perda ao fogo. Rio de Janeiro, 2012a.

ASSOCIAÇÃO BRASILEIRA DE NORMAS TÉCNICAS. NBR NM 20: cimento Portland e suas matérias primas: análise química: determinação de dióxido de carbono por gasometria. Rio de Janeiro, 2012e.

ASSOCIAÇÃO BRASILEIRA DE NORMAS TÉCNICAS. NBR NM 22: cimento Portland com adições de materiais pozolânicos: análise química: método de arbitragem. Rio de Janeiro, 2012 d.

BANTHIA, N.; GUPTA, R. Influence of polypropylene fiber geometry on plastic shrinkage cracking in concrete. Cement and Concrete Research, v. 36, p. 1263-1267, 2006.

BOUZIADI, F.; BOULEKBACHE, B.; HAMRAT, M. The effects of fibers on the shrinkage of high-strength concrete under various curing temperatures. Construction and Building Materials, v. 114, p. 40-48, 2016.

CARLSWÄRD, J. Shrinkage cracking of steel fiber reinforced self-compacting concrete overlays: test methods and theoretical modelling. Sweden, 2006. 261 f. Doctoral - Structural Engineering, Department of Civil and Environmental Engineering Division of Structural Engineering, Luleå University of Technology, Sweden, 2006.

EUROPEAN STANDARD. EN 197-1: Cement - Part1: Composition, specifications and conformity criteria for common cements. Brussels, 2000

GASPAR, P. L.; BRITO, J. Durabilidade, estados limite e vida útil de rebocos em fachadas. APFAC, 2010. Disponível em:

https://www.apfac.pt/congresso2010/comunicacoes/Paper\%2091_2010.pdf. Acesso em: 20 jan. 2020.

GESOGLU, M. et al. Strain hardening ultra-high-performance fiber reinforced cementitious composites: effect of fiber type and concentration. Composites Part B, v. 103, p. 74-83, 2016.

GÜNEYISI, E.; GESOGLU, M.; ÖZBAY, E. Strength and drying shrinkage properties of self-compacting concretes incorporating multi-system blended mineral admixtures. Construction and Building Materials, v. 24, p. 1878-1887, 2010. 
GUO, J.; YANG, Z.; GAO, G. Effect of Polypropylene fiber on properties of aeolian-sand mortar. Materials Science and Engineering, v. 472, p. 1-11, 2019.

INNOCENTINI, M. D. M. Permeability optimization and performance evaluation of hot aerosol filters made using foam incorporated alumina suspension. Journal Hazard Materials, v. 162, p, 212-221, 2009.

ISLAM, G. M. S.; DAS GUPTA, S. Evaluating plastic shrinkage and permeability of polypropylene fiber reinforced concrete. International Journal of Sustainable Built Environment, v. 5, p. 345-354, 2016.

ITIM, A.; EZZIANE, K.; KADRI, E-H. Compressive strength and shrinkage of mortar containing various amounts of mineral additions. Construction and Building Materials, v. 25, p. 3603-3609, 2011.

KAKOOEI, S. et al. The effects of polypropylene fibers on the properties of reinforced concrete structures. Construction and Building Materials, v. 27, p. 73-77, 2012.

MA, Y.; TAN, M.; WU, K. Effect of different geometric polypropylene fibers on plastic shrinkage cracking of cement mortars. Materials and Structures, v. 35, p. 165-169, 2002.

MEHTA, P. K.; MONTEIRO, P. J. M. Concreto: estrutura, propriedades e materiais. São Paulo: Ibracon, 2008.

NILI, M.; AFROUGHSABET, V. The effects of silica fume and polypropylene fibers on the impact resistance and mechanical properties of concrete. Construction and Building Materials, v. 24, p. 927-933, 2010.

PELISSER, F. et al. Effect of the addition of synthetic fibers to concrete thin slabs on plastic shrinkage cracking. Construction and Building Materials, v. 24, p. 2171-2176, 2010.

QUARCIONI, V. A. et al. Aplicação de método de ensaio de permeabilidade ao ar em argamassas moldadas em laboratório. In: SIMPÓSIO BRASILEIRO DE TECNÓLOGIA DE ARGAMASSAS, 9., Belo Horizonte, 2011. Anais [...] Belo Horizonte: PCC, ANTAC, 2011.

QUARCIONI, V. A. et al. Estimativa da porosidade de argamassas de cimento e cal pelo método de cálculo de volumes. Ambiente Construído, v. 9, n. 4, p. 175-187, out./dez. 2009.

RAMEZANIANPOUR, A. A. et al. Laboratory study on the effect of polypropylene fiber on durability, and physical and mechanical characteristic of concrete for application in sleepers. Construction and Building Materials, v. 44, p. 411-418, 2013.

ROMANO, R. C. de O. Incorporação de ar em materiais cimentícios aplicados em construção civil. São Paulo, 2013. Tese (Doutorado em Engenharia de Construção Civil e Urbana) - Escola Politécnica, Universidade de São Paulo, São Paulo, 2013.

ROMANO, R. C. O.; TORRES, D. R.; PILEGGI, R. G. Impact of aggregate grading and airentrainment on the properties of fresh and hardened mortars. Construction and Building Materials, v. 82, p. 219-226, 2015. 
SAIZ-MARTÍNEZA, P. et al. Comparative study of the influence of three types of fibre in the shrinkage of recycled mortar. Materials Construction, v. 68, n. 332, e168, 2018.

SALVADOR G. A. B. Otimização da distribuição granulométrica do agregado miúdo para o uso em revestimentos de argamassa na cidade de Santana do livramento. Porto Alegre, 2005. 128 f. Trabalho de Conclusão (Mestrado em Engenharia) - Curso de Mestrado Profissionalizante em Engenharia, Escola de Engenharia, Universidade Federal do Rio Grande do Sul, Porto Alegre, 2005.

ŞANAL, I.; ÖZYURT, N.; HOSSEINI, A. Characterization of hardened state behavior of self-compacting fiber-reinforced cementitious composites (SC-FRCC's) with different beam sizes and fiber types. Composites Part B, v. 105, p. 30-45, 2016.

SELMO, S. M. S. Agregados miúdos para argamassas de revestimento. In: SIMPÓSIO NACIONAL DE AGREGADOS, 1., São Paulo, 1986. Anais. São Paulo, EPUSP, 1986.

SILVA, N. G. da et al. Efeitos do ar incorporado nas propriedades do estado endurecido em argamassas de cimento e areia. In: CONGRESSO BRASILEIRO DO CONCRETO, 51., Curitiba, 2009. Anais [...] Curitiba: Ibracon, 2009.

SILVA, N. G.; CAMPITELI, V. C. Correlação entre módulo de elasticidade dinâmico e resistências mecânicas de argamassas de cimento, cal e areia. Ambiente Construído, Porto Alegre, v. 8, n. 4, p. 21-35, 2008.

SUN, Z.; XUB, Q. Microscopic, physical and mechanical analysis of polypropylene fiber reinforced concrete. Materials Science and Engineering A, v. 527, p. 198-204, 2009.

VALCUENDE, M. et al. Influence of limestone filler and viscosity modifying admixture on the shrinkage of self-compacting concrete. Cement and Concrete Research, v. 42, p. 583$592,2012$.

YOUSEFIEH, N. et al. Influence of fibers on drying shrinkage in restrained concrete. Construction and Building Materials, v. 148, p. 833-845, 2017. 


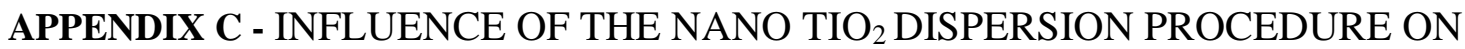 FRESH AND HARDENED RENDERING MORTAR PROPERTIES ${ }^{10}$ (Article C)
}

\begin{abstract}
This study was carried out to evaluate the influence of $\mathrm{n}-\mathrm{TiO}_{2}$ dispersion on fresh and hardened rendering mortar properties. Five compositions were evaluated with dispersed polypropylene microfibers (PPMF): a reference, without $\mathrm{n}-\mathrm{TiO}_{2}$ addition, and four using two commercial samples of $\mathrm{n}-\mathrm{TiO}_{2}$, evaluated in two dispersion conditions. Although the materials were the same in all formulations, the water content was modified to maintain the same mortar consistency as determined by flow table results. The fresh properties of the mortars were determined by means of squeeze flow and air entrainment tests, while hardened properties were evaluated by capillary water absorption, air-permeability, dynamic elastic modulus, drying shrinkage, split tensile strength according to the Brazilian test, and porosity by the Archimedes immersion method. The results obtained have shown that the fresh and hardened mortar properties were affected by the dispersion procedure and the properties of the $\mathrm{n}-\mathrm{TiO}_{2}$ samples, indicating that adding $\mathrm{n}-\mathrm{TiO}_{2}$ in a dispersed form was more effective in controlling fresh hardened mortar properties. On the other hand, drying shrinkage results are not influenced by the dispersion procedure but by the characteristics of $n-\mathrm{TiO}_{2}$.
\end{abstract}

Keywords: $\mathrm{n}-\mathrm{TiO}_{2}$. Dispersion condition. Drying shrinkage of mortars. Rendering mortars for the facade. Degradation process.

\footnotetext{
${ }^{10}$ S. R. A. Dantas, R. Serafini, R. C. de. O. Romano, F. Vittorino, K. Loh, Influence of the nano $\mathrm{TiO}_{2}$ dispersion procedure on fresh and hardened rendering mortar properties, Constr. Build. Mater. 215 (2019) 544-556. https://doi.org/10.1016/j.conbuildmat.2019.04.190
} 


\section{INTRODUCTION}

The uniformity of nanoparticle dispersion into rendering mortar (random or agglomerated) affects the properties of materials. Particle size and shape, as well as the method of adding to the mixture, are points of great importance which should be considered.

The microstructure of the system governs the rheological properties of dispersions. In those systems, the solid particles are relatively small, and the interparticle forces are significantly pronounced to influence the microstructure, the state of aggregation of the dispersion, and, consequently, the mechanical and rheological properties of the system [1].

A significant impact on the fresh state properties of compositions is generated when $n-\mathrm{TiO}_{2}$ are added in cement-based materials due to the strong tendency towards agglomerate formation due to their ultrafine size [2,3], increasing the water content to the mixture and affecting the hardened state properties. Therefore, the addition of $\mathrm{n}-\mathrm{TiO}_{2}$ as a dry powder into the cement paste presents difficulties regarding homogeneity due to the dry insertion of the compound. Besides, the $\mathrm{n}-\mathrm{TiO}_{2}$ material is wasted since a considerable amount of the product is not available on the surface for photocatalytic activity.

Fine particles, such as $\mathrm{n}-\mathrm{TiO}_{2}$, tend to agglomerate due to their low mass and high surface area, factors that cause surface forces to predominate over gravitational forces. According to the DLVO (Derjaguin-Landau-Verwey-Overbeek) theory, the dispersion state of a system of electrically charged particles in a suspension is governed by the sum of the potential energies of attraction and repulsion of the particles [4]. These potential energies are determined by three main characteristics, in order of importance: a) surface electrical charges, b) $\mathrm{pH}$ of the medium, and c) surface area [5]. As the balance of electric charges on the surfaces of different particles is not always in equilibrium, generated attraction forces are stronger than those of repulsion [6].

In a road surface pavement application study, the $\mathrm{n}-\mathrm{TiO}_{2}$ dispersion accounted for different concrete performances. Nanoparticle addition to the cement matrix caused the formation of agglomerates of low mechanical resistance while adding the material in a dispersed and "loose" procedure promoted the homogenization of $\mathrm{n}-\mathrm{TiO}_{2}$ in concretes [7].

The increase in $\mathrm{n}-\mathrm{TiO}_{2}$ particle concentration in the dispersions produces a more viscous suspension, and the increased viscosity could be attributed to the agglomeration of $\mathrm{n}-\mathrm{TiO}_{2}[8]$. In this sense, the use of the concept of particle packing as a strategy for the development of 
coating mortars can be a great ally as it enables the production of mortars with low cement consumption [9].

The packing models assume that the larger grains form voids that are progressively filled by smaller grains, resulting in high density by reducing the volume of voids between the grains. In addition to particle size distribution and specific surface area, other properties influence particle packing, such as morphology, coarse particle porosity, and particle aggregation. Therefore, an excellent granulometric design must be polymodal, where mixing and compaction techniques also influence the porosity of a mixture for a given particle size distribution [6].

Porosity, specific surface area, and solid content are particle properties that influence the fresh and hardened state parameters, as the spread, air incorporation, mechanical strength, modulus of elasticity, permeability, adhesion, and others. These factors greatly influence the mortar capacity of withstanding aggressive agents such as water, oxygen, carbon dioxide, chlorides, and aggressive solutions [7]. In this context, these parameters can be associated with the service life and durability of a building and evaluate the susceptibility of these fluids to permeate into a porous medium.

The particle dispersion stands as a challenge that needs to be addressed to add nanomaterials in cement matrixes [10]. Regarding the literature data, it becomes evident that additional factors influence the photocatalytic efficiency of the different n- $\mathrm{TiO}_{2}$ samples. Particle characteristics like size, morphology, or surface constitution account for the different photocatalytic activities. In particular, catalyst particle size seems to have a noticeable influence on photocatalytic activity [11].

Thus, the main goal of this study was to experimentally evaluate the influence of $\mathrm{n}-\mathrm{TiO}_{2}$ dispersion on fresh and hardened rendering mortar properties.

\section{EXPERIMENTAL PROGRAM}

\subsection{Materials}

The mortars used in this study were prepared using white Portland cement (WHITE CEM I 52.5R EN 197-1), dolomites \#20, \#40, and \#80, commercial air-entraining agent (AEA) based on sodium lauryl sulfate molecules, water-retaining agents based on cellulosic ether molecules, and polypropylene microfibers. The amount of all these raw materials was kept constant, but the water content of each mixture was modified to maintain mortar consistency. 
Two different samples of commercial $\mathrm{n}-\mathrm{TiO}_{2}$ powder were used in the mixtures, and the comparisons were made using five sets of specimens as described in Table 1.

Ref. represents the composition formulated without the addition of $\mathrm{n}-\mathrm{TiO}_{2}$, and the specimens to which P25 and PC105 had been added were marked with a " $p$ " and a "d," which stood for Standard Energy Mix (SEM) and High Energy of Dispersion (HED) respectively.

Table 1 - Specimen Description. SEM - mortar mixed using standard energy mix; HED - mortar mixed using high energy of dispersion

\begin{tabular}{lllr}
\hline \multicolumn{1}{c}{ Mixtures } & \multicolumn{1}{c}{ Description $^{1}$} & \multicolumn{1}{c}{ Specimens } & Quant \\
\hline Ref. & Mortar without $\mathrm{TiO}_{2}$ addition $(\mathrm{SEM})$ & cylindrical / prismatic & $05 / 03$ \\
$\mathrm{Ref}+\mathrm{P} 25 \mathrm{~d}$ & Mortar with $\mathrm{HED} \mathrm{TiO}_{2}$ addition & cylindrical / prismatic & $05 / 03$ \\
$\mathrm{Ref}+\mathrm{P} 25 \mathrm{p}$ & Mortar with $\mathrm{SEM} \mathrm{TiO}_{2}$ addition & cylindrical / prismatic & $05 / 03$ \\
$\mathrm{Ref+PC105d}$ & Mortar with $\mathrm{HED} \mathrm{TiO}_{2}$ addition & cylindrical / prismatic & $05 / 03$ \\
$\mathrm{Ref}+\mathrm{PC} 105 \mathrm{p}$ & Mortar with $\mathrm{SEM} \mathrm{TiO}_{2}$ addition & cylindrical / prismatic & $05 / 03$ \\
\hline
\end{tabular}

Note: ${ }^{1}$ All compositions were mixed using dispersed PPMF addition.

Source: Author (2019)

\subsection{Methods}

\subsubsection{Raw material Characteristics}

The specific surface area (SSA) of materials was measured using the BET method. The equipment used was an $\mathrm{N}_{2}$ gas/vapor adsorption in a Belsorp Max equipment with a pretreatment of the specimens at a temperature of $60^{\circ} \mathrm{C}$ and a pressure of $7 \times 10^{5} \mathrm{MPa}$ for $24 \mathrm{~h}$ in a Belprep II - vac equipment. The real density analysis was determined using the Helium pycnometry method in a Quantachrome MVP 5DC multipycnometer. Particle size distribution of the finer particles was determined by laser granulometry in a Malvern Mastersizer LongBed with a detection range of $0.1-355 \mathrm{~mm}$. The dolomites particle size distribution was determined employing a Dynamic Image Analyser (QicPic - Sympatec) with a detection range of $1-4000 \mathrm{~mm}$. The raw material characteristics are presented in Table 2 and Figure 1.

Table 2 - Raw material characteristics

\begin{tabular}{lccccc}
\hline \multicolumn{1}{c}{ Materials } & \multicolumn{2}{c}{ Characteristics diameter $(\mu \mathrm{m})$} & Specific surface area & Average density \\
& $\mathrm{d}_{10}$ & $\mathrm{~d}_{50}$ & $\mathrm{~d}_{90}$ & $\left(\mathrm{~m}^{2} / \mathrm{g}\right)$ & $\left(\mathrm{g} / \mathrm{cm}^{3}\right)$ \\
\hline White Portland cement & 2.6 & 17.7 & 19.5 & 0.86 & 3.05 \\
Dolomite \#20 & 975 & 1242 & 1620 & 0.16 & 2.90 \\
Dolomite \#40 & 24.3 & 230 & 740 & 0.56 & 2.94 \\
Dolomite \#80 & 4.5 & 38.3 & 134 & 0.80 & 2.81 \\
$\mathrm{TiO}_{2}$ (P25) & 1.38 & 3.90 & 17.7 & 49.4 & 3.84 \\
$\mathrm{TiO}_{2}$ (PC105) & 0.66 & 1.50 & 4.60 & 79.8 & 3.62 \\
\hline
\end{tabular}

Source: Author (2019) 


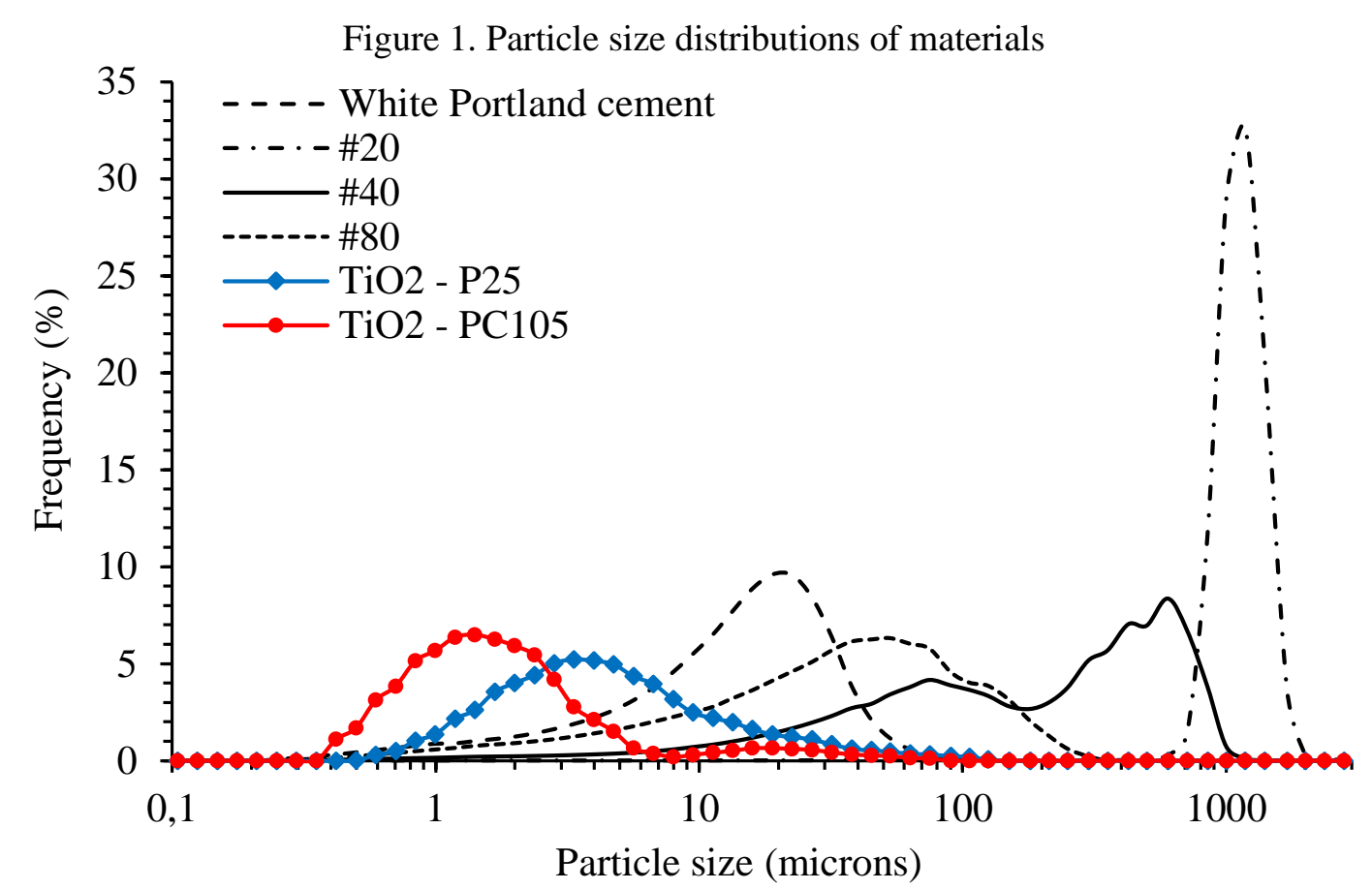

Source: Author (2019)

Figure 2 shows the mineralogical composition of white Portland cement and n- $\mathrm{TiO}_{2}$ obtained by X-ray diffraction: IPT 15742 -CT-OBRAS-LMCC-Q-PE-092 - “Mineralogical analysis by X-ray diffraction" and IPT 15458 - Q-PE-089 - "Determination of phases analysis of Portland cement and Portland cement clinker using the Rietveld method of analysis by powder diffraction", according to ASTM guidelines [12]. Equipment used: Rigaku model Windmax 1000, operating on copper $\mathrm{Ka}$ rad radiation with $40 \mathrm{kV}-20 \mathrm{~mA}$ and $2 \% \mathrm{~min}$ sweep $^{11}$. Table 3 shows the determined chemical composition according to ABNT and ASTM standards [13-20].

\footnotetext{
${ }^{11}$ The compound identification was performed using a Panalytical X-pert HighScore Plus software (version 4.5 (4.5.0.22741), and diffraction patterns and structures provided by the free Crystallography Open Database (COD) database in 2016) and, eventually, diffraction patterns and ICDD (International Center for Diffraction Data) and ICSD (International Center for Structure Data) structures, respectively.
} 
Figure 2. X-ray diffraction of white Portland cement and $\mathrm{TiO}_{2}$

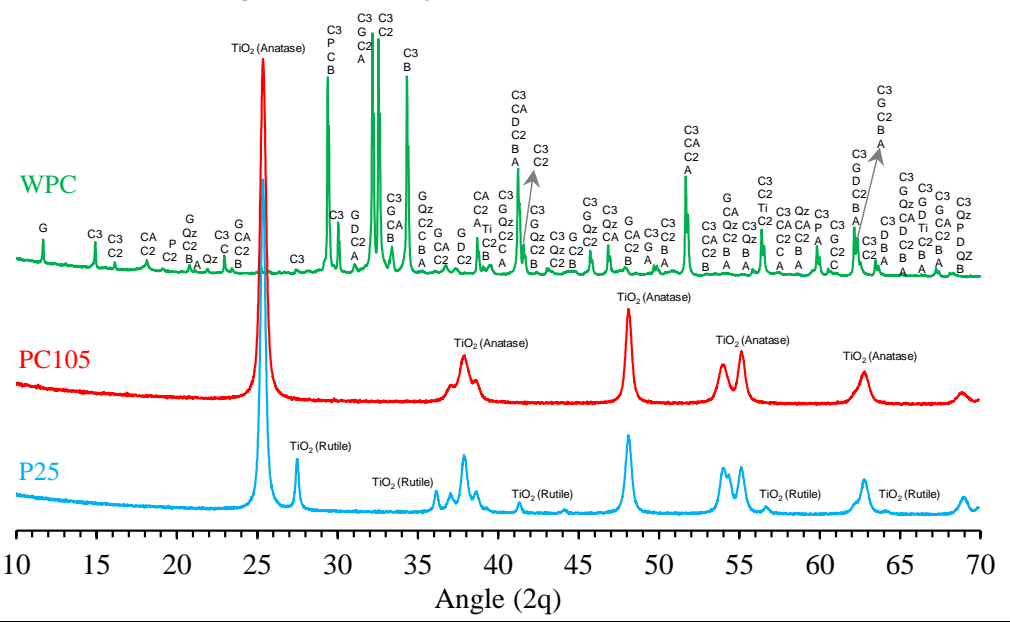

Alite / Hatrurite (C3)

Akermanite - Gelenite (A)

Anhydrite (AN)

Bassanite (B)

Belite / Larnite (C2)

Calcite $(\mathrm{C})$

C3A-ortho (CA)

Dolomite (D)

Free lime (LM)

Gypsum $(\mathrm{G})$

Portlandite $(\mathrm{P})$

Quartz / Cristobalite (Qz)

$\mathrm{TiO} 2$ - Anatase

$\mathrm{TiO} 2$ - Rutile

\begin{tabular}{|c|c|c|}
\hline Phase & ICSD code & ICDD code \\
\hline Alite & $81100 / 22501$ & - \\
\hline Akermanite - Gelenite & 160345 & - \\
\hline Anhydrite & 27474 & - \\
\hline Bassanite & - & 96-101-0919 \\
\hline Belite & 421708 & - \\
\hline Calcite & - & $96-901-6707$ \\
\hline C3A-ortho & 6287 & - \\
\hline Free lime & - & $96-900-6738$ \\
\hline Gypsum & 27876 & - \\
\hline Portlandite & 202223 & - \\
\hline Quartz & - & $96-900-6688$ \\
\hline $\mathrm{TiO}_{2}-$ Anatase & 93098 / 202243 & - \\
\hline $\mathrm{TiO}_{2}-$ Rutile & 51938 & - \\
\hline
\end{tabular}

Source: Author (2019)

Table 3 - Chemical composition of cement and $\mathrm{n}-\mathrm{TiO}_{2}$ samples

\begin{tabular}{lcc|cc}
\hline Compound & $\begin{array}{c}\text { White CEM I } \\
(\%)\end{array}$ & $\begin{array}{c}\text { Limited NBR- } \\
12989 / 93\end{array}$ & P25 & PC105 \\
\hline $\mathrm{LOI}$ & 2.48 & $\leq 27.0$ & --- & --- \\
$\mathrm{TiO}_{2}$ & --- & --- & 99.7 & 99.6 \\
$\mathrm{SiO}_{2}$ & 21.6 & --- & 0.25 & --- \\
$\mathrm{Al}_{2} \mathrm{O}_{3}$ & 4.60 & --- & --- & 0.12 \\
$\mathrm{FeO}_{3}$ & 0.33 & --- & 0.02 & 0.03 \\
$\mathrm{CaO}$ & 67.5 & --- & --- & --- \\
$\mathrm{MgO}$ & 0.59 & $\leq 10.0$ & --- & --- \\
$\mathrm{SO}_{3}$ & 2.83 & $\leq 4.0$ & --- & --- \\
$\mathrm{Na}_{2} \mathrm{O}$ & 0.13 & --- & --- & --- \\
$\mathrm{K}_{2} \mathrm{O}$ & 0.61 & --- & --- & --- \\
$\mathrm{Alkaline}$ equivalent (in $\left.\mathrm{Na}_{2} \mathrm{O}\right)$ & 0.53 & --- & --- & --- \\
$\mathrm{CaO}$ & 2.26 & --- & --- & --- \\
$\mathrm{RI}$ & 0.43 & $\leq 7.0$ & --- & --- \\
$\mathrm{CO}_{2}$ & 0.67 & $\leq 25.0$ & --- & --- \\
\hline
\end{tabular}

Note - Alkaline equivalent (in $\mathrm{Na}_{2} \mathrm{O}$ ) $=\% \mathrm{Na}_{2} \mathrm{O}+0.658 \times \% \mathrm{~K}_{2} \mathrm{O} /$ LOI: Loss on ignition

Source: Author (2019) 


\subsubsection{Compositions}

The compositions were developed without granulometric changes of coarse particles, but the mobility parameters were affected due to the characteristics of the $n-\mathrm{TiO}_{2}$ used. It should be stressed that each composition was mixed with a different amount of water, aiming to maintain the same workability defined in the flow-table tests. The consumption, in $\mathrm{kg} / \mathrm{m}^{3}$, of each raw material in the compositions is described in Table 4.

Table 4 - Consumption, in $\mathrm{kg} / \mathrm{m}^{3}$, of each raw material

\begin{tabular}{lccc}
\hline Composition & Ref & Ref+P25 & Ref+PC105 \\
\hline WPC 40 & 351 & 337 & 342 \\
Dolomite \# 20 & 195 & 187 & 190 \\
Dolomite \# 40 & 1111 & 1067 & 1084 \\
Dolomite \# 80 & 292 & 281 & 285 \\
Water retainer & 1.95 & 1.87 & 1.90 \\
Air-entrainment & 0.16 & 0.15 & 0.15 \\
Deionized water & 332 & 354 & 344 \\
Polypropylene microfibers & 1.4 & 1.4 & 1.4 \\
$\mathrm{TiO}_{2}$ (P25) & --- & 16.8 & --- \\
$\mathrm{TiO}_{2}$ (PC105) & --- & --- & 17.1 \\
\hline
\end{tabular}

Source: Author (2019)

Figure 3 shows the particle size distribution of each composition, and Table 5 shows the packing and mobility parameters that resulted in the proportioning of raw materials. Interparticle separation (IPS) represents the mean distance to separate the finer particles assuming that all are completely dispersed, and maximum paste thickness (MPT) indicates the distance between the coarse particles, having been calculated in this work disregarding the air-voids, but considering the differences in the water content used in each mixing.

The IPS concept is particularly applicable to fine particle suspensions, as in the case of n$\mathrm{TiO}_{2}$, where surface forces are predominant, considering the effect of particle size distribution and predicting particle contact $(\mathrm{d}=0)$ when the amount of the liquid phase is lower than the porosity of the packaged system [9]. The lower the porosity of the system, regulated by particle size distribution, the higher is the IPS value of the paste, and the greater is the amount of the free liquid phase to separate the particles [21]. Particle separation must be at least 50 $\mathrm{nm}$ for movement to occur [4]. Studies suggest similar values for the water layer between the particles of $41 \mathrm{~nm}[22]$ and $45 \mathrm{~nm}$ [23], respectively. 
Figure 3. Particle size distribution of each composition

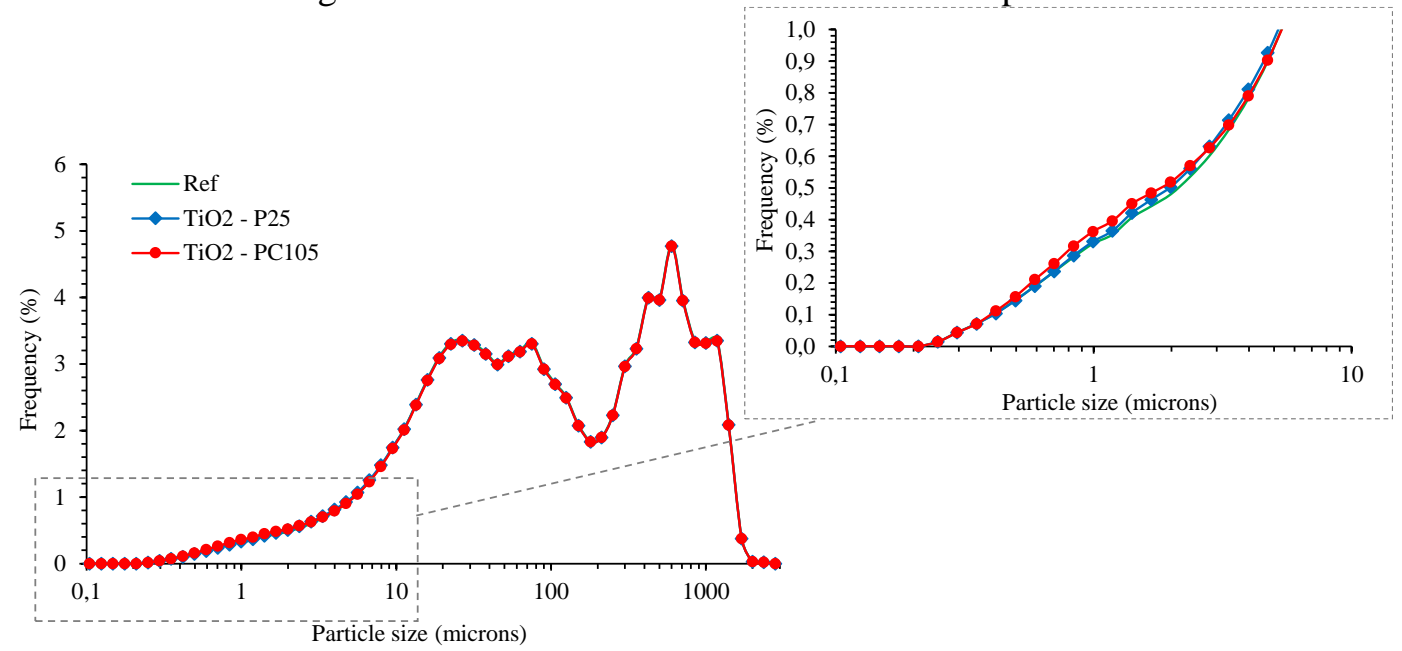

Source: Author (2019)

Table 5 - Particle packing and mobility

\begin{tabular}{lccc}
\hline Composition & Ref & Ref+P25 & Ref+PC105 \\
\hline Packing porosity (\%) & 8.7 & 8.5 & 8.5 \\
Packing porosity - finer particles (\%) & 14.1 & 13.9 & 13.8 \\
Volumetric Surface Area $\left(\mathrm{m}^{2} / \mathrm{cm}^{3}\right)$ & 1.79 & 3.08 & 3.88 \\
IPS (micra)* & 0.49 & 0.31 & 0.23 \\
MPT (micra)** & 16.9 & 18.0 & 17.6 \\
\hline
\end{tabular}

Note: *interparticle separation / **maximum paste thickness

Source: Author (2019)

To increase the flowability of a mortar, it is necessary to maximize the MPT value to provide the lowest contact among the coarse grains. The MPT has a close relationship with the fresh and the hardened state's properties of coating mortars. For values lower than $20 \mu \mathrm{m}$, the compressive loads to spread mortars increase significantly because the aggregates' friction is higher. Above this value, the compressive load falls smoothly as a function of the MPT increase, and this value may change according to the specific properties of each mortar evaluated $[24,25]$.

The mobility and packaging parameters were used to define the mortar composition, but no correlation was observed with the properties obtained. That fact shows that the products' characteristics also depend on chemical and surface parameters, which were not considered in this work.

\subsubsection{Mixing process}

Figure 4 shows the stages used to mix the mortars. The set of specimens show only small differences. The mixing procedure of the raw materials used to prepare the specimens is detailed below. 
- Reference mortars (mixtures without the addition of n-TiO2): water was added into the bowl of the Hobart N50 mixer. Then microfibers were added, and Standard Energy Mix (SEM) was applied for the $90 \mathrm{~s}$ using: $30 \mathrm{~s}$ in speed 1 (low), $30 \mathrm{~s}$ in speed 2 (high), and $30 \mathrm{~s}$ speed 1 (low). The dry powder was added for $1 \mathrm{~min}$ with the equipment turned off. A period of $30 \mathrm{~s}$ was allowed for particle wetting, and then the equipment was turned on, and the mixing was performed for $90 \mathrm{~s}$ using the same procedure described previously.

- Ref+P25p and Ref+PC105p mortars: the n- $\mathrm{TiO}_{2}$ was homogenized with all the dry powder (cement and dolomites) in a plastic bag for the $30 \mathrm{~s}$ before the addition. The procedure used to disperse microfibers, add the dry powder and mix the mortar was the same as the reference mortars.

- Ref+P25d and Ref+PC105d mortars: all the water and n-TiO 2 were added to a metallic vessel, adapted from a cocktail mixer. The suspension was dispersed under High Energy Dispersion (HED) (10.000 rpm with cawles type propellant) for $30 \mathrm{~s}$ and, then the microfibers were inserted. From that moment on, the mixing procedure was the same as described previously.

Figure 4. SEM (a-b); HED equipment (c); suspension after HED (d)

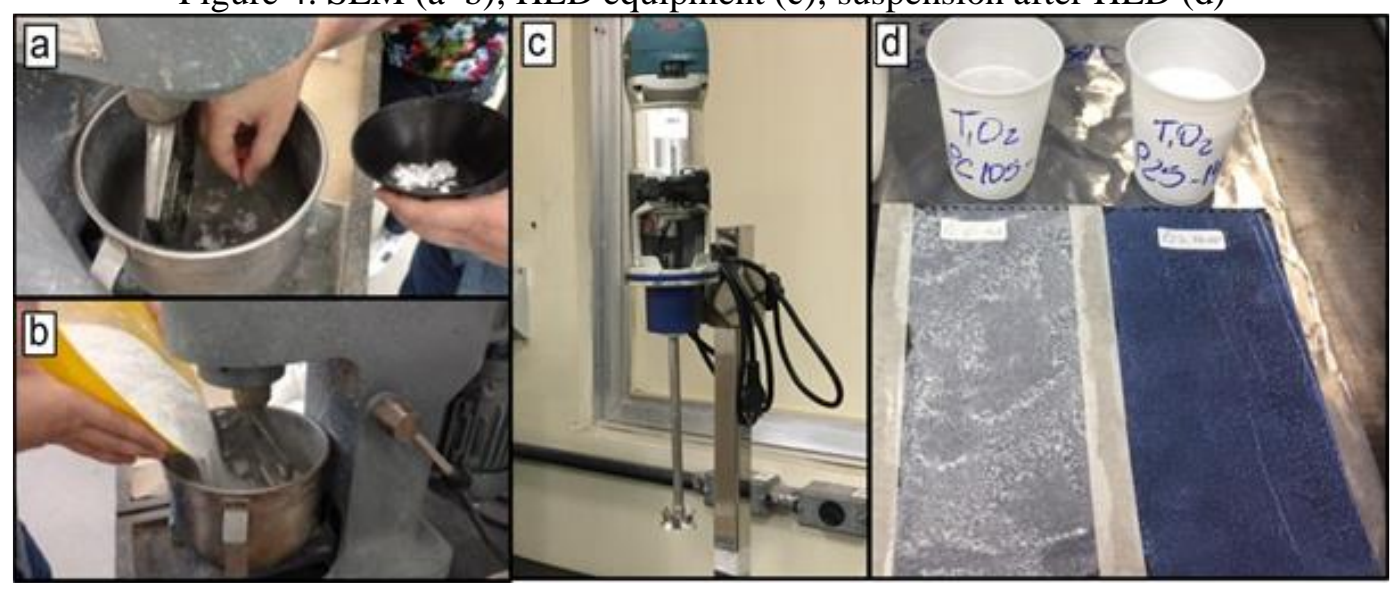

Source: Author (2019)

\subsubsection{Fresh state properties}

After mixing, the fresh state properties were evaluated using the flow table test [26], as shown in Figure 5, squeeze flow test [27] Figure 6, and air incorporation by gravimetric method [28]. 
Figure 5. Consistency according to the flow table method

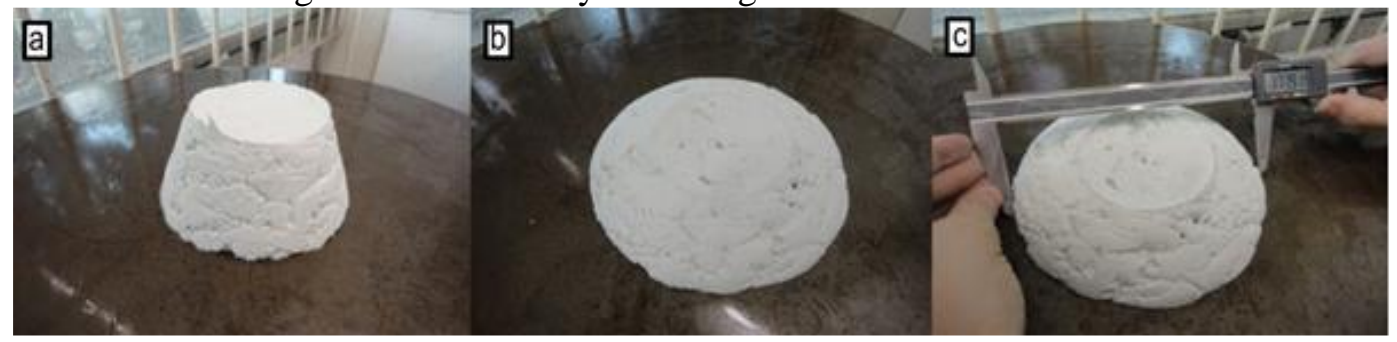

Source: Author (2019)

Squeeze Flow: tests were conducted on a universal testing machine (Instron 5569) with a $1 \mathrm{kN}$ load cell. Samples were prepared on a metallic plate with smooth surfaces to ensure a nonabsorption condition, and a cylindric mold (diameter of $101 \mathrm{~mm}$ and width of $20 \mathrm{~mm}$ ) was used. The tests were performed using a displacement rate of $0.1 \mathrm{~mm} / \mathrm{s}$, to a maximum displacement of $18 \mathrm{~mm}$ or a maximum load of $1 \mathrm{kN}$.

Figure 6. Preparation of sample (a); beginning (b) and; the end of test (c)

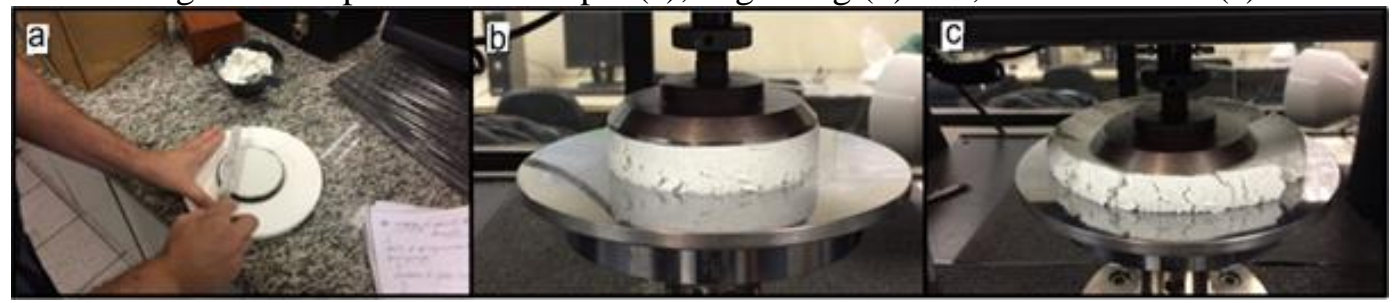

Source: Author (2019)

Air-entrainment: tests were done according to the gravimetric method, using a $400 \mathrm{ml}$ volume cup, and the mass used to fill it was quantified. The values of air entrainment were calculated based on the mortar's water content and the real density of the dry powder.

\subsubsection{Hardened state properties evaluation}

The moulded specimens were cured for 28-days under controlled temperature and humidity (respectively, at $23{ }^{\circ} \mathrm{C}$ and $50 \%$ ). The hardened properties were measured by water absorption by capillarity [29], air-permeability, dynamic elasticity modulus (E) [30], split tensile strength by the Brazilian test method [31], porosity (the Archimedes method), and drying shrinkage test [32]. The results were statistically evaluated using a one-way ANOVA and followed by a Tukey test.

The porosity of specimens: measured according to the Archimedes water immersion test, based on the dry, wet, and immersed masses. The mass is determined on the dried specimens after immersion in water and under vacuum for $2.5 \mathrm{~h}$ (Figure 7 ). The total porosity was calculated according to Eq. 1, where ${ }_{\rho \mathrm{REL}}$ is the relative mortar density obtained by gas $\mathrm{He}$ pycnometry. 
Figure 7. Porosity test (Archimedes water immersion test)

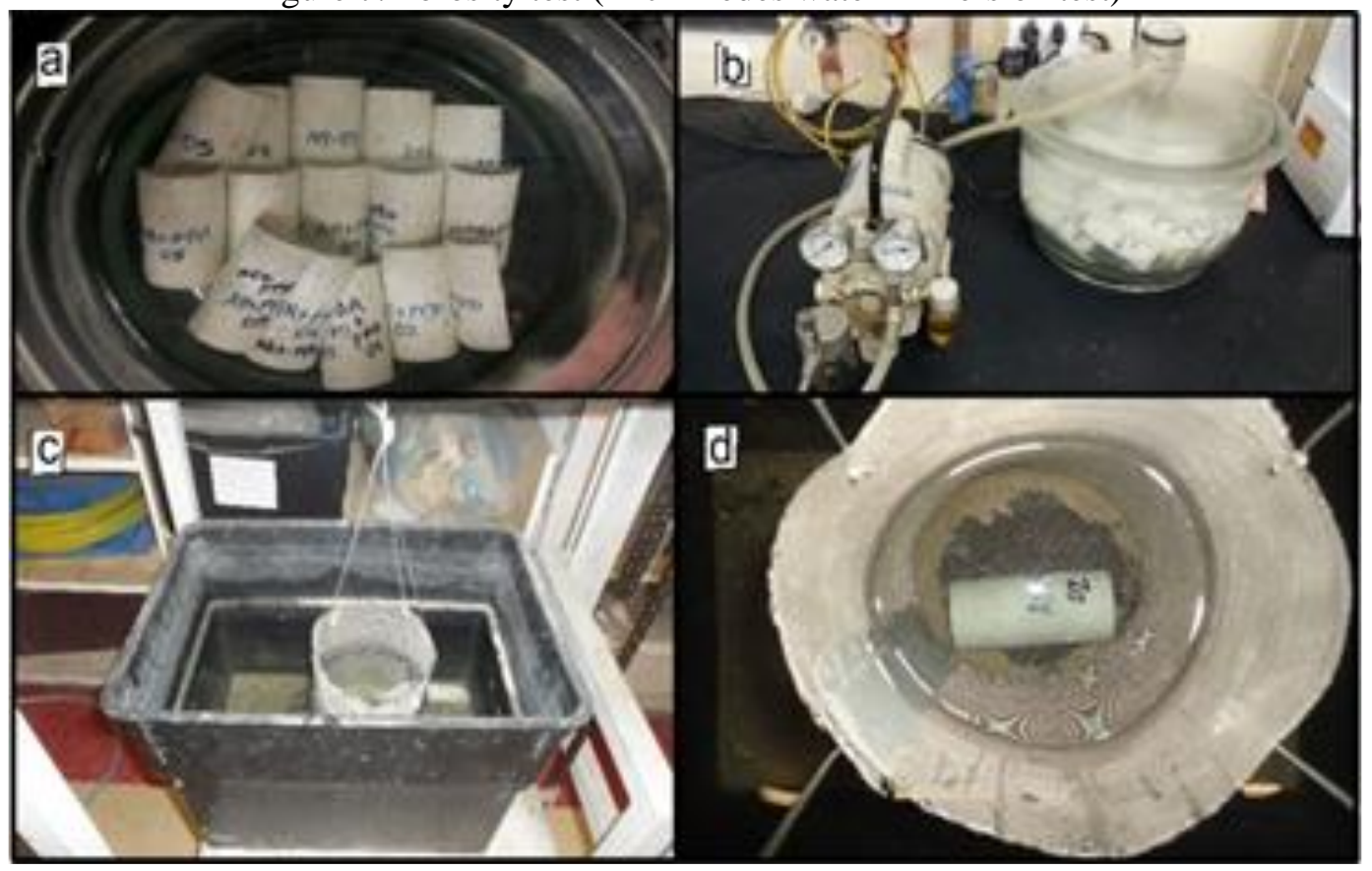

Note: Vacuum insertion (a-b); mass measurement [dry, wet, immersed (c-d)].

Source: Author (2019)

Air-permeability: measured according to the vacuum-decay method [33-36]. The apparatus employed was a vacuum pump connected to a suction chamber that is was in contact with the surface of the mortar. When the vacuum pump is turned on, a transducer registered the pressure variations as a function of time until the pressure stabilized. Specimens were sealed using PVC plastic (Fig. 8a) to guarantee the unidirectional flow. The test starts when the vacuum is turned off, and the time it takes for the applied vacuum pressure to extinguish is quantified (Fig. 8b and c). The permeability (expressed in $\mathrm{k} 1\left(\mathrm{~m}^{2}\right)$ values) was calculated using the Forchheimer equation [Eq. 2], concerning two basic hypotheses: negligible aircompressibility and the use of just the linear part of the equation.

$\frac{\Delta P}{L}=\frac{\mu}{k_{1}} v_{S}+\frac{\rho}{k_{2}} v_{S}^{2}$

$\mathrm{L}$ is the sample thickness, $\mu$ and $\rho$ are, respectively, the fluid viscosity and density, vs is the speed of air-percolation and $\Delta \mathrm{P}$ is the pressure variation, through which vs, $\mu$ and $\rho$ are measured or calculated. The term $\rho v s / k_{1}$ shows the viscous effect of the fluid-solid interaction, while the term $\rho v s^{2} / \mathrm{k}_{2}$ represents the inertial effects. The terms $\mathrm{k}_{1}$ and $\mathrm{k}_{2}$ are thus known as Darcian and no-Darcian permeability constants, about Darcy's law, a simpler and earlier empirical model for permeability description. However, $\mathrm{k}_{2}$ was not used to compare the results in this work [37]. 
Figure 8. Air-permeability

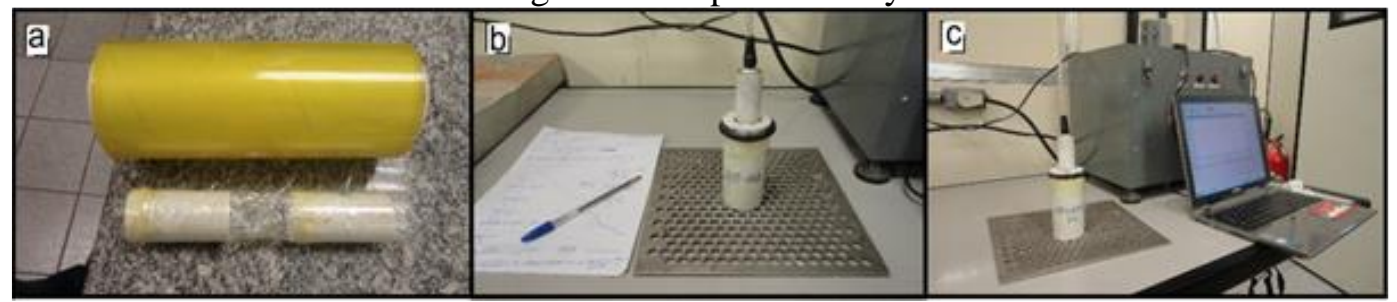

Note: Sample preparation (8a); Measurement process $(b-c)$

Source: Author (2019)

Dynamic elasticity modulus (E): measured according to the Brazilian standard using a PUNDIT (Portable Ultrasonic Nondestructive Digital Indicating Tester) equipment with 200 $\mathrm{kHz}$ frequency transducers and a circular cross-section with a $20 \mathrm{~mm}$ diameter.

Split tensile strength: measured according to the Brazilian standard using an Emic DL10000 equipment with a continuously applied load rate of $400 \mathrm{~N} / \mathrm{s}$ until the test specimens rupture, as shown in Figure 9.

Figure 9. Tensile strength in diametrical compression, according to Brazilian standard

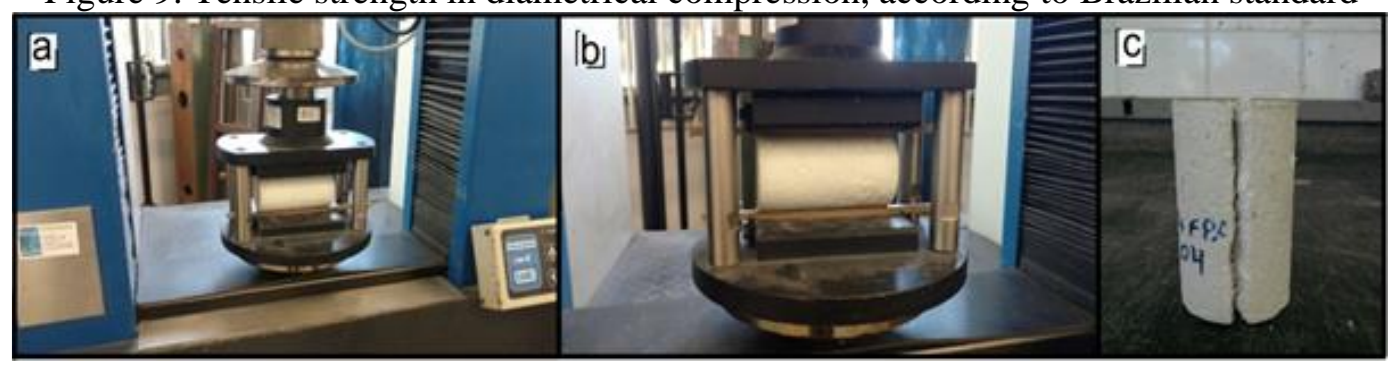

Note: Determination according to Brazilian standard (a-b); specimen after the test (c) Source: Author (2019)

Water absorption by capillarity: the specimen was partially sealed with beeswax at one of their ends at the height of $\pm 3 \mathrm{~cm}$ to avoid water absorption, thus forcing the water to penetrate only through the contact area. The specimens were placed on grids inside a box containing a water height of $1 \mathrm{~cm}$ (Figure 10). The water absorption of the specimens was determined by weighing in the following intervals: $0 \mathrm{~h}$ (dry mass), 150, 300, $1 \mathrm{~h}, 2 \mathrm{~h}, 4 \mathrm{~h}, 8 \mathrm{~h}$, $24 \mathrm{~h}$, and $48 \mathrm{~h}$.

Figure 10. Water absorption by capillarity

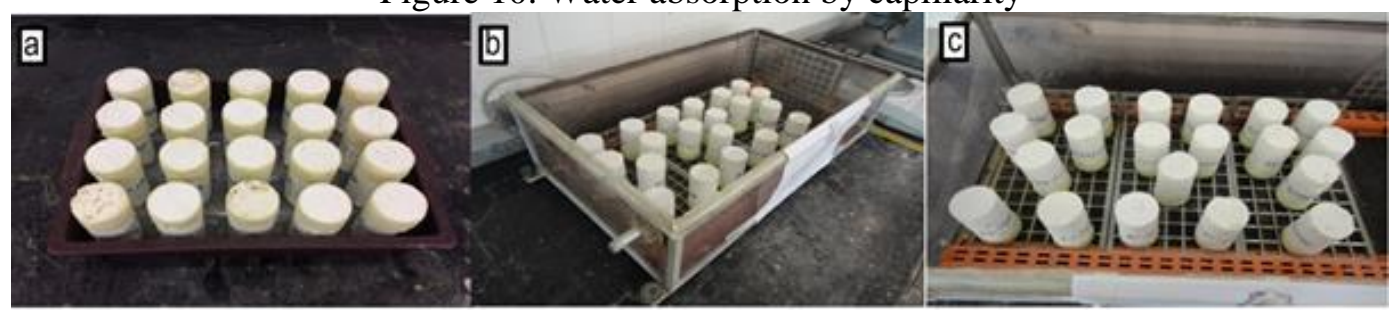

Note: Sample preparation (a); Sub-immersion process (b-c)

Source: Author (2019) 
Dimensional variation (shrinkage): measured according to Brazilian standards, using $25 \times 25$ x $285 \mathrm{~mm}$ test specimens. The dimensional variation of the specimens was determined by a comparator clock with a resolution of $0.001 \mathrm{~mm}$ at intervals of 2 times a day for 28 days, as shown in Figure 11.

Figure 11 - Dimensional variation (Shrinkage)

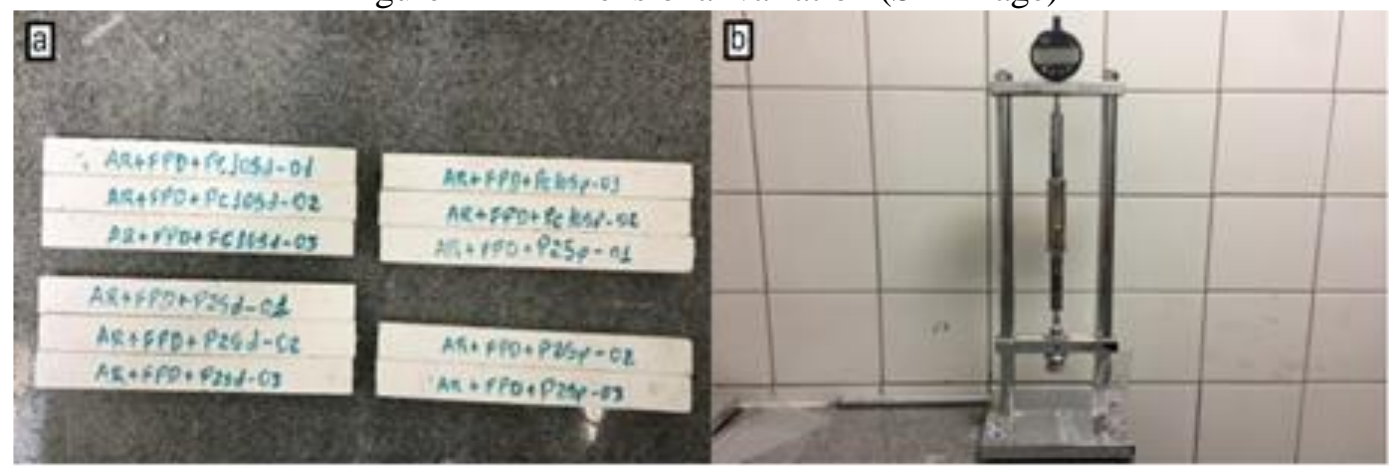

Note - Specimens (11a); Comparator clock (11b)

Source: Author (2019)

\section{RESULTS AND DISCUSSION}

\subsection{Fresh state properties}

Table 6 shows the spreading of mortars obtained by the flow-table test and the air incorporation results. The rendering mortars must present spreading capacity to be considered adequate to be applied in facades. In the flow-table test, the spreading is considered a preponderant factor.

The Brazilian standard does not indicate an ideal flow result in flow-table tests. Based on previously conducted studies, the target for this kind of test was $220 \pm 10 \mathrm{~mm}$. The compositions that do not reach this range were rejected (Ref+P25p and Ref+PC105p with water constant).

The results indicate that it was impossible to maintain the same amount of kneading water used in the reference mortars because adding $\mathrm{n}-\mathrm{TiO}_{2}$ in the mixture required higher water content. When the same water content used to prepare the reference mortars is maintained, there is a spreading detriment in all the mixtures.

With different specific surface areas, the different $\mathrm{n}-\mathrm{TiO}_{2}$ samples required other volumes of water for the same degree of spreading. Thus, for the amount of water added per $n-\mathrm{TiO}_{2}$ samples, the mortar that presented the best spreading (workability) and with a lower volume of air incorporated was the mortar Ref+P25d. This means that when the consistency of the mortars with the addition of $\mathrm{n}-\mathrm{TiO}_{2}$ is evaluated through the flow-table test and the volumes 
of water, the addition method and the $\mathrm{n}-\mathrm{TiO}_{2}$ sample used directly influence the results. Thus, the following steps of this study were carried out using only accepted compositions.

Table 6 - Entrained air and flow table test results

\begin{tabular}{lccc}
\hline \multicolumn{1}{c}{ Mixtures } & $\begin{array}{c}\text { Spreading } \\
(\mathrm{mm})\end{array}$ & $\begin{array}{c}\text { Entrained air } \\
(\%)\end{array}$ & $\begin{array}{c}\text { Water added } \\
(\mathrm{g})\end{array}$ \\
\hline Reference Mortar & $227 \pm 2.0$ & 26.1 & 425.0 \\
Ref+P25p (water constant) & $178 \pm 1.1$ & - & 425.0 \\
Ref+P25p (consistency constant) & $219 \pm 1.8$ & 28.8 & 467.5 \\
Ref+P25d & $229 \pm 3.7$ & 24.3 & 467.5 \\
Ref+PC105p (water constant) & $203 \pm 0.8$ & - & 425.0 \\
Ref+PC105p (consistency constant) & $218 \pm 0.5$ & 27.0 & 447.0 \\
Ref+PC105d & $213 \pm 2.0$ & 25.5 & 447.0 \\
\hline
\end{tabular}

Source: Author (2019)

In the civil engineering sector, the squeeze flow method has been used to evaluate the rheological behavior of pastes, plasters, extruded building materials, and different types of mortars as an alternative, complementary method. That method has been applied to simulate processing and application conditions such as difficulties in rotational techniques as slipping, material-shear element interfaces, measuring fiber-containing pastes. The test geometry changes during gap reduction and creates flow conditions similar to those that involve the processing and application of mortars, like pumping and spraying, spreading and finishing, squeezing between bricks.

The test compresses a cylindrical specimen between two parallel polished metallic plates as a reference condition and controls the displacement rate. Compared to other types of rheological methods, this test does not simulate the most common problem: the loss of contact between the material and the sheer element, especially for materials with plastic characteristics such as mortars. The method is adequate to evaluate both mixtures of any level of consistency and blends with the addition of fibers. In the case of rendering mortars, the test simulates the processing conditions as spreading, levelling, and finishing. Figure 12 shows the results obtained in the mortars $5 \mathrm{~min}$ after mixing, and Table 7 illustrates a quantitative evaluation. 
Figure 12 - Squeeze flow results. Percentage presented indicates the water content in each
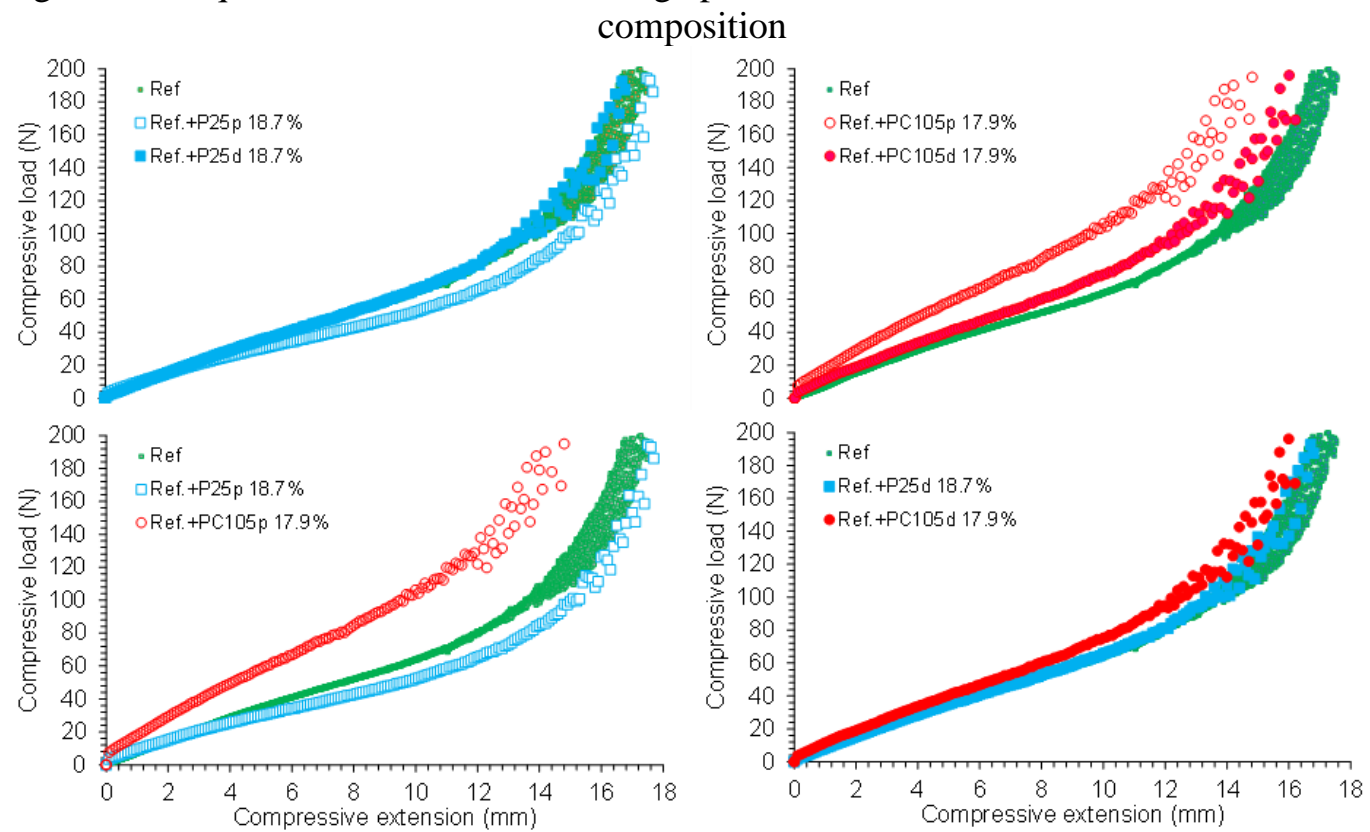

Source: Author (2019)

Table 7 - Summary of load and displacement of the mortars in fresh state

\begin{tabular}{|c|c|c|c|}
\hline Mixtures & $\begin{array}{l}\text { Spreading } \\
\text { Flow table } \\
(\mathrm{mm})\end{array}$ & $\begin{array}{l}\text { Load with displacement of } \\
10 \mathrm{~mm} \\
(\mathrm{~N})\end{array}$ & $\begin{array}{l}\text { Displacement } \\
\text { with } 100 \mathrm{~N} \\
(\mathrm{~mm})\end{array}$ \\
\hline Reference Mortar & 227 & 63.9 & 14.0 \\
\hline Ref $+P 25 p$ & 219 & 52.2 & 15.3 \\
\hline Ref+P25d & 229 & 65.7 & 13.3 \\
\hline Ref+PC105p & 218 & 106.2 & 9.6 \\
\hline Ref $+\mathrm{PC} 105 \mathrm{~d}$ & 213 & 75.1 & 12.5 \\
\hline
\end{tabular}

Source: Author (2019)

In the flow table method, the mortars are evaluated as a function of their weight. The squeeze flow test simulates the mortars being applied to different spreading conditions, and the better dispersion condition of the particles can result in lower compressive loads. In this study, the results were considered for a $1 \mathrm{~cm}$ thick and a $10 \mathrm{~cm}$ displacement mortar.

No differences were observed between the specimens with $\mathrm{n}-\mathrm{TiO}_{2}-\mathrm{P} 25$ and the reference, indicating that this type of titanium does not require high mixing energy for its dispersion. On the other hand, in the case of the $n-\mathrm{TiO}_{2}-\mathrm{PC} 105$ sample, there is a clear difference when comparing the squeeze flow spreading of the prepared samples with standard and high shear energy.

When the composition was mixed with (SEM), the presence of the $\mathrm{n}-\mathrm{TiO}_{2}-\mathrm{PC} 105$ sample resulted in a higher load for the same compressive displacement, resulting from the higher agglomeration and retention of some of the water used to promote particle spacing and improve flow. On the other hand, with (HED) condition of $\mathrm{n}-\mathrm{TiO}_{2}$ promoted by the increase 
of the sheer energy, the spreading of this mortar was similar to that of the reference, showing that the agglomerates were broken, and the flow facilitated.

According to Romano et al. [38], the use of (HED) is more efficient for the dispersion of fine particles compared to the (SEM). The authors applied the same concept used in this article. They concluded that using (SEM) with lower shear energy did not significantly improve the dispersion, even with an increase in the mixing time, since the obtained particle size curves were similar and with coarser particles. On the other hand, the use of (HED) resulted in a reduction in coarser particles. Thus, it could be concluded that the higher dispersion efficiency is directly related to the increase in the population of particles with smaller diameters.

When it is observed the mortars Ref+P25 (powdered or dispersed), there is practically no difference in workability in the fresh state, as compared with the reference or between them. On the other hand, for the mortar Ref+PC105 in the dispersed form, no difference was observed in comparison with the reference mortars, but when the (SEM) of n- $\mathrm{TiO}_{2}$ was used (Ref+PC105p), the spreading showed small changes, as it needed more effort to obtain the same displacement. In other words, the (HED) of n- $\mathrm{TiO}_{2}-\mathrm{PC} 105$ improved the workability of that mortar for conventional applications using spreading.

Comparing different samples of $\mathrm{n}-\mathrm{TiO}_{2}$, it is clear that using different dispersion conditions of $\mathrm{n}-\mathrm{TiO}_{2}$, no differences were observed between them, but the particle agglomeration in the (SEM) condition resulted in considerable differences. It is possible to observe that even after the application of (HED), n- $\mathrm{TiO}_{2}-\mathrm{PC} 105$ presents a higher concentration of clustered particles, showing a creamy consistency than $\mathrm{n}-\mathrm{TiO}_{2}-\mathrm{P} 25$ suspension, as shown in Figure $4 \mathrm{C}$, illustrating that $\mathrm{n}-\mathrm{TiO}_{2}-\mathrm{PC} 105$ would need more effort to be applied, and that can result in differences in the productivity and sometimes affecting the quality of the applied coating.

The results show that although the (HED) is an efficient method for the deagglomeration of $n$ $\mathrm{TiO}_{2}$ particles, the impact of changing the mixing energy depended on the $\mathrm{n}-\mathrm{TiO}_{2}$ sample used.

\subsection{Hardened state properties}

The properties of $\mathrm{n}-\mathrm{TiO}_{2}$ were evaluated as a function of the dispersion condition. Figure 13 summarizes the hardened properties results for each mortar, such as porosity, airpermeability, split tensile strength, and modulus of elasticity, while the average results of the capillary coefficient for each mortar are shown in Figure 14. 
Figure 13. Summary of hardened mortar properties

$$
\begin{aligned}
& \square \text { Total porosity (\%) } \\
& \square \text { Apparent porosity (\%) }
\end{aligned}
$$

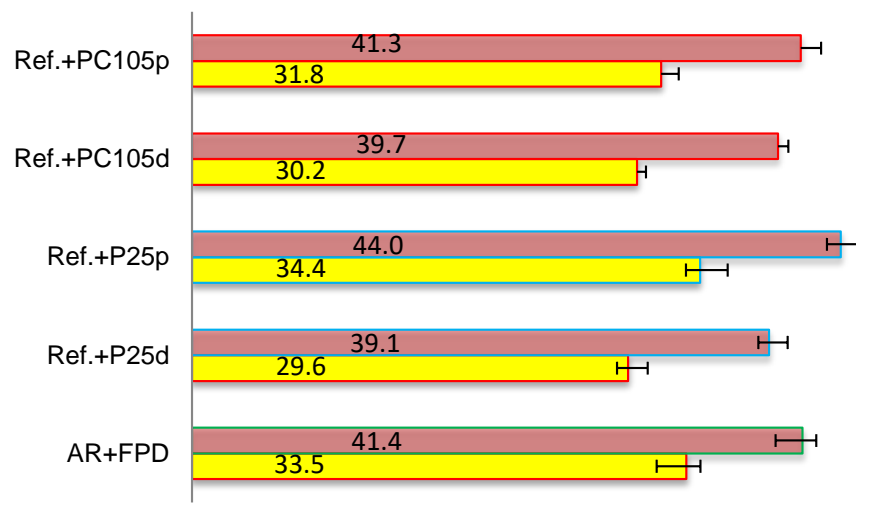

Tensile strength in diametral compression (MPa)

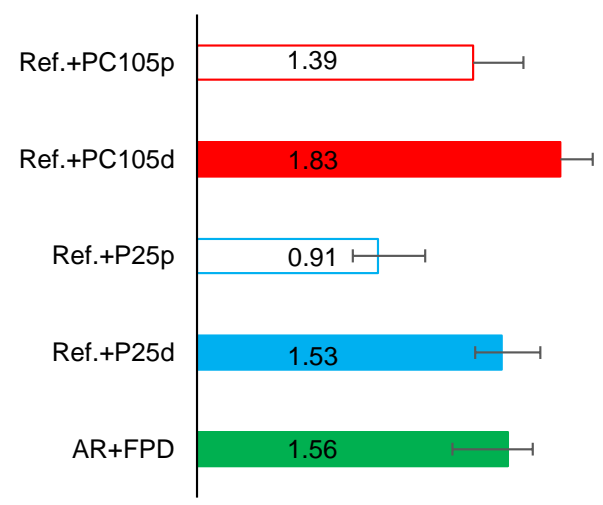

Air permeability $\left(\times 10^{-11} \mathrm{~m}^{2}\right)$

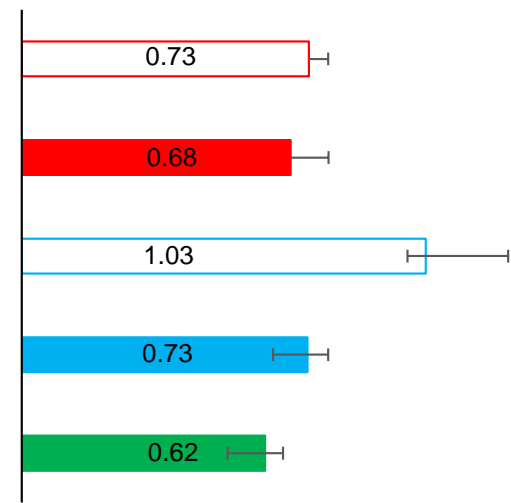

Dynamic modulus of elasticity (GPa)

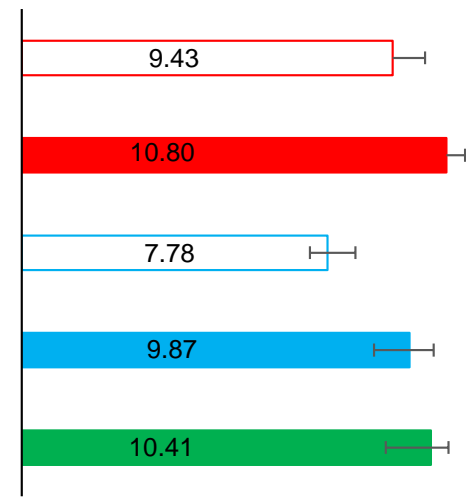

Source: Author (2019)

Figure $14-$ Water absorption by capillarity $\left(\mathrm{W}\right.$, in $\left.\mathrm{kg} / \mathrm{m}^{2} \mathrm{x} \sqrt{h}\right)$.

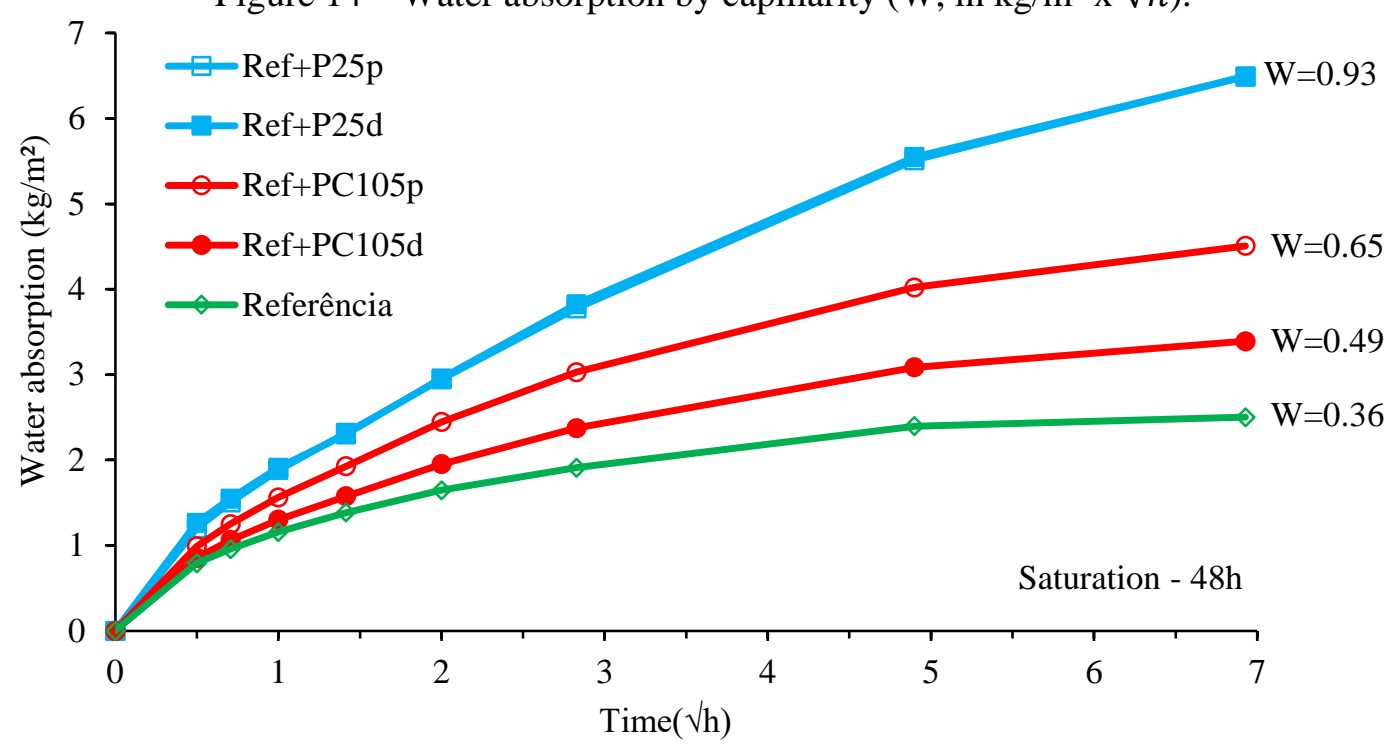

Note: Monitoring of Ref+P25 ( $\mathrm{d}$ and $\mathrm{p}$ ) were similar

Source: Author (2019)

Mortar water content largely impacts mortar properties, and it can have a stronger influence on mortar properties than binder type or the nature of the aggregate. Mortar porosity, density, and water absorption are more significantly affected by water content than aggregate quality 
[39]. Excessive water lowers a mortar's mechanical strength and increases the risk of fracturing by shrinkage.

The porosities of the mortars show differences when observed and comparing the samples and procedure of $\mathrm{n}-\mathrm{TiO}_{2}$ addition. For the addition of $\mathrm{n}-\mathrm{TiO}_{2}$ using the (HED) procedure, a lower porosity, regardless of the sample, is observed when compared to the reference mortars. However, no significant differences were observed when comparing the two samples with each other, even with the granulometric differences between both. This is due to the addition procedure of the $\mathrm{n}-\mathrm{TiO}_{2}$, which did not allow a fast agglomeration of its particles during the mixing process and did not require a larger volume of water for the process of homogenization and workability the mixtures. In relation to the (SEM), better performance can be observed for sample $\mathrm{n} \mathrm{TiO}_{2}-\mathrm{PC} 105$ compared to sample $\mathrm{n}-\mathrm{TiO}_{2}-\mathrm{P} 25$. As a very small particle, the direct addition procedure caused agglomeration of the $\mathrm{n}-\mathrm{TiO}_{2}$ particles during the mixing process, altering the workability and thus requesting a higher volume of water, as observed in Table 6. This increase in water volume caused a direct impact on the porosity of the mortars since allowing a larger amount of air caused a greater number of voids.

When comparing the split tensile strength versus the total porosity of the system in the experimental test, a moderate correlation $\left(\mathrm{R}^{2}=0.67\right)$ was expected. Was observed between a decrease in the split tensile strength and an increase in the porosity of the specimens. This is related to the fact that total porosity in the hardened state results from the air voids resulting from the air entrainment and water content. As the aggregates usually used in the composition of these materials have very low porosity and mechanical resistance of $130 \mathrm{MPa}$ or higher, the strength of conventional mortars is defined by the porosity of the hydrated cement paste added to the defects present in its microstructure [37,40]. For the five mixtures evaluated, the $\mathrm{Ref}+\mathrm{P} 25 \mathrm{p}$ mortar presented on average a lower tensile strength in the diametrical compression since it has a greater total porosity, confirming the previously found results.

The total porosity and the dynamic modulus of elasticity of the mortars show a significant correlation $\left(\mathrm{R}^{2}=0.88\right)$. A decreasing trend line is observed, which means that a higher total porosity results in a smaller modulus of elasticity. The smaller the modulus, the higher the mortar's deformation capacity, thus reducing the possibility of cracking in the hardened state [41]. The reduction of the modulus of elasticity is paired with a reduction in the mechanical strength due to the increase in total porosity. Mechanical strength reduction may be a relevant factor in laying structural or even regular masonry; however, it does not seem to be of great importance for rendering mortars, except for adherence and integrity purposes. Following the 
same pattern of tensile strength, among the five mixtures evaluated, the mortar Ref $+\mathrm{P} 25 \mathrm{p}$ presented the lowest values in the modulus of elasticity. The correlation between tensile strength and modulus of elasticity was very high in this study.

The dynamic modulus of elasticity versus air permeability evaluation also shows a good correlation $\left(\mathrm{R}^{2}=0.70\right)$. A downward trend is also observed, which means that a higher modulus of elasticity results in a lower air permeability because both properties are related to the porosity.

The greater the modulus, the lower the deformation capacity of the mortar, increasing the possibility of cracking in the hardened state, which is rather inappropriate for coating mortars. The increase in modulus of elasticity is paired with increased tensile strength due to lower total porosity. However, no such relationships are observed for mortar Ref $+\mathrm{P} 25 \mathrm{~d}$. Note that even with lower total porosity, the mortar has a lower tensile strength, a lower modulus of dynamic elasticity, and a higher air permeability when compared to mortar Ref+PC105d. That behavior can be allied to the characteristics of the $\mathrm{n}-\mathrm{TiO}_{2}-\mathrm{P} 25$ sample, where greater incorporation of air in the standard energy mix product and a higher amount of water used in the composition resulted in such porosity values and, thus, the changes in the hardened state that directly affected the modulus of elasticity.

Thus, considering the evaluated property and the results obtained, among the five mixtures evaluated, the reference mortar was the one with the lowest air permeability values, followed by the Ref+PC105d mortar due to its lower total porosity.

The mortar permeability at 28-days was evaluated by the capillary coefficient obtained by water absorption as a function of time. For water absorption tests on rendering mortars, all mixtures reached saturation after $48 \mathrm{~h}$ of sub-immersion. The addition of air-entraining additives in the mortars studied shows a larger internal air volume for the mortars containing powdered $\mathrm{n}-\mathrm{TiO}_{2}$, as shown in Table 6.

As far as the capillary coefficients obtained, the results showed that for the mixtures containing n- $\mathrm{TiO}_{2}-\mathrm{P} 25$ sample directly added or dispersed, there was no difference between the two regarding water absorption, offering the same capillary coefficient. However, they showed a higher absorption index when compared to the others. For mixtures with the n$\mathrm{TiO}_{2}-\mathrm{PC} 105$ sample, a lower absorption rate is observed when the compound is added to the mixture with the high energy of dispersion (HED) procedure. 
Two statistical methods were used to determine the influence of $n-\mathrm{TiO}_{2}$ dispersion in terms of statistical significance: one-way ANOVA and the Tukey test. Those methods were used to indicate which dispersion method showed the lowest variation, as can be observed, as an example, in Table 8, for tensile strength.

Table 8 - Summary of statistical analysis of variance evaluating the impact of $\mathrm{TiO}_{2}$ dispersion in the tensile strength

\begin{tabular}{lcccc}
\hline \multicolumn{1}{c}{ Group } & Count & Sum & Average & Variance \\
\hline AR-FPD & 5 & 7.82 & 1.56 & 0.02 \\
AR-FPD+P25d & 4 & 6.13 & 1.53 & 0.04 \\
AR-FPD+P25p & 5 & 4.55 & 0.91 & 0.06 \\
AR-FPD+PC105d & 5 & 9.13 & 1.83 & 0.03 \\
AR-FPD+PC105p & 5 & 6.94 & 1.39 & 0.06 \\
\hline
\end{tabular}

\begin{tabular}{l|cccccc}
\hline Source of variation & SQ & GL & MQ & Fcalc & P-value & F critic \\
\hline Between groups & 2.28 & 4 & 0.570 & 14.10 & $1.7 \mathrm{E}-05$ & 2.90 \\
In the groups & 0.77 & 19 & 0.040 & & & \\
& & & & & & \\
Total & 3.05 & 23 & & & & \\
\hline
\end{tabular}

Source: Author (2019)

All parameters were evaluated statistically and performed in the same procedure. However, since the table would be the same in all cases, the authors selected only one example of the data output in the Anova table. Table 9 presents a comparative summary of the values of $F$,

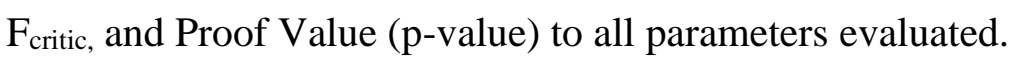

Table 9 - Summary of statistical analysis of variance evaluating the impact of $\mathrm{TiO}_{2}$ dispersion in others

\begin{tabular}{lllll}
\hline \multicolumn{1}{c}{ Property } & p-value & \multicolumn{1}{c}{ F } & F-critic & \multicolumn{1}{c}{ Result } \\
\hline Total Porosity & $5.2 \mathrm{E}-05$ & 11.49 & 2.87 & Statistically different \\
Apparent porosity & $4.7 \mathrm{E}-05$ & 11.68 & 2.87 & Statistically different \\
Modulus of elasticity & $2.7 \mathrm{E}-06$ & 17.43 & 2.87 & Statistically different \\
Tensile strength & $1.7 \mathrm{E}-05$ & 14.10 & 2.90 & Statistically different \\
Air-permeability & $5.6 \mathrm{E}-04$ & 8.56 & 2.96 & Statistically different \\
Water absorption by capillarity - W & $4.6 \mathrm{E}-08$ & 28.95 & 2.87 & Statistically different \\
\hline
\end{tabular}

Source: Author (2019)

Although the one-way ANOVA test can demonstrate differences in the evaluated samples, it cannot clearly identify these differences and where they are. So, Tukey's test was applied to compare the mortars in pairs and identify the real differences.

A paired Tukey test analysis showed that the compositions formulated with the $\mathrm{n}-\mathrm{TiO}_{2}-\mathrm{P} 25$ sample, regardless of the $\mathrm{n}-\mathrm{TiO}_{2}$ dispersion process, showed meaningful changes about the other compositions for all evaluated properties. In addition, when compared to each other, 
they also presented statistically significant differences, except for water absorption by capillarity, where the dispersion model showed no difference, as shown in Figure 14.

The mortars with n- $\mathrm{TiO}_{2}-\mathrm{PC} 105$ sample, when compared to each other, as a function of the dispersion process, presented differences only concerning the results of the modulus of elasticity and tensile strength. When compared to the n- $\mathrm{TiO}_{2}-\mathrm{P} 25$ sample, they showed suggestive differences from the other compositions for all properties, demonstrating that those differences are from the characteristics of each $\mathrm{n}-\mathrm{TiO}_{2}$ and not directly from the dispersion procedure.

Comparisons with the reference mortars showed that there were statistical changes in the evaluated properties for the n-TiO2-P25 sample, regardless of the dispersion procedure, except for air permeability and total porosity when used in powder. For the n- $\mathrm{TiO}_{2}-\mathrm{PC} 105$ sample, there were no statistically significant differences in the evaluated properties, except for capillary water absorption.

In sum, it has been observed that regardless of the $\mathrm{n}-\mathrm{TiO}_{2}$ samples, when the compound was more efficiently dispersed, the properties in the hardened state were more satisfactory, even though the amount of kneading water was maintained for each product. In other words, the dispersion process improved microstructural homogeneity and potentialized the effects of both cement and $\mathrm{n}-\mathrm{TiO}_{2}$ on the mixtures evaluated. Figures 15 and 16 show the evolution of the drying shrinkage as a function of time and the water amount for the five specimens. Each point in the graph corresponds to the average shrinkage values of three moulded samples to each specimen, and the interval is also shown. Differences between specimens may occur as part of the error associated with the experimental process.

The results show the same trend in the drying shrinkage intensity at the beginning of the process. However, such results also show that the reference mortars exhibit a lower retraction when compared with others due to the amount of kneading water used in the mixing.

It was observed that among the evaluated mortars containing $\mathrm{n}-\mathrm{TiO}_{2}$, those with the addition of the $\mathrm{n}-\mathrm{TiO}_{2}-\mathrm{PC} 105$ sample were the ones that presented better performances in terms of shrinkage results. On the other hand, the drying shrinkage rate is much higher after the 28 days for mixtures with the $\mathrm{n}-\mathrm{TiO}_{2}-\mathrm{P} 25$ sample, regardless of the dispersion procedure. 


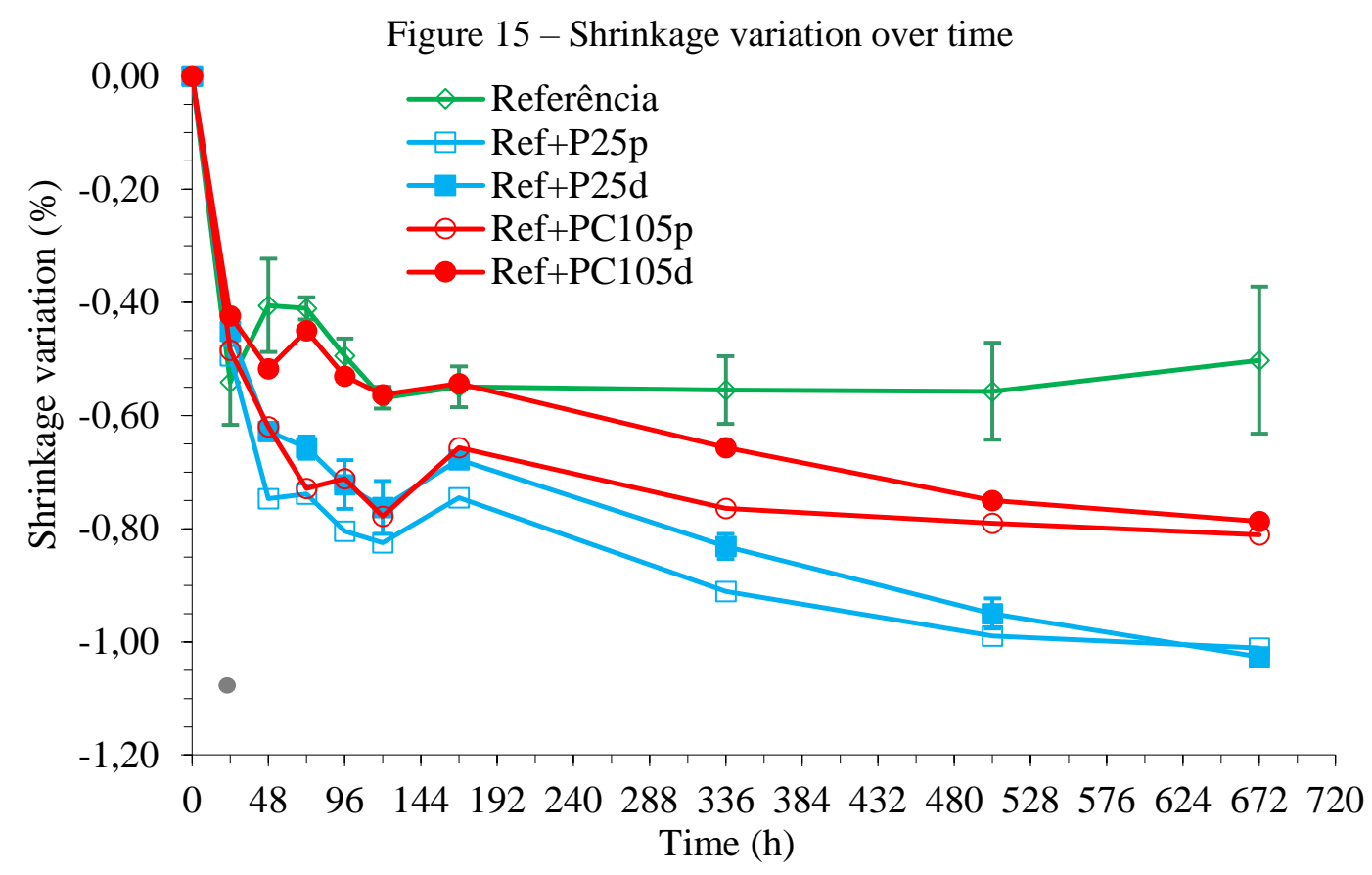

Source: Author (2019)

Figure 16 - Shrinkage variation by added water

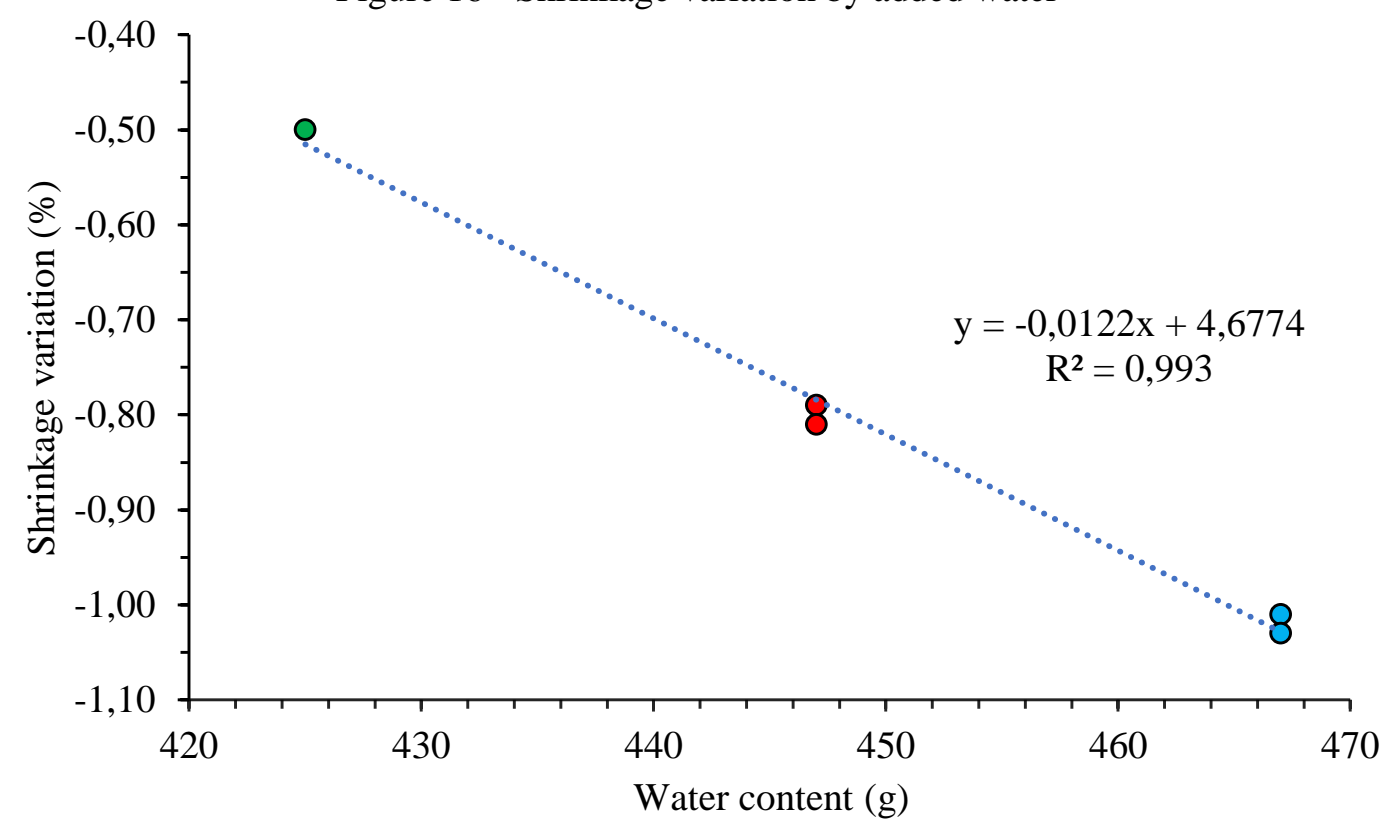

Source: Author (2019)

Results showed that when the compositions with different samples of $\mathrm{n}-\mathrm{TiO}_{2}$ are compared, the dispersion procedure makes no difference in shrinkage after the 28 days, but rather the sample of $\mathrm{n}-\mathrm{TiO}_{2}$ and amount of water used in the mixtures.

\section{CONCLUSIONS}

Based on the results obtained, the main considerations of this study are: 
Although the parameters of mobility and particle packing were used to define the mortars compositions, no correlation was observed in the resulting properties.

$>$ The dispersion condition showed a significant change in spreading in all the mortars. When the consistency of the mortars with $\mathrm{n}-\mathrm{TiO}_{2}$ addition was evaluated employing the flow-table test using the same volumes of water, the addition method and the n$\mathrm{TiO}_{2}$ sample used directly influenced the results. It means that when $\mathrm{n}-\mathrm{TiO}_{2}$ is dispersed in a Standard Energy Mix (SEM), there is a difference in spreading. When $\mathrm{n}-\mathrm{TiO}_{2}$ is dispersed in high energy (HED), no difference was observed in squeeze flow spreading.

In the hardened state, porosity, tensile strength, modulus of elasticity, air-permeability, and water absorption by capillarity were statistically different from the properties observed for the reference composition and in a function of the dispersion methods and the $\mathrm{n}-\mathrm{TiO}_{2}$ sample evaluated.

$>$ It was observed that regardless of the $\mathrm{n}-\mathrm{TiO}_{2}$ sample when the compound was more efficiently dispersed, the properties in the hardened state were more satisfactory, even though the amount of kneading water was maintained for each product. In other words, the dispersion process improved microstructural homogeneity, potentializing the effects of the cement and $n-\mathrm{TiO}_{2}$ on the mixtures.

$>$ In terms of drying shrinkage results, that phenomenon is associated with the $\mathrm{n}-\mathrm{TiO}_{2}$ sample, and the amount of water used in the mixture, not with the $\mathrm{n}-\mathrm{TiO}_{2}$ dispersion procedure. The effect of the $\mathrm{n}-\mathrm{TiO}_{2}$ on dimensional variation control is potentially increased by dispersion since it guarantees $\mathrm{n}-\mathrm{TiO}_{2}$ homogeneity on rendering mortars. 


\section{REFERENCE}

[1] MIKULáěK, P.; WAKEMAN, R.J; MARCHANT, J.Q. The influence of pH and temperature on the rheology and stability of aqueous titanium dioxide dispersions. Chemical Engineering, v. 67, p.97-102, 1997.

[2] SENFF L; LABRINCHA, J. A; FERREIRA, V. M; HOTZA, D; REPETTE, W. L. Effect of nano-silica on rheology and fresh properties of cement pastes and mortars. Construction and Building Materials, v.23, 2487-2491, 2009.

[3] SENFF, L; HOTZA, D; REPETTE, W. L; FERREIRA, V. M; LABRINCHA, J. A. Effect of nanosilica and microsilica on the microstructure and the hardened properties of cement pastes and mortars. Advance in Applied Ceramics, v.109, p.104-110, 2010.

[4] OLIVEIRA, I. R. et al. Particle Dispersion and Packaging. São Paulo: Fazendo Arte, 2000 [in Portuguese].

[5] PLANK, J.; HIRSCH, C. Impact of zeta potential on early cement hydration phases on superplasticizer adsorption. Cement and Concrete Research, v.37, p.537-542, 2007.

[6] DAMINELI, B. L. CONCEPTS FOR FORMULATION OF CONCRETES WITH LOW CONSUMPTION OF LIGANTS: RHEOLOGICAL CONTROL, PACKAGING, AND DISPERSION OF PARTICLES. 2013. 265 f. Thesis (PhD) - Civil Engineering Engineering Course, Civil and Urban Construction Engineering, Polytechnic School of the University of São Paulo, São Paulo, 2013 [in Portuguese].

[7] MELO, J. V. S. de; TRICHÊS, G. Study of the influence of nano-TiO ${ }_{2}$ on the properties of Portland cement concrete for application on road surfaces. Road Materials and Pavement Design, v.19, p.1011-1026, 2017.

[8] PINHO, L.; MOSQUERA, M. J. Photocatalytic activity of $\mathrm{TiO}_{2}-\mathrm{SiO}_{2}$ nanocomposites applied to buildings: Influence of particle size and loading. Applied Catalysis B: Environmental, v.134-135, p.205-221, 2013.

[9] MACIEL, M. H.; BERNARDO, H. M.; SOARES, G. S.; ROMANO, R. C. de O.; CINCOTTO, M. A.; PILEGGI, R. G. Effect of the variation of cement consumption on coating mortars produced based on the concepts of mobility and packaging of particles. Ambiente Construido, v.18, p.245-259, 2018 [in Portuguese].

[10] SANCHEZ, F.; SOBOLEV, K. Nanotechnology in concrete - A review. Construction and Building Materials, v.24, p.2060-2071, 2010.

[11] LACKHOFF, M. et al. Photocatalytic activity of semiconductor-modified cement: influence of semiconductor type and cement ageing. Applied Catalysis B: Environmental, v.43, p.205-2016, 2002.

[12] ASTM C1365-06: Standard Test Method for Determination of the Proportion of Phases in Portland cement and Portland-Cement Clinker Using X-Ray Powder Diffraction Analysis, 2011. 
[13] ABNT, NBR NM 18: Portland cement - Chemical analysis - Determination of fire loss, item 5.1, Rio de Janeiro, 2012 [in Portuguese].

[14] ABNT, NBR NM 11-2: Portland cement - Chemical analysis - Optional method for determination of major oxides by complexometry - Part 2: Method ABNT, items 5.1.2 a 5.2.4, Rio de Janeiro, 2012 [in Portuguese].

[15] ABNT, NBR NM 16: Portland cement - Chemical analysis - Elective method Determination of sulphuric anhydride, Rio de Janeiro, 2012 [in Portuguese].

[16] ASTM C114-15: Standard Test Methods for Chemical Analysis of Hydraulic Cement.

[17] ABNT, NBR 13810: Determination of metals - Atomic Absorption Spectrometry Method, Rio de Janeiro, 1997 [in Portuguese].

[18] ABNT, NBR NM 13: Portland cement - Chemical analysis - Determination and free calcium oxide by ethylene glycol, Rio de Janeiro, 2013 [in Portuguese].

[19] ABNT, NBR NM 22: Portland cement with additions of pozzolanic materials - Chemical analysis - Arbitrage method, item 6.7, Rio de Janeiro, 2012 [in Portuguese].

[20] ABNT, NBR NM 20: Portland cement and its raw materials - Chemical analysis Determination of carbon dioxide by gasometry, Annex B, Rio de Janeiro, 2012 [in Portuguese].

[21] ROMAnO, R. C. O.; CARDOSO, F. A.; PILEGGI, R. G. Concrete Properties in the Fresh State. In: ISAIA, G. C. Concrete: science and technology. São Paulo: Arte Interativa, 2011 [in Portuguese].

[22] BROUWERS, H. J. H.; RADIX, H. J. Self-compacting concrete: theoretical and experimental study. Cement and Concrete Research, n.35, p.2116-2136, 2005.

[23] MARQUARDT, I. Determination of the composition of self-compacting concretes on the basis of the water requirements of the constituent materials - presentation of a new concept. Betonwerk + Fertigteiltechnik - BFT, n.11, p.22-30, 2002.

[24] ROMANO, R.C.O.; TORRES, D.R.; PILEGGI, R.G. Impact of aggregate grading and air-entrainment on the properties of fresh and hardened mortars. Construction and Building Materials, v.82, p.219-226, 2015.

[25] CARDOSO, F. A.; JOHN, V. M.; PILEGGI, R. G. Rheological Behavior of Mortars under Different Squeezing Rates. Cement and Concrete Research, v.39, p.748-753, 2009.

[26] ABNT, NBR 13276: Mortar for laying and coating of walls and ceilings - Determination of consistency index, Rio de Janeiro, 2016 [in Portuguese].

[27] ABNT, NBR 15839: Laying mortar and coating of walls and ceilings - Rheological characterization by the squeeze-flow method, Rio de Janeiro, 2010 [in Portuguese]. 
[28] ABNT, NBR 13278: Mortar for laying and coating of walls and ceilings - Determination of mass density and built-in air entrained, Rio de Janeiro 2005 [in Portuguese].

[29] ABNT, NBR 15259: Mortar for laying and coating walls and ceilings - Determination of water absorption by capillarity and capillary coefficient, Rio de Janeiro, 2005 [in Portuguese].

[30] ABNT, NBR 15630: Mortar for laying and coating of walls and ceilings - Determination of dynamic modulus of elasticity through ultrasonic wave propagation, Rio de Janeiro, 2009 [in Portuguese].

[31] ABNT, NBR 7222: Concrete and mortar - Determination of tensile strength by diametrical compression of cylindrical specimens, Rio de Janeiro 2011 [in Portuguese].

[32] ABNT, NBR 15261: Mortar for laying and coating of walls and ceilings - Determination of dimensional variation (shrinkage or linear expansion), Rio de Janeiro, 2005 [in Portuguese].

[33] SALVADOR G.A.B. Optimization of aggregates granulometric distribution for use in rendering mortar in Santana do Livramento - RS. Thesis (MSc); 2005 [in Portuguese].

[34] SELMO S.M.S. Finer aggregates to rendering mortars. In: Simpósio Nacional de Materiais de Construção: Agregados, São Paulo; 1986. p.27-43 [in Portuguese].

[35] ROMANO, R.C.O. Air incorporation in cementitious materials applied in civil construction. Thesis (PhD). Polytechnic School of the University of São Paulo. Department of Civil Construction Engineering; 2013. 200p. [in Portuguese].

[36] INNOCENTINI M.D.M; RODRIGUES V.P; ROMANO R.C.O; PILEGGI R.G; SILVA G.M.C; COURY JR. Permeability optimization and performance evaluation of hot aerosol filters made using foam incorporated alumina suspension. Hazardous Materials, v.162, p.212-221, 2009.

[37] QUARCIONI, V. A. et al. Estimation of porosity of cement and lime mortars by volume calculation method. Ambiente Construido, v.4, p.175-187, 2009. [in Portuguese].

[38] ROMANO, R.C.O et al. Influence of the dispersion process in the silica fume properties. Ceramica. v.54, p.456-461, 2008 [in Portuguese].

[39] Pavía S. \& Toomey B.: Influence of the aggregate quality on the physical properties of natural feebly-hydraulic lime mortars. Materials and Structures, v.41, p.559-569, 2008.

[40] MEHTA, P. K.; MONTEIRO, P. J. M. Concrete: microstructure, properties and materials. São Paulo: Ibracon, 2008. 674 p. [in Portuguese].

[41] SILVA, N. G. da et al. EFFECTS OF AIR INCORPORATED IN THE PROPERTIES OF THE HARDENED STATE IN MORTARS WITH CEMENT AND SAND. In: CONGRESS BRASILEIRO CONCRETE, 51, 2009, Curitiba. Anais... . Curitiba: Ibracon, 2009 [in Portuguese]. 


\title{
APPENDIX D - EVALUATION OF RHEOLOGICAL PROPERTIES OF MORTAR WITH $\mathrm{TIO}_{2}$ ADDITION $^{12}$ (Article D)
}

\begin{abstract}
Adding $\mathrm{TiO}_{2}$ to coating mortars is carried out to promote self-cleaning through photocatalytic activity. However, this addition influences the workability of the mortar and, consequently, the application stage as the $\mathrm{TiO}_{2}$ used can present a large number of fine particles and a high surface area, increasing the demand for mixing water, requiring consistency adjustments before coating. In this work, three mortars (two with the addition of different types of $\mathrm{TiO}_{2}$ and one reference) were developed on a laboratory scale to maintain similar workability, using the flow table test. The amount of kneading water was changed to maintain a spread of $220 \pm 10 \mathrm{~mm}$, and the content of air-entrained was kept constant, around $25 \%$. The mortars were evaluated using the squeeze flow method. Then, a blind test was performed to assess the mason sensitivity during handling and application of the coating, and all mortars were considered similar. However, the yield of the compositions with $\mathrm{TiO}_{2}$ addition was lower compared to the reference composition, making it possible to explain the results based on the physical parameters of the formulations and with a more in-depth analysis of the rheological indices obtained by the squeeze flow test.
\end{abstract}

Keywords: Photocatalytic mortar. $\mathrm{TiO}_{2}$. Squeeze flow. Rheology. Yield.

\footnotetext{
${ }^{12}$ Dantas, S. R. A.; Lima, F. J. N. de; Romano, R. C. de O.; Pileggi, R.; Loh, K. Evaluation of rheological properties of mortar with $\mathrm{TiO}_{2}$ addition. Ambiente Construído, Porto Alegre, v. 21, n. 4, p. 7-21, out./dez. 2021. http://dx.doi.org/10.1590/s1678-86212021000400556
} 


\section{INTRODUCTION}

Mechanisms for evaluating the rheological properties of mortars, particularly their applicability, are usually carried out in a sensorial and tactile way and not by their physical behavior. The mason classifies the mortar according to the ease or difficulty in handling it, for example: hard or soft, cohesive or non-cohesive.

It is common practice for masons to deliberately increase the amount of water without any control, only using their experience and preference of mortar consistency when the mortar does not show the desired characteristic. This procedure often negatively affects the properties of the mortars in the hardened state, such as setting time, shrinkage, low adhesion, high porosity and permeability, and the occurrence of cracks (ISAIA, 2017).

Such procedures, based on empirical knowledge, besides being subjective, induce many errors that impair the mortar quality and do not enable us to measure any possible rheological parameters to quantify the material workability. Thus, determining the mortar rheological properties is of fundamental importance, as they guide the purchase decisions of materials, increase durability, productivity, as well as efficiency at construction sites (AZEVEDO et al., 2017).

Additionally, characteristics such as the particle size distribution, real density, and the specific surface area are factors that greatly influence the mortar capacity of withstanding aggressive agents such as water, oxygen, carbon dioxide, chlorides, and aggressive solutions (MELO; TRICHÊS, 2017).

In general, it can be admitted that all exterior surfaces are candidates for having photocatalytic properties, as long as they receive sunlight, a source of ultraviolet radiation, essential for the catalysis of chemical reactions through $\mathrm{TiO}_{2}$ (PARAMÊS; BRITO, 2010). However, the addition of $\mathrm{TiO}_{2}$ can lead to a great impact on the fresh state properties of compositions when $\mathrm{TiO}_{2}$ is added in cement-based materials due to the strong tendency towards agglomerate formation due to its ultrafine size (SENF, 2009; SENF et al., 2010). Therefore, the rheological evaluation of the mortars with $\mathrm{TiO}_{2}$ addition is an important step for developing products with adequate consistency for the in-field application.

The microstructure of the system governs the rheological properties of the dispersions. In these systems, the solid particles are relatively small, and the interparticle forces are significantly pronounced to influence the microstructure, the aggregation state of the dispersion, and, consequently, the mechanical and rheological properties of the system 
(MIKULÁĔKK; WAKEMAN; MARCHANT, 1997). In this context, the squeeze flow test proves to be an excellent alternative and simulates the processing conditions such as spreading, leveling, and finishing (CARDOSO; JOHN; PILEGGI, 2009).

In this study, the rheological properties of mortars with and without $\mathrm{TiO}_{2}$ addition were evaluated on a laboratory scale to define similar workability between them, as well as the mason's sensitivity during the mortar application in-situ correlating the results after both procedures.

\section{EXPERIMENTAL PROGRAM}

This research observed how the $\mathrm{TiO}_{2}$ addition could affect the rheological properties of rendering mortars. An experimental program was previously performed in the laboratory, monitoring the characteristics in the fresh state, using a consistency test (flow table), airentrainment, and squeeze flow. In the second stage, the compositions were produced and applied at a construction site according to the same criteria adopted in the laboratory, observing the maintenance of the characteristics previously determined. The aspects related to the mason's sensitivity to the mortar application were monitored, and the final results were correlated with the rheological parameters obtained on a laboratory scale.

\subsection{Material and Methods}

Mortars were formulated using white Portland cement (EUROPEAN..., 2000), dolomites $\# 20$, \#40, and \#80, an air-entraining agent based on lauryl sulfate molecules, water retention agents based on cellulosic ether molecules, and two different commercial samples of powdered $\mathrm{TiO}_{2}$, according to previous evaluations by the authors in Dantas et al. (2019a, 2020).

\subsubsection{Characteristics of raw material}

Table 1 shows the specific surface area, real density, and the parameters related to the particle size for raw materials, while Figure 1 illustrates the particle size distribution. All the tests were performed following Dantas et al. (2019a, 2020).

Two points can be considered essential for the $\mathrm{TiO}_{2}$ relationship with the mortar rheology, the specific surface area and the particle size presented by each $\mathrm{TiO}_{2}$. Although both samples have a large number of fine particles and the specific surface area has a direct relationship with cement hydration, there are some contradictions related to the $\mathrm{TiO} 2$ impacts on the hydration process of the cement matrix (FOLLI et al., 2010; CHEN; KOU; POON, 2012; 
YANG et al., 2015; SALMAN; EWEED; HAMEED, 2016; HAMIDI; ASLANI, 2019). However, the influence of $\mathrm{TiO}_{2}$ nanoparticles on cement hydration products is subject to debate and will be discussed in another article.

Table 1 - Raw material characteristics

\begin{tabular}{lccccc}
\hline \multicolumn{1}{c}{ Material } & \multicolumn{3}{c}{ Particle size $(\mu \mathrm{m})$} & $\begin{array}{c}\text { Specific surface area } \\
\left(\mathrm{m}^{2} / \mathrm{g}\right)\end{array}$ & $\begin{array}{c}\text { Average density } \\
\left(\mathrm{g} / \mathrm{cm}^{3}\right)\end{array}$ \\
\hline White Portland cement & 2.6 & 17.7 & 19.5 & 0.86 & 3.05 \\
Dolomite \#20 & 975 & 1242 & 1620 & 0.16 & 2.90 \\
Dolomite \#40 & 24.3 & 230 & 740 & 0.56 & 2.94 \\
Dolomite \#80 & 4.5 & 38.3 & 134 & 0.80 & 2.81 \\
$\mathrm{TiO}_{2}$ (P25) & 1.38 & 3.90 & 17.7 & 49.4 & 3.84 \\
$\mathrm{TiO}_{2}$ (PC105) & 0.66 & 1.50 & 4.60 & 79.8 & 3.62 \\
\hline
\end{tabular}

Source: Dantas et al. (2019a)

Figure 1 - Material particle size distribution

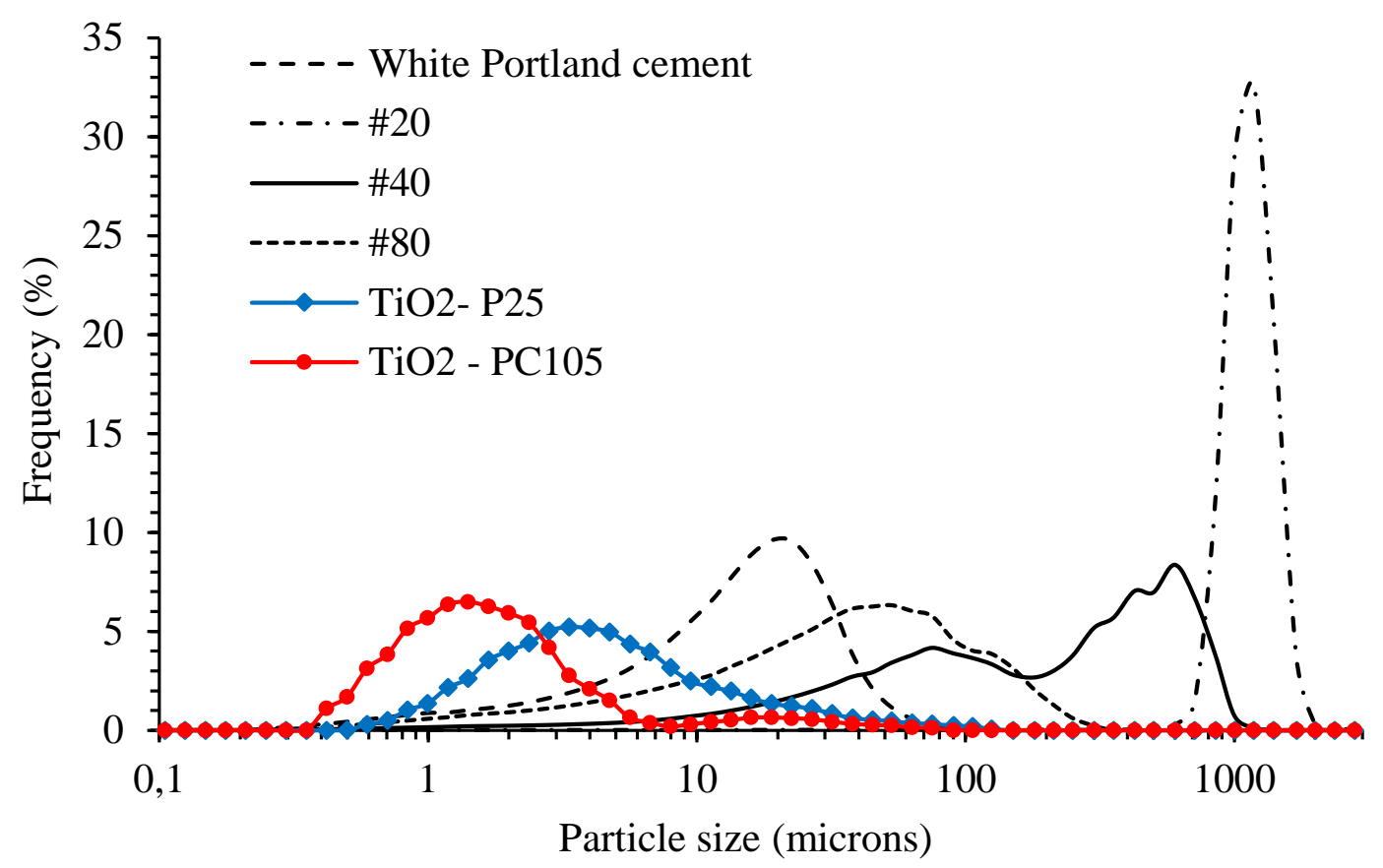

Source : Dantas et al. (2019a)

Figure 2 shows the mineralogical composition of white Portland cement and the $\mathrm{TiO}_{2}$ sample by X-ray diffraction, and Table 2 illustrates the chemical composition according to that described in Dantas et al. (2019a).

Despite high chemical purity, the two $\mathrm{TiO}_{2}$ samples present differences in their crystalline structures, P25 (rutile + anatase) and PC105 (anatase). The $\mathrm{TiO}_{2}$ crystalline phases have a direct relationship with the bandgap energy. In other words, they are responsible for $\mathrm{TiO}_{2}$ absorption and activation at different wavelengths by solar radiation, where the anatase phase is considered more reactive. 
The chemical analysis detected amounts of calcium, silicon, aluminum, and iron. Bogue calculation was applied to determine the quantities of the clinker phases. Results indicated the presence of high content of C3S (68.9\%) and C2S (9.9\%) in the clinker composition, which is also composed of C3A (11.6\%) and C4AF (1.0\%). A small amount of carbonate was also detected as an addition, but the presence of free lime indicates the incomplete burning during clinker production, showing a cement with common characteristics for the type of binder.

Figure 2 - X-ray diffractograms of white Portland cement and $\mathrm{TiO}_{2}$ sample

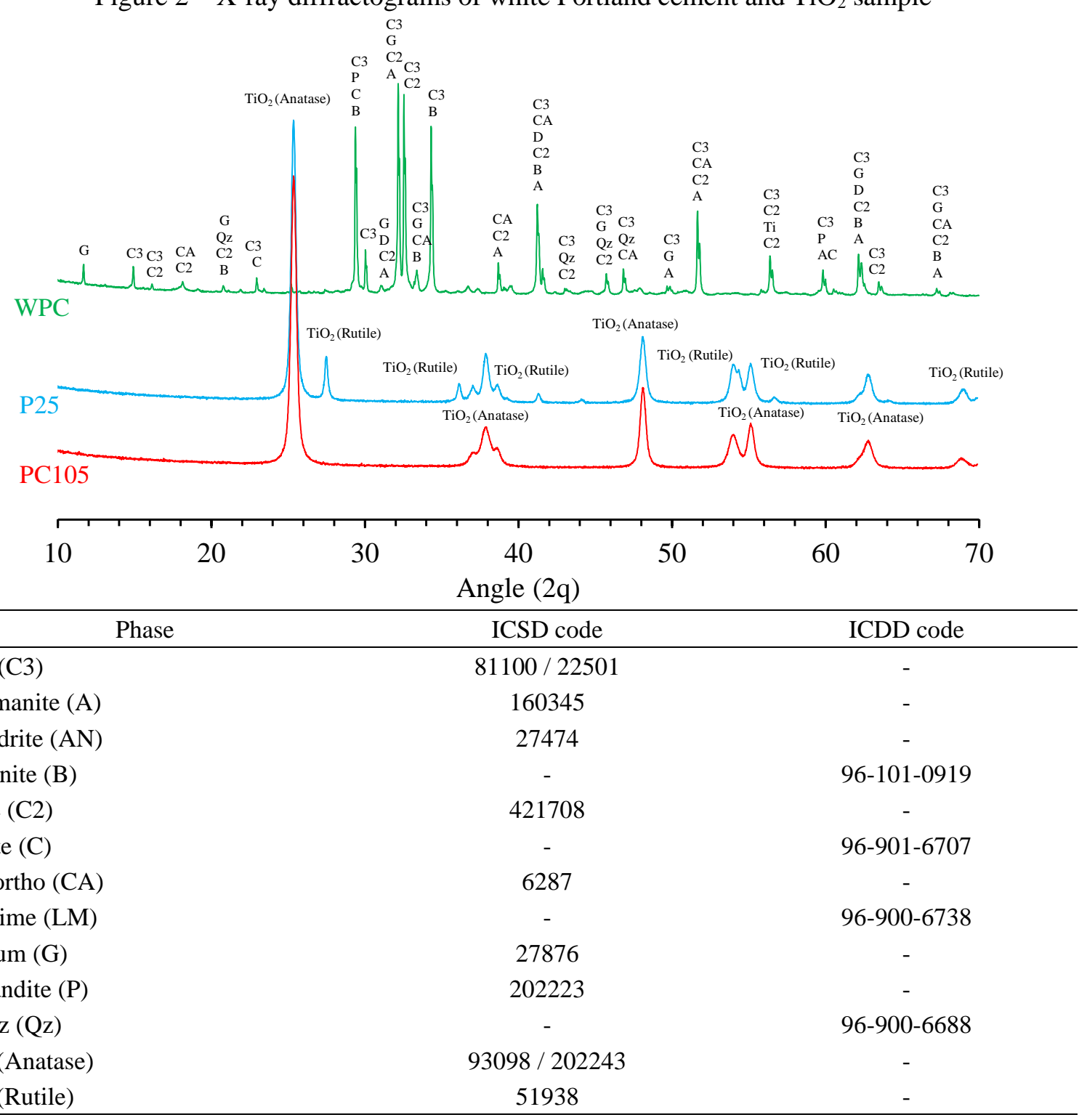

Source: Dantas et al. (2019a) 
Table 2 - Chemical composition of cement and $\mathrm{TiO}_{2}$

\begin{tabular}{|c|c|c|c|c|}
\hline Compound & White CEM I (\%) & NBR $16697 *$ & $\mathrm{P} 25$ & PC105 \\
\hline LOI & 2.48 & $\leq 27.0$ & --- & +-- \\
\hline $\mathrm{TiO}_{2}$ & --- & --- & 99.7 & 99.6 \\
\hline $\mathrm{SiO}_{2}$ & 21.6 & --- & 0.25 & --- \\
\hline $\mathrm{Al}_{2} \mathrm{O}_{3}$ & 4.60 & --- & --- & 0.12 \\
\hline $\mathrm{FeO}_{3}$ & 0.33 & --- & 0.02 & 0.03 \\
\hline $\mathrm{CaO}$ & 67.5 & --- & --- & --- \\
\hline $\mathrm{MgO}$ & 0.59 & $\leq 10.0$ & --- & --- \\
\hline $\mathrm{SO}_{3}$ & 2.83 & $\leq 4.5$ & --- & --- \\
\hline $\mathrm{Na}_{2} \mathrm{O}$ & 0.13 & --- & --- & --- \\
\hline $\mathrm{K}_{2} \mathrm{O}$ & 0.61 & --- & --- & --- \\
\hline Alkaline equivalent $\left(\right.$ in $\mathrm{Na}_{2} \mathrm{O}$ ) & 0.53 & --- & --- & --- \\
\hline $\mathrm{CaO}$ & 2.26 & --- & --- & --- \\
\hline RI & 0.43 & $\leq 7.0$ & --- & --- \\
\hline $\mathrm{CO}_{2}$ & 0.67 & $\leq 27.0$ & --- & --- \\
\hline
\end{tabular}

Note: Alkaline equivalent $\left(\right.$ in $\left.\mathrm{Na}_{2} \mathrm{O}\right)=\% \mathrm{Na}_{2} \mathrm{O}+0.658 \times \% \mathrm{~K}_{2} \mathrm{O} /$ LOI: Loss on ignition

Source: adapted from Dantas et al. (2019a). *ABNT (2021)

\subsection{Experimental design}

The mixing procedure used to prepare the specimens was done in two different conditions, in a laboratory and at the construction site, using different mixing equipment but the same steps. The mixing procedure in the laboratory scale was done according to details by Dantas et al. (2019a, 2020), shown briefly below for the reader's convenience.

\subsubsection{Compositions}

Comparisons were performed using three sets of mixtures according to that described in Table 3.

Table 3 - Mixture description

\begin{tabular}{cc}
\hline Mixture & Description \\
\hline Ref. & Mortar without $\mathrm{TiO}_{2}$ addition \\
$\mathrm{P} 25$ & Mortar with $\mathrm{TiO}_{2}-\mathrm{P} 25$ addition \\
PC105 & Mortar with $\mathrm{TiO}_{2}-\mathrm{PC} 105$ addition \\
\hline
\end{tabular}

Source: Author (2021)

Materials were selected based on the assumption of maintaining the same matrix previously evaluated by Dantas et al. (2019a), as shown in Table 4. The water content was changed to preserve the same workability of every mortar. As the $\mathrm{TiO}_{2}$ presents different densities, the consumption of each one in the composition is different, even with a similar percentage purposed. 
Table 4 - Consumption, in $\mathrm{kg} / \mathrm{m}^{3}$, of each raw material

\begin{tabular}{lccc}
\hline \multicolumn{1}{c}{ Composition } & Ref & P25 & PC105 \\
\hline White Portland cement & 351 & 337 & 342 \\
Dolomite \# 20 & 195 & 187 & 190 \\
Dolomite \# 40 & 1111 & 1067 & 1084 \\
Dolomite \# 80 & 292 & 281 & 285 \\
Viscosity modifier & 1.95 & 1.87 & 1.90 \\
Air-entrainment & 0.16 & 0.15 & 0.15 \\
Water & 332 & 354 & 344 \\
Polypropylene microfibers & 1.4 & 1.4 & 1.4 \\
$\mathrm{TiO}_{2}$ (P25) & --- & 16.8 & --- \\
$\mathrm{TiO}_{2}$ (PC105) & --- & --- & 17.1 \\
\hline $\mathrm{SO}^{\text {PCE Aur }}$
\end{tabular}

Source: Author (2021)

\subsubsection{Laboratory scale mixing procedure}

Reference mortar: water and microfibers were mixed with Standard Energy Mix (SEM) for 90 seconds using a Hobart N50 mixer. Then, the powder was added, and a period of 30 seconds was given to wet the particles. Then, the mixing was performed for plus 90 seconds.

P25 and PC105 mortars: The $\mathrm{TiO}_{2}$ was dispersed under High Energy Dispersion (HED) with $10,000 \mathrm{rpm}$ for 30 seconds. After that, the microfibers were added, and the mixing was done according to the procedure described previously.

\subsubsection{Fresh state properties}

Fresh state properties were evaluated using a flow table test (ABNT, 2016), squeeze flow test (ABNT, 2010), and air-entrainment using the gravimetric method (ABNT, 2005) as shown in Figures 3 and 4.

Flow table test: the table was wet, and the cone was placed at the center of the table. After that, the cone was filled with fresh mortar in three equal layers. Each layer was tamped 15, 10, and 5 times with a tamping rod. Then, we waited 30 seconds before lifting the cone. After the cone was lifted, the table went up and down 30 times in the $30 \mathrm{~s}$ causing the mortar to flow. After this, the flow mortar diameter was measured.

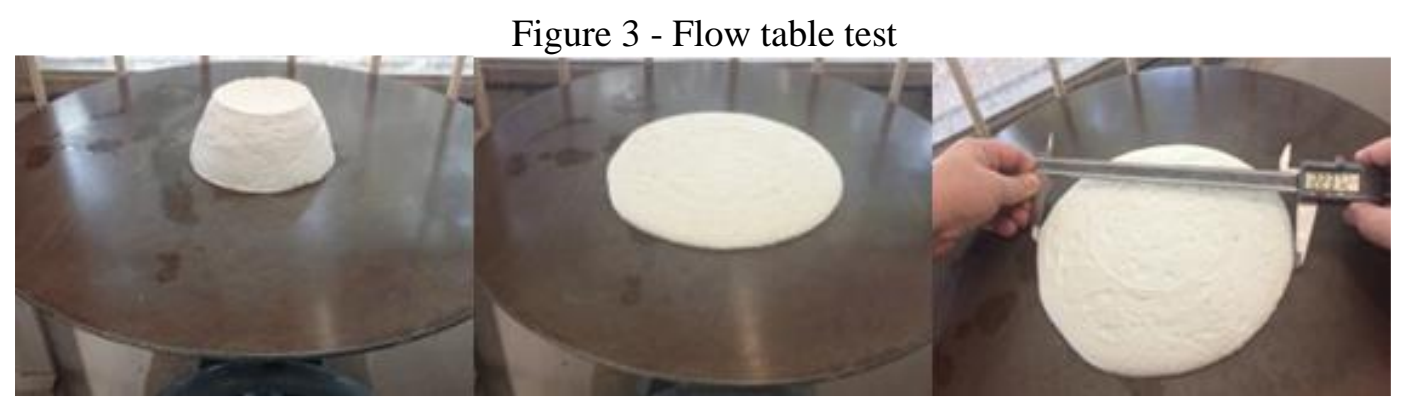

(a)

(b)

(c)

Source: Author (2021) 
Figure 4 - Squeeze Flow test

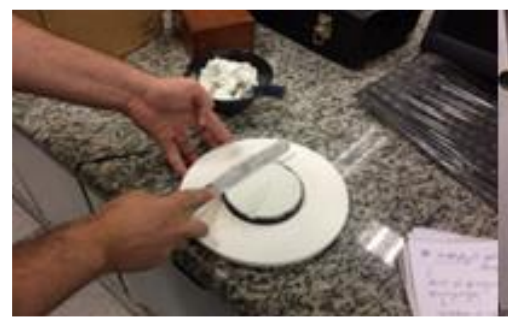

(a)

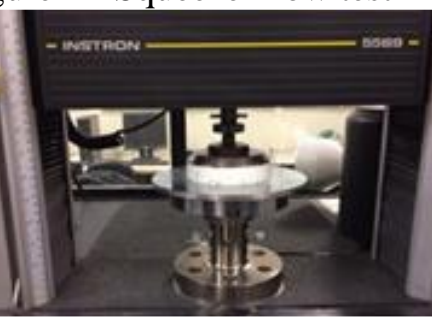

(b)

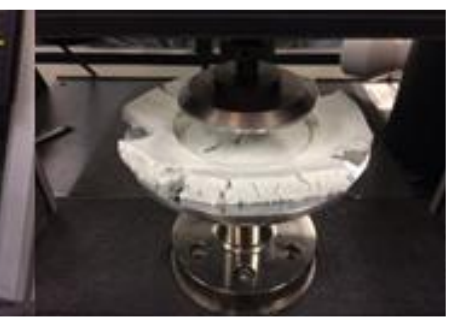

(c)

Source: Author (2021)

Squeeze flow: conducted on a universal testing machine (Instron 5569) with a $1 \mathrm{kN}$ load cell. Samples were prepared in a metallic plate with smooth surfaces to ensure a non-absorption condition, and a PVC cylindric mold (diameter of $101 \mathrm{~mm}$ and width of $20 \mathrm{~mm}$ ) was used. After the molding process, the rigid PVC mold, used as a template, was removed because the material presented an initial consistency to maintain its shape. In this configuration, the material can deform freely in the radial direction. The sample and the upper disk had the same diameter allowing alignment. The tests were performed using a displacement rate of $0.1 \mathrm{~mm} / \mathrm{s}$ to a maximum displacement of $18 \mathrm{~mm}$ or maximum load of $1 \mathrm{kN}$, as shown in Figure 4.

Squeeze flow results in a load (or tension) per displacement response. There are three phases of the material's behavior: elastic or low-stress (I), plastic or viscous flow, without a significant increase in tension to maintain the deformation (II), and a high-stress region with flow resistance due to coarse particle interaction (III), as shown in Figure 5.

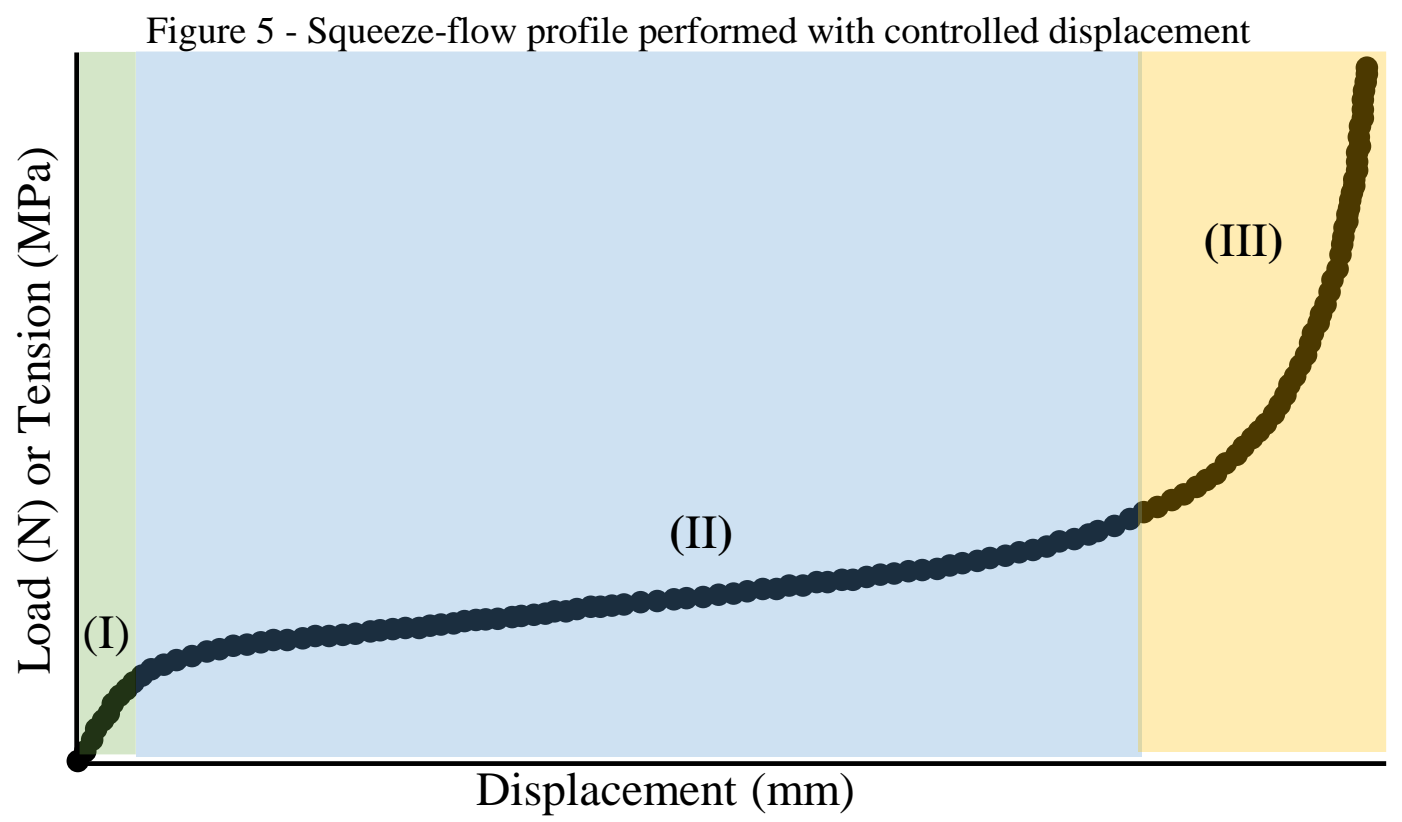

Note: Elastic or low-stress (I); Plastic and/or viscous flow (II); and Strain hardening (III)

Source: Adapted from Cardoso, Pileggi, and John (2010) 
Air-entrainment: tests were performed according to the gravimetric method, using a $400 \mathrm{ml}$ volume cup, determining the mass needed to fill it. The air-entrainment values were calculated based on the mortar water content and the real density of the dry powder.

\subsubsection{Mixing procedure at the construction site}

Reference mortar: water was added to the concrete mixer, and then microfibers were added for 3 min with the equipment turned off. After that, the dry powder was added for 1 min with the equipment turned off, and the concrete mixer was covered for 1 min for particle wetting. Hereafter, the equipment was turned on, and the mixing was performed for $5 \mathrm{~min}$.

P25 and PC105 mortar: water was added into the concrete mixer, and then microfibers were added for 3 min with the equipment turned off. Afterward, the $\mathrm{TiO}_{2}$ was added for 3 min with the equipment turned off. After that, the dry powder was added for $1 \mathrm{~min}$ with the equipment turned off, and the mixing was done according to the procedure described previously.

An illustration of the step-by-step mixing is presented in Figure 6.

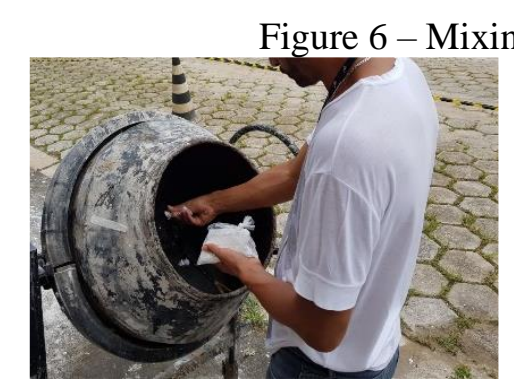

(a) Microfiber addition and mixing

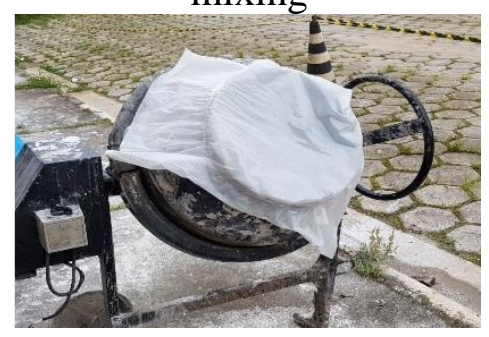

(d) Particle weting

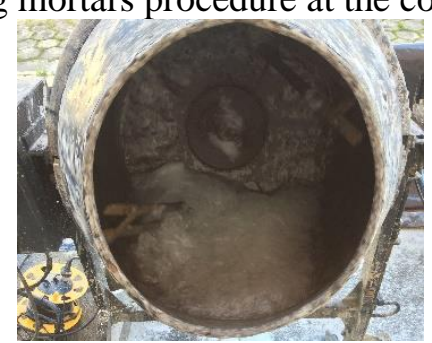

(b) Microfiber addition

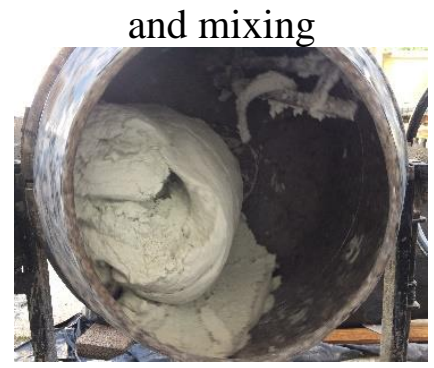

(e) Mixing mortar

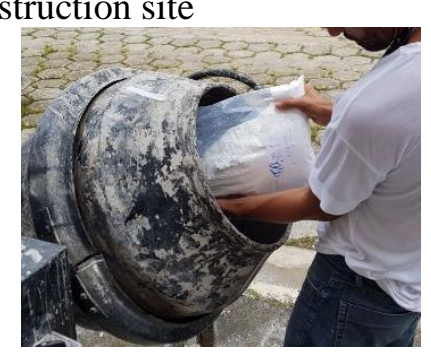

(c) $\mathrm{TiO}_{2}$ addition

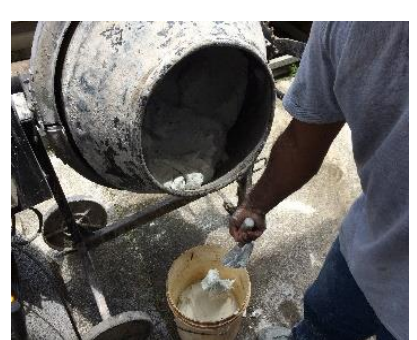

(f) Mixing mortar

Source: Author (2021)

\subsubsection{Applying mortars}

A mason applied mortars on $1.2 \mathrm{~m} \times 1.2 \mathrm{~m}$ concrete substrates (panels), aiming to find a maximum thickness of $1 \mathrm{~cm}$ as recommended by the literature and with the minimum possible roughness as described in Dantas, Vittorino, and Loh (2019b). First, the preparation of the base for the application of mortar was performed (Figure 7a). To ensure the desired thickness, a wooden template $1 \mathrm{~cm}$ high was installed on both sides of the panel (Figure $7 \mathrm{~b}$ ), followed 
by leveling the mortar (Figure 7c). After the application and leveling of mortar, the finishing process was carried out, as shown in Figures $7 \mathrm{~d}, 7 \mathrm{e}$, and $7 \mathrm{f}$.

Figure 7 - Procedure of mortar application in-situ

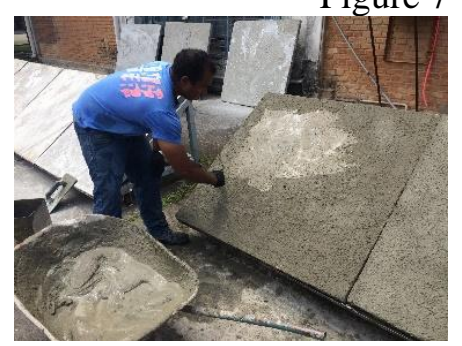

(a)

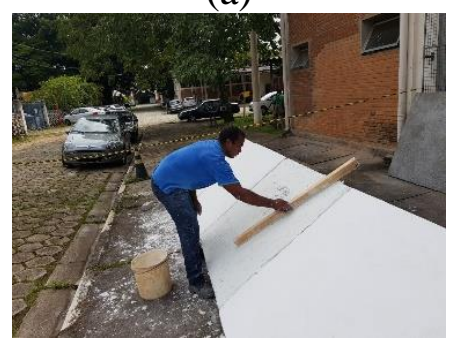

(d)

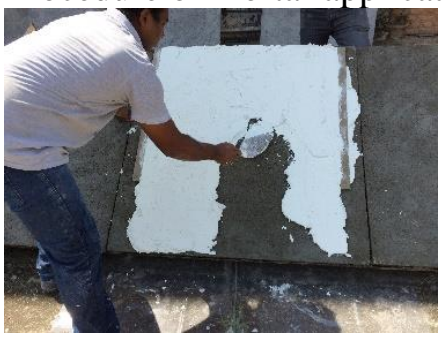

(b)

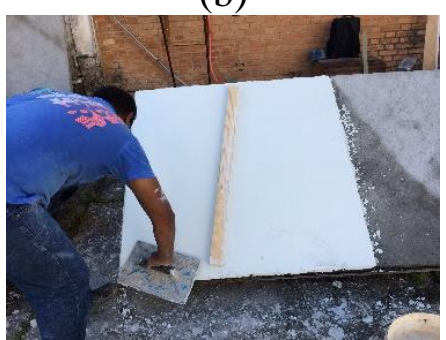

(e)

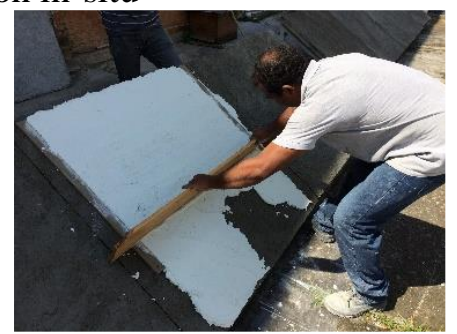

(c)

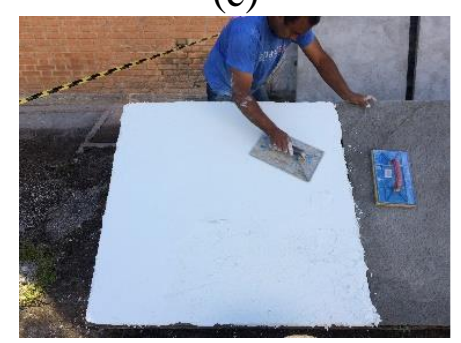

(f)

Source: Author (2021)

\subsubsection{Determination of mortar yield}

To calculate the mortar yield, the total mass of mortar produced (mt) was annotated at the beginning of the application. The area of application was kept constant $(1.2 \times 1.2 \mathrm{~m})$, as well as the thickness of $10 \mathrm{~mm}$. Therefore, the volume produced (V) was the same. At the end of the application, the amount remaining (mf) was weighed, and the yield was calculated according to what is shown in Equation (1), where each $\mathrm{m} 3$ produced represents the use of $1 \mathrm{~kg}$ of mortar.

$Y=\frac{V}{m_{t}-m_{f}}$

Eq. 1

\section{RESULTS AND DISCUSSION}

\subsection{Fresh state properties}

Table 5 shows the mortars spreading by the flow table, the air-entrained, and a summary of some quantitative results of the squeeze flow test (the load at the displacement of $10 \mathrm{~mm}$ and the displacement at the load of $100 \mathrm{~N}$ ).

Results indicate that it was impossible to maintain the same amount of kneading water as used in the reference mortar because adding the finer $\mathrm{TiO}_{2}$ particles with their higher specific surface area requires more water to recover and separate these particles. 
Table 5 - Air-entrained and flow table and squeeze flow test results

\begin{tabular}{cccccc}
\hline Mixture & $\begin{array}{c}\text { Spreading } \\
(\mathrm{mm})\end{array}$ & $\begin{array}{c}\text { Air-entrained } \\
(\%)\end{array}$ & $\begin{array}{c}\text { Water added } \\
(\mathrm{g})\end{array}$ & $\begin{array}{c}\text { Load at } \\
\text { Displacement } \\
10 \mathrm{~mm}(\mathrm{~N})\end{array}$ & $\begin{array}{c}\text { Displacement at } \\
100 \mathrm{~N}(\mathrm{~mm})\end{array}$ \\
\hline Ref. & 227 & 26.1 & 425.0 & 63.9 & 14.0 \\
P25 & 229 & 24.3 & 467.5 & 65.7 & 13.3 \\
PC105 & 213 & 25.5 & 447.0 & 75.1 & 12.5 \\
\hline
\end{tabular}

Source: Author (2021)

The Brazilian standard does not specify an ideal flow result in flow table tests. Based on previous studies carried out by Dantas et al. (2020), where the target for this kind of test was $220 \pm 10 \mathrm{~mm}$, it can be observed that all mortars meet the requirements. Additionally, it was decided to keep the air-entrained around $25 \%$ because the air bubbles also affect the workability, applicability, and yield.

The squeeze flow test is adequate to evaluate mixtures with any level of consistency. To coat with mortars, the test simulates processing conditions such as spreading and finishing. Similar curves indicated that there was no workability impact even with the imposition of a more severe shear condition. According to the mason, who applied the mortars, the qualitative perception of the consistency of the mortar was also maintained. This is a relevant factor since the flow of the mix is of significant importance in real-scale applications. Figure 8 shows the results obtained with mortars 5 min after mixing.

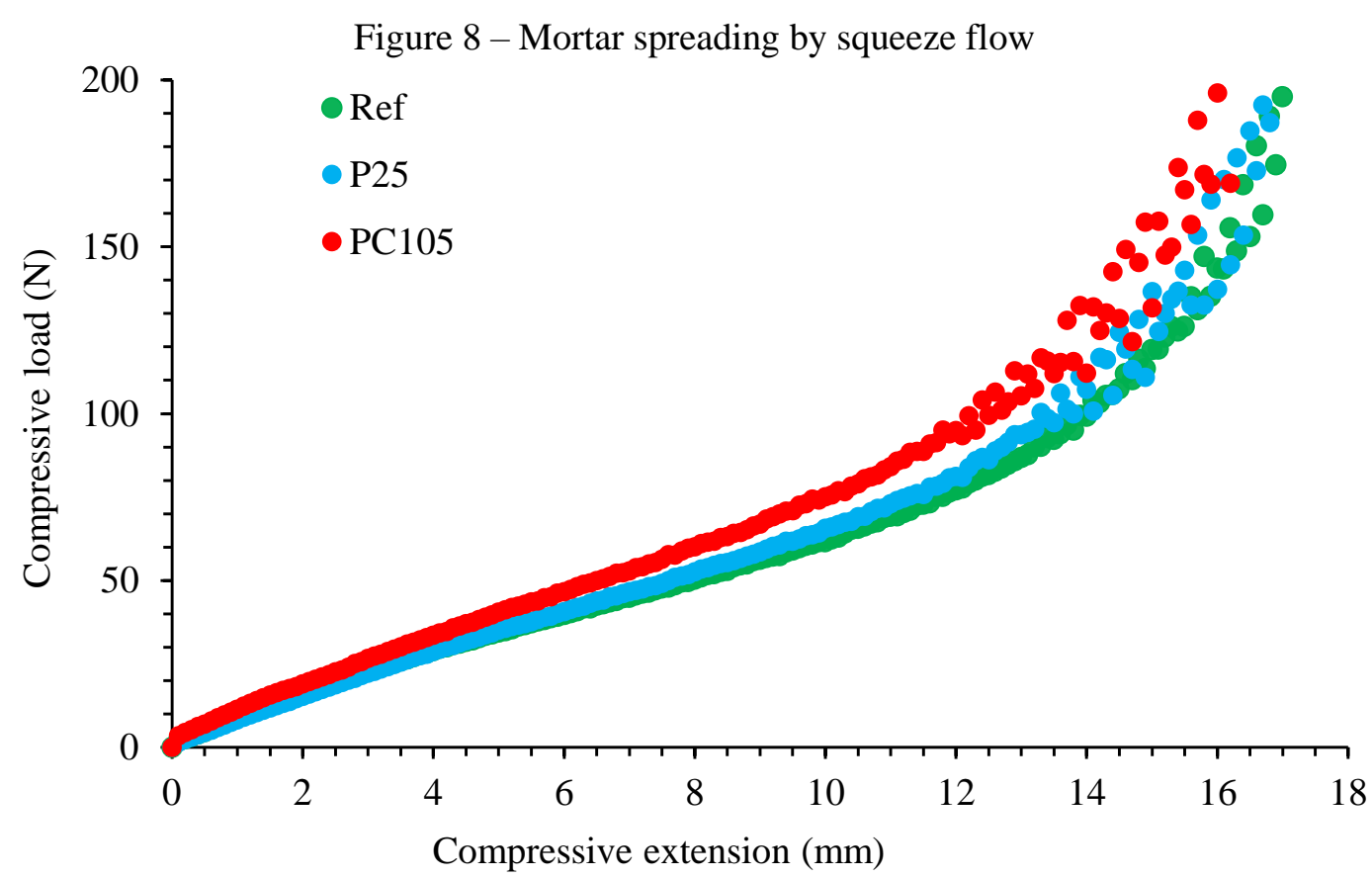

Source: Author (2021)

Using a small displacement, the mortars behave as a solid exhibiting an elastic deformation. They could be related to the material yield stress. At the first stage, all mortars present a 
similar behavior, where the increase of the elongation displacement and radial shear can be observed, exceeding the forces that kept the material under elastic behavior, indicating that the mortar is flowing.

From this stage, differences in the mortar with $\mathrm{TiO}_{2}$ were observed. The compressive load of the mortar with PC105 in 50\% of compressive extension (10 mm) was around $22 \%$ higher than the reference mortar and around 15\% higher than the P25 mortar. Large deformations without a significant increase in the compressive load may indicate that the mortar presents adequate workability and easy application.

There is a significant increase in the compressive load at the larger compressive extension, even with the material presenting low deformation. This is because the particles are in contact, increasing the frictional forces and a significant interaction through the fibre interlacing, causing some restrictive flow effects. This stage is characterized by this kind of material behavior and tends to be hampered due to the high loads involved, which are obtained after around $70 \%$ of the compressive extension of each mortar.

The elongational stress profile $\left(\sigma_{B}\right)$ and elongational viscosity $\left(\eta_{B}\right)$ over shear rate $\left(\dot{\varepsilon_{B}}\right)$, according to equations (2) to (4) (STEFFE, 1996), was based on the results of compressive load vs compressive extension and presented in Figure 9.

$A_{P}$ is the upper disk area, $(F)$ is the compressive obtained force during the test $(v)$ is the speed of the upper disk displacement, $(t)$ is the time, $(R)$ is the upper disk radius, $(h)$ is the sample height at each displacement and $\left(h_{0}\right)$ is the initial sample height.

$\sigma_{B}=\frac{F}{A_{P}}$

$\eta_{B}=\frac{\sigma_{B}}{\dot{\varepsilon}_{B}}=2 F\left[\frac{h_{0}-(v * t)}{v \pi R^{2}}\right]$

$\dot{\varepsilon_{B}}=\frac{v}{2 h}=\frac{v}{2\left[h_{0}-(v * t)\right]}$

All the mortars were similar and showed an increase in the stress and elongational viscosity values at the low elongational shear strain. On the other hand, at the higher elongational shear strain, the difference between the elongational viscosity and elongational stress in the mortar with the PC105 addition showed higher values than other mortars. 
Figure 9 - Elongational stress (above) and viscosity (below) over the shear rate of mortars
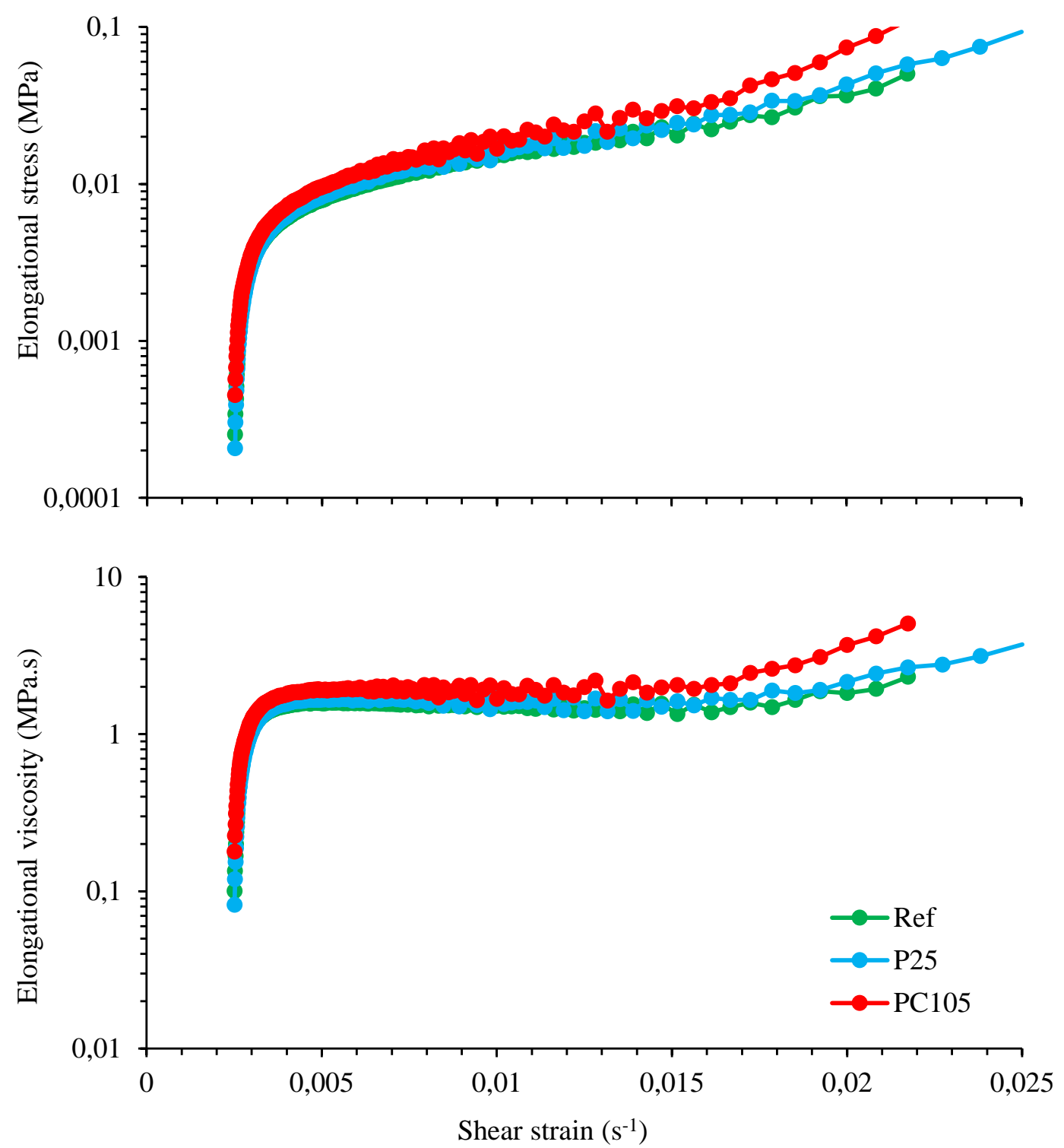

Source: Author (2021)

A rheological parameter of higher practical interest for mortar application on vertical surfaces is the yield stress. Since the product must have adequate consistency to be applied to the specimens, the use of this theory is appropriate to calculate the yield stress by the squeeze flow method. The yield stress determined indirectly from the profile presented in Figure 5, and which corresponds to the transition point from the region (I) to (II), is related to elongational yield stress. This point is defined based on the intersection of linear extrapolations of these respective phases.

Mortars evaluated in this study did not present a well-defined transition point from elastic to the plastic regime, making it impossible to calculate the yield stress indirectly. The power-law model was used to relate the yield stress $\left(\tau_{0}\right)$ with the consistency index $(\mathrm{K})$ and rheological 
coefficient $(n)$ of mortars, as indicated in Equation (5). Where $(\gamma)$ is the shear rate (DELHAYE; POITOU; CHAOUCHE, 2000; ENGMANN; SERVAIS; BURBIDGE, 2005).

$\tau_{0}=K(\dot{\gamma})^{n}$

Eq. 5

As the yield stress is unknown, the rheological parameters $(n)$ and $(K)$ can be determined using Equation (6), which corresponds to the normal force applied to the sample in situations where the strain, velocity, and sample area remain constant during the test (STEFFE, 1996; ENGMANN; SERVAIS; BURBIDGE, 2005). These conditions were maintained in the squeeze flow test of this study.

$F=\frac{3^{(n+1) / 2} r^{2} \pi K v^{n}}{h^{n}}$

Applying the natural logarithm to both sides of Equation (6), we have equation (7), where $(n)$ corresponds to the slope of the linear part of the curve $\ln (F)$ by $\ln (1 / h),(B)$ is obtained from the intersection with the y-axis, corresponding to Equation (8), and $(K)$ is determined according to Equation (9).

$$
\begin{aligned}
& \ln (F)=\ln \left(3^{(n+1) / 2} r^{2} \pi K v^{n}\right)+n \ln \left(\frac{1}{h}\right) \\
& \mathrm{B}=\ln \left(3^{(n+1) / 2} r^{2} \pi K v^{n}\right) \\
& K=\frac{e^{B}}{3^{(n+1) / 2} r^{2} \pi v^{n}}
\end{aligned}
$$

Considering that all mortars presented very close $\ln (F)$ vs $\ln (1 / h)$ curves, the rheological parameters $(n)$ and $(K)$ of the power-law model were illustrated for the reference sample where the $\mathrm{x}$-axis corresponds to the values of $\ln (1 / h)$. It is always negative because as $h>$ 0 , then $0<1 / h<1$ and in this interval, the function (ln) assumes negative values. Table 6 shows the values found for each mortar, while Figure 10 shows, for illustrative purposes, an example of a curve for calculating the rheological parameters.

Mortars showed close $(n)$ values, indicating that regardless of the $\mathrm{TiO}_{2}$ addition, the rheological behaviors are similar. However, this trend is not observed for $(K)$ values. The reference mortar presents the lowest value $\left(305.3 \mathrm{kPa} \cdot \mathrm{s}^{\mathrm{n}}\right)$, followed by P25 (385.9 kPa.s $26.4 \%$ higher than Ref.), while the PC105 mortar showed a higher value $\left(491.1 \mathrm{kPa} . \mathrm{s}^{\mathrm{n}}\right)$, approximately $61 \%$ higher than the reference mortar. Differences in consistency directly impact spreading, as demonstrated by the PC105 mortar, which presented 
a higher $(K)$ value than the reference and P25 mortars but resulted in lower spreading potential. Therefore, this can be challenging during the application stage.

Table 6 - Rheological parameters

\begin{tabular}{cccc}
\hline Rheological parameter & Ref. & P25 & PC105 \\
\hline$n$ & 1,05 & 1,09 & 1,12 \\
$K\left(\mathrm{kPa} . \mathrm{s}^{\mathrm{n}}\right)$ & 305,3 & 385,9 & 491,2 \\
\hline
\end{tabular}

Source: Author (2021)

Figure 10 - Example of curve representation of $\ln (\mathrm{F}) \mathrm{vs} \ln (1 / \mathrm{h})$

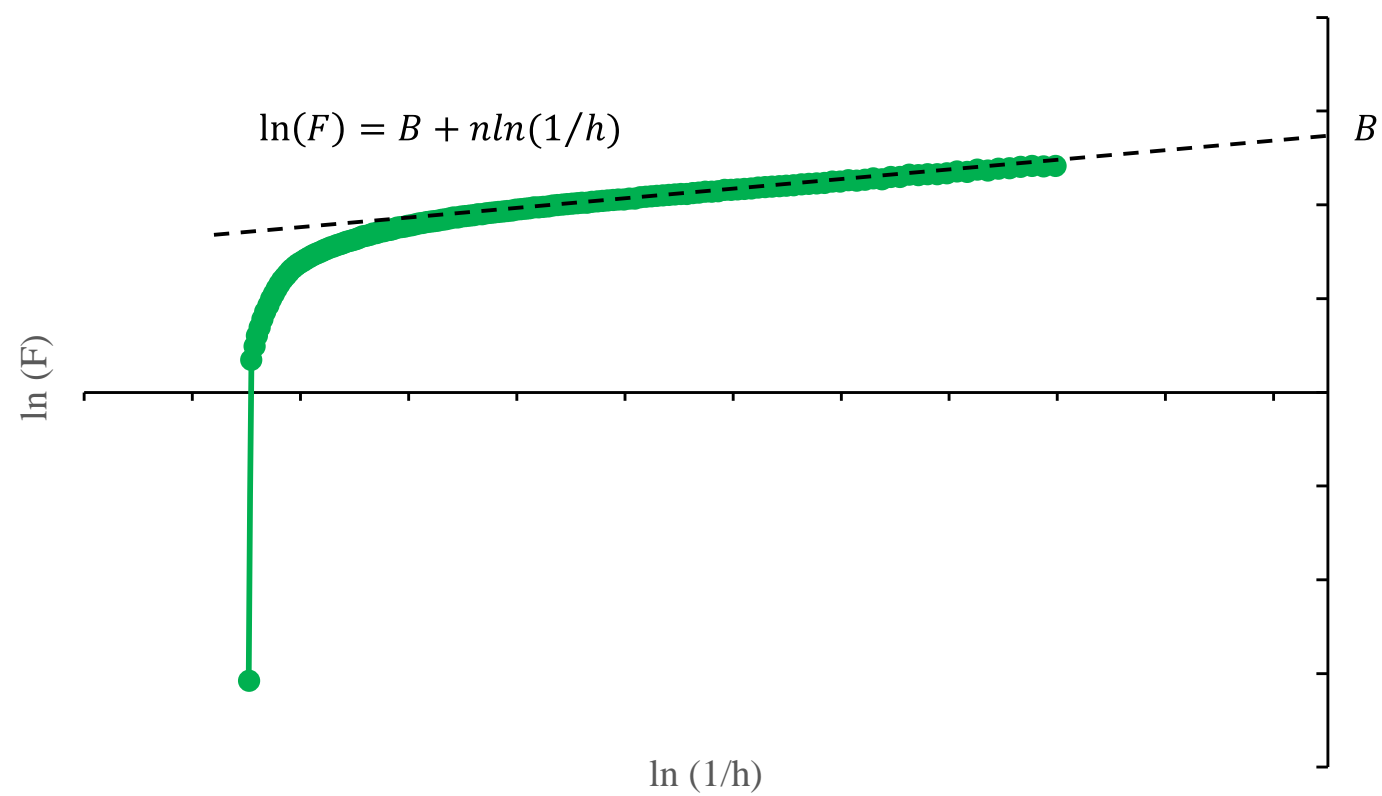

Source: Author (2021)

\subsection{Applying the mortars}

Mortars evaluated at the laboratory scale have the same consistency using the flow table test, adopting a spread of $220 \pm 10 \mathrm{~mm}$. However, the water content varied due to the high $\mathrm{TiO}_{2}$ particle surface area added to the cement matrix (Table 1). Despite that, this test did not provide complete information about the material rheological behavior, making it necessary to perform the squeeze flow test.

Squeeze flow results showed very small differences in the parameter related to the workability $[(n)$ and $(K)$ from the Power law equation]. However, these differences were only noticed at the laboratory scale due to the equipment sensitivity. No differences between the mortars were detected at the construction site by the professional responsible for the application. In other words, the effort required to handle it was similar. As a result, correction with water in the consistency was not necessary, as is usual in construction sites, using only the water previously defined. Therefore, the mortars developed on a laboratory scale met the objective proposed in this work. 
Thus, the changes in the yield were calculated, promoted only using $\mathrm{TiO}_{2}$ (P25 and PC105), according to equation (1), and the results are shown in Figure 11, illustrating a decrease of approximately $7 \%$ compared to reference mortar. It should be made clear that the yield calculation was obtained according to the application made only by one mason, and the correlations presented below cannot be discussed as a rule for other types of mortar or when other professionals apply the products.

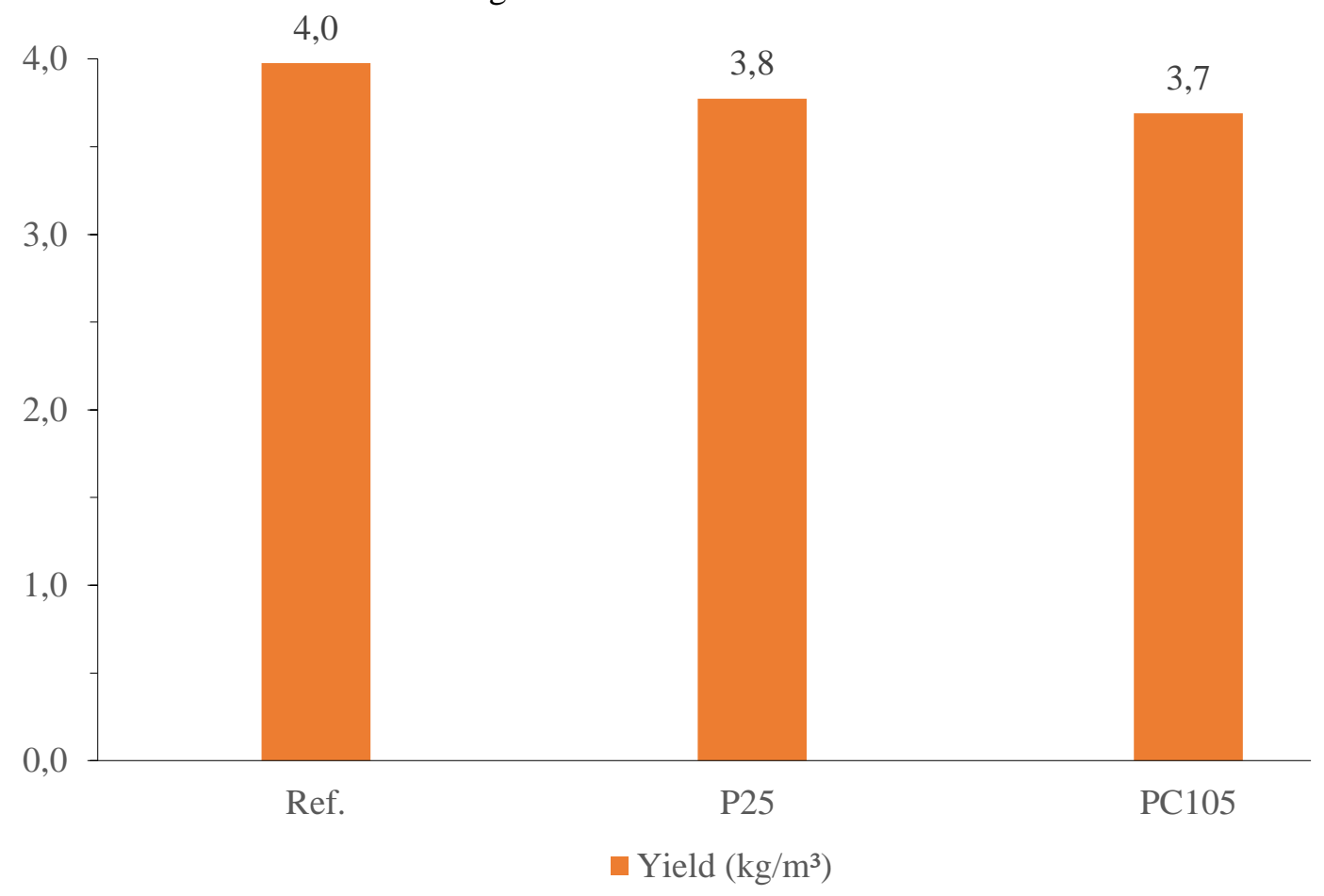

Source: Author (2021)

This reduction was correlated to the changes in the mortar's rheological behavior measured on a laboratory scale, caused by the $\mathrm{TiO}_{2}$ addition, as shown in Figure 12. 
Figure 12 - Correlation between yield with rheological parameters (n, K)

- Ref. OP25 PC105
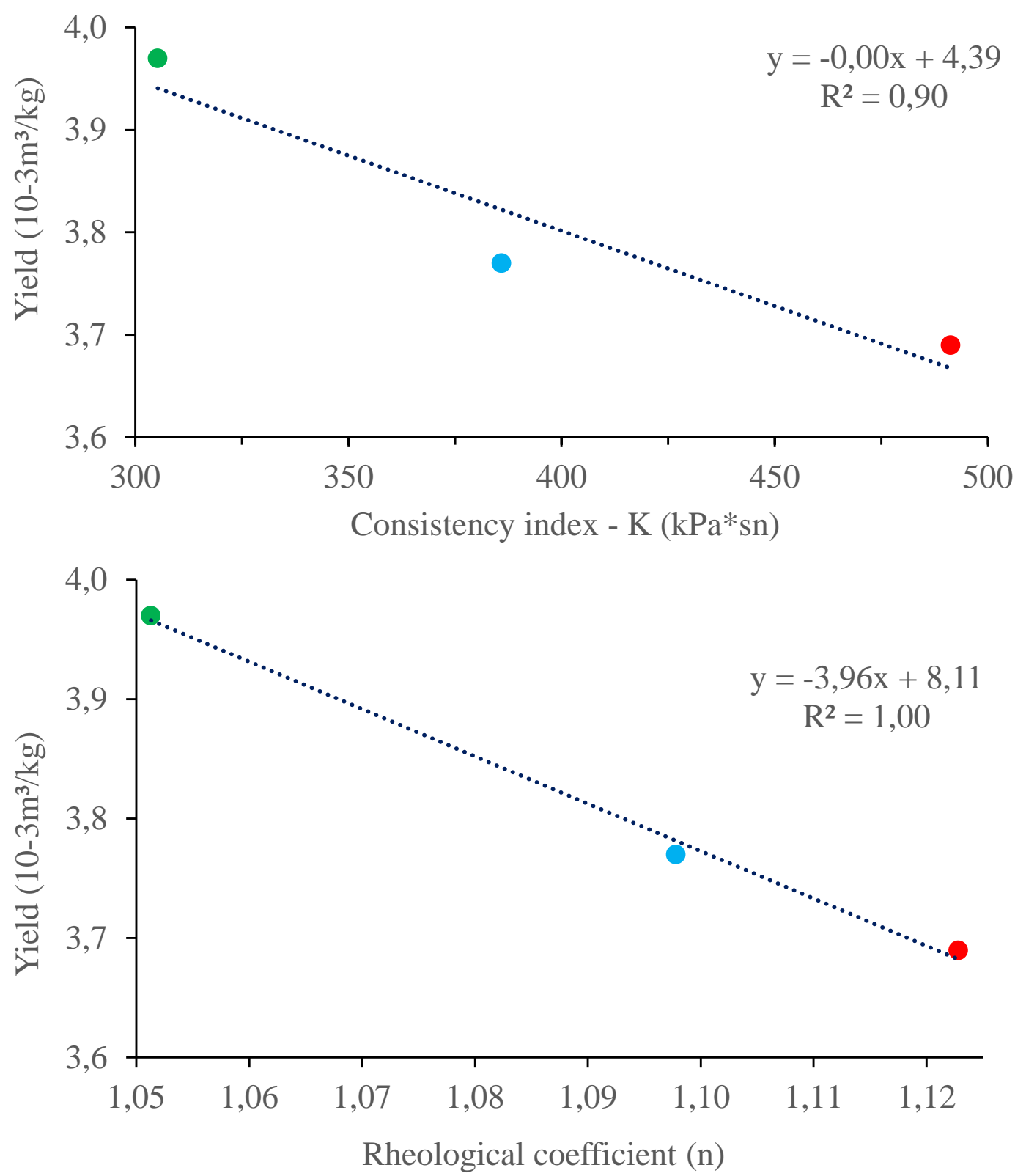

Source: Author (2021)

Regarding the rheological behavior, it can be concluded that the $\mathrm{TiO}_{2}$ addition was a major factor that influenced the yield, even with the minimal difference observed in the squeeze flow test. Therefore, it was observed that both the rheological coefficient $(n)$ and consistency index $(K)$ presented an excellent correlation with the parameters of mortar application in-situ. However, the use of finer $\mathrm{TiO}_{2}$ particles resulted in changes in the real density, specific surface area, and packing porosity, leading to the necessity for a higher amount of water for mortar mixing, affecting the solid content, corroborating with the studies presented by Senff et al. $(2013,2015)$ and Joshaghani et al. (2020). 
A way to combine all these variables in a single factor is by calculating the interparticle separation distance (IPS), according to Equation (10).

$I P S=\frac{2}{V S A} x\left[\frac{1}{V_{S}}-\left(\frac{1}{1-P_{o f}}\right)\right]$

Where:

(VSA) is the volumetric surface area (product between the specific area and the real density of the powder);

(Vs) is the volumetric fraction of solids; and

$\left(\mathrm{P}_{\mathrm{of}}\right)$ is the particle packing porosity.

The IPS can be defined as the average distance between any adjacent particles in the mixture, assuming that they are all separate, that is, not agglomerated (OLIVEIRA, 2000), and significantly influencing the rheological behavior of mortars.

The IPS concept is particularly applicable to fine particle suspensions, where surface forces are predominant, considering the effect of particle size distribution and predicting particle contact $(d=0)$ when the amount of the liquid phase is lower than the porosity of the packaged system (MACIEL et al., 2018). Thus, the yield results were also correlated with the IPS to monitor the impact of these physical changes on the compositions during the application insitu. The results are shown in Figure 13.

Thus, it can be concluded that the proper development of the compositions, based on the concept of IPS and the adequacy of the rheological properties of mortars in the laboratory led to a better understanding of their rheological behavior, thus enabling the production of different compositions with similar applications, according to the mason's perception. 
Figure 13 - Correlation between yield with IPS

-Ref. •P25 •PC105

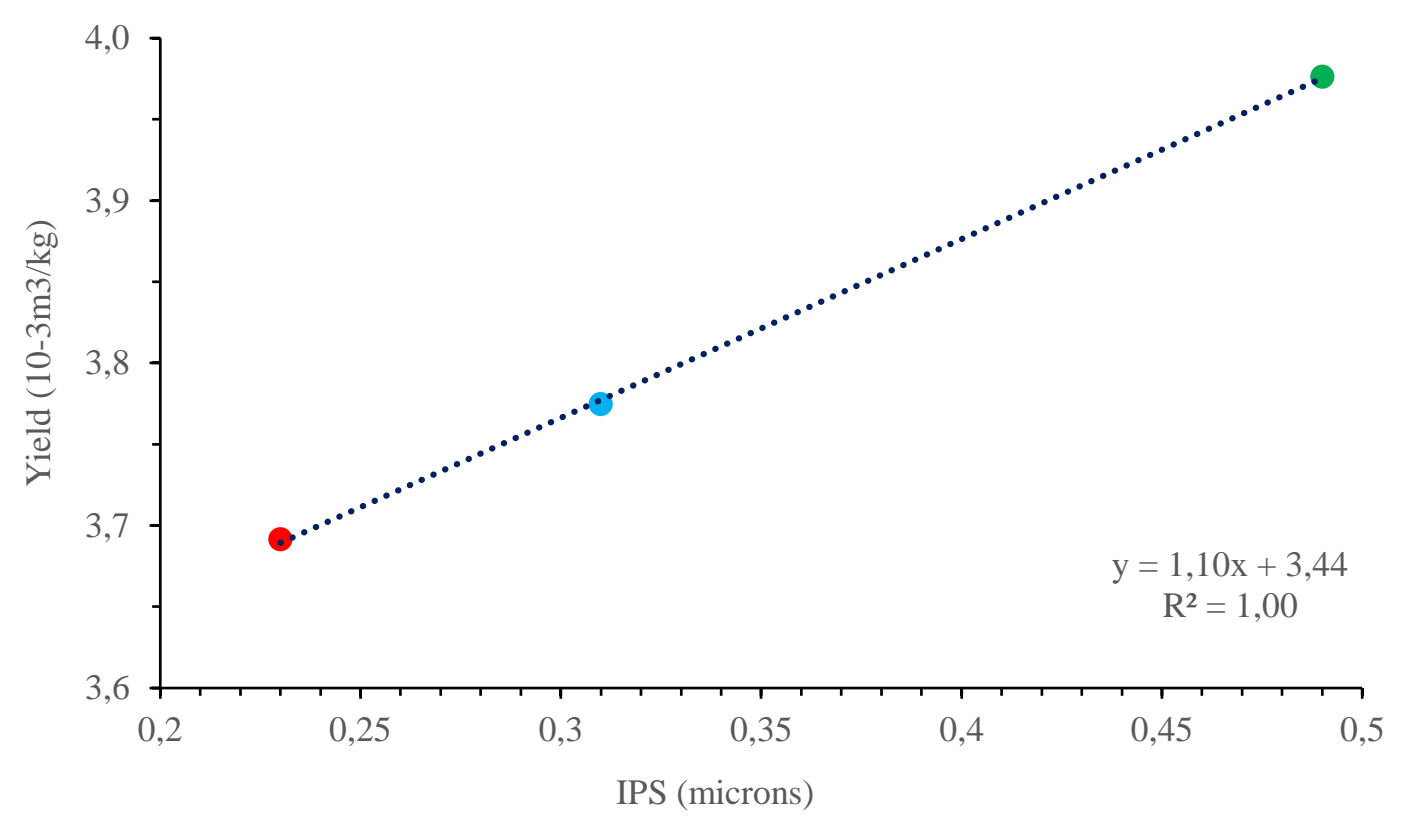

Source: Author (2021)

\section{CONCLUSIONS}

The results obtained in this study showed:

Even with the adequacy of mortar fluidity using flow table (spreading $220 \pm 10 \mathrm{~mm}$ ), sensitive rheological differences were detected by the squeeze flow test;

$>$ The $\mathrm{TiO}_{2}$ type was responsible for the changes in the rheological behavior of mortar according to the results of consistency index $(K)$ and rheological parameter $(n)$ obtained from the power-law in the results of squeeze flow;

$>$ Regarding the consistency, it was observed that due to the physical characteristics of $\mathrm{TiO}_{2}$, such as a specific surface area, particle size, and density, the PC105 mortar presented a slight difficulty in terms of the flow than the reference mortars and with P25;

The reference mortar showed the greatest spreading rate and the lower consistency index, reflecting a higher yield. The PC105 mortar, on the other hand, showed the lower spreading and highest consistency index, resulting in a lower yield, while the P25 mortar presented an intermediate performance;

$>$ Thus, it can be concluded that even though the workability of mortars with $\mathrm{TiO}_{2}$ was considered similar during the application in the field by the mason, the slight differences observed only by the squeeze flow test in the laboratory scale were reflected in the yield; and 
Additionally, changes in yield could be evaluated based on the concept of IPS (interparticle separation distance), which presented an excellent correlation, showing the impact of the physical parameters of each composition in the performance during the application. 


\section{REFERENCES}

ASSOCIAÇÃO BRASILEIRA DE NORMAS TÉCNICAS. NBR 13276: Argamassa para assentamento e revestimento de paredes e tetos - Determinação do índice de consistência, Rio de Janeiro, 2016.

ASSOCIAÇÃO BRASILEIRA DE NORMAS TÉCNICAS. NBR 13278: Argamassa para assentamento e revestimento de paredes e tetos - Determinação da densidade de massa e do teor de ar-incorporado, Rio de Janeiro 2005.

ASSOCIAÇÃO BRASILEIRA DE NORMAS TÉCNICAS. NBR 15839: Argamassa de assentamento e revestimento de paredes e tetos - Caracterização reológica pelo método squeeze-flow, Rio de Janeiro, 2010.

ASSOCIAÇÃO BRASILEIRA DE NORMAS TÉCNICAS. NBR 16697: Cimento Portland Requisitos, Rio de Janeiro 2018.

AZEVEDO, A. R. G. de et al. Influence of incorporation of glass waste on the rheological properties of adhesive mortar. Construction and Building Materials, v.148, p-359-368, 2017.

EUROPEAN STANDARD. EN 197-1: cement: part 1: composition, specifications, and conformity criteria for common cement. Brussels, 2000.

CARDOSO, F. A; JOHN, V. M; PILEGGI, R. G. Rheological behavior of mortars under different squeezing rates. Cement and Concrete Research, v.39, p-748-753, 2009.

CARDOSO, F. A; JOHN, V. M; PILEGGI, R. G. Squeeze-flow aplicado a argamassas de revestimentos: Manual de utilização. EPUSP, 2010 [in Portuguese].

CHEN, J.; KOU, S.-C.; POON, C.-S. Hydration and properties of nano- $\mathrm{TiO}_{2}$ blended cement composites. Cement and Concrete Composites, v. 34, p. 642-649, 2012.

DANTAS, S. R. A; VITTORINO, F; LOH, K. Photocatalytic performance of white cement mortars exposed in urban atmosphere. Global Journal of Research in Engineering: C (Chemical Engineering), v. 19, n. 2, p. 1-13, 2019 b.

DANTAS, S. R. A. et al. Influence of polypropylene microfibre (PPMF) dispersion procedure on fresh and hardened rendering mortar properties. Ambiente Construído, Porto Alegre, v. 20, n. 2, p. 7-23, abr./jun. 2020.

DANTAS, S. R. A. et al. Influence of the nano $\mathrm{TiO}_{2}$ dispersion procedure on fresh and hardened rendering mortar properties. Construction and Building Materials, v. 215, p. 544556, 2019a.

DELHAYE, N.; POITOU, A.; CHAOUCHE, M. Squeeze flow of highly concentrated suspensions of spheres. Journal of Non-Newtonian Fluid Mechanics, v. 94, n. 1, p. 67-74, 2000. 
ENGMANN, J.; SERVAIS, C.; BURBIDGE, A. S. Squeeze flow theory and applications to rheometry: a review. Journal of Non-Newtonian Fluid Mechanics, v. 132, n. 1/3, p. 1-27, 2005 .

FOLLI, A. et al. Engineering photocatalytic cements: Understanding $\mathrm{TiO}_{2}$ surface chemistry to control and modulate photocatalytic performances. Journal of the American Ceramic Society, v. 93, p. 3360-3369, 2010.

HAMIDI, F.; ASLANI, F. TiO ${ }_{2}$-based photocatalytic cementitious composites: materials, properties, influential parameters, and assessment techniques. Nanomaterials, v. 9, p. 1-33, 2019.

ISAIA, G. C. (ed.). Materiais de construção civil e princípios de ciência e engenharia de materiais. São Paulo: IBRACON, v.1, 3ª ed., 2017.

JOSHAGHANI, A. et al. Effects of nano-TiO2, nano-A12O3, and nano-Fe2O3 on rheology, mechanical, and durability properties of self-consolidating concrete (SCC): An experimental study. Construction Building end Materials, v. 245, 2020.

MACIEL, M. H. et al. Effect of the variation of cement consumption on coating mortars produced based on the concepts of mobility and packaging of particles. Ambiente Construído, Porto Alegre, v. 18, n. 1, p. 245-259, jan./mar. 2018.

MELO, J. V. S; TRICHÊS, G. Study of the influence of nano- $\mathrm{TiO}_{2}$ on the properties of Portland cement concrete for application on road surfaces. Road Materials Pavement Design, v. 19, p. 1011-1026, 2017.

MIKULÁĔK, P.; WAKEMAN, R. J.; MARCHANT, J. Q. The influence of $\mathrm{pH}$ and temperature on the rheology and stability of aqueous titanium dioxide dispersions, Chemical Engineering, v. 67, p. 97-102, 1997.

OLIVEIRA, I. R.; STUDART, A. R.; PILEGGI, R. C.; PANDOLFELLI, V. C. Dispersão e Empacotamento de Partículas: princípios e aplicações em processamento cerâmico. São Paulo: Fazendo Arte, 2000. 224 p. ISBN 85-86425-15-X.

PARAMÉS, J; BRITO, J. de. Materiais de construção nanotecnológicos de auto-limpeza Self-cleaning nanotechnologic construction materials. Teoria e Prática na Engenharia Civil, v. 15, p. 55-62, 2010.

SALMAN, M. M.; EWEED, K. M.; HAMEED, A. M. Influence of partial replacement $\mathrm{TiO}_{2}$ nanoparticles on the compressive and flexural strength of ordinary cement mortar. AlNahrain Journal for Engineering Sciences, v. 19, p. 265-270, 2016.

SENFF, L. Effect of nanosilica on rheology and fresh properties of cement pastes and mortars, Construction and Building Materials, v. 23, p. 2487-2491, 2009.

SENFF, L. et al. Effect of nanosilica and microsilica on the microstructure and the hardened properties of cement pastes and mortars, Advanced Applied Ceramics Journal, v. 109, p. 104-110, 2010. 
SENFF, L. et al. Formulation of mortars with nano-SiO 2 end nano- $\mathrm{TiO}_{2}$ for degradation of pollutants in buildings. Composites Part B: Engineering, v. 44, n. 1, p. 40-47, 2013.

SENFF, L. et al. The influence of $\mathrm{TiO}_{2}$ nanoparticles and polyacrylonitrile fibers on the rheological behavior and hardened properties of mortars. Construction and Building Materials, v. 75, p. 315-330, 2015.

STEFFE, J. F. Rheological methods in food process engineering. 2. ed. Michagan: Freeman Press, 1996. 428 p.

YANG, L. et al. Effects of nano- $\mathrm{TiO}_{2}$ on strength, shrinkage, and microstructure of alkali activated slag pastes. Cement and Concrete Composites, v. 57, p. 1-7, 2015. 
APPENDIX E - EFFECTS OF SURFACE ROUGHNESS AND LIGHT SCATTERING ON
THE ACTIVATION ON TIO 2 ON MORTAR PHOTOCATALYTIC PROCESS ${ }^{13}$ (Article E)

\section{ABSTRACT}

Purpose: To assess the effects of the activation of $\mathrm{TiO}_{2}$ as a function of different roughness scales and light scattering on mortar surfaces. Methods: Commercial samples of $\mathrm{TiO}_{2}$ in powder and suspension form were compared using seven mortar samples with distinct treatments of $\mathrm{TiO}_{2}$. Optical profilometer, Scanning Electron Microscopy, and EDS elemental mapping were used to evaluate the influence of roughness on the activation of $\mathrm{TiO}_{2}$. Conclusions: Activation of $\mathrm{TiO}_{2}$ by diffuse solar radiation is as or more important than direct solar radiation; Micro-roughness has no direct relationship with the activation of $\mathrm{TiO}_{2}$; The presence of different roughness scales and the use of the same particle size of $\mathrm{TiO}_{2}$ affect the dispersion process of $\mathrm{TiO}_{2}$; Different particle sizes of $\mathrm{TiO}_{2}$ helped in the formation of $\mathrm{TiO}_{2}$ magnetic mesh which improves system efficiency, and; Suspension of $\mathrm{TiO}_{2}$ does not guarantee better effectiveness of the system due to imperfect film formation.

Keywords: Mortar surface. Light scattering. UV Light. $\mathrm{TiO}_{2}$ activation. Photocatalysis.

\footnotetext{
${ }^{13}$ S. R. A. Dantas, R. C. de. O. Romano, F. Vittorino, K. Loh. Effects of surface roughness and light scattering on the activation of $\mathrm{TiO}_{2}$ on mortar photocatalytic process, Constr. Build. Mater. 270 (2021) 121421. https://doi.org/10.1016/j.conbuildmat.2020.121421
} 


\section{INTRODUCTION}

$\mathrm{TiO}_{2}$ nanoparticles (NPs) are commonly used in photocatalytic processes aiming to obtain self-cleaning surfaces [1-5], and, at the same time, the few investigations on $\mathrm{TiO}_{2}$ microparticles (MPs) reinforce the idea of the low efficacy of larger particles for this purpose [6,7]. Among the factors that may influence photocatalytic activity, the following three are considered relevant: (i) the amount of photoactive $\mathrm{TiO}_{2}$ particles (active sites) on the surface, (ii) particle size and morphology of $\mathrm{TiO}_{2}$, and (iii) crystalline structure of $\mathrm{TiO}_{2}[8,9]$.

The shape and particle size of $\mathrm{TiO}_{2}$ are significant since photocatalytic activity depends on both [3]. Another point is that UV radiation is strongly absorbed, with the strongest visible light scattering power, at the particle size of $\mathrm{TiO}_{2}$ of approximately $0.2 \mu \mathrm{m}$ [10]. However, this could be applying well to spherical pigment particles separated by large distances compared to the light wavelength, but it is less useful when particles are packed [11].

The addition of $\mathrm{TiO}_{2}$ powder on the cement matrix results in problems because it is introduced in the dry state, and it also has a strong tendency to form agglomerates; however, the efficiency of the photocatalytic activity can be increased if $\mathrm{TiO}_{2}$ is applied as a suspension [12-14]. Considering that no real surface is perfectly smooth and no two rough surfaces are identical [15], surface roughness can affect how $\mathrm{TiO}_{2}$ particles can be activated by solar radiation incidence, which can lead to a micro-shading effect in $\mathrm{TiO}_{2}$ particles caused by the different roughness scales existing on surfaces.

The extent to which surface roughness affects wave scattering becomes essential when the scattering properties of a surface strongly depend on a range of roughness scales around the wavelength of the incident wave and when a rough surface exhibits more than one scale of roughness [15]. Therefore, modern nanotechnology considers that surfaces roughness needs to improve the study of interactions at the nano- and microscales [16].

Rough surface measurement techniques are generally classified as contact and non-contact methods. Typically, a minimum of two surface parameters are needed to characterize a rough surface: a height and a spatial parameter [17]. However, the difficulties associated with rough surface measurement arise from the nature of the surface, once roughness is not an intrinsic surface property and depends on sample length and the sampling interval used [15].

This study discusses the effects of the form of application of $\mathrm{TiO}_{2}$-powder, and suspension on the activation of $\mathrm{TiO}_{2}$ as a function of roughness surfaces using an optical profilometer, Scanning Electron Microscopy, EDS elemental mapping, and the electromagnetic wave 
theory to understand how the phenomenon of light reflection occurs and the influence of roughness on photocatalytic activity considering the different roughness scales of mortar surfaces.

This research does not present the best procedure for the use of $\mathrm{TiO}_{2}$ if added in the cement matrix or applied as a suspension since both methods have limitations that hinder the activation of $\mathrm{TiO}_{2}$ by $\mathrm{UV}$ light. However, $\mathrm{TiO}_{2}$ must have a particle size that allows an excellent dispersion to form the cake cover. In other words, these particles can be activated by solar radiation (direct or diffuse) at the time of the incidence of UV light, thereby limiting the influence of micro-shading and pollution particles on this activation and, consequently, causing a more effective photocatalysis process.

\section{MATERIAL AND METHODS}

This research observed the effects of the activation of $\mathrm{TiO}_{2}$ as a function of different roughness scales and light scattering on mortar surfaces with distinct treatments of $\mathrm{TiO}_{2}-$ either in powder and suspension form. Thus, an experimental program was developed in which samples were observed at different scales, with an observation path from the larger scale to a more refined scale using optical profilometry tests to observe the surface microscopic distribution, passing to scanning electron microscopy (SEM) to identify the morphology and formation of $\mathrm{TiO}_{2}$ film from the suspensions, and finally, arriving at EDS elementary mapping to observe the presence and dispersion of $\mathrm{TiO}_{2}$ powder when added in mortar.

\subsection{Experimental design}

Commercial samples of $\mathrm{TiO}_{2}$ in powder and suspension were compared using seven mortar samples with distinct treatments of $\mathrm{TiO}_{2}$. The P25p and PC105p powder forms were added to the cement matrix after being pre-dispersed in water. The P25s and PC105s are suspensions prepared by the author in the laboratory using High Energy of Dispersion (HED), while PCS7s and E502s are commercial suspensions. All suspensions were applied as a spray to the surfaces of specimens, as recommended by the manufacturer, as well as the paint in the painted specimens so that the same application pattern could be maintained.

The experimental design compared four suspension samples of $\mathrm{TiO}_{2}$ with two powder samples of $\mathrm{TiO}_{2}$. Because of the dimensions and exposure conditions of the specimens, mortar samples are compared in pairs, while the reference has three samples to participate in each group. The specimens are divided into three groups (1-3) and assembled according to 
logic: G1 - comparing the same samples of $\mathrm{TiO}_{2}$ powder and suspensions prepared in the laboratory; G2 - comparing different samples of $\mathrm{TiO}_{2}$ powder with different commercial suspensions of $\mathrm{TiO}_{2}$, and; $\mathrm{G} 3$ - comparing all samples of $\mathrm{TiO}_{2}$ in suspension form, as described in Table 1. The final design of the specimens exposed to solar radiation is shown in Figure 1.

Table 1 -Description of the specimens

\begin{tabular}{cccccc}
\hline Group & $\begin{array}{c}\text { Mortar } \\
\text { (painted) }\end{array}$ & $\begin{array}{c}\text { Mortar } \\
\text { (unpainted) }\end{array}$ & $\begin{array}{c}\text { Mortar } \\
\text { (unpainted) }\end{array}$ & $\begin{array}{c}\text { Mortar } \\
\text { (unpainted) }\end{array}$ & $\begin{array}{c}\text { Mortar } \\
\text { (unpainted) }\end{array}$ \\
\hline G1 & Ref. & P25p & PC105p & P25s & PC105s \\
G2 & Ref. & P25p & PC105p & PC-S7s & E502s \\
G3 & Ref. & P25s & PC105s & PC-S7s & E502s \\
\hline
\end{tabular}

Note: $\mathrm{p}=$ Powder $/ \mathrm{s}=$ Suspension

Source: Author (2021)

Figure 1. Design and exposure to solar radiation of specimens

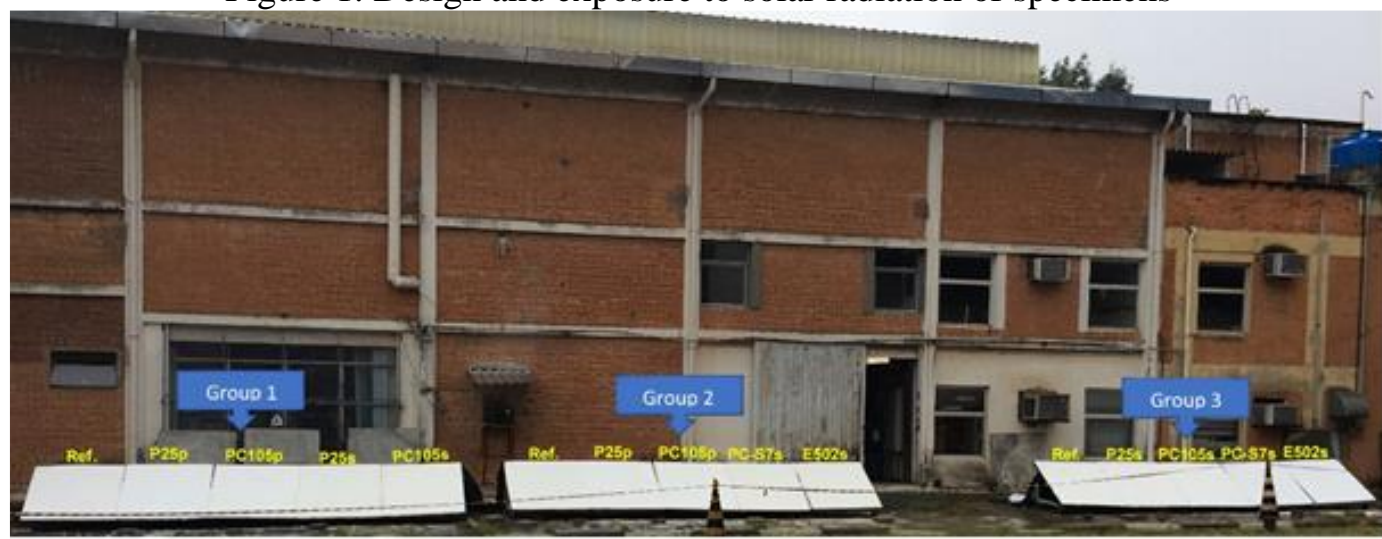

Source: Author (2021)

\subsection{Materials characterization}

The characteristics of the raw materials are presented in Table 2. The specific surface area, real density, particle size of $\mathrm{TiO}_{2}$, and particle size distribution of dolomite were determined accord Dantas et al. [18]. Figure 2 presents the particle size distributions of materials.

Table 2 - Characteristics of the raw materials

\begin{tabular}{lccccc}
\hline Material & \multicolumn{3}{c}{$\begin{array}{c}\text { Particle Size } \\
(\mu \mathrm{m})\end{array}$} & $\begin{array}{c}\text { Specific surface } \\
\text { area } \\
\left(\mathrm{m}^{2} / \mathrm{g}\right)\end{array}$ & $\begin{array}{c}\text { Average density } \\
\left(\mathrm{g} / \mathrm{cm}^{3}\right)\end{array}$ \\
\hline White Portland cement & 2.6 & 17.7 & 19.5 & 0.86 & 3.05 \\
Dolomite \#20 & 975 & 1242 & 1620 & 0.16 & 2.90 \\
Dolomite \#40 & 24.3 & 230 & 740 & 0.56 & 2.94 \\
Dolomite \#80 & 4.5 & 38.3 & 134 & 0.80 & 2.81 \\
$\mathrm{TiO}_{20}$ (P25 - powder) & 1.38 & 3.90 & 17.7 & 49.4 & 3.84 \\
$\mathrm{TiO}_{2}$ (PC105 - powder) & 0.66 & 1.50 & 4.60 & 79.8 & 3.62 \\
$\mathrm{TiO}_{2}$ (PC-S7 - suspension) & 0.06 & 0.09 & 0.12 & 70.7 & --- \\
$\mathrm{TiO}_{2}$ (E502 - suspension) & 4.09 & 8.60 & 17.25 & 0.82 & --- \\
\hline $\mathrm{SOu}_{90}$ & & & & \\
\hline
\end{tabular}

Source: Author (2021) 
Figure 2. Particle size distribution of materials

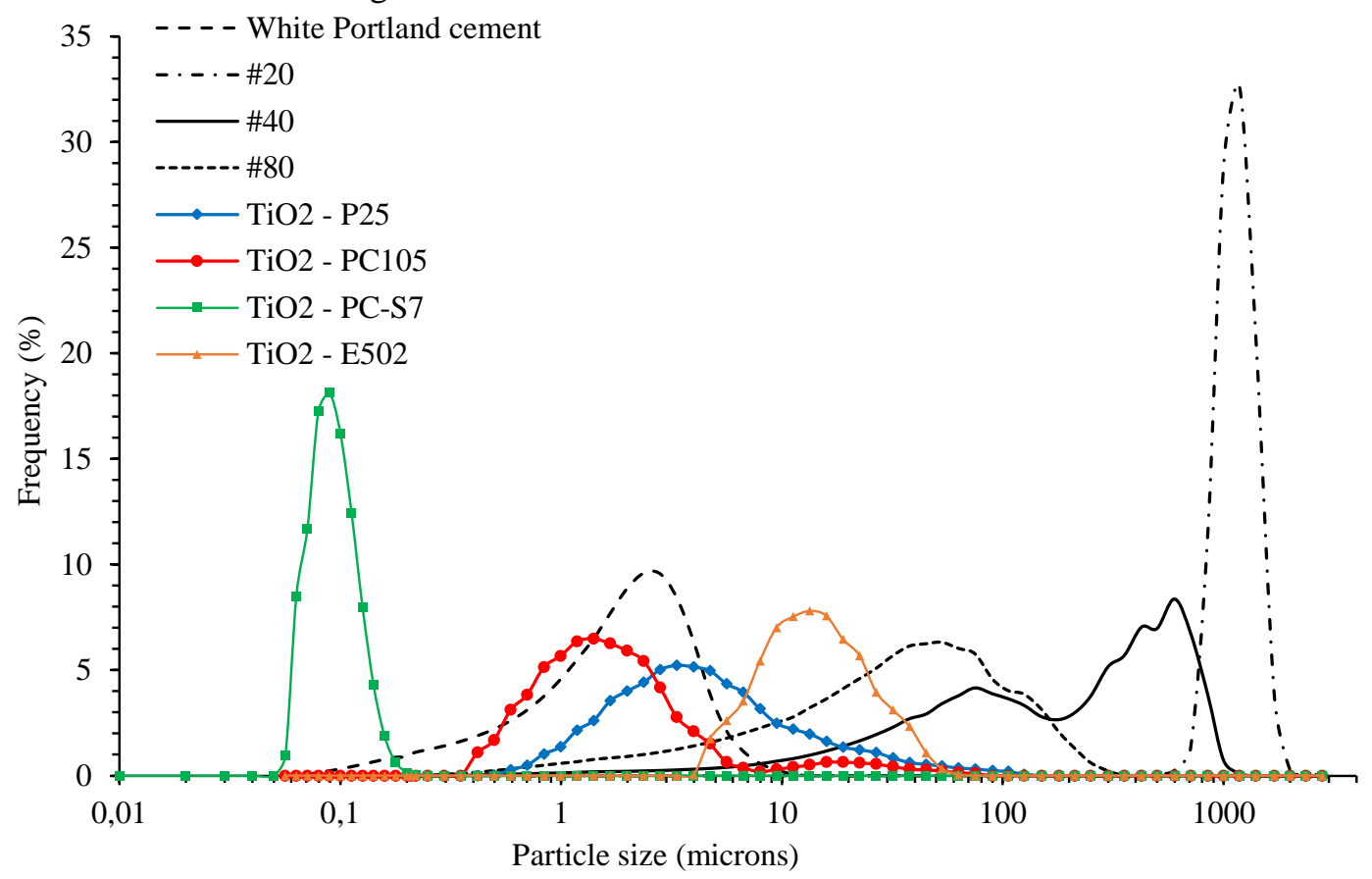

Source: Author (2021)

According to Table 2 and Figure 2, two points can be considered essential for understanding the relationship of $\mathrm{TiO}_{2}$ with the roughness measured and its potential activation by $\mathrm{UV}$ radiation: specific surface area and particle sizes presented by each $\mathrm{TiO}_{2}$ type. It is known that the smaller the particle size of $\mathrm{TiO}_{2}$, the larger its specific areas and the greater the tendency to agglomerate. Consequently, there are more dispersion problems for the material on a very rough surface, as well as its activation through solar radiation, either on a surface containing $\mathrm{TiO}_{2}$ in its matrix or covered by a film, as will be shown further in this study.

Figure 3 shows the mineralogical compositions of the commercial powder samples (P25 and PC105) and suspension samples (PC-S7 and E502) of $\mathrm{TiO}_{2}$ determined by X-ray diffraction. Table 3 presents the amount of rutile and anatase quantified using the Rietveld method.

Table 3 - Phases observed in $\mathrm{TiO}_{2}$ and amount of rutile and anatase

\begin{tabular}{lccc}
\hline \multicolumn{1}{c}{ Sample } & Phase & ICSD code & $\%$ \\
\hline PC105 & Anatase & 93098 & 100 \\
P25 & Anatase / Rutile & $202243 / 51938$ & $87.8 / 12.2$ \\
PCS7 & Anatase & $82080 / 202243$ & $29.5 / 70.5$ \\
E502 & Anatase Nanocrystaline & 154602 & 100 \\
\hline
\end{tabular}

Source: Author (2021) 
Figure 3. X-ray diffractograms of samples of $\mathrm{TiO}_{2}$

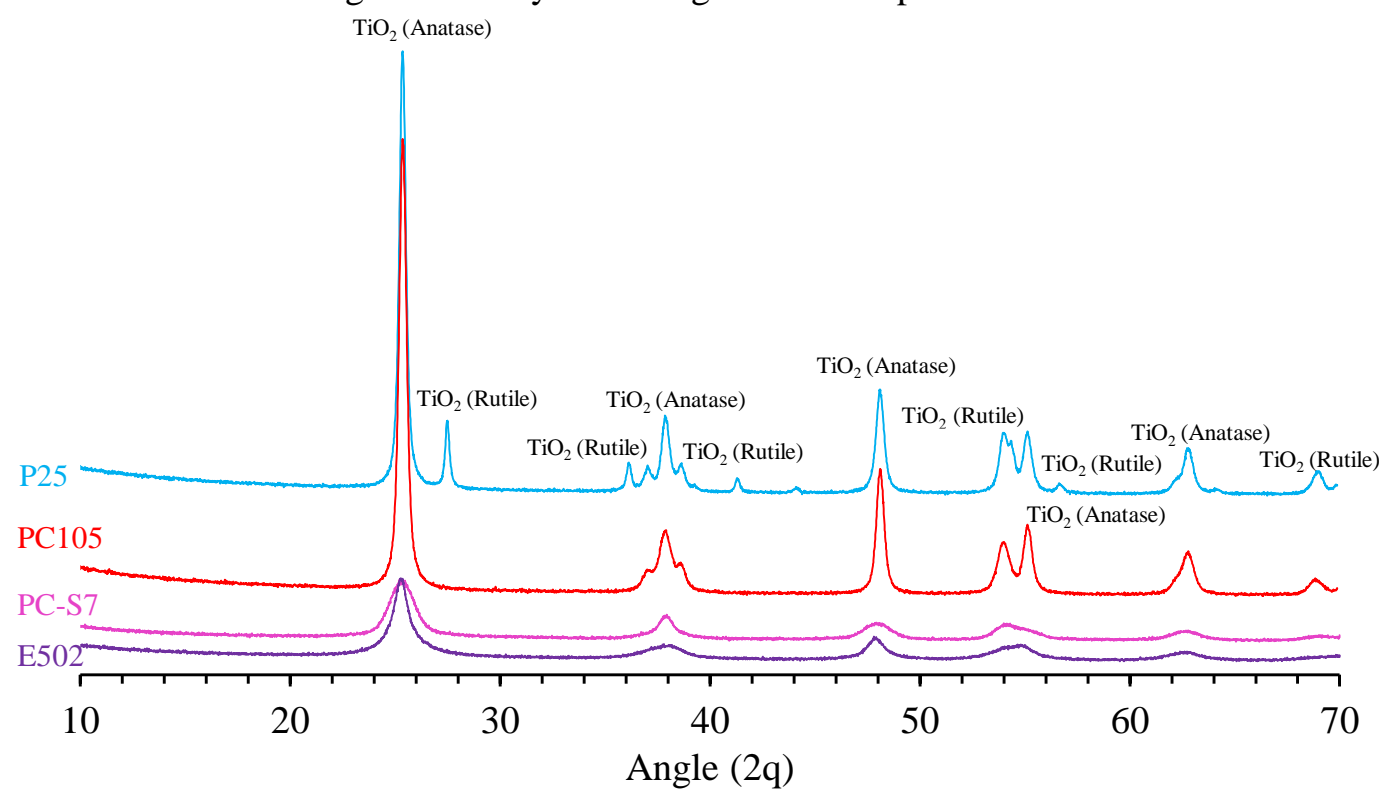

Source: Author (2021)

Table 4 shows the chemical composition of samples of $\mathrm{TiO}_{2}$ determined by semiquantitative chemical analysis by X-ray fluorescence $(\mathrm{XRF})^{14,15}$ : Procedure IPT15101-CT-WORKSLMCC-Q-PE-087 - Revision 0 of 03/28/2014 "Qualitative, semi-quantitative, or quantitative chemical analysis by X-ray fluorescence spectrometry," following the Brazilian Association of Technical Standards (ABNT) [19].

Table 4-Chemical composition of samples of $\mathrm{TiO}_{2}$ by XRF

\begin{tabular}{|c|c|c|c|c|}
\hline Compound & P25 (\%) & PC105 (\%) & PC-S7 (\%) & E502 (\%) \\
\hline $\mathrm{TiO}_{2}$ & 99.7 & 99.6 & 96.1 & 90.6 \\
\hline $\mathrm{SiO}_{2}$ & 0.25 & --- & 0.21 & 1.17 \\
\hline $\mathrm{Al}_{2} \mathrm{O}_{3}$ & --- & 0.12 & 0.09 & 0.46 \\
\hline $\mathrm{FeO}_{3}$ & 0.02 & 0.03 & --- & --- \\
\hline $\mathrm{CaO}$ & --- & --- & 0.14 & 1.21 \\
\hline $\mathrm{MgO}$ & --- & --- & 0.20 & 0.64 \\
\hline $\mathrm{P}_{2} \mathrm{O}_{5}$ & --- & --- & 2.77 & 4.28 \\
\hline $\mathrm{ZrO}$ & --- & 0.03 & 0.04 & --- \\
\hline $\mathrm{Nb}_{2} \mathrm{O}_{5}$ & --- & 0.26 & 0.41 & --- \\
\hline $\mathrm{CdO}$ & --- & --- & 0.13 & --- \\
\hline $\mathrm{V}_{2} \mathrm{O}_{5}$ & --- & --- & --- & 1.56 \\
\hline $\mathrm{CuO}$ & 0,02 & 0.03 & --- & --- \\
\hline $\mathrm{Er}_{2} \mathrm{O}_{3}$ & -- & 0.10 & --- & --- \\
\hline
\end{tabular}

Source: Author (2021)

\footnotetext{
${ }^{14}$ For liquid samples, a Panalytical X-ray fluorescence spectrometer model Minipal Cement was used; using a sample holder with a $3.6 \mu \mathrm{m}$ polyester x-ray film, the test was determined on the "in nature" sample. The semiquantitative results are estimated by the manufacturer's internal standards and the curve called "OMNIAN".

${ }^{15}$ For solid samples, a Panalytical X-ray fluorescence spectrometer, Minipal Cement model was used from inserts fused in a Claisse model M4 fusion machine, using mixture fluxes of lithium tetraborate/lithium metaborate, brand MAXXIFLUX $(66.57 \% \mathrm{Li} 2 \mathrm{~B} 4 \mathrm{O} 7,32.73 \% \mathrm{LiBO} 2$ and $0.70 \% \mathrm{LiBr})$, with a proportion of 0.5 $\mathrm{g}$ of sample and $6.75 \mathrm{~g}$ of fondant. The semi-quantitative results are estimated by the manufacturer's internal standards and the curve called "OMNIAN" and they have been normalized to $100 \%$.
} 
Figure 3 and Table 3 show that, except for the $\mathrm{TiO}_{2}-\mathrm{P} 25$ sample, all other samples have the same crystalline phase. The crystalline phases of $\mathrm{TiO}_{2}$ have a direct relationship with the bandgap energy, being it $3.2 \mathrm{eV}$ for the anatase phase and $3.0 \mathrm{eV}$ for the rutile phase, therefore responsible for absorption and activation by solar radiation as will be discussed later.

Table 4 shows that, concerning chemical compositions, $\mathrm{TiO}_{2}$ powders (P25 and PC105) have greater purity than suspensions (PC-S7 and E502), the latter being of lower concentration but which cannot be associated with a lower photodegradation power when evaluated under the photocatalysis aspect.

\subsection{Mortar composition}

Compositions were developed without granulometric changes of coarse particles, and the consumption, in $\mathrm{kg} / \mathrm{m}^{3}$, of each material is described in Table 5 .

Table 5 - Consumption, in $\mathrm{kg} / \mathrm{m}^{3}$, of each raw material

\begin{tabular}{|c|c|c|c|c|c|c|c|}
\hline Material & Ref. $^{1}$ & P25p & PC105p & $\mathrm{P} 25 \mathrm{~s}^{2}$ & $\mathrm{PC} 105 \mathrm{~s}^{2}$ & PC-S7s ${ }^{2}$ & $E 502 s^{2}$ \\
\hline White Portland cement & 351 & 337 & 342 & 351 & 351 & 351 & 351 \\
\hline Dolomite \# 20 & 195 & 187 & 190 & 195 & 195 & 195 & 195 \\
\hline Dolomite \# 40 & 1111 & 1067 & 1084 & 1111 & 1111 & 1111 & 1111 \\
\hline Dolomite \# 80 & 292 & 281 & 285 & 292 & 292 & 292 & 292 \\
\hline Water retainer & 1.95 & 1.87 & 1.90 & 1.95 & 1.95 & 1.95 & 1.95 \\
\hline Air entrainment & 0.16 & 0.15 & 0.15 & 0.16 & 0.16 & 0.16 & 0.16 \\
\hline Water & 332 & 354 & 344 & 332 & 332 & 332 & 332 \\
\hline $\begin{array}{l}\text { Polypropylene } \\
\text { microfibers }\end{array}$ & 1.4 & 1.4 & 1.4 & 1.4 & 1.4 & 1.4 & 1.4 \\
\hline $\mathrm{TiO}_{2}(\mathrm{P} 25)$ & --- & 16.8 & --- & 0.5 & --- & --- & --- \\
\hline $\mathrm{TiO}_{2}(\mathrm{PC} 105)$ & --- & --- & 17.1 & --- & 0.5 & --- & --- \\
\hline $\mathrm{TiO}_{2}(\mathrm{PC}-\mathrm{S} 7)$ & --- & --- & --- & --- & --- & $* *$ & --- \\
\hline $\mathrm{TiO}_{2}(\mathrm{E} 502)$ & --- & --- & --- & --- & --- & --- & $* * *$ \\
\hline
\end{tabular}

Note: : Specimens painted by spray after 28 days of field-cured (1); Suspensions applied by spray after 28 days of field-cured (2); Spray Rate: $15 \mathrm{~m}^{2} / \mathrm{L}(* *)$; Spray Rate: $10 \mathrm{~m}^{2} / \mathrm{L}(* * *)$

Source: Author (2021)

\subsection{Setup of mixing and application process}

The mixing procedure to prepare the mortar samples and suspensions is described below. Mortars were prepared and applied by a mason on specimens with $1.2 \mathrm{~m} \times 1.2 \mathrm{~m}$ dimensions described by Dantas, Vittorino, and Loh [20]. Figures 4 - 6 show the mixing and application in situ.

- Reference mortar: water was added to the construction mixer, and then microfibers were added. Mixing was performed for $5 \mathrm{~min}$; after that, the dry powder was added, 
and 1 min was allowed for particle wetting. Hereafter, mixing was performed for more than 5 min.

- P25p and PC105p mortar: water was added to the construction mixer, and then microfibers were added. Mixing was performed for $5 \mathrm{~min}$; after that, $\mathrm{TiO}_{2}$ powder was added for $1 \mathrm{~min}$, followed by all the dry powder, and 1 min was allowed for particle wetting. Then, mixing was performed for more than $5 \mathrm{~min}$.

- P25s and PC105s suspensions were prepared in the laboratory, based on the total solid residues of PC-S7s and E502s suspensions. The quantity equivalent to $14.4 \mathrm{~g}$ for each powder sample (P25p and PC105p) was mixed with $100 \mathrm{ml}$ of deionized water using HED (2000 rpm with cowles propellant) for $5 \mathrm{~min}$. After that, the suspensions were applied on black polypropylene (PP) plastic surfaces to observe adhesion.

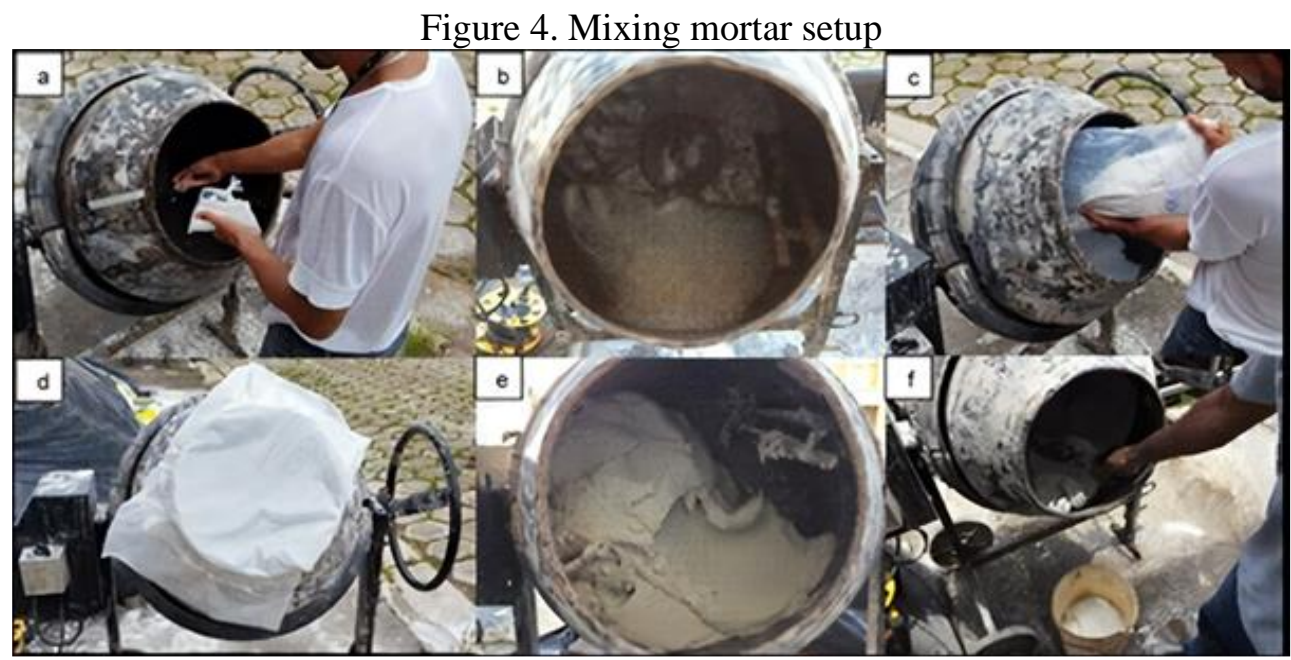

Note: Addition of microfibers and mixing ( $\mathrm{a}-\mathrm{b})$; Addition of $\mathrm{TiO}_{2}(\mathrm{c})$; particle wetting (d); mixing of mortar (e - f).

Source: Author (2021)

Figure 5. Mortar application by mason in situ

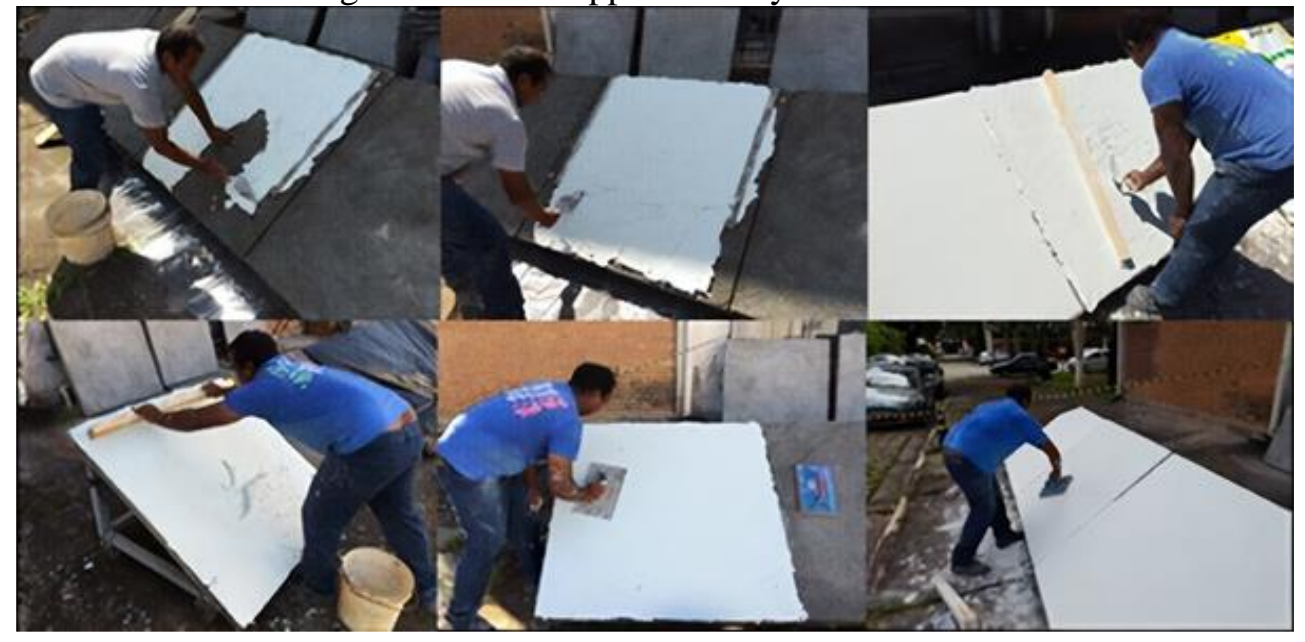

Source: Author (2021) 
Figure 6. Impregnation suspension test

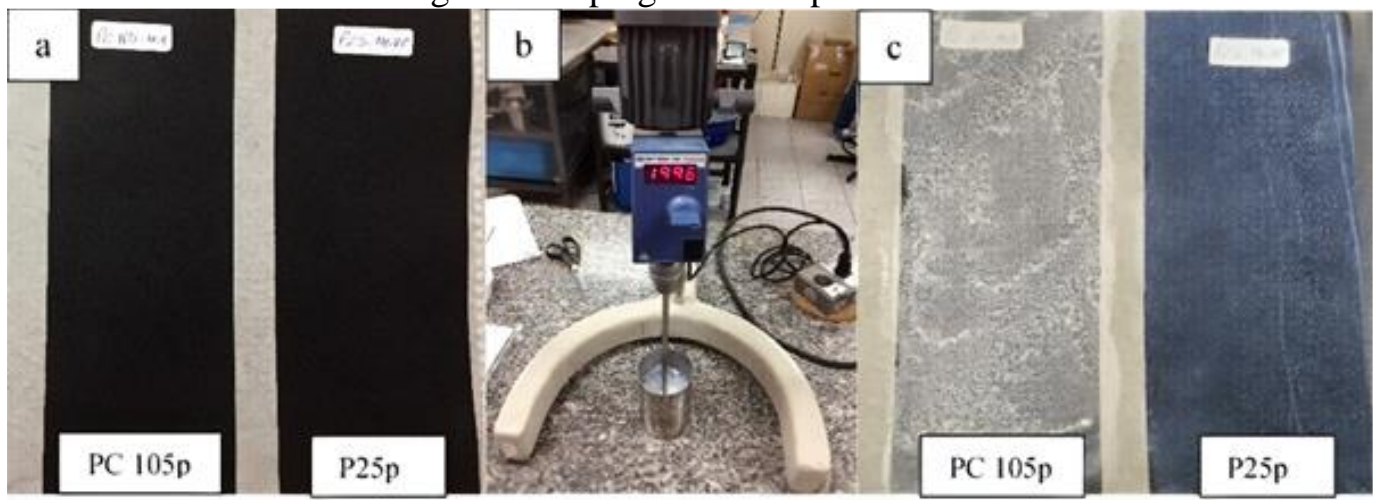

Note: PP surfaces before suspension impregnation (a); HED equipment (b); suspension impregnation after HED (c)

Source: Author (2021)

\subsection{Surface characterization}

The parameters used to describe the rough surface depend only on the sampling length and instrument resolution [21]. This study used an optical profilometer (non-contact method), Scanning Electron Microscopy (SEM), and EDS elemental mapping for surface characterization.

The shape and structure of seven different mortar samples with an area of $10 \mathrm{~mm}$ x $10 \mathrm{~mm}$ were analyzed employing eight measurements for each mortar sample by laser interferometry using a Bruker NPFLEX ${ }^{\mathrm{TM}}$ optical profilometer according to the following parameters: $5 \mathrm{x}$ objective lens (Michelson) with monochromatic green light and $2 \mathrm{x}$ multiplier factor, measured area $\mathrm{x}=623.4 \mu \mathrm{m}$ and $\mathrm{y}=467.5 \mu \mathrm{m}$ and interval sampling of $0.974 \mu \mathrm{m}$, scan speed equal to $5 \mathrm{x}$ and noise limit (valid pixels) of $1 \%$, and distance in " $\mathrm{z}$ " equivalent to $800 \mu \mathrm{m}$.

The measurements by optical profilometer allowed the creation of Gaussian distributions for each of the eight measures. From these Gaussian distributions, assuming a normal distribution, defined by the mean and variance values of each measurement, an equivalent normal curve for each sample was created from the linear combination of the results obtained from these eight measurements. The result is expressed in terms of probability density, which allows the comparison of the equivalent curves for each of the samples. To confirm and understand the equivalent curves found, a variation coefficient was applied for the mortar samples.

The mortar samples were characterized using the FEI Quanta 3D FEG scanning electron microscope (SEM) and the elemental microanalysis by EDAX detector, Genesis version. Mortar samples were sectioned with a dry diamond saw, impregnated in vacuum by epoxy 
resin, and polished with silicon carbide and diamond paste to obtain a smooth surface. A control mortar sample without impregnation was used to compare the surfaces where $\mathrm{TiO}_{2}$ was added. All mortar samples were covered with gold, and an electron backscatter detector was used to contrast the light and heavy elements better. The voltage used was $20 \mathrm{kV}$, and the working distance (WD) was approximately $10 \mathrm{~mm}$.

In order to confirm the P25p and PC105p dispersion on the surfaces of mortar samples, EDS elemental mapping was done. The EDS map was made using a Thermo detector by Noran system (SIX). The images were obtained with a secondary electron detector (SEI) using a JEOL-JSM 6300 scanning electron microscope. Mortar samples were metalized with $\mathrm{Au} / \mathrm{Pd}$ for 120 seconds and fixed on a microscope sample holder at four different points: (i) top layer, corresponding to the exposed surface; (ii) upper layer $(\approx 2 \mathrm{~mm})$; (iii) middle layer $(\approx 50 \mathrm{~mm})$, and; (iv) bottom layer ( $\approx 100 \mathrm{~mm}$ ). An acceleration voltage of $20 \mathrm{kV}$ and magnification of $50 \mathrm{x}$ was used with an image acquisition of approximately 1 hour.

\section{RESULTS}

\subsection{Surface characterization}

\subsubsection{Surface topography (Profilometer)}

Average roughness for each mortar sample is shown in Figure 7 and proves that, despite the same base of composition and same operator being used, the specimens presented different roughness levels, which demonstrates the phenomenon of random roughness resulting from variation in the application process even when produced in similar ways. 
Figure 7. Surface topography of specimens

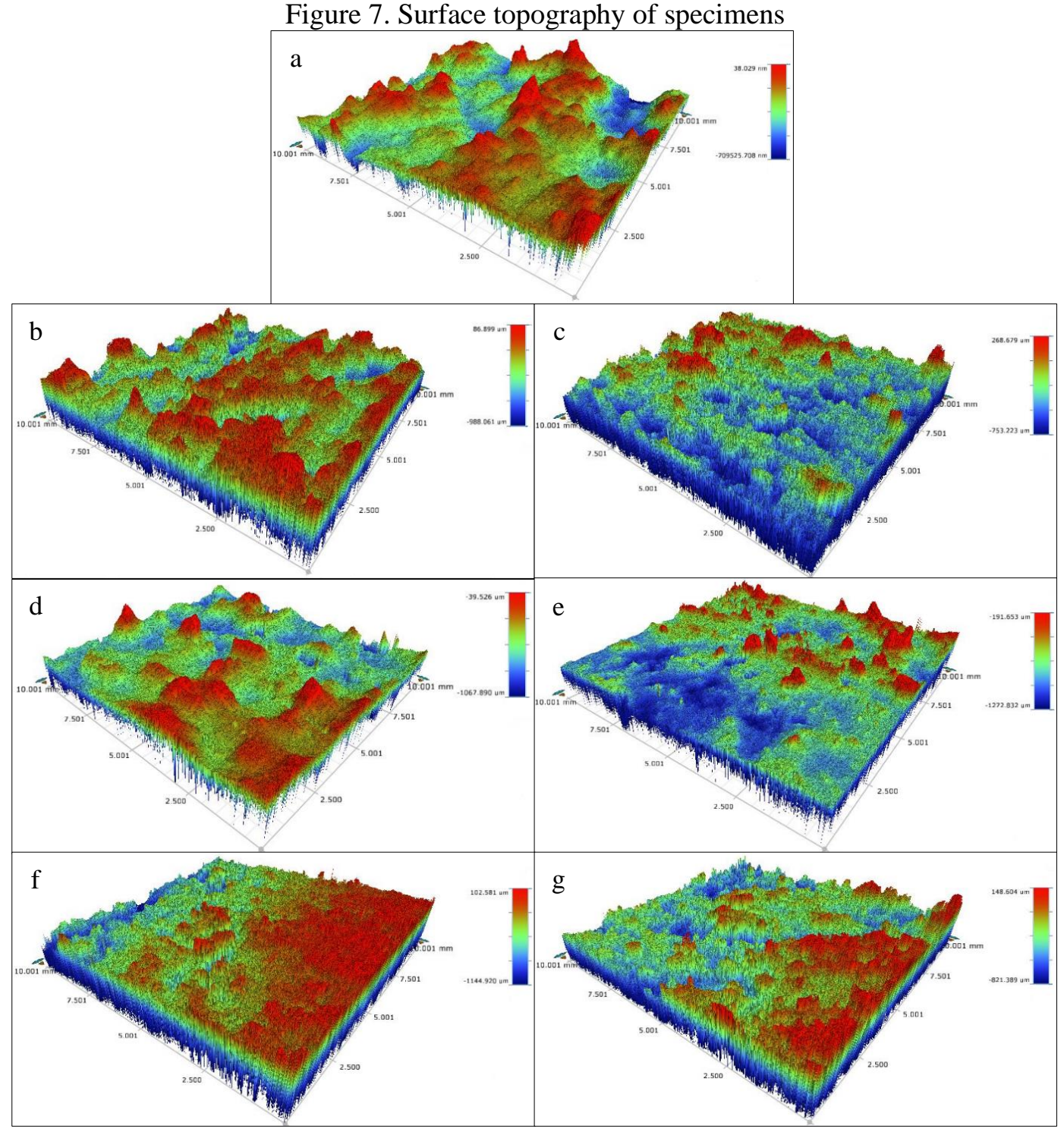

Note: Ref_painted (a); P25p (b); PC105p (c); P25s (d); PC105s (e); PC-S7s (f); E502s (g) Source: Author (2021)

One known roughness model assumes that the roughness profile follows a Gaussian process with some correlation function [16]. However, a surface with exponential correlations may be misrepresented as a surface with Gaussian correlations because of the sampling interval used [22]. Thus, when considering height parameters to define the roughness of mortar samples, although no normality test has been applied, the curves apparently present a normal distribution, as shown in Figure 8. 
Figure 8. Surface normal distribution

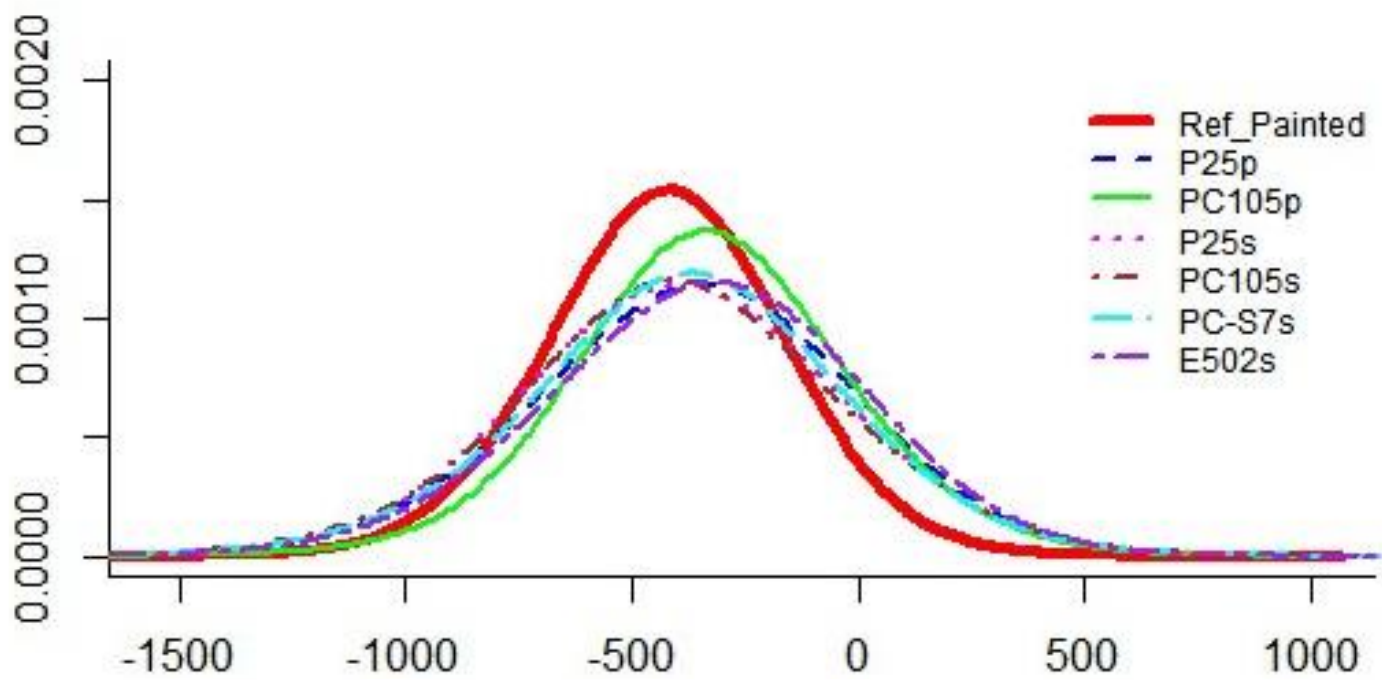

Source: Author (2021)

According to the graph, because of the amplitude (height) of the curves, it is possible to observe that the only specimens with significant roughness differences are Ref_painted and PC105p. On the other hand, the other samples could be considered virtually equal, as shown by the values of the coefficients of variation (CV) in Table 6.

Table 6 -Variation coefficient of mortar samples

\begin{tabular}{lccccccc}
\hline Material & Ref. & P25p & PC105p & P25s & PC105s & PC-S7s & E502s \\
\hline Equivalent average & -397 & -378 & -332 & -380 & -364 & -347 & -343 \\
Equivalent variance & 8012 & 14718 & 10793 & 15067 & 11250 & 13872 & 13858 \\
$\begin{array}{l}\text { Equivalent standard } \\
\text { deviation }\end{array}$ & 90 & 121 & 104 & 123 & 106 & 118 & 118 \\
Coefficient of variation* & $23 \%$ & $32 \%$ & $31 \%$ & $32 \%$ & $29 \%$ & $34 \%$ & $34 \%$ \\
\hline
\end{tabular}

Note: * values are shown in module

Source: Author (2021)

It should be noted that, although the PC105p sample has a higher CV than the PC105s sample when evaluating the standard deviation, it is observed that the PC105p sample has a lower value and, therefore, a curve more closed and higher than the PC105s sample. This is because the PC105s sample has higher averages than the PC105p sample, which leads to a higher standard deviation and consequent lower $\mathrm{CV}$, and it is shown tangled with the other samples in the graph.

Roughness profiles were made using the values for the $\mathrm{X}$-axis of all measurements taken for each mortar sample and represent what could be considered the maximum, medium, and minimum roughness for each specimen at the beginning of the urban environment exposure.

When evaluating the maximum, medium, and minimum roughness, the results demonstrate the differences in amplitudes (peaks and valleys) between all mortar samples. Except for the 
P25p mortar sample, which presented maximum roughness in a positive scale, the other mortar samples showed negative values in their scales, with a great variety of these scales when comparing profiles, which demonstrates the heterogeneity of mortar samples and the randomization process with roughness production, thus hindering the homogenization of the scales when presenting profiles as shown in Figures 9 - 11.

Considering the peak and valley heights shown in the profiles, when applying the amplitude of $-400 \mu \mathrm{m}$ to $400 \mu \mathrm{m}$ in the P25p and PC105p profile mortar sample, for example, a roughness of less than $1 \mathrm{~mm}$ was observed. This scale seems a typical aggregate and impossible for human control with the naked eye. In other words, the operator will not be able to smooth or even equalize something intrinsic to the material, making it impossible to control the surface on these scales.

Similarly, there is a high variation for the spots from the medium roughness of each sample. It is possible to notice great heterogeneity when comparing the spots in the same mortar and much more when compared between the different samples. The micro-roughness found in these spots has a direct relationship with the dispersion of $\mathrm{TiO}_{2}$ added to the mixture, as well as with the deposit of natural pollutants (dirt) on the surfaces of the specimens since they are exposed to the urban environment, which impacts the photodegradation process. 
Figure 9. Roughness profile and spot details
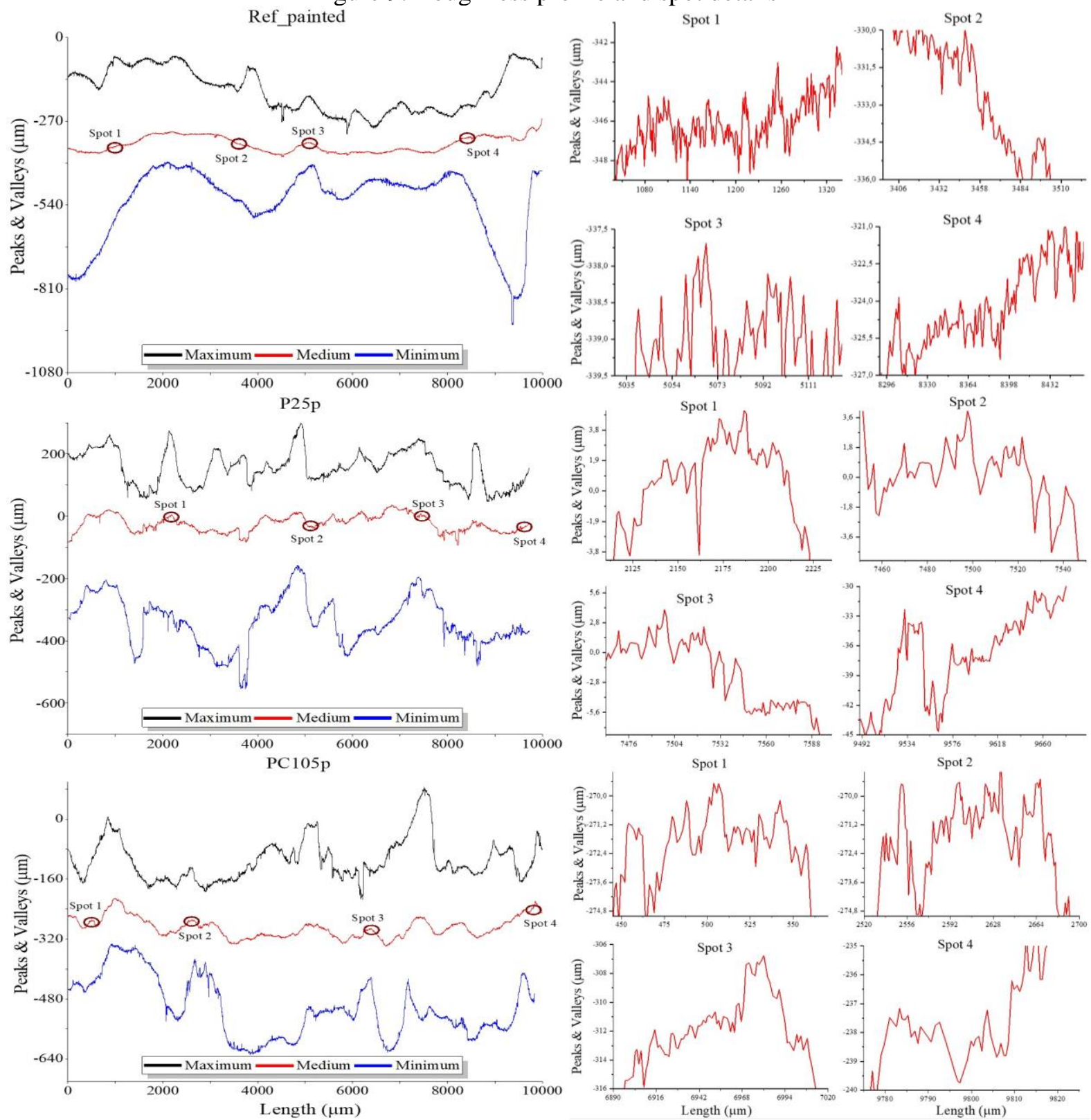

Note: Ref_painted, P25p, and PC105p mortar samples

Source: Author (2021) 
Figure 10. Roughness profile and spot details
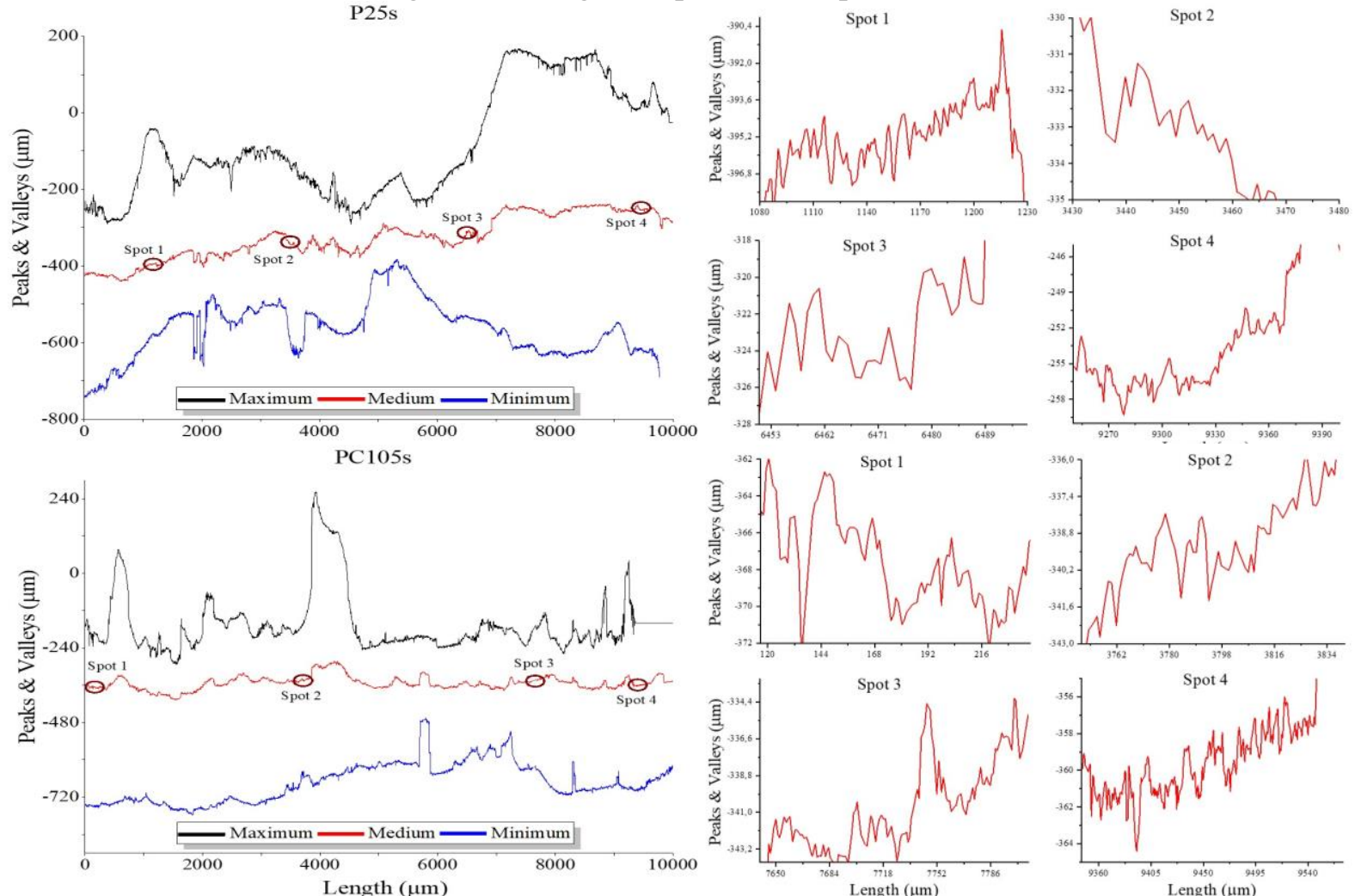

Note: P25s and PC105s mortar samples

Source: Author (2021)

Figure 11. Roughness profile and spot details
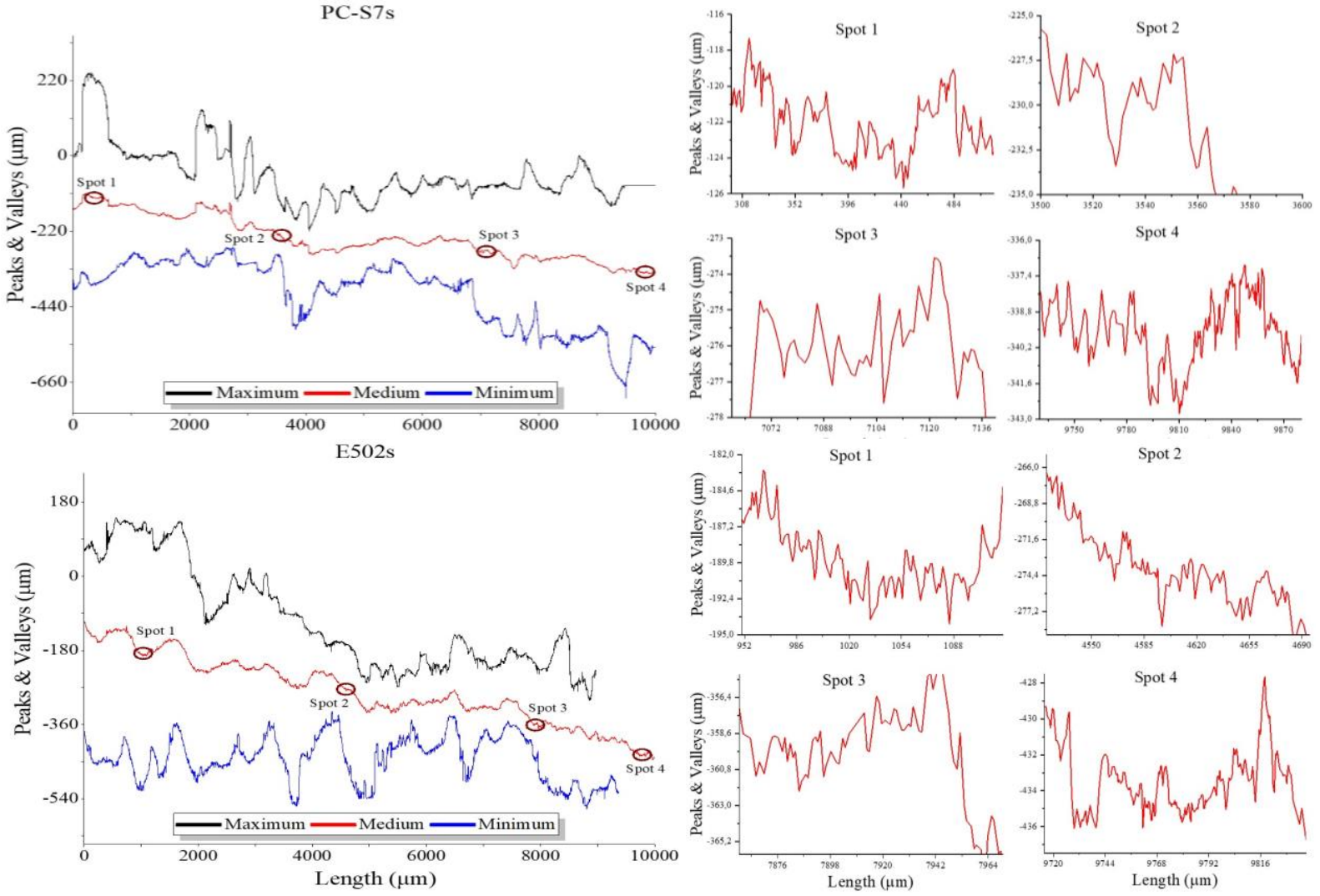

Note: PC-S7s and E502s mortar samples

Source: Author (2021) 


\subsubsection{Scanning Electron Microscopy (SEM)}

Regarding the measurements of each mortar surface by scanning electron microscope, for the P25p and PC105p mortar samples, the roughness measured was of the mortar itself. On the other hand, for the Ref_painted, P25s, PC105s, PC-S7s, and E502s mortar samples, the roughness measured is not from only the mortar but of the film layer caused by painting and by the $\mathrm{TiO}_{2}$ suspension applied. The amplitude measurements in these profiles indicate the passage of the profilometer once on the film and once on the mortar, which shows the noncontinuity of the film layer and the micro-roughness of the mortar and the film layer, respectively.

Moreover, the scanning electron microscope observations show that for Ref_painted, P25s, PC105s, PC-S7s, and E502s mortar samples, a film layer was formed, although not continuous as expected, which shows flawed spots on the film's layers, as indicated by points (1) and (2) in the images. The other pictures allow the observation at other scales to better understand the formation of a film layer in these surfaces, as shown in Figures 12 -14.

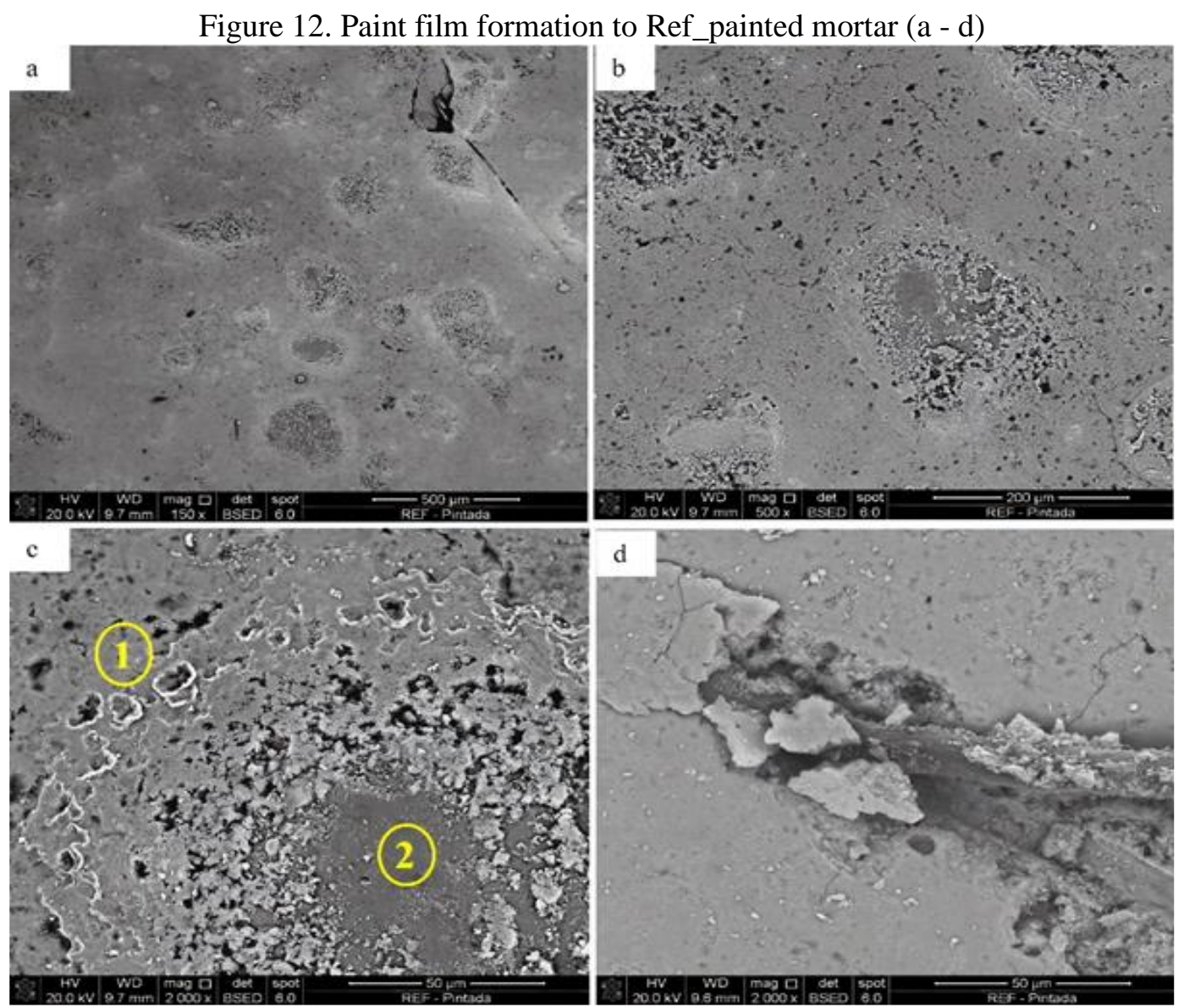

Note: At $500 \mu \mathrm{m}$ scale (a); At $200 \mu \mathrm{m}$ scale (b); At $50 \mu \mathrm{m}$ (1c); Paint film flawed spot at $50 \mu \mathrm{m}$ (2c); Polypropylene microfibers at $50 \mu \mathrm{m}$ scale (d).

Source: Author (2021) 
Figure 13. Formation of $\mathrm{TiO}_{2}$ film to P25s mortar (a - d); PC105s mortar $(\mathrm{e}-\mathrm{h})$
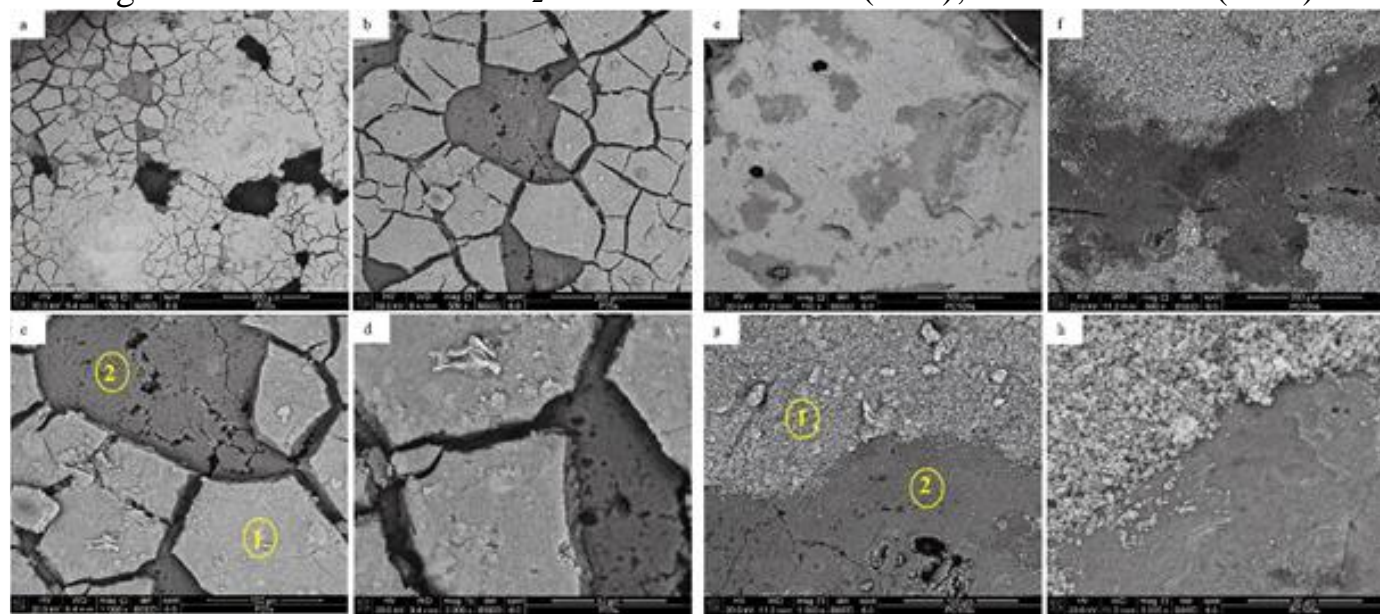

Note: At $500 \mu \mathrm{m}$ scale (a, e); At $200 \mu \mathrm{m}$ scale (b, f); At $100 \mu \mathrm{m}(1 \mathrm{c} ; 1 \mathrm{~g}) ; \mathrm{TiO}_{2}$ film flawed spot at 100 $\mu \mathrm{m}(2 \mathrm{c}, 2 \mathrm{~g}) ;$ At $50 \mu \mathrm{m}(\mathrm{d}) ;$ At $20 \mu \mathrm{m}(\mathrm{h})$.

Source: Author (2021)

Figure 14. Formation of $\mathrm{TiO}_{2}$ film to PC-S7s mortar (a - d); E502s mortar (e - h)
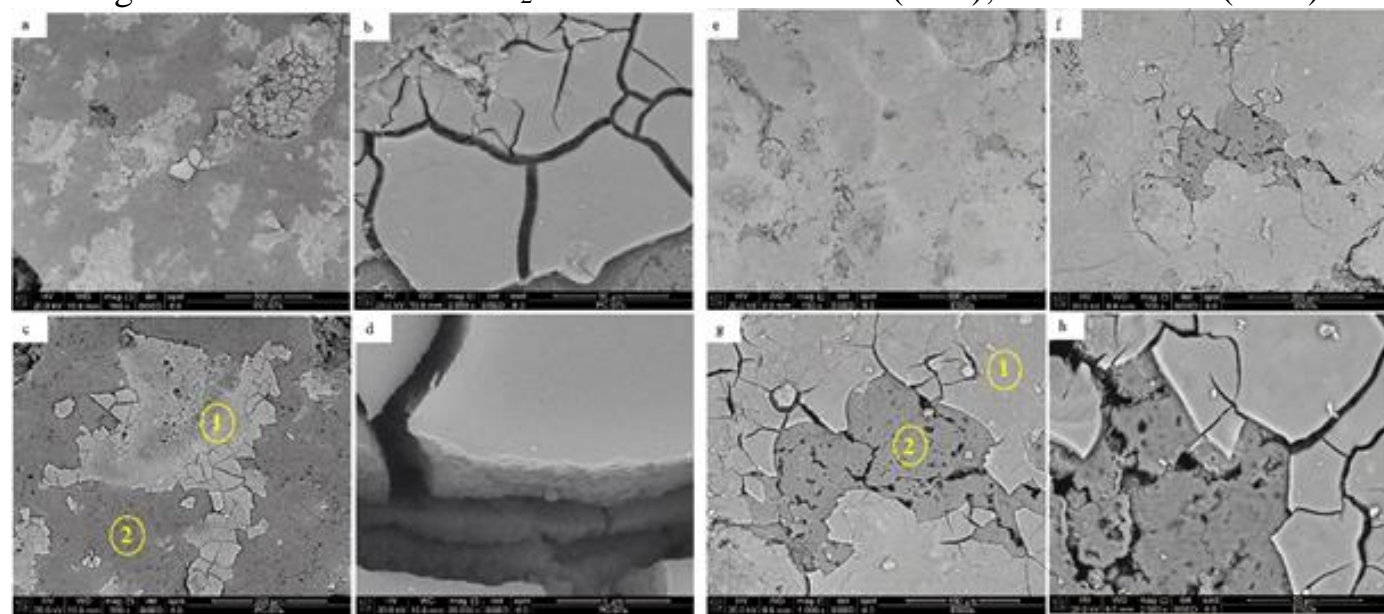

Note: At $500 \mu \mathrm{m}$ scale (a, e); At $200 \mu \mathrm{m}$ scale (f); At $200 \mu \mathrm{m}$ (1c); $\mathrm{TiO}_{2}$ film flawed spot at $200 \mu \mathrm{m}$ (2c); At $100 \mu \mathrm{m}(1 \mathrm{~g})$; $\mathrm{TiO}_{2}$ film flawed spot in $100 \mu \mathrm{m}(2 \mathrm{~g})$; At $50 \mu \mathrm{m}(\mathrm{b}, \mathrm{h})$; At $5 \mu \mathrm{m}(\mathrm{d})$.

Source: Author (2021)

Microscopic images demonstrate that in none of the surfaces where $\mathrm{TiO}_{2}$ suspensions have applied, the formation of a complete film layer could be observed, and the E502s suspension had the most homogeneous film layer, as can be seen in images 14e and 14f. All suspensions followed an application pattern recommended and specified by the manufacturer in spray mode. However, it is important to remember that the incomplete film layer formation considerably influences the photocatalysis process since failures in their formations will not provide the correct activation of $\mathrm{TiO}_{2}$.

Regarding the P25p and PC105p mortar samples, particle morphology could be observed added to the mixture from the microscopy images. Despite that, when evaluating the dispersion of $\mathrm{TiO}_{2}$ powder, the images did not identify good dispersion of $\mathrm{TiO}_{2}$ as it presented 
a large space between particles, which could be evaluated as the absence of $\mathrm{TiO}_{2}$ on the surface of mortar samples. Particle morphology and mortar surfaces are identified by numbers (1) and (2), respectively. Other images allow the observation of particle morphology and dispersion at different scales, which brings a greater understanding of the dispersion of $\mathrm{TiO}_{2}$ in these surfaces, as shown in Figure 15.

Figure 15. $\mathrm{TiO}_{2}$ particle dispersion to P25p mortar (a - d); PC105p mortar $(\mathrm{e}-\mathrm{h})$
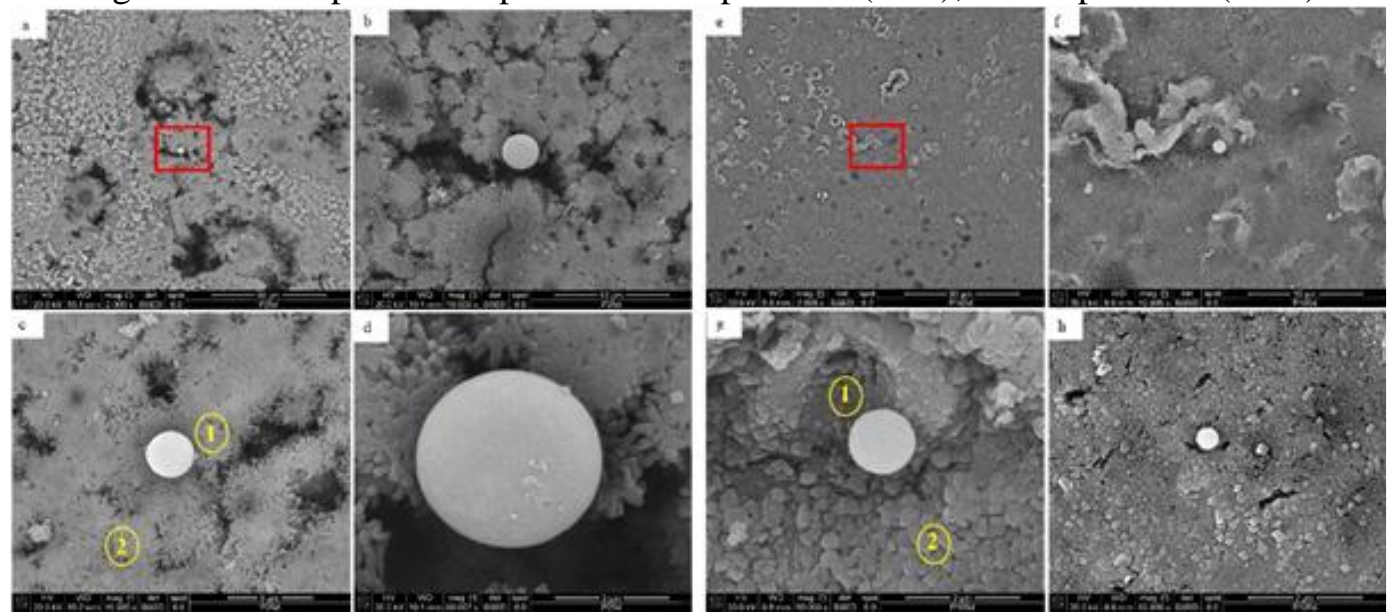

Note: At $50 \mu \mathrm{m}$ scale (a, e); At $10 \mu \mathrm{m}$ scale (b, f); Morphology of $\mathrm{TiO}_{2}$ at $5 \mu \mathrm{m}$ scale (1c); Mortar surface at $5 \mu \mathrm{m}(2 \mathrm{c}) ;$ ); Morphology of $\mathrm{TiO}_{2}$ at $2 \mu \mathrm{m}$ scale (1g); Mortar surface at $2 \mu \mathrm{m}(2 \mathrm{~g})$; Morphology of $\mathrm{TiO}_{2}$ at $2 \mu \mathrm{m}$ scale $(\mathrm{d}, \mathrm{h})$

Source: Author (2021)

\subsubsection{Elemental mapping (EDS)}

Despite the results found with electron microscopy, elemental mapping showed a higher P25p and PC105p concentration in the surface of mortar samples, as well as their distribution in lower layers, as shown in Figure 16.

The mortar samples exhibit practically the same amount of $\mathrm{TiO}_{2}$ in the top layer. However, PC105p presented more agglomeration areas, which was already expected considering the dimensions of its particles. Dispersion difference only begins to appear from the upper layer. The P25p sample reveals a high drop in the amount of particles in the upper layer, from 105 to $20 \mathrm{~K}$, as shown in Figure $16(\mathrm{a}-\mathrm{b})$, and the amount of particles remained practically the same in the middle and bottom layers, 26-27 K, as shown in Figure 16 (c - d). On the other hand, PC105p reveals a low drop in the amount of the particles in the upper layer, from 116 to $64 \mathrm{~K}$, as shown in Figure $16(\mathrm{e}-\mathrm{f})$, and the amount of particles remained practically the same in the middle and bottom layers, 19-21 K, as shown in Figure 16 ( $\mathrm{g}-\mathrm{h}$ ).

Another point is the dispersion of $\mathrm{TiO}_{2}$ in the deep layers of mortar. Despite the decreased number of counts $(\mathrm{K}), \mathrm{P} 25 \mathrm{p}$ seems to maintain the same distribution, while the dispersion 
seems to change in PC105p probably because the particles are more distant and, therefore, less likely to agglomerate in a smaller quantity.

These results highlight the dispersion of $\mathrm{TiO}_{2}$ in mortar surfaces and also the possibility of natural replacement of the photocatalytic layer during the process of surface wear. In other words, as the top layer undergoes during the process of natural wear, it can be automatically replaced by the upper layer just below it, which has the same photocatalytic properties that make it a better performance surface.

Figure 16. Dispersion of $\mathrm{TiO}_{2}$ in surfaces to P25p mortar (a - d); PC105p mortar $(e-h)$
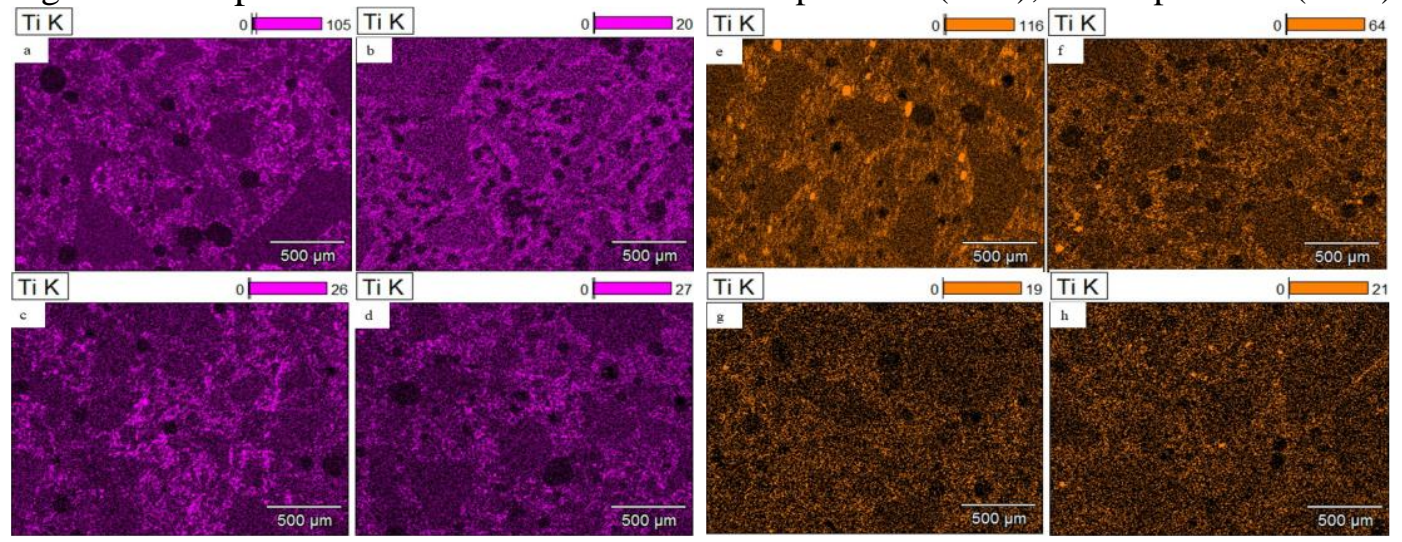

Note: Top layer (a); upper layer (b); middle layer (c); bottom layer (d). The colors are used to better differentiate between the two $\mathrm{TiO}_{2}$.

Source: Author (2021)

\section{DISCUSSION}

\subsection{Dispersion of $\mathrm{TiO}_{2}$ on the surface}

Considering the micro-roughness scale, it is possible to think that a perfect dispersion of $\mathrm{TiO}_{2}$ promotes a complete and homogeneous distribution of $\mathrm{TiO}_{2}$ over the entire surface. This layer would provide a full activation of $\mathrm{TiO}_{2}$ and greater system efficiency regarding photocatalytic activity.

This concept was considered in the roughness of mortar samples, which would create the idea about coverage representing a homogeneous distribution of $\mathrm{TiO}_{2}$ as a functional cake cover, something that would seem like a film by the UV radiation, but which is a magnetic network in the nano- and microscales. Therefore, considering an excellent dispersion in measured roughness, the red line in the surface of the PC105p and P25s mortar samples would be the representation of the cake cover to be found, since it is about a measured roughness, in other words, real surfaces, as shown in Figures 17 and 18. 
Figure 17. Example of cake cover in the measured micro-roughness of the mortar sample with addition of $\mathrm{TiO}_{2}$

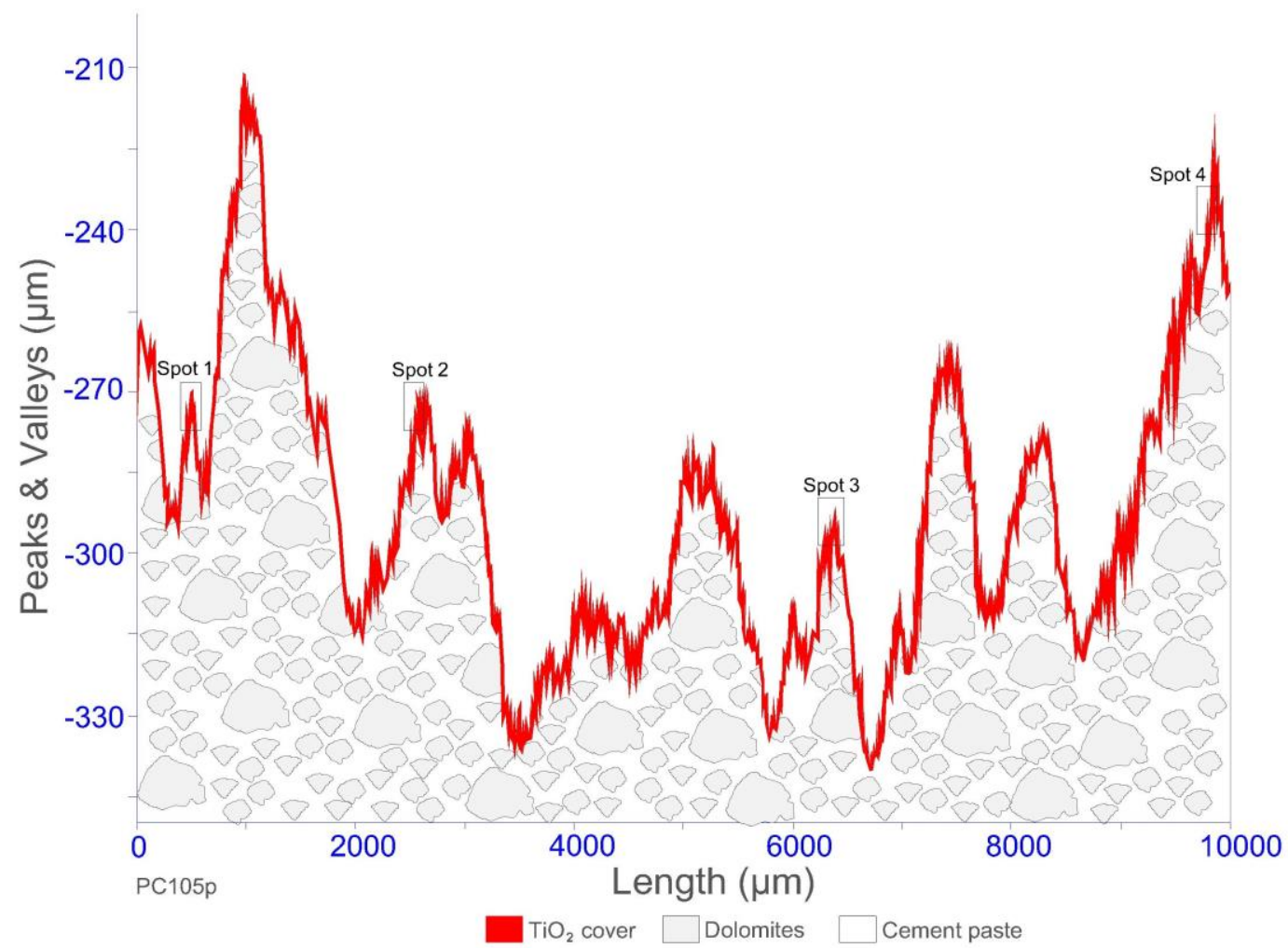

Source: Author (2021)

Figure 18. Example of cake cover in the measured micro-roughness of the mortar sample with suspension of $\mathrm{TiO}_{2}$

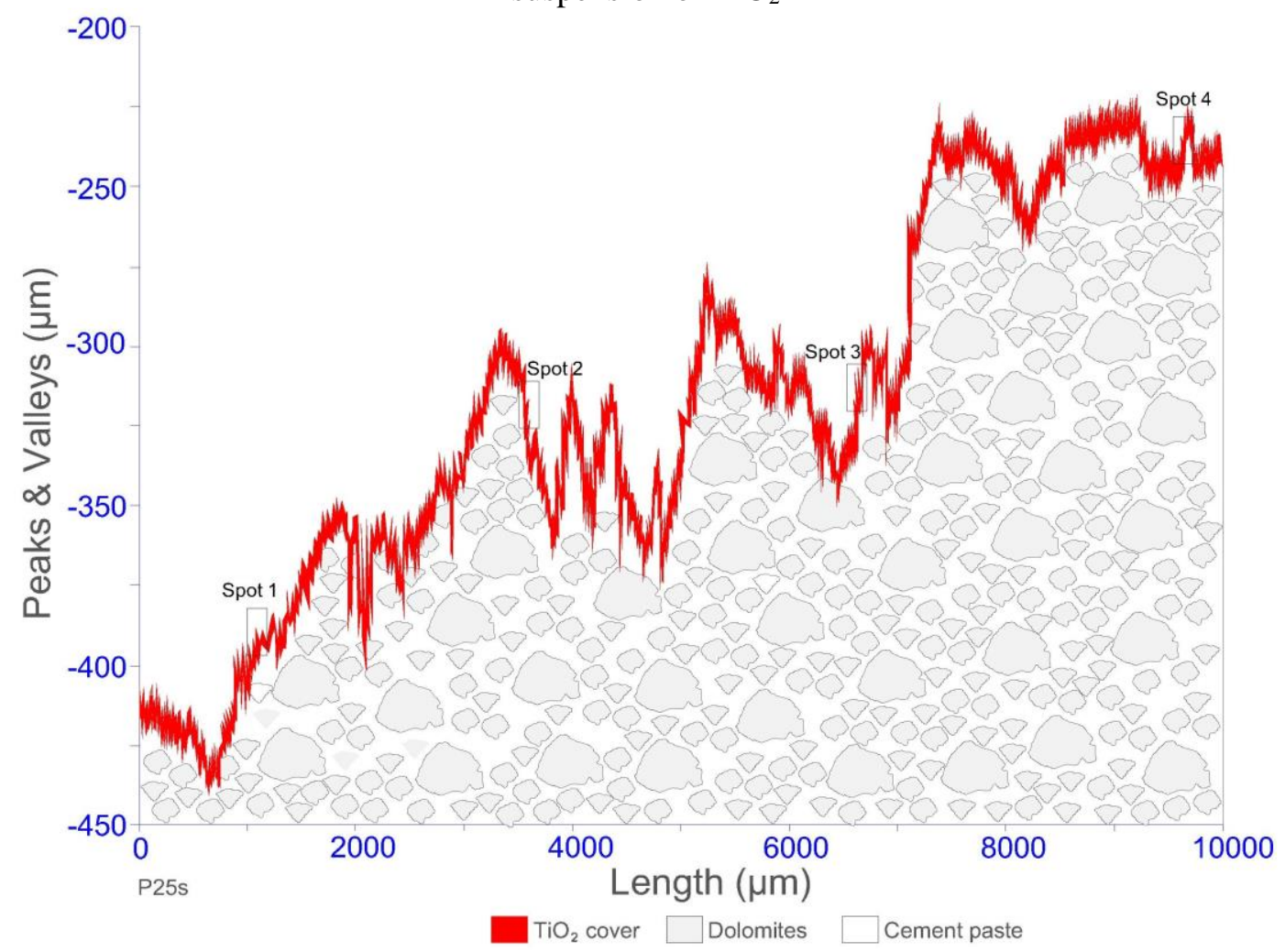

Source: Author (2021) 
Surface evaluation on the degradation of atmospheric pollutants, considering that the cake cover coats this surface, leads to a scenario, at first, that the surface is entirely covered by $\mathrm{TiO}_{2}$ particles and pollution particles (PM10) above them. In a favorable situation, $\mathrm{TiO}_{2}$ breaks the contact angles of PM10, and these particles can be carried away in the presence of rain, which provides the self-cleaning process.

However, not being a situation that can be guaranteed, some aspects could be considered: (i) $\mathrm{TiO}_{2}$ will not be able to degrade the dirt deposited on the mortar with the same speed as the deposition, in other words, PM10 particles will deposit faster than $\mathrm{TiO}_{2}$ can degrade them; (ii) if the smaller PM10 particle is deposited in the valleys, it would not be able to be carried away by the rain as other larger particles would cover it, and; (iii) considering the roughness, if there are $\mathrm{TiO}_{2}$ particles deposited in the valleys and covered by PM10 particles, UV rays cannot reach these $\mathrm{TiO}_{2}$ particles, and therefore, activate them.

Starting from this last hypothesis and observing all particle sizes involved in the process (PM $=10 \mu \mathrm{m}$ and $\mathrm{TiO}_{2}=0.1 \mu \mathrm{m}$ to $9 \mu \mathrm{m}$ [d50]), this makes it quite evident that PM10 particles easily cover all $\mathrm{TiO}_{2}$ particles, as well as the surface where they are deposited, thus creating a layer and preventing the activation of $\mathrm{TiO}_{2}$. Hence, when thinking about the dispersion of $\mathrm{TiO}_{2}$ particles over micro-roughness, it is also necessary to think about the distribution of pollution particles on this same surface, which will use different roughness as an adhesion point.

Thereby, when considering the average diameters of the $\mathrm{TiO}_{2}$ particles used in this study, as well as the characteristic diameter of the PM10 particles applied to the surfaces measured from the profilometer, it was possible to draw a probable dispersion for these particles in such surfaces. Thus, when evaluating the specific points of the average roughness of PC105p (d50 $=1.5 \mu \mathrm{m})$ and $\mathrm{P} 25 \mathrm{~s}(\mathrm{~d} 50=3.90 \mu \mathrm{m})$ mortar, a probable dispersion of $\mathrm{TiO}_{2}$ and $\mathrm{PM} 10$ particles $(10 \mu \mathrm{m})$ is considered in each surface, which leads to a direct impact in the photodegradation of this pollutant with the non-activation of $\mathrm{TiO}_{2}$ particles from their covering by PM10 particles, as shown in Figures 19 and 20.

Therefore, in a micrometric scale, where the light interacts with the surface and define light reflections, considering the existing micro-roughness, there would certainly be difficulties in the homogeneous activation of $\mathrm{TiO}_{2}$ in surfaces, which would require, first, a partial PM10 degradation in the top layer that would allow the passage of UV rays to activate bottom $\mathrm{TiO}_{2}$ particles and consequently a higher PM10 degradation. 
Figure 19. Example of possible dispersion of $\mathrm{TiO}_{2}(\mathrm{~d} 50=1.5 \mu \mathrm{m})$ and PM10 $(10 \mu \mathrm{m})$ in measured micro-roughness of the mortar sample with the addition of $\mathrm{TiO}_{2}$

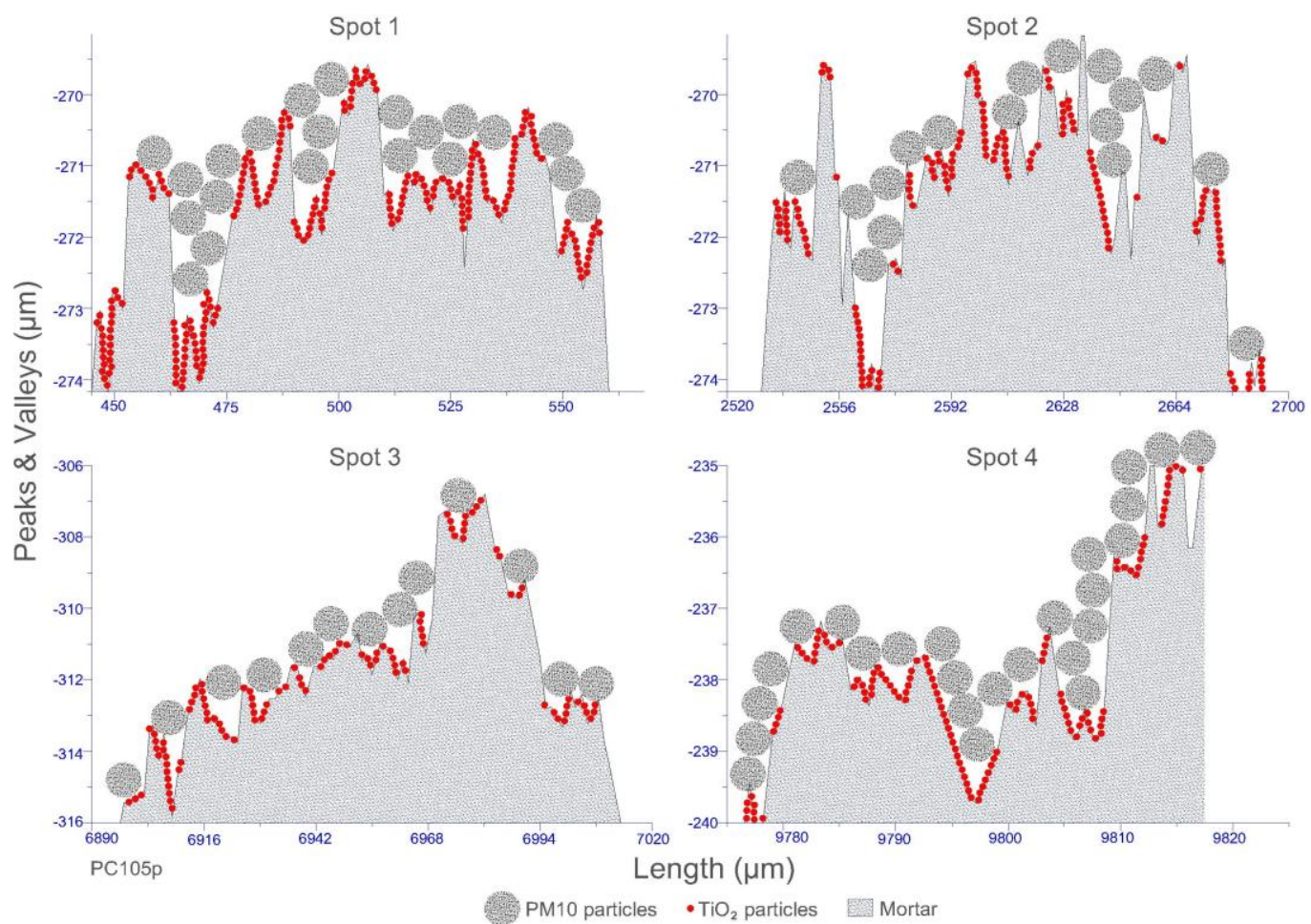

Source: Author (2021)

Figure 20. Example of possible dispersion of $\mathrm{TiO}_{2}\left(\mathrm{~d}_{50}=3.90 \mu \mathrm{m}\right)$ and PM10 $(10 \mu \mathrm{m})$ in measured micro-roughness of the mortar sample with the suspension of $\mathrm{TiO}_{2}$

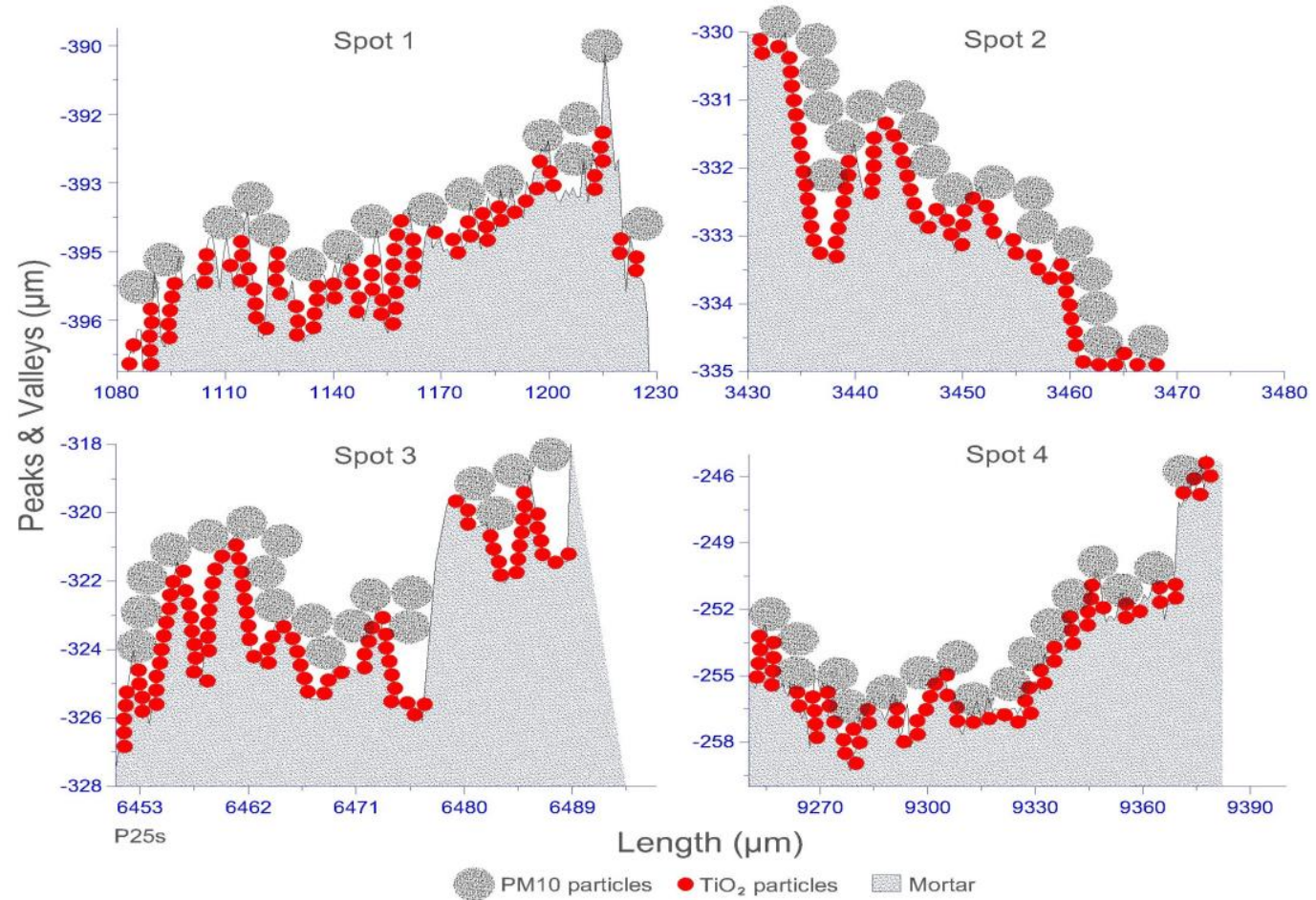

Source: Author (2021) 


\subsection{Agglomerated or dispersed $\mathrm{TiO}_{2}$ ?}

In general, the literature assumes that the more dispersed the particles, the better the effect of $\mathrm{TiO}_{2}$. However, it is important to point out some items about this dispersion, and what scale limit should be considered. Thinking about several nearby agglomeration points so that some clusters of $\mathrm{TiO}_{2}$ can be present in different positions, thus making the whole process more effective, may not be a problem. The presence of different, close enough, cluster sizes of $\mathrm{TiO}_{2}$ so that when one of these spots finishes working, there is still another one to receive the wavelength and start the activation again can make the system even more effective.

Considering the concept of a pixelated network, each pixel would be a cluster of $\mathrm{TiO}_{2}$ connected by a $\mathrm{TiO}_{2}$ wire forming a magnetic mesh so that the wavelength reached each pixel ( $\mathrm{TiO}_{2}$ cluster) and made the network swing. The wavelength can be imagined as a ball, and the $\mathrm{TiO}_{2}$, with various particle sizes, forming a network that holds this ball, as shown in Figure $21(\mathrm{a}, \mathrm{b})$. If the net is punctured or fragmented, the ball will pass through the hole without touching (vibration), and therefore, without activating the net, as shown in Figure 21 (c, d).

The focus should not be on whether the network is composed of nano- or microparticles but on the composition between all these scales creating connections, in which smaller particles, with higher surface area and therefore more likely to agglomerate, would be used as clusters, while larger particles, with smaller surface area and easier dispersion, would be used as the wires that would provide the connections between clusters, thus contributing to the better formation of the functional cake cover and activation of $\mathrm{TiO}_{2}$ particles.

A study performed by Suh et al. [23], through the elemental mapping of Ti using EDX in SEM images of $\mathrm{TiO}_{2} / \mathrm{CO}_{3}-\mathrm{LDH}$, has revealed that the distribution of $\mathrm{TiO}_{2}$ based on $\mathrm{CO}_{3}-\mathrm{LDH}$ is in the aggregate form. The scale seen in the author's research indicates clusters of $\mathrm{TiO}_{2}$ up to $700 \mathrm{~nm}$. Thus, for the nanoscale network proposed, $\mathrm{TiO}_{2}$ needs to present an agglomeration as naturally observed by the authors, which would not be challenging given the various particle sizes sold in the market and which would allow UV radiation to activate all the different $\mathrm{TiO}_{2}$ particles present in the system.

Dantas, Vittorino, and Loh [20] have observed the formation of clusters of $\mathrm{TiO}_{2}$ in whiter areas in the surface of mortar specimens, which suggests that they were more active and that the $\mathrm{TiO}_{2}$ present in the other areas of the mortar was not so effective probably because these 
areas were entirely covered by pollution particles and not activated. Therefore, the dirt particle did not degrade, and the specimens had no self-cleaning.

Figure 21. Example of $\mathrm{TiO}_{2}$ pixelated network forming a magnetic mesh

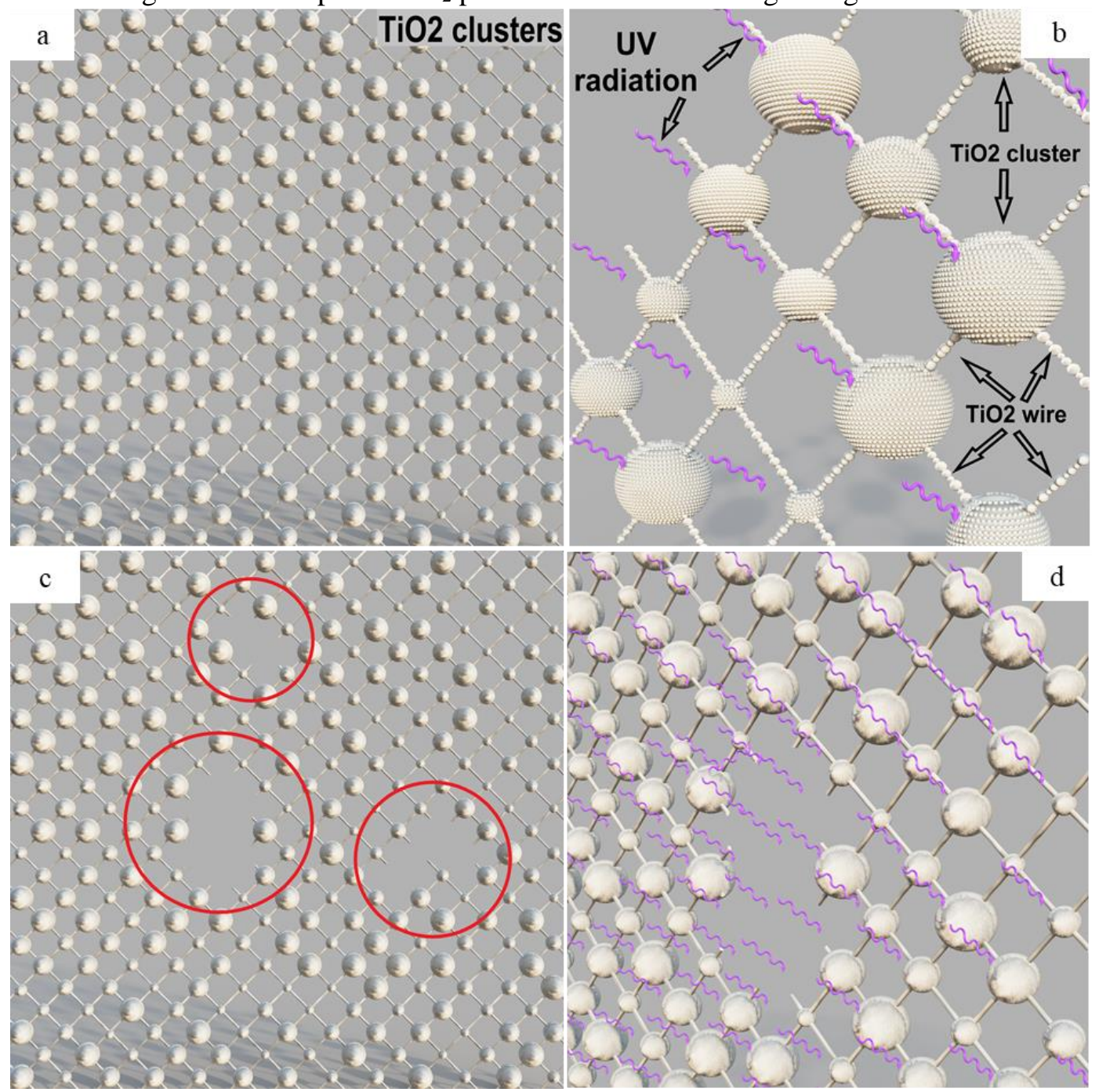

Source: Author (2021)

As a result, taking into account that the issue of network formation and dispersion is a function of the distribution of the particle size of $\mathrm{TiO}_{2}$ in a dry state before being added, the use of $\mathrm{TiO}_{2}$ powder could be an alternative if this product presents a large distribution of particle sizes of $\mathrm{TiO}_{2}$, which would provide greater chances in the network's formation with no particle size having high predominance in a restrict distribution range. Thereby, the concept of interparticle separation (IPS) for $\mathrm{TiO}_{2}$ becomes a topic to be observed as the dimensions of particles are helpful to understand whether they would allow the formation of cake cover. 


\subsection{UV radiation light and $\mathrm{TiO}_{2}$ particles}

Reflectance measurement processes allow the observation of the activation of $\mathrm{TiO}_{2}$ when the angle of UV light incidence occurs directly on surfaces. However, in this condition, the micro- and nano-roughness of the surface can have a shading effect on $\mathrm{TiO}_{2}$ particles and therefore impair the total activation of $\mathrm{TiO}_{2}$.

Considering macro-roughness, light reflection can be better understood and worked. However, at the nano- and micro-roughness levels, which need further studies, the direction of light reflection changes greatly and can difficult the activation of $\mathrm{TiO}_{2}$. Parkins ([24,] apud [15]) also includes a reflection coefficient that depends on the surface inclination. Close together points on the surface give rise to the diffuse signal, while points on the surface contribute to the specular signal.

Solar energy distribution between direct and diffuse radiation is necessary for the activation of $\mathrm{TiO}_{2}$. If direct radiation could cause higher activation of $\mathrm{TiO}_{2}$ due to more energy, it is necessary to think that because of the existence of nano- and micro-roughness, there is the effect of micro-shading of the $\mathrm{TiO}_{2}$ particles according to the sun path, as well as the irradiation of the surface only for a few hours of the day. On the other hand, despite the lower energy, diffuse radiation can irradiate the surface for many hours and still eliminate the effect of micro-shading since it will radiate on the surface from all sides.

In other words, the existence of an extremely rough surface, in addition to causing a high index of micro-shading due to peaks and valleys, allows great dirt adhesion. Under this condition, diffuse radiation plays a fundamental role in the activation of $\mathrm{TiO}_{2}$, as it allows valleys to be unaffected by the shadows of the peaks since diffuse radiation would come from anywhere. Therefore, the question to be answered is whether diffuse radiation has enough energy to enable the activation of $\mathrm{TiO}_{2}$ when the numerous surface interactions are considered.

The relationship between direct and diffuse solar radiation is variable throughout the day, and in the first hours of the day, this relationship is almost $1 / 1$. Whereas UV is a small fraction of this ratio, the radiation rate used by $\mathrm{TiO}_{2}$ in photocatalytic processes should be considered. The $\mathrm{TiO}_{2}$ absorbs radiation in the UV range of 315 - $380 \mathrm{~nm}$, and the anatase crystalline phase has a range of $3.2 \mathrm{eV}$ corresponding to a wavelength of approximately $380 \mathrm{~nm}$, while the rutile crystalline phase has a range of $3.0 \mathrm{eV}$, which corresponds to a wavelength of $413 \mathrm{~nm}$ [25]. 
Although radiation with a wavelength below $380 \mathrm{~nm}$ can excite the electrons of the valence band $(\mathrm{BV})$ to the conduction band $(\mathrm{BC})$ of the material, the $\mathrm{TiO}_{2}$ that has a more extensive commercial application absorbs in the UV range only approximately $3 \%-5 \%$ of the solar energy that reaches the terrestrial surface. This way, $\mathrm{TiO}_{2}$ does not take advantage of all the solar radiation incidents in the photocatalytic processes [25-27].

Considering that at noon in São Paulo (Brazil), the total solar radiation is $\approx \mathbf{1 . 8} \times \mathbf{1 0}^{\mathbf{2 5}} \mathbf{e V}$, it is known that only $5 \%$ of this amount corresponds to the UV required in the activation of $\mathrm{TiO}_{2}$, therefore the energy of $\approx \mathbf{9 . 0} \times \mathbf{1 0}^{\mathbf{2 3}} \mathbf{e V}$. Taking the lowest absorption rate of $\mathrm{TiO} 2(3 \%)$ as a

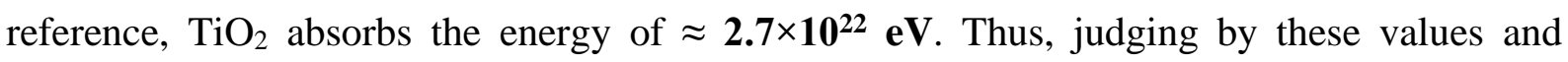
considering that the activation energy of $\mathrm{TiO}_{2}$ is in the order of a few eV $(3.0 \mathrm{eV}$ and $3.2 \mathrm{eV})$, it is possible to perceive that the diffused solar radiation energy in the early hours of the day will be enough to promote the activation of $\mathrm{TiO}_{2}$, which makes diffuse radiation, in these cases, as or more important than direct radiation, since regardless of the surface roughness, it will allow the activation of $\mathrm{TiO}_{2}$ for long periods of the day, as shown in Figures 22 and 23, if the $\mathrm{TiO}_{2}$ particles are not shaded by pollution particles, as shown in Figures 19 and 20.

Figure 22. Example of activation of cake cover by UV radiation on the measured micro-roughness of the mortar sample with addition of $\mathrm{TiO}_{2}$

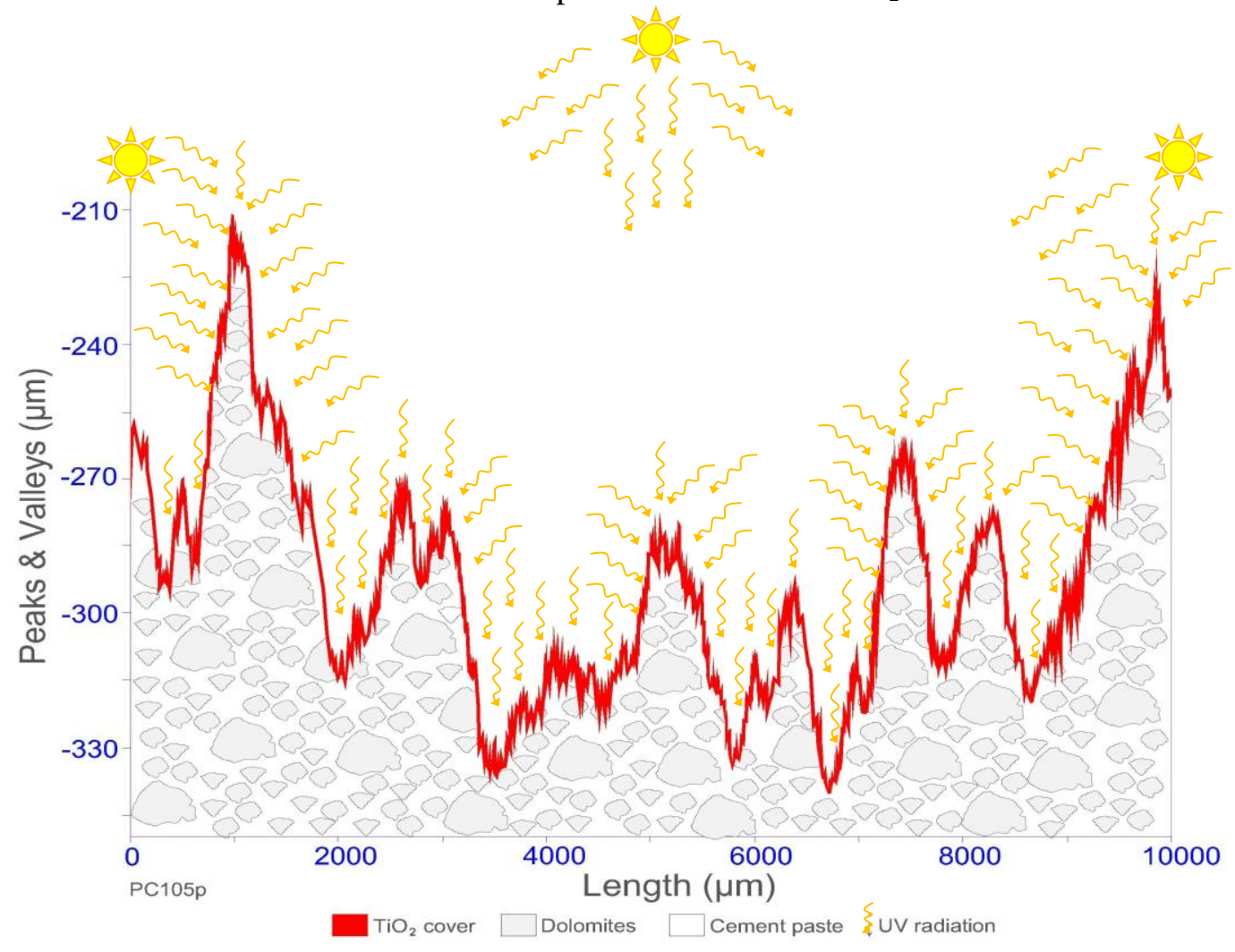

Source: Author (2021) 
Figure 23. Example of activation of cake cover by UV radiation on the measured micro-roughness of the mortar sample with suspension of $\mathrm{TiO}_{2}$

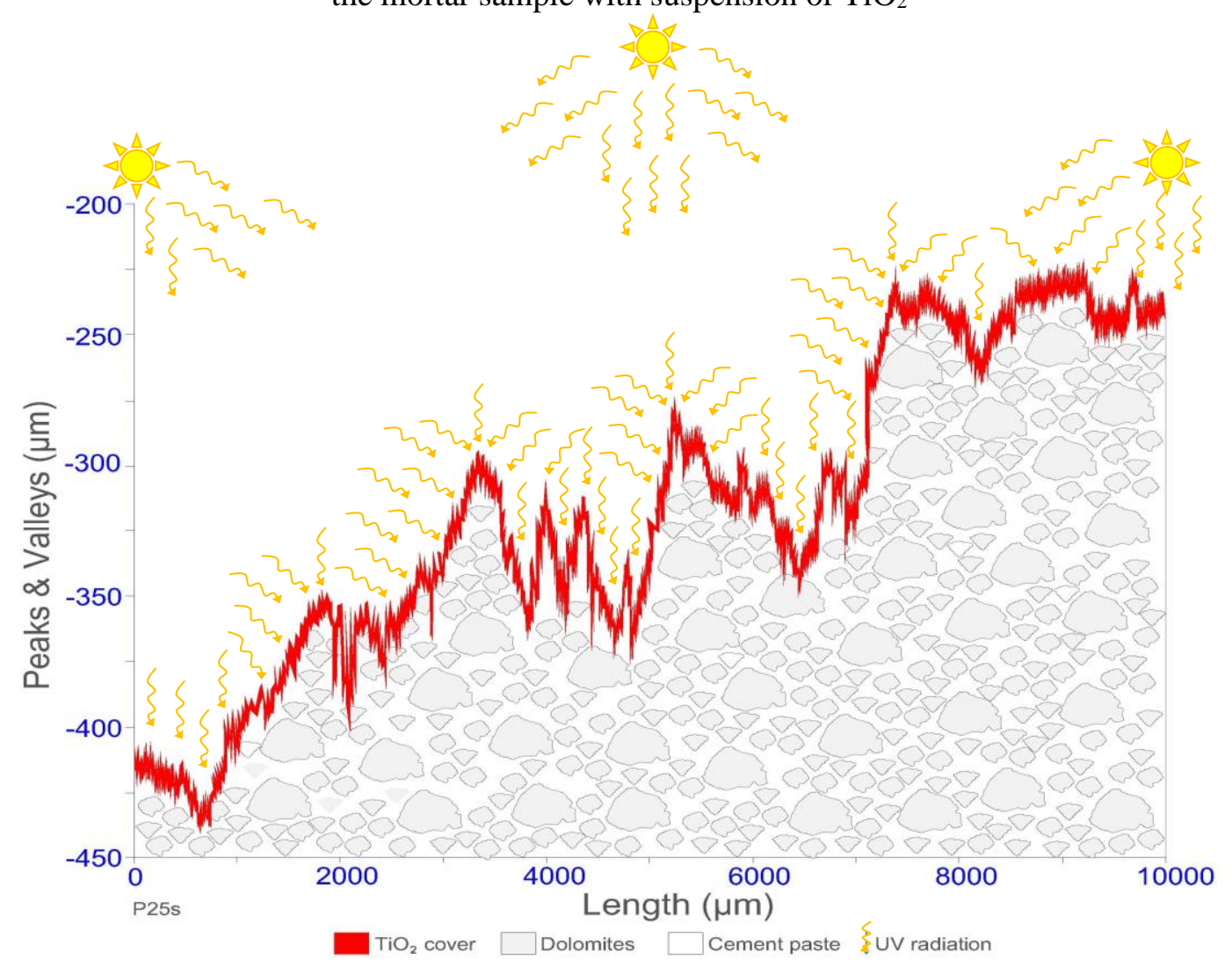

Source: Author (2021)

As with many theories for the interaction of waves with rough surfaces, it is assumed that any part of the incident beam interacts only once with the surface before being spread. However, even if there is a finite possibility that for certain directions of the energy of the scattered waves, a second interaction or additional interactions with the surface may occur, this will not interfere in the activation of $\mathrm{TiO}_{2}$, as, given the energy needed for the activation of $\mathrm{TiO}_{2}$, the numerous light interactions will not cause any damage to its activation, regardless of $\mathrm{TiO}_{2}$ treatments added or applied as a suspension.

Consequently, it is still necessary to consider that in both $\mathrm{TiO}_{2}$ treatments, added or applied as a suspension, pollution particles can shade the $\mathrm{TiO}_{2}$ particles at the valleys and limit their activation. Thus, for the activation of $\mathrm{TiO}_{2}$ and its effectiveness in the photocatalytic process in rough surfaces, it is necessary to investigate the interaction of $\mathrm{TiO}_{2}$ in the nano- and micrometric scales and its dispersion process in these surfaces. Moreover, the effect of solar radiation incident beam must be considered in these particles and surfaces. Then, the largest number of active particles on the surface must be obtained to improve the system's efficiency. 
A practical approach that could be evaluated by the building industry, whether with the use of $\mathrm{TiO}_{2}$ in powder or suspension, would be the care with the $\mathrm{TiO}_{2}$ mixture when added to the cementitious matrix, providing better dispersion of the compound. Regarding the suspension care, the production and finishing surface is essential to achieve a good covering and thus allowing a greater activation and maintenance of the photocatalytic activity over time.

\section{CONCLUSIONS AND REMARKS}

This study describes an approach for evaluating how the microscale roughness affects the distribution of $\mathrm{TiO}_{2}$ and contributes to the adhesion of pollution particles, which affects the activation of $\mathrm{TiO}_{2}$ by solar radiation. The main findings can be summarized as follows:

Activation of $\mathrm{TiO}_{2}$ is not limited only to direct solar radiation, with diffuse solar radiation being as or more important because of the longer surface irradiation time;

$>$ Micro-roughness has no direct relationship with the activation of $\mathrm{TiO}_{2}$. However, it can supply a higher adhesion to dirt and prevent the activation of $\mathrm{TiO}_{2}$.

$>$ The presence of different roughness scales and the use of the same $\mathrm{TiO}_{2}$ particle size affect the process of dispersion of $\mathrm{TiO}_{2}$ in surfaces;

$>$ Different $\mathrm{TiO}_{2}$ particle sizes can help in the formation of the $\mathrm{TiO}_{2}$ pixelated network and enhance its activation, thus providing a better system efficiency;

$>$ The use of suspension of $\mathrm{TiO}_{2}$ does not guarantee better effectiveness, since the formation of an imperfect film layer in the surface, caused by a deficient application or the characteristics of the $\mathrm{TiO}_{2}$ particles used, reduces UV radiation and consequently system efficiency;

The outcomes highlighted how the microscale roughness could not be considered advantageous when exploited in relation to the adhesion to dirt and, consequence, the nonactivation of $\mathrm{TiO}_{2}$ by solar radiation. Thus, considering that in the angstrom and nano-scales, different interaction mechanisms are involved in tribological processes [16], the possibility of tribological processes impacting the dispersion of $\mathrm{TiO}_{2}$ particles should be studied, as well as their influence on the self-cleaning process.

Tribology is a nanoscale issue that can affect the agglomeration of $\mathrm{TiO}_{2}$; this agglomeration is causally linked to the formation of $\mathrm{TiO}_{2}$ clusters, which in turn can also be impacted by the particle size distribution of the construction of $\mathrm{TiO}_{2}$ pixelated network. Thus, based on this theory, about the $\mathrm{TiO}_{2}$ producer, what suggests is to increase the range of the particle size of $\mathrm{TiO}_{2}$ should be increased from $1 \mu \mathrm{m}$ to $80 \mu \mathrm{m}$ instead of $20 \mu \mathrm{m}$ to $30 \mu \mathrm{m}$ to achieve a more 
efficient $\mathrm{TiO}_{2}$ pixelated mesh. The discussion could reach the level that the presence of $\mathrm{TiO}_{2}$ clusters is not exactly a photocatalysis problem, but rather it can help the entire process.

On the other hand, this opens the space to discuss that changing $\mathrm{TiO}_{2}$ powder by suspension of $\mathrm{TiO}_{2}$ may not be an advantage. Suppose at first, and the suspension applied to the surfaces may present a better performance concerning self-cleaning. In that case, its useful life is undoubtedly shorter than in mortar with $\mathrm{TiO}_{2}$ since it does not allow the change in film layer without a new suspension application. 


\section{REFERENCE}

[1] DARIANI, R. S.; ESMAEILI, A.; MORTEZAALI, A.; DEHGHANPOUR, S. Photocatalytic reaction and degradation of methylene blue on $\mathrm{TiO}_{2}$ nano-sized particles. Optik, v.127, p.7143-7154, 2016.

[2] FENG, D.; XIE, N.; GONG, C.; LENG, Z.; XIAO, H.; LI, H.; SHI, X. Portland Cement Paste Modified by $\mathrm{TiO}_{2}$ Nanoparticles: A Microstructure Perspective. Industrial \& Engineering Chemistry Research, v.52, p.11575-11582, 2013.

[3] LIAO, D. L.; LIAO, B. Q. Shape, size and photocatalytic activity control of $\mathrm{TiO}_{2}$ nanoparticles with surfactants. Journal of Photochemistry and Photobiology A: Chemistry, v.187, p.363-369, 2007.

[4] LIAO, D. L.; WU, G. S.; LIAO, B. Q. Zeta potential of shape-controlled $\mathrm{TiO}_{2}$ nanoparticles with surfactants. Colloids and Surfaces A: Physicochemical and Engineering Aspects, v.348, p.270-275, 2009.

[5] OliveirA, A. H. P. de; MOURA, J. A. S.; OliVEIRA, H. P. de. Preparação e Caracterização de Microfibras de Poli (Álcool Vinílico) / Dióxido de Titânio. Polímeros, Instituto de Pesquisa em Ciência dos Materiais, Universidade Federal do Vale do São Francisco - UNIVASF. Juazeiro, 2012.

[6] MUNAFÒ, P.; GOFFREDO, G. B.; QUAGLIARINI, E. TiO 2 -based nanocoatings for preserving architectural stone surfaces: An overview. Construction and Building Materials, v.84, p.201-218, 2015.

[7] PINHO, L.; MOSQUERA, M. J. Photocatalytic activity of $\mathrm{TiO}_{2}-\mathrm{SiO}_{2}$ nanocomposites applied to buildings: Influence of particle size and loading. Applied Catalysis B: Environmental, v.134-135, p.205-221, 2013.

[8] JANG, H. D.; KIM, S. Effect of Particle Size and phase composition of titanium dioxide on photocatalytic properties. Journal of Nanoparticles Research, v.3, p.141-147, 2001.

[9] WADE, J. An investigation of TiO-ZnFe O Nanocomposites for visible light photocatalysis. Master Thesis. University of South Florida, Department of Electrical Engineering. 108p. 2005.

[10] LEVINSON, R; BERDAHL, P; AKBARI, H. Solar spectral optical properties of pigments - Part II: survey of common colorants, Solar Energy Materials \& Solar Cells, v.89, p.351-389, 2005.

[11] LEVINSON, R; BERDAHL, P; AKBARI, H. Solar spectral optical properties of pigments-Part I: model for deriving scattering and absorption coefficients from transmittance and reflectance measurements, Solar Energy Materials \& Solar Cells, v.89, p.319-349, 2005.

[12] SENFF L; LABRINCHA, J. A; FERREIRA, V. M; HOTZA, D; REPETTE, W. L. Effect of nano-silica on rheology and fresh properties of cement pastes and mortars. Construction and Building Materials, v.23, p.2487- 2491, 2009. 
[13] SENFF, L; HOTZA, D; REPETTE, W. L; FERREIRA, V. M; LABRINCHA, J. A. Effect of nanosílica and microsílica on the microstructure and the hardened properties of cement pastes and mortars. Advance in Applied Ceramics, v.109, p.104-110, 2010.

[14] HUSKEN, G.; HUNGER, M.; BROUWERS, H.J.H. Experimental study of photocatalytic concrete products for air purification. Building and Environment, v. 44, p. 2463-2474, 2009.

[15] OGILVY, J, A. Wave scattering from rough surfaces. Reports on Progress in Physics, v. 50, p.1553-1608, 1987.

[16] BORODICH, F. M; PEPELYSHEV, A; SAVENCU, O. Statistical approaches to description of rough engineering surfaces at nano and microscales. Tribology International, v. 103, p.197-207, 2016.

[17] POON, C, Y; SAYLEST, R, S; JONES, T, A. Surface measurement and fractal characterization of naturally fractured rocks. Journal of Physics D: Applied Physics, v.25, p.1269-1275, 1992.

[18] DANTAS, S. R. A; SERAFINI, R; ROMANO, R. C. de O; VITTORINO, F; LOH, K. Influence of the nano $\mathrm{TiO}_{2}$ dispersion procedure on fresh and hardened rendering mortar properties, Construction and Building Materials, v.215, p.544-556, 2019.

[19] ABNT, NBR 14656: Portland cement and raw materials - Chemical analysis by X-ray spectrometry - Test method, Rio de Janeiro, 2001 [in Portuguese].

[20] DANTAS, S. R. A; VITTORINO, F; LOH, K. Photocatalytic Performance of White Cement Mortars Exposed in Urban Atmosphere, Global Journal of Researches in Engineering: C (Chemical Engineering), v.19, Issue 2, version 1, p.1-13, 2019.

[21] CHEN, Z; LIU, Y; ZHOU, P. A comparative study of fractal dimension calculation methods for rough surface profiles. Chaos, Solitons and Fractals, v.112, p.24-30, 2018.

[22] OGILVY, J, A; FOSTER, J, R. Rough surfaces: gaussian or exponential statistics? Journal of Physics D: Applied Physics, v.32, p.1243-1251, 1989. Springer, 418 pp, 2015.

[23] SUH, MIN-JEONG; SHEN, Y; CHAN, C, K; KIM, JAE-HONG. Titanium Dioxide Layered Double Hydroxide Composite Material for Adsorption-Photocatalysis of Water Pollutants, Langmuir XXXX, XXX, XXX-XXX, 2019. DOI: 10.1021/acs.langmuir.9b00539

[24] PARKINS, B. E. Journal of the Acoustical Society of America, v.41, p.126-34, 1967.

[25] DIOS, J. de; CAMPO, J. M. del; COLORADO, D. Decontamination through photocatalytic $\mathrm{TiO}_{2}$ additions. Past, Present and Future. $2^{\text {nd }}$ International Conference on Emerging Trends in Engineering and Technology (icetet'2014), May 30-31, 2014, London (United Kingdom), [s.1.], p.145-152, 30 May 2014. International Institute of Engineers.

[26] MILLS, A.; HUNTE, S. L. An overview of semiconductor photocatalysis, Journal of photochemistry and photobiology A: Chemistry, v.108, p.1-35, 1997. 
[27] LI, D.; HUANG, H.; CHEN, X.; CHEN, Z.; LI, W.; YE, D.; FU, X. New synthesis of excellent visible-light $\mathrm{TiO}_{2-\mathrm{x}} \mathrm{N}_{\mathrm{x}}$ photocatalyst using a very simple method, Journal of SolidState Chemistry, v.180, p.2630-2634, 2007. 


\title{
APPENDIX F - COMPARISON OF REFLECTANCE TO SOLAR RADIATION BETWEEN MORTARS TREATED WITH TIO $_{2}$ AND PAINTED MORTARS AFTER THREE YEARS OF EXPOSURE ${ }^{16}$ (Article F)
}

\begin{abstract}
The incident solar radiation on the building envelope is strongly affected by the urban characteristics and building facade materials. This paper reports a study on the variation in the solar reflectance of mortar specimens with different treatments of $\mathrm{TiO}_{2}$ - powder (addition) and suspension (cover) - compared with white painted specimens and exposed in the long term. The solar reflectance of mortars was evaluated at biweekly intervals over three years to reach their degradation over time. The results obtained for the white painted specimens revealed that they practically maintained the exact value of their initial reflectance to solar radiation over three years of exposure ending with $73 \%$ of its index. In addition, the comparison between the white painted specimens and specimens with $\mathrm{TiO}_{2}$ powder addition showed a mean solar reflectance difference of $28.25 \%$, showing that difference certainly would be noticed by the final user in terms of absorption and color change. The study also revealed that comparison between the specimens with $\mathrm{TiO}_{2}$ in powder addition and specimens with $\mathrm{TiO}_{2}$ in suspension showed a mean solar reflectance difference of $8.5 \%$ and demonstrate that result will not identify by the final user concerning the absorption and color change, and not indicate their preference since both showed the same effectiveness in mean after three years of exposure.
\end{abstract}

Keywords: Solar reflectance, $\mathrm{TiO}_{2}$ treatments, cool surfaces, aging, weathering.

\footnotetext{
${ }^{16}$ S. R. A. Dantas, F. Vittorino, K. Loh. Comparison of reflectance to solar radiation between mortars treated with $\mathrm{TiO}_{2}$ and painted mortars after three years of exposure. Journal of Building Engineering.

Manuscript Number: JBE-D-21-02912_R1 - Under Review
} 


\section{INTRODUCTION}

Increasing light reflectance and thermal emittance on the facades can be feasible against the building's warming [1]. It can also help reduce urban heat islands, improve indoor and outdoor thermal comfort, and reduce energy consumption [2,3]. Also, on average, urban overheating causes an additional peak electricity demand close to $21( \pm 10.4) \mathrm{W}$ per degree of temperature increase and person, and a supplemental cooling energy penalty close to $0.7 \mathrm{kWh}$ per square meter of city and degree of temperature increase [4]

The reflectance of a building's coating usually is characterized by the percentage of total solar reflectance, where low values are associated with darker colors. In contrast, light colors typically have a high index [5]. Therefore, the total solar reflectance optimization can be valuable to match the best external paint coating characteristics with the building environment. However, it must also be pointed out that buildings displaying an exterior coating with a total solar reflectance value lower than $25 \%$ become very dark and can, thus, be considered by the public opinion, not aesthetic [6].

According to Aoyama et al. [7], solar reflectance decreased by 5\% to $10 \%$ between three and six months with self-cleaning paint and $20 \%$ to $23 \%$ with conventional paint. The decrease of solar reflectance was likely due to dirt accumulation, and self-cleaning paint retained its cleanliness better than traditional paint after outdoor exposure. After one year, solar reflectance decreased by $8 \%$ with self-cleaning paint and $17 \%$ with conventional paint.

An optimum solar reflectance should define according to a building's use, insulation, and weather conditions [8]. In particular, by decreasing the reflectivity of surrounding surfaces and ground, the energy output of the facades of the building can drop down to $-37 \%$ in the worst case [9]. Thus, it is necessary to develop coatings with high initial solar reflectance and, principally, persistent solar reflectance with long-term durability [10, 11].

In the construction industry, nanotechnology creates the possibility to produce materials with novel functionalities and improved characteristics. The construction sector developed nanomaterials products because of their enhanced properties such as higher durability, fire resistance, thermal stability, and self-cleaning properties [12]. Moreover, the implementation of self-cleaning agents and photocatalytic coatings on the surface of the reflective materials can reduce the optical weatherization caused by most of the environmental factors [13].

The photocatalytic coating with $\mathrm{TiO}_{2}$ can maintain the solar reflectance of opaque building envelopes [11] and make those more efficient by maintaining their initially high solar 
reflectance values over long periods, besides their environmental benefits result from their depolluting properties. Furthermore, a further aspect related to the presence of $\mathrm{TiO}_{2}$ refers to its potential as cool pigment, where surfaces do not overheat under the sun as they present a high solar reflectance [14]. However, building surfaces can significantly diminish those benefits over time with the exposition to the ambient environment due to soiling deposition and biological growth [15-22].

The efficacy of the photocatalytic coatings varies with exposure location. The self-cleaning ability of the coatings is deeply dependent even on the type of $\mathrm{TiO}_{2}$ particle used in the synthesis of the nanocomposites. Visually, it is observed that the soil deposited in layers onto the membrane surfaces penetrating the micropores in the surface, effectively anchoring the soil to the membrane and offering resistance to removal by rain events. Besides, seasonal effects are observed with partial inhibition during the dry season and reactivation during the rainy season [23-25].

Another point, while some studies have found a higher activity of the anatase phase [26, 27], others have reported the mixed-phase anatase/rutile to show a better photocatalytic performance [28]. On the other hand, when applied like a film, the performance is influenced by film characteristics as composition, bulk, surface structure, nanostructure, atomic to nanoscale roughness, hydroxyl concentration, and impurity concentration [29-33].

Thus, this research measured the effectiveness of different types of $\mathrm{TiO}_{2}$ with specific treatments - either in powder and suspension form - on mortar surfaces exposed in the long term as a function to evaluate and compare the effectiveness of different types of $\mathrm{TiO}_{2}$ in various states of application (addition and cover) with the white commercial paint, concerning the reflectance to solar radiation in São Paulo, Brazil.

\section{MATERIAL AND METHODS}

A group of specimens using commercial samples of $\mathrm{TiO}_{2}$, even in powder and suspension form, were produced with different treatments of $\mathrm{TiO}_{2}$ and compared each other and with painted representatives concerning to evaluate the effectiveness of different types of $\mathrm{TiO}_{2}$ in various states of application regarding reflectance to solar radiation.

A mason applied mortars on $1.2 \mathrm{~m} \times 1.2 \mathrm{~m}$ concrete substrates (panels), aiming to find a maximum thickness of $1 \mathrm{~cm}$ as recommended by the literature and with the minimum possible roughness described in previous studies [34,35]. First, the substrate was finished with cement paste to achieve regularization, the homogenization of water absorption, enhanced adhesion, 
and to prevent an increase in the consumption of the mortars. After, to ensure the desired thickness, a wooden template $1 \mathrm{~cm}$ high was installed on both sides of the panels, followed by leveling the mortar. After the application and leveling of mortar, the finishing process was carried out.

Tests were carried out on specimens under exposure to an urban environment for thirty-seven months in the city of São Paulo (Latitude: 23 33' 15" S; Longitude: 46 44' 1" W) in the northwest direction with a slope of $33^{\circ}$ concerning to the ground to maximize exposure to sunlight, as shown in Fig.1.

\subsection{Experimental design}

Accord to the previous studies [36], the P25p and $\mathrm{PC} 105 \mathrm{p} \mathrm{TiO}_{2}$ powder samples were added to the cement matrix after being pre-dispersed in water. The P25s and PC105s are suspensions prepared by the author in the laboratory using High Energy of Dispersion (HED) ${ }^{17}$, while PC$\mathrm{S} 7 \mathrm{~s}$ and E502s are commercial suspensions of $\mathrm{TiO}_{2}$. As the manufacturer's recommendation, the commercial suspensions of $\mathrm{TiO}_{2}$ were applied as a spray to the surfaces of specimens. The authors took the same procedure to the suspension produced in the laboratory and the paint in the painted examples maintaining the same application pattern.

The experimental program compared four types of suspension of $\mathrm{TiO}_{2}$ and two types of powder samples of $\mathrm{TiO}_{2}$ with the paint samples. Specimens treated with $\mathrm{TiO}_{2}$ are exposed in pairs and painted examples in three. The group exposition (G1-G3) is G1 - comparison between powder samples of $\mathrm{TiO}_{2}$ and suspensions of $\mathrm{TiO}_{2}$ prepared in the laboratory with the paint; G2 - comparison between powder samples of $\mathrm{TiO}_{2}$ and commercial suspensions of $\mathrm{TiO}_{2}$ with the paint and; G3 - comparison of all samples of $\mathrm{TiO}_{2}$ in suspension form with the paint. The final layout of specimens is described in Table 1 as well as the final design exposed to solar radiation is shown in Figure1.

Table 1-Description of the specimens

\begin{tabular}{cccccc}
\hline Group & $\begin{array}{c}\text { Mortar } \\
\text { (painted) }\end{array}$ & $\begin{array}{c}\text { Mortar } \\
\text { (unpainted) }\end{array}$ & $\begin{array}{c}\text { Mortar } \\
\text { (unpainted) }\end{array}$ & $\begin{array}{c}\text { Mortar } \\
\text { (unpainted) }\end{array}$ & $\begin{array}{c}\text { Mortar } \\
\text { (unpainted) }\end{array}$ \\
\hline G1 & Ref. & P25p & PC105p & P25s & PC105s \\
G2 & Ref. & P25p & PC105p & PC-S7s & E502s \\
G3 & Ref. & P25s & PC105s & PC-S7s & E502s \\
\hline
\end{tabular}

Source: Dantas et al [36]. Note: $\mathrm{p}=$ Powder / $\mathrm{s}=$ Suspension

\footnotetext{
${ }^{17} \mathrm{P} 25 \mathrm{~s}$ and PC105s suspensions were prepared in laboratory based on the results of the total solid residues of PC-S7s and E502s suspensions. The quantity equivalent to $14.4 \mathrm{~g}$ for each powder sample (P25p and PC105p) was mixed with $100 \mathrm{ml}$ of deionized water using HED (2000 rpm with cowles propellant) for $5 \mathrm{~min}$. After that, the suspensions were applied on black polypropylene (PP) plastic surfaces to observe adhesion [36].
} 
Figure 1. Exposure to solar radiation of specimens

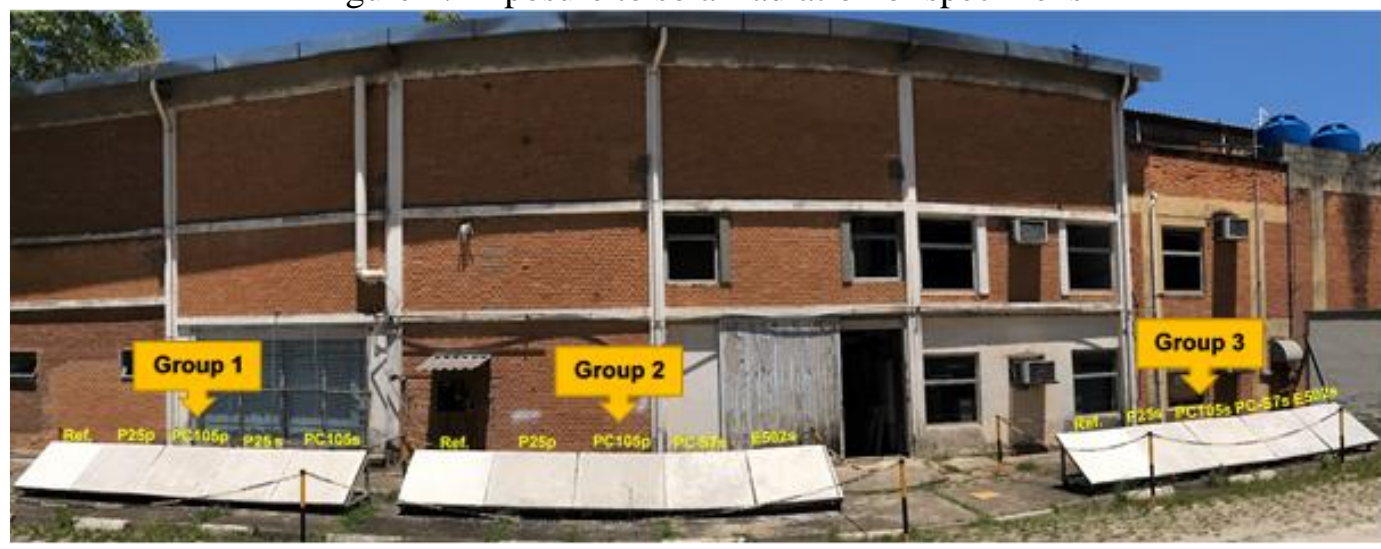

Source: Author (2021)

\subsection{Materials characterization}

The characteristics of the raw materials were performed according to previous studies by authors [36,37] and here described again to the convenience of the readers. Mortars were formulated using white Portland cement (WHITE CEM I 52.5R EN 197-1), dolomites \#20, \#40, and \#80, commercial air-entraining agent based on sodium lauryl sulfate molecules, water-retaining agents based on cellulosic ether molecules, and polypropylene microfibers.

The specific surface area was measured using the BET method with an $\mathrm{N}_{2}$ gas/vapor adsorption in a Belsorp Max equipment and a pre-treatment of the specimens at a temperature of $60^{\circ} \mathrm{C}$ and a pressure of $7 \times 10^{-5} \mathrm{MPa}$ for $24 \mathrm{~h}$ in a Belprep II - vac equipment. The absolute density was determined by the Helium pycnometry method in a Quantachrome MVP 5DC multipycnometer, as shown in Table 2.

Particle size distribution was determined by laser granulometry in a Malvern Mastersizer LongBed with a detection range of $0.1-355 \mu \mathrm{m}$, and the dolomites particle size distribution was determined employing a Dynamic Image Analyzer (QicPic - Sympatec) with range detection of $1-4000 \mu \mathrm{m}$, as presented in Table 2 and Figure 2.

Table 2 - Raw materials characteristics

\begin{tabular}{|c|c|c|c|c|c|}
\hline Material & \multicolumn{3}{|c|}{$\begin{array}{l}\text { Particle Size } \\
\qquad(\mu \mathrm{m})\end{array}$} & $\begin{array}{c}\text { Specific surface } \\
\text { area } \\
\left(\mathrm{m}^{2} / \mathrm{g}\right)\end{array}$ & $\begin{array}{c}\text { Average density } \\
\qquad\left(\mathrm{g} / \mathrm{cm}^{3}\right)\end{array}$ \\
\hline White Portland cement (WPC) & 2.6 & 17.7 & 19.5 & 0.86 & 3.05 \\
\hline Dolomite \#20 & 975 & 1242 & 1620 & 0.16 & 2.90 \\
\hline Dolomite \#40 & 24.3 & 230 & 740 & 0.56 & 2.94 \\
\hline Dolomite \#80 & 4.5 & 38.3 & 134 & 0.80 & 2.81 \\
\hline $\mathrm{TiO}_{2}-\mathrm{P} 25 \mathrm{p}$ (powder) & 1.38 & 3.90 & 17.7 & 49.4 & 3.84 \\
\hline $\mathrm{TiO}_{2}-\mathrm{PC} 105 \mathrm{p}$ (powder) & 0.66 & 1.50 & 4.60 & 79.8 & 3.62 \\
\hline $\mathrm{TiO}_{2}-\mathrm{PC}-\mathrm{S} 7 \mathrm{~s}$ (suspension) & 0.06 & 0.09 & 0.12 & 70.7 & --- \\
\hline $\mathrm{TiO}_{2}-\mathrm{E} 502 \mathrm{~s}$ (suspension) & 4.09 & 8.60 & 17.25 & 0.82 & --- \\
\hline
\end{tabular}

Source: Dantas et al. [36] 
Figure 2. The particle size distribution of materials.

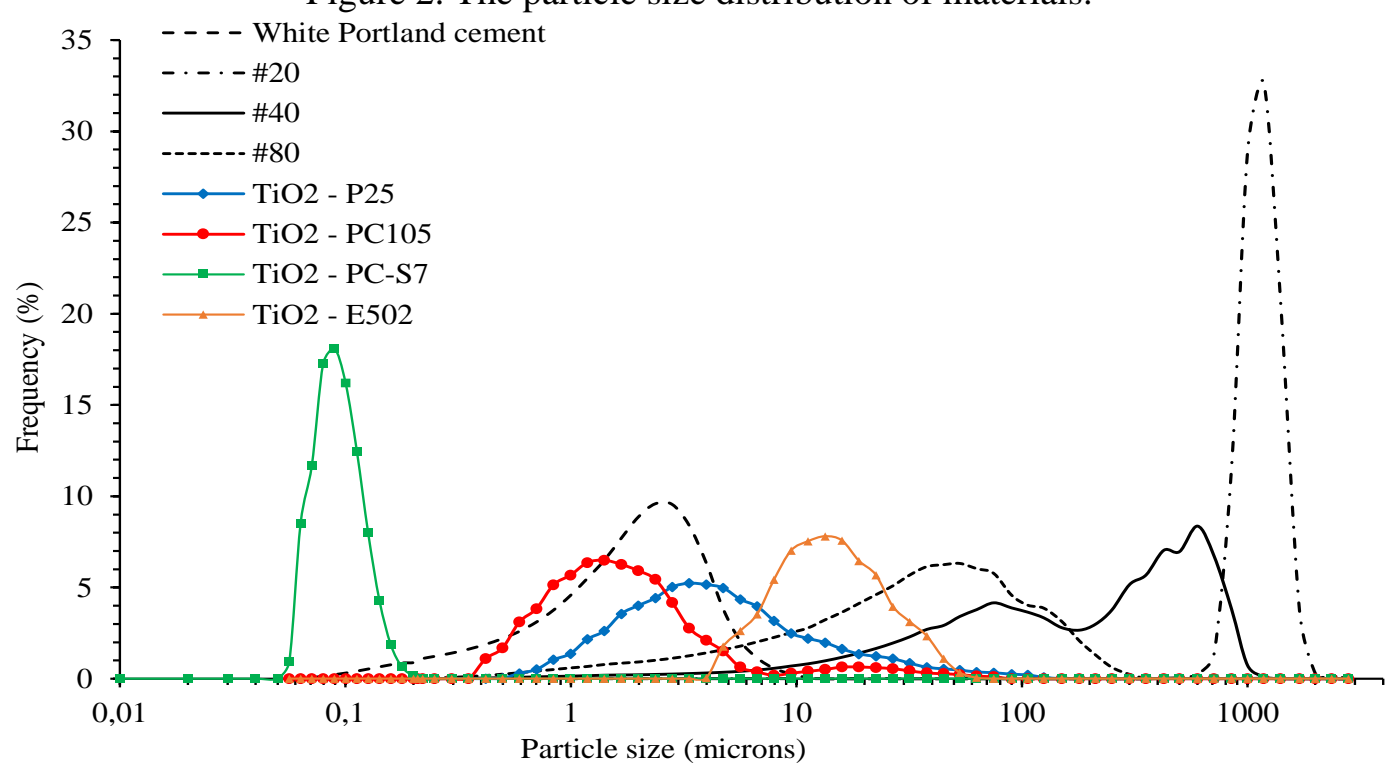

Source: Dantas et al. [36]

Figure 3 shows the mineralogical compositions of white Portland cement, commercial powder (P25p and PC105p), and suspension (PC-S7s and E502s) of $\mathrm{TiO}_{2}$ samples, determined by $\mathrm{X}$ ray diffraction (XRD). Procedure IPT 15742 CT-OBRAS-LMCC-Q-PE-092 - "Mineralogical analysis by X-ray diffraction" and IPT 15458 - Q-PE-089 "Determination of phases analysis of Portland cement and Portland cement clinker using the Rietveld method of analysis by powder diffraction," according to ASTM C1365-06 [38]. Equipment used: Rigaku model Windmax 1000, operating on copper $\mathrm{K} \alpha$ rad radiation with $40 \mathrm{kV}-20 \mathrm{~mA}$ and $2 \%$ min sweep. Also, Table 3 presents the amount of rutile and anatase quantified using the Rietveld method.

Figure 3. X-ray diffractograms of $\mathrm{WPC}$ and $\mathrm{TiO}_{2}$ samples

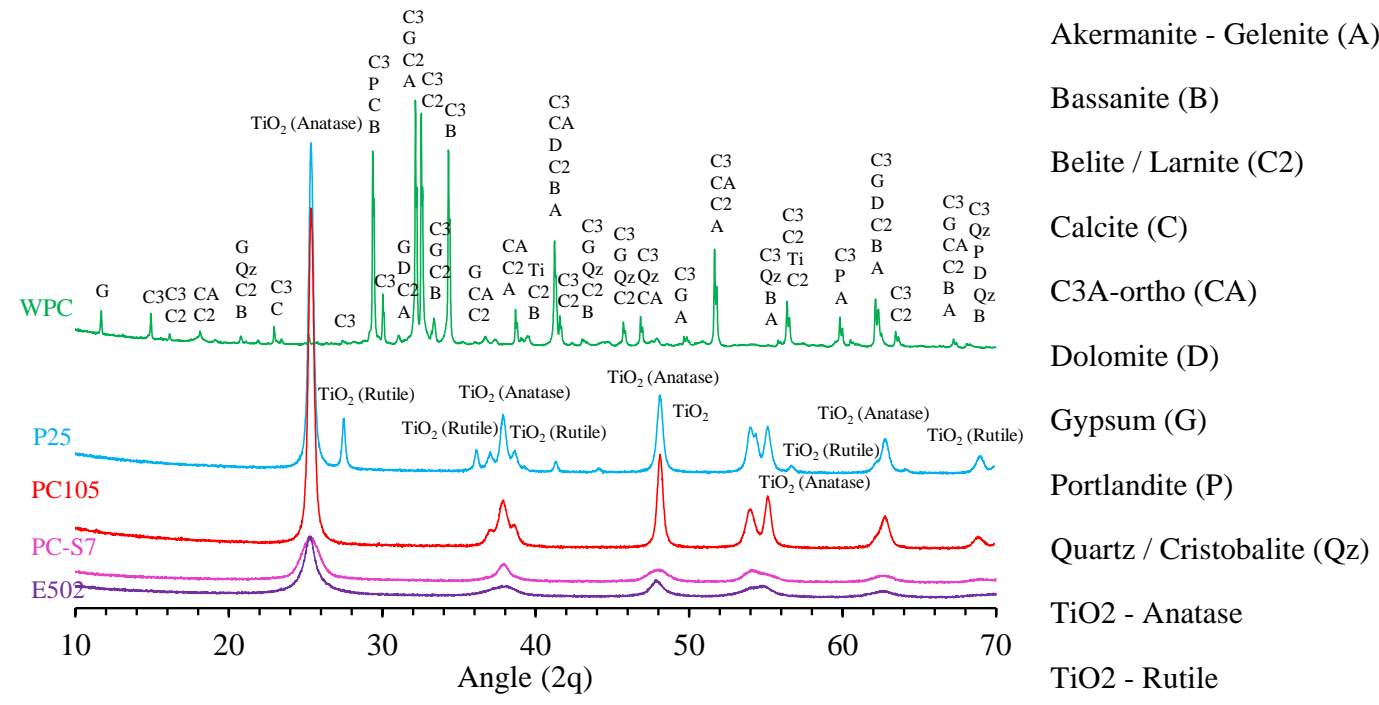

Source: Author (2021) 
Table 3 - Phases observed in $\mathrm{TiO}_{2}$ samples

\begin{tabular}{llccc}
\hline \multicolumn{1}{c}{ Sample } & \multicolumn{1}{c}{ Phase } & ICSD code & ICDD code & $\%$ \\
\hline PC105p (powder) & Anatase & 93098 & - & 100 \\
P25p (powder) & Anatase / Rutile & $202243 / 51938$ & - & $87.8 / 12.2$ \\
PC-S7s (suspension) & Anatase & $82080 / 202243$ & - & 100 \\
E502s (suspension) & Anatase & 154602 & - & 100 \\
\hline
\end{tabular}

Source: Author (2021)

Table 4 shows the chemical composition of samples of $\mathrm{TiO}_{2}$ determined by semi-quantitative chemical analysis by X-ray fluorescence (XRF). Procedure IPT15101-CT-WORKS-LMCCQ-PE-087 - Revision 0 of 03/28/2014 "Qualitative, semi-quantitative, or quantitative chemical analysis by X-ray fluorescence spectrometry," following the Brazilian Association of Technical Standards - ABNT [39].

Table 4 -Chemical composition of samples by XRF

\begin{tabular}{lcccccc}
\hline $\mathrm{Compound}$ & $\begin{array}{c}\text { WPC } \\
(\%)\end{array}$ & $\begin{array}{c}\mathrm{P} 25 \\
(\%)\end{array}$ & $\begin{array}{c}\mathrm{PC} 105 \\
(\%)\end{array}$ & $\begin{array}{c}\text { PC-S7 } \\
(\%)\end{array}$ & $\begin{array}{c}\text { E502 } \\
(\%)\end{array}$ & $\begin{array}{c}\text { Limited NBR } \\
16697 / 18\end{array}$ \\
\hline $\mathrm{LOI}$ & 2.48 & --- & --- & --- & --- & $\leq 27.0$ \\
$\mathrm{TiO}_{2}$ & --- & 99.7 & 99.6 & 96.1 & 90.6 & --- \\
$\mathrm{SiO}_{2}$ & 21.6 & 0.25 & --- & 0.21 & 1.17 & --- \\
$\mathrm{Al}_{2} \mathrm{O}_{3}$ & 4.60 & --- & 0.12 & 0.09 & 0.46 & --- \\
$\mathrm{FeO}_{3}$ & 0.33 & 0.02 & 0.03 & --- & --- & --- \\
$\mathrm{CaO}$ & 67.5 & --- & --- & 0.14 & 1.21 & --- \\
$\mathrm{MgO}$ & 0.59 & --- & --- & 0.20 & 0.64 & $\leq 10.0$ \\
$\mathrm{SO}_{3}$ & 2.83 & --- & --- & --- & --- & $\leq .5$ \\
$\mathrm{Na}_{2} \mathrm{O}$ & 0.13 & --- & --- & --- & --- & --- \\
$\mathrm{K}_{2} \mathrm{O}$ & 0.61 & --- & --- & --- & --- & --- \\
$\mathrm{Na} 2 \mathrm{O}$ & 0.53 & --- & --- & --- & --- & --- \\
$\mathrm{CaO}$ & 2.26 & --- & --- & --- & --- & --- \\
$\mathrm{RI}_{\mathrm{CO}}$ & 0.43 & --- & --- & --- & --- & $\leq .0$ \\
$\mathrm{CO}_{2}$ & 0.67 & --- & --- & --- & --- & $\leq 27.0$ \\
$\mathrm{P}_{2} \mathrm{O}_{5}$ & --- & --- & --- & 2.77 & 4.28 & --- \\
$\mathrm{ZrO}$ & --- & --- & 0.03 & 0.04 & --- & --- \\
$\mathrm{Nb}_{2} \mathrm{O}_{5}$ & --- & --- & 0.26 & 0.41 & --- & --- \\
$\mathrm{CdO}$ & --- & --- & --- & 0.13 & --- & --- \\
$\mathrm{V}_{2} \mathrm{O}_{5}$ & --- & --- & --- & --- & 1.56 & --- \\
$\mathrm{CuO}$ & --- & 0,02 & 0.03 & --- & --- & --- \\
$\mathrm{Er}_{2} \mathrm{O}_{3}$ & --- & --- & 0.10 & --- & --- & --- \\
\hline
\end{tabular}

Note: Alkaline equivalent (in $\mathrm{Na}_{2} \mathrm{O}$ ) $=\% \mathrm{Na}_{2} \mathrm{O}+0.658 \% \mathrm{~K}_{2} \mathrm{O} /$ LOI: Loss on ignition.

Source: Author (2021)

According to Fig. 3 and Table 3, it is possible to observe that except for the $\mathrm{TiO}_{2}-\mathrm{P} 25$ sample that shows two crystalline phases (anatase and rutile), all other samples have the same crystalline phase (anatase). Concerning the structures, it is well known that these two principal phases exhibit different photocatalytic performances and hopes that a mixture of anatase and rutile show a more pronounced catalytic effect [12]. Besides, the crystalline 
phases of $\mathrm{TiO}_{2}$ directly correlate with the bandgap energy and are responsible for absorption and activation by solar radiation [36].

Moreover, Table 3 shows that the $\mathrm{TiO}_{2}$ powders (P25p and PC105p) have greater purity than suspensions (PC-S7s and E502s), the latter being of lower concentration. However, this cannot be associated with a lower or higher photodegradation power or higher reflectance index when evaluated under the photocatalysis aspect.

\subsection{Mortar composition}

As was observed in previous studies [36], the compositions were developed without granulometric changes of coarse particles, but the mobility parameters were affected due to the characteristics of the $\mathrm{n}-\mathrm{TiO} 2$ used. It should be stressed that each composition was mixed with a different amount of water, aiming to maintain the same workability defined in the flow-table tests. The consumption, in $\mathrm{kg} / \mathrm{m}^{3}$, of each raw material in the compositions is described in Table 5.

Table 5 - Consumption, in $\mathrm{kg} / \mathrm{m}^{3}$, of each raw material

\begin{tabular}{lccccccc}
\hline Material & Ref. $^{1}$ & P25p & PC105p & P25s $^{2}$ & PC105s $^{2}$ & PC-S7s $^{2}$ & E502s $^{2}$ \\
\hline White Portland cement & 351 & 337 & 342 & 351 & 351 & 351 & 351 \\
(WPC) & 195 & 187 & 190 & 195 & 195 & 195 & 195 \\
Dolomite \# 20 & 1111 & 1067 & 1084 & 1111 & 1111 & 1111 & 1111 \\
Dolomite \# 40 & 292 & 281 & 285 & 292 & 292 & 292 & 292 \\
Dolomite \# 80 & 1.95 & 1.87 & 1.90 & 1.95 & 1.95 & 1.95 & 1.95 \\
Viscosity modifier & 0.16 & 0.15 & 0.15 & 0.16 & 0.16 & 0.16 & 0.16 \\
Air entrainment & 332 & 354 & 344 & 332 & 332 & 332 & 332 \\
Water & 1.4 & 1.4 & 1.4 & 1.4 & 1.4 & 1.4 & 1.4 \\
Polypropylene & --- & 16.8 & --- & 0.5 & --- & --- & --- \\
microfibers & --- & --- & 17.1 & --- & 0.5 & --- & --- \\
$\mathrm{TiO}_{2}$ (P25) & --- & --- & --- & --- & -- & $* *$ & --- \\
$\mathrm{TiO}_{2}$ (PC105) & --- & --- & --- & --- & --- & --- & $* * *$ \\
$\mathrm{TiO}_{2}$ (PC-S7) & $\mathrm{TiO}_{2}$ (E502) & &
\end{tabular}

Note: Specimens painted by spray after 28 days of field-cured (1); Suspensions applied by spray after 28 days of field-cured (2); Spray Rate: $15 \mathrm{~m}^{2} / \mathrm{L}(* *)$; Spray Rate: $10 \mathrm{~m}^{2} / \mathrm{L}$ (***)

Source: Author (2021)

\subsection{Measuring reflectance index}

The determination of reflectance index to solar radiation was based on ASTM E1918-16 [40] and ANSI/ASHRAE-74 [41]. A procedure correction for the reflectance calculation was adopted to correct reflectance considering the covering of adjacent specimens and ground reflection - IPT 18075 - "Reflectance to solar radiation of horizontal surfaces," according to ASTM E1918 [40]. 
Data were collected over three years, a period equivalent to three cycles of rainy summers in São Paulo, Brazil, observing the participation of the climate in the whole process. Days for measurement were selected with consideration of the uniformity of the sky conditions. Usually, the weather and the incidence of a clear sky are pretty typical to the location, with sunny days all over the year. Therefore, measurements for cloudy sky conditions were not considered. Measurements were performed at fortnightly intervals, and the yearly duration was organized according to the seasons for the south hemisphere: summer (December, January, February), fall (March, April, May), winter (June, July, August), and spring (September, October, November).

The measures happened from $11 \mathrm{~h} 00$ am to $13 \mathrm{~h} 00 \mathrm{pm}$ due to the highest incidence of global solar radiation in front of analyzed surfaces avoiding the solar incidence inclination higher than $45^{\circ}$ concerning panels. The measurements were carried using two Kipp \& Zonen pyranometers sensors, Delft / Holland model CM3, showing response to the wavelengths in the measurement range of $305-2800 \mathrm{~nm}$ and maximum radiation of $2000 \mathrm{~W} / \mathrm{m}^{2}$. The signal generated by the sensors varies from $0-50 \mathrm{mV}$, and the sensitivity from $0-35 \mu \mathrm{V} / \mathrm{W} / \mathrm{m}^{2}$. Data acquisition system was employed using a datalogger ALMEMO, model 2890-9 with a 6.5-digit display and RS232 output (Figure 4d).

Data were collected in-situ from the fixation of one the pyranometer on a metal rod $70 \mathrm{~cm}$ (Fig. 4c) in length to measure the reflected radiation. Another pyranometer, to measuring incident radiation, was positioned facing upwards in a parallel plane (Figure 4a). The pyranometer was placed perpendicular with $30 \mathrm{~cm}$ height from the specimen surface (Figure 4b), passing through its center. Once the pyranometers were positioned, the surfaces of the adjacent specimens were covered with black foam with a low reflectance index to prevent radiation reflected by neighboring surfaces from interfering with the surface results to be measured. After positioning the pyranometers and covering the adjacent specimens, an acquisition time of 20 seconds was employed, allowing a total of 15 measurements per specimen. The measurement procedure is shown in Figure 4. 
Figure 4. Reflectance measurement process

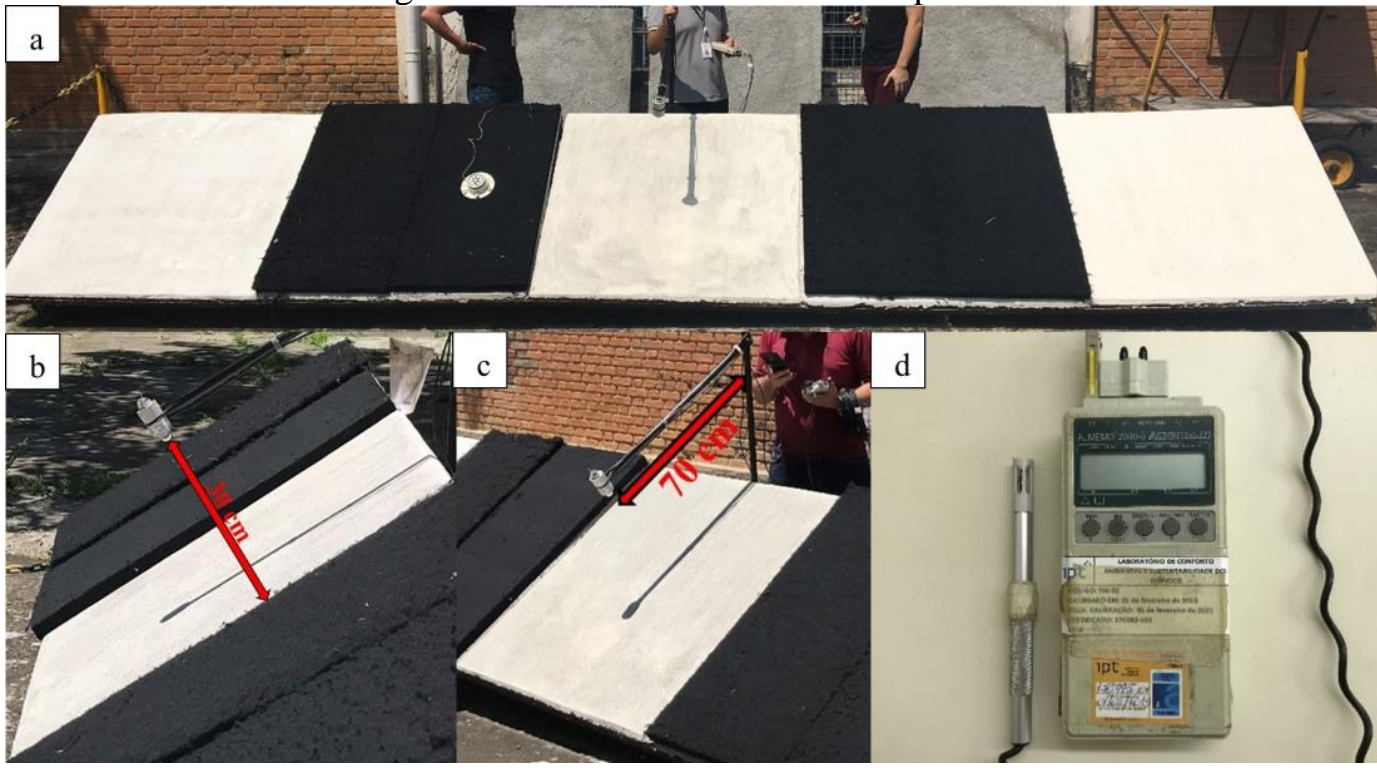

Note: Covering adjacent surfaces and parallel pyranometer for data collection (a); Distance from reflected radiation pyranometer to the surface specimen (b); Length of the metal rod (c); Data acquisition system $(\mathrm{d})$.

Source: Author (2021)

\section{RESULTS}

When the results are compared with the author's previous studies [34], the initial reflectance of the painted and powder specimens has fallen much more than those currently, as shown in Figure 5. The results indicate that the excellent preparation of the specimens and the studies about the rheological characteristics and the effects of surface roughness of the mortars as was evaluated in previous works $[35,36]$ by the author had significant influences on their reflectance.

The analysis shows no clear distinction between them concerning the reflectance to solar radiation for the first year of exposure (March/18 to February/19), presenting a tangled group without many differences; thus, all can be considered virtually equal configuring a single large block.

From March/19, it is possible to observe some distinctions about the P25p and PC105p specimens that show relevant downfall in their reflectance values. That difference becomes more evident throughout 2020, showing a higher fall at the end of the year. Although with recoveries in its indexes three years after (April/21), they are still below the range of the suspensions. 
Figure 5. Mean specimens reflectance results

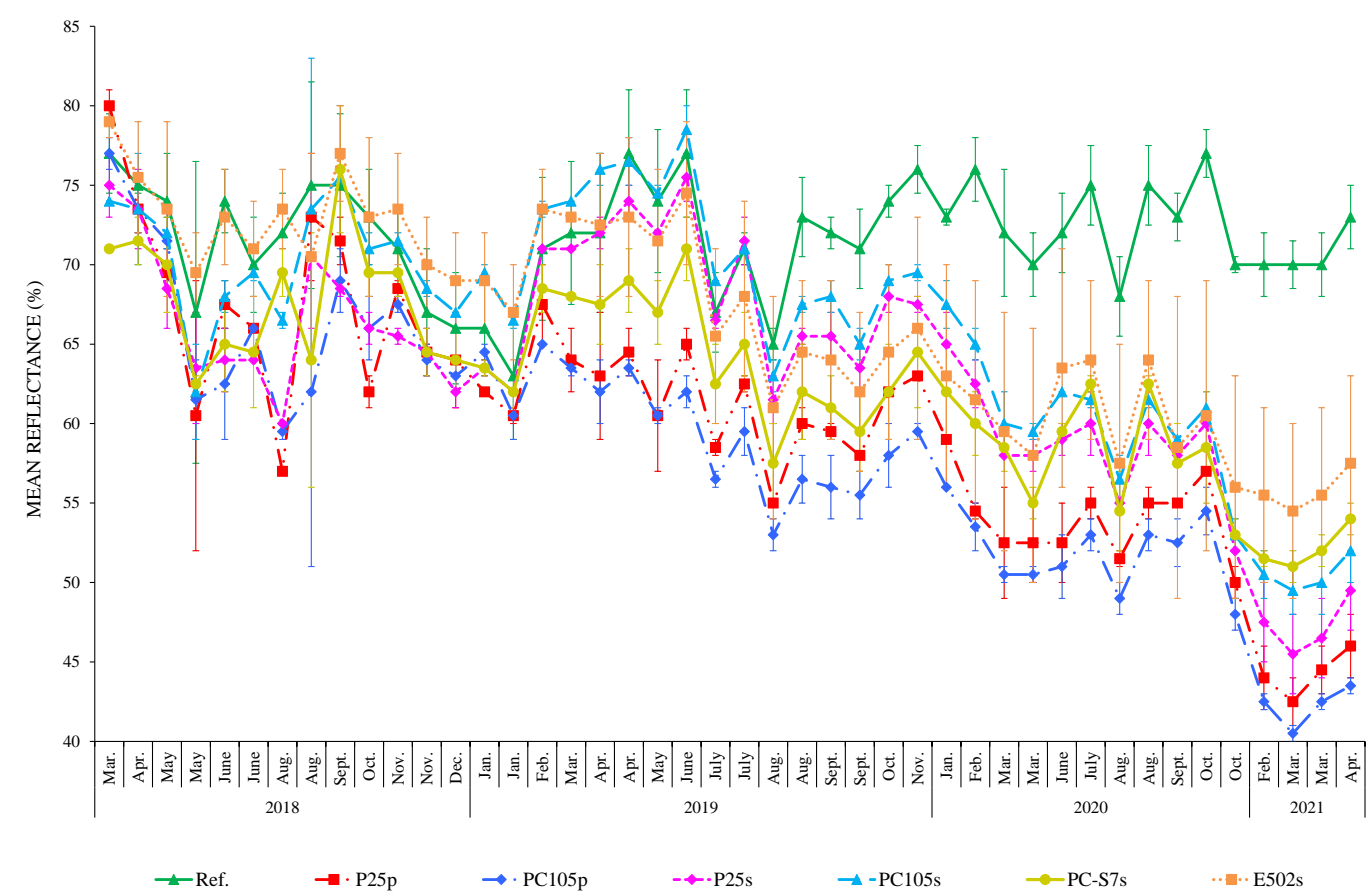

Note: Error bars were represented around the mean

Source: Author (2021)

Regarding the specimens with $\mathrm{TiO}_{2}$ suspensions applied, it is possible to observe that although they fall rapidly in their indexes, they also seem to recover quickly. These fall in the measurements may be allied to applying the material, maybe some failure of the surface coverage when adopting the spray method indicated by the manufacturers.

Another point is about the error bars and their variability. Despite not considering the metrological uncertainty of the sensors used for the measurement, in March/18, error bars were small or nonexistent in all specimens, increasing over time. That behavior can indicate that their variation is either caused by the natural surface deterioration of the specimens or the lousy formation of suspension film and not due to the equipment limitation.

Even though variability among specimens, the results demonstrate that when considering all of them individually in the period from March/18 to August/19, nothing would justify the advantage of one over another. Some oscillations denote a distance between the specimens (March/19 to June/19), but all could be regarded as equal in the end, considering the error bars.

The significant differentiation starts from August/19, with the jump in the painted specimens, going to another level, obtaining better performance. On the other hand, the specimens with $\mathrm{TiO}_{2}$ suspensions seem to form a block, as shown in Figure 6. 
Figure 6. Mean reflectance results of the reference samples and $\mathrm{TiO}_{2}$ suspensions

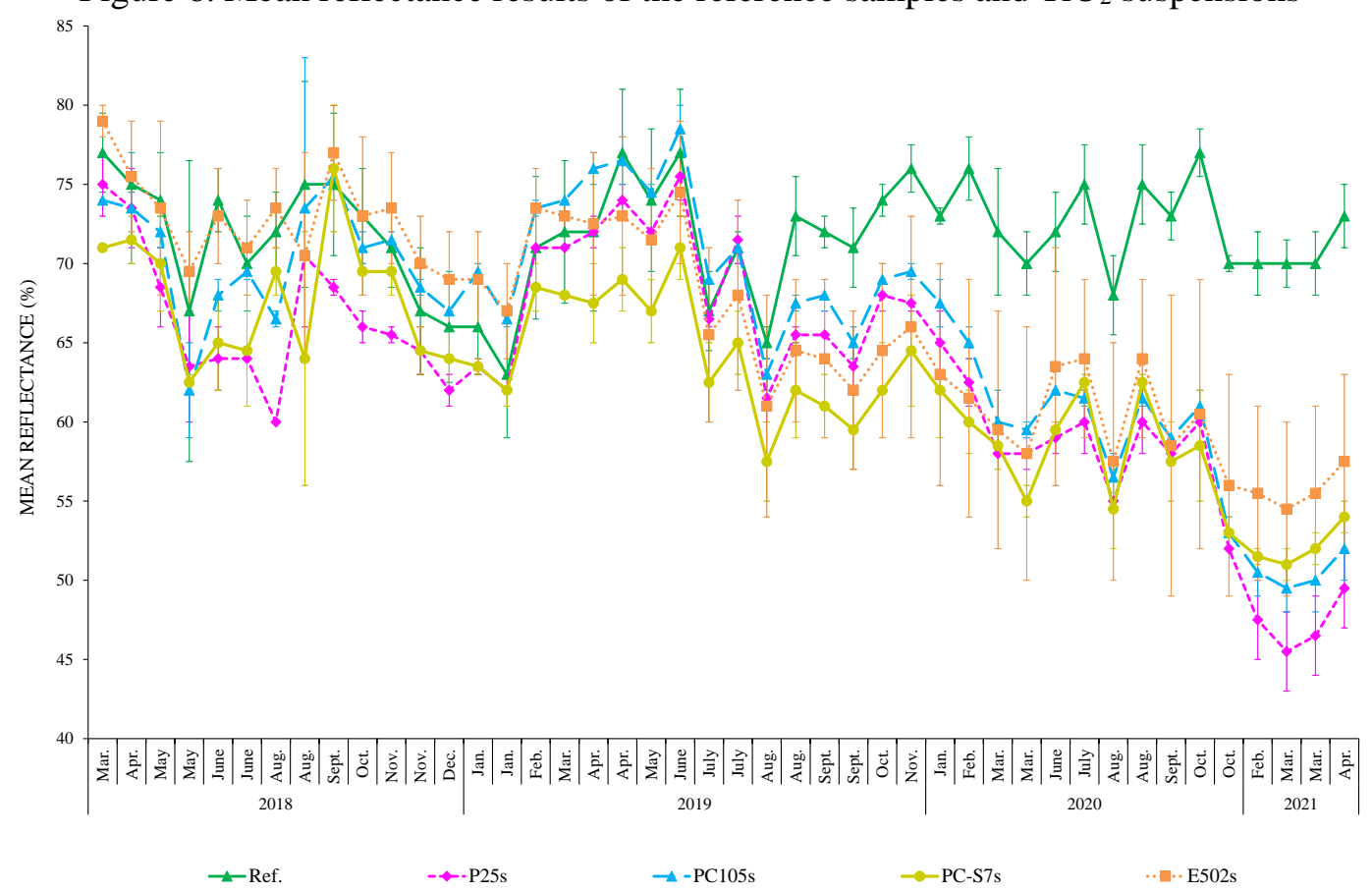

Source: Author (2021)

It is noticed that painted specimens and the specimens with $\mathrm{TiO}_{2}$ suspensions from August/18 all index of reflectance fall until January/19. This occurrence is probably due to the accumulation of dirt caused by little rain, returning to recover its indexes as soon as the summer season with a higher volume of rain. Another drop is observed from June/19 in the winter season and a little volume of rain. After that, the index goes up again with the spring and summer with a higher volume of rain.

That specimen's behavior demonstrates that the surface coverage by paint and $\mathrm{TiO}_{2}$ suspensions presents a product capable of recovering its performance. However, it is essential to remember that the rupture of the film formed by the paint and suspensions application which protect these surfaces have not yet occurred, showing that although there is a fall, as long as the cover is present, only the exposure to the climate makes its recovery, without the need for human intervention.

Accord the answers and from a qualitative point of view and engineering decision-making. Since all presented the same performance, there would be no justification for choosing one suspension over another in the first year of exposure or changing the paint for suspensions and vice-versa. Perhaps it is possible to choose other evaluation criteria such as cost, maintenance, the form of application, or durability for the product choice, in that case in particular. 
In the same way, it is possible to observe a tremendous difference in painted specimen's performance when comparing with specimens with $\mathrm{TiO}_{2}$ powder addition. It is possible to perceive a large gap between the initial reflectance for all the representatives and those presented so far, demonstrating that specimens with $\mathrm{TiO}_{2}$ powder samples showed a much more pronounced downward trend and a low performance, without any recovery index that can reach the painted specimens again, as shown in Figure 7.

Figure 7. Mean reflectance results of the reference samples and $\mathrm{TiO}_{2}$ powder

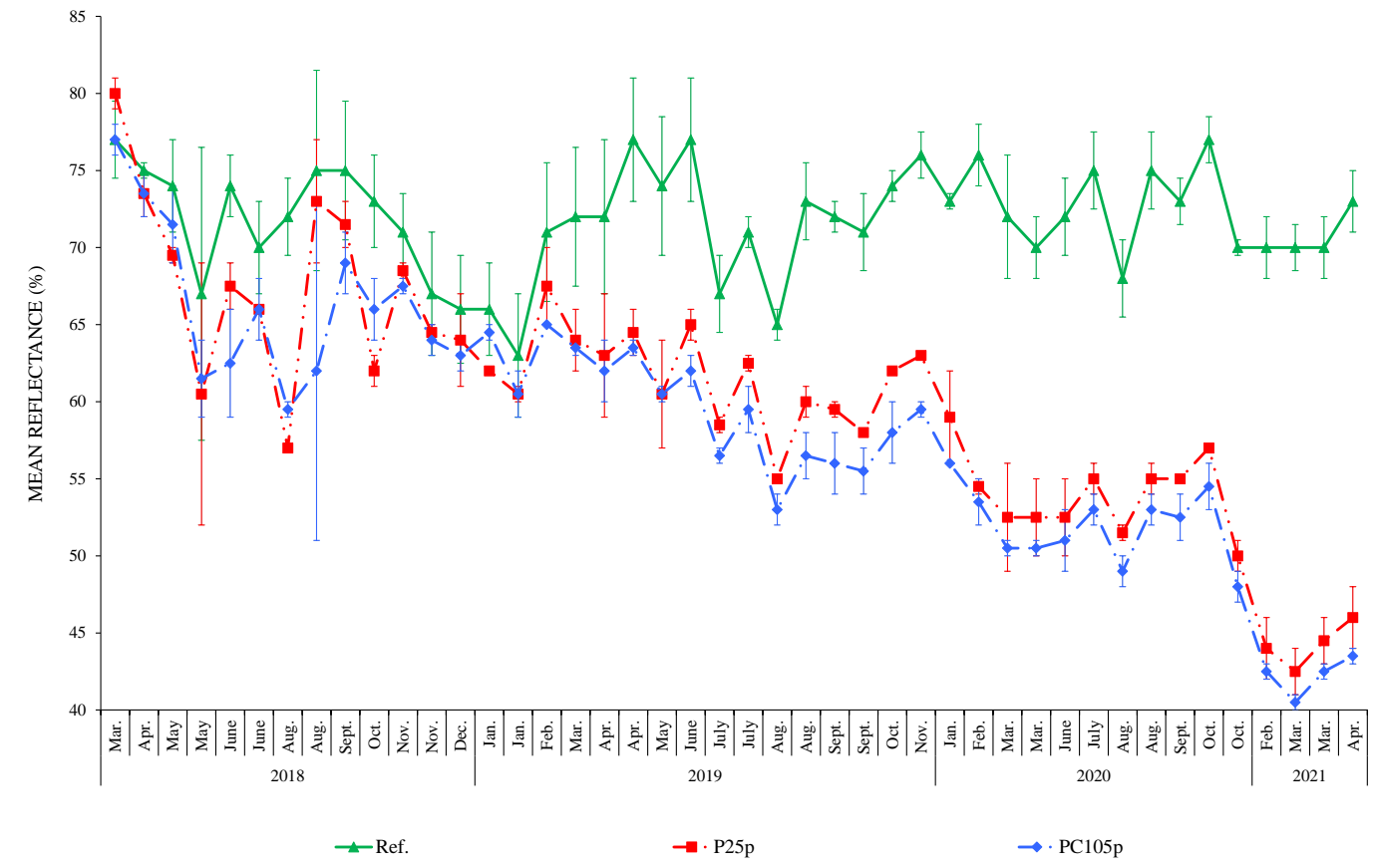

Source: Author (2021)

\subsection{Twin specimens behavior}

Considering that each mortar had two identical or "twins" specimens and assumed that significant differences could influence the reflectance results in the production of those twins, the behavior between the twin specimens was evaluated to eliminate this possible variable in the discussion.

By and large, in the first ages of the painted specimens and specimens with powder $\mathrm{TiO}_{2}$ samples, we can observe a certain dissonance in the measurement results from May/18 to August/18 with the reflectance measures for one of the pairs observed in all groups. These large fluctuations do not seem to be due to the metrological issue but rather to the material itself, which over time becomes more homogeneous, showing some variations in their initial results. 
The painted specimens, from September/18 to June/19, after exchanging positions between them, separate and run in parallel, maintaining a certain distance between their pairs. After that, they assume a qualitatively similar character. The behavior can be considered the same for the three specimens and evaluated as a block to the reflectance to solar radiation, as shown in Figure 8.

Figure 8. Reflectance results for the three long-term painted specimens

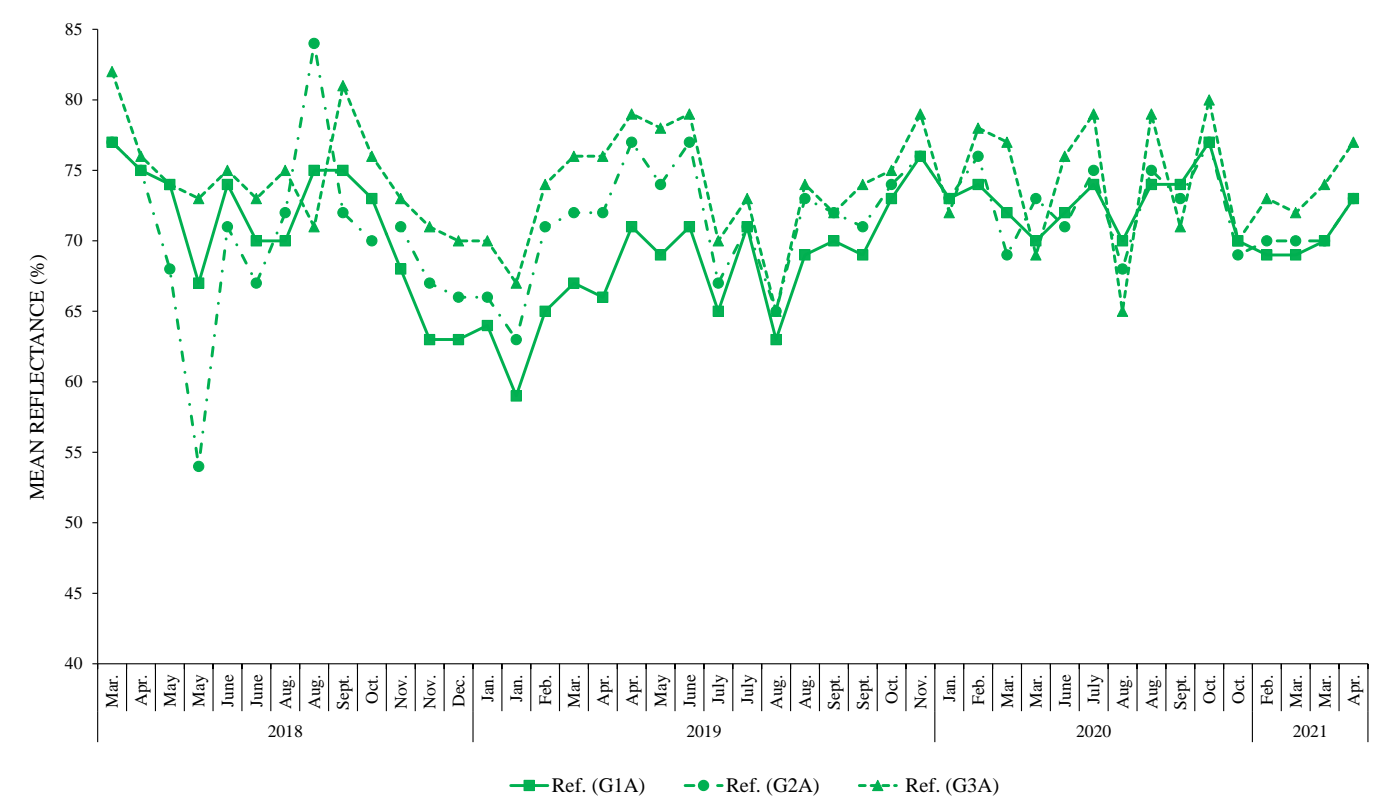

Source: Author (2021)

For the specimens with $\mathrm{TiO}_{2}$ powder addition, these fluctuations at the beginning may have been caused by the production process of the specimens themselves, which induced these initial higher variations, with the possible heterogeneities leading to a slightly higher roughness. After, the homogeneity of the surfaces caused by the washing processes, as leaching, where the weathering itself was able to homogenize the surfaces.

However, unlike the painted specimens, for all specimens with $\mathrm{TiO}_{2}$ powder, the homogenization process starts in the following months after the disturbs in measurement observed in their first months of exposure. That behavior happens not only for the same type of $\mathrm{TiO}_{2}$ but also for evaluating the two different types of $\mathrm{TiO}_{2}$ used, denoting that specimens behave very similarly despite few differences in measurements, being qualitatively and statistically classified as equal, as can be seen in Figures 9 and 10. 
Figure 9. Long-term reflectance results for specimens with the addition of $\mathrm{TiO}_{2}$

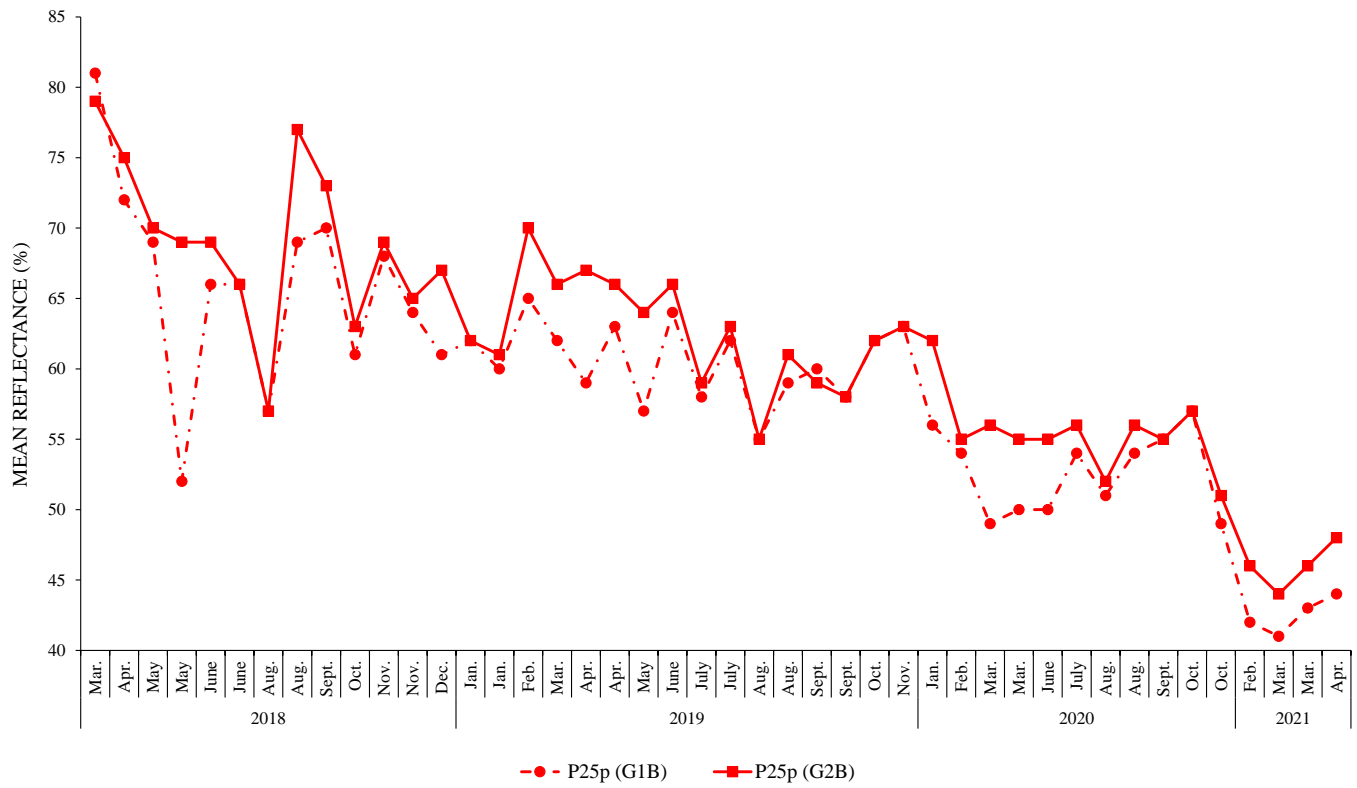

Note: P25p

Source: Author (2021)

Figure 10. Long-term reflectance results for specimens with the addition of $\mathrm{TiO}_{2}$

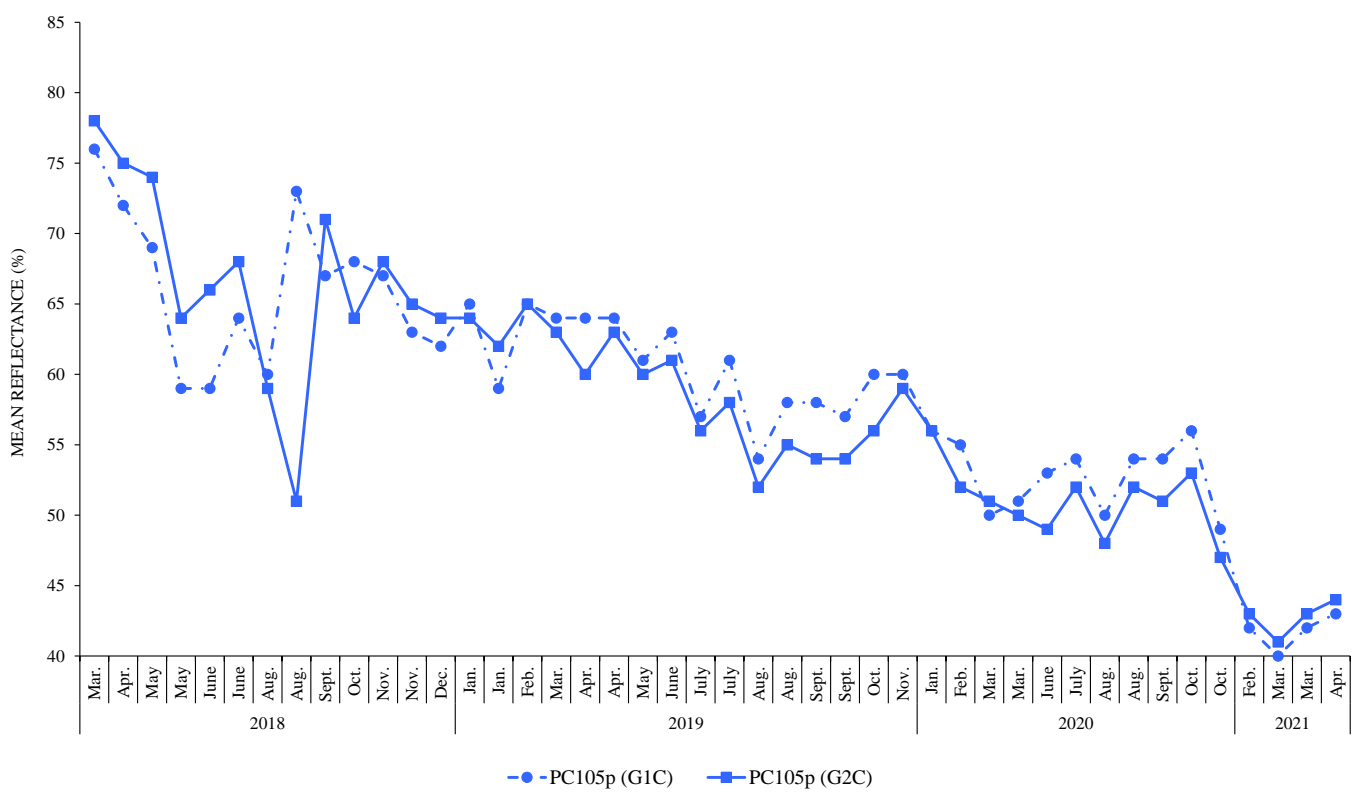

Note: PC105p

Source: Author (2021)

To the specimens with $\mathrm{TiO}_{2}$ suspensions applied, two critical points must be listed: i) the fluctuation in their reflectance indexes in the initial ages are lower when compared to the groups of painted and powder specimens and, ii) the specimens covered with $\mathrm{TiO}_{2}$ suspensions produced in the laboratory (P25s and PC105s) showed much fewer differences among their twins than the commercial suspensions (PC-S7s and E502s), demonstrating that 
the suspension prepared in the laboratory was more effective in producing the homogeneous material than commercial suspensions, as can be seen in Figures 11-14.

Figure 11. Long-term reflectance results for specimens with a suspension of $\mathrm{TiO}_{2}$

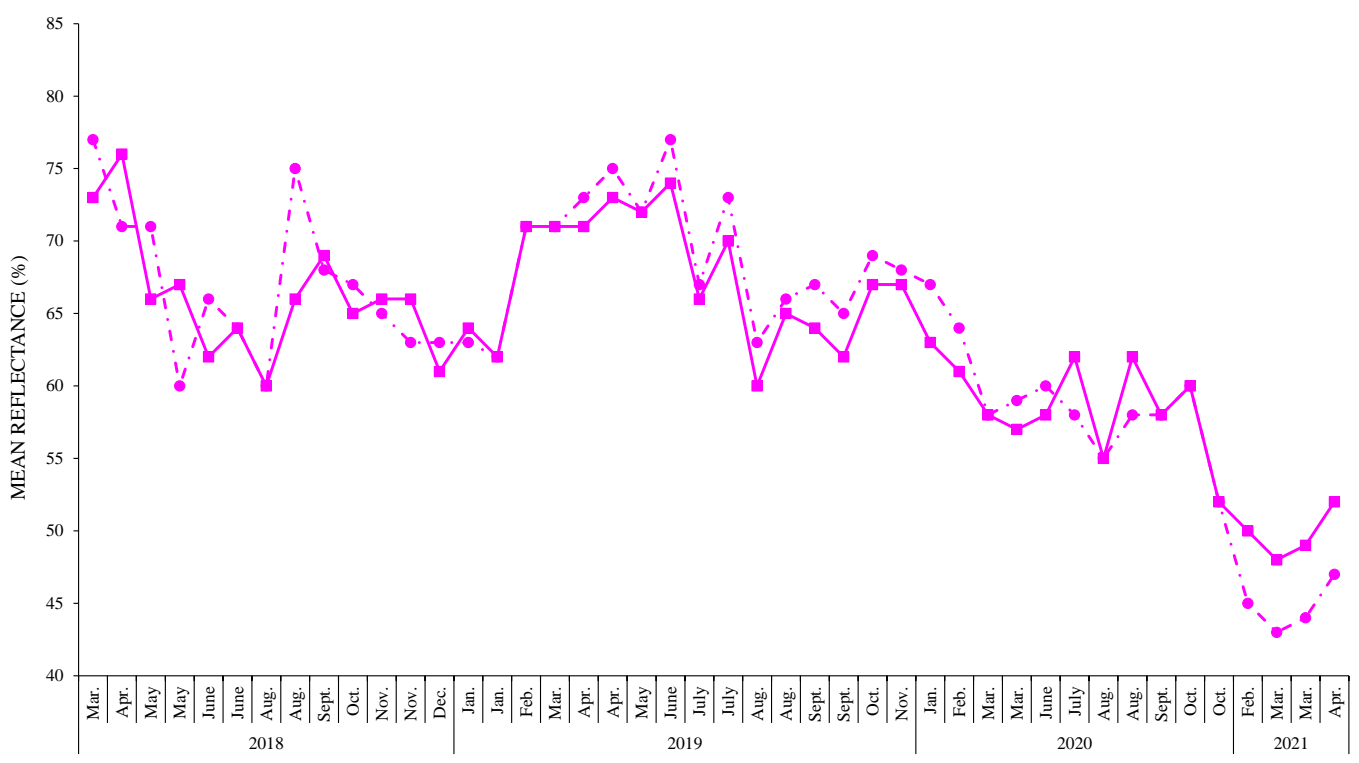

Note: Make in the laboratory - P25s

Source: Author (2021)

Figure 12. Long-term reflectance results for specimens with a suspension of $\mathrm{TiO}_{2}$

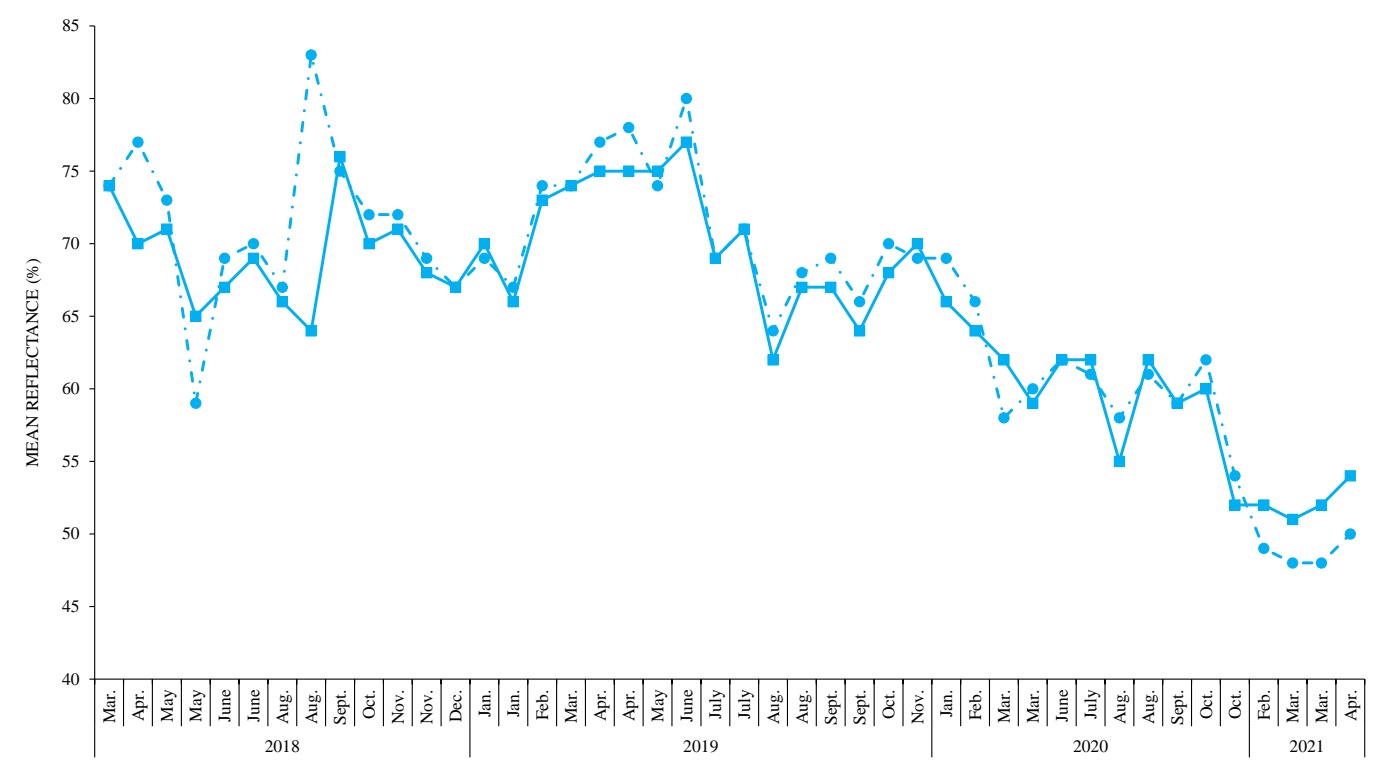

Note: Make in the laboratory - PC105s

Source: Author (2021) 
Figure 13. Long-term reflectance results for specimens with a suspension of $\mathrm{TiO}_{2}$

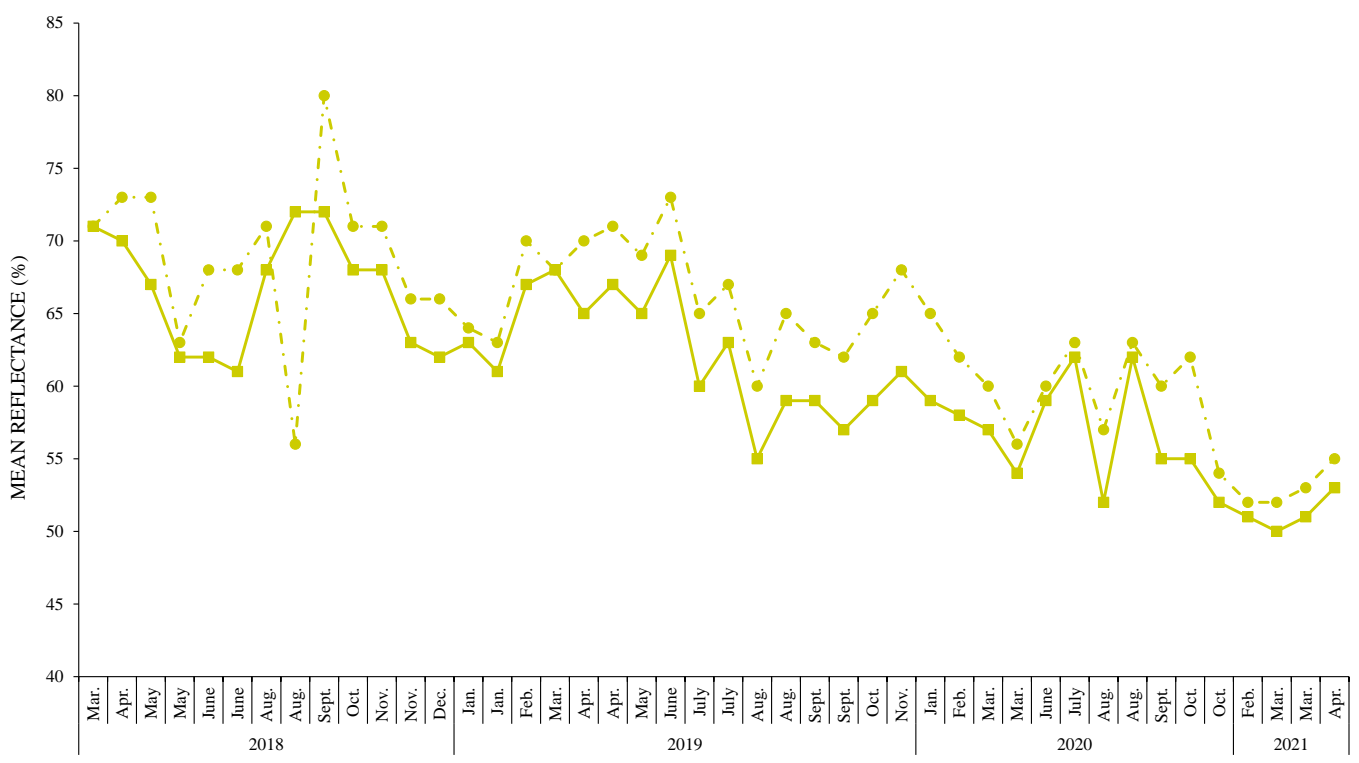

- - PC-S7s (G2D) $\quad-$-PC-S7s (G3D)

Note: Commercial - PC-S7s

Source: Author (2021)

Figure 14. Long-term reflectance results for specimens with a suspension of $\mathrm{TiO}_{2}$

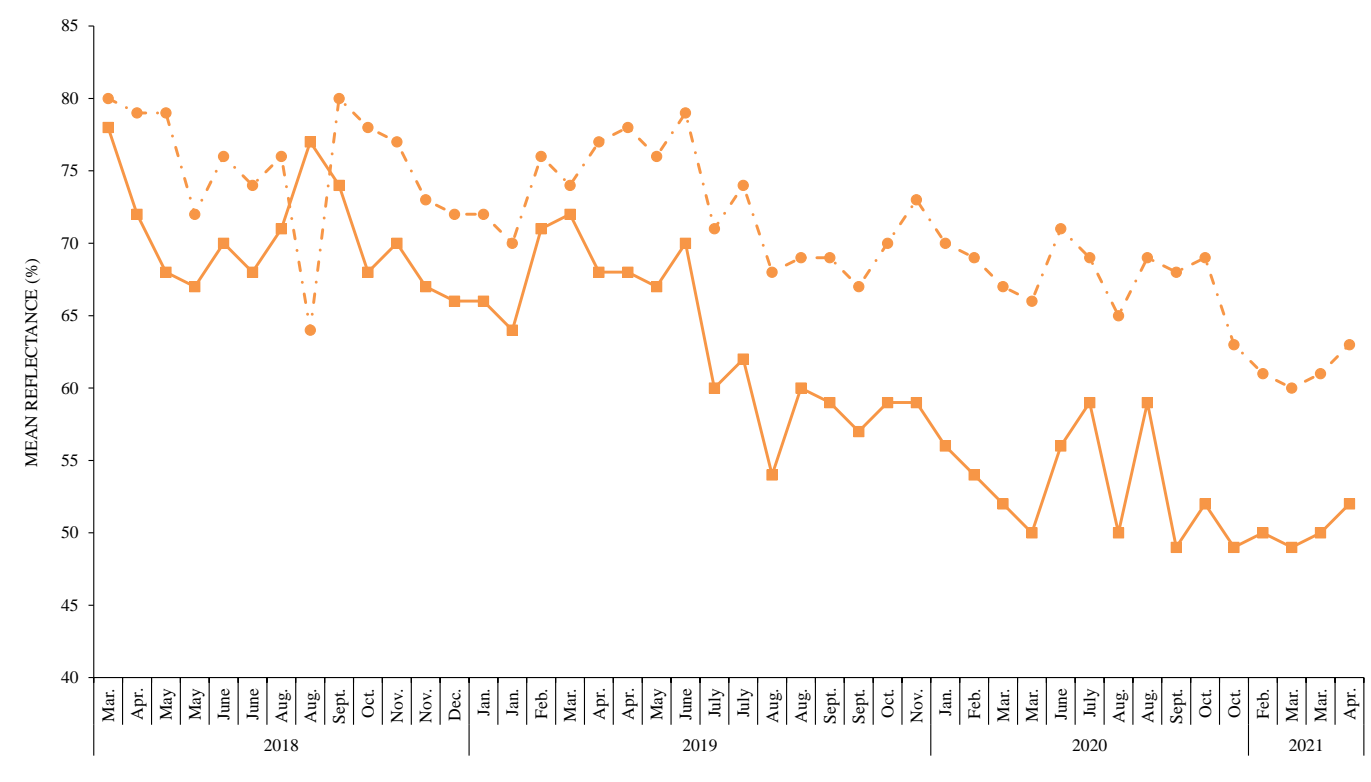

Note: Commercial - E502s

Source: Author (2021)

After the first months of the dissonance of the reflectance index in the specimens covered with the $\mathrm{TiO}_{2}$ suspension produced in the laboratory, a homogenization process occurs, where the slight initial differences disappear. Nevertheless, at the beginning of 2021, slight differences between them appear again, but not enough to classify them differently. On the other hand, among the specimens covered with $\mathrm{TiO}_{2}$ commercial suspensions, it is possible to 
observe that this homogenization never happened for the E502s twin specimens, showing large differences between them.

In the case of the specimens covered with the E502s suspension, it observed over the years is that they have presented a great difference between them accentuated over time. That behavior could be attached to the heterogeneity of the microstructure of $\mathrm{TiO}_{2}$ that compose the suspension, such as dimensions, amount and physical-chemical characteristics, or even, and more probably, attached to questions regarding the suspension's adhesion to the substrate (base), which allowed a good homogeneity of the material in one specimen. Simultaneously, the other showed defects, since the difference between both is 11 points, concerning the reflectance to solar radiation.

This adverse behavior presented by specimens covered with the E502s suspension may be related to the application process of the material; once even at the initial age, there is already a difference that is getting bigger as the twin specimens get older. When compared to the other specimens, even with fluctuations, these did not exhibit this systematic behavior presented by the E502s specimens, where it can be seen that the range created by the difference between the twin specimens is almost homogeneous in the first months. Afterward, it is very distant, differing totally from the other suspensions and other specimens in general.

To know the real difference in the specimens concerning reflectance to solar radiation, the angular coefficient of each specimen was calculated. With that, the reflectance variation lost over time of each specimen could be known. As was shown in the graphs over time, it observed that except for the examples covered by the E502s commercial suspension sample, the behavior of all pairs of specimens over the years concerning reflectance to solar radiation could be considered similar. In other words, with exception to the E502s suspension sample, that results to eliminate the possibility of influence of the twins in the final results of reflectance to solar radiation, as shown in Figures $15-17$. 
Figure 15. The angular coefficient for painted specimens

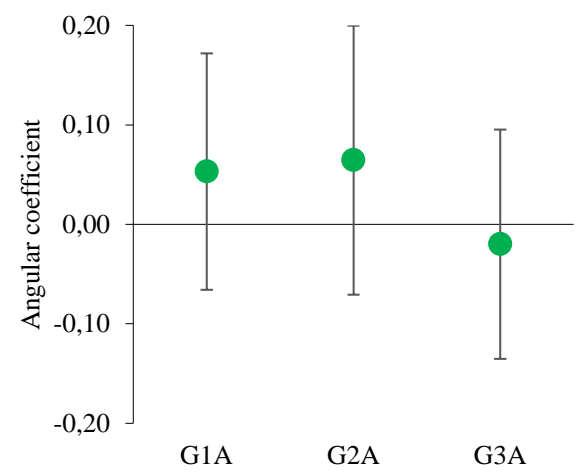

Source: Author (2021)

Figure 16. The angular coefficient for specimens with the addition of $\mathrm{TiO}_{2}$
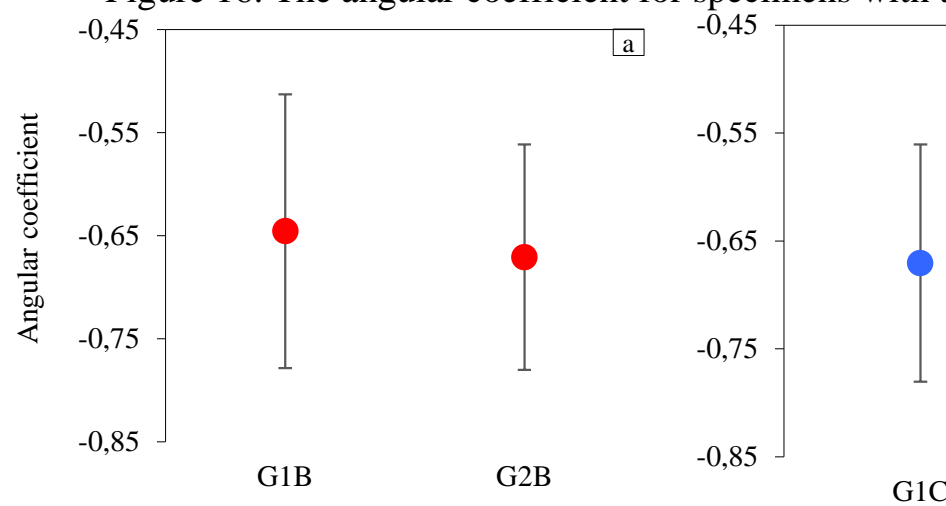

Note: P25p (a); PC105p (b)

Source: Author (2021)

Figure 17. The angular coefficient for specimens with the suspension of $\mathrm{TiO}_{2}$
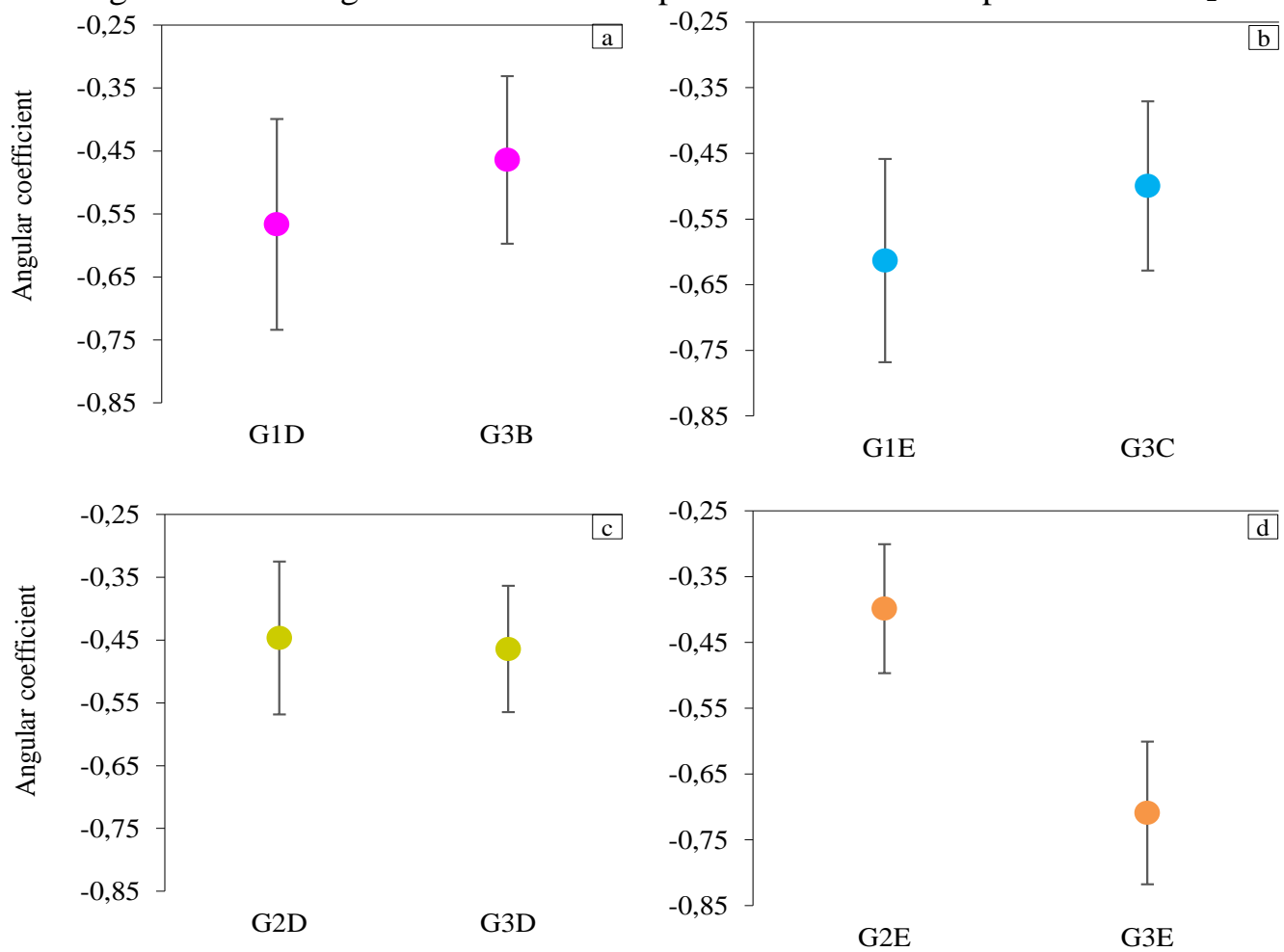

Note: Make in laboratory - P25s (a), PC105s (b); Commercial - PC-S7s (c), E502s (d)

Source: Author (2021) 


\subsection{Blocks of samples}

According to the behavior presented by each specimen and their peers over time, as well as the results found for angular coefficient analysis, it is possible to consider, in qualitative terms, for a better evaluation of the reflectance to solar radiation over time, the division of the specimens into three large blocks: (i) painted specimens (ref.), (ii) specimens with $\mathrm{TiO}_{2}$ suspensions applied (suspensions) and (iii) specimens with $\mathrm{TiO}_{2}$ added to the cementitious matrix (powder), as shown in Figure 18.

Figure 18. Mean reflectance results of the formed specimen blocks

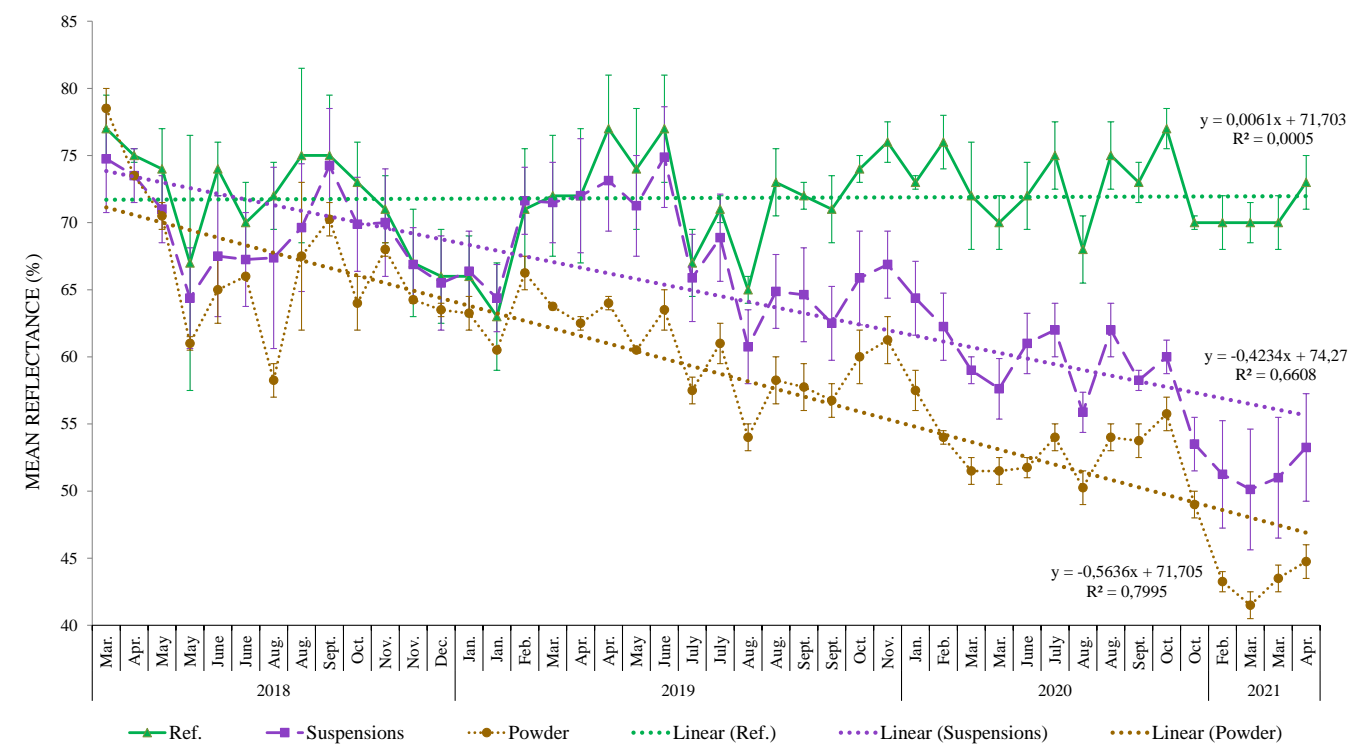

Note 1: Ref. (painted); Suspensions (P25s, PC105s, PC-S7s e E502s); Powder (P25p e PC105p).

Note 2: Error bars were represented around the mean.

Source: Author (2021)

When the specimens are graded in blocks, a more evident behavior of the three sets can be observed. From the error bars rating, the comparison between the three blocks verified that the significant difference between the specimens starts from February/19, as was observed previously. All the specimens were still mixed until this moment, as noticed in the mean reflectance measurement evaluation in Figure 5.

The ranking of the specimens in blocks proved that, as mentioned in the individual rating, from March/18 to August/19, the painted specimens and the specimens with $\mathrm{TiO}_{2}$ suspensions can be considered equal, presenting distance between them only from August/19. On the other hand, the block of specimens with $\mathrm{TiO}_{2}$ powders has already started to drop in performance since March/19, precisely one year after the beginning of their exposure. It was then maintaining this distance between the other specimens over the years, demonstrating 
metrologically through the error bars. Although oscillations allow a higher approximation between suspension blocks, they showed so far performed worse than the other specimens.

It is possible to say that all specimens changed their reflectance indexes during the years of exposure in general lines. However, if a line were drawn for the painted specimens block, a line parallel to the $\mathrm{X}$-axis can be seen. In contrast, we would have a downline for the others, as shown in Figure 18, indicating that the reflectance to solar radiation has not changed over the years for the painted specimens. On the other hand, the changes were significant to the specimens with the $\mathrm{TiO}_{2}$ suspension and specimens with $\mathrm{TiO}_{2}$ powder treatments, as cited by the authors in previous studies for the same exposure period [34].

\section{DISCUSSION}

Over the years, luminous efficacy has been used to precisely calculate illuminance from solar radiation measurements. Nevertheless, the measurement of light has not been widely utilized in meteorological stations. Therefore, methods for assessing illuminance on a horizontal surface using the measured total horizontal solar irradiance have been the subject of analysis for many researchers [42]

Considering that the whole process would occur in an ideal structure, in summary, the analysis of the results of reflectance to solar radiation would allow to us considered that: i) the participation of solar radiation, with the activation of $\mathrm{TiO}_{2}$ and, ii) the incidence of rains, completing the process of photocatalysis, besides the responsibility for carrying the dirt on the surface providing a cleaner surface, and therefore, whiter, causing a positive reflectance response. Thus, completing this cycle over time leads to lower maintenance costs and better building facade performance.

\subsection{Solar radiation and the reflectance measurements}

However, it is necessary to observe the actual participation of each phenomenon in this process, starting with solar radiation in the behavior of the specimens, as shown in Figure 19. 
Figure 19. Mean reflectance results and solar radiation on the horizontal surface

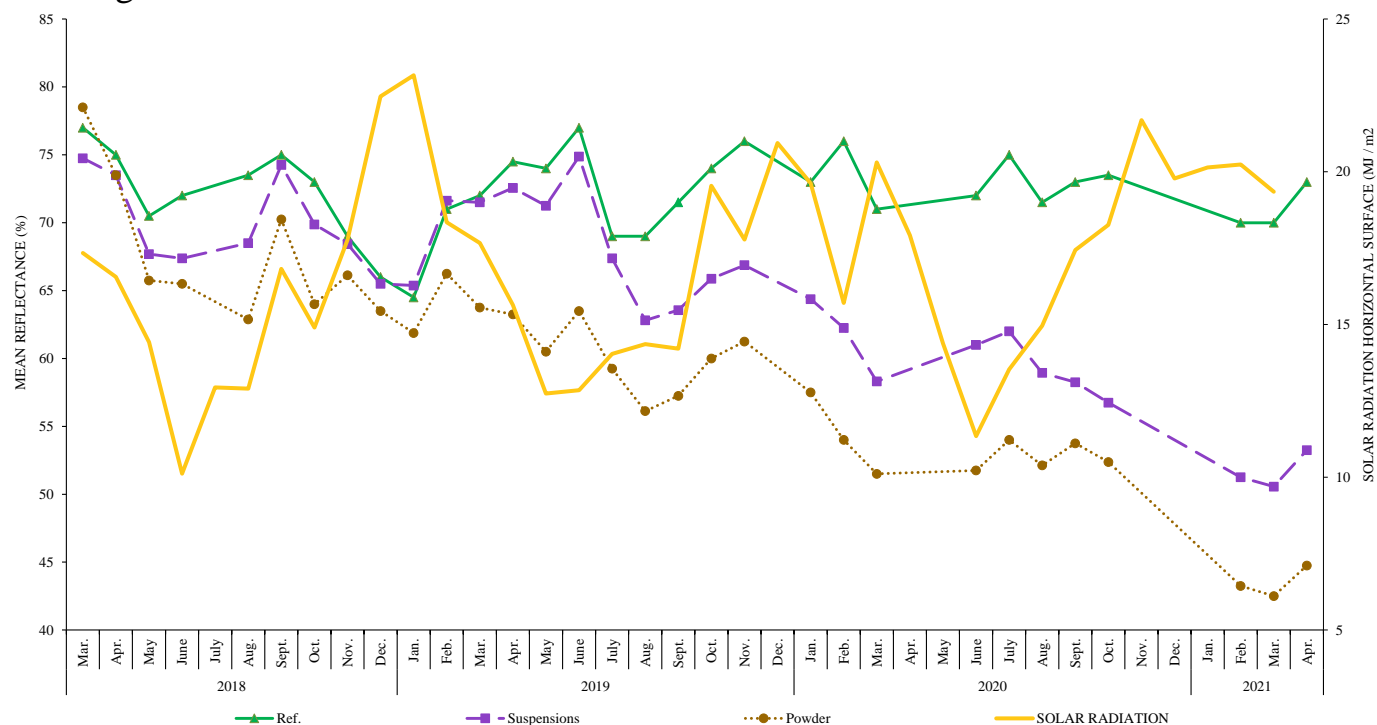

Source: Institute of Astronomy, Geophysics and Atmospheric Sciences (IAG) (2021)

A macroscopic analysis of radiation versus reflectance over time can be noticed that for the first months of exposure (March/18 to November/18), despite some intermittences, qualitatively speaking, when the solar radiation rates fall, the reflectance index of the specimens falls as well, and vice-versa. Nevertheless, from November/18 to January/19, there is a break in this logic, with solar radiation rising and the reflectance index of the specimens falling. Also, from February/19 to June/19, the same behavior happened in the last period, but with an inverted ratio, when the solar radiation falls, the reflectance of specimens rises, happening again from June/20. In other words, it seems a process that alternates. Nevertheless, the second period (November/18 to January/19) is different from what happens in the initial months (March/18 to November/18).

This behavior can demonstrate that they are independent phenomena, or the contrary, the whole time they would be floating together and not present the variations as was shown. The graph shows that it could have inverted phenomena (one goes up and the other goes down and vice-versa). However, this does not happen when rating the first period (March/18 to November/18). It has no separation of the axes. In other words, if it were a direct cause and effect relationship, the inversions observed from the second period (November/18 to January/19) should be present, even in the first period (March/18 to November/18).

The logical analysis says that if it's considered only the solar radiation to explain the behavior of reflectance indexes, the results show no correlation between the phenomena. Therefore, we believe that solar radiation does not explain the specimens' behavior that caused the measured reflectance indexes as a first point. Since, in the first period (March/18 to November/18), 
there is a fluctuation together indicating a cause-and-effect relationship (cause = radiation/effect $=$ reflectance), then showing in the subsequent periods an inverted cause and effect relationship, where this first period denies all the comes next.

In the second period (November/18 to January/19), it can be observed that the more global solar radiation, less reflectance index of the specimens and in the third period (February/19 to June/19) with the less global solar radiation (direct or indirect one), more reflectance index of the specimens. This occurrence is not reasonable because reasonableness says that the more solar radiation, the more $\mathrm{TiO}_{2}$ activation. Nevertheless, the periods presented do not seem to confirm such a direct relationship. Even though it can be justified by some physical or morphological phenomenon attached to the $\mathrm{TiO}_{2}$ behavior, the discussion is contrary to what is defended, which is, more global solar radiation (direct or indirect one), more photocatalysis happens. Thereby, what is expected is to see these surfaces cleaning more and with greater reflectance. So, be it by logic, more significant radiation - more excellent cleaning, the conclusion would be that there is no direct relationship between solar radiation and reflectance to solar radiation in that case.

Dantas et al. [36] found that the minimum of diffuse solar radiation is enough to activate the $\mathrm{TiO}_{2}$ particles and start the photocatalytic process. Suppose the minimum solar radiation in the first hours of the day is already capable of activating $\mathrm{TiO}_{2}$. The evaluation of the graph still has shown a drop in the reflectance rates. We can conclude that the results measured concerning the solar radiation in the specimens, certainly not, are allied only to solar radiation. Still, the accumulation of dirt on the specimens surfaces as well. That is, without carrying the dirt (dust, pollution) deposited on the surfaces of the specimens, what we have is a saturation of this dirt preventing the passage of sunlight to reactivating $\mathrm{TiO}_{2}$, and consequently, downing the reflectance indexes, even if the levels of solar radiation are high.

\subsection{Solar radiation and dirt saturation}

Still, according to Dantas et al. [36], $\mathrm{TiO}_{2}$ particles entrenched in nano valleys and microroughness of the coating can remain inactive due to the accumulation of dirt. That situation preventing the passage of UV rays and their consequent activation, thus, avoiding the photocatalysis process until these dirt particles, which for the most part have larger dimensions than $\mathrm{TiO}_{2}$, are oxidized and carried by rain.

Considering that the oxidation process through photocatalysis is slower than the deposition of dirt particles or the proliferation of certain fungi on surfaces of the specimens. Combining 
these points with the information previously discussed, we can evaluate more clearly why the reflectance does not seem to respond directly to the highest radiation index shown in Fig. 15. The reflectance index does not accompany the solar radiation index, not because there is no relationship with each other, but because the surfaces of the specimens have lots of dirt accumulation. Because of that accumulation, even though there is a high index to solar radiation available, the particles of $\mathrm{TiO}_{2}$ are covered by this dirt and are inactive states.

As with occurs in the water decontamination process by $\mathrm{TiO}_{2}$, where there is a problem known as poisoning ${ }^{18}$, here we take the same term to explain the situation in the surfaces of the specimens evaluated. In other words, there is the photocatalysis process being activated by solar radiation on the specimen's surfaces and consequent oxidation of pollutants. However, as the oxidated dirt is not being removed enough, it causes a saturation on their surfaces, leading to less and less oxidation of the pollutants and a low or no activation of $\mathrm{TiO}_{2}$. These events are causing poisoning of the photocatalytic process, and as a result, the drop of the indexes of reflectance to solar radiation.

By and large, we can consider that if on one side, there is solar radiation activating the photocatalysis process, but on the other side there is no rain or a very sharp drop in rainfall indexes, it will have a dirt accumulation, and the dropping the indexes of reflectance to solar radiation, leading by consequence the indication that there was no recovery on the part of the exposed surfaces.

\subsection{Rainfall and the self-cleaning}

It is known that solar radiation will activate $\mathrm{TiO}_{2}$. However, suppose there is an accumulation of dirt, and this dirt has been covering the particles of $\mathrm{TiO}_{2}$. In that case, a lack of rain will not happen self-cleaning since that accumulation of dirt will prevent the $\mathrm{TiO}_{2}$ from reactivating for a new oxidation process. In other words, the process decay until the surface is cleaned by rain or mechanical cleaning. Thereby, discuss rain is necessarily discussed self-cleaning. So, it is necessary to observe the relationship between the rain and the indexes of reflectance solar radiation on the specimens, as shown in Figure 20.

\footnotetext{
${ }^{18}$ Decrease in the catalytic activity of $\mathrm{TiO}_{2}$ during the photocatalysis process due to the saturation by the
} accumulation of oxidation by-products on the catalyst surface [43]. 
Figure 20. Mean reflectance results and total monthly rainfall

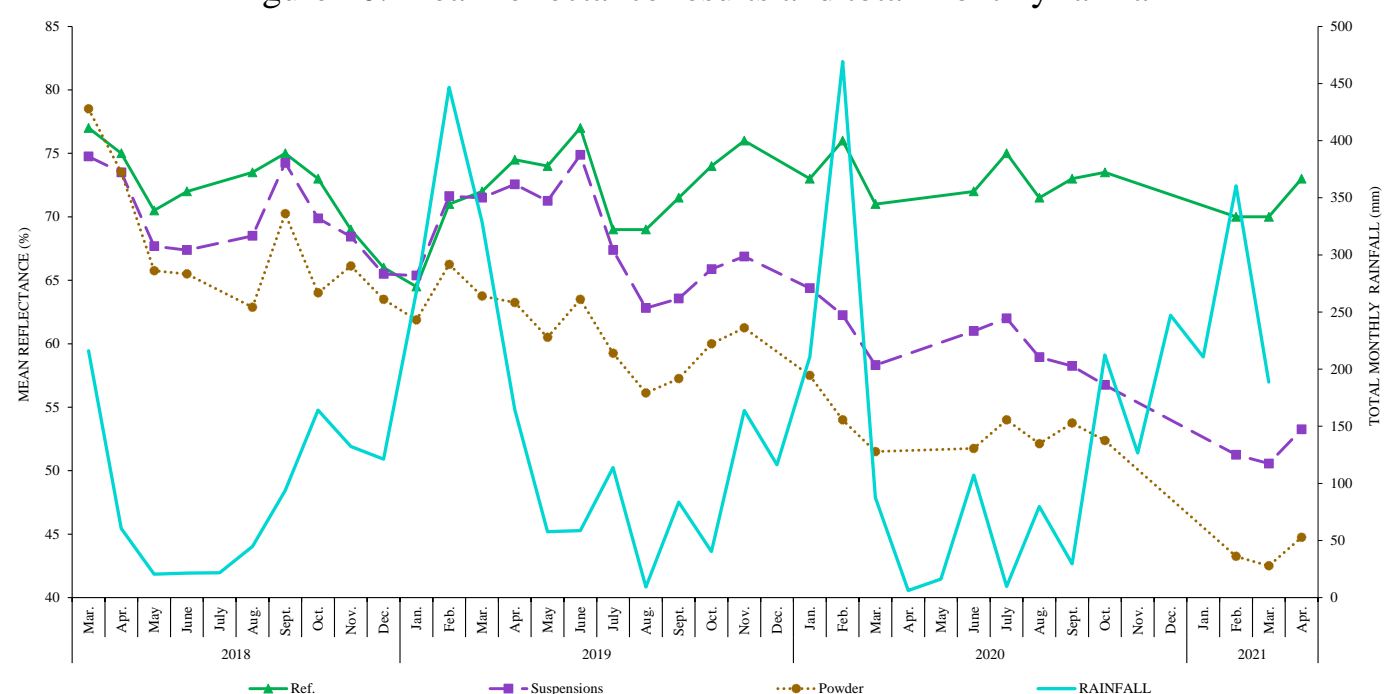

Source: Institute of Astronomy, Geophysics, and Atmospheric Sciences - IAG / Technological Center for Hydraulics - CTH (2021)

Applying the same logic used to solar radiation indexes, what is observed, in general, is that with the fall of the rain indexes, the indexes of reflectance to solar radiation fall as well. When the rainfall indexes rise, an improvement in the reflectance index starts at the same time. Until this point, the rain can be seen as the cause, raising or lowering the reflectance rates to solar radiation of the specimens, as shown in March/18 to November/18. Hence, this behavior indicates that it is the rain, effectively the parameter for the analysis until this moment.

The evaluation of the period from November/18 to March/19 reinforces this statement after almost five months of consecutive rain. The reflectance to the solar radiation index of the groups of painted specimens and the specimens with $\mathrm{TiO}_{2}$ suspensions returned their indexes close to their initial values. After that, gradually decreasing in the subsequent four months (April/18 to July/18), there is a period of little rain due to the dry season in São Paulo. According to what was seen in studies by Tang et al. [23] and Munafò, Godofredo, and Quagliarini [24], where the seasonal effects were observed, and a partial inhibition during the dry season and reactivation during the rainy season was noticed.

Two reasons can explain this recovery of the reflectance index to initial values for the groups of painted specimens and specimens with $\mathrm{TiO}_{2}$ suspension. Firstly, there were no large volumes of rain from March/18 to November/18. On the contrary, there was a sharp fall from June/18 to August/18 and a slight recovery in October/18, but not enough to cause great cleanliness of the exposed surfaces, which would justify the low retrieval of reflectance since they still presented a considerable degree of soiling. 
Changes between March/19 and July/19, where the painted specimens and specimens with $\mathrm{TiO}_{2}$ suspensions after being thoroughly cleaned by rain, have a remarkable recovery. That is, washings that occurred between November/18 and March/19 were so efficient that they raised the reflectance of these blocks to an initial situation, absolutely removing the entire layer of dirt oxidized and still present on the surfaces, allowing the $\mathrm{TiO}_{2}$ to be reactivated and causing the process as a whole constantly, that is, first photocatalysis and then self-cleaning of surfaces.

The other point refers to the physical condition of the specimens that allowed the indexes to recover. Until the period considered between March/18 and July/19, the specimens had a few more than a year of exposure. That time is not enough for there to be a physical deterioration of them. Neither of the films covers them, allowing these specimens to return their reflectance indexes to the initial condition.

For the group with $\mathrm{TiO}_{2}$ powder treatment, the same reasoning could not be applied since these specimens seem to undergo the process of deterioration (leaching, acid rain) of their surfaces more quickly. A point to be mentioned in favor is their durability on the surfaces over time. Although they present lower values than the other specimens, it was not possible to notice the loss of the film from the painted and suspensions that cover the specimens, which would demonstrate their value due to the permanence on the surface for more time.

Another aspect relates to studies made by Sleiman et al. [44], which observed that the reflectance of some products with high initial solar reflectance tended to lose. In contrast, others with very low initial solar reflectance tended to become more reflective as they aged. In the case of specimens treated with $\mathrm{TiO}_{2}$ powder sample, we talk about the permanence of the $\mathrm{TiO}_{2}$ on the specimens, while the film of the other specimens suffers a crack and consequent failure.

Although it can be seen that the reflectance to solar radiation of the film is falling over time, there has not yet been an abrupt drop to the point of showing the theory that the permanence of the powder $\mathrm{TiO}_{2}$ is more resistant. By and large, the rupture of the film covering the specimens causes a substantial fall in their reflectance index due to the sharp decay of the surfaces. That occurrence demonstrates that even though the surfaces with powder $\mathrm{TiO}_{2}$ show lower reflectance values to solar radiation, it may still be an advantage because it is still constant, even if on a smaller scale. 
Overall, when evaluating the following months (August/19 and September/19), we can confirm the cause and effect relationship between rainfall and the recovery of the specimens' reflectance to solar radiation indexes. Immediately after a period of heavy rain, the specimens respond to the phenomenon by raising their rates and decreasing when the rainfall volume is also low, showing this apparent cause and effect relationship. Revealing that the direct connection of self-cleaning is always with rain, while solar radiation, as previously indicated, will permanently activate photocatalysis, as long as it has the possibility of reaching the target, that is, the $\mathrm{TiO}_{2}$ particles.

\subsection{Specimens behaviors as to absorption caused by color}

The effect of the heat island can be counterbalanced by using reflective or light-colored materials on the surfaces of buildings, thereby increasing the albedo of the city as a whole and improving the indoor and outdoor thermal comfort of buildings. According to the Brazilian Association of Technical Standards - ABNT 15575/13 [45], in the case of wall absorption, in the absence of a definition in the project, the simulation should adopt as alternatives as: $\alpha=$ 0.3 (Low absorption), $\alpha=0.5$ (Medium absorption) and $\alpha=0.7$ (High absorption).

When these concepts are used to the mortars evaluated, it is possible to notice that when the reflectance to solar radiation index measured for the specimens with $\mathrm{TiO}_{2}$ powder treatment is compared to the painted examples, its great chance the final user would already perceive the difference in terms of thermal comfort of the building. That perception would happen considering the difference of $28.25 \%$ in their mean reflectance indexes to solar radiation measured in the beginning and final studies, indicating that these mortars are darker and consequently had more absorption than the specimens painted.

On the other hand, it would not happen if this comparison occurred between the block treated with the $\mathrm{TiO}_{2}$ suspension and the block with $\mathrm{TiO}_{2}$ powder treatment, which shows a difference of $8.5 \%$ in the mean index of reflectance to solar radiation when considered the same period and compared to each other. Therefore, for the final user, the thermal comfort sensation would be the same for both materials (powder and suspension) of $\mathrm{TiO}_{2}$, as shown in Figure 21. 
Figure 21. Adapted by ABNT 15575/13 [45] for the reflectance of opaque surfaces

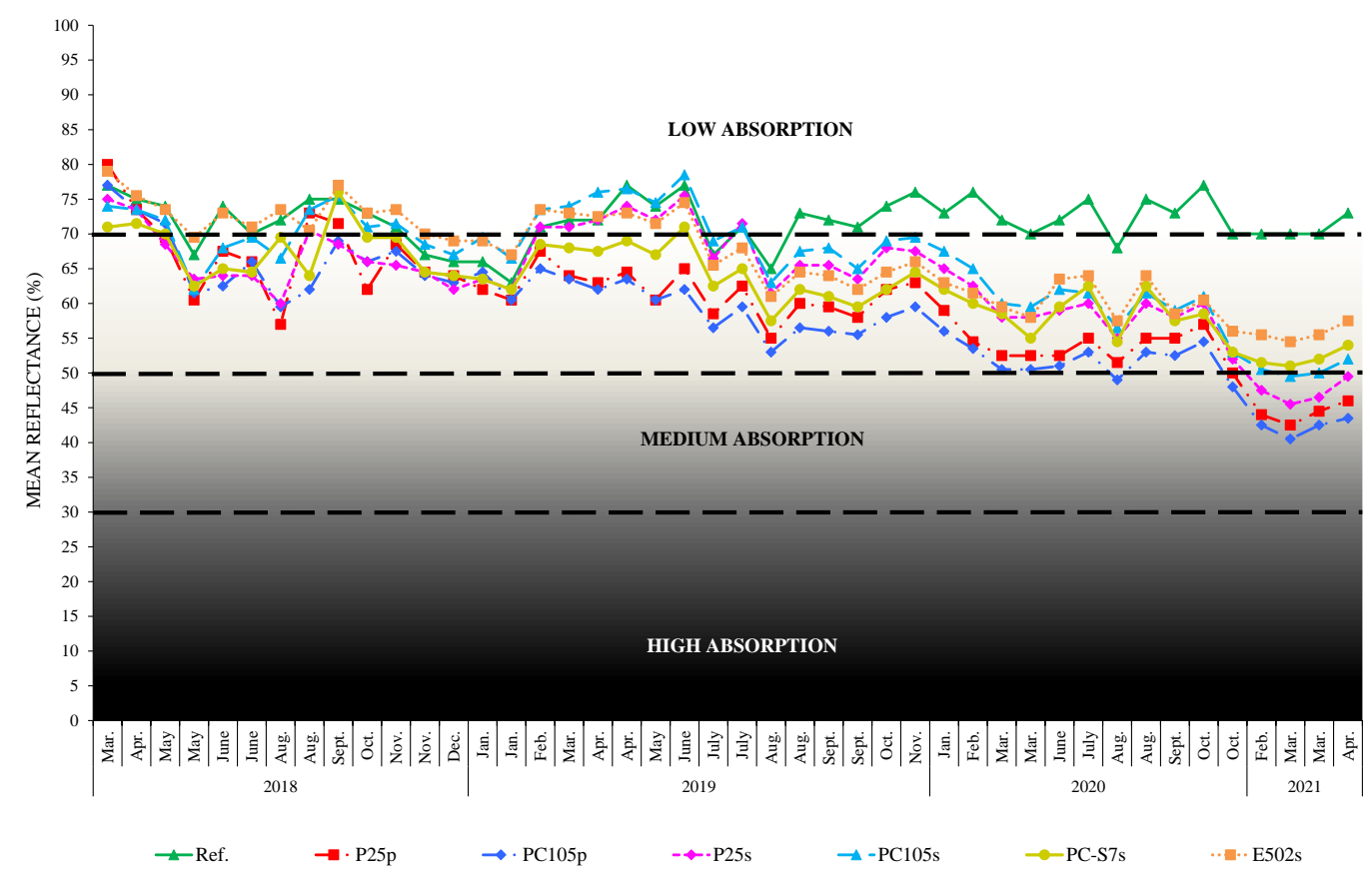

Note: $70 \%$ (Low absorption), 50\% (medium absorption) and 30\% (high absorption) Source: Author (2021)

Thus, from the point of view of the absorbance performance of building and taking the ranges indicated by the Brazilian Association of Technical Standards - ABNT, it is observed that the painted specimens can be considered with excellent performance after three years of exposure since they ending with $73 \%$ of their reflectance to solar radiation. On the other hand, according to the same standard, the specimens treated with the suspension and powder of $\mathrm{TiO} 2$ could be considered an average performance since they end with $53.25 \%$ and $44.75 \%$ of their reflectance to solar radiation after three years of exposure.

\section{CONCLUSIONS}

This study describes an approach for evaluating how the different types and treatments of $\mathrm{TiO}_{2}$ affect the maintenance of initial conditions in terms of its reflectance to solar radiation compared to painted on mortar surface-exposed long time. The main findings can be summarized as follows:

Painted specimens maintained their initial reflectance to solar radiation after three years of exposure ending with $73 \%$ of their index.

$>$ The comparison between the painted specimens with the specimens treated with $\mathrm{TiO}_{2}$ powder showed a difference between $28.25 \%$ regarding their reflectance to solar radiation. The final user would already perceive that difference in terms of absorption and color change. 
The comparison between the specimens treated with $\mathrm{TiO}_{2}$ in powder and specimens treated with $\mathrm{TiO}_{2}$ in suspension form shows a difference of $8.5 \%$ in reflectance index to solar radiation. The final user will not perceive the absorption and color change result and not indicate their preference since both showed the same effectiveness in mean after three years of exposure. 


\section{REFERENCE}

[1] AKBARI, H.; LEVINSON, R.; STERN, S. Procedure for measuring the solar reflectance of flat or curved roofing assemblies. Solar Energy, v.82, p. 648-655, 2008.

[2] SANTAMOURIS, M.; PAPANIKOLAOU, N.; LIVADA, I.; KORONAKIS, I.; GEORGAKIS, C.; ARGIRIOU, A.; ASSIMAKOPOULOS, D. N. On the impact of urban climate on the energy consumption of buildings, Solar Energy, v.70, p. 201-216, 2001.

[3] WERLE, A. P.; DE SOUZA, M. L.; LOH, K.; ANDO, R.; JOHN, V. M. The performance of a self-cleaning cool cementitious surface. Energy and Buildings, v. 114, p. $200-205$, 2016.

[4] SANTAMOURIS, M; FIORITO, F. On the impact of modified urban albedo on ambient temperature and heat related mortality. Solar Energy. V.216, p. 493-507, 2021

[5] GRANADEIRO, V.; ALMEIDA, M.; SOUTO, T.; LEAL, V.; MACHADO, J.; MENDES, A. Thermochromic Paints on External Surfaces: Impact Assessment for a Residential Building through Thermal and Energy Simulation. Energies. v.13, p.1912, 2020.

[6] SOUTO, T.; ALMEIDA, M.; VÍTOR LEAL, MACHADO, J.; MENDES, A. Total Solar Reflectance Optimization of the External Paint Coat in Residential Buildings Located in Mediterranean Climates. Energies, v.13, p. 2729, 2020.

[7] AOYAMA, T.; SONODA, T.; NAKANISHI, Y.; TANABE, J.; TAKEBAYASHI, H. Study on aging of solar reflectance of the self-cleaning high reflectance coating. Energy and Buildings. V. 157, p. 92-100, 2017.

[8] ROMEO, C.; ZINZI, M. Impact of a cool roof application on the energy and comfort performance in an existing non-residential building. A Sicilian case study, Energy and Building, v. 67, p. 647-657, 2013.

[9] BOCCALATTE, A.; FOSSA, M.; MÉNÉZO, C. Best arrangement of BIPV surfaces for future NZEB districts while considering urban heat island effects and the reduction of reflected radiation from solar façades. Renewable and Sustainable Energy Reviews, v.160, p. 686-697, 2020.

[10] BRETZ, S. E.; AKBARI, H. Long-term performance of high-albedo roof coatings. Energy and building, v. 25, p.159-167, 1997.

[11] WU, Y.; KRISHNAN, P.; ZHANG, M-H.; YU, L. E. Using photocatalytic coating to maintain solar reflectance and lower cooling energy consumption of buildings. Energy and Buildings, v. 164, p. 176 - 186, 2018.

[12] TRUFFIER-BOUTRY, D.; FIORENTINO, B.; BARTOLOMEI, V.; SOULAS, R.; SICARDY, O.; BENAYAD, A.; DAMLENCOURT, J.-F.; PÉPIN-DONAT, B.; LOMBARD, C.; GANDOLFO, A.; WORTHAM, A.; BROCHARD, G.; AUDEMARD, A.; PORCAR, L.; G. GEBEL, G.; GLIGOROVSKI, S. Characterization of photocatalytic paints: a relationship between the photocatalytic properties - release of nanoparticles and volatile organic compounds. Environmental Science Nano, v. 4, p. 1998 - 2009, 2017. 
[13] KUMAR, S.; VERMA, N. K.; SINGLA, M. L. 2013. Study on reflectivity and photostability of $\mathrm{Al}$-doped $\mathrm{TiO}_{2}$ nanoparticles and their reflectors. J. Mater. Res. v. 28 p. 521-528, 2013.

[14] PAOLINI, R.; BORRONI, D.; PEDEFERRI, M.; DIAMANTI, M. V. Self-cleaning building materials: The multifaceted effects of titanium dioxide. Construction and Building Materials. v.182, p. 126-133, 2018.

[15] SYNNEFA, A.; SANTAMOURIS, M. White or light colored cool roofing materials, Advanced Development Cool Materials Built Environment, v. p. 33-71, 2013.

[16] CHENG, M.-D.; MILLER, W.; NEW, J.; BERDAHL, P. Understanding the long-term effects of environmental exposure on roof reflectance in California. Construction and Building Materials, v. 26, p. 516-526, 2012.

[17] LEVINSON, R.; BERDAHL, P.; ASEFAWBERHE, A.; AKBARI, H. Effects of soiling and cleaning on the reflectance and solar heat gain of a light-colored roofing membrane. Atmospheric Environment, V. 39, p. 7807-7824, 2005.

[18] LEVINSON, RM; BERDAHL, PH; BERHE, A. A.; AKBARI, H. Effects of soiling and cleaning on the reflectance and solar heat gain of a light-colored roofing membrane. Atmospheric environment, v. 39, p. 7807-7824, 2005.

[19] BERDAHL, PH; AKBARI, H; ROSE, LS Aging of reflective roofs: soot deposition. Applied Optics, v. 41, p. 2355-2360, 2002.

[20] FERRARI, C.; TOUCHAEI, A, G.; SLEIMAN, M.; LIBBRA, A.; MUSCIO, A.; SILIGARDI, C.; AKBARI, H. Effect of aging processes on solar reflectivity of clay roof tiles, Advances in Building Energy Research, v.8, p. 28-40, 2014.

[21] FAVEZ, O.; CACHIER, H.; CHABAS, A.; AUSSET, P.; LEFEVRE, R. Crossed optical and chemical evaluations of modern glass soiling in various European urban environments. Atmospheric environment, v. 40, p. 7192-7204, 2006.

[22] SLEIMAN, M.; KIRCHSTETTER, TW; BERDAHL, P.; GILBERT, HE; QUELEN, S.; MARLOT, L.; PREBLE, CV; CHEN, S.; MONTALBANO, A.; ROSSELER, O.; AKBARI, H.; LEVINSON, R.; DESTAILLATS, H. Soiling of building envelope surfaces and its effect on solar reflectance-Part II: development of an accelerated aging method for roofing materials. Solar Energy Materials \& Solar Cells, v. 122, p. 271-281, 2014.

[23] TANG, X.; ROSSElER, O.; CHEN, S.; DE L'AULNOIT, S. H.; LUSSIER, M. J.; ZHANG, J.; BAN-WEISS, G.; GILBERT, H.; LEVINSON, R.; DESTAILLATS, H. Selfcleaning and de-pollution efficacies of photocatalytic architectural membranes. Applied Catalysis B: Environmental, v. 281, p. 119260, 2021.

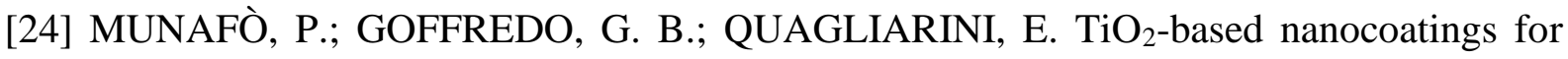
preserving architectural stone surfaces: An overview. Construction and Building Materials, v. 84 , p. $201-218,2015$. 
[25] PAOLINI, R.; ZINZI, M; POLI, T.; CARNIELO, E.; MAININI. A. G. Effect of ageing on solar spectral reflectance of roofing membranes: Natural exposure in Roma and Milano and the impact on the energy needs of commercial buildings. Energy and Buildings. v.84, p. 333-343, 2014.

[26] MIAO, L.; TANEMURA, S.; KONDO, Y.; IWATA, M.; TOH, S.; KANEKO, K. Microstructure and bactericidal ability of photocatalytic $\mathrm{TiO}_{2}$ thin films prepared by rf helicon magnetron sputtering. Applied Surface Science, v. 238, p. 125-131, 2004.

[27] TANEMURA, S.; MIAO, L.; WUNDERLICH, W.; TANEMURA, M.; MORI, Y.; TOH, S.; KANEKO, K. Fabrication and characterization of anatase/rutile- $\mathrm{TiO}_{2}$ thin films by magnetron sputtering: A review. Science Technology of Advanced Materials, v. 6, p. 11$17,2005$.

[28] JIANG, D.; ZHANG, S.; ZHAO, H. Photocatalytic Degradation Characteristics of Different Organic Compounds at $\mathrm{TiO}_{2}$ Nanoporous Film Electrodes with Mixed Anatase/Rutile Phases. Environmental Science Technology, v. 41, p. 303-308, 2007.

[29] OHTANI, T.; OGAWA, Y.; NISHIMOTO, S. Photocatalytic Activity of AmorphousAnatase Mixture of Titanium (IV) Oxide Particles Suspended in Aqueous Solutions. Journal Physical Chemistry B, v.101, p. 3746-3752, 1997.

[30] YU, J.; ZHAO, X.; DU, J.; CHEN, W. Preparation, microstructure and photocatalytic activity of the porous $\mathrm{TiO}_{2}$ anatase coating by sol-gel processing. Journal of Sol-Gel Science and Technology, v. 17, p. 163-171, 2000.

[31] NAM, H.; AMEMYIMA, T.; MURABAYASHI, M.; ITOH, K. Photocatalytic Activity of Sol-Gel $\mathrm{TiO}_{2}$ Thin Films on Various Kinds of Glass Substrates: The Effects of $\mathrm{Na}+$ and Primary Particle Size. Journal Physical Chemistry, v. 108, p. 8254-8259, 2004.

[32] KUBACKA, A.; COLÓN G.; FERNÁNDEZ-GARCÍA, M. Cationic (V, Mo, Nb, W) doping of $\mathrm{TiO}_{2}$-anatase: A real alternative for visible light-driven photocatalysts. Catalysis Today, v. 143, p. 286-292, 2009.

[33] NAVABPOUR, P.; OSTOVARPOUR, S.; TATTERSHALL, C.; COOKE, K.; KELLY, P.; VERRAN, J.; WHITEHEAD, K.; HILL, C.; RAULIO, M.; PRIHA, O. Photocatalytic $\mathrm{TiO}_{2}$, and Doped $\mathrm{TiO}_{2}$ Coatings to Improve the Hygiene of Surfaces Used in Food and Beverage Processing - A Study of the Physical and Chemical Resistance of the Coatings. Coatings, v.4, p. 433-449, 2014.

[34] DANTAS, S. R. A; VITTORINO, F; LOH, K. Photocatalytic Performance of White Cement Mortars Exposed in Urban Atmosphere, Global Journal of Research in Engineering: C (Chemical Engineering), v.19, Issue 2, version 1, p.1-13, 2019.

[35] DANTAS, S. R. A.; LIMA, F. J. N. de; ROMANO, R. C. de O.; PILEGGI, R.; LOH, K. Evaluation of rheological properties of mortar with $\mathrm{TiO}_{2}$ addition. Ambiente Construído, Porto Alegre, v. 21, n. 4, p. 7-21, out./dez. 2021. ISSN 1678-8621 Associação Nacional de Tecnologia do Ambiente Construído. 
[36] DANTAS, S. R. A.; ROMANO, RC DE O.; VITTORINO, F.; LOH, K. Effects of surface roughness and light scattering on the activation of $\mathrm{TiO}_{2}$ on mortar photocatalytic process. Construction and Building Materials, v. 270, p. 121421, 2021.

[37] DANTAS, S. R. A; SERAFINI, R; ROMANO, R. C. de O; VITTORINO, F; LOH, K. Influence of the nano $\mathrm{TiO}_{2}$ dispersion procedure on fresh and hardened rendering mortar properties, Construction and Building Materials, v.215, p.544-556, 2019.

[38] AMERICAN SOCIETY FOR TESTING AND MATERIAL - ASTM. C1365-06: Standard Test Method for Determination of the Proportion of Phases in Portland cement and Portland-Cement Clinker Using X-ray Powder Diffraction Analysis, 2011.

[39] BRAZILIAN ASSOCIATION OF TECHNICAL STANDARDS - ABNT. NBR 14656: Portland cement and raw materials - Chemical analysis by X-ray spectrometry - Test method, Rio de Janeiro, 2001 (in Portuguese).

[40] AMERICAN SOCIETY FOR TESTING AND MATERIAL - ASTM. E1918-16 "Standard Test Method for Measuring Solar Reflectance of Horizontal and Low-Sloped Surfaces in the Field." 2016.

[41] AMERICAN NATIONAL STANDARDS INSTITUTE / AMERICAN SOCIETY OF HEATING, REFRIGERATING, AND AIR CONDITIONING ENGINEERS - ANSI/ ASHRAE 74 (1988) - "Method for Measuring Solar Optical Properties of Materials, procedure E."

[42] HEIM, D; KNERA, D. A novel photometric method for the determination of reflected solar irradiance in the built environment. Renewable and Sustainable Energy Reviews, v.137, p.110451, 2021.

[43] MALATO, S.; FERNÁNDEZ-IBÁÑEZ, P.; MALDONADO, M.I.; BLANCO, J.; GERNJAK, W. Decontamination and disinfection of water by solar photocatalysis: Recent overview and trends. Catalysis Today, v. 147, p. 1 - 59, 2009.

[44] SLEIMAN, M.; BAN-WEISS, G.; GILBERT, HE; FRANCOIS, D.; BERDAHL, P.; KIRCHSTETTER, TW; DESTAILLATS, H.; LEVINSON, R. Soiling of building envelope surfaces and its effect on solar reflectance-Part I: Analysis of roofing product databases. Solar Energy Materials \& Solar Cells, v. 95, p. 3385 - 3399, 2011.

[45] BRAZILIAN ASSOCIATION OF TECHNICAL STANDARDS - ABNT. NBR 15575: Residential buildings - Performance - Part 1: General requirements, Rio de Janeiro, 2013 (in Portuguese). 


\title{
APPENDIX G - MAINTENANCE OF INITIAL LIGHTNESS ON MORTARS TREATED WITH $\mathrm{TiO}_{2}$ IN THE LONG TERM ${ }^{19}$ (Article G)
}

\begin{abstract}
The importance of colors is not limited to the aesthetic but also other parameters like thermal comfort. Painting of light colors on the building's external surfaces increases its reflection to the solar radiation, reducing the heat gains, while dark colors can increase solar heat gains absorbing more radiation. Regarding the $\mathrm{TiO}_{2}$ answer to the lightness on the facade different samples of $\mathrm{TiO}_{2}$ were tested. First, in the laboratory as to methylene blue dye degradation and second in a natural environment using different forms of treating (suspension and powder) on mortars, measured by a spectrophotometer over three years to determine the loss of lightness over time. The methylene blue test showed that the $\mathrm{TiO}_{2}-\mathrm{P} 25 \mathrm{p}, \mathrm{TiO}_{2}-\mathrm{PC}-\mathrm{S} 7 \mathrm{~s}$, and $\mathrm{TiO}_{2}-\mathrm{E} 502 \mathrm{~s}$ samples had the same effectiveness after exposure to artificial UV radiation, while the $\mathrm{TiO}_{2}$ PC105p sample presented the worst performance. Concerning the lightness, after thirty-seven months of the natural exposition, the white painted specimens had the best results than specimens with $\mathrm{TiO}_{2}$ suspensions and specimens with $\mathrm{TiO}_{2}$ in powder. Beyond, regarding the absorptivity, the white painted specimens could be considered with low absorptivity, while the specimens treated with $\mathrm{TiO}_{2}$ suspension and those treated with $\mathrm{TiO}_{2}$ powder could be as medium absorptivity. About the visual aesthetic perception, the study concludes that for the final user, there is no significant difference in white painted specimens, while for the other (powder and suspension), the color difference can be noticed very well in three years of exposure.
\end{abstract}

Keywords: Lightness. $\mathrm{TiO}_{2}$ treatments. Color difference. Aesthetic aging. Sooty effect.

\footnotetext{
${ }^{19}$ S. R. A. Dantas, F. Vittorino, K. Loh. Maintenance of initial lightness on mortars treated with $\mathrm{TiO}_{2}$ in the long term. Solar Energy Journal.

Manuscript Number: SEJ-D-21-02211 - Under Review
} 


\section{INTRODUCTION}

Materials used on the facades respond to the building's visual aesthetic condition and have an essential role in their thermal balance and, consequently, the city. The use of specific materials that present high reflectivity values reduces thermal gains and results in an efficient passive technique to reduce demand for electrical energy in the thermal conditioning of environments [1-4].

The use of retroreflective (RR) materials have demonstrated as higher cooling potential than traditional coatings, and new coatings as the thermochromic coatings, can respond thermally to the environment and change reversibly their color presenting high advantages, show itself as another option in the war against the heat gains by the buildings $[1,5,6]$.

In addition, cool white coatings and white membranes can reach an average of $45^{\circ} \mathrm{C}$, depending on local ambient conditions [1]. On the other hand, dark colors applied to exterior surfaces can increase solar heat gains absorbing more radiation, impacting the buildings' energy performance and the outdoor air temperatures [6,7].

Therefore, the goal is to search for technologies that allow more excellent durability of external coatings minimizing the effect of pollution, which helps in the thermal control of buildings without requiring major interventions in terms of maintenance. In this aspect, advanced photocatalytic oxidation (POA) using $\mathrm{TiO}_{2}$ may offer a solution in maintaining that facades for longer, saving time and money on cleanings and restorations, beyond enhances the brightness of the materials given the $\mathrm{TiO}_{2}$ high refractive index [8-10].

Visual aesthetic perception is the capacity to visually perceive a particular attribute added to other features of objects, such as form, color, and movement. The perceptions are part of the result of the one visual system where the information is originating in the photoreceptors and processed by multiple layers of receptive fields and opponent combinations, producing the basis for visual perceptions, among which are includes brightness, lightness, color, depth, and movement $[11,12]$.

Also, the color perception changes significantly with ambient light conditions and depends on several factors $[13,14]$. To the Human Visual System (HVS) model, the color depends on the physical characteristics of the electromagnetic radiation that reaches the retina, where the perception process becomes a mental phenomenon and no longer a physical phenomenon. Thus, because it is a subjective phenomenon, the sensation of color also depends on the 
observer, since in bright sunlight, the colors tend to be of less contrast than in indoor light, for instance $[14,15]$.

Considering that the human eye is much more sensitive to lightness than chromaticness, if the energy emitted by the source is low, the color will appear as a more or less dark shade. If the energy is high, the color will be perceived as vivid and brilliant. So, adding to the emitted color a white light (e.g., sunlight), whose spectral energy density is more or less uniform at all wavelengths, the color will become all the paler and more whitish the higher this spectral density concerning pure color energy [16].

Thus, the main question is how to relate color by visual evaluation with results obtained with instrumental equipment, and the CIELAB color space may be the solution. The CIELAB color space has an important characteristic; the measured distance between colors in this space is a good approximation of perceived visual distance. To sum up, the perceived color threshold, known as Just Noticeable Difference (JND), can be used to increase the correlation of objective assessments (equipment) with subjective assessments (visual evaluation), since when calculating the distance between colors, the JND is the threshold from which two colors are perceived as distinct colors by the human eye [17].

However, since the perception of appearance includes concepts of color and translucency, the simple specification of the three-color parameters by an instrument for a given illumination and observation geometry would be incomplete to determine the appearance of a translucent material. The lack of a clear delimitation between the visual evaluation criteria and the color difference by instrumental colorimetry indicates that other factors besides the color difference alone can influence the visual perception [18].

So, concerning all until here exposed, this research measured the effectiveness of different types of $\mathrm{TiO}_{2}$ with distinct application forms - either in powder and suspension - on mortar surfaces exposed to a natural environment in the long term as a function to maintain their initial lightness conditions.

\section{MATERIAL AND METHODS}

\subsection{Materials}

The mixtures were the same used in previous studies [19,20] and were prepared using white Portland cement (WHITE CEM I 52.5R EN 197-1), dolomites \#20, \#40, and \#80, commercial air-entraining agent based on lauryl sulfate molecules, water retention agents based on cellulosic ether molecules, polypropylene microfibers, and different samples of $\mathrm{TiO}_{2}$ (powder 
and suspension) form. The amount of all these raw materials was kept constant, but the water content of each mixture was modified to maintain mortar consistency, as was evaluated in Dantas et al. [20].

\subsection{Materials characterization}

Table 1 shows the specific surface area, real density, and the parameters related to the particle size for raw materials, while Figure 1 illustrates the particle size distribution. All the tests were performed following Dantas et al. [19-21] and show again to the reader's convenience.

Table 1 - Characteristics of the raw materials

\begin{tabular}{lccccc}
\hline Material & \multicolumn{3}{c}{ Particle Size $(\mu \mathrm{m})$} & $\begin{array}{c}\text { Specific surface area } \\
\left(\mathrm{m}^{2} / \mathrm{g}\right)\end{array}$ & $\begin{array}{c}\text { Average density } \\
\left(\mathrm{g} / \mathrm{cm}^{3}\right)\end{array}$ \\
\hline White Portland cement & 2.6 & 17.7 & 19.5 & 0.86 & 3.05 \\
Dolomite \#20 & 975 & 1242 & 1620 & 0.16 & 2.90 \\
Dolomite \#40 & 24.3 & 230 & 740 & 0.56 & 2.94 \\
Dolomite \#80 & 4.5 & 38.3 & 134 & 0.80 & 2.81 \\
$\mathrm{TiO}_{2}$ (P25 - powder) & 1.38 & 3.90 & 17.7 & 49.4 & 3.84 \\
$\mathrm{TiO}_{2}$ (PC105 - powder) & 0.66 & 1.50 & 4.60 & 79.8 & 3.62 \\
$\mathrm{TiO}_{2}$ (PC-S7 - suspension) & 0.06 & 0.09 & 0.12 & 70.7 & --- \\
$\mathrm{TiO}_{2}$ (E502 - suspension) & 4.09 & 8.60 & 17.25 & 0.82 & -- \\
\hline $\mathrm{S}_{50}$ & & & & & \\
\hline
\end{tabular}

Source: Dantas et al. [19]

Figure 1. Particle size distribution of materials

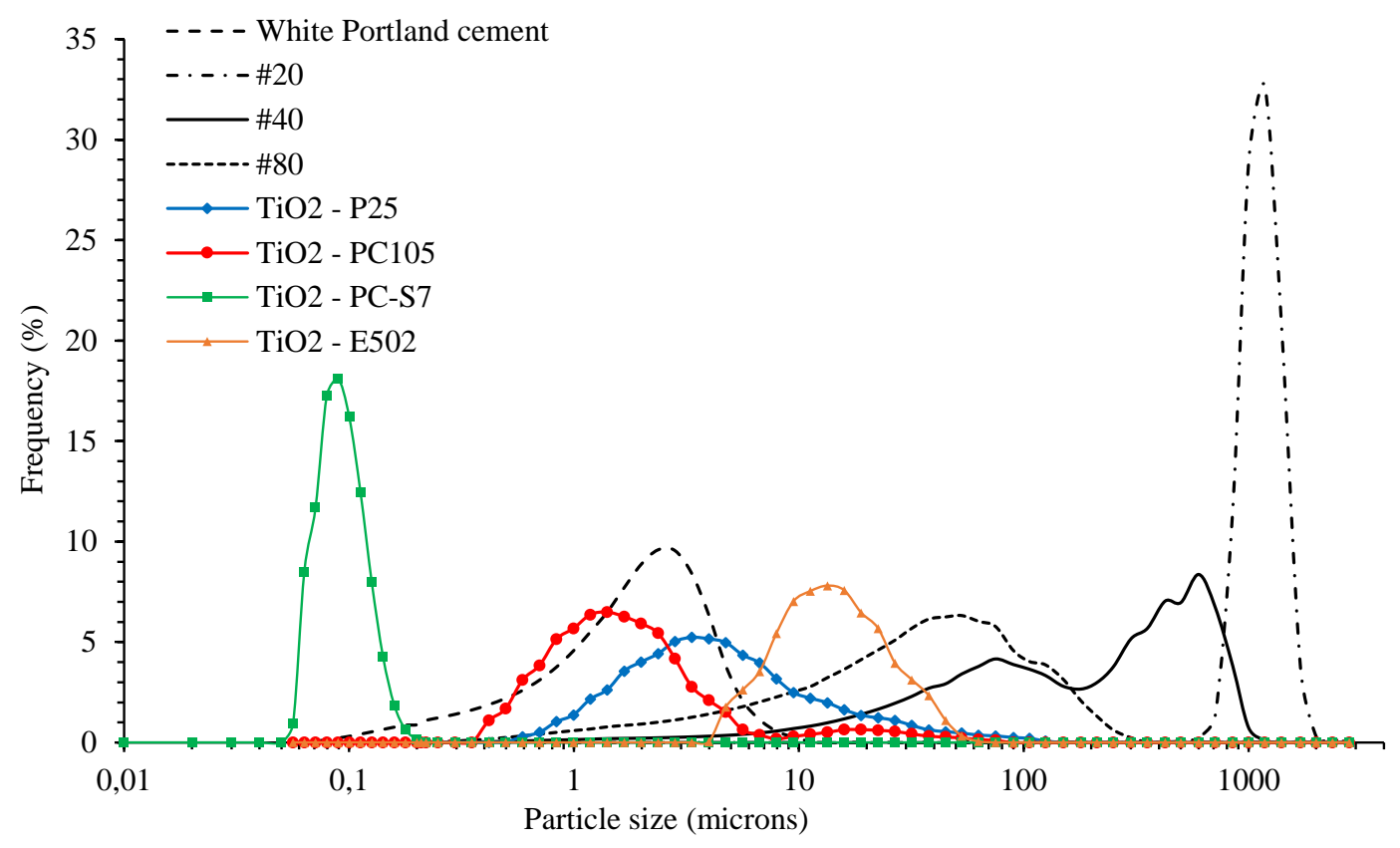

Source: Dantas et al. [19] 
Figure 2 shows the X-ray diffraction (XRD) of white Portland cement (WPC) and $\mathrm{TiO}_{2}$ samples, according to ASTM C1365-06 [22]. The equipment used was the Rigaku model Windmax 1000, operating on copper $\mathrm{K} \alpha$ rad radiation with $40 \mathrm{kV}-20 \mathrm{~mA}$ and $2 \%$ min sweep. Table 2 presents the amount of cement Portland and the phases of $\mathrm{TiO}_{2}$ using the Rietveld method.

Figure 2. X-ray diffractograms of $\mathrm{WPC}$ and $\mathrm{TiO}_{2}$ samples

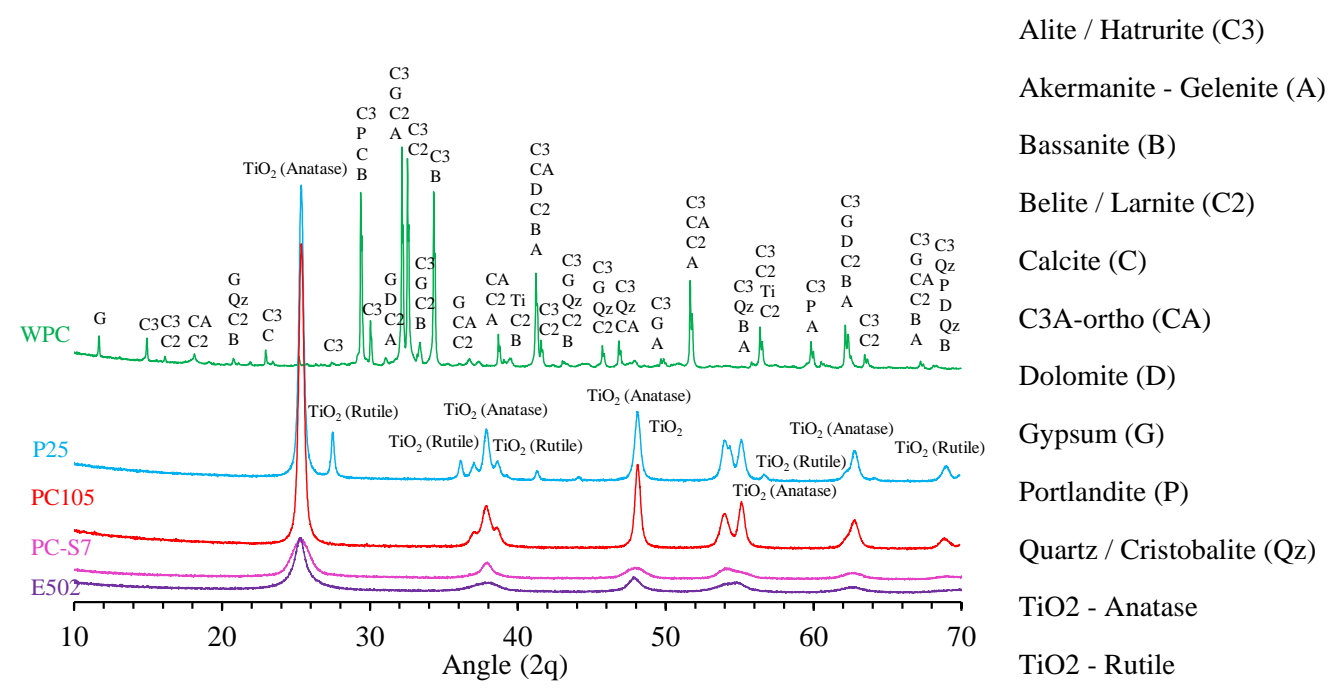

Source: Author (2021)

Table 2 - Phases observed in WPC and $\mathrm{TiO}_{2}$ samples

\begin{tabular}{llccc}
\hline \multicolumn{1}{c}{ Sample } & \multicolumn{1}{c}{ Phase } & ICSD code & ICDD code & $\%$ \\
\hline \multirow{5}{*}{ WPC } & Alite & $81100 / 22501$ & - & 67.5 \\
& Akermanite & 160345 & - & 0.2 \\
& Bassanite & - & $96-101-0919$ & 0.5 \\
& Belite & 421708 & - & 18.6 \\
& Calcite & - & $96-901-6707$ & 4.3 \\
& C3A-ortho & 6287 & - & 1.9 \\
& Gypsium & 27876 & - & 3.3 \\
PC105p & Portlandite & 202223 & - & 1.9 \\
P25p & Quartz & - & $96-900-6688$ & 0.6 \\
PCS7s & Anatase & 93098 & - & 100 \\
E502s & Anatase / Rutile & $202243 / 51938$ & - & $87.8 / 12.2$ \\
\hline Auch & Anatase & $82080 / 202243$ & - & $29.5 / 70.5$ \\
\hline
\end{tabular}

Source: Author (2021)

Table 3 shows the chemical composition of samples of $\mathrm{TiO}_{2}$ determined by semi-quantitative chemical analysis by X-ray fluorescence (XRF) following the Brazilian Association of Technical Standards - ABNT 14656-01 [23].

Table 3-Chemical composition of samples by XRF

\begin{tabular}{ccccccc}
\hline \multirow{2}{*}{ Compound } & WPC & P25 & PC105 & PC-S7 & E502 & Limited NBR \\
& $(\%)$ & $(\%)$ & $(\%)$ & $(\%)$ & $(\%)$ & $16697 / 18$ \\
\hline
\end{tabular}




\begin{tabular}{|c|c|c|c|c|c|c|}
\hline LOI & 2.48 & --- & --- & --- & --- & $\leq 27.0$ \\
\hline $\mathrm{TiO}_{2}$ & --- & 99.7 & 99.6 & 96.1 & 90.6 & --- \\
\hline $\mathrm{SiO}_{2}$ & 21.6 & 0.25 & --- & 0.21 & 1.17 & --- \\
\hline $\mathrm{Al}_{2} \mathrm{O}_{3}$ & 4.60 & --- & 0.12 & 0.09 & 0.46 & --- \\
\hline $\mathrm{FeO}_{3}$ & 0.33 & 0.02 & 0.03 & --- & --- & --- \\
\hline $\mathrm{CaO}$ & 67.5 & --- & --- & 0.14 & 1.21 & --- \\
\hline $\mathrm{MgO}$ & 0.59 & --- & --- & 0.20 & 0.64 & $\leq 10.0$ \\
\hline $\mathrm{SO}_{3}$ & 2.83 & --- & --- & --- & --- & $\leq 4.5$ \\
\hline $\mathrm{Na}_{2} \mathrm{O}$ & 0.13 & --- & --- & --- & --- & --- \\
\hline $\mathrm{K}_{2} \mathrm{O}$ & 0.61 & --- & --- & --- & --- & --- \\
\hline $\mathrm{Na}_{2} \mathrm{O}$ & 0.53 & --- & --- & --- & --- & --- \\
\hline $\mathrm{CaO}$ & 2.26 & --- & --- & --- & --- & --- \\
\hline RI & 0.43 & --- & --- & --- & --- & $\leq 7.0$ \\
\hline $\mathrm{CO}_{2}$ & 0.67 & --- & --- & --- & --- & $\leq 27.0$ \\
\hline $\mathrm{P}_{2} \mathrm{O}_{5}$ & --- & --- & --- & 2.77 & 4.28 & --- \\
\hline $\mathrm{ZrO}$ & --- & --- & 0.03 & 0.04 & --- & --- \\
\hline $\mathrm{Nb}_{2} \mathrm{O}_{5}$ & --- & --- & 0.26 & 0.41 & --- & --- \\
\hline $\mathrm{CdO}$ & --- & --- & --- & 0.13 & --- & --- \\
\hline $\mathrm{V}_{2} \mathrm{O}_{5}$ & --- & --- & --- & --- & 1.56 & --- \\
\hline $\mathrm{CuO}$ & --- & 0,02 & 0.03 & --- & --- & --- \\
\hline $\mathrm{Er}_{2} \mathrm{O}_{3}$ & --- & --- & 0.10 & --- & --- & --- \\
\hline
\end{tabular}

Note: Alkaline equivalent (in $\left.\mathrm{Na}_{2} \mathrm{O}\right)=\% \mathrm{Na}_{2} \mathrm{O}+0.658 \% \mathrm{~K}_{2} \mathrm{O} / \mathrm{LOI}$ : Loss on ignition.

Source: Author (2021)

According to Figure 2 and Table 2, it is possible to observe that except for the $\mathrm{TiO}_{2}-\mathrm{P} 25 \mathrm{p}$ sample that shows two crystalline phases (anatase and rutile), all other samples have the same crystalline phase (anatase). It is well known that these two principal phases exhibit different photocatalytic performances and hopes that a mixture of them shows a more pronounced catalytic effect [24]. Besides, the crystalline phases of $\mathrm{TiO}_{2}$ directly correlate with the bandgap energy and are responsible for absorption and activation by solar radiation [19].

\subsection{Mortar composition}

The consumption, in $\mathrm{kg} / \mathrm{m}^{3}$, of each material is described in Table 4.

Table 4 - Consumption, in $\mathrm{kg} / \mathrm{m}^{3}$, of each raw material

\begin{tabular}{lccccccc}
\hline Material & Ref. & P25p & PC105p & P25s $^{2}$ & PC105s $^{2}$ & PC-S7s $^{2}$ & E502s $^{2}$ \\
\hline White Portland cement & 351 & 337 & 342 & 351 & 351 & 351 & 351 \\
(WPC) & 195 & 187 & 190 & 195 & 195 & 195 & 195 \\
Dolomite \# 20 & 1111 & 1067 & 1084 & 1111 & 1111 & 1111 & 1111 \\
Dolomite \# 40 & 292 & 281 & 285 & 292 & 292 & 292 & 292 \\
Dolomite \# 80 & 1.95 & 1.87 & 1.90 & 1.95 & 1.95 & 1.95 & 1.95 \\
Viscosity modifier & 0.16 & 0.15 & 0.15 & 0.16 & 0.16 & 0.16 & 0.16 \\
Air entrainment & 332 & 354 & 344 & 332 & 332 & 332 & 332 \\
Water & 1.4 & 1.4 & 1.4 & 1.4 & 1.4 & 1.4 & 1.4 \\
$\begin{array}{l}\text { Polypropylene } \\
\text { microfibers }\end{array}$ & --- & 16.8 & --- & 0.5 & --- & --- & --- \\
TiO $_{2}$ (P25) & & & & & & &
\end{tabular}


$\mathrm{TiO}_{2}(\mathrm{PC} 105)$

17.1

0.5

$\mathrm{TiO}_{2}(\mathrm{PC}-\mathrm{S} 7)$

$\mathrm{TiO}_{2}(\mathrm{E} 502)$

$-----$

Note: Specimens painted by spray after 28 days of field-cured (1); Suspensions applied by spray after 28 days of field-cured (2); Spray Rate: $15 \mathrm{~m}^{2} / \mathrm{L}$ (**); Spray Rate: $10 \mathrm{~m}^{2} / \mathrm{L}$ (***)

Source: Author (2021)

\subsection{Determination of methylene blue dye}

First, to verify the reactivity of $\mathrm{TiO}_{2}$ samples (powder and suspension) before exposition to the natural environment, the degradation of methylene blue dye test was done in the laboratory with the sample's exposition to artificial UV radiation.

Solutions of $20 \mathrm{mg} / \mathrm{L}$ of each reagent sample $\left(\mathrm{TiO}_{2}\right)$ and $5 \mathrm{mg} / \mathrm{L}$ of methylene blue were prepared. The solutions were exposed to artificial UV radiation with $0 \mathrm{~min}, 60 \mathrm{~min}, 120 \mathrm{~min}$, and 240 min with constant stirring. Then, the absorbance was measured at a wavelength of $660 \mathrm{~nm}$. The measurements were performed according to general guidelines of procedure IPT5078 - CT-OBRAS LMCC-Q-PE-070 - Revision 02 of 26.10.2012, based on the Brazilian Association of Technical Standards guidelines ABNT 9695-12 [25].

\subsection{Specimens' exposition}

The experimental design compared four suspension samples of $\mathrm{TiO}_{2}$ (two produced in the laboratory and two commercial) and two commercial powder samples of $\mathrm{TiO}_{2}$ with each other and between the white painted mortars. The $\mathrm{TiO}_{2}-\mathrm{P} 25 \mathrm{p}$ and $\mathrm{TiO}_{2}-\mathrm{PC} 105 \mathrm{p}$ powder samples were added to the cement matrix after being pre-dispersed in water. The $\mathrm{TiO}_{2}-\mathrm{P} 25 \mathrm{~s}$ and $\mathrm{TiO}_{2}$ PC105s are suspensions prepared by the author in the laboratory using High Energy of Dispersion (HED), while $\mathrm{TiO}_{2}-\mathrm{PC}-\mathrm{S} 7 \mathrm{~s}$ and $\mathrm{TiO}_{2}-\mathrm{E}_{50} \mathrm{~S}_{2} \mathrm{~S}$ are commercial suspensions and were applied as a coating to the surfaces of mortars as well as the paint in the painted mortars, so, that the same application pattern could be maintained [19].

For that exposition, fifteen specimens with $1.20 \times 1.20 \mathrm{~m}$ of dimensions were produced. All the specimens treated with $\mathrm{TiO}_{2}\left(\mathrm{TiO}_{2}\right.$ powder addition or $\mathrm{TiO}_{2}$ coating) were exposed in peers, while the specimens white painted have been exposed in three to better analysis in each group. The specimens are exposed in groups (G1 - G3) according to the description: G1 comparison between mortars with powder samples of $\mathrm{TiO}_{2}$ and mortar with suspensions of $\mathrm{TiO}_{2}$ prepared in the laboratory with painted mortars; G2 - comparison between mortars with powder samples of $\mathrm{TiO}_{2}$ and mortars with commercial suspensions of $\mathrm{TiO}_{2}$ with painted mortars and; G3 - comparison of all mortars with samples of $\mathrm{TiO}_{2}$ in suspension form with 
painted mortars. The final layout of specimens is described in Table 5 as well as the design of exposition to the natural environment is shown in Figure 3, while the measurements of solar radiation and rainfall over three years are shown in Figures 4 and 5.

Table 5-Description of the specimens

\begin{tabular}{|c|c|c|c|c|c|}
\hline Group & $\begin{array}{c}\text { Mortar } \\
\text { (White painted) }\end{array}$ & $\begin{array}{c}\text { Mortar } \\
\text { (With } \mathrm{TiO}_{2} / \\
\text { without paint) }\end{array}$ & $\begin{array}{c}\text { Mortar } \\
\text { (With } \mathrm{TiO}_{2} / \\
\text { without paint) }\end{array}$ & $\begin{array}{c}\text { Mortar } \\
\text { (With } \mathrm{TiO}_{2} / \\
\text { without paint) }\end{array}$ & $\begin{array}{c}\text { Mortar } \\
\text { (With } \mathrm{TiO}_{2} / \\
\text { without paint) }\end{array}$ \\
\hline G1 & Ref. & P25p & PC105p & $\mathrm{P} 25 \mathrm{~s}$ & PC105s \\
\hline G2 & Ref. & P25p & PC105p & PC-S7s & $\mathrm{E} 502 \mathrm{~s}$ \\
\hline G3 & Ref. & $\mathrm{P} 25 \mathrm{~s}$ & PC105s & PC-S7s & $\mathrm{E} 502 \mathrm{~s}$ \\
\hline
\end{tabular}

Source: Adapted from Dantas et al. [19]. Note: $\mathrm{p}=$ Powder $/ \mathrm{s}=$ Suspension

Figure 3. Exposure to solar radiation of specimens

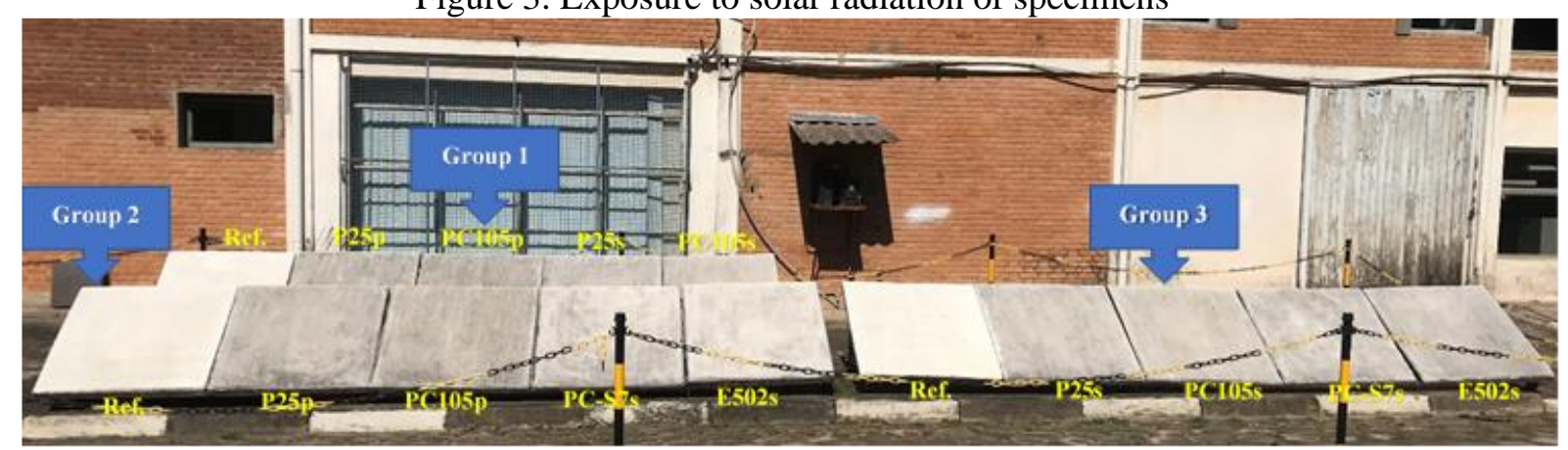

Source: Author (2021)

Figure 4. Measurements to solar radiation over three years of exposition

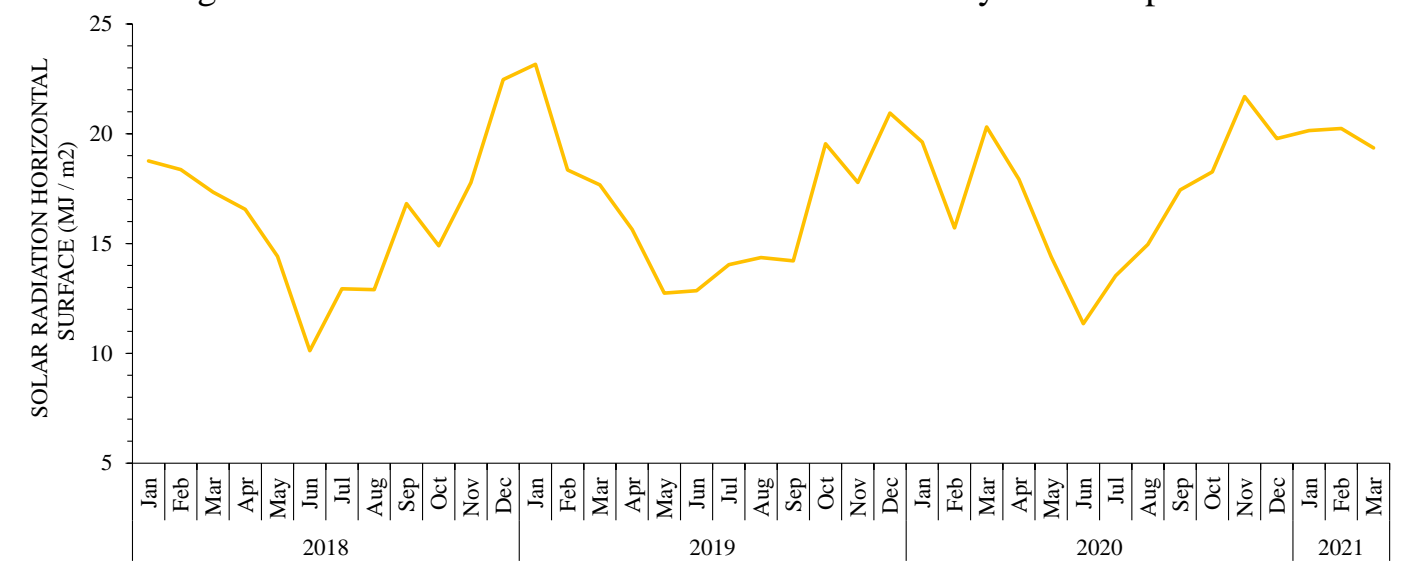

Source: Author (2021) 
Figure 5. Measurements of rainfall over three years of exposition

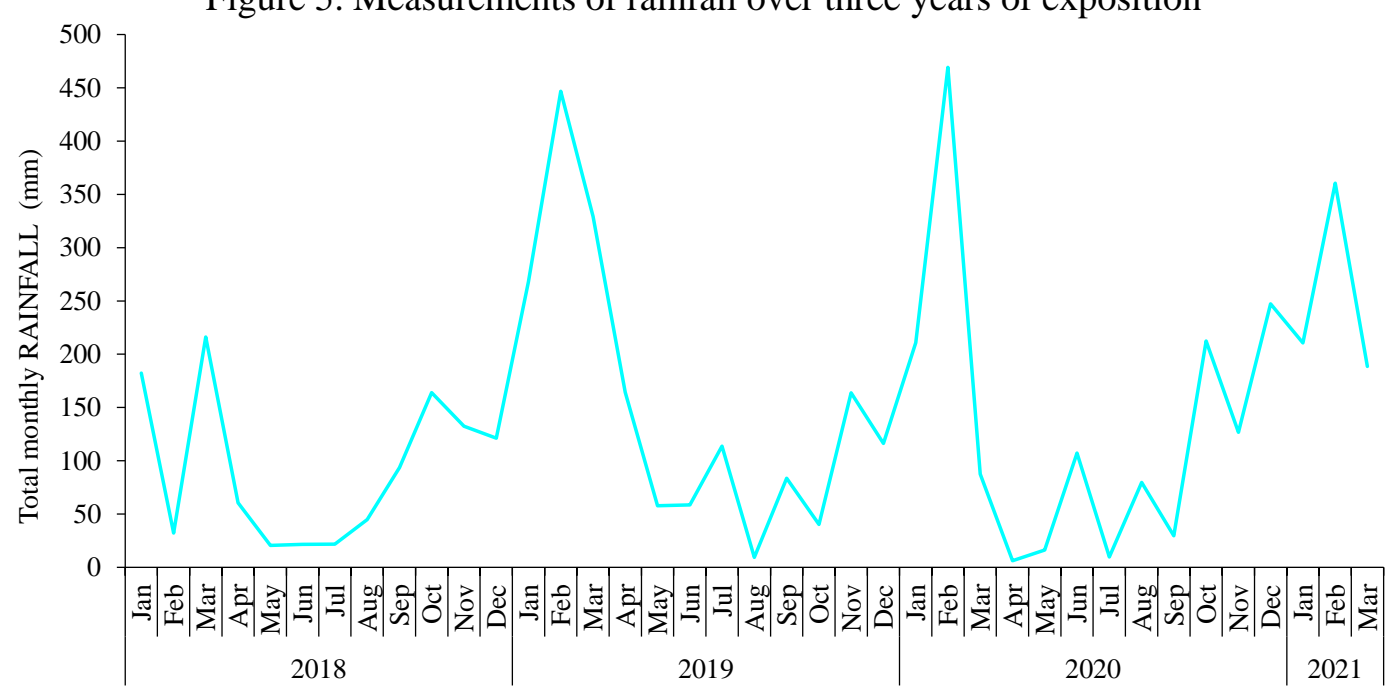

Source: Author (2021)

\subsection{Measuring of lightness}

To determine the lightness, a procedure based on the ASTM D2244-21 [26] was adopted. Data were collected over three years, observing the changes of color in the long term. The measurements were performed in-situ at semiannual intervals using a Color Guide Sphere diffuse $/ 8^{\circ}$ spin spectrophotometer (Figure 6a) with geometric measurements of $45^{\circ} / 0^{\circ}$ circular, with $400-700 \mathrm{~nm}$ measurement area, $20 \mathrm{~nm}$ spectral resolution and photometric range $0-100 \%, 0.01$ resolution. The illuminant D65 and observer with $10^{\circ}$ and reproducibility $<0.02 \Delta \mathrm{E}^{*}$ were considered.

The results are express according to the CIELab color space, where $\mathrm{L}^{*}$ means lightness [black $=0$ units and white $=100$ units $]$ and $\mathrm{a}^{*}$ and $\mathrm{b}^{*}$ are coordinates from green to red $\left(-\mathrm{a}^{*}\right.$ to $\left.+\mathrm{a}^{*}\right)$ and blue to yellow $\left(-b^{*}\right.$ to $\left.+b^{*}\right)$ with values ranging from -128 to +128 , respectively. Thus, the CIELab color space (Figure $6 \mathrm{~b}$ ) covers the entire spectrum visible to the human eye and represents it uniformly.

Considering the exposure of the mortars in peers ( $\mathrm{a}$ and $\mathrm{b}$ ), to calculate the color, an average was applied between its pairs, obtaining the average values of $\mathrm{L}^{*}, \mathrm{a}^{*}$, and $\mathrm{b}^{*}$ coordinates. The initial color of the mortars $(t=0)$ was accepted before exposure to natural weathering. For each exposed mortar, five measurements were taken as shown in Figure $6 \mathrm{c}$ and calculated according to equations (1-3).

$$
\begin{aligned}
& \mathrm{L}_{(t)}^{*}=\frac{\left(\sum_{i=1}^{5} \mathrm{~L}_{(a)}^{*}+\sum_{i=1}^{5} \mathrm{~L}_{(b)}^{*}\right)}{10} \\
& \mathrm{a}_{(t)}^{*}=\frac{\left(\sum_{i=1}^{5} \mathrm{a}_{(a)}^{*}+\sum_{i=1}^{5} \mathrm{a}_{(b)}^{*}\right)}{10}
\end{aligned}
$$


$\mathrm{b}_{(t)}^{*}=\frac{\left(\sum_{i=1}^{5} \mathrm{~b}_{(a)}^{*}+\sum_{i=1}^{5} \mathrm{~b}_{(b)}^{*}\right)}{10}$

Eq. 3

To obtain the specimens, color differences equations (4-6) were used. The calculation was always done concerning the initial measurement.

$\begin{array}{rrr}\Delta \mathrm{L}_{(t)}^{*} & =\mathrm{L}_{(t)}^{*}-\mathrm{L}_{(t=0)}^{*} & \text { Eq. } 4 \\ \Delta \mathrm{a}_{(t)}^{*}=\mathrm{a}_{(t)}^{*}-\mathrm{a}_{(t=0)}^{*} & \text { Eq. } 5 \\ \Delta \mathrm{b}_{(t)}^{*}=\mathrm{b}_{(t)}^{*}-\mathrm{b}_{(t=0)}^{*} & \text { Eq. } 6\end{array}$

The final quantitative demonstration of color differences $\left(\Delta \mathrm{L}_{\mathrm{F}}^{*}, \Delta \mathrm{a}^{*} \mathrm{~F}\right.$, and $\left.\Delta \mathrm{b}_{\mathrm{F}}{ }_{\mathrm{F}}\right)$ between the specimens over the three years of exposure was calculated according to equations (7-9).

$\Delta \mathrm{L}_{F}^{*}=\frac{\sum_{i=1}^{8} \Delta \mathrm{L}_{(t)}^{*}}{8}$

$\Delta \mathrm{a}_{F}^{*}=\frac{\sum_{i=1}^{8} \Delta \mathrm{a}_{(t)}^{*}}{8}$

Eq. 8

$\Delta \mathrm{b}_{F}^{*}=\frac{\sum_{i=1}^{8} \Delta \mathbf{b}_{(t)}^{*}}{8}$

Eq. 9

Figure 6. Measuring of lightness process

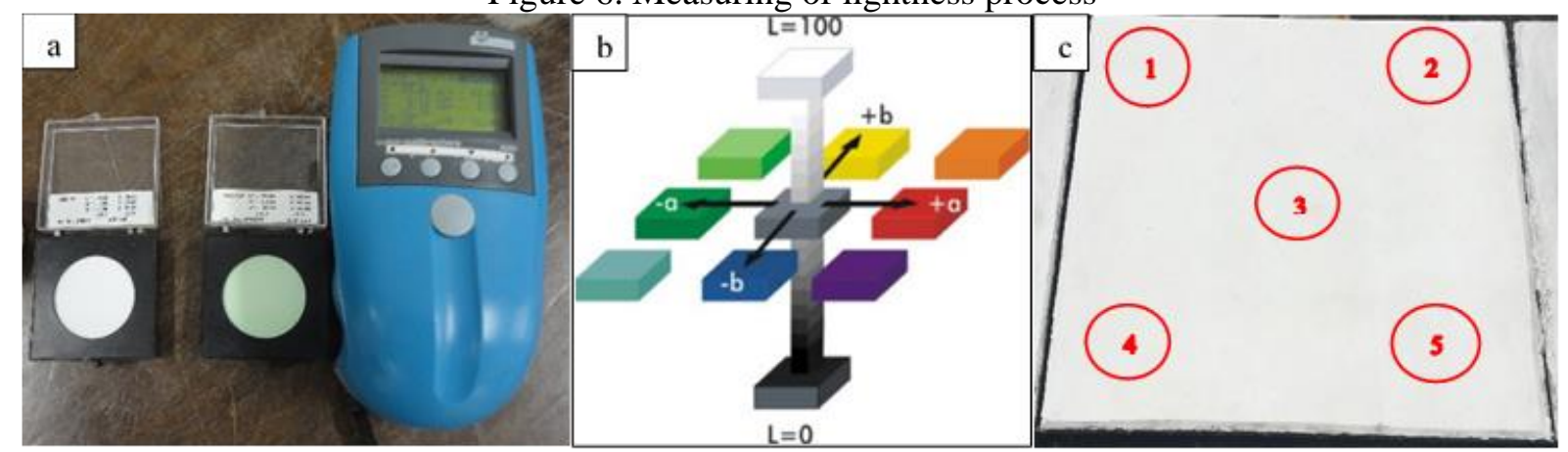

Note: Spectrophotometer equipment (a); Color coordinates by CIELab color space (b); Measuring points on surface specimens (c)

Source: Author (2021)

\subsection{Calculation of Yellowness Index (YI)}

Accord ASTM E284 [27], Yellowness Index (YI) is a number calculated from colorimetric or spectrophotometric data to characterize the change in color of the specimen from colorless, or from a preferred white, toward yellow. In this study, the objective was measuring the transition from white to yellow, and the index was calculated accord to ASTM E313-20 [28] for illuminant D65 and observer with $10^{\circ}$, the same used to measuring of lightness, and the Yellowness Index was calculated according to equations (10),

$\mathrm{YI}=\frac{100\left(\mathrm{C}_{\mathrm{x}} \mathrm{X}-\mathrm{C}_{\mathrm{z}} \mathrm{Z}\right)}{Y}$

Eq. 10 
where $\mathrm{X}, \mathrm{Y}, \mathrm{Z}$ are the $\mathrm{CIE}$ tristimulus values and coefficients, $\mathrm{C}_{\mathrm{X}}$ and $\mathrm{C}_{\mathrm{Z}}$ can be obtained from Table 6 for the chosen illuminant and observer.

Table 6 - Coefficients for Yellowness Index

\begin{tabular}{lcccc}
\hline \multirow{2}{*}{ Coefficient } & \multicolumn{4}{c}{ CIE Standard Illuminant and Standard Observer } \\
\cline { 2 - 5 } $\mathrm{C}_{\mathrm{X}}$ & $\mathrm{C} / 2^{\circ}(1931)$ & $\mathrm{D} 65 / 2^{\circ}(1931)$ & $\mathrm{C} / 10^{\circ}(1964)$ & $\mathrm{D} 65 / 10^{\circ}(1964)$ \\
$\mathrm{C}_{\mathrm{Z}}$ & 1.2769 & 1.2985 & 1.2871 & 1.3013 \\
\hline
\end{tabular}

Source: Adapted from ASTM E313-20 [28]

\section{RESULTS AND DISCUSSION}

\subsection{Methylene blue dye determination}

The results of the methylene blue dye determinations of $\mathrm{TiO}_{2}$ samples are described in Table 7.

Table 7 - Methylene blue dye laboratory determination

\begin{tabular}{lcccc}
\hline \multicolumn{1}{r}{ Samples } & \multicolumn{2}{c}{ Content of methylene blue after exposure to artificial UV radiation $(\mathrm{mg} / \mathrm{L})$} \\
& $0 \mathrm{~min}$ & $60 \mathrm{~min}$ & $120 \mathrm{~min}$ & $240 \mathrm{~min}$ \\
\hline P25p & 5.4 & 2.6 & 1.0 & $<0.1$ \\
PC105p & 4.4 & 4.0 & 3.5 & 3.1 \\
PC-S7s & 5.7 & 1.8 & 1.0 & 0.3 \\
E502s & 4.4 & 0.9 & 0.2 & $<0.1$ \\
\hline
\end{tabular}

Note: The solutions were prepared with $20 \mathrm{mg} / \mathrm{L}$ (mass/volume) of each sample. The initial content of methylene blue content was $5 \mathrm{mg} / \mathrm{L}$.

Source: Author (2021)

Regarding the results of methylene blue dye, it is possible to observe that, although the degradation performed by the $\mathrm{TiO}_{2}-\mathrm{E} 502$ s sample presents a better efficiency than the others, degrading about $80 \%$ of the solution in the first $60 \mathrm{~min}$ of exposure. In the end, considering the remaining content of the dye, it is possible to say that $\mathrm{TiO}_{2}-\mathrm{P} 25 \mathrm{p}, \mathrm{TiO}_{2}-\mathrm{PC}-\mathrm{S} 7 \mathrm{~s}$, and $\mathrm{TiO}_{2}-$ E502s samples have the same effectiveness ( $\pm 99.9 \%)$, even providing different degradation over time. On the other hand, the $\mathrm{TiO}_{2}-\mathrm{PC} 105 \mathrm{p}$ sample presents the worst performance, degrading only $29.5 \%$ of the compound at the end of the tests.

Considering the results presented by the $\mathrm{TiO}_{2}-\mathrm{E} 502$ s sample in the laboratory, it is possible to suppose that it could maintain the same performance in the natural exposure. In other words, the $\mathrm{TiO}_{2}-\mathrm{E} 502 \mathrm{~s}$ sample could present a faster response to the degradation of pollutants, not allowing the accumulation of dirt on the surface of the specimens and, therefore, offer better performance than other samples treated with $\mathrm{TiO}_{2}$, also in the natural environment. 
On the other hand, this behavior can be considered opposite when compared to the $\mathrm{TiO}_{2}$ PC105p sample, which takes much longer to provide the same degradation effect and, for consequence, would allow more easily the accumulation of dirt on it, thus leading to lower effectiveness, or even the temporary inactivity of the $\mathrm{TiO}_{2}$ sample, since it totally covered by dirt, and therefore, not activated by solar radiation.

\subsection{Loss of lightness on the specimen's surface}

Considering the differences of lightness $\left(\Delta \mathrm{L}^{*}\right)$ on the specimens over time, measurements showed that Ref. (white painted) was the best specimen because it changed fewer than other specimens treated with $\mathrm{TiO}_{2}$ (powder and coating) at the end of the test.

To the Ref. specimen, the $\Delta \mathrm{L}^{*}$ F was less than 10 CIELab units of loss of lightness over three years of exposure. On the other hand, the other specimens have higher values of $\Delta \mathrm{L}^{*} \mathrm{~F}$, showing more than 20 CIELab units of loss of lightness, thus, double value when are compared with the Ref. specimen, demonstrating that the $\mathrm{L}^{*}$ changed a lot, as shown in Figure 7.

Figure 7. Loss of lightness $\left(\Delta \mathrm{L}^{*}\right)$ on the specimens

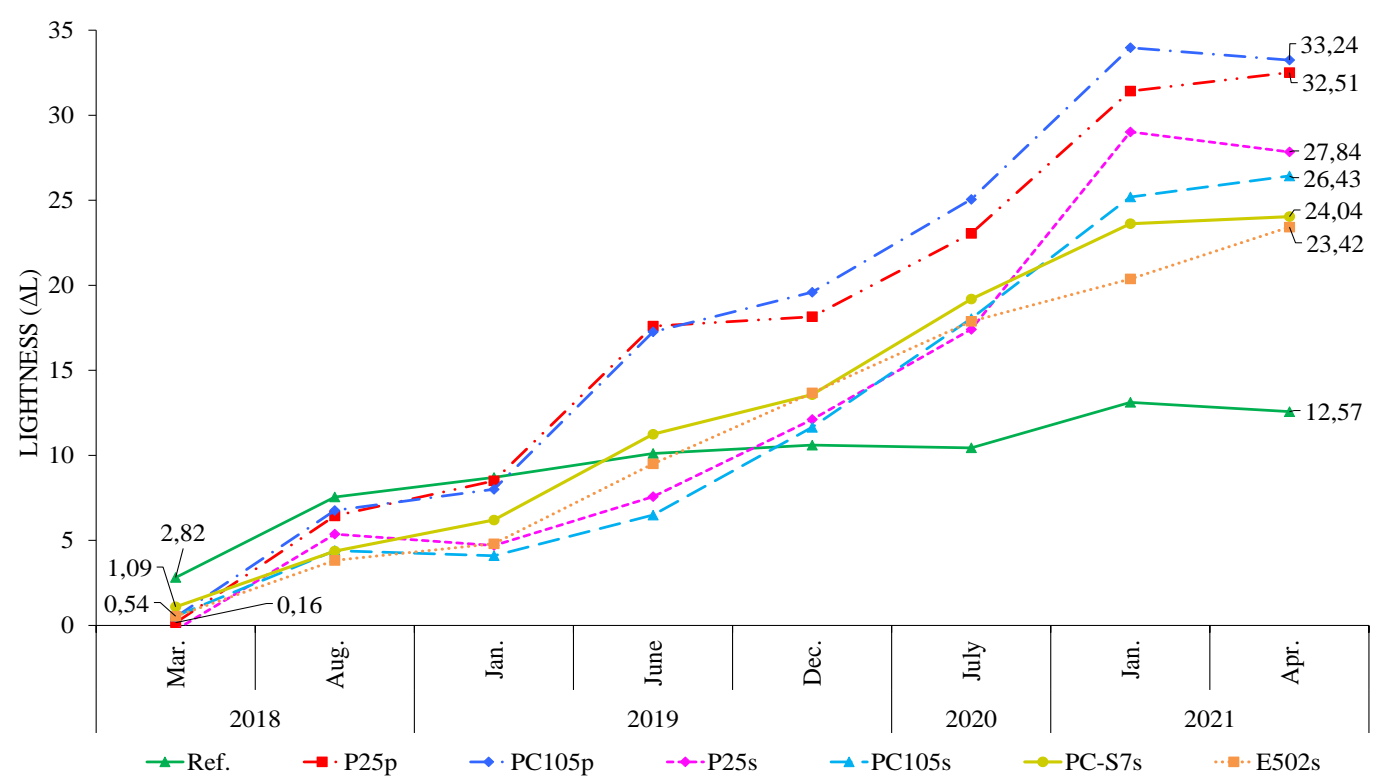

Source: Author (2021)

However, to observe the influence of the peers of specimens in those results, the twins were evaluated to know if there were different behaviors between them and if that difference would significantly influence the lightness. As a result, it was observed that except for one twin belonging to the specimens covered by the $\mathrm{TiO}_{2}$-E502s commercial suspension sample, the behavior of all peers of specimens over three years of exposure could be considered similar, as shown in Figure 8. 
Figure 8. Lightness of twin specimens over three years
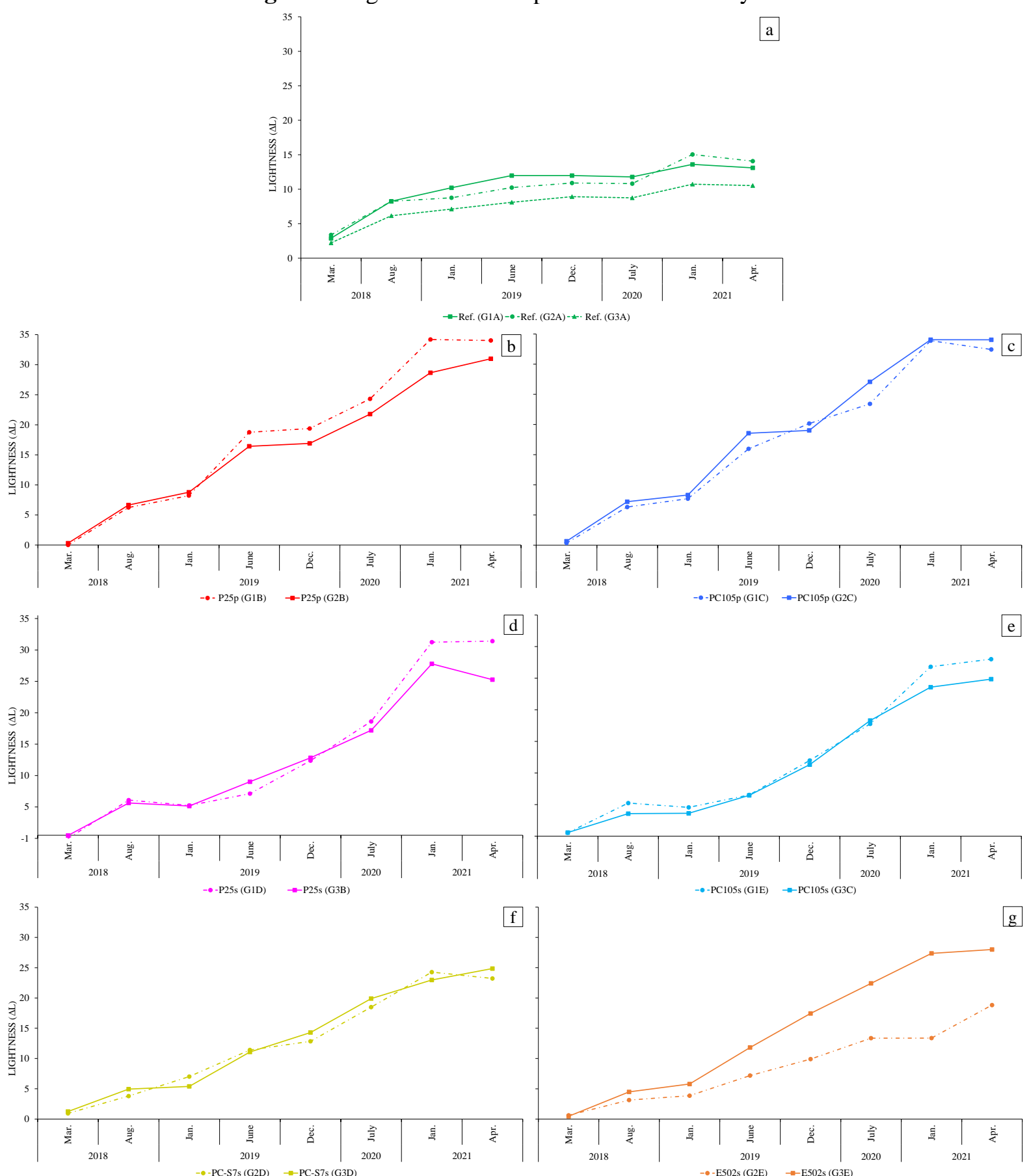

Note: Ref. [white painted] (a), P25p (b), PC105p (c), P25s (d), PC105s (e); PC-S7s (f) and E502s (g) Source: Author (2021)

The results showed by the specimens not only eliminate the possibility of an influence of the twins in the lightness but also indicate the sense of humans cannot notice that difference. In other words, when evaluated and compared with each other by naked eyes, the color difference between them cannot be perceived. On the other hand, the difference can be easily identified when comparing all the specimens with each other, in other words, when comparing 
the Ref. (white painted) with $\mathrm{TiO}_{2}$ suspension (P25s, PC105s, PC-S7s, and E502s) and $\mathrm{TiO}_{2}$ powder addition (P25p, PC105p).

About the behavior of twins' specimens covered by the $\mathrm{TiO}_{2}-\mathrm{E} 502 \mathrm{~s}$ suspension is observed that they started to show a significant difference from Jan./19, almost one year after their exposition, accentuating the differences over time. That behavior could be attached to the material characteristics concerning the microstructure of the $\mathrm{TiO}_{2}$, such as dimensions, amount, and physical-chemical characteristics.

Another possibility could be concerning the suspension's adhesion to the substrate (base) as well as was observed by the authors in the previous study [19]. The hypothesis is that the application pattern adopted allowed a good homogeneity and adhesion of the material in one specimen, while in the other, it showed defects that allowed those different behaviors by the sample.

\subsection{Chromatic plane and yellowness index}

About the coordinates, $\mathrm{a}^{*}$ and $\mathrm{b}^{*}$, considering the whole scale of the chromatic plane (-128 to $+128)$ and applying that scale to specific coordinates: from green $\left(-\mathrm{a}^{*}\right)$ to red $\left(+\mathrm{a}^{*}\right)$ and from blue $\left(-b^{*}\right)$ to yellow $\left(+b^{*}\right)$, it is observed that the bars are completely flat, or even imperceptible. However, to better observation and quantify the influence of these coordinates, the zoom was used and allowed observing that even use a major scale, the results found for the coordinates $\mathrm{a}^{*}$ and $\mathrm{b}^{*}$ do not demonstrate a considerable interference in the results of chromaticness over three years of exposure, as shown in Figure 9.

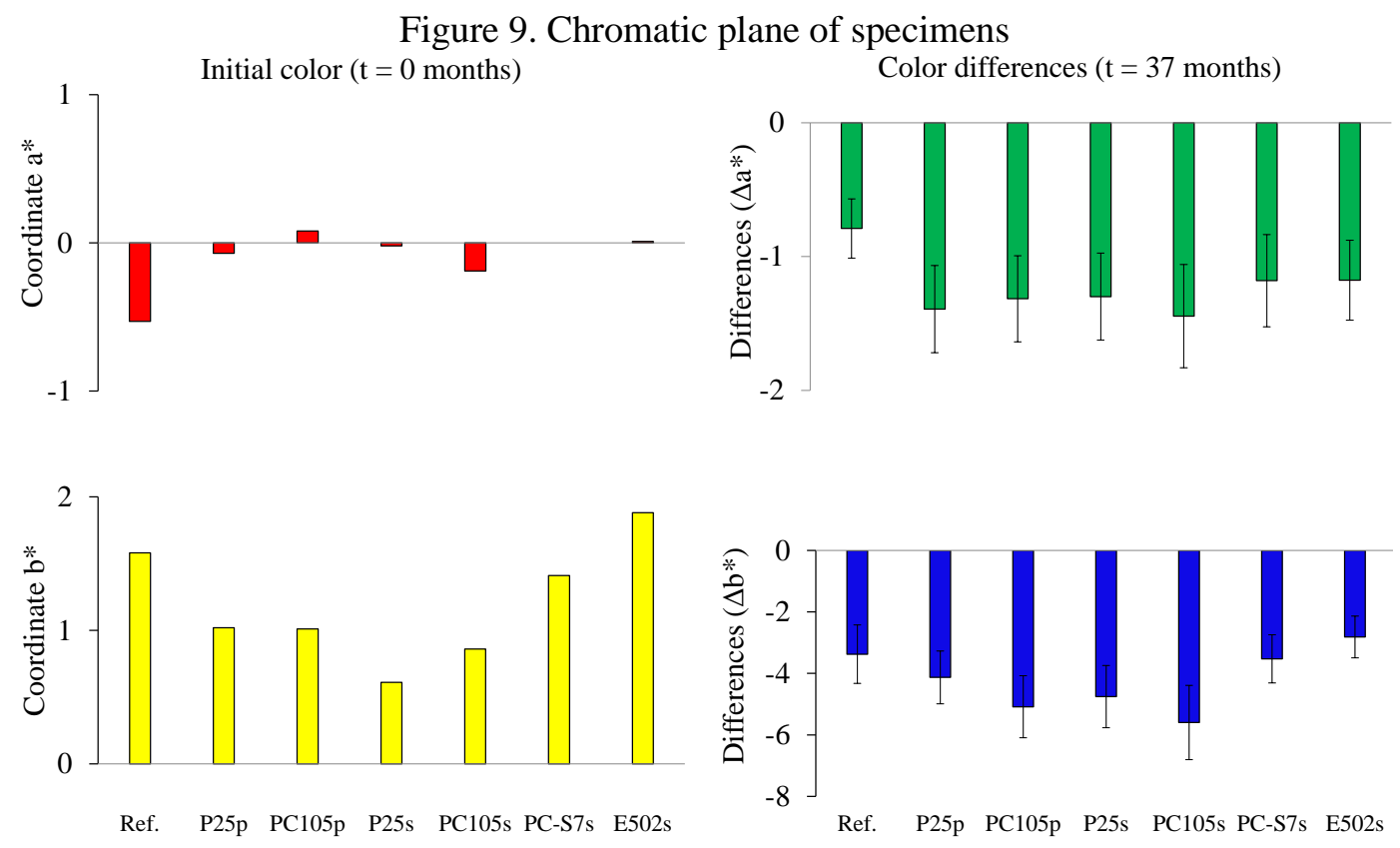

Source: Author (2021) 
The coordinates evaluation reveals that specimens present low differences after thirty-seven months of exposition concerning the chromatic plane, about 2 CIELab units to coordinate $\mathrm{a}^{*}$ and around 8 CIELab units to coordinate $b^{*}$.

It is observed that these values do not represent a significant contribution in the color difference of the specimens over three years, principally when are considered the whole CIELab scale of measurement $(-128$ to +128$)$ of the chromatic plane, demonstrating that who is dominating the color difference in the specimens, is the lightness indeed, and not the chromaticness, since the specimens not presenting a substantial chromatic effect (blue, yellow, green, and red) yet.

Furthermore, when the specimens are evaluated using the interpretation of the components $\Delta \mathrm{a}^{*}$ and $\Delta \mathrm{b}^{*}$ showed by the ASTM D-2244-21 [26], it is observed that after thirty-seven months of exposure, the specimens show greener $\left(-\Delta \mathrm{a}^{*}\right)$ and bluer $\left(-\Delta \mathrm{b}^{*}\right)$ but not more yellow $\left(+b^{*}\right)$ as well as was observed at the beginning of the test.

On the whole, chromaticness contribution is negligible and very minimal to the point of defining anything. As a result, chromaticness cannot be considered in this discussion until this time. Nevertheless, that situation can be changed in the long term of natural exposition, especially with the rupture of the polymeric film formed by the paint, causing yellowness of the surface of the specimen, as well as the rupture of the $\mathrm{TiO}_{2}$ film formed by the application of the $\mathrm{TiO}_{2}$ suspensions, as demonstrated in Dantas et al. [19], wherefrom that point the chromaticness can have the relevant participation in the specimen's color difference.

The Yellowness Index (YI) results are indicated in Figure 10 and show that even the equipment has to get measured some levels of yellowness on the specimens over three years of exposure, this phenomenon is not possible to see by the naked eye yet, indicating that this period of exposure seems was not enough to demonstrate this kind of phenomenon, consequently, showing no influence on the specimen's whiteness. Thus, as well as observed in the chromaticness aspect, it cannot be considered until this exposition time. 
Figure 10. Yellowness Index (YI) of specimens over three years of natural exposure

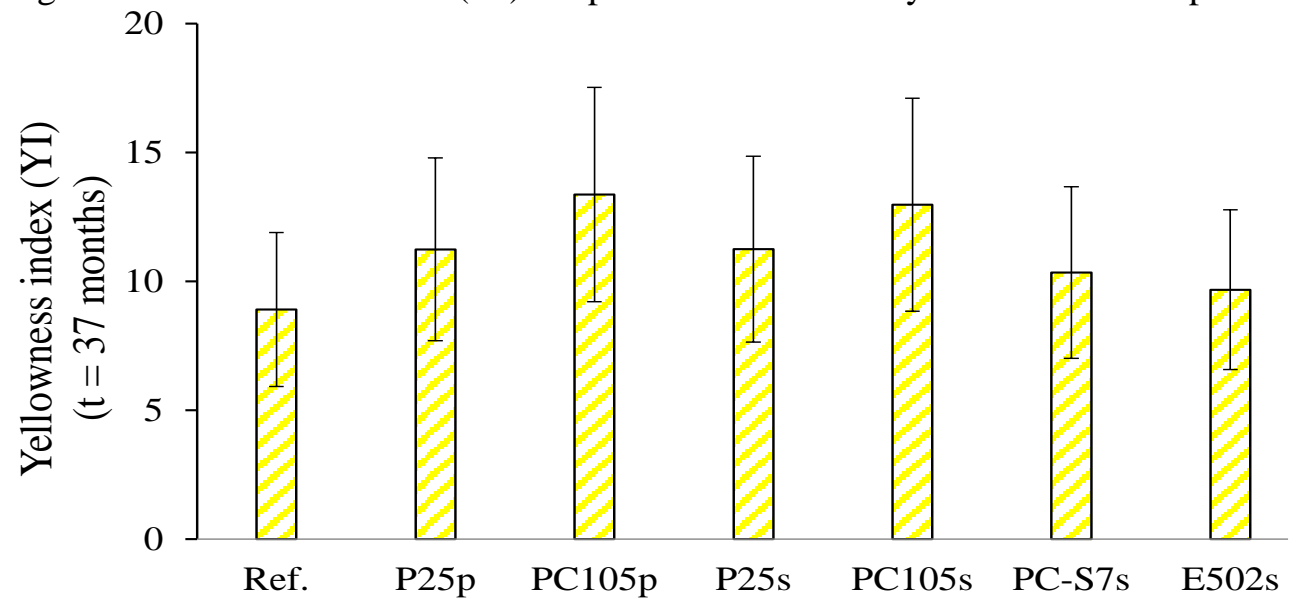

Source: Author (2021)

\subsection{CIELab color difference ( $\left.\Delta \mathbf{E}^{*}\right)$ and Just Noticeable Difference (JND)}

To comprehend and evaluate the final color difference, it is necessary to see the difference in a general plan indicated by the Euclidean distance. Expressed as $\Delta \mathrm{E}^{*}$ and based on $\mathrm{L}^{*} \mathrm{a}^{*} \mathrm{~b}^{*}$ coordinates, the total color difference $\left(\Delta \mathrm{E}^{*}\right)$ between two colors is calculated as follows the equation (11), and this measurement scale was planned to be a single number metric for decisions of the accepted or rejected type.

$\Delta \mathrm{E} *=\sqrt{(\Delta L *)^{2}+(\Delta a *)^{2}+(\Delta b *)^{2}}$

Eq. 11

The outcome of this application in the specimens evaluated could be seen in Figure 11, wherein according to the answers find it is possible to observe that the effect indicated by the graph reflect what can be seen in-situ, in other words, the Ref. (white painted) remains more whiteness. In contrast, the others are darker and dirtier, even presenting different shades of each other.

Figure 11. Specimens color difference $\left(\Delta \mathrm{E}^{*}\right)$ measured over three years of natural exposure

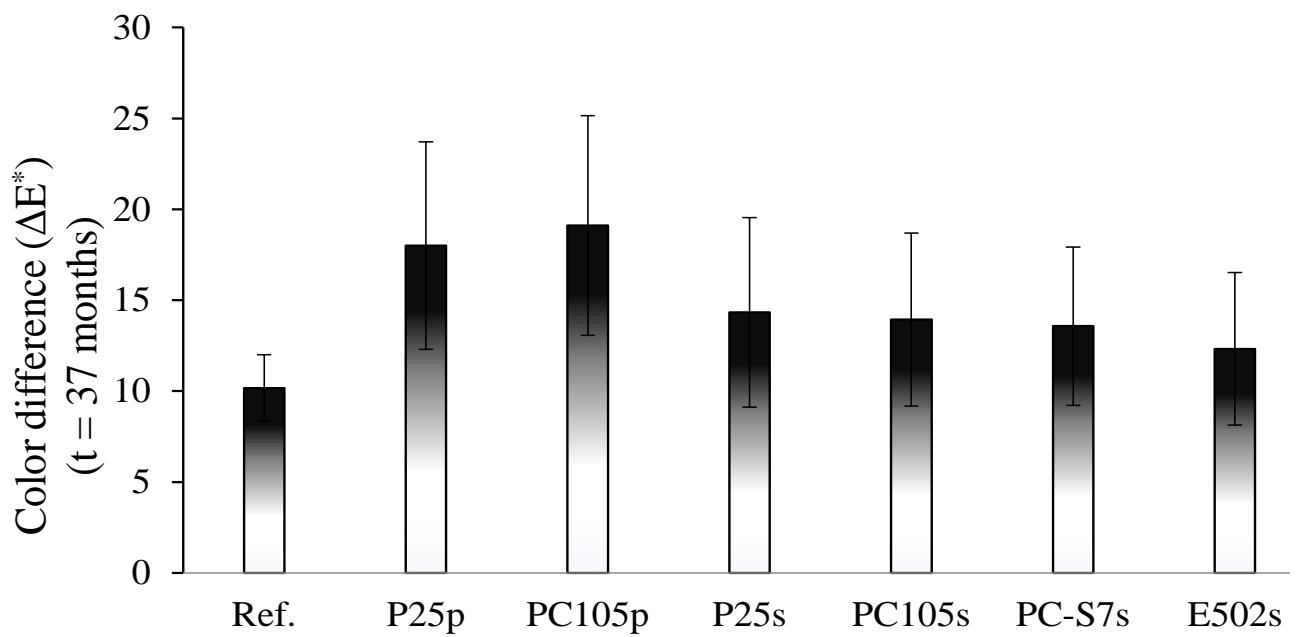

Source: Author (2021) 
According to Johnston and Kao [18], color evaluation by visual comparisons may not be a reliable method, given the results of inconsistencies inherent in perception and specifications among observers. However, the final judgment will be depending on the observer, and this upshot only confirms that although that $\Delta \mathrm{E}^{*}$ results can be used as color differentiation, they should only be taken as a general guide since it is possible to obtain the same value of $\Delta \mathrm{E}^{*}$ for two colors that appear different when saturation is not considered or is not adequately weighted $[29,30]$.

By and large, this is happening because the accurate description of the color is challenging due to the many influencing factors that form the final perception since it is well known that the HVS does not operate on a wavelength basis, but rather as a result of the integrated simulation of each of the three different cone types: Long (L), Medium (M), and Short (S) [7]. In that case, the use of Just Noticeable Difference (JND) could be a help. Calculating the distance between the colors, the JND is the limit beyond which the human eye perceives two colors as distinct colors. A difference of approximately $\Delta \mathrm{E}^{*}=2.3$ units is already responsible for a JND. In the constant region, the JND is $1 \%-3 \%$, and it is called Weber-Fechner fraction and means that a luminance difference of $1 \%-3 \%$ is just enough to be perceived if the background illumination is in the range between 0.1 and $1000 \mathrm{~cd} / \mathrm{m} 2$ [7].

Munafò, Goffredo, and Quagliarini [31] point out that conventionally, $\Delta \mathrm{E}^{*}=1$ is considered the only noticeable difference (JND) by the human eye. While to Bellan, Salmon, and Cass [32], the minimum surface coverage (3.6\%) required to trigger the detection of dirt by the human eye between clean and dirty surfaces corresponds to $\Delta \mathrm{E}^{*} \approx 1$. However, various authors have reported different values of JND in a more generic range of 2-3 units.

In this way, this color perception threshold can be used to increase the correlation between objective and subjective evaluation [15,8]. According to Souza [17], there is no consensus on the precise value of JND, and it may assume the reference to the ranges of values according to the scenario used, as shown in Table 8.

Table 8 - Different scenarios of JND

\begin{tabular}{ll|ll}
\hline & Generic scenario & \multicolumn{2}{c}{ Industrial perspective } \\
\hline between 0.38 to 0.73 & just noticeable difference (JND) & between 1.1 and 2.8 & accurate color tolerance \\
around 1.75 & above JND difference & between 2.9 and 5.6 & normal color tolerance \\
over 5.0 & high color differences & above 5.6 & high tolerance \\
\hline
\end{tabular}

Source: Adapted from Souza [17] 
Therefore, taking the JND bands as a reference and applying them to the exposed specimens, it is possible to observe that all samples present high color differences when the generic scenario is considered. Hence, in consonance with the JND scale and the naked eyes observation, specimens with $\mathrm{TiO}_{2}$ powder addition (P25p and PC105p) can be interpreted as a dark color, followed by specimens with coating by $\mathrm{TiO}_{2}$ suspension (P25s, PC105s, PC-S7s, and E502s) that can be considered as gray color and finally, the Ref. (white painted) show as white color.

\subsection{Solar absorption by color and aesthetic perception}

Table 9 shows the limits to the absorptivity $(\alpha)$ as a function of color according to the Brazilian Association of Technical Standards - ABNT 15575-13 [33] and Lamberts, Dutra, and Pereira [34]. Also, Table 10 shows the results of a study realized by Santamouris, Synnefa, Karlessi [1] about some materials of dark and white color as to their solar reflectance and emissivity.

\begin{tabular}{lc|lc}
\multicolumn{2}{c}{ Table 9-Absorptivity $(\alpha)$ as a function of color } \\
\hline \multicolumn{2}{c}{ NBR 15575 } & \multicolumn{2}{|c}{ Lamberts, Dutra, Pereira } \\
\hline Color & $\alpha$ & Color & $\alpha$ \\
Light & 0.30 & Light & 0.20 to 0,50 \\
Average & 0.50 & Average & 0.50 to 0.70 \\
Dark & 0.70 & Dark & 0.70 to 0.90 \\
\hline
\end{tabular}

Source: Adapted by ABNT [33] and Lamberts, Dutra, and Pereira [34]

Table 10 - Representative values of solar reflectance and infrared emittance of materials

\begin{tabular}{lcc}
\hline \multicolumn{1}{c}{ Material } & Solar reflectance & Infrared emittance \\
\hline Coatings & & \\
White & $0.70-0.85$ & $0.80-0.90$ \\
Conventional dark colored coatings & $0.04-0.20$ & $0.80-0.90$ \\
Tiles & & \\
White clay tile & $0.60-0.75$ & $0.85-0.90$ \\
White concrete tile & $0.60-0.75$ & $0.85-0.90$ \\
Grey concrete tile & $0.18-0.25$ & $0.85-0.90$ \\
Dark colored concrete tile & $0.04-0.40$ & $0.85-0.90$ \\
Membranes & & \\
White membrane & $0.65-0.85$ & $0.80-0.90$ \\
Black & $0.04-0.05$ & $0.80-0.90$ \\
\hline
\end{tabular}

Source: Adapted by Santamouris, Synnefa, Karlessi [1]

Applying these concepts to the specimens evaluated, it is possible to observe that Ref. (white painted) specimens could be classified as white coating or light color since it presents 86.26 CIELab units of their lightness after three years of exposure and absorptivity below 0.30 . The 
specimens coating by $\mathrm{TiO}_{2}-\mathrm{P} 25 \mathrm{~s}, \mathrm{TiO}_{2}-\mathrm{PC} 105 \mathrm{~s}, \mathrm{TiO}_{2}-\mathrm{PC}-\mathrm{S} 7 \mathrm{~s}$, and $\mathrm{TiO}_{2}-\mathrm{E} 502 \mathrm{~s}$ suspension that showed values of $65.85,68.48,69.70$, and 69.87 CIELab units, respectively, after thirtyseven months of exposure, could be considered white membrane or light color, and present a medium absorptivity when the limits in Table 9 and 10 are considered.

Finally, the specimens with $\mathrm{TiO}_{2}-\mathrm{P} 25 \mathrm{p}$ and $\mathrm{TiO}_{2}-\mathrm{PC} 105 \mathrm{p}$ addition can be considered with a medium absorptivity and off-white color, showing values of 61.39 and 60.99 CIELab units of their lightness, respectively, as shown in Figure 12.

Figure 12. Specimens' lightness according to Brazilian Association of Technical Standards - ABNT [33] for the opaque surfaces

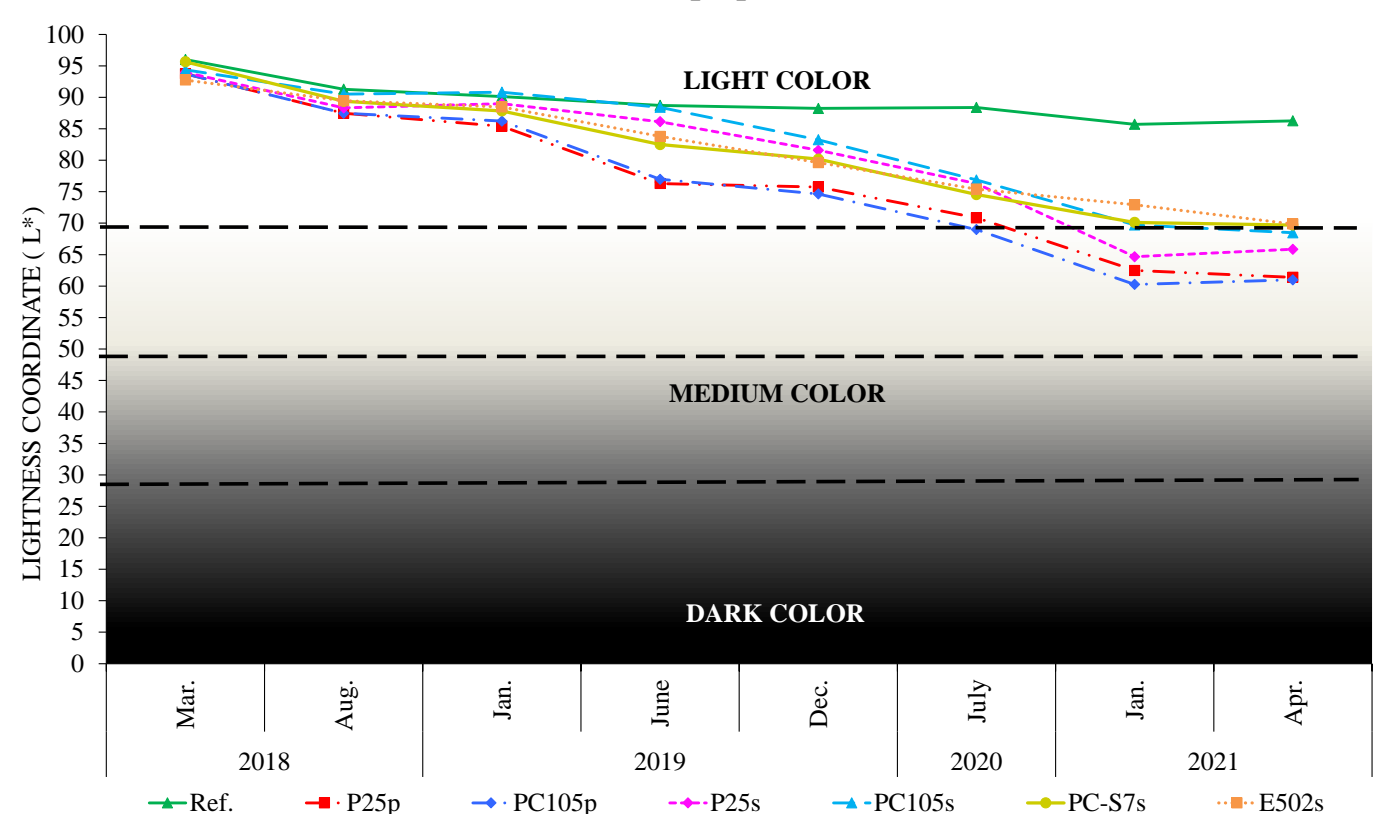

Note: $70 \%$ (light color), $50 \%$ (medium color) and 30\% (dark color)

Source: Author (2021)

However, about the aesthetic perception, concerning the final decision making between the paint application or materials with $\mathrm{TiO}_{2}$ on building facades, the results can a little be different, since the gap of 17.78 CIELAB units on average between the Ref. (white painted) specimens and the group covered by suspension of $\mathrm{TiO}_{2}(\mathrm{P} 25 \mathrm{~s}, \mathrm{PC} 105 \mathrm{~s}, \mathrm{PC}-\mathrm{S} 7 \mathrm{~s}$, and E502s), and the 25.07 CIELAB units of the difference between the group with $\mathrm{TiO}_{2}$ addition (P25p and PC105p) it is possible to see without effortless, showing, at first sight, the difference between the human vision and the instrumental measurements in the color evaluation, as shown in Figures. 13-16. 
Figure 13. Instrumental evaluation of specimen's lightness results in the long term of exposure

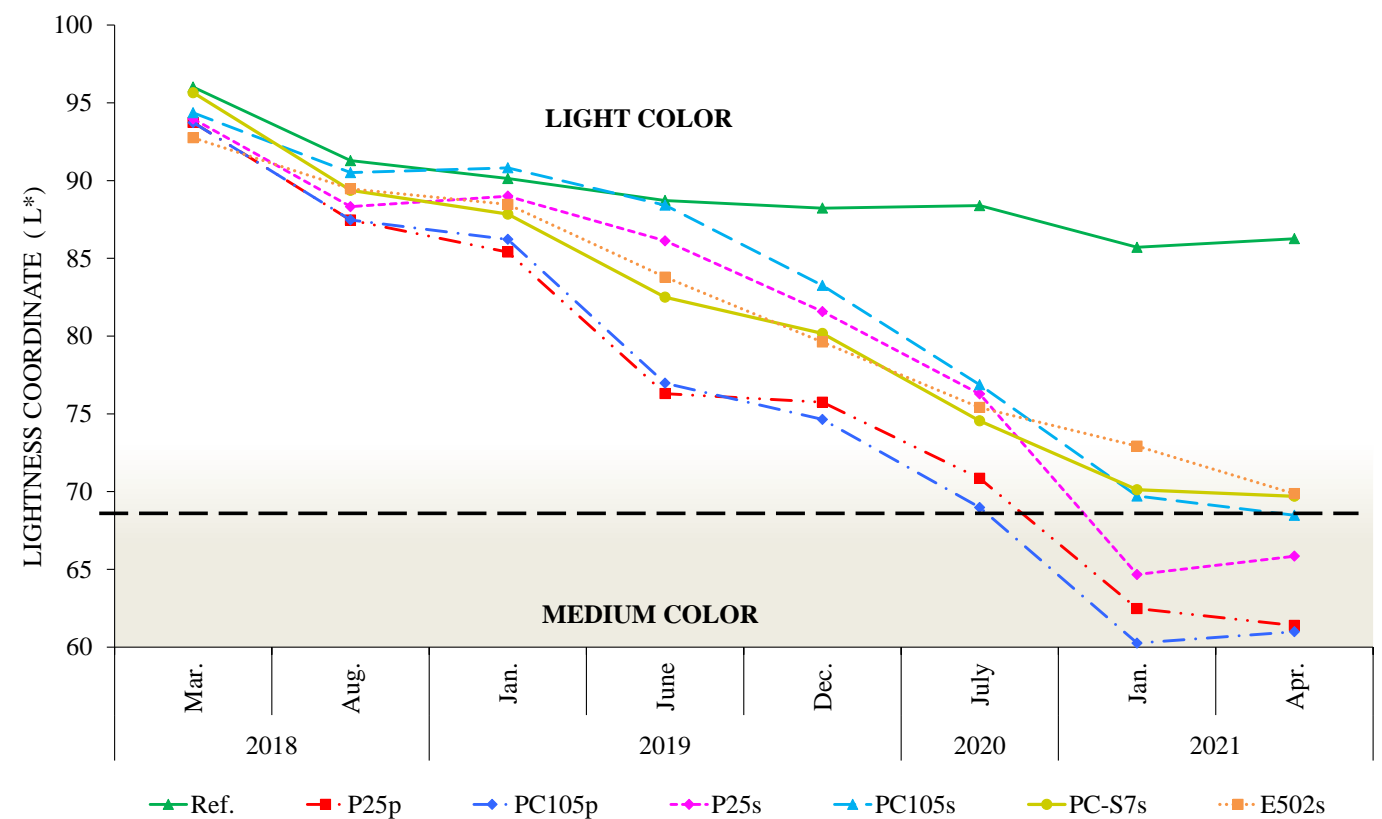

Source: Author (2021)

Figure 14. Visual evaluation specimens over time (Group 1)

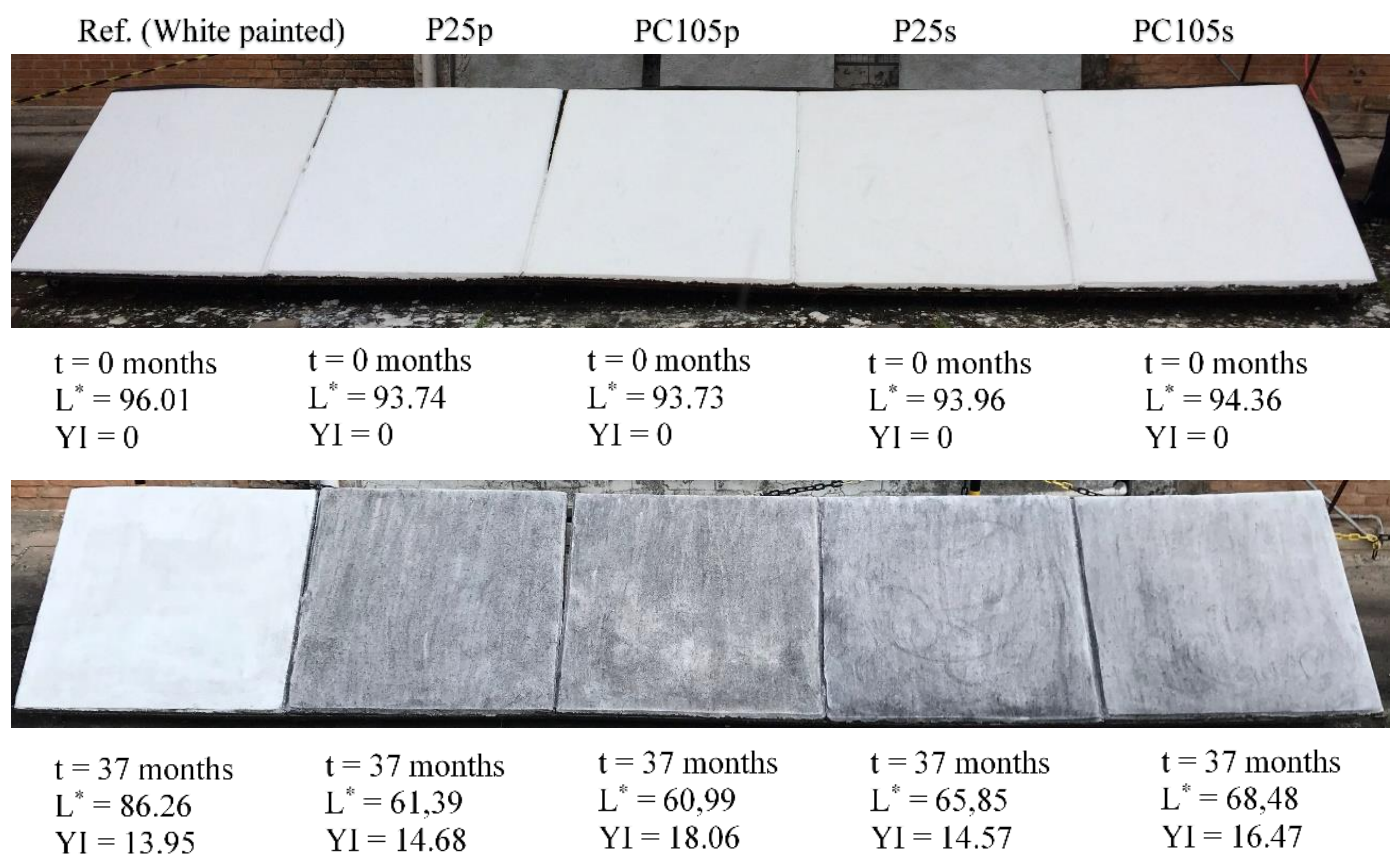

Source: Author (2021) 
Figure 15. Visual evaluation of specimens over time (Group 2)

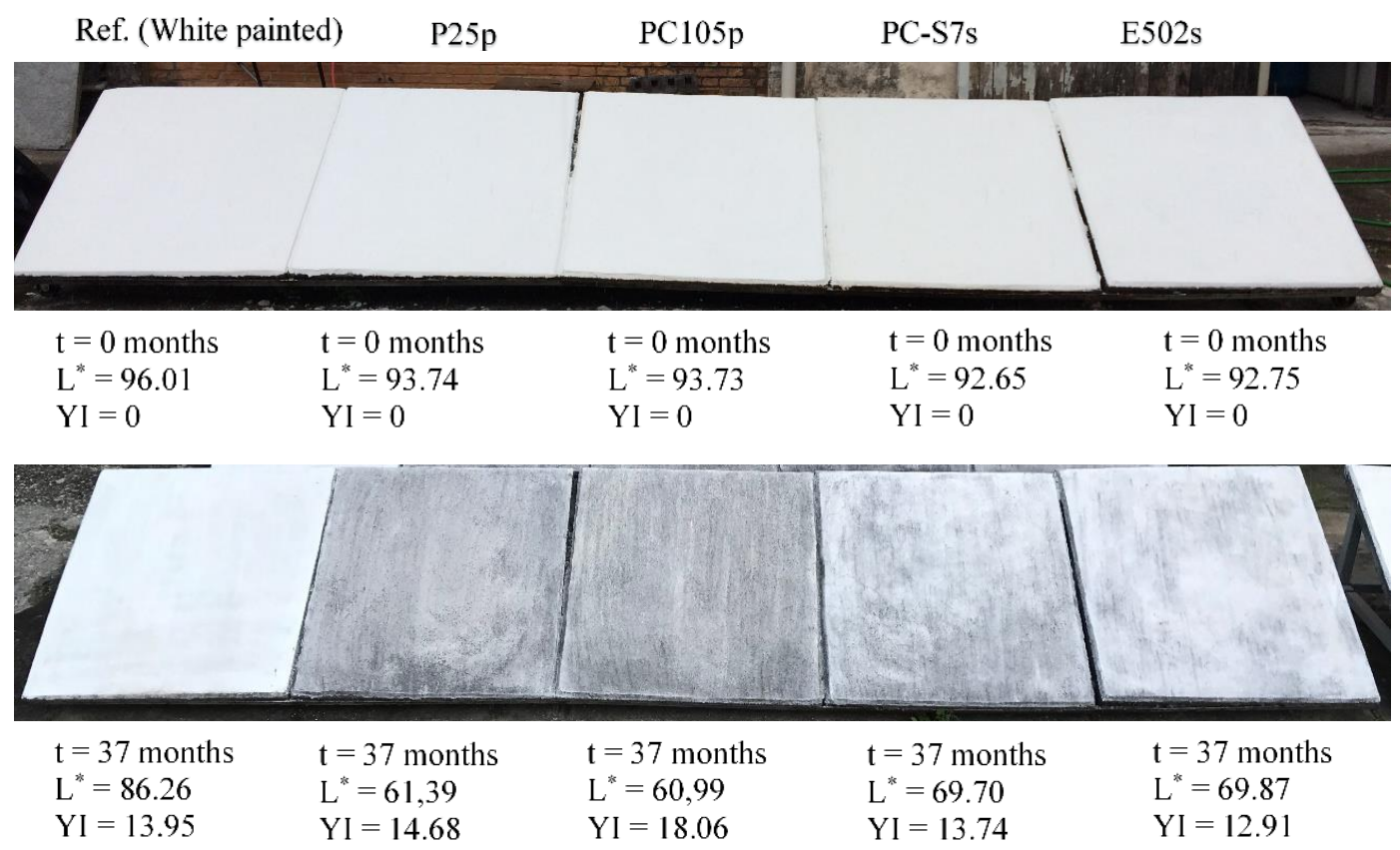

Source: Author (2021)

Figure 16. Visual evaluation of specimens over time (Group 3)

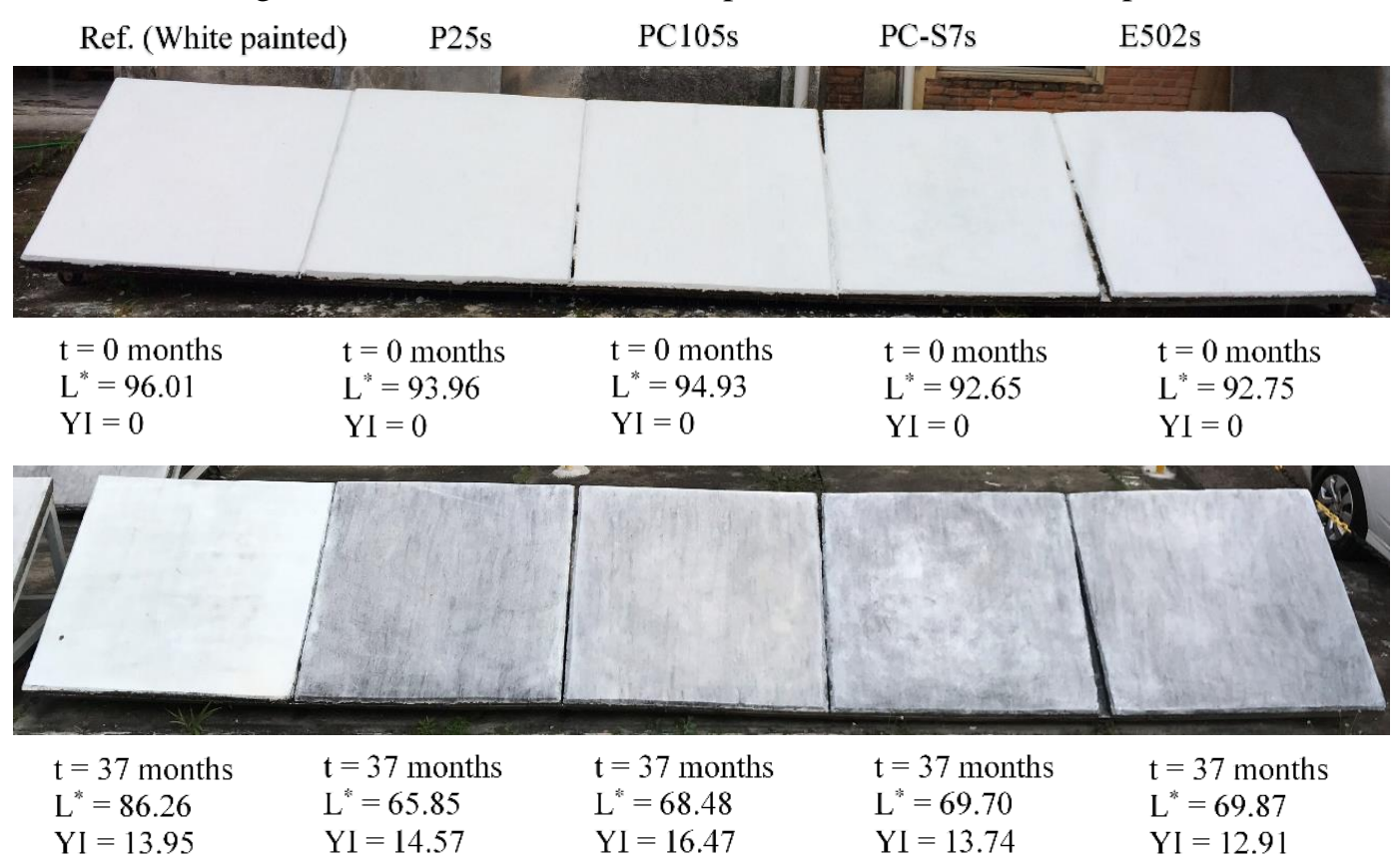

Source: Author (2021)

By and large, when the steps adopted by ABNT [33], as well as the results found with the $\Delta \mathrm{E}^{*}, \Delta \mathrm{L}^{*}$, and $\mathrm{JND}$, this study shows that considering all aspects in a general evaluation, for the final user who has a sensation of aesthetic comfort of the building facade, there is no difference on Ref. (white painted) specimens over three years of exposure, results that were also concluded by Loh et al. [35]. 
On the other hand, for all other specimens treated by $\mathrm{TiO}_{2}$ suspensions and $\mathrm{TiO}_{2}$ powder, the difference can be noticed very well after three years of exposure. Furthermore, compared to the specimens treated with the suspension of $\mathrm{TiO}_{2}$ and specimens treated with powder of $\mathrm{TiO}_{2}$ addition, the final user does not perceive differences. In other words, this difference measuring by the pyranometers is not perceived by the human senses yet.

\section{CONCLUSIONS}

This study described an approach for evaluating how the different types and treatments (suspension and powder) of $\mathrm{TiO}_{2}$ on mortars affect the maintenance of initial conditions in terms of their lightness when compared to white painted mortar exposed in the long term. The main findings can be summarized as follows:

Determining the methylene blue dye in the laboratory, the $\mathrm{TiO}_{2}-\mathrm{E} 502 \mathrm{~s}$ presented a better efficiency degrading about $80 \%$ of the compound already in the first 60 min of exposure. However, at the end of the tests, considering the remaining content of the dye, it is possible to say that $\mathrm{TiO}_{2}-\mathrm{E} 502 \mathrm{~s}, \mathrm{TiO}_{2}-\mathrm{P} 25 \mathrm{p}$, and $\mathrm{TiO}_{2}-\mathrm{PC}-\mathrm{S} 7 \mathrm{~s}$ samples have the same effectiveness ( $\pm 99.9 \%$ ), even providing different degradation of the dye over time. About the $\mathrm{TiO}_{2}-\mathrm{PC} 105 \mathrm{p}$ sample, this presented the worst performance, degrading only $29.5 \%$ of the compound.

$>$ Over three years of exposure, the white painted specimens showed the best results compared to the other. Besides, all $\mathrm{TiO}_{2}$ suspensions had better results than the $\mathrm{TiO}_{2}$ powder. Nevertheless, among the $\mathrm{TiO}_{2}$ suspensions, it cannot be said that there is the best, since all of them presented the same results when seen with the naked eye;

$>$ White painted specimens could be classified as white coating since it presents after three years of exposure 86.26 CIELab units of their lightness and absorptivity below 0.30 .

$>$ The specimens covered by $\mathrm{TiO}_{2}-\mathrm{P} 25 \mathrm{~s}, \mathrm{TiO}_{2}-\mathrm{PC} 105 \mathrm{~s}, \mathrm{TiO}_{2}-\mathrm{PC}-\mathrm{S} 7 \mathrm{~s}$, and $\mathrm{TiO}_{2}-\mathrm{E} 502 \mathrm{~s}$ suspension showed lightness values of 65.85, 68.48, 69.70, and 69.87 CIELab units, respectively, could be considered white membranes as well, showing intermediate absorptivity.

$>$ The specimens $\mathrm{TiO}_{2}-\mathrm{P} 25 \mathrm{p}$ and $\mathrm{TiO}_{2}-\mathrm{PC} 105 \mathrm{p}$ with $\mathrm{TiO}_{2}$ addition can be considered with a medium absorptivity and off-white color since they show after thirty-seven months of exposure, values of 61.39 and 60.99 CIELab units of their lightness, respectively. 
Concerning the visual aesthetic perception, the study concludes that no significant difference in painted specimens for the final user over three years. On the other hand, to all other specimens treated with $\mathrm{TiO}_{2}$ (suspensions and powder), the changes can be noticed very well when considered in the same period. 


\section{REFERENCE}

[1] SANTAMOURIS, M; SYNNEFA, A; KARLESSIET, T. Using advanced cool materials in the urban built environment to mitigate heat islands and improve thermal comfort conditions. Solar Energy, v. 85, n. 12, p. 3085-3102, 2011.

[2] ALCHAPAR, N. L.; CORREA, E. N.; CANTÓN, M. A. Índice de Reflectancia Solar de Revestimientos Verticales: potencial para la mitigación de la isla de calor urbana. Ambiente Construído, Porto Alegre, v. 12, n. 3, p.107-123, Jul. /Sept. 2012.

[3] AKBARI, H.; MENON, S.; ROSENFELD, A. Global cooling: increasing worldwide urban albedos to offset CO2. Climatic Change 95. 2009

[4] GOULART, S. Sustainability in Buildings and Urban Spaces - Discipline Thermal Performance of Buildings - Energy Efficiency Laboratory in buildings, Federal University of Santa Catarina, UFSC - handout - Available at:

https://labeee.ufsc.br/sites/default/files/disciplinas/ECV5161_Sustentabilidade_apostila_0_0.p

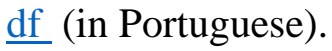

[5] ROSSI, F.; PISELLO, AL.; NICOLINI, A.; FILIPPONI, M.; PALOMBO, M. Analysis of retroreflective surfaces for urban heat island mitigation: a new analytical model. Applied Energy. v.114, p. 621-631, 2014.

[6] ROSSI, F.; CASTEllani, B.; PRESCIUTTI, A.; MORINI, E.; FILIPPONI, M.; NICOLINI, A.; SANTAMOURIS, M. Retroreflective façades for urban heat island mitigation: Experimental investigation and energy evaluations. Applied Energy. v.145, p. 8$20,2015$.

[7] BUENO, B.; NORFORD, L.; PIGEON, G.; BRITTER, R. A. Resistance-capacitance network model for the analysis of the interactions between the energy performance of buildings and the urban climate. Building Environment. v.54, p.16-25, 2012.

[8] DANTAS, S. R. A.; VITTORINO, F.; LOH, K. The effectiveness of $\mathrm{TiO}_{2}$ additions to mortar to maintain initial conditions in terms of its reflectance to solar radiation. Ambiente Construído, Porto Alegre, v. 17, n. 3, p. 39-56, jul./set. 2017. ISSN 1678-8621 Associação Nacional de Tecnologia do Ambiente Construído.

[9] ZAILAN, S. N.; BOUAISSI, A.; MAHME D, N.; ABDULLAH, M. M. AL B. Influence of $\mathrm{ZnO}$ Nanoparticles on Mechanical Properties and Photocatalytic Activity of Self-cleaning $\mathrm{ZnO}$-Based Geopolymer Paste. Journal of Inorganic and Organometallic Polymers and Materials. 2020.

[10] DIAMANTI, M. V. et al. Photocatalytic and Self- Cleaning Activity of Colored Mortar Containing $\mathrm{TiO}_{2}$. Construction And Building Materials, v.46, p.167-174, Sept. 2013.

[11] DILAURA, David L. (ed.). The lighting handbook: reference and application. 10. ed. New York, NY: Illuminating Engineering Society Of North America, 2011.

[12] CELA-CONDE, C. J.; MARTY, G.; MAESTÚ, F.; ORTIZ, T.; MUNAR, E.; FERNÁNDEZ, A.; ROCA, M.; ROSSELLÓ, J.; QUESNEY, F. Activation of the prefrontal cortex in the human visual aesthetic perception. National Academy of Sciences. v.101(16), p. 6321-6325, 2004. 
[13] NADENAU, M. Integration of human color vision models into high quality image compression. Lausanne, 2000. Thèse (Docteur ès sciences techniques) - École Polytechnique Fédérale de Lausanne, Lausanne, 2009.

[14] LOPES, L. da C. Metrological color control applied to digital printing of textile materials. Rio de Janeiro, 2009. Dissertation (Master in Metrology for Industrial Quality) Pontifical Catholic University of Rio de Janeiro - PUC-Rio, Rio de Janeiro, 2009 (in Portuguese).

[15] BARCELLOS, R. New method of mapping color spaces through specialized artificial neural networks. São Carlos, 2011. Thesis (Ph.D. in Sciences) - São Carlos School of Engineering, University of São Paulo, São Carlos, 2011 (in Portuguese).

[16] LOPES, J. M. B. Cor e Luz. Lisbon, 2003. Instituto Superior Técnico, University of Lisbon, Lisbon, 2003 (in Portuguese).

[17] SOUZA, R. C. C. Image evaluation through structural similarity and the concept of minimum noticeable color difference. Rio de Janeiro, 2009. Dissertation (Master in Electronic Engineering) - School of Engineering, State University of Rio de Janeiro, Rio de Janeiro, 2009 (in Portuguese).

[18] JOHNSTON, W. M.; KAO, E. C. Assessment of Appearance Match by Visual Observation and Clinical Colorimetry. Journal of Dental Research, Ohio, p. 819-822, May 1989.

[19] DANTAS, S. R. A.; ROMANO, RC DE O.; VITTORINO, F.; LOH, K. Effects of surface roughness and light scattering on the activation of $\mathrm{TiO}_{2}$ on mortar photocatalytic process. Construction and Building Materials, v. 270, p. 121421, 2021.

[20] DANTAS, S. R. A; SERAFINI, R; ROMANO, R. C. de O; VITTORINO, F; LOH, K. Influence of the nano $\mathrm{TiO}_{2}$ dispersion procedure on fresh and hardened rendering mortar properties, Construction and Building Materials, v.215, p.544-556, 2019.

[21] DANTAS, S. R. A.; LIMA, F. J. N. de; ROMANO, R. C. de O.; PILEGGI, R.; LOH, K. Evaluation of rheological properties of mortar with $\mathrm{TiO} 2$ addition. Ambiente Construído, Porto Alegre, v. 21, n. 4, p. 7-21, out./dez. 2021. ISSN 1678-8621 Associação Nacional de Tecnologia do Ambiente Construído.

[22] AMERICAN SOCIETY FOR TESTING AND MATERIAL - ASTM C1365-06: Standard Test Method for Determination of the Proportion of Phases in Portland cement and Portland-Cement Clinker Using X-ray Powder Diffraction Analysis, 2011.

[23] BRAZILIAN ASSOCIATION OF TECHNICAL STANDARDS - ABNT. NBR 14656: Portland cement and raw materials - Chemical analysis by X-ray spectrometry - Test method, Rio de Janeiro, 2001 (in Portuguese).

[24] TRUFFIER-BOUTRY, D.; FIORENTINO, B.; BARTOLOMEI, V.; SOULAS, R.; SICARDY, O.; BENAYAD, A.; DAMLENCOURT, J.-F.; PÉPIN-DONAT, B.; LOMBARD, C.; GANDOLFO, A.; WORTHAM, A.; BROCHARD, G.; AUDEMARD, A.; PORCAR, L.; G. GEBEL, G.; GLIGOROVSKI, S. Characterization of photocatalytic paints: a relationship 
between the photocatalytic properties - release of nanoparticles and volatile organic compounds. Environmental Science Nano, v. 4, p. 1998 - 2009, 2017.

[25] BRAZILIAN ASSOCIATION OF TECHNICAL STANDARDS - ABNT. NBR 9695: Fire extinguishing powder: Determination of phosphorus content - Test method, Rio de Janeiro, 2012 (in Portuguese).

[26] AMERICAN SOCIETY FOR TESTING AND MATERIAL - ASTM. D2244-21: standard practice for calculation of color tolerances and color differences from instrumentally measured color coordinates.

[27] AMERICAN SOCIETY FOR TESTING AND MATERIAL - ASTM E284-17. Standard Terminology of Appearance, 2017.

[28] AMERICAN SOCIETY FOR TESTING AND MATERIAL - ASTM E313-20. Standard Practice for Calculating Yellowness and Whiteness Indices from Instrumentally Measured Color Coordinates, 2020.

[29] BRAINARD, D. H. 5 - Color Appearance and Color Difference Specification. The Science of Color (Second Edition), p. 11-216, 2003.

[30] SHARMA, G.; WY. W.; DALAL, E. N. The CIEDE2000 Color-Difference formula: implementation notes, supplementary test data, and mathematical observations. Color Research and Application, v. 30, p. 21-30, 2004.

[31] MUNAFÒ, P.; GOFFREDO, G. B.; QUAGLIARINI, E. TiO2-Based Nanocoatings for Preserving Architectural Stone Surfaces: an overview. Construction And Building Materials, v. 84, p. 201-218, jun. 2015.

[32] BELlAN, L. M.; SALMON, L. G.; CASS, G. R. A Study on the Human Ability to Detect Soot Deposition on to Works of Art. Environmental Science and Technology, 2000; v. 34, p. 1946-1952, 2000.

[33] BRAZILIAN ASSOCIATION OF TECHNICAL STANDARDS - ABNT. NBR 15575: Residential buildings - Performance - Part 1: General requirements, Rio de Janeiro, 2013 (in Portuguese).

[34] LAMBERTS, R.; DUTRA, L.; PEREIRA, F. Energy Efficiency in Architecture. p. 192, São Paulo, 1997.

[35] LOH, K.; CARDOSO, E. L.; SATO, N. M., N.; SHIRAKAWA, M.; JOHN, V. M. Outdoor Paint Ageing of Brazilian Paints - Part two. International Conference on Durability of Building Materials and Components. Porto - Portugal, 2011. 
APPENDIX H - SURFACE TOPOGRAPHY OF THE SPECIMENS

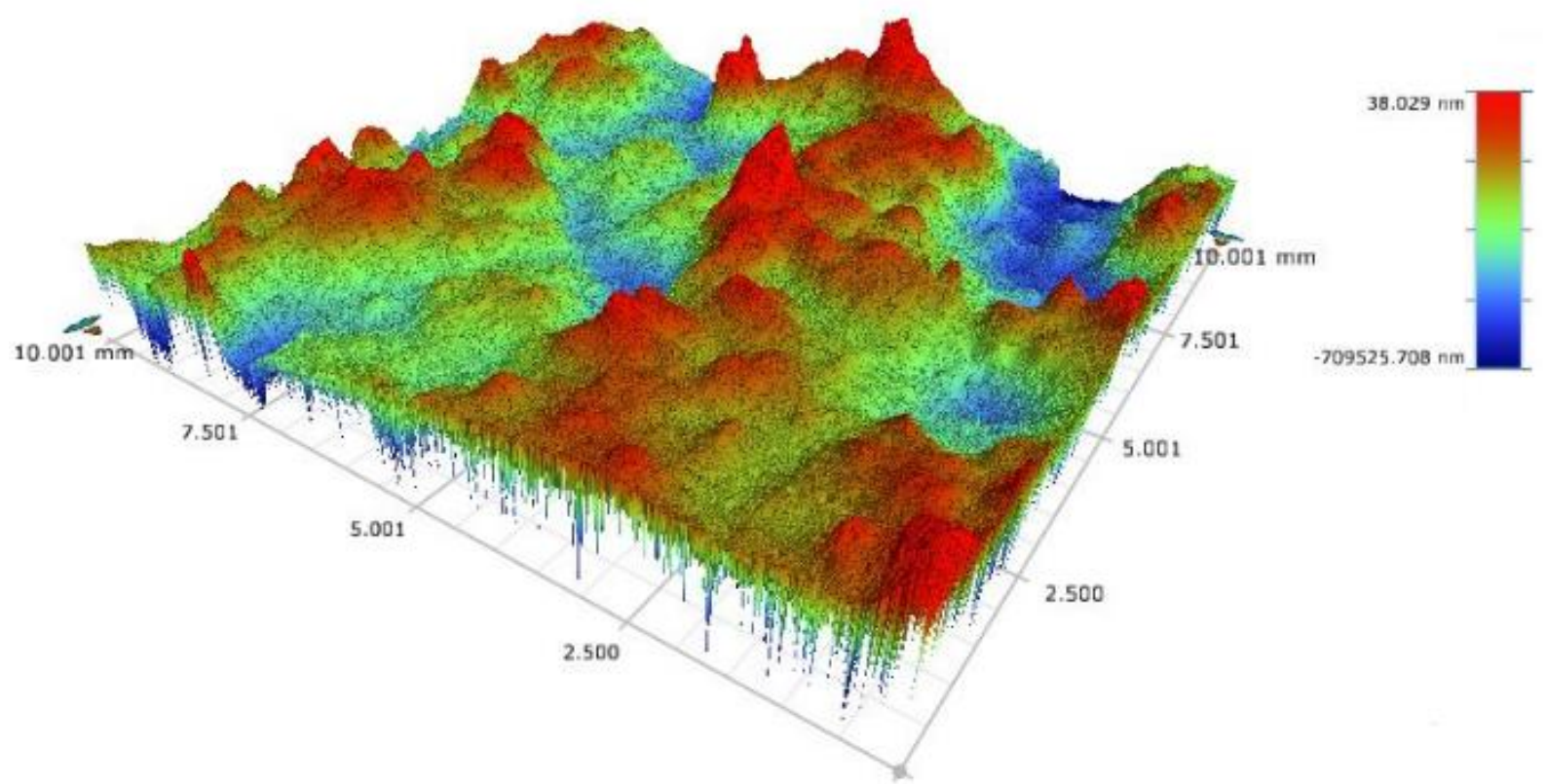

Note: Ref_painted

Source: Author (2021)

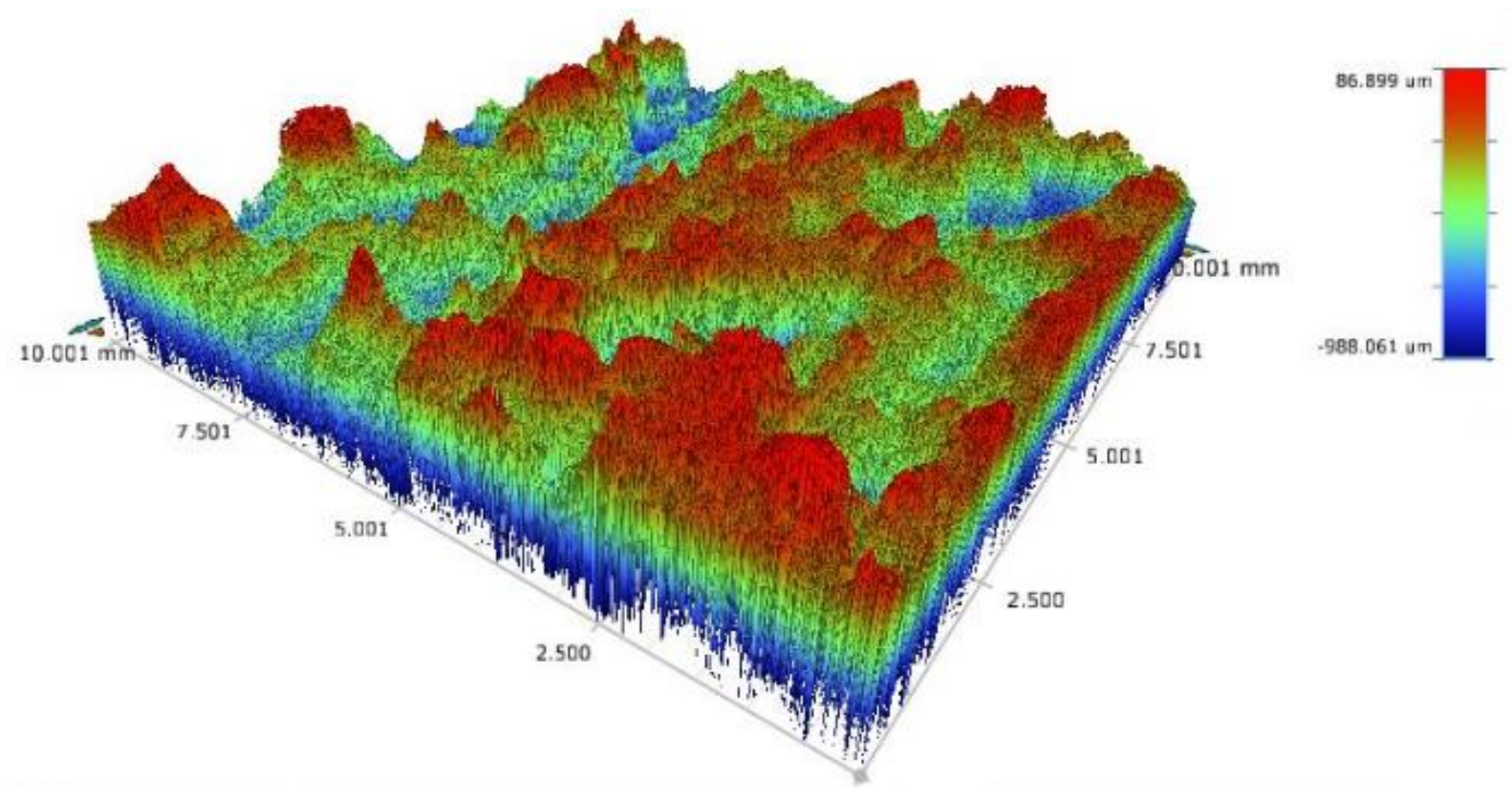

Note: P25p

Source: Author (2021) 

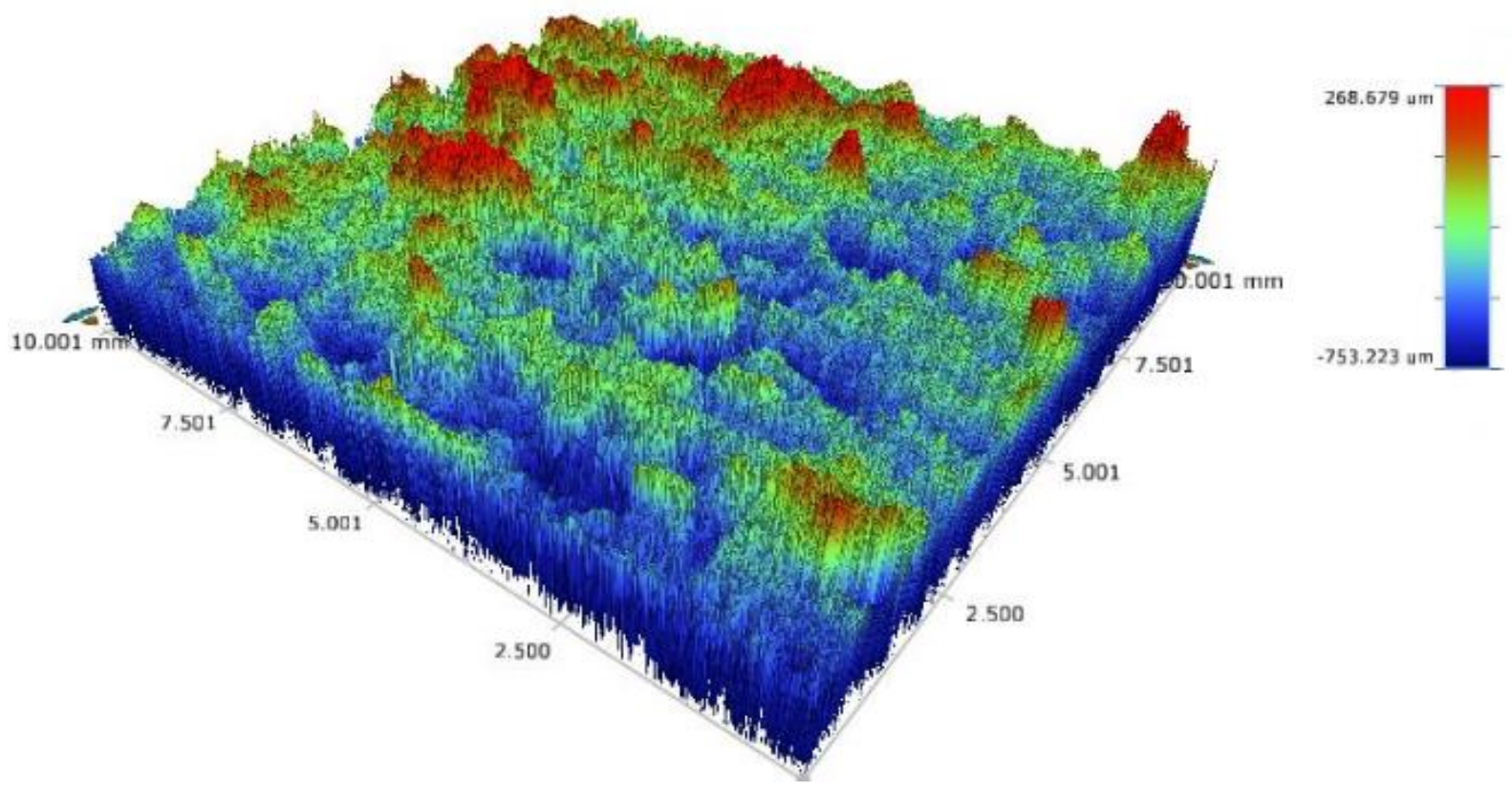

Note: PC105p

Source: Author (2021)

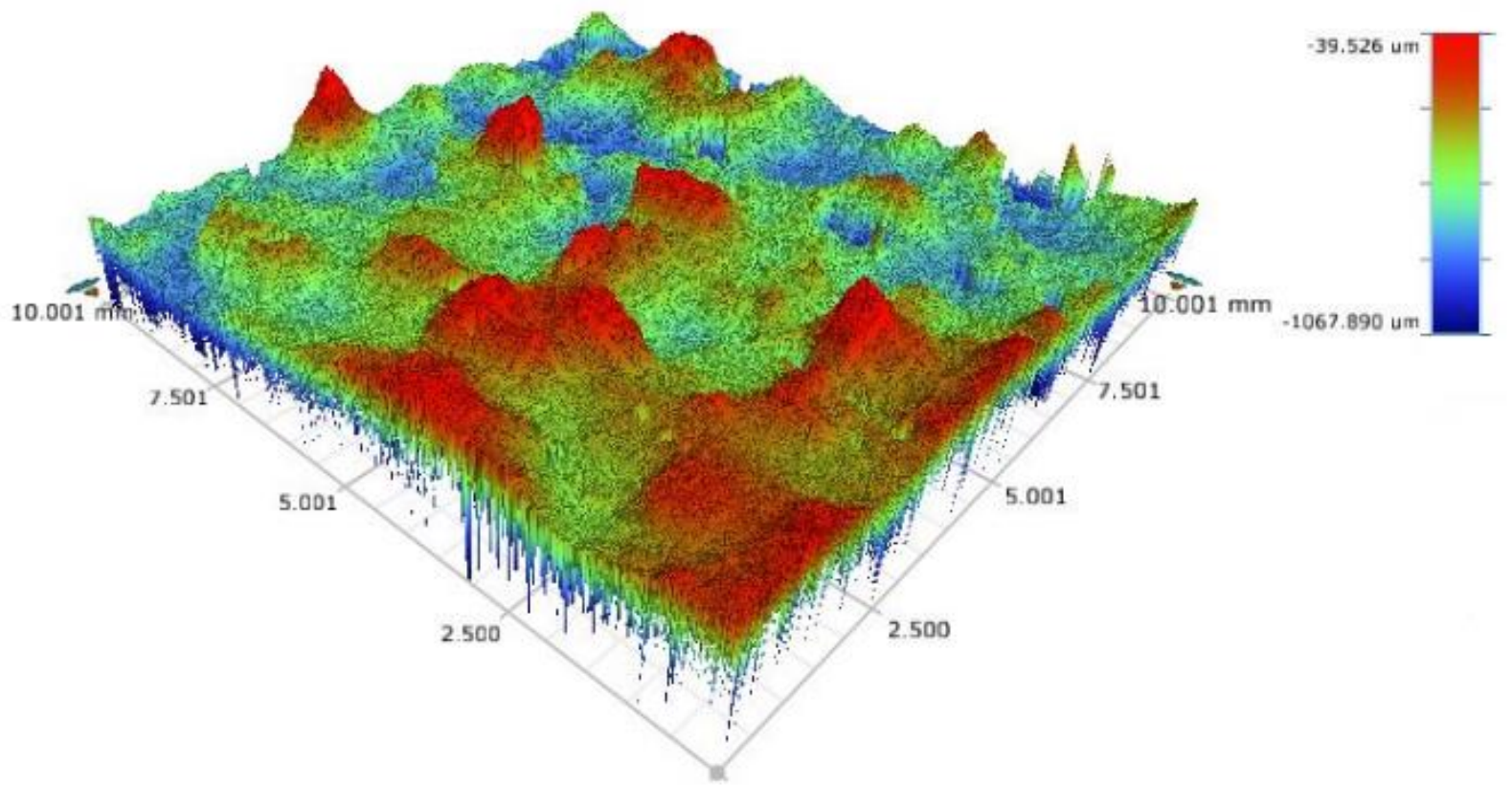

Note: P25s

Source: Author (2021) 


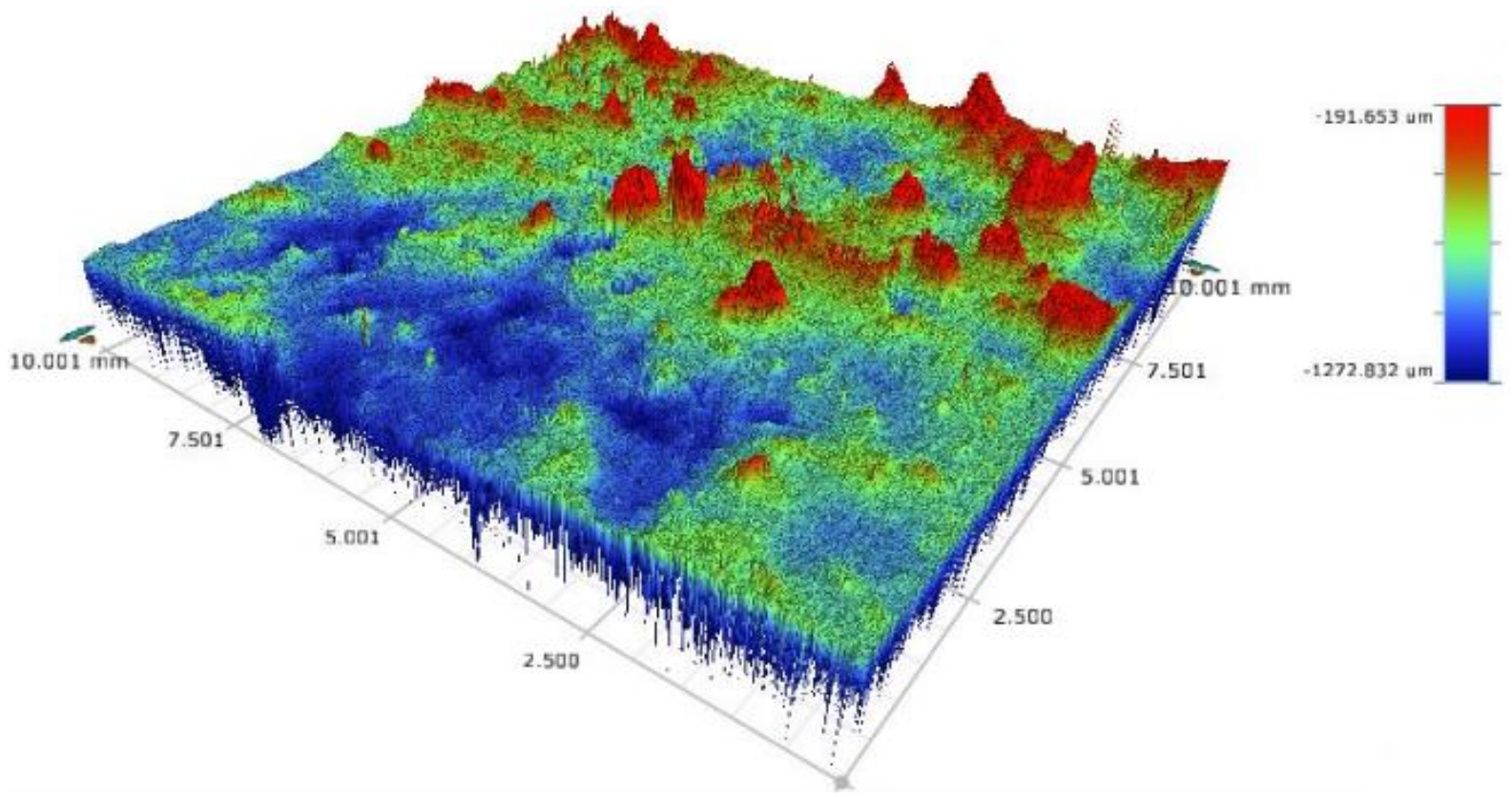

Note: PC105s

Source: Author (2021)

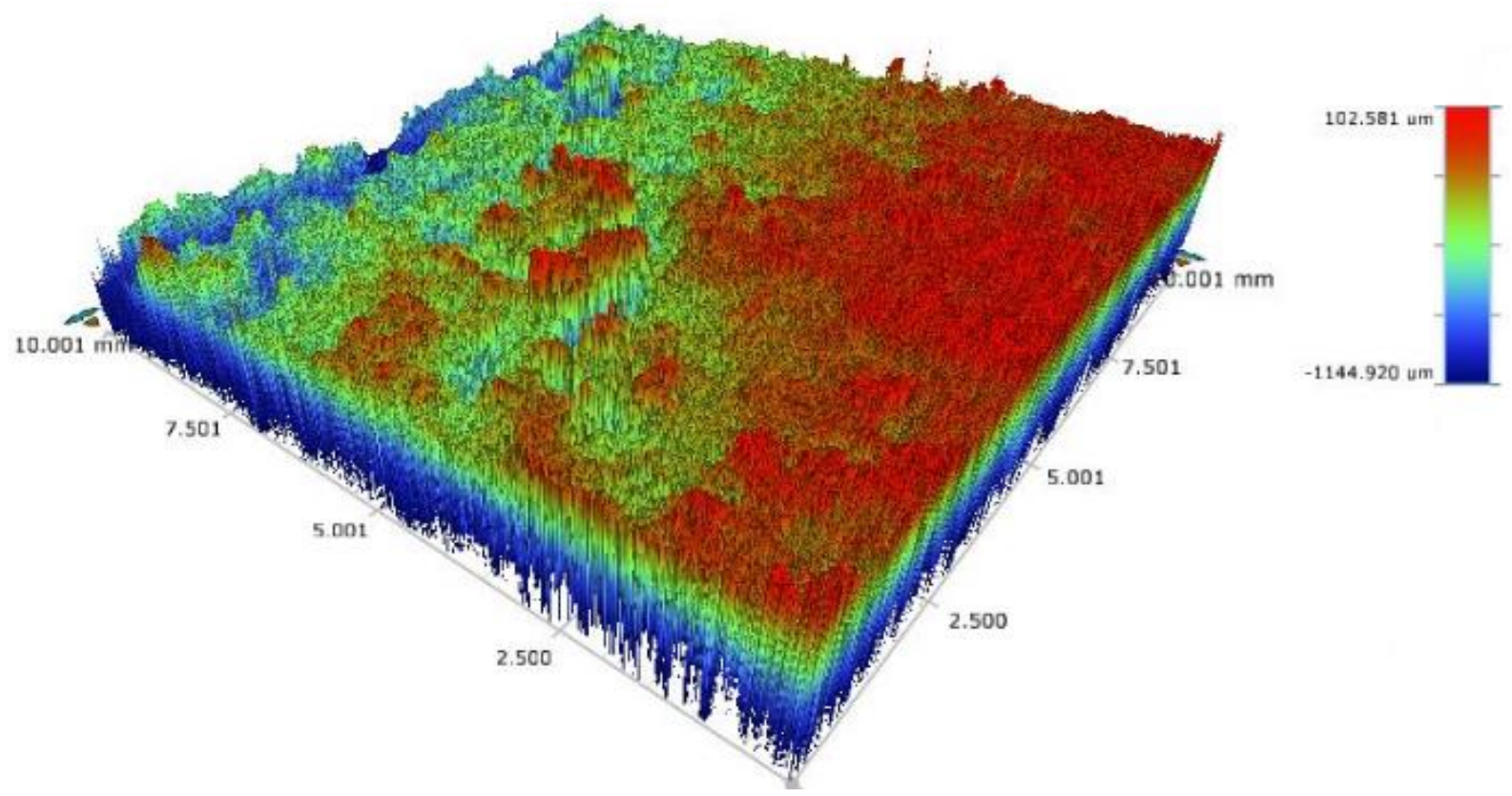

Note: PC-S7s

Source: Author (2021) 


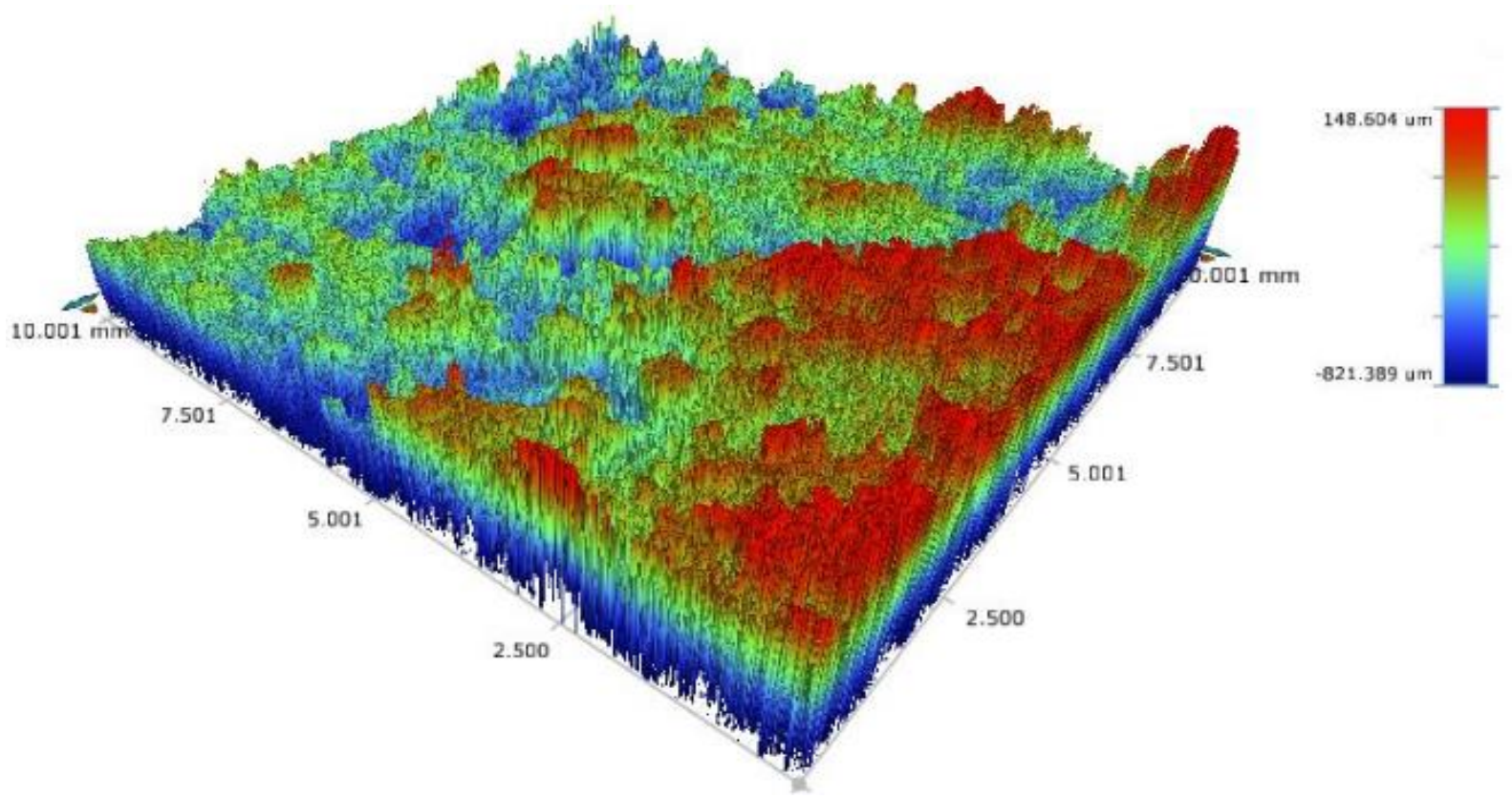

Note: E502s

Source: Author (2021) 
APPENDIX I - ROUGHNESS PROFILE OF THE SPECIMENS
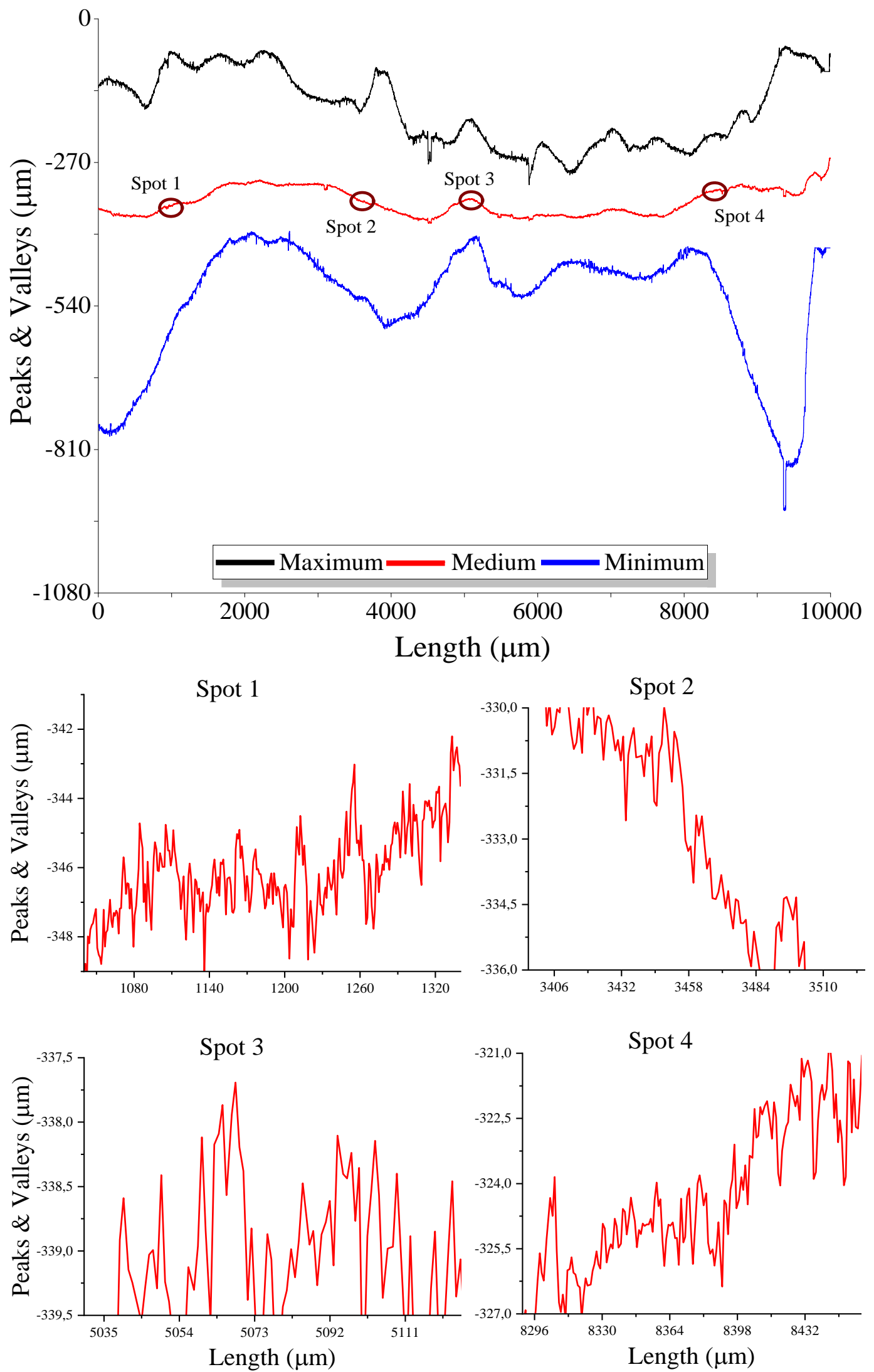

Note: Ref_painted

Source: Author (2021) 

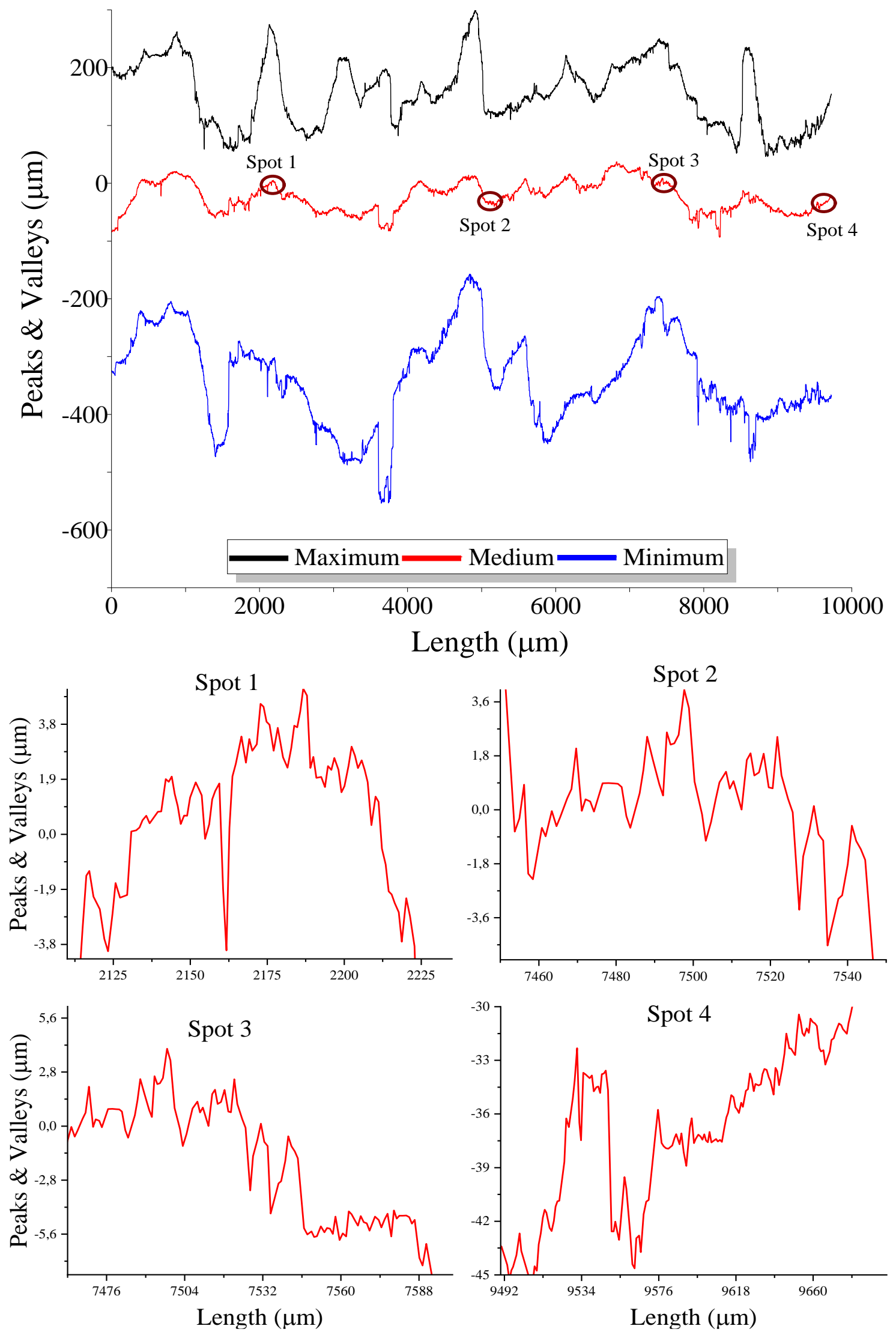

Note: P25p

Source: Author (2021) 

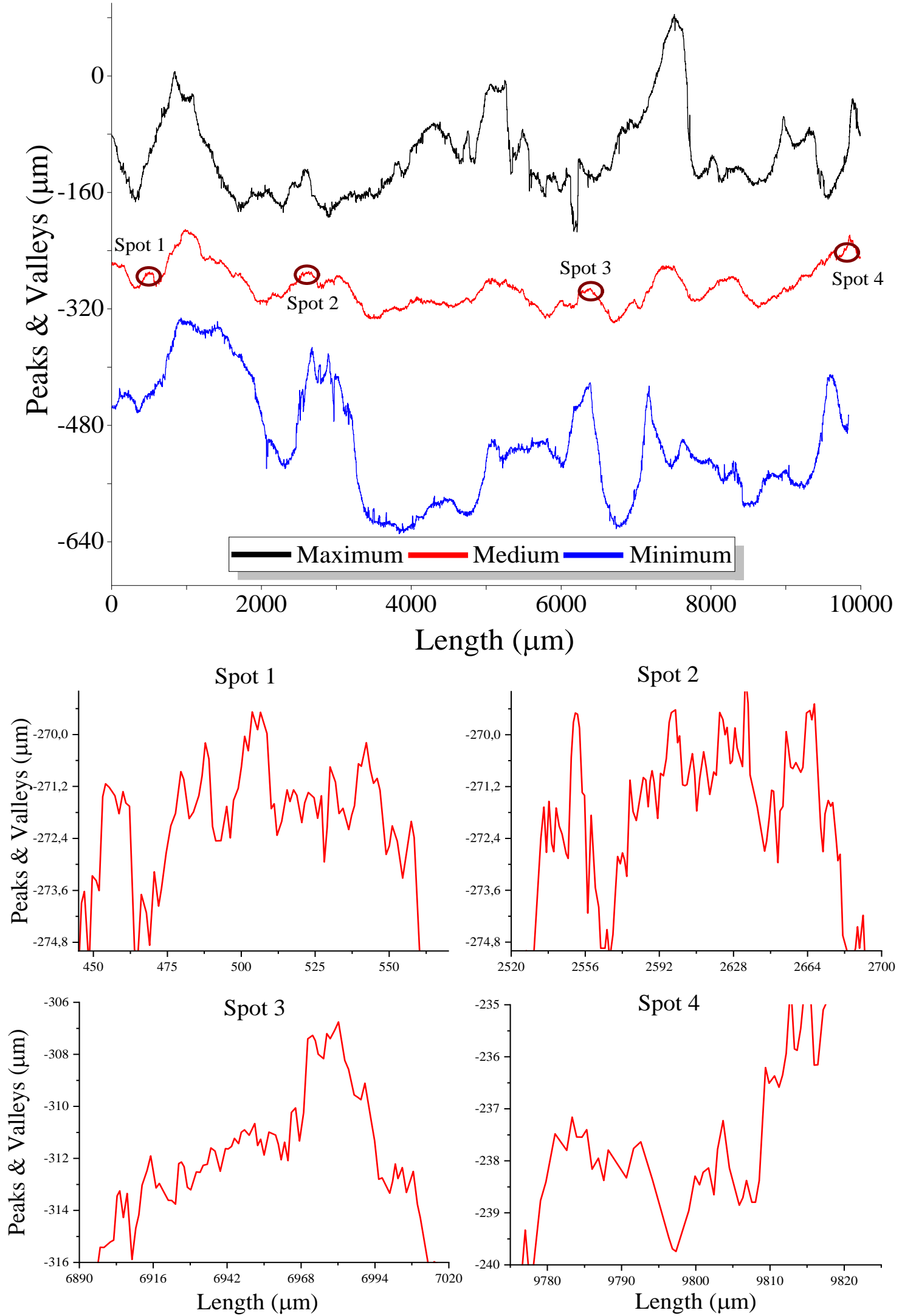

Note: PC105p

Source: Author (2021) 

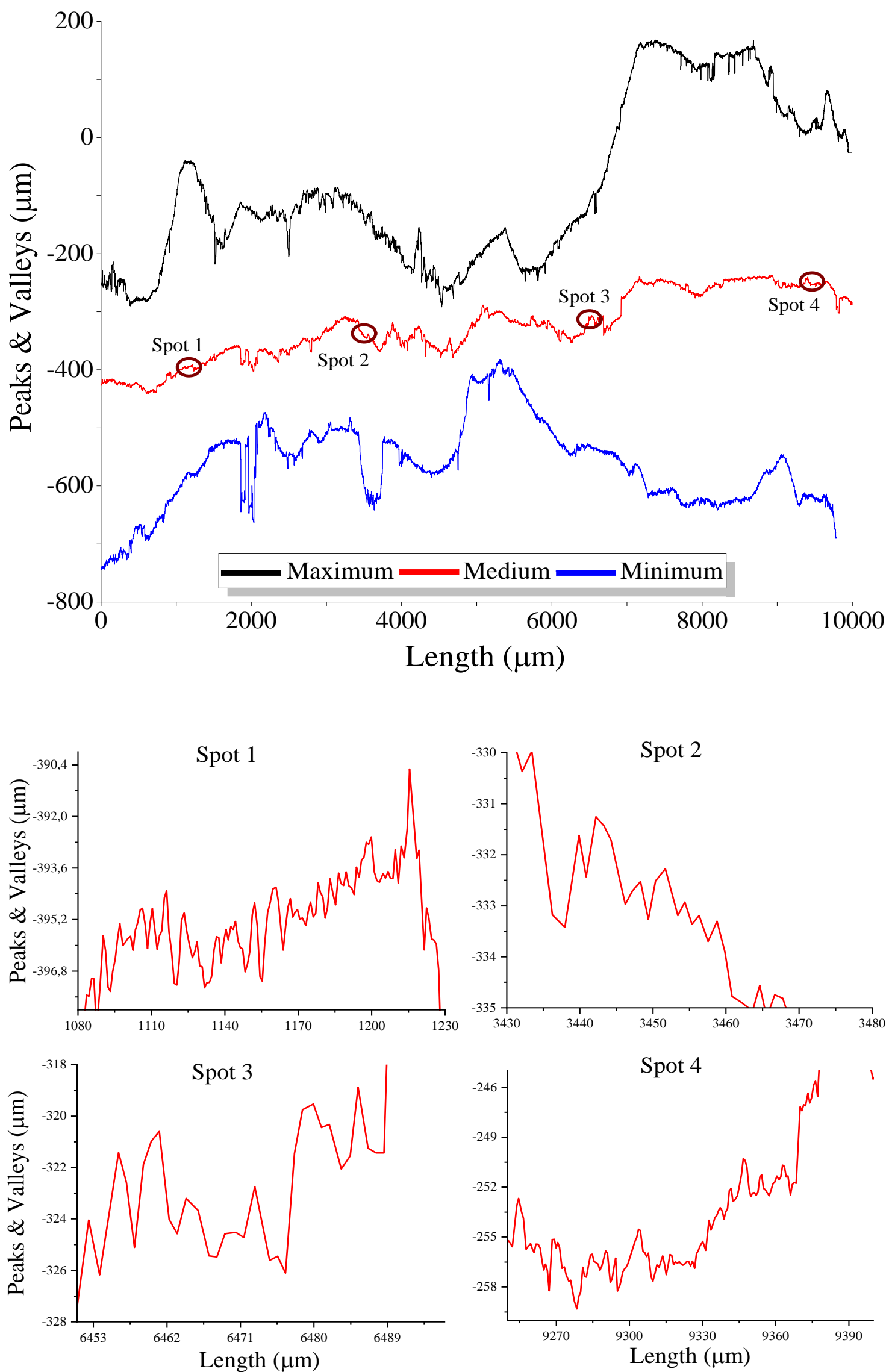

Note: P25s

Source: Author (2021) 

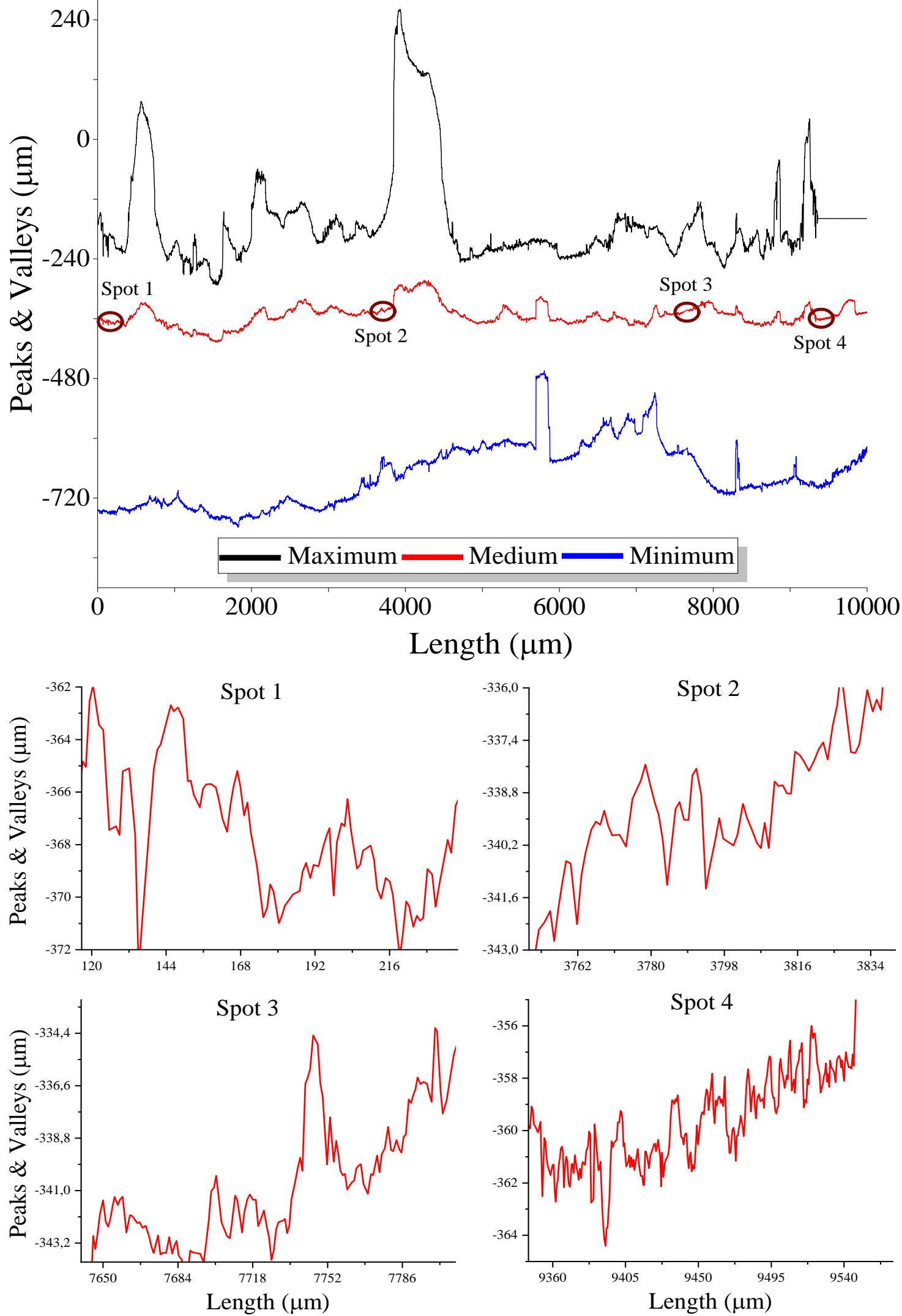

Note: PC105s

Source: Author (2021) 

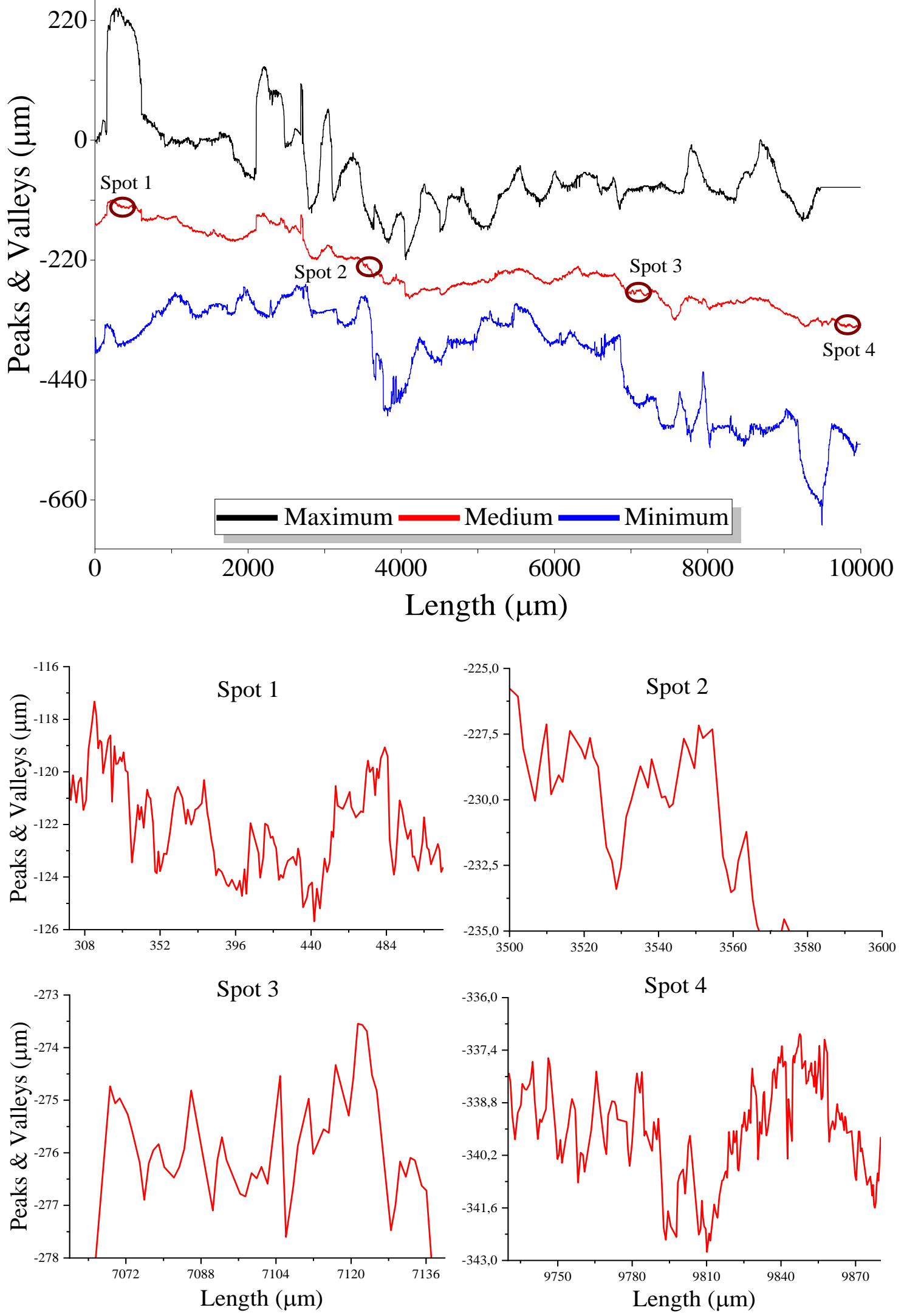

Note: PC-S7s

Source: Author (2021) 

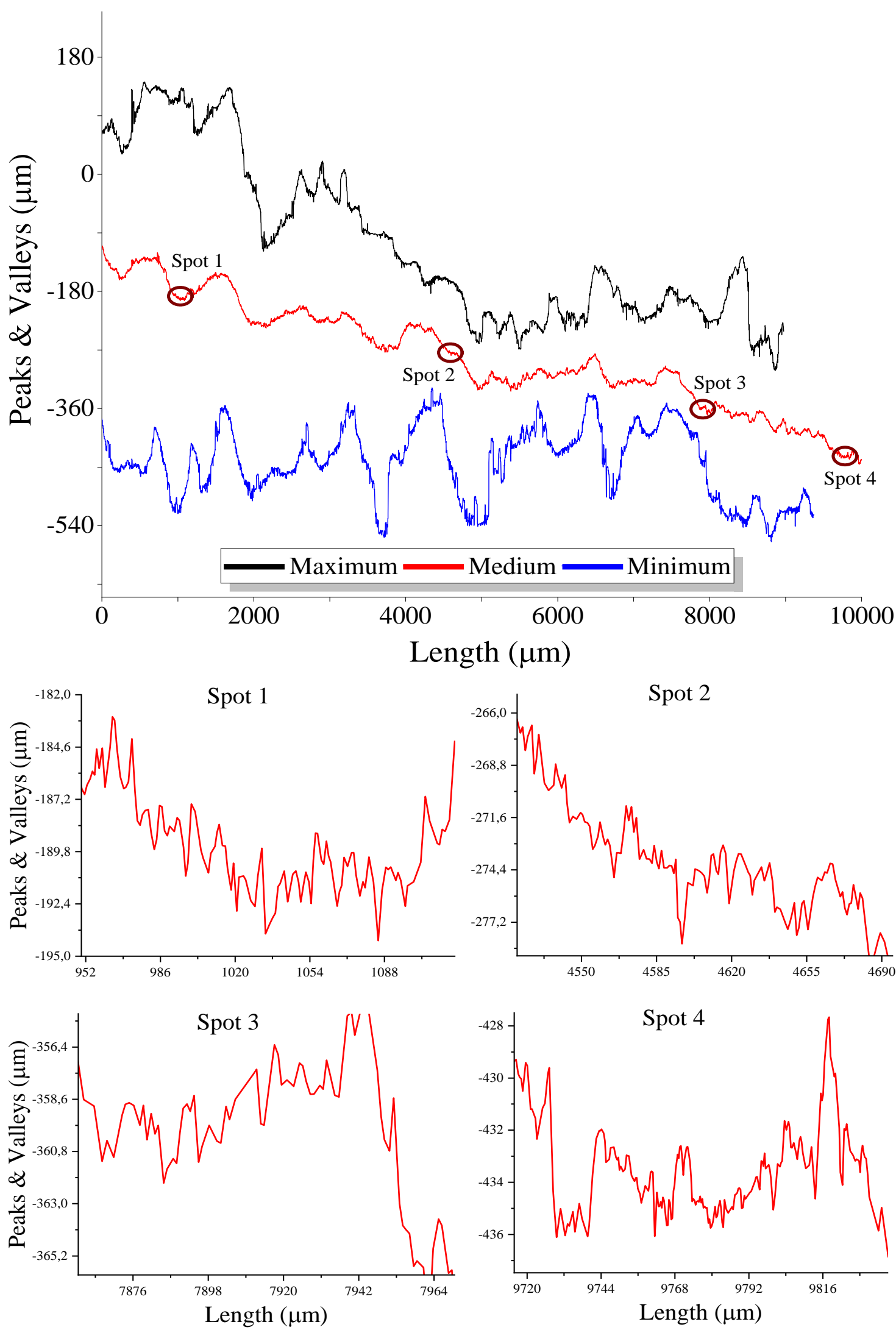

Note: E502s

Source: Author (2021) 


\section{APPENDIX J - SCANNING ELECTRON MICROSCOPY (SEM) OF THE SPECIMENS}
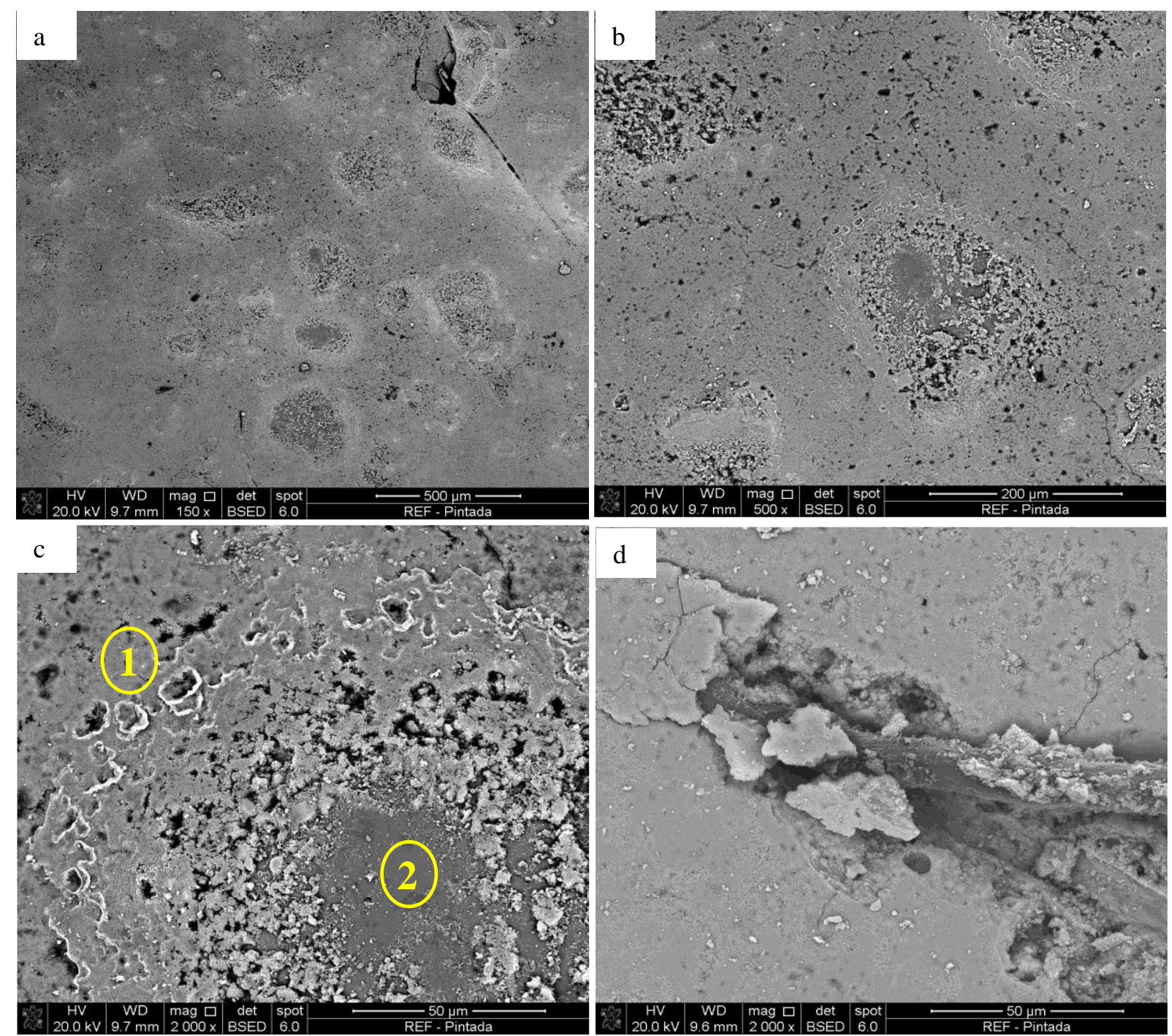

Note: Ref_painted mortar - Paint film formation at $500 \mu \mathrm{m}$ scale (a); Paint film formation at $200 \mu \mathrm{m}$ scale (b); Paint film formation at $50 \mu \mathrm{m}$ (1c); Paint flawed film spot at $50 \mu \mathrm{m}$ (2c); Polypropylene microfibers at $50 \mu \mathrm{m}$ scale (d).

Source: Author (2021) 


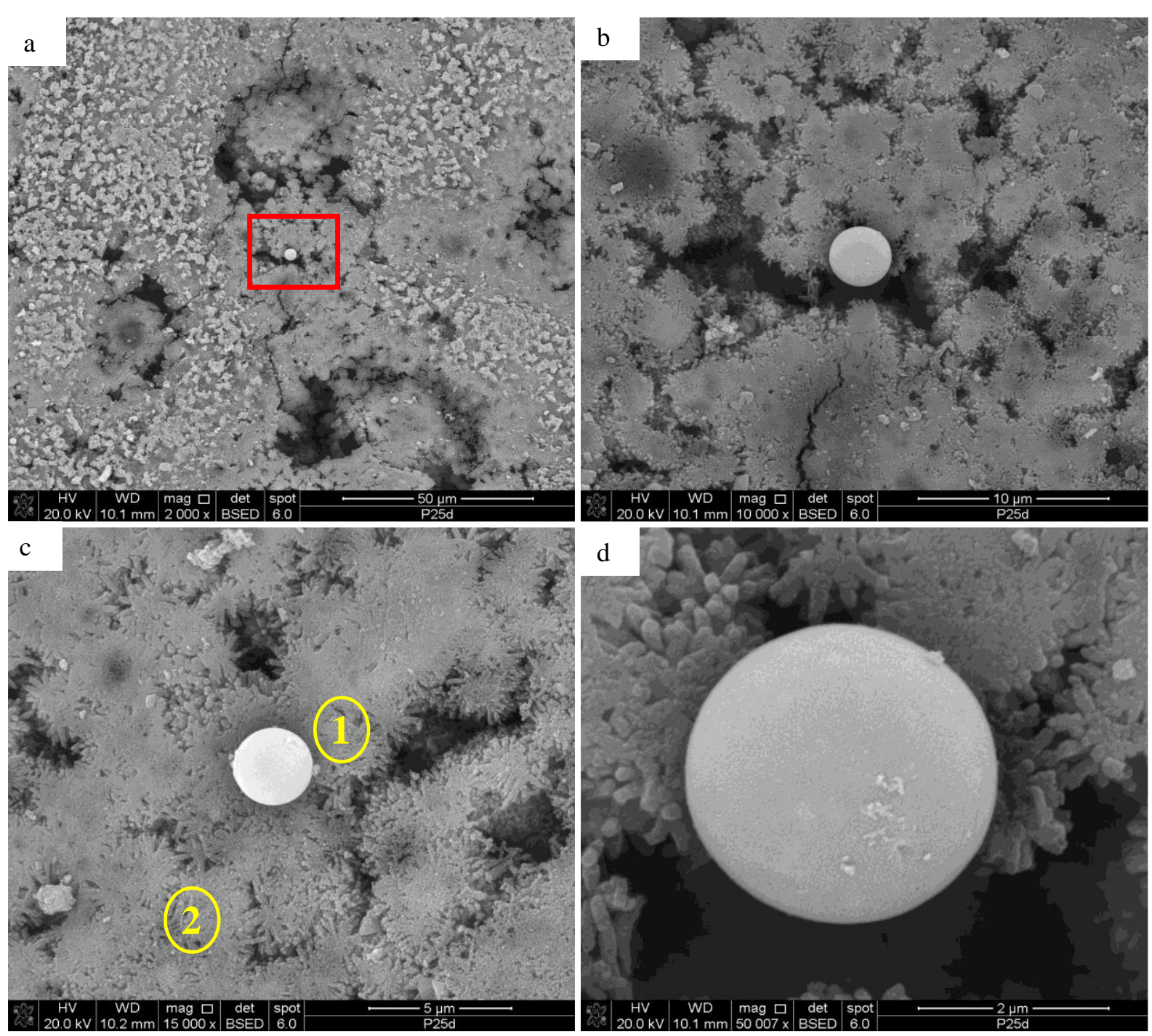

Note: P25p mortar - $\mathrm{TiO}_{2}$ particle dispersion at $50 \mu \mathrm{m}$ scale (a); $\mathrm{TiO}_{2}$ particle dispersion at $10 \mu \mathrm{m}$ scale (b); Morphology of $\mathrm{TiO}_{2}$ at $5 \mu \mathrm{m}$ scale (1c); Mortar surface at $5 \mu \mathrm{m}(2 \mathrm{c})$; Morphology of $\mathrm{TiO}_{2}$ at $2 \mu \mathrm{m}$ scale (d).

Source: Author (2021)

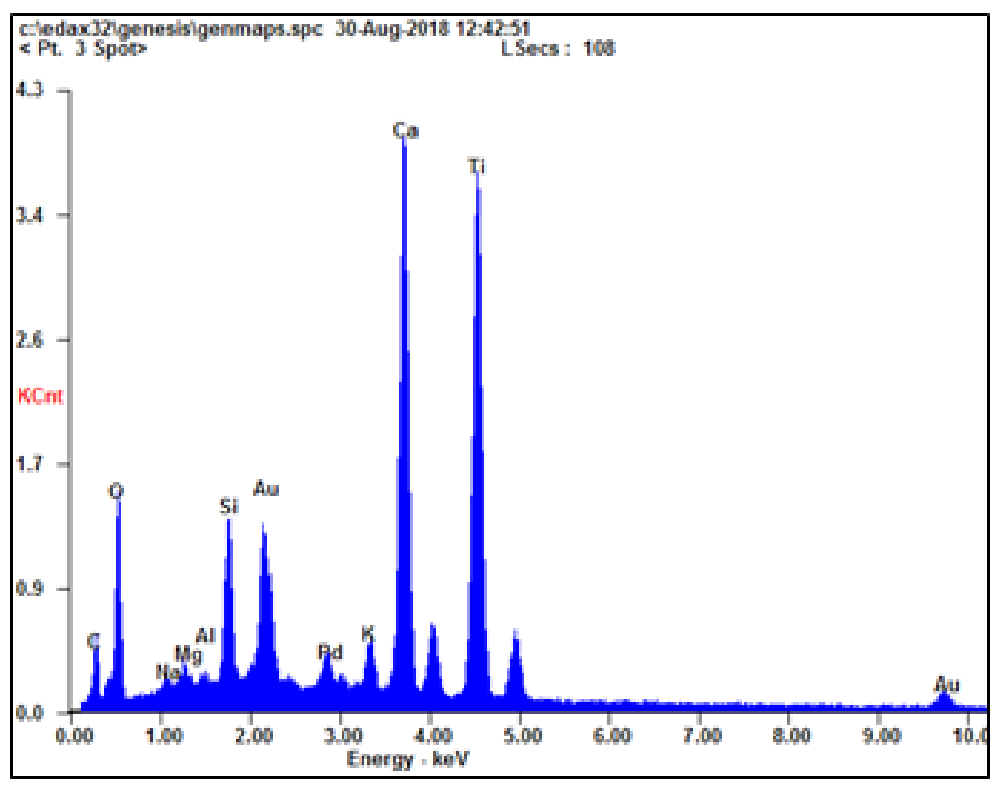

\begin{tabular}{||l|l|l|}
\hline Element & Wt\% & At\% \\
\hline $\boldsymbol{C K}$ & 07.91 & 19.04 \\
\hline $\boldsymbol{O K}$ & 22.72 & 41.07 \\
\hline $\mathbf{N a K}$ & 00.81 & 01.02 \\
\hline $\boldsymbol{M g K}$ & 00.95 & 01.13 \\
\hline $\boldsymbol{A l K}$ & 00.51 & 00.55 \\
\hline SiK & 03.75 & 03.87 \\
\hline $\boldsymbol{P d L}$ & 02.84 & 00.77 \\
\hline $\boldsymbol{K K}$ & 01.78 & 01.31 \\
\hline $\boldsymbol{C a K}$ & 18.88 & 13.63 \\
\hline TiK & 25.73 & 15.54 \\
\hline AuL & 14.11 & 02.07 \\
\hline Matrix & Correction & ZAF \\
\hline
\end{tabular}



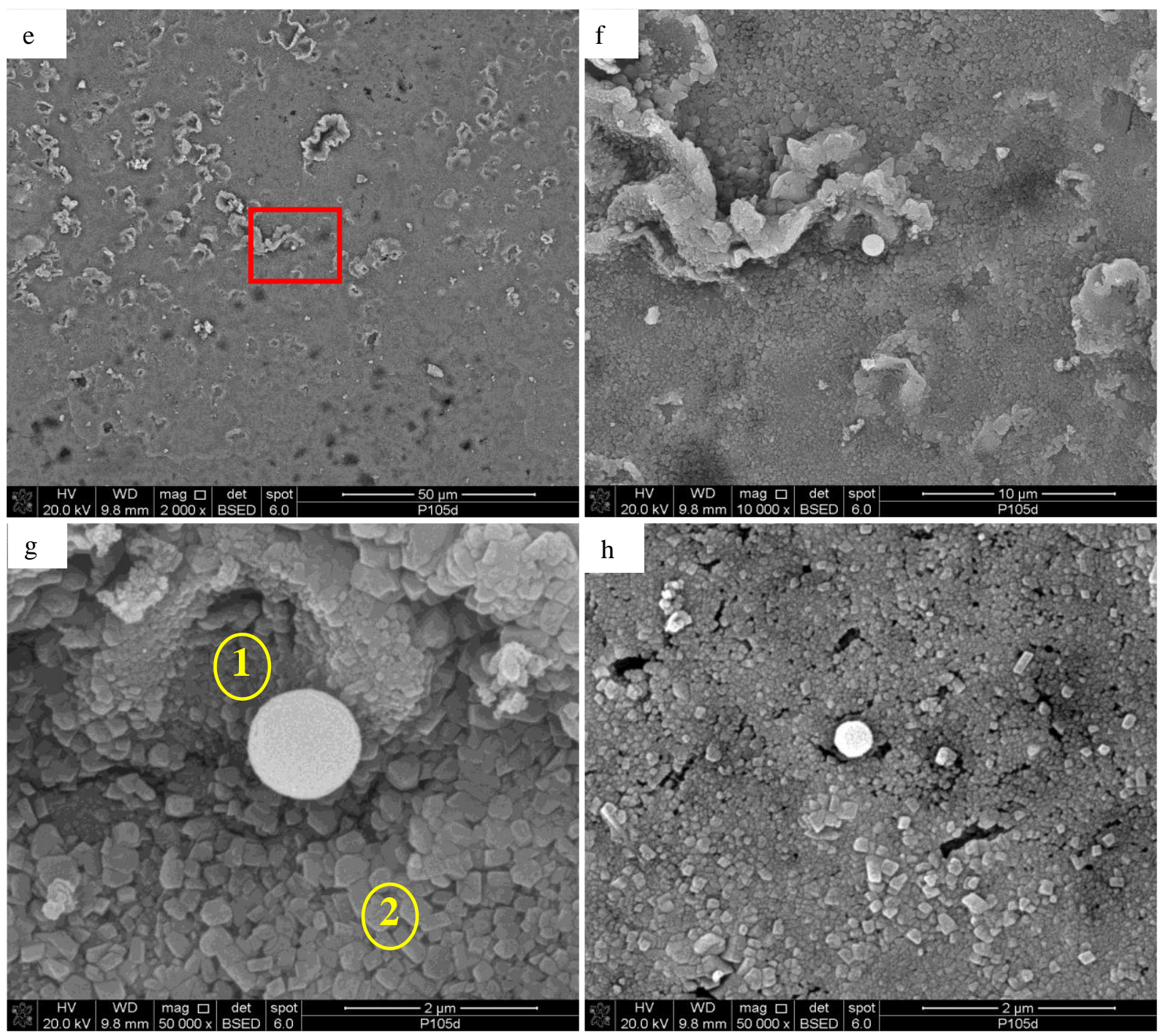

Note: $\mathrm{PC} 105 \mathrm{p}$ mortar - $\mathrm{TiO}_{2}$ particle dispersion at $50 \mu \mathrm{m}$ scale (e); $\mathrm{TiO}_{2}$ particle dispersion at $10 \mu \mathrm{m}$ scale (f); Morphology of $\mathrm{TiO}_{2}$ at $2 \mu \mathrm{m}$ scale (1g); Mortar surface at $2 \mu \mathrm{m}(2 \mathrm{~g})$; Morphology of $\mathrm{TiO}_{2}$ at $2 \mu \mathrm{m}$ scale (h).

Source: Author (2021)

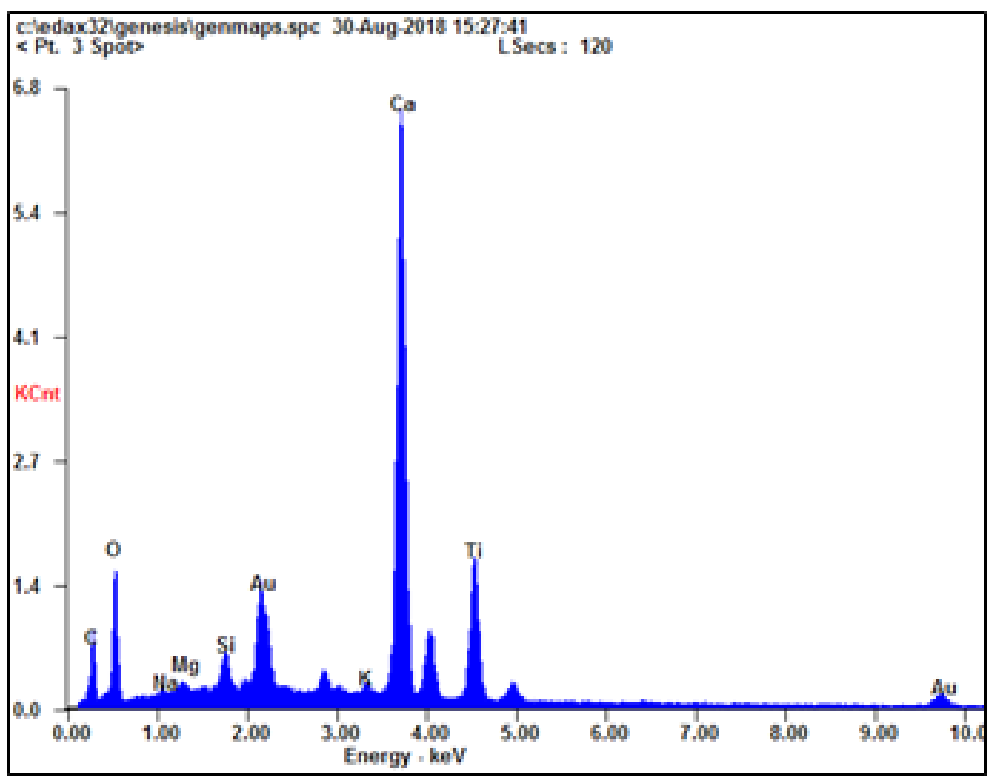

\begin{tabular}{||l|l|l|}
\hline Element & Wt\% & At\% \\
\hline $\boldsymbol{C K}$ & 12.02 & 27.30 \\
\hline $\boldsymbol{O K}$ & 23.09 & 39.37 \\
\hline $\mathbf{N a K}$ & 00.41 & 00.49 \\
\hline $\boldsymbol{M g K}$ & 00.60 & 00.67 \\
\hline $\mathbf{S i K}$ & 01.42 & 01.38 \\
\hline $\boldsymbol{P d} \boldsymbol{L}$ & 00.76 & 00.19 \\
\hline $\boldsymbol{K K}$ & 00.68 & 00.48 \\
\hline $\boldsymbol{C a K}$ & 30.83 & 20.98 \\
\hline TiK & 11.50 & 06.55 \\
\hline \hline AuL & 18.69 & 02.59 \\
\hline Matrix & Correction & ZAF \\
\hline
\end{tabular}



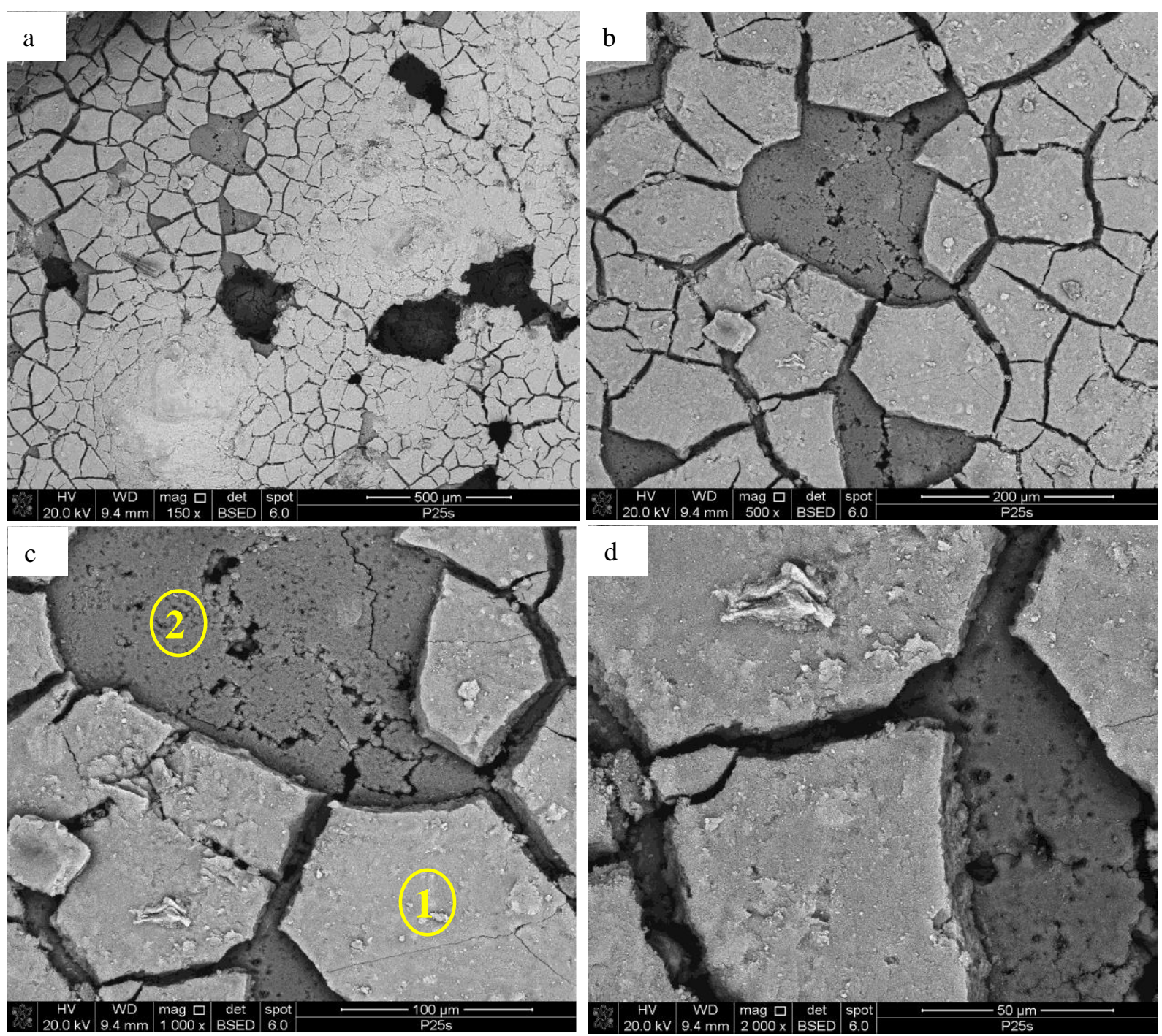

Note: P25s mortar - Formation of $\mathrm{TiO}_{2}$ film at $500 \mu \mathrm{m}$ scale (a); Formation of $\mathrm{TiO}_{2}$ film at $200 \mu \mathrm{m}$ scale (b); Formation of $\mathrm{TiO}_{2}$ film at $100 \mu \mathrm{m}$ (1c); $\mathrm{TiO}_{2}$ film flawed spot at $100 \mu \mathrm{m}$ (2c); Formation of $\mathrm{TiO}_{2}$ film at $50 \mu \mathrm{m}(\mathrm{d})$.

Source: Author (2021)

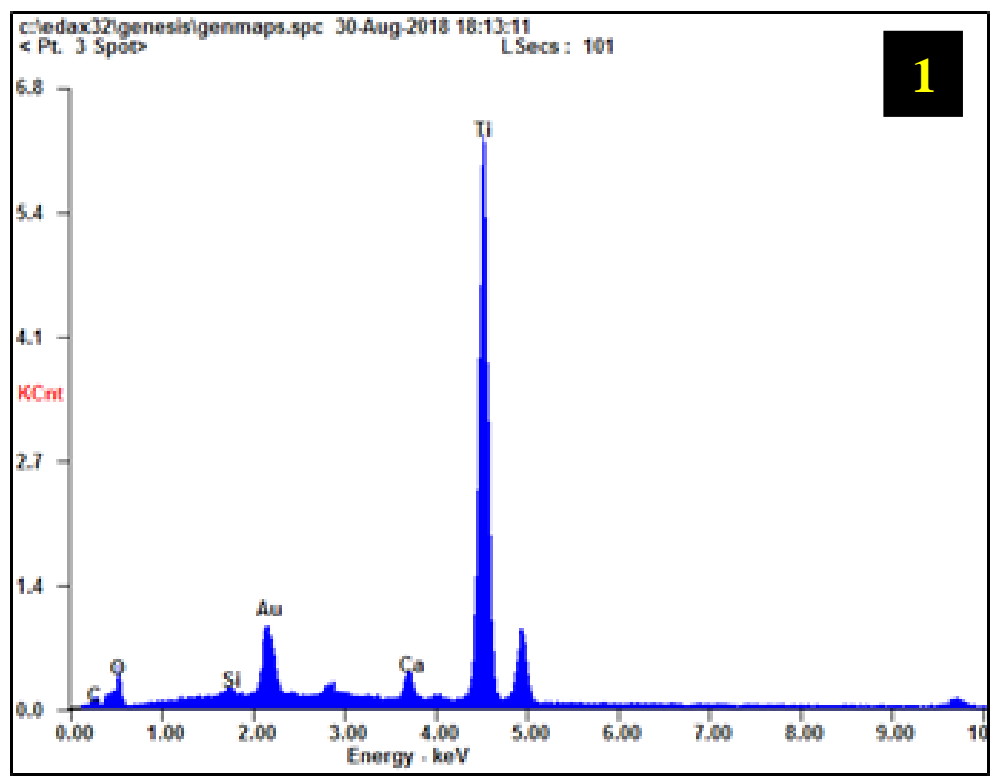

\begin{tabular}{||l|l|l|}
\hline Element & Wt\% & At\% \\
\hline $\boldsymbol{C K}$ & 02.62 & 08.41 \\
\hline $\boldsymbol{O K}$ & 13.35 & 32.16 \\
\hline SiK & 00.59 & 00.82 \\
\hline $\boldsymbol{A u M}$ & 14.26 & 02.79 \\
\hline $\boldsymbol{P d L}$ & 00.46 & 00.17 \\
\hline $\boldsymbol{C a K}$ & 02.40 & 02.30 \\
\hline TiK & 66.32 & 53.36 \\
\hline Matrix & Correction & ZAF \\
\hline
\end{tabular}



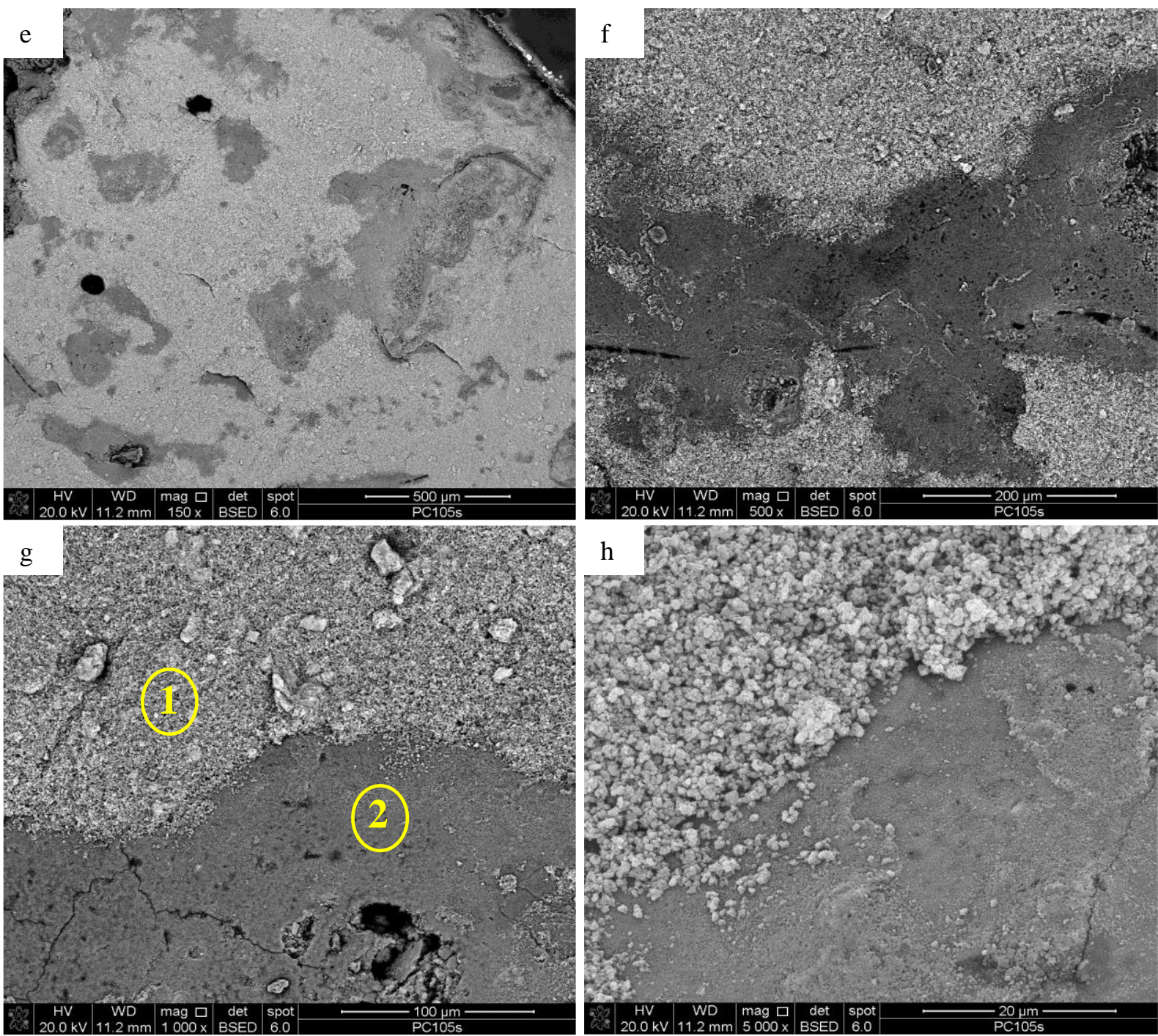

Note: PC105s mortar - Formation of $\mathrm{TiO}_{2}$ film at $500 \mu \mathrm{m}$ scale (e); Formation of $\mathrm{TiO}_{2}$ film at $200 \mu \mathrm{m}$ scale (f); Formation of $\mathrm{TiO}_{2}$ film at $100 \mu \mathrm{m}(1 \mathrm{~g}) ; \mathrm{TiO}_{2}$ film flawed spot at $100 \mu \mathrm{m}(2 \mathrm{~g})$; Formation of $\mathrm{TiO}_{2}$ film at $20 \mu \mathrm{m}(\mathrm{h})$.

Source: Author (2021)

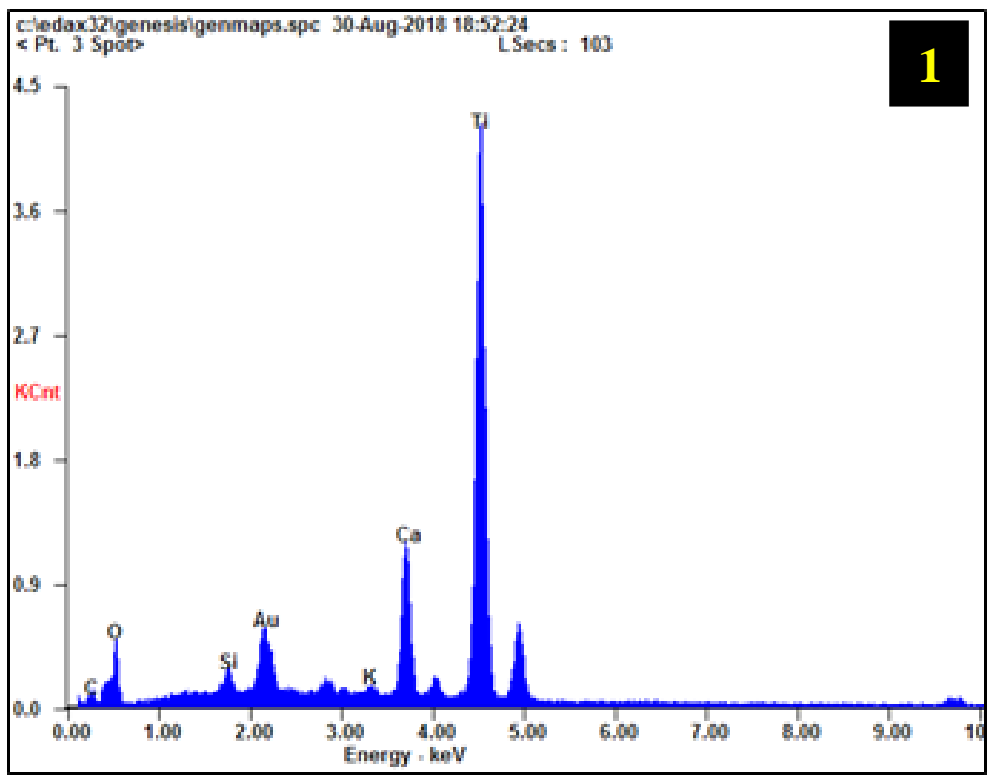

\begin{tabular}{||l|l|l|}
\hline Element & Wt\% & At\% \\
\hline CK & 03.34 & 09.48 \\
\hline OK & 18.07 & 38.46 \\
\hline SiK & 01.30 & 01.58 \\
\hline $\boldsymbol{A u M}$ & 10.54 & 01.82 \\
\hline $\boldsymbol{P d L}$ & 00.66 & 00.21 \\
\hline $\boldsymbol{K K}$ & 00.61 & 00.53 \\
\hline $\boldsymbol{C a K}$ & 09.70 & 08.24 \\
\hline TiK & 55.78 & 39.67 \\
\hline Matrix & Correction & ZAF \\
\hline \hline
\end{tabular}



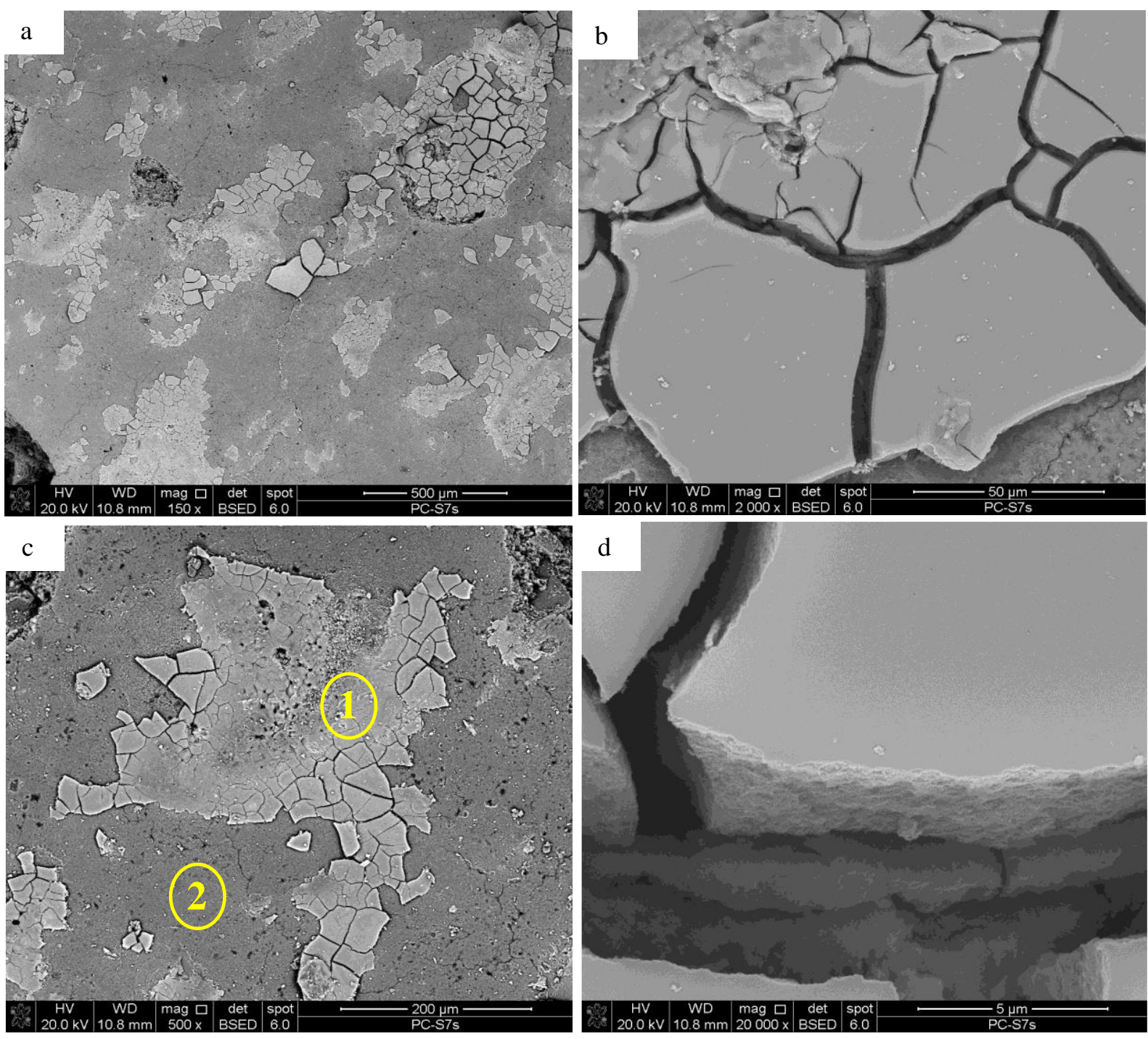

Note: PC-S7s mortar - Formation of $\mathrm{TiO}_{2}$ film at $500 \mu \mathrm{m}$ scale (a); Formation of $\mathrm{TiO}_{2}$ film at $50 \mu \mathrm{m}$ (b); Formation of $\mathrm{TiO}_{2}$ film at $200 \mu \mathrm{m}(1 \mathrm{c}) ; \mathrm{TiO}_{2}$ film flawed spot at $200 \mu \mathrm{m}(2 \mathrm{c})$; Formation of $\mathrm{TiO}_{2}$ film at $5 \mu \mathrm{m}(\mathrm{d})$.

Source: Author (2021)

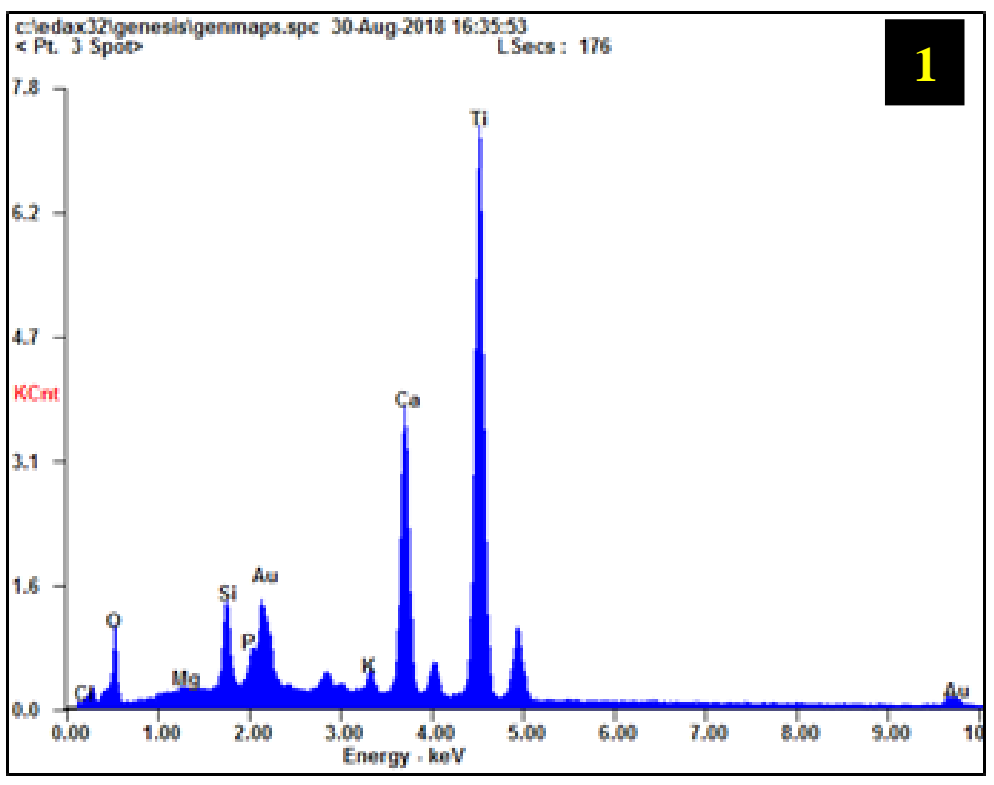

\begin{tabular}{||l|l|l|}
\hline Element & Wt\% & At\% \\
\hline OK & 15.65 & 37.13 \\
\hline MgK & 00.74 & 01.15 \\
\hline SiK & 03.60 & 04.86 \\
\hline $\boldsymbol{P K}$ & 01.95 & 02.39 \\
\hline $\boldsymbol{P d L}$ & 01.24 & 00.44 \\
\hline KK & 01.27 & 01.23 \\
\hline CaK & 15.14 & 14.34 \\
\hline TiK & 44.73 & 35.44 \\
\hline AuL & 15.68 & 03.02 \\
\hline Matrix & Correction & ZAF \\
\hline
\end{tabular}




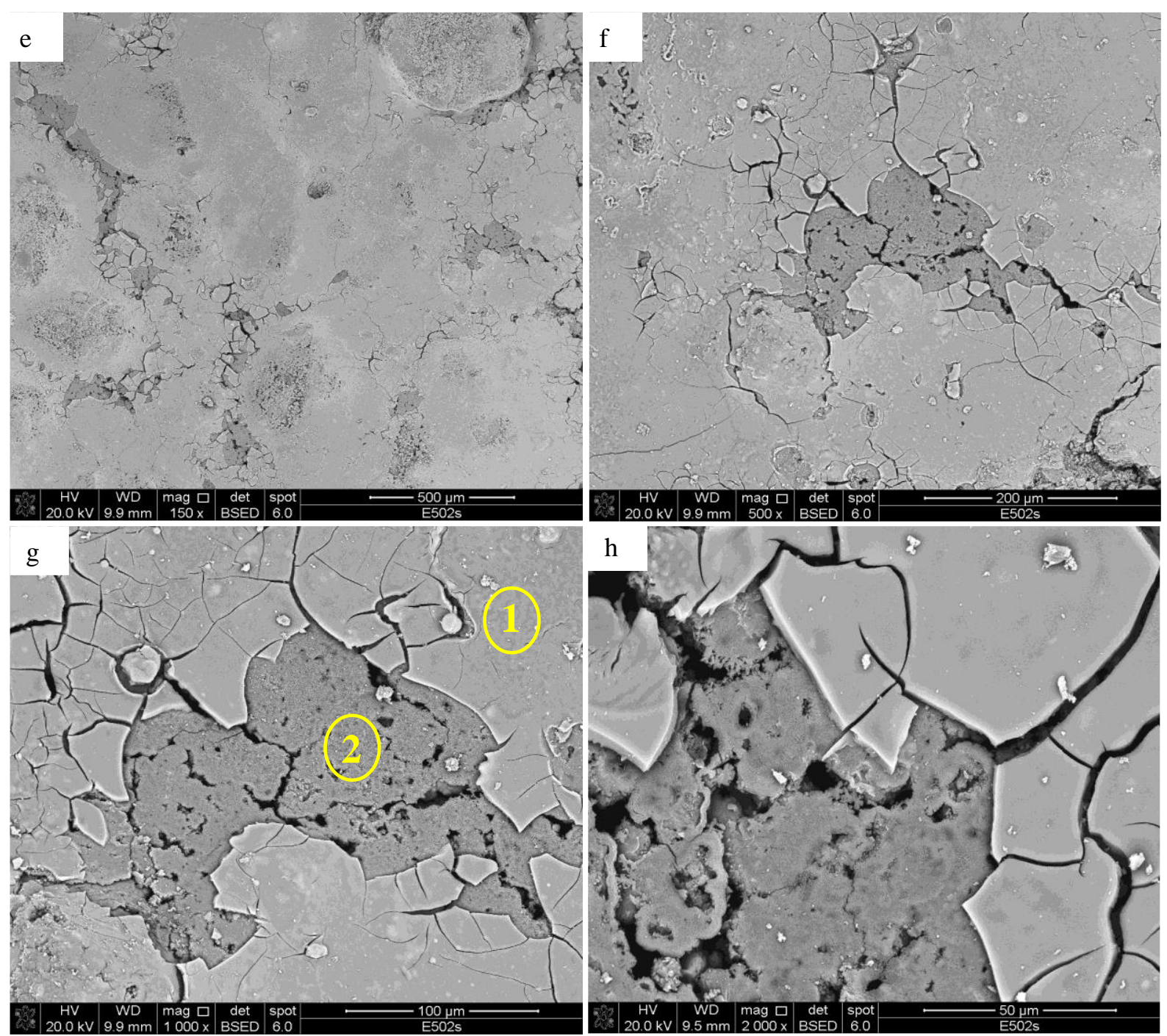

Note: E502s mortar - Formation of $\mathrm{TiO}_{2}$ film at $500 \mu \mathrm{m}$ scale (e); Formation of $\mathrm{TiO}_{2}$ film at $200 \mu \mathrm{m}$ scale (f); Formation of $\mathrm{TiO}_{2}$ film at $100 \mu \mathrm{m}(1 \mathrm{~g}) ; \mathrm{TiO}_{2}$ film flawed spot in $100 \mu \mathrm{m}(2 \mathrm{~g})$; Formation of $\mathrm{TiO}_{2}$ film at $50 \mu \mathrm{m}(\mathrm{h})$.

Source: Author (2021)

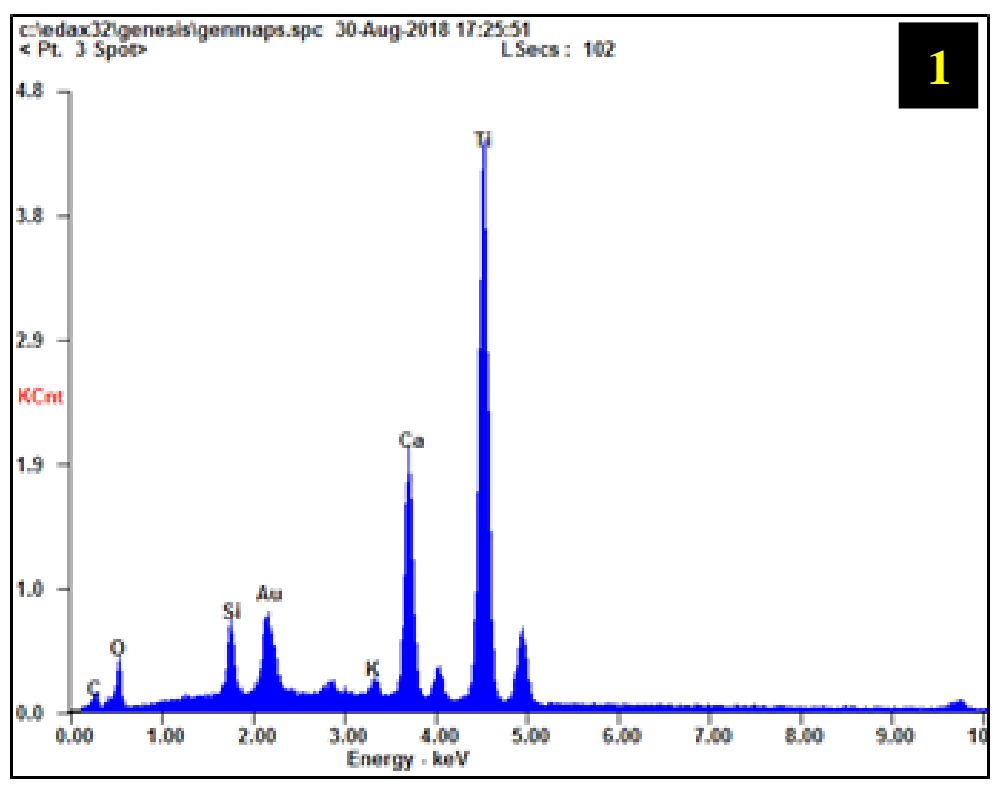

\begin{tabular}{||l|l|l|}
\hline \hline Element & Wt\% & At\% \\
\hline $\boldsymbol{C K}$ & 03.75 & 11.34 \\
\hline OK & 12.68 & 28.82 \\
\hline SiK & 03.02 & 03.92 \\
\hline $\boldsymbol{A u M}$ & 12.46 & 02.30 \\
\hline $\boldsymbol{P d L}$ & 00.99 & 00.34 \\
\hline $\boldsymbol{K K}$ & 01.22 & 01.14 \\
\hline $\boldsymbol{C a K}$ & 14.35 & 13.02 \\
\hline TiK & 51.52 & 39.12 \\
\hline Matrix & Correction & ZAF \\
\hline \hline
\end{tabular}




\section{APPENDIX K - ELEMENTAL MAPPING (EDS) OF THE SPECIMENS}

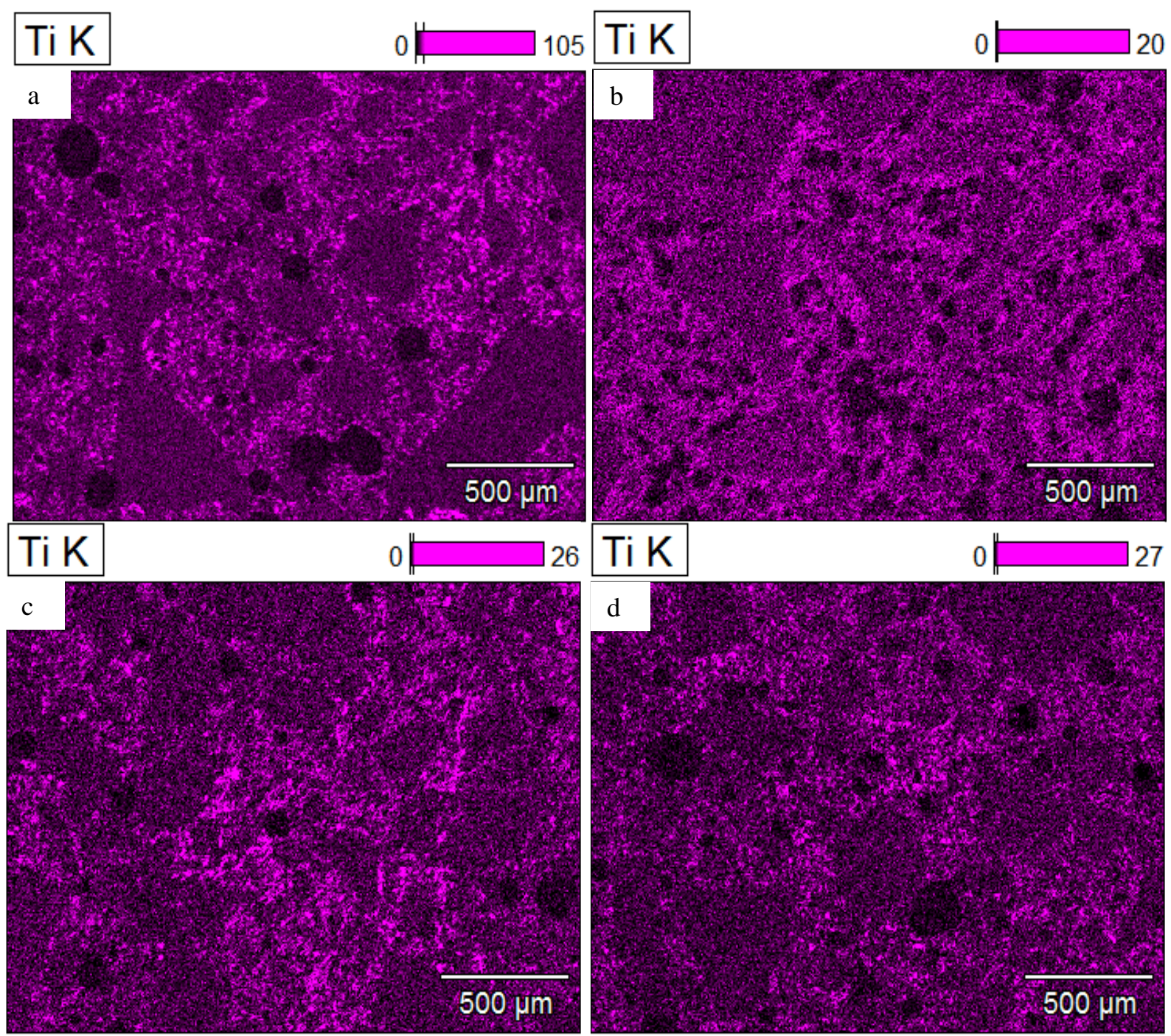

Note: P25p mortar - Top layer (a); Upper layer (b); Middle layer (c); Bottom layer (d). The colors are used to better differentiate between the two $\mathrm{TiO}_{2}$.

Source: Author (2021)

\begin{tabular}{|c|c|c|c|c|c|}
\hline $\begin{array}{l}\text { Element } \\
\text { Line }\end{array}$ & Weight \% & $\begin{array}{l}\text { Weight \% } \\
\text { Error }\end{array}$ & Atom \% & Formula & Compnd \% \\
\hline$O K$ & 26.77 & $+/-0.78$ & 43.38 & $\mathrm{O}$ & 26.77 \\
\hline $\operatorname{Mg} K$ & 11.15 & $+/-0.14$ & 11.90 & $\mathrm{Mg}$ & 11.15 \\
\hline Al K & 3.25 & $+/-0.21$ & 3.13 & $\mathrm{Al}$ & 3.25 \\
\hline Si $K$ & 13.32 & $+/-0.15$ & 12.30 & $\mathrm{Si}$ & 13.32 \\
\hline $\mathrm{CaK}$ & 4424 & $+/-018$ & 2861 & $\mathrm{Ca}$ & 4424 \\
\hline$T i K$ & 1.26 & $+/-0.09$ & 0.68 & $\mathrm{Ti}$ & 1.26 \\
\hline Total & 100.00 & & 100.00 & & 100.00 \\
\hline
\end{tabular}

Note: Quantitative Results - EDS_P25p_Top layer

Source: Author (2021) 


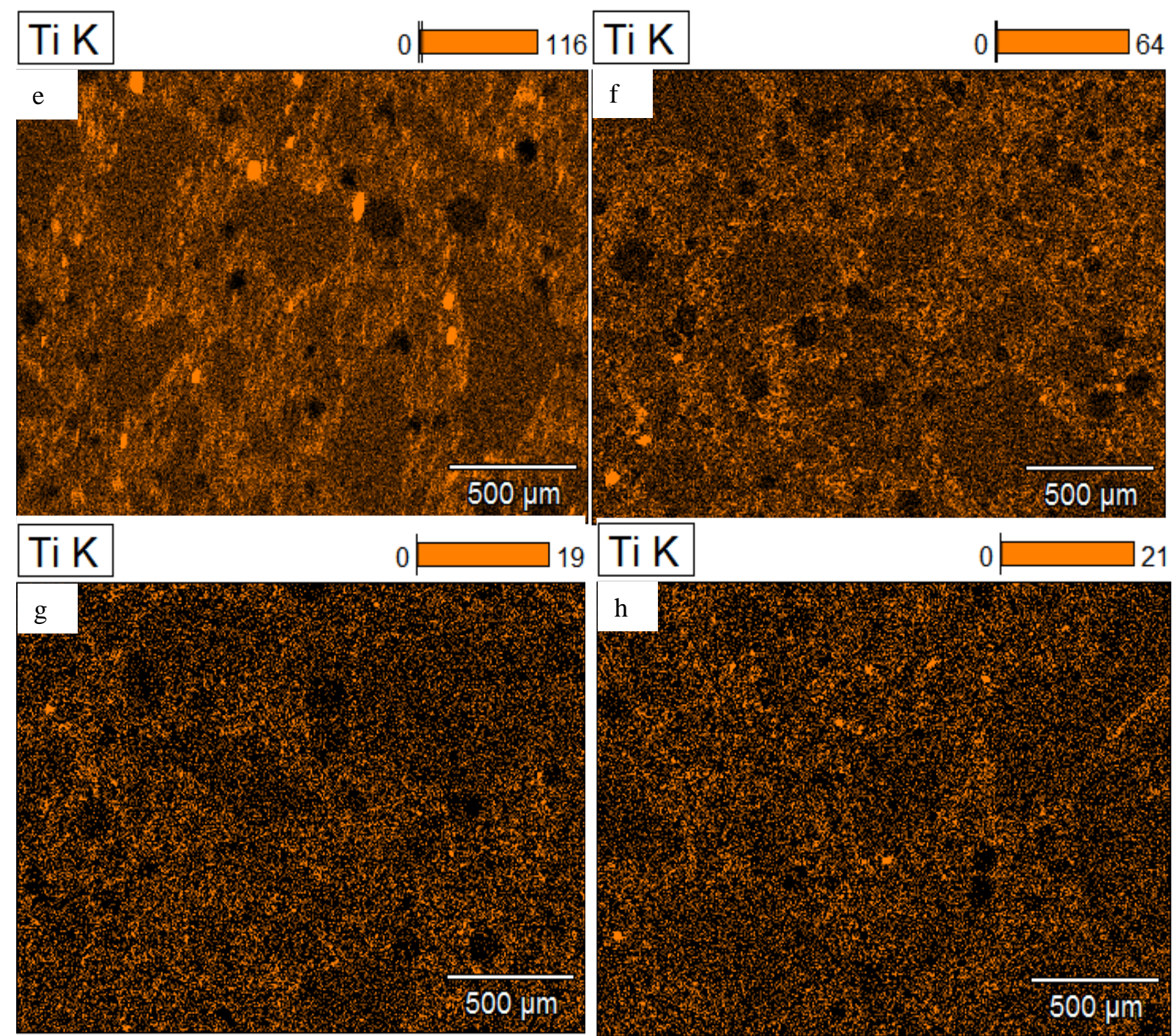

Note: PC105p mortar - Top layer (a); Upper layer (b); Middle layer (c); Bottom layer (d). The colors are used to better differentiate between the two $\mathrm{TiO}_{2}$.

Source: Author (2021)

\begin{tabular}{|cccccc}
$\begin{array}{l}\text { Element } \\
\text { Line }\end{array}$ & Weight \% & $\begin{array}{c}\text { Weight \% } \\
\text { Error }\end{array}$ & Atom \% & Formula & Compnd \% \\
\hline $\boldsymbol{O} \boldsymbol{K}$ & 24.48 & $+/-0.60$ & 40.69 & $\mathrm{O}$ & 24.48 \\
$\boldsymbol{M g} \boldsymbol{K}$ & 11.70 & $+/-0.14$ & 12.80 & $\mathrm{Mg}$ & 11.70 \\
$\boldsymbol{A l} \boldsymbol{K}$ & 3.26 & $+/-0.22$ & 3.21 & $\mathrm{Al}$ & 3.26 \\
Si $\boldsymbol{K}$ & 11.49 & +-0.15 & 10.88 & $\mathrm{Si}$ & 11.49 \\
$\boldsymbol{C a} \boldsymbol{K}$ & 4776 & $+/-0.19$ & 31.68 & $\mathrm{Ca}$ & 47.76 \\
\hline Ti $\boldsymbol{K}$ & 1.31 & $+/-0.10$ & 0.73 & $\mathrm{Ti}$ & 1.31 \\
\hline Total & 100.00 & & 100.00 & & 100.00 \\
\hline
\end{tabular}

Note: Quantitative Results - EDS_PC105p_Top layer

Source: Author (2021) 